Prepared in cooperation with the U.S. Army Corps of Engineers

\title{
Hydrogeologic Framework, Hydrology, and Water Quality in the Pearce Creek Dredge Material Containment Area and Vicinity, Cecil County, Maryland, 2010-11
}

Scientific Investigations Report 2012-5263 
Cover photograph: Pearce Creek Dredge Material Containment Area. Photograph taken by Cheryl A. Dieter, 2/13/2009. 


\section{Hydrogeologic Framework, Hydrology, and Water Quality in the Pearce Creek Dredge Material Containment Area and Vicinity, Cecil County, Maryland, 2010-11}

By Cheryl A. Dieter, Michael T. Koterba, Otto S. Zapecza, Charles W. Walker, and Donald E. Rice

Prepared in cooperation with the U.S. Army Corps of Engineers

Scientific Investigations Report 2012-5263 


\section{U.S. Department of the Interior \\ KEN SALAZAR, Secretary \\ U.S. Geological Survey \\ Marcia K. McNutt, Director}

U.S. Geological Survey, Reston, Virginia: 2013

For more information on the USGS - the Federal source for science about the Earth, its natural and living resources, natural hazards, and the environment, visit http://www.usgs.gov or call 1-888-ASK-USGS.

For an overview of USGS information products, including maps, imagery, and publications, visit http://www.usgs.gov/pubprod

To order this and other USGS information products, visit http://store.usgs.gov

Any use of trade, firm, or product names is for descriptive purposes only and does not imply endorsement by the U.S. Government.

Although this information product, for the most part, is in the public domain, it also may contain copyrighted materials as noted in the text. Permission to reproduce copyrighted items must be secured from the copyright owner.

Suggested citation:

Dieter, C.A., Koterba, M.T., Zapecza, O.S., Walker, C.W., and Rice, D.E., 2013, Hydrogeologic framework, hydrology, and water quality in the Pearce Creek Dredge Material Containment Area and vicinity, Cecil County, Maryland, 2010-11: U.S. Geological Survey Scientific Investigations Report 2012-5263, 219 p. with Appendixes 


\section{Contents}

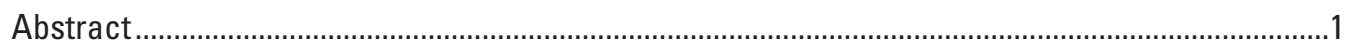

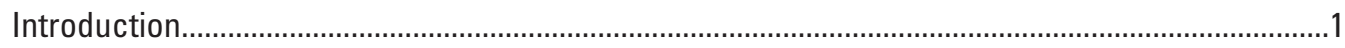

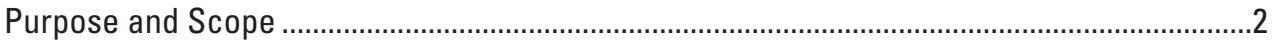

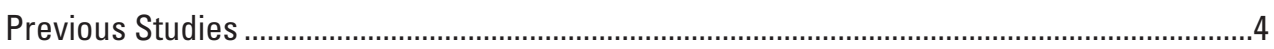

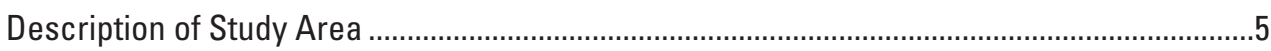

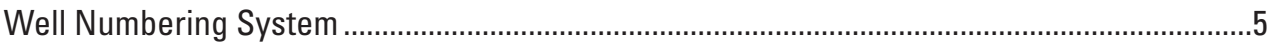

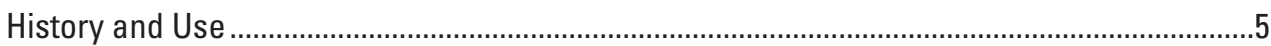

Methods of Water-Quality Data Collection and Data Quality..........................................................

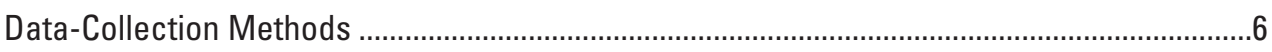

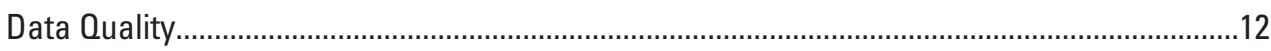

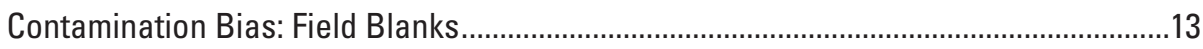

Measurement Uncertainty: Duplicate Samples ……………........................................13

Matrix Bias: Spiked Groundwater Samples .....................................................................15

Measurement Accuracy: Standard Reference Samples and Ionic Mass Balances ....19

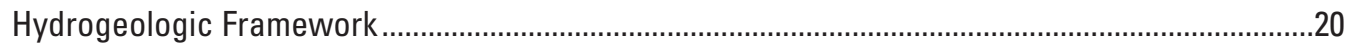

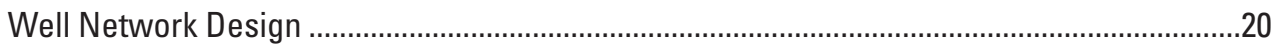

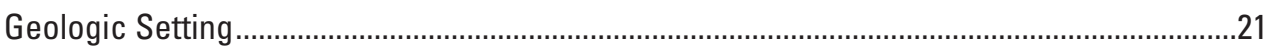

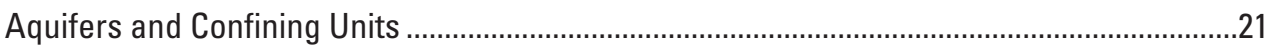

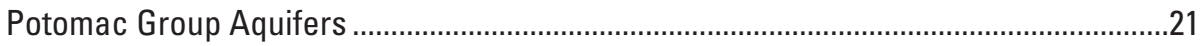

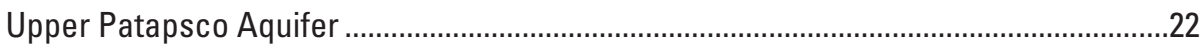

Upper Patapsco Aquifer Deep Water-Bearing Zone ....................................................23

Confining Unit Between the Upper Patapsco Aquifer Shallow and Deep Water-

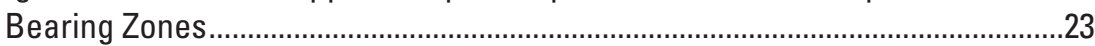

Upper Patapsco Aquifer Shallow Water-Bearing Zone ..................................................32

Upper Patapsco Confining Unit .......................................................................................32

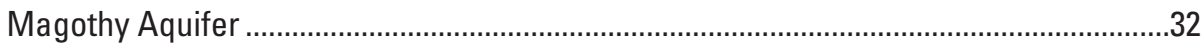

Matawan Confining Unit and Fill ................................................................................32

Chemical Composition of Sediments .....................................................................................

Northern Chesapeake Bay Sediments ..........................................................................33

Dredge Material Containment Area and Vicinity Sediments............................................33

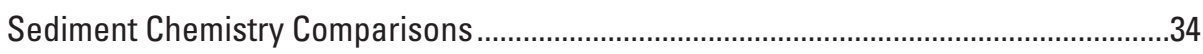

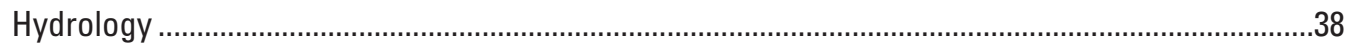

Water-Level Synoptic Assessments and Continuous Data Collection .....................................38

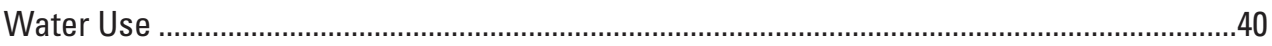

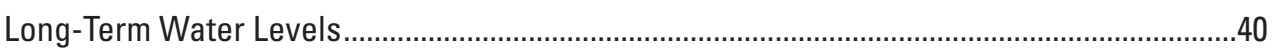

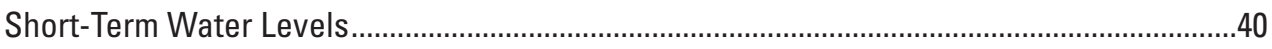

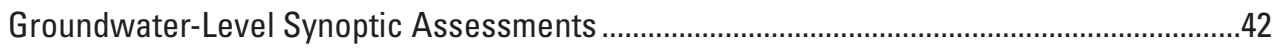

Magothy Aquifer: May 19-20, 2010, Synoptic Assessment ..............................................44

Magothy Aquifer: August 17-18, 2010, Synoptic Assessment .......................................47

Magothy Aquifer: March 18, 2011, Synoptic Assessment. ............................................47

Upper Patapsco Aquifer Shallow Water-Bearing Zone: May 19-20, 2010, Synoptic Assessment .....................................................................................4

Upper Patapsco Aquifer Shallow Water-Bearing Zone: August 17-18, 2010, Synoptic Assessment 
Upper Patapsco Aquifer Shallow Water-Bearing Zone: March 18, 2011, Synoptic Assessment

Upper Patapsco Aquifer Deep Water-Bearing Zone: May 19-20, 2010,

Synoptic Assessment

Upper Patapsco Aquifer Deep Water-Bearing Zone: August 17-18, 2010,

Synoptic Assessment .49

Perched Groundwater Zone: August 17-18, 2010, Synoptic Assessment......................49

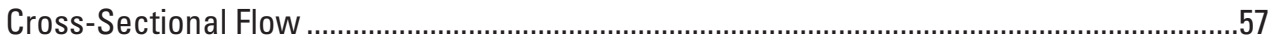

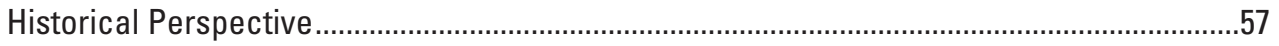

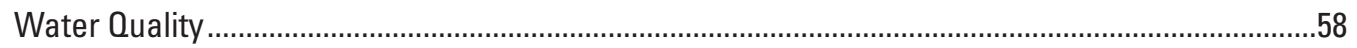

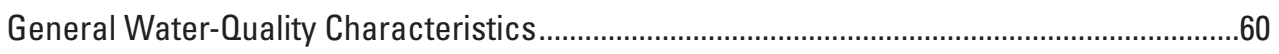

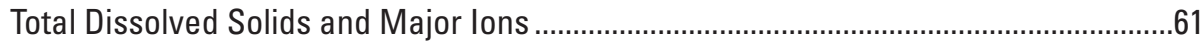

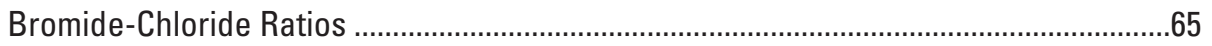

Total Dissolved Solids and General Patterns in Groundwater Flow..............................69

Electromagnetic-Induction Logging ........................................................................

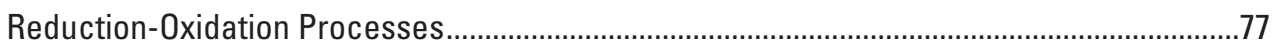

Historical Influences on Reduction-0xidation Processes ...............................................77

Terminal Electron Acceptor Process Analysis ...............................................................81

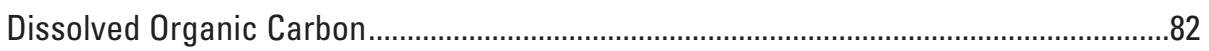

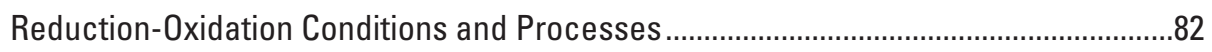

Mixed Reduction-Oxidation Processes and pH..........................................................108

Extended Implications of Reduction-0xidation Processes on Groundwater Quality...113

Additional Water-Quality Indicators Illustrate Effect of Dredge Material Containment Area on Local Groundwater Quality...........................................................................114

Pesticides and Wastewater Compounds..................................................................114

Low Level of Detection Pesticide Survey ………….................................................119

Wastewater Compound Survey.................................................................................. 120

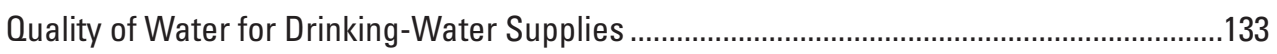

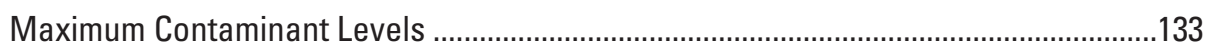

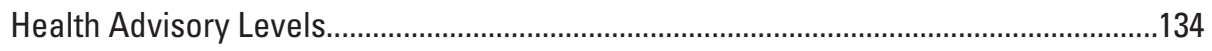

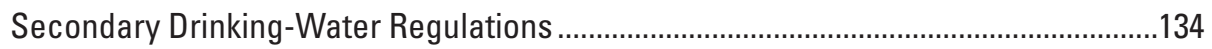

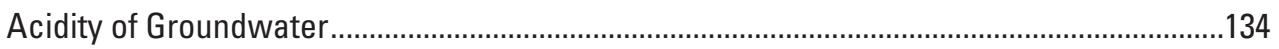

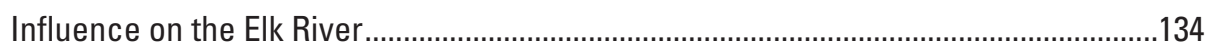

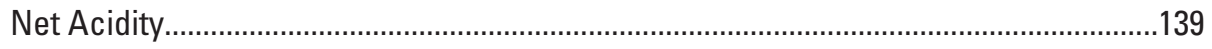

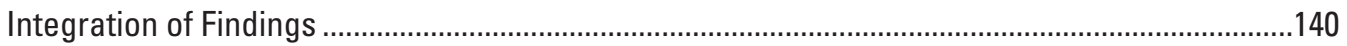

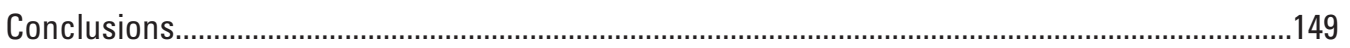

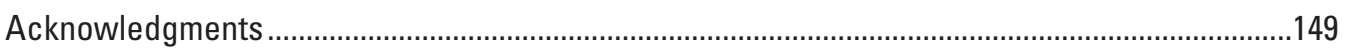

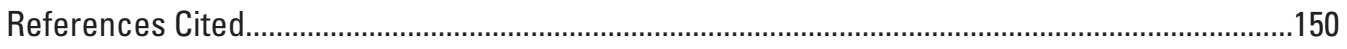

Appendixes A-C:

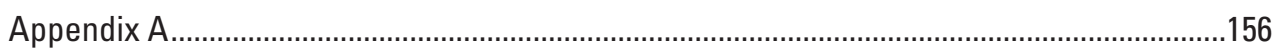

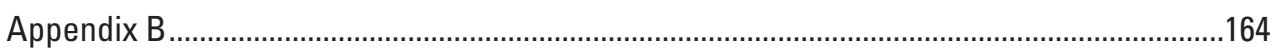

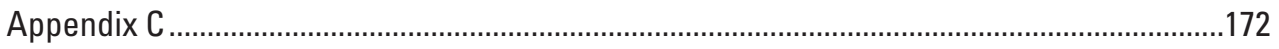




\section{Figures}

1. Map showing location of the Pearce Creek Dredge Material Containment Area, Cecil County, Maryland.

2. Map showing Pearce Creek Dredge Material Containment Area (DMCA) and vicinity, Cecil County, Maryland, 2009...

3. Map showing general topography and drainage characteristics of the study area before installation of the Pearce Creek Dredge Material Containment Area,

Cecil County, Maryland, circa 1890.

4. Map showing general topography and drainage characteristics of the study area during the installation of the Pearce Creek Dredge Material Containment Area, Cecil County, Maryland, circa 1944 ..

5. Map showing general topography and drainage characteristics of the study area after closure of the Pearce Creek Dredge Material Containment Area, Cecil County, Maryland, circa 1990s

6. Map showing selected wells and surface-water sites used by the U.S. Geological Survey for water-quality data collection in the Pearce Creek Dredge Material Containment Area (DMCA) and vicinity, Cecil County, Maryland, 2010-11

7. Map showing the monitoring well network, Pearce Creek Dredge Material Containment Area (DMCA) and vicinity, Cecil County, Maryland, 2010-11

8. Maps showing $A$, Structure contours of the top of the upper Patapsco aquifer deep water-bearing zone, $B$, thickness of the confining unit between the upper Patapsco aquifer shallow and deep water-bearing zones, $C$, structure contours on the top of the upper Patapsco aquifer shallow water-bearing zone, and $D$, thickness of the upper Patapsco aquifer shallow water-bearing zone, in the Pearce Creek Dredge Material Containment Area (DMCA) and vicinity, Cecil County, Maryland, 2010-11...

9. Maps showing $A$, Thickness of the upper Patapsco confining unit, $B$, structure contours on the top of the Magothy aquifer, $C$, thickness of the Magothy aquifer, and $D$, thickness of the Matawan confining unit in the Pearce Creek Dredge Material Containment Area (DMCA) and vicinity, Cecil County, Maryland, 2010-11 _.....25

10. Map showing well locations and lines of hydrogeologic sections, Pearce Creek Dredge Material Containment Area (DMCA) and vicinity, Cecil County, Maryland ........26

11. Hydrogeologic section $A-B$, correlation based on gamma logs at boreholes (wells) indicated, Pearce Creek Dredge Material Containment Area and vicinity, Cecil County, Maryland.

12. Hydrogeologic section $B-C$, correlation based on gamma logs at boreholes (wells) indicated, Pearce Creek Dredge Material Containment Area and vicinity, Cecil County, Maryland.

13. Hydrogeologic section $A-E$, correlation based on gamma logs at boreholes (wells) indicated, Pearce Creek Dredge Material Containment Area and vicinity, Cecil County, Maryland.

14. Hydrogeologic section $D-E$, correlation based on gamma logs at boreholes (wells) indicated, Pearce Creek Dredge Material Containment Area and vicinity, Cecil County, Maryland.

15. Hydrogeologic section $F-G$, correlation based on gamma logs at boreholes (wells) indicated, Pearce Creek Dredge Material Containment Area and vicinity, Cecil County, Maryland 
16. Map showing selected wells used by the U.S. Geological Survey for water-level data collection and the location of lines of section for groundwater flow $A-A^{\prime}$ and $B-B^{\prime}$ in the Pearce Creek Dredge Material Containment Area (DMCA) and vicinity, Cecil County, Maryland.

17. Map showing observation wells and lake gage with installed water-level transducer, Pearce Creek Dredge Material Containment Area (DMCA) and vicinity, Cecil County, Maryland

18. Graph showing altitude of water levels in well CE Dd 81 near Pearce Creek Dredge Material Containment Area (DMCA), Cecil County, Maryland, March 1983-June 2011

19. Graph showing average daily altitude of water levels in observation wells in the Pearce Creek Dredge Material Containment Area (DMCA) and vicinity, Cecil County, Maryland, January 2010-February 2011

20. Graph showing altitude of water levels in observation wells and Pearce Creek Lake from September 26-0ctober 6, 2010, in the Pearce Creek Dredge Material Containment Area (DMCA) and vicinity, Cecil County, Maryland.

21. Map showing potentiometric surface of the Magothy aquifer, May 19-20, 2010, in the Pearce Creek Dredge Material Containment Area (DMCA) and vicinity, Cecil County, Maryland..

22. Map showing potentiometric surface of the Magothy aquifer, August 17-18, 2010, in the Pearce Creek Dredge Material Containment Area (DMCA) and vicinity, Cecil County, Maryland.

23. Map showing potentiometric surface of the Magothy aquifer, March 18, 2011, in the Pearce Creek Dredge Material Containment Area (DMCA) and vicinity, Cecil County, Maryland.

24. Map showing potentiometric surface of the upper Patapsco aquifer shallow waterbearing zone, May 19-20, 2010, in the Pearce Creek Dredge Material Containment Area (DMCA) and vicinity, Cecil County, Maryland

25. Map showing potentiometric surface of the upper Patapsco aquifer shallow waterbearing zone, August 17-18, 2010, in the Pearce Creek Dredge Material Containment Area (DMCA) and vicinity, Cecil County, Maryland

26. Map showing potentiometric surface of the upper Patapsco aquifer shallow waterbearing zone, March 18, 2011, in the Pearce Creek Dredge Material Containment Area (DMCA) and vicinity, Cecil County, Maryland

27. Map showing potentiometric surface of the upper Patapsco aquifer deep waterbearing zone, May 19-20, 2010, in the Pearce Creek Dredge Material Containment Area (DMCA) and vicinity, Cecil County, Maryland.

28. Map showing potentiometric surface of the upper Patapsco aquifer deep water-bearing zone, August 17-18, 2010, in the Pearce Creek Dredge Material Containment Area (DMCA) and vicinity, Cecil County, Maryland...

29. Map showing potentiometric surface of a perched groundwater zone, August 17-18, 2010, in the Pearce Creek Dredge Material Containment Area (DMCA) and vicinity, Cecil County, Maryland.

30. Hydrogeologic section showing groundwater altitudes and flow directions along line $A-A^{\prime}$, May 2010, in the Pearce Creek Dredge Material Containment Area and vicinity, Cecil County, Maryland

31. Hydrogeologic section showing groundwater altitudes and flow directions along line $B-B^{\prime}$, May 2010, in the Pearce Creek Dredge Material Containment Area and vicinity, Cecil County, Maryland 
32. Map showing wells completed in the Magothy and upper Patapsco aquifers with available groundwater data which appear to be not overly affected by human activities or land use near the Pearce Creek Dredge Material Containment Area and vicinity, Cecil County, Maryland

33. Trilinear diagram for samples with $A$, total dissolved solids less than $\mathbf{3 0 0}$ milligrams per liter ( $\mathrm{mg} / \mathrm{L})$ and $B$, total dissolved solids greater than $300 \mathrm{mg} / \mathrm{L}$ collected in the Pearce Creek Dredge Material Containment Area and vicinity, Cecil County, Maryland

34. Map showing concentrations of total dissolved solids in water-quality samples collected from selected surface waters and selected wells completed in the perched water-bearing zone or Magothy aquifer in the Pearce Creek Dredge Material Containment Area (DMCA) and vicinity, Cecil County, Maryland, 2010-11 ......66

35. Map showing concentrations of total dissolved solids in water-quality samples collected from selected surface waters and selected wells completed in the upper Patapsco aquifer shallow water-bearing zone in the Pearce Creek Dredge Material Containment Area (DMCA) and vicinity, Cecil County, Maryland, 2010-11

36. Map showing concentrations of total dissolved solids in water-quality samples collected from selected surface waters and selected wells completed in the upper Patapsco aquifer deep water-bearing zone in the Pearce Creek Dredge Material Containment Area and vicinity, Cecil County, Maryland, 2010-11.

37. Graph showing ratios of the concentration of bromide to the concentration of chloride as a function of the concentration of chloride for selected surface- and groundwater samples collected in the Pearce Creek Dredge Material Containment Area (DMCA) and vicinity, Cecil County, Maryland, 1995-96

38. Graph showing ratios of the concentration of bromide to the concentration of chloride as a function of the concentration of chloride for selected surface- and groundwater samples collected in the Pearce Creek Dredge Material Containment Area (DMCA) and vicinity, Cecil County, Maryland, 2010-11

39. Map showing selected wells used by the U.S. Geological Survey for water-quality descriptions along sections $A-A^{\prime}, B-B^{\prime}$, and $C-C^{\prime}$ in the Pearce Creek Dredge Material Containment Area (DMCA) and vicinity, Cecil County, Maryland

40. Hydrogeologic section showing ratios of the concentration of bromide to the concentration of chloride in water-quality samples along line $A-A$ 'and collected from selected surface waters, and from selected wells completed in the perched water-bearing zone Magothy aquifer, or upper Patapsco aquifer shallow or deep water-bearing zone in the Pearce Creek Dredge Material Containment Area (DMCA) and vicinity, Cecil County, Maryland, 2010-11

41. Hydrogeologic section showing concentrations of total dissolved solids in waterquality samples along line $A-A^{\prime}$ and collected from selected surface waters, and from selected wells completed in the perched water-bearing zone Magothy aquifer, or upper Patapsco aquifer shallow or deep water-bearing zone in the Pearce Creek Dredge Material Containment Area (DMCA) and vicinity, Cecil County, Maryland, 2010-11

42. Hydrogeologic section showing concentrations of total dissolved solids in waterquality samples along line $B-B^{\prime}$ and collected from selected wells completed in the Magothy aquifer or upper Patapsco aquifer shallow or deep water-bearing zone in the Pearce Creek Dredge Material Containment Area (DMCA) and vicinity, Cecil County, Maryland, 2010-11

43. Hydrogeologic section showing concentrations of total dissolved solids in waterquality samples along line $C-C^{\prime}$ and collected from selected surface waters and from selected wells completed in the Magothy aquifer or upper Patapsco aquifer shallow or deep water-bearing zone in the Pearce Creek Dredge Material Containment Area (DMCA) and vicinity, Cecil County, Maryland, 2010-11 
44. Hydrogeologic section showing electromagnetic-induction logs, total dissolved solids concentrations (in milligrams per liter), and hydrogeology along line $A-B$..........79

45. Hydrogeologic section showing electromagnetic-induction logs, total dissolved solids concentrations (in milligrams per liter), and hydrogeology along line $B-C \ldots \ldots \ldots . . .80$

46. Map showing concentrations of dissolved organic carbon in water-quality samples collected from selected surface waters and from selected wells completed in the perched water-bearing zone or Magothy aquifer in the Pearce Creek Dredge Material Containment Area (DMCA) and vicinity, Cecil County, Maryland, 2010-11 ......85

47. Map showing concentrations of dissolved organic carbon in water-quality samples collected from selected surface waters and from selected wells completed in the upper Patapsco aquifer shallow water-bearing zone in the Pearce Creek Dredge Material Containment Area (DMCA) and vicinity, Cecil County, Maryland, 2010-11 ......86

48. Hydrogeologic section showing concentrations of dissolved organic carbon in water-quality samples along line $A-A^{\prime}$ and collected from selected surface waters and from selected wells completed in the perched water-bearing zone, Magothy aquifer, or upper Patapsco aquifer shallow or deep water-bearing zone in the Pearce Creek Dredge Material Containment Area (DMCA) and vicinity, Cecil County, Maryland, 2010-11.

49. Map showing predominant reduction-oxidation conditions and processes associated with selected surface waters and with selected wells completed in the perched water-bearing zone or Magothy aquifer in the Pearce Creek Dredge Material Containment Area (DMCA) and vicinity, Cecil County, Maryland, 2010-11

50. Hydrogeologic section showing concentrations of dissolved oxygen in waterquality samples along line $A-A^{\prime}$ and collected from selected surface waters and from selected wells completed in the perched water-bearing zone, Magothy aquifer, or upper Patapsco aquifer shallow or deep water-bearing zone in the Pearce Creek Dredge Material Containment Area (DMCA) and vicinity, Cecil County, Maryland, 2010-11

51. Hydrogeologic section showing concentrations of dissolved nitrate plus nitrite nitrogen in water-quality samples along line $A-A^{\prime}$ and collected from selected surface waters and selected wells completed in the perched water-bearing zone, Magothy aquifer, or upper Patapsco aquifer shallow or deep water-bearing zone in the Pearce Creek Dredge Material Containment Area (DMCA) and vicinity, Cecil County, Maryland, 2010-11.

52. Map showing concentrations of dissolved ammonia nitrogen in water-quality samples collected from selected surface waters and from selected wells completed in the perched water-bearing zone or Magothy aquifer in the Pearce Creek Dredge Material Containment Area (DMCA) and vicinity, Cecil County, Maryland, 2010-11

53. Map showing concentrations of dissolved ammonia nitrogen in water-quality samples collected from selected surface waters and from selected wells completed in the upper Patapsco aquifer shallow water-bearing zone in the Pearce Creek Dredge Material Containment Area (DMCA) and vicinity, Cecil County, Maryland, 2010-11.

54. Hydrogeologic section showing concentrations of dissolved ammonia nitrogen in water-quality samples along line $A-A^{\prime}$ and collected from selected surface waters and from selected wells completed in the perched water-bearing zone, Magothy aquifer, or upper Patapsco aquifer shallow or deep water-bearing zone in the Pearce Creek Dredge Material Containment Area (DMCA) and vicinity, Cecil County, Maryland, 2010-11. 
55. Hydrogeologic section showing concentrations of dissolved manganese in waterquality samples along line $A-A^{\prime}$ and collected from selected surface waters and from selected wells completed in the perched water-bearing zone Magothy aquifer, or upper Patapsco aquifer shallow or deep water-bearing zone in the Pearce Creek Dredge Material Containment Area (DMCA) and vicinity, Cecil County, Maryland, 2010-11

56. Map showing concentrations of dissolved manganese in water-quality samples collected from selected surface waters and from selected wells completed in the perched water-bearing zone or Magothy aquifer in the Pearce Creek Dredge Material Containment Area (DMCA) and vicinity, Cecil County, Maryland, 2010-11 ......96

57. Hydrogeologic section showing concentrations of dissolved iron in water-quality samples along line $A-A^{\prime}$ and collected from selected surface waters and from selected wells completed in the perched water-bearing zone Magothy aquifer, or upper Patapsco aquifer shallow or deep water-bearing zone in the Pearce Creek Dredge Material Containment Area and vicinity, Cecil County, Maryland, 2010-11 .......97

58. Map showing concentrations of dissolved iron in water-quality samples collected from selected surface waters and from selected wells completed in the perched water-bearing zone or Magothy aquifer in the Pearce Creek Dredge Material Containment Area (DMCA) and vicinity, Cecil County, Maryland, 2010-11

59. Map showing concentrations of dissolved iron in water-quality samples collected from selected surface waters and from selected wells completed in the upper Patapsco aquifer shallow water-bearing zone in the Pearce Creek Dredge Material Containment Area (DMCA) and vicinity, Cecil County, Maryland, 2010-11 ......99

60. Map showing concentrations of dissolved sulfate in water-quality samples collected from selected surface waters and from selected wells completed in the perched water-bearing zone or Magothy aquifer in the Pearce Creek Dredge Material Containment Area (DMCA) and vicinity, Cecil County, Maryland, 2010-11

61. Map showing concentrations of dissolved sulfate in water-quality samples collected from selected surface waters and from selected wells completed in the upper Patapsco aquifer shallow water-bearing zone in the Pearce Creek Dredge Material Containment Area (DMCA) and vicinity, Cecil County, Maryland, 2010-11 ....101

62. Map showing predominant reduction-oxidation conditions and processes associated with selected surface waters and with selected wells completed in the upper Patapsco aquifer shallow water-bearing zone in the Pearce Creek Dredge Material Containment Area (DMCA) and vicinity, Cecil County, Maryland, 2010-11

63. Map showing concentrations of dissolved manganese in water-quality samples collected from selected surface waters and from selected wells completed in the upper Patapsco aquifer shallow water-bearing zone in the Pearce Creek Dredge Material Containment Area (DMCA) and vicinity, Cecil County, Maryland, 2010-11

64. Map showing predominant reduction-oxidation conditions and processes associated with selected surface waters and with selected wells completed in the upper Patapsco aquifer deep water-bearing zone in the Pearce Creek Dredge Material Containment Area (DMCA) and vicinity, Cecil County, Maryland, 2010-11

65. Hydrogeologic section showing concentrations of dissolved sulfate in waterquality samples along line $A-A^{\prime}$ and collected from selected surface waters and from selected wells completed in the perched water-bearing zone, Magothy aquifer, or upper Patapsco aquifer shallow or deep water-bearing zone in the Pearce Creek Dredge Material Containment Area (DMCA) and vicinity, Cecil County, Maryland, 2010-11. 
66. Hydrogeologic section showing the predominant reduction-oxidation conditions and processes along line $A-A^{\prime}$ associated with selected surface waters and with selected wells completed in the perched water-bearing zone, Magothy aquifer, or upper Patapsco aquifer shallow or deep water-bearing zone in the Pearce Creek Dredge Material Containment Area (DMCA) and vicinity, Cecil County,

Maryland, 2010-11

67. Hydrogeologic section showing the predominant reduction-oxidation conditions and processes along line $C-C^{\prime}$ and collected from selected surface waters and selected wells completed in the perched water-bearing zone, Magothy aquifer, or upper Patapsco aquifer shallow or deep water-bearing zone in the Pearce Creek Dredge Material Containment Area (DMCA) and vicinity, Cecil County, Maryland, 2010-11

68. Hydrogeologic section showing the predominant reduction-oxidation conditions and processes along line $B-B^{\prime}$ associated with selected wells completed in the Magothy aquifer or in the upper Patapsco aquifer shallow or deep water-bearing zone in the Pearce Creek Dredge Material Containment Area (DMCA) and vicinity, Cecil County, Maryland, 2010-11.

69. Hydrogeologic section showing the $\mathrm{pH}$ in water-quality samples along line $A-A^{\prime}$ and collected from selected surface waters and from selected wells completed in the perched water-bearing zone, Magothy aquifer, or upper Patapsco aquifer shallow or deep water-bearing zone in the Pearce Creek Dredge Material Containment Area (DMCA) and vicinity, Cecil County, Maryland, 2010-11

70. Hydrogeologic section showing the $\mathrm{pH}$ in water-quality samples along line $C-C^{\prime}$ and collected from selected surface waters and from selected wells completed in the Magothy aquifer or upper Patapsco aquifer shallow or deep water-bearing zone in the Pearce Creek Dredge Material Containment Area (DMCA) and vicinity, Cecil County, Maryland, 2010-11.

71. Hydrogeologic section showing concentrations of dissolved aluminum in waterquality samples along line $A-A^{\prime}$ and collected from selected surface waters and from selected wells completed in the perched water-bearing zone, Magothy aquifer, or upper Patapsco aquifer shallow or deep water-bearing zone in the Pearce Creek Dredge Material Containment Area (DMCA) and vicinity, Cecil County, Maryland, 2010-11....

72. Map showing concentrations of dissolved beryllium in water-quality samples collected from selected surface waters and from selected wells completed in the upper Patapsco aquifer shallow water-bearing zone in the Pearce Creek Dredge Material Containment Area (DMCA) and vicinity, Cecil County, Maryland, 2010-11.

73. Hydrogeologic section showing concentrations of dissolved beryllium in waterquality samples along line $A-A^{\prime}$ and collected from selected surface waters and from selected wells completed in the Magothy aquifer or upper Patapsco aquifer shallow or deep water-bearing zone in the Pearce Creek Dredge Material Containment Area (DMCA) and vicinity, Cecil County, Maryland, 2010-11

74. Map showing concentrations of dissolved arsenic in water-quality samples collected from selected surface waters and from selected wells completed in the upper Patapsco aquifer shallow water-bearing zone in the Pearce Creek Dredge Material Containment Area (DMCA) and vicinity, Cecil County, Maryland, 2010-11 ....118

75. Map showing the number of pesticides detected with low-level analytical methods in water-quality samples collected from selected surface waters and from survey wells completed in the perched water-bearing zone or Magothy aquifer in the Pearce Creek Dredge Material Containment Area (DMCA) and vicinity, Cecil County, Maryland, 2010-11. 
76. Hydrogeologic section showing the number of pesticides detected with low-level analytical methods in water-quality samples along line $A-A^{\prime}$ and collected from survey wells completed in the Magothy aquifer or upper Patapsco aquifer shallow or deep water-bearing zone in the Pearce Creek Dredge Material Containment Area (DMCA) and vicinity, Cecil County, Maryland, 2010-11

77. Hydrogeologic section showing the number of pesticides detected with low-level methods in water-quality samples along line $B-B^{\prime}$ and collected from survey wells completed in the Magothy aquifer in the Pearce Creek Dredge Material Containment Area (DMCA) and vicnity, Cecil County, Maryland, 2010-11

78. Map showing the number of pesticides detected with low-level analytical methods in water-quality samples collected from selected surface waters and from survey wells completed in the upper Patapsco aquifer shallow water-bearing zone in the Pearce Creek Dredge Material Containment Area (DMCA) and vicinity, Cecil County, Maryland, 2010-11

79. Map showing the number of wastewater compounds detected in water-quality samples collected from selected surface waters and from survey wells completed in the perched groundwater zone or Magothy aquifer in the Pearce Creek Dredge Material Containment Area (DMCA) and vicinity, Cecil County, Maryland, 2010-11 ....130

80. Map showing the number of wastewater compounds detected in water-quality samples collected from selected surface waters and from survey wells completed in the upper Patapsco aquifer shallow water-bearing zone in the Pearce Creek Dredge Material Containment Area (DMCA) and vicinity, Cecil County, Maryland, 2010-11

81. Hydrogeologic section showing the number of wastewater compounds detected in water-quality samples along line $A-A^{\prime}$ and collected from selected surface waters and from selected wells completed in the perched water-bearing zone, Magothy aquifer, or upper Patpsco aquifer shallow or deep water-bearing zone in the Pearce Creek Dredge Material Containment Area (DMCA) and vicinity, Cecil County, Maryland, 2010-11

82. Map showing net acidity in water-quality samples from selected surface waters and from selected wells completed in the perched water-bearing zone or Magothy aquifer in the Pearce Creek Dredge Material Containment Area (DMCA) and vicinity, Cecil County, Maryland, 2010-11.

83. Map showing net acidity in water-quality samples from selected surface waters and from selected wells completed in the upper Patapsco aquifer shallow waterbearing zone in the Pearce Creek Dredge Material Containment Area (DMCA) and vicinity, Cecil County, Maryland, 2010-11.

84. Hydrogeologic section showing net acidity in water-quality samples along line $A-A^{\prime}$ from selected surface waters and from selected wells completed in the perched water-bearing zone, Magothy aquifer, or upper Patapsco aquifer shallow or deep watering-bearing zone in the Pearce Creek Dredge Material Containment Area (DMCA) and vicinity, Cecil County, Maryland, 2010-11

85. Hydrogeologic section showing the net acidity in water-quality samples along line $C-C^{\prime}$ from selected surface waters and from selected wells completed in the perched water-bearing zone, Magothy aquifer, or upper Patapsco aquifer shallow or deep watering-bearing zone in the Pearce Creek Dredge Material Containment Area (DMCA) and vicinity, Cecil County, Maryland, 2010-11

86. Hydrogeologic section showing the net acidity in water-quality samples along line $B-B^{\prime}$ and from selected wells completed in the Magothy aquifer or upper Patapsco aquifer shallow or deep watering-bearing zone in the Pearce Creek Dredge Material Containment Area (DMCA) and vicinity, Cecil County, Maryland, 2010-11. 


\section{Tables}

1. Stability criteria used for water-quality parameters during water-quality sampling in the Pearce Creek Dredge Material Containment Area and vicinity, 2010-11

2. Contamination bias: Summary of evaluation of field-blank quality-control data for water-quality samples collected in the Pearce Creek Dredge Material Containment Area and vicinity, 2010-11....

3. Measurement precision: Summary statistics for the relative differences in measurements between duplicate samples, by constituent types, obtained from the analyses of sequential groundwater samples collected in the Pearce Creek Dredge Material Containment Area and vicinity, 2010

4. Matrix bias: Summary statistics for the recovery of pesticides on the basis of U.S. Geological Survey Organic Chemistry Research Laboratory low-level analytical methods and laboratory spikes for groundwater samples collected in the Pearce Creek Dredge Material Containment Area and vicinity, 2010.

5. Summary statistics for spike and surrogate recoveries for selected pesticides and other wastewater compounds in groundwater samples collected in the Pearce Creek Dredge Material Containment Area and vicinity, 2010-11

6. Measurement accuracy: Equivalence mass balance errors for groundwater samples collected in the Pearce Creek Dredge Material Containment Area and vicinity, 2010-11

7. Stratigraphic correlation chart of geologic and hydrogeologic units in the Pearce Creek Dredge Material Containment Area and vicinity ..

8. Summary data on the chemical composition of shallow Chesapeake Bay sediments and pore water from fresh sediment-core samples, 2005-06.

9. Summary data on chemical composition of sediments in and underlying the Pearce Creek Dredge Material Containment Area from sediment-core samples obtained from selected boreholes, 1995-96.

10. Summary data on chemical composition of sediments in the vicinity of the Pearce Creek Dredge Material Containment Area from sediment-core samples obtained from selected boreholes, 1995-96.

11. Wells in the Pearce Creek Dredge Material Containment Area and vicinity in which water levels were measured during the May 2010, August 2010, and March 2011 synoptic assessments to delineate the potentiometric surface in three aquifers

12. Chemical characteristics of natural water and water affected by residential activities in the surficial aquifer of the Delmarva Peninsula...

13. Available groundwater-quality data that do not appear to be overly affected by any land use in the Magothy and upper Patapsco aquifers in the Pearce Creek Dredge Material Containment Area and vicinity

14. Terminal electron acceptor classification criteria for redox categories and processes, and related reduction reactions, assigned on the basis of water-quality data obtained from groundwater samples collected in the Pearce Creek Dredge Material Containment Area and vicinity, 2010-11

15. Classification of redox categories and processes assigned on the basis of waterquality data obtained from groundwater and surface-water samples collected in the Pearce Creek Dredge Material Containment Area and vicinity, 2010-11

16. Summary of pesticides detected with low-level analytical methods in groundwater and surface-water samples collected in the Pearce Creek Dredge Material 
17. Characteristics and summary of detections of organic wastewater compounds associated with groundwater samples collected from selected wells in the Pearce Creek Dredge Material Containment Area (DMCA) and vicinity, 2010

18. Summary of water-quality constituents with concentrations exceeding 2009 U.S. Environmental Protection Agency Safe Drinking Water Act standards for at least one groundwater or surface-water site in the Pearce Creek Dredge Material Containment Area and vicinity, Maryland, 2010-11.....

19. Reduction-oxidation conditions and processes and Federal Safe Drinking Water Act exceedances for domestic groundwater supplies in the Pearce Creek Dredge Material Containment Area and vicinity, 2010-11

\section{Conversion Factors and Datums}

\begin{tabular}{lcl}
\multicolumn{1}{l}{ Inch/Pound to SI } & \multicolumn{1}{c}{ Multiply } & \multicolumn{1}{c}{ To obtain } \\
\hline & Length & \\
\hline inch (in.) & 2.54 & centimeter $(\mathrm{cm})$ \\
inch (in.) & 25.4 & millimeter $(\mathrm{mm})$ \\
foot (ft) & 0.3048 & meter $(\mathrm{m})$ \\
mile (mi) & 1.609 & kilometer $(\mathrm{km})$ \\
\hline & Area & \\
\hline acre & 4,047 & square meter $\left(\mathrm{m}^{2}\right)$ \\
\hline & Volume & \\
\hline gallon (gal) & 3.785 & liter $(\mathrm{L})$ \\
cubic yard (yd $\left.{ }^{3}\right)$ & 0.7646 & cubic meter $\left(\mathrm{m}^{3}\right)$ \\
\hline & Flow rate & \\
\hline gallon per minute (gal/min) & 0.06309 & liter per second $(\mathrm{L} / \mathrm{s})$ \\
million gallons per day (Mgal/d) & 0.04381 & cubic meter per second $\left(\mathrm{m}^{3} / \mathrm{s}\right)$ \\
inch per year (in/yr) & 25.4 & millimeter per year $(\mathrm{mm} / \mathrm{yr})$ \\
\hline
\end{tabular}

Temperature in degrees Celsius $\left({ }^{\circ} \mathrm{C}\right)$ may be converted to degrees Fahrenheit $\left({ }^{\circ} \mathrm{F}\right)$ as follows:

${ }^{\circ} \mathrm{F}=\left(1.8 x^{\circ} \mathrm{C}\right)+32$

Vertical coordinate information is referenced to the North American Vertical Datum of 1988 (NAVD 88).

Horizontal coordinate information is referenced to the North American Datum of 1983 (NAD 83).

Altitude, as used in this report, refers to distance above the vertical datum.

Specific conductance is given in microsiemens per centimeter at 25 degrees Celsius $\left(\mu \mathrm{S} / \mathrm{cm}\right.$ at $\left.25^{\circ} \mathrm{C}\right)$.

Concentrations of chemical constituents in water are given either in milligrams per liter (mg/L) or micrograms per liter ( $\mu \mathrm{g} / \mathrm{L})$. 


\section{Abbreviations and Acronyms}

$\begin{array}{ll}\text { BQS } & \text { Branch of Quality Systems of the U.S. Geological Survey } \\ \text { BVE } & \text { Bay View Estates residential community } \\ \text { C\&D Canal } & \text { Chesapeake and Delaware Canal } \\ \text { DMCA } & \text { Dredge Material Containment Area } \\ \text { DOC } & \text { dissolved organic carbon } \\ \text { HAL } & \text { health advisory level } \\ \text { LRL } & \text { laboratory reporting level } \\ \text { MB } & \text { mass balance } \\ \text { MCL } & \text { maximum contaminant level } \\ \text { MES } & \text { Maryland Environmental Service } \\ \text { MPMV } & \text { most probable median value } \\ \text { NAVD 88 } & \text { North American Vertical Datum of 1988 } \\ \text { NFM } & \text { National Field Manual of the U.S. Geological Survey } \\ \text { NGVD 29 } & \text { National Geodetic Vertical Datum of 1929 } \\ \text { NTRU } & \text { nephelometric turbidity ratio units } \\ \text { NWIS } & \text { National Water Information System } \\ \text { NWQL } & \text { National Water Ouality Laboratory of the U.S. Geological Survey } \\ \text { OGRL } & \text { Organic Geochemistry Research Laboratory of the U.S. Geological Survey } \\ \text { PAH } & \text { polyaromatic hydrocarbon } \\ \text { OC } & \text { quality control } \\ \text { RSD } & \text { relative sample difference } \\ \text { SC } & \text { specific conductance } \\ \text { SDWA } & \text { Federal Safe Drinking Water Act } \\ \text { SDWR } & \text { Secondary Drinking Water Regulations } \\ \text { SRS } & \text { standard reference sample } \\ \text { SSSPD } & \text { submersible, stainless-steel, positive-displacement pump } \\ \text { TDS } & \text { total dissolved solids } \\ \text { TEAP } & \text { terminal electron acceptor process } \\ \text { UPA } & \text { upper Patapsco aquifer } \\ \text { USACE } & \text { U.S. Army Corps of Engineers } \\ \text { USEPA } & \text { U.S. Environmental Protection Agency } \\ \text { USGS } & \text { U.S. Geological Survey } \\ \text { WSC } & \text { Water Science Center of the U.S. Geological Survey } \\ \text { WVS } & \text { West View Shores residential community } \\ & \end{array}$




\title{
Hydrogeologic Framework, Hydrology, and Water Quality in the Pearce Creek Dredge Material Containment Area and Vicinity, Cecil County, Maryland, 2010-11
}

\author{
By Cheryl A. Dieter, Michael T. Koterba, Otto S. Zapecza, Charles W. Walker, and Donald E. Rice
}

\section{Abstract}

In 2009, to support an evaluation of the feasibility of reopening the Pearce Creek Dredge Material Containment Area (DMCA) in Cecil County, Maryland, for dredge-spoil disposal, the U.S. Geological Survey (USGS) began to implement a comprehensive study designed to improve the understanding of the hydrogeologic framework, hydrology, and water quality of shallow aquifers underlying the DMCA and adjacent communities, to determine whether or not the DMCA affected groundwater quality, and to assess whether or not groundwater samples contained chemical constituents at levels greater than maximum allowable or recommended levels established by the U.S. Environmental Protection Agency Safe Drinking Water Act.

The study, conducted in 2010-11 by USGS in cooperation with the U.S. Army Corps of Engineers, included installation of observation wells in areas where data gaps led earlier studies to be inconclusive. The data from new wells and existing monitoring locations were interpreted and show the DMCA influences the groundwater flow and quality. Groundwater flow in the two primary aquifers used for local supplies - the Magothy aquifer and upper Patapsco aquifer (shallow water-bearing zone) - is radially outward from the DMCA toward discharge areas, including West View Shores, the Elk River, and Pearce Creek Lake. In addition to horizontal flow outward from the DMCA, vertical gradients primarily are downward in most of the study area, and upward near the Elk River on the north side of the DMCA property, and the western part of West View Shores. Integrating groundwater geochemistry data in the analysis, the influence of the DMCA is not only a source of elevated concentrations of dissolved solids but also a geochemical driver of redox processes that enhances the mobilization and transport of redox-sensitive metals and nutrients. Groundwater affected by the DMCA is in the Magothy aquifer and upper Patapsco aquifer (shallow water-bearing zone). Based on minimal data, the water quality in the upper Patapsco aquifer deep water-bearing zone does not seem to have been impacted by the DMCA.

\section{Introduction}

The U.S. Army Corps of Engineers (USACE), Philadelphia District's mission includes managing the water resources of the Delaware River basin. The agency is responsible for maintaining a navigable channel for large ocean-going and smaller vessels along the Chesapeake and Delaware Canal (C\&D Canal) (fig. 1). The C\&D Canal allows shipping vessels to go from the Delaware River to the Chesapeake Bay, and ultimately to the Port of Baltimore, thereby reducing the 300-mi (mile) trip south along the Atlantic Coast of Delaware, Maryland, and Virginia to the mouth of the Chesapeake Bay, and from there north in the bay to the Port of Baltimore. The C\&D Canal became navigable in 1829 , albeit the canal was much narrower than it is today.

To maintain navigability, the C\&D Canal periodically (generally annually or biennially) needs to be dredged, and the dredged material disposed. Dredging and disposal of this dredged material is the responsibility of the USACE. The USACE acquired a total of 996 acres of land, which is referred to in this report as the Pearce Creek Dredge Material Containment Area (DMCA) property, in 1937 as part of new (then) dredging work to deepen the C\&D Canal (T. Kelly, USACE, written commun., 2012). In 1937, perimeter dikes were built around an area of approximately 260 acres, which is referred to in this report as the DMCA (bermed area), and a sluice was constructed that would allow water to leave the bermed area and flow into Pearce Creek. Subsequently, an additional sluice was constructed near the mouth of Pearce Creek, which limited the discharge from Pearce Creek to the Elk River and created what is referred to in this report as Pearce Creek Lake. Dredge materials were placed in the DMCA bermed area at the site in 1937 and 1938, and then again from the 1960s until the last placement of materials in 1993 (T. Kelly, USACE, written commun., 2012). In 1989, the dikes at the DMCA were raised to their current (2010-11) elevation, approximately 35 to $40 \mathrm{ft}$ (feet) relative to the North American Vertical Datum of 1988 (NAVD 88), by bulldozing sediment within the DMCA bermed area to build the higher dikes (T. Kelly, USACE, written commun., 2012). It is estimated that 4.0 million cubic 


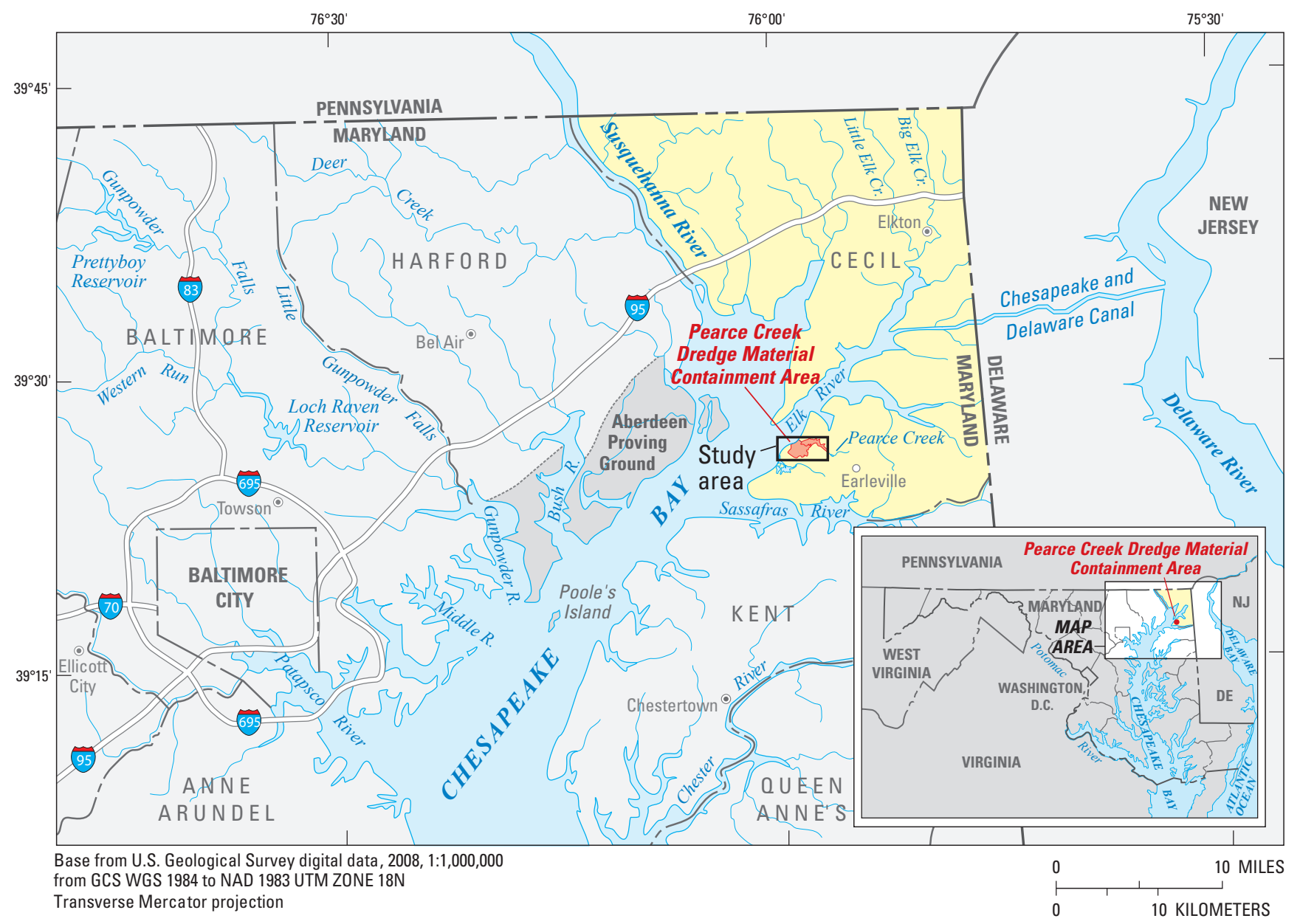

Figure 1. Location of the Pearce Creek Dredge Material Containment Area, Cecil County, Maryland.

yards of material was placed at the DMCA during this time (T. Kelly, USACE, written commun., 2012).

Since 1993, the USACE has placed dredge materials at open-water sites, such as Pooles Island, located $18 \mathrm{mi}$ to the southwest of the DMCA, in the Chesapeake Bay. In preparation for the closure of all open-water disposal sites in the Chesapeake Bay by the State of Maryland on December 31, 2010, the USACE began looking for alternative disposal locations. Pearce Creek DMCA is the preferred option for the USACE because of its available capacity and proximity to the C\&D Canal, which will result in lower dredging, transport, and placement costs than alternatives such as Court House Point or Poplar Island, $7 \mathrm{mi}$ to the northeast and $50 \mathrm{mi}$ to the south of the DMCA, respectively (D. Sirkis, USACE, written commun., 2009).

The USACE asked the U.S. Geological Survey (USGS) to conduct a study of the Pearce Creek DMCA and vicinity (fig. 2), to define the hydrogeologic framework, and to determine groundwater flow directions both laterally and vertically in the shallow groundwater flow system. The USACE also asked the USGS to determine whether or not chemical constituents in groundwater were greater than maximum allowable and (or) recommended U.S. Environmental Protection Agency
(USEPA) Safe Drinking Water Act (SDWA) standards in (1) shallow private domestic wells adjacent to the DMCA, (2) shallow groundwater between the DMCA and Elk River, and (3) shallow groundwater upgradient of the DMCA. The final task was to determine whether or not the DMCA has affected groundwater quality adjacent to the site. In 2010, the USGS began an investigation of the Pearce Creek DMCA and vicinity. The results of the investigation are presented in this report.

\section{Purpose and Scope}

The purpose of this report is twofold: first, to present the results of the USGS study to describe the hydrogeologic framework, hydrology, and quality of groundwater in the USACE Pearce Creek DMCA and vicinity; and second, to assess whether or not the DMCA has affected the quality of groundwater for domestic drinking-water supplies in the vicinity of the DMCA. Understanding the interrelations among the hydrogeologic setting, groundwater flow, and groundwater quality are critical to understanding and illustrating the effect of the DMCA on drinking-water supplies in the study area. Thus, this report includes a description of the hydrogeology, 

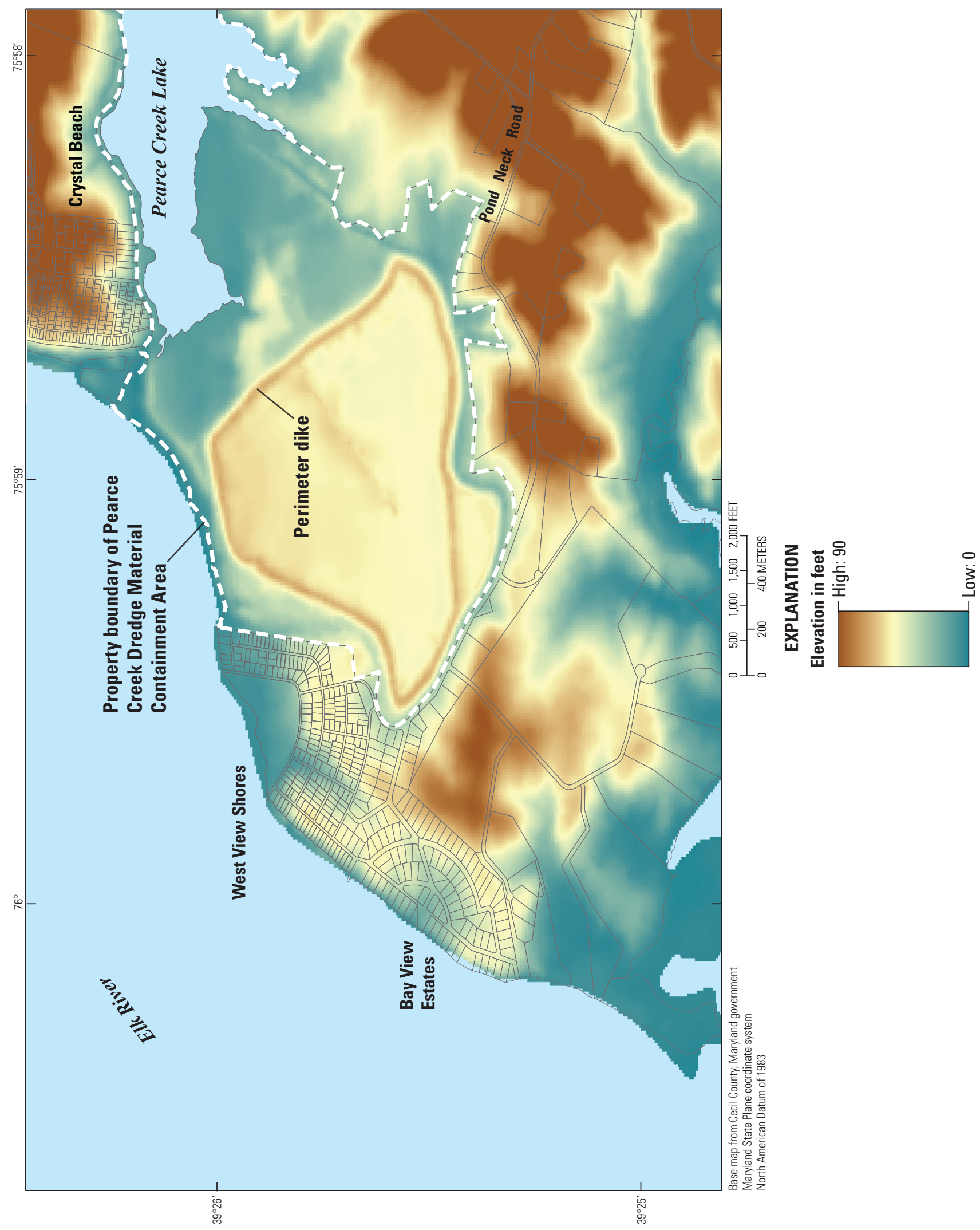

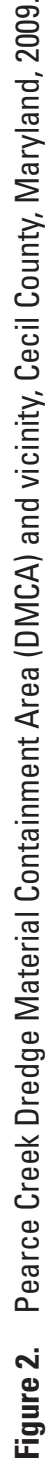


which serves as the framework to describe the groundwater hydrology in the study area. The description of the groundwater hydrology includes a discussion of factors affecting temporal and spatial variations in groundwater levels and patterns in flow in the major water-bearing zones used for groundwater supplies in the study area. In turn, the described patterns in both horizontal and vertical groundwater flow form the basis for a discussion of the general chemistry of groundwater in the study area. The general chemistry of groundwater is developed and described based on surface-water samples and groundwater samples collected from observation and water-supply wells in the study area. The data obtained from these wells documenting groundwater quality also are evaluated to determine if concentrations of chemical constituents are greater than maximum allowable or recommended levels established by the U.S. Environmental Protection Agency Safe Drinking Water Act. The hydrogeologic framework, hydrology, and groundwater quality are then integrated to present the overall interpretation, or understanding, of groundwater sources, flow, and quality in the study area. An "integration of findings" section provides the synopsis of major findings. A set of appendixes provides details of the data-collection methods and the data resulting from the study.

\section{Previous Studies}

Various studies were conducted at the Pearce Creek DMCA in the 1990s after the last dredge materials were placed in 1993. There were concerns by local residents and Maryland State regulators that the DMCA had contributed to poor groundwater quality in the communities surrounding the site.

Maryland Environmental Service (MES) conducted a Phase I study of the local groundwater chiefly on the basis of available data and information for the Maryland Port Administration and the USACE (Maryland Environmental Service, 1995). They compared groundwater-quality data from the local community to groundwater-quality data available for the DMCA, Crystal Beach, and the relevant surficial and confined aquifers in Cecil County, Md. They also compared selected water-quality parameters for groundwater and surface water (for example, Elk River, Pearce Creek Lake outlet, and DMCA effluent). MES (1995) concluded that groundwater in some domestic-supply wells in the West View Shores (WVS) community yielded elevated concentrations of metals (manganese, iron, calcium, sodium, and potassium), sulfate, and chloride. Wells with elevated concentrations of metals, sulfate, and chloride chiefly were completed at elevations of approximately -50 to $-100 \mathrm{ft}$ NAVD 88 . (NAVD 88 is the vertical datum to which altitudes are referenced in this report. Sea level is similar, but not exactly $0 \mathrm{ft}$ NAVD 88.) The concentrations in the wells located in WVS differed from typical existing groundwater concentrations in relation to Crystal Beach and to the relevant aquifers in Cecil County, Md. The MES (1995) also presented evidence that the elevated concentrations appeared related to the oxidation of sulfide-rich sediments. Identification of the source(s) of the elevated concentrations in groundwater and the sulfide-rich sediments were inconclusive. MES (1995) was not able to determine whether elevated concentrations of metals, sulfate, and chloride in groundwater reflected brackish water that intruded from Elk River or Chesapeake Bay, groundwater that flowed from the DMCA, or acidic groundwater from either of the above or other sources that reacted with in-situ sediments. Insufficient data on the hydrogeology, sediment, and groundwater chemistry, as well as groundwater flow in and near the WVS community resulted in the inability to identify the source(s) of the elevated concentrations of metals, sulfate, and chloride in their domestic-supply wells.

As a followup to the MES (1995) report, Black \& Veatch Special Projects Corporation was contracted by the USACE to prepare a work plan and conduct a second Phase I study to determine the groundwater flow system in the Pearce Creek DMCA and collect geochemical data below the Pearce Creek DMCA. The findings were published in Black \& Veatch Special Projects Corp., 1996. The results of Black \&Veatch Special Projects Corp. (1996) were incorporated into a Phase II report by the U.S. Army Corps of Engineers (1996).

The U.S. Army Corps of Engineers, (1996) Phase II study included an analysis of the geology, hydrogeology, soil chemistry, and groundwater quality of the Pearce Creek DMCA and WVS community. The USACE concluded that (a) the Pearce Creek DMCA was not the source of elevated concentrations of metals, sulfate, and chloride because the area beneath the DMCA was underlain by a continuous confining unit, and (b) that the groundwater with elevated concentrations of metals, sulfate, and chloride originated from another source, possibly upgradient of the DMCA, or from intrusion of brackish water from Elk River and Chesapeake Bay (U.S. Army Corps of Engineers, 1996). Thus, the USACE concluded that further use of the Pearce Creek DMCA would not result in future problems for local community water supplies.

An additional review of existing data was conducted by Roy F. Weston, Inc., for the USACE, and the results were published in a final report (R.F. Weston, Inc., 1998). The purpose of that report was to determine the local hydrogeologic framework, potential groundwater flow paths from the Pearce Creek DMCA to domestic-supply wells in WVS, and to use geochemical and statistical methods to identify sources of groundwater recharge in WVS. R.F. Weston, Inc., determined that groundwater flow paths had the potential to allow groundwater to flow from the Pearce Creek DMCA into domestic-supply wells in WVS, but there were insufficient data to determine a definitive pathway. R.F. Weston, Inc., also noted that the geochemistry is complex, and that the source of geochemical signatures in the WVS could be from saltwater intrusion or could reflect regional groundwater flow and quality patterns. R.F. Weston, Inc., concluded that most of their analysis indicates that the Pearce Creek DMCA was not responsible for the degraded groundwater quality in the WVS, that there were insufficient data to determine the source of the poor quality of groundwater, and that possibly a local landfill area or residential plumbing could be contributing to the degraded groundwater quality in this community. 


\section{Description of Study Area}

The Pearce Creek DMCA is located in Cecil County, Md. (fig. 1), on the eastern bank of the Chesapeake Bay near the confluence of the Elk River and the Chesapeake Bay. The site is located on Pond Neck approximately 7 mi west of Cecilton, Md. Several small communities border the Pearce Creek DMCA, including WVS, Bay View Estates, and Crystal Beach (fig. 2).

The climate in the study area is humid with well-defined seasons. The average annual precipitation in the area is approximately 45 inches per year and is relatively evenly distributed throughout the year. The mean tidal range on the Elk River, 8 mi north of the Pearce Creek DMCA, is $2.2 \mathrm{ft}$.

Review of Maryland State well permits indicates development of the WVS community mainly occurred after WWII in the 1940s and 1950s. Initially, numerous wells were installed typically at depths greater than $100 \mathrm{ft}$ below land surface. However, many wells installed as replacement wells in the 1990s and 2000s were installed at shallower depths of less than $70 \mathrm{ft}$. The development of Bay View Estates, which borders the study area to the southwest of WVS, historically was controlled by a single landowner. Consequently, development occurred later and at a slower pace in this community than in WVS.

\section{Well Numbering System}

In this report, wells are identified by their USGS "local site name," such as CE Dd 81, or CE Dd 124. The first two letters, "CE," indicate the county in which the well is located, Cecil County, Md., in this example. The third and fourth letters, "Dd," indicate the 5-minute quadrangle in which the well is located (LaMotte, 2010). The last two or three numbers indicate the order (sequentially) that the well was inventoried in the USGS National Water Information System (NWIS) database. The 5-minute quadrangles are designated by uppercase letters from north to south, and lowercase letters from west to east. Most of the wells in this report are in Cecil County, Md., and they are in the 5-minute quadrangle "Dd." Therefore, for brevity, the wells are sometimes only identified by the last two or three digits, which is the case in this report. Appendix A lists the USGS local site names and other information, such as well depths and screened intervals, for each well discussed in this report. Appendix A also lists the well names used in some of the previous site investigations, in the column titled "USACE well name."

\section{History and Use}

At the time the USACE acquired the property for the DMCA, the site was a groundwater discharge zone with a natural wetland that drained directly into the Elk River, or into Pearce Creek, which in turn naturally flowed into the Elk River (fig. 3). After the USACE acquired the property, the agency created drainage canals and other structures, such as berms and dikes, on the property (fig. 4). The berms and dikes were formed from cut and fill operations, by the agency likely using naturally deposited sediments within the DMCA property boundary (D. Sirkis, USACE, oral commun., 2011). Since the initial purchase of the site for dredge material disposal, the site has undergone many changes. The site is no longer freely draining. Pearce Creek is now a freshwater lake, after a land bridge was created at the mouth of the lake. The level in the lake can be raised or lowered through controlled releases at the lake outlet. Berms have been created at the site, and dredge material has been placed at the site. In addition to the sediment routinely dredged from the canal, a considerable amount of water from the Elk River routinely was mixed with dredged sediment to create slurry that was pumped into the DMCA. The containment area (within the berms) is currently (2012) 260 acres (fig. 5).

\section{Methods of Water-Quality Data Collection and Data Quality}

Water-quality measurements and samples, which provide extensive data on the physical and chemical characteristics of groundwater and major surface waters in the study area (appendix B, table B1), were collected at 36 observation wells distributed throughout the study area, 15 domestic water-supply wells mainly located in WVS and along Pond Neck Road, and two surface-water sites-Elk River and Pearce Creek Lake (fig. 6). The selected wells provide coverage of the three major water-bearing zones - one in the Magothy aquifer and two (one shallow and one deep) in the upper Patapsco aquifer-beneath the DMCA and vicinity; the domestic wells provide an indication of the quality of groundwater obtained by residents mainly from the Magothy Formation and the upper Patapsco Formation outside of the DMCA property boundary (appendix A, table A1).

In relation to the wells chosen for data collection, historical records indicate there initially were many intermediate to deep supply wells in the WVS area, but residents abandoned many of these wells for shallow wells from about 1990 to about 2005. Although residents initially indicated their deep wells still existed and could be used for this study, onsite inspections of a number of these wells found none suitable for use. Logistical reasons (availability of open space and homeowner permission) limited installation of wells in the elevated central part of WVS, which further limited the ability to gather water-quality data from intermediate or greater depths in the area.

Water-quality data and samples also were collected from the two major surface waters in the area (fig. 6). In addition to providing an indication of their current (2010-11) water quality, data from Elk River provides an indication of the quality of water used to dispose of dredged sediments in the DMCA. In addition, water from the DMCA drained into Pearce Creek 


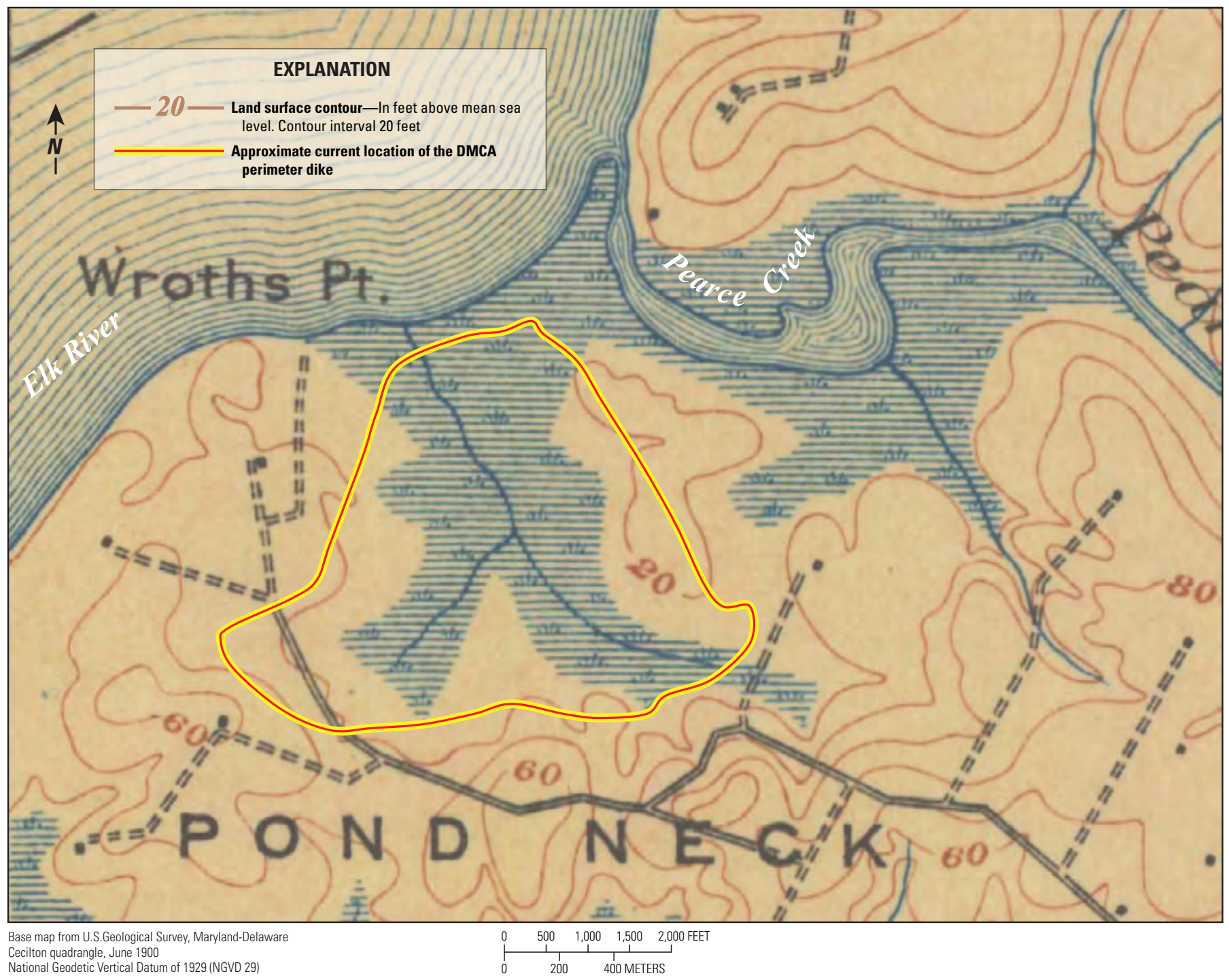

Figure 3. General topography and drainage characteristics of the study area before installation of the Pearce Creek Dredge Material Containment Area (DMCA), Cecil County, Maryland, circa 1890.

Lake; thus, data collection also included obtaining waterquality data and samples at the outlet of Pearce Creek Lake.

Except for wastewater and pesticide compounds, similar water-quality measurements and samples were obtained from all wells and surface-water sites (appendix A, table A1). Data collection for wastewater and pesticide compounds was conducted mainly at selected shallow observation wells in the study area, at all domestic water-supply wells, and at both surface-water sites.

Water-quality data from most observation wells (30 of 35 ) and all supply wells were obtained during April through mid-June, 2010 (appendix B, table B1). Data from five additional monitoring wells (three of which were installed late in 2010), two existing wells, and the two nearby surface-water sites-Elk River and Pearce Creek Lake-were collected from late January through February in 2011. Data collection during both of these periods included quality-control samples and measurements at selected wells and surface-water sites (appendix B, table B2) to help determine the accuracy and comparability of the water-quality data. The collected waterquality and quality-control data have been summarized in a manner consistent with their use to address the objectives of this report (appendix B, tables B3 and B4, respectively).

\section{Data-Collection Methods}

Water-quality data collection at each well or surfacewater site was conducted by two local USGS Water Science Center (WSC) sampling teams - one in Baltimore, Md., and one in Dover, Del. Groundwater data-collection activities performed by either team included (a) purging to remove water that had been standing in a well, (b) flushing wetted equipment during the final stages of purging with groundwater to condition this equipment before final in-field measurements of 


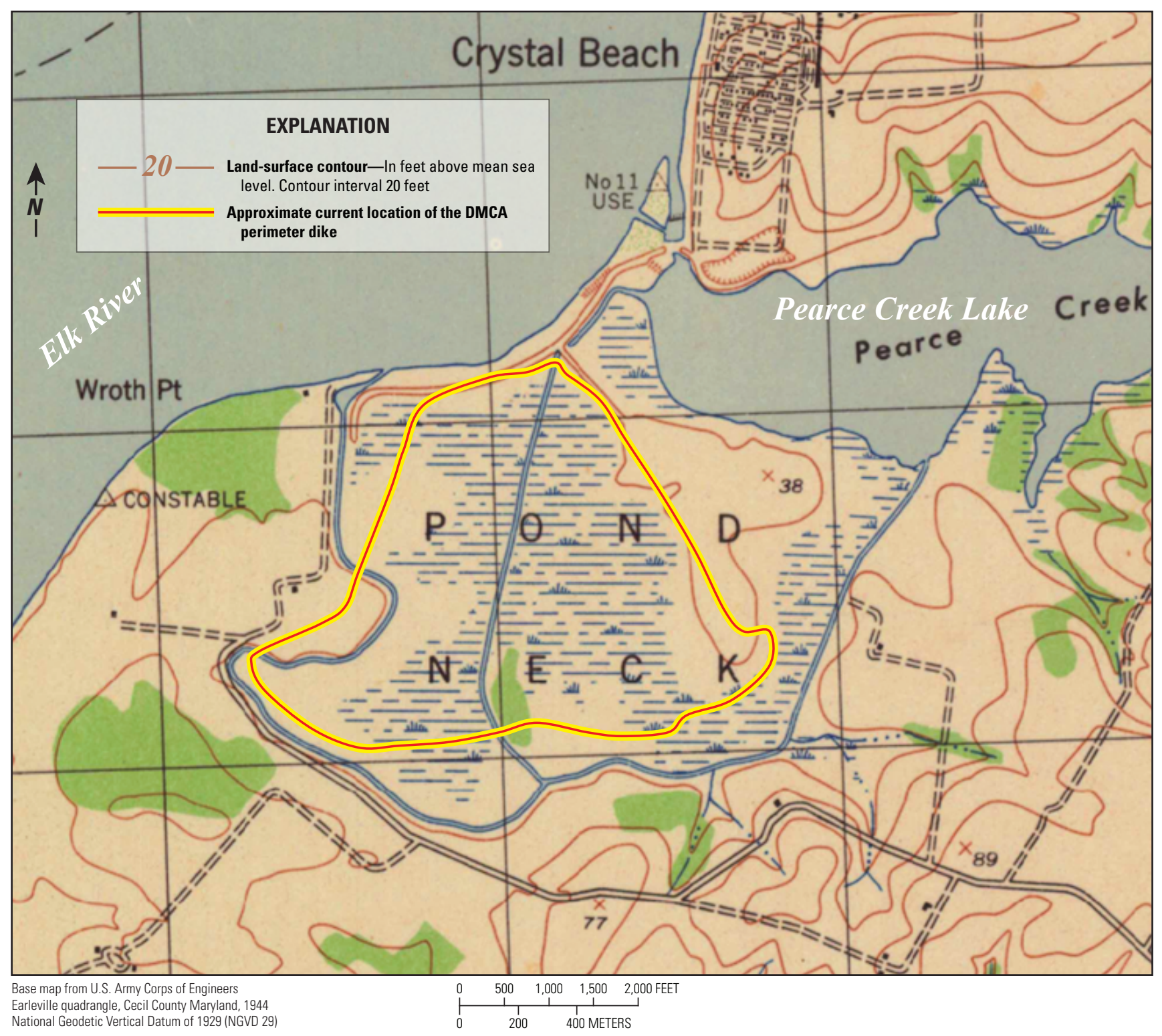

Figure 4. General topography and drainage characteristics of the study area during the installation of the Pearce Creek Dredge Material Containment Area (DMCA), Cecil County, Maryland, circa 1944.

selected water-quality parameters were obtained, and (c) collecting, processing, and, as necessary, preserving, samples until their analyses by the WSC team, or their shipment, by chain of custody, to selected USGS laboratories for analyses.

Data collection at each surface-water site involved the use of equipment and procedures similar to those used to obtain groundwater samples; equipment was conditioned with surface water before final in-field measurements or samples were obtained. In the case of Elk River, the surface-water sample was collected soon after high tide at mid-channel, as a composite of approximately 1.5-liter samples collected at thirteen 3-ft intervals beginning $3 \mathrm{ft}$ below the river surface. Equipment was conditioned with river water at each depth interval before the sample was collected. At the Pearce
Creek Lake outlet, samples were sequentially collected and processed in a manner identical to that used for groundwater samples.

Equipment and methods used for data collection were chosen in accordance with the USGS National Field Manual (NFM; U.S. Geological Survey, variously dated). (Parts of the USGS NFM have been written and revised by many authors over many years as procedures and protocols are refined, and as such the USGS NFM is not referenced by specific authors or publication years.) The methods for data collection were also based on the expected well and groundwater-quality conditions in the study area. Equipment and method selection also was guided by historical studies of groundwater quality conducted in the Pearce Creek study area in the 1990s (Maryland Environmental Service, 1995; U.S. Army Corps of 

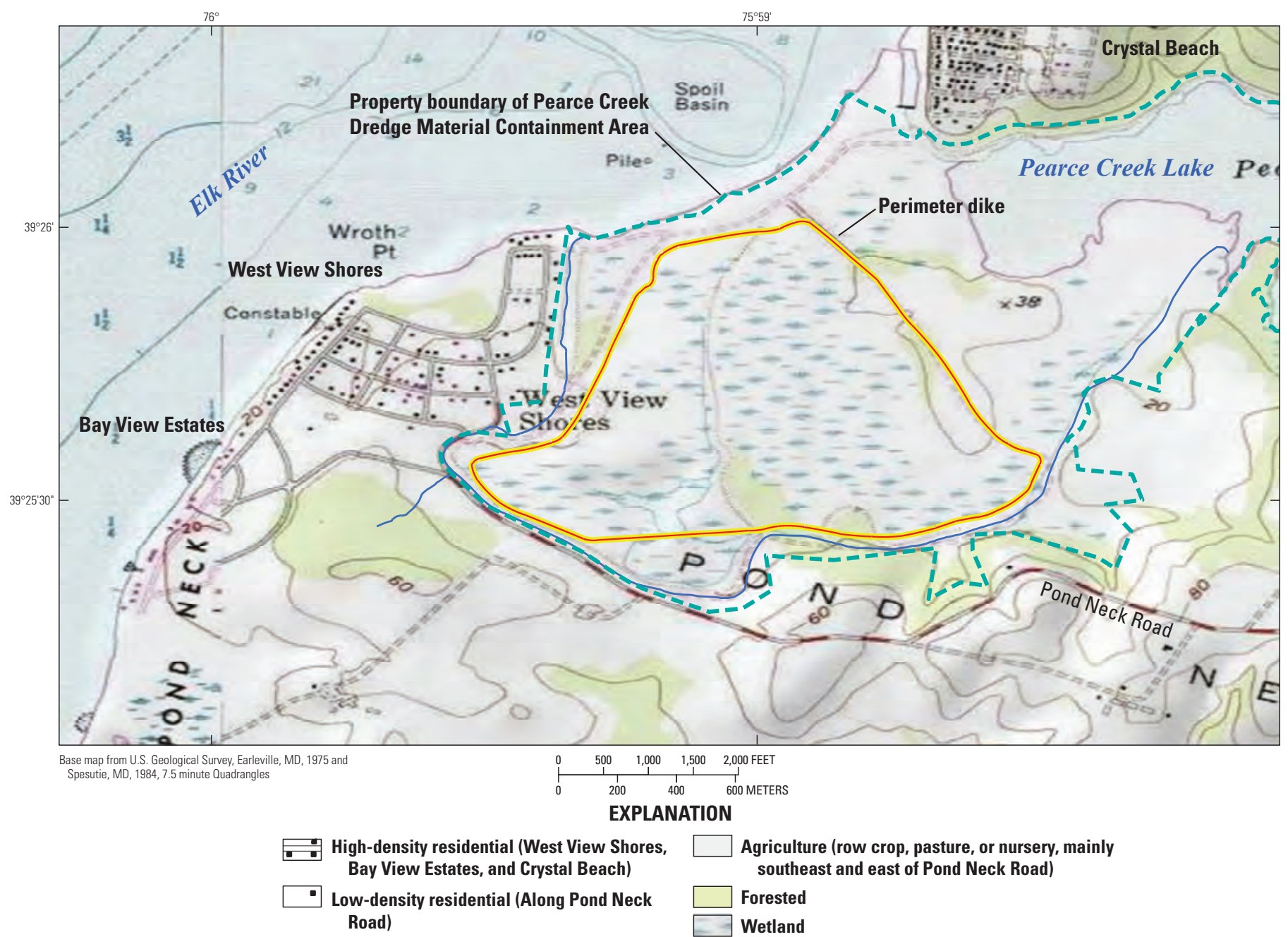

Figure 5. General topography and drainage characteristics of the study area after closure of the Pearce Creek Dredge Material Containment Area, Cecil County, Maryland, circa 1990s.

Engineers, 1996; and R.F. Weston, Inc., 1998), combined with recent (2009-10) site visits by the USGS to obtain geophysical and video logs, and by USACE contractors during the development or redevelopment of selected newly installed or existing monitoring wells. Collectively, these historical studies and site visits indicated that groundwater in the study area could be suboxic [a zone of water, between the oxic and anoxic zones, in which the concentration of oxygen (and sulfur) is very low] to anoxic with elevated concentrations of dissolved solids, including major ions, metals, dissolved organic carbon (DOC), and possibly hydrogen sulfide. Video logs of standing water in wells before and after their development revealed suspended sediments in most wells, which likely consisted of metal hydroxide or oxide precipitates and (or) fine silts or clays. Thus, data-collection equipment and procedures were chosen and employed to (a) ensure wells were adequately purged to remove standing water and suspended sediments, (b) properly condition sampling equipment, (c) obtain accurate in-field water-quality measurements and suitable groundwater samples, and (d) adequately clean reusable equipment onsite, or at the designated cleaning area in the study area, before proceeding to reuse that equipment at the next site.

To adequately prepare each observation well for data collection, purging was conducted in stages with a submersible, stainless-steel, and positive-displacement (SSSPD) pump. During the first stage, purging was conducted with a relatively high pumping rate, approximately $1-3$ gal/min (gallons per minute), given there was no obvious continued decline in the water level in the well. The purpose of this stage of purging was to remove standing water and suspended solids. Purging at this pumping rate was conducted until the equivalent of at least two times the initial volume of water standing in the well casing had been removed, and the turbidity of discharged water declined to 5 NTRU (nephelometric turbidity ratio units) or less. During the next stage, generally high purging rates were decreased to reduce the potential for mixing between groundwater entering and already standing in the well, and to help ensure lateral groundwater flow to the well. Purging was 


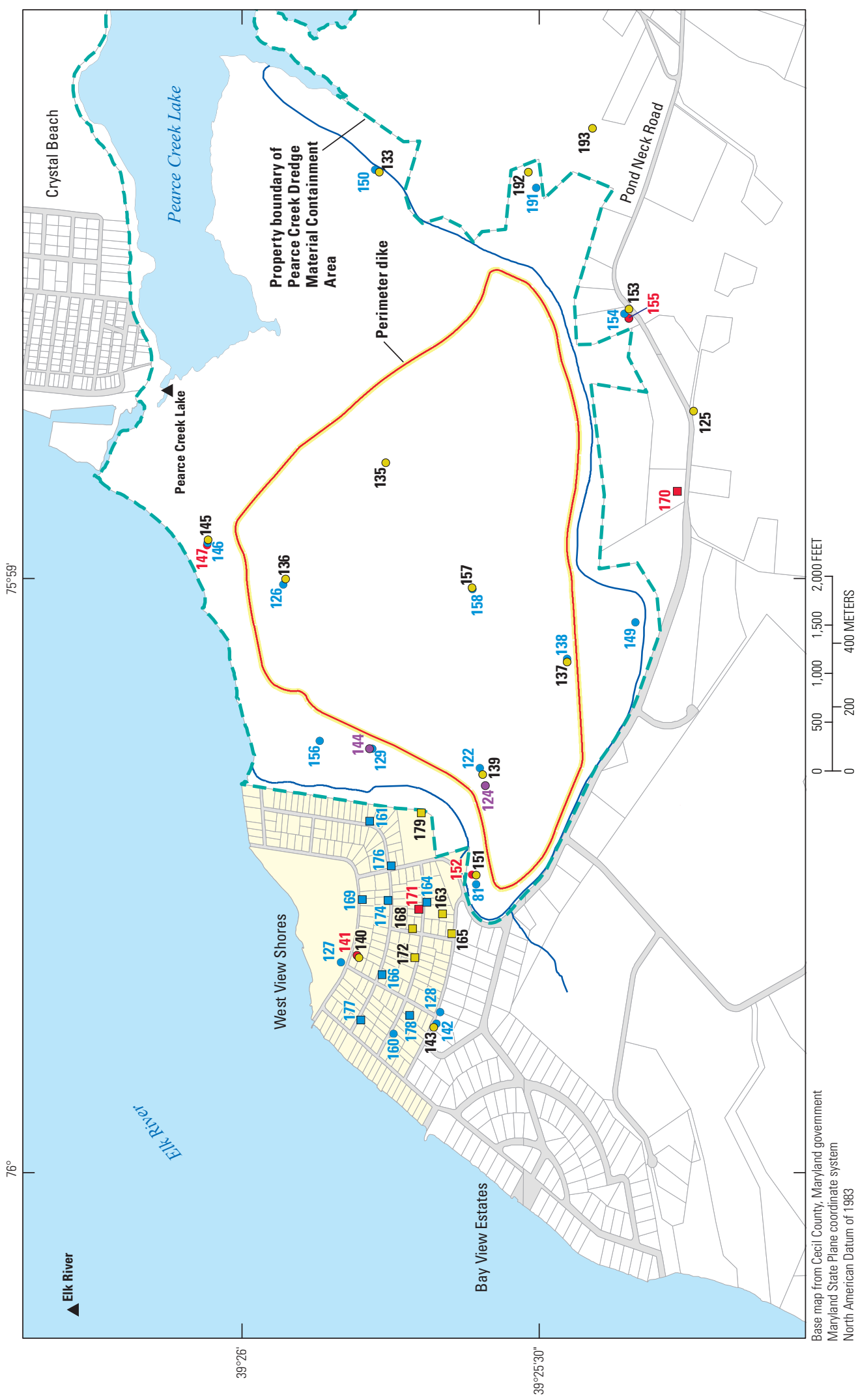

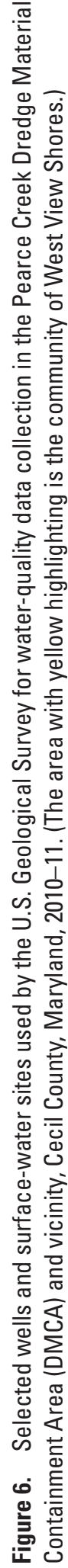


then continued until at least a third volume of standing water was removed from the well, turbidity measurements declined to less than 1 NTRU, water levels were relatively stable, and other selected water-quality purging parameters were stable (table 1).

Equipment used to purge the well and to obtain groundwater for water-quality measurements and samples was selected in accordance with USGS NFM procedures (Lane and others, 2003) with modifications to account for differences in well depth, type, and construction. For shallow monitoring wells with less than $10-15 \mathrm{ft}$ of water standing above the well screen, pumping to purge the well and obtain in-field measurements and samples of groundwater was conducted with a single SSSPD pump fitted with dedicated and cleaned polychlorofluorocarbon-lined polyethylene sample tubing. The pump head was installed within 2 to $3 \mathrm{ft}$ of the top of the well screen, and the pump system was used to purge the well, condition equipment, obtain in-field measurements, and collect groundwater samples. Generally the pumping rate was initially set at 1 to $2 \mathrm{gal} / \mathrm{min}$ or less, but ultimately reset to a low rate of flow (generally a few tenths of a gallon per minute) during the final stage of purging.

Although the above approach was successful at most shallow wells, repeated attempts to use this approach, or other low-flow purging procedures, were unsuccessful at two shallow observation wells (appendix A, table A1, well CE Dd 148 and well CE Dd 159). Despite several attempts by the USACE contractor to develop these wells, recovery rates for these two shallow wells were very low, and recovery water in these wells always was highly turbid and contained high levels of finely sized suspended solids. Recoveries were too low to adequately purge the wells and collect samples representative of groundwater.

For moderate to deep monitoring wells with more than 10 to $15 \mathrm{ft}$ of standing water above the top of the well screen, purging and groundwater data and sample collection were conducted with two SSSPD pumps. A small SSSPD pump similar to that used for shallow monitoring wells was installed to a depth of 2 to $3 \mathrm{ft}$ from the top of the well screen. A large SSSPD then was installed generally 10 to $12 \mathrm{ft}$ above the small pump. The large shallow pump mainly was used to purge and ultimately maintain the upward flow of groundwater into the well. This pump generally was operated at an initially high rate of flow (up to a few gallons per minute) during the initial stage of purging. The pumping rate was then reduced, as needed, to achieve purging requirements during the final stage of purging. The small deep SSSPD pump was started and operated at a low rate of flow (similar to that used for shallow monitoring wells) at the onset of the final stage of purging. Ultimately, the small deep SSSPD pump was used to obtain water-quality measurements and samples.

For domestic water-supply wells, purging, conditioning, and the collection of water-quality measurements and samples were conducted with the existing submersible supply pump in the well. Except for the rate of pumping, the domestic watersupply wells were sampled with the same methodology that was used for the monitoring wells. Groundwater from each supply well was obtained from a standard water spigot. This spigot generally was located on the water-supply distribution line either before or just after the pressurized supply tank, and before any type of water-treatment system. If the spigot was located before the supply tank, a second spigot after the supply tank but before the water-treatment system was used to create continuous and sufficient discharge from the supply tank to keep the well pump running and reduce any backflow from the tank or the water-distribution system beyond the tank. If the spigot was located just after the supply tank, spigot flow generally was split into a dedicated and cleaned polychlorofluorocarbon-lined polyethylene sample line and a waste line. Flows at the spigot and through the waste line then were regulated to continuously drop the pressure in the supply tank to keep the well pump running. In addition, and regardless of where the spigot used for data and sample collection was located, all through and shutoff values associated with the water treatment

Table 1. Stability criteria used for water-quality parameters during water-quality sampling in the Pearce Creek Dredge Material Containment Area and vicinity, 2010-11.

$\left[ \pm\right.$, plus or minus; ${ }^{\circ} \mathrm{C}$, degrees Celsius; $\%$, percent; $\mu \mathrm{S} / \mathrm{cm}$, microsiemens per centimeter at $25{ }^{\circ} \mathrm{C} ;>$, greater than; $<$, less than; mg/L, milligrams per liter; $\mathrm{mV}$, millivolts; NTRU, nephelometric turbidity ratio units]

\begin{tabular}{|c|c|}
\hline Field measurement & $\begin{array}{l}\text { Stability criteria between successive measurements taken at 3- to } \\
\text { 5-minute intervals for at least three intervals }\end{array}$ \\
\hline \multicolumn{2}{|c|}{ Multiparameter sonde, continuous measurements } \\
\hline Temperature (thermistor) & $\pm 0.2{ }^{\circ} \mathrm{C}$ \\
\hline $\mathrm{pH}$ & \pm 0.1 standard unit \\
\hline Specific electrical conductance (SC) & $\pm 3 \%$ for $\mathrm{SC}>100 \mu \mathrm{S} / \mathrm{cm}$ \\
\hline Dissolved-oxygen concentration (polarographic or optical) & $\pm 0.2 \mathrm{mg} / \mathrm{L}$, if $0.5 \mathrm{mg} / \mathrm{L}$ or greater \\
\hline Reduction-oxidation potential & $\pm 20 \mathrm{mV}$ (as data are reported to nearest $10 \mathrm{mV}$ ) \\
\hline \multicolumn{2}{|c|}{ Spectrophotometer, point-in-time measurements } \\
\hline Turbidity (nephelometric) & $\pm 5 \%$ for Turbidity $<100$ NTRU \\
\hline
\end{tabular}


system were closed to prevent backflow through the system to the spigot.

At each monitoring or supply well, in-field measurements of well discharge were obtained at the end of the purging (beginning of sampling) to help characterize the quality of groundwater. Except for turbidity, all measurements were obtained in accordance with the USGS NFM (Gibs and others, 2007), at 5- to 10-minute increments, on well discharge, in an enclosed chamber equipped with a multiparameter sonde fitted with probes for $\mathrm{pH}$, temperature, specific conductance, redox potential, and the concentration of dissolved oxygen (appendix B, table B5). Spectrophotometric measurements of turbidity were obtained in accordance with the USGS NFM (Anderson, 2005), with a turbidity sensor (nephelometric turbidity ratio units), at similar time increments, on grab samples of well discharge (appendix B, tables B2 and B5).

At each monitoring or supply well, samples of groundwater were collected, processed, and preserved in portable chambers with dedicated liners, and in accordance with the USGS NFM (U.S. Geological Survey, 2006), with several modifications to help ensure samples reflected groundwater unaltered by the manner of collection. Regarding samplecollection order, raw-water samples for hydrogen sulfide, net acidity, and acid neutralization capacity were collected first. Filtered samples for dissolved inorganic constituents (trace elements, major ions, and nutrients) and DOC were collected immediately after the raw-water samples, in the order listed, to reduce potential bias in trace-element and major-ion concentrations from potential sediment loading of the filter (Radtke and others, 2002). Samples for dissolved pesticide and then wastewater compounds were collected and filtered after the collection of the DOC sample, using a second filter, and only at selected (mainly shallow) monitoring wells and all domestic water-supply wells.

Filter selection and use followed USGS NFM guidance (Radtke and others, 2002) with some minor modifications in the preconditioning of filters and filtering procedure given groundwater characteristics in the study area. Samples for dissolved inorganic constituents and organic carbon were filtered through a polypropylene encapsulated $0.2-\mu \mathrm{m}$ (micrometer) effective pore size pleated polysulfonyl filter. Before use, this filter was pre-rinsed with USGS WSC laboratory de-ionized $[0.055 \mu \mathrm{S} / \mathrm{cm}$ (microsiemens per centimeter)] activated-carbon filtered water, hereafter referred to as simply USGS WSC laboratory-grade water, and, on the day of use, purged with high-purity, dried nitrogen gas to remove air (oxygen) and excess water from the filter. Samples for dissolved pesticides and wastewater compounds were filtered through a stainlesssteel plate filter containing a $0.70-\mu \mathrm{m}$ effective-pore-size, 142-millimeter-diameter baked, glass fiber, which also was pre-rinsed with USGS National Water Quality Laboratory (NWQL) Pesticide-Volatile Organic Compound grade water.

Additional steps taken to ensure that filtered samples for dissolved constituents reflected groundwater included the following: (a) Sample bottles that required pre-rinsing were each rinsed with USGS WSC laboratory-grade water rather than with groundwater - to avoid the oxidation of the latter and the possible formation of chemical precipitates in the groundwater rinse that could contaminate the sample bottle before the actual sample was collected;

(b) To remove residual rinsate, and to reduce oxidation of the groundwater sample by air before it was entirely collected, all sample bottles were filled with groundwater from the bottom up with a dedicated extension tube and were allowed to overflow before they were capped with little to no head space;

(c) For samples collected with a capsule filter, which contains considerable head space above and below the pleated filter, the capsule was attached to the sample tubing, inverted, and filled from the bottom up to displace the nitrogen gas and fill the entire filter housing. The dedicated extension tube was connected to the outflow stem of the filter, and sample flow discharged through the filter system to condition it before dissolved samples were collected.

For those samples that required chemical preservationdissolved samples for trace elements, major ions, and selected nutrients - the samples were acidified with the appropriate reagent-grade acid to a $\mathrm{pH}$ of 2 or less immediately after filtration. Dissolved samples for nutrients, organic carbon, and pesticides and wastewater compounds, which required physical preservation (chilling to at least $4{ }^{\circ} \mathrm{C}$ (degrees Celsius)), were placed on ice immediately after collection, and maintained and shipped in this state.

Upon completion of sampling at a well site, all nondedicated sample-wetted equipment to be reused at a subsequent well site was initially rinsed and flushed with WSC deionized tap water to remove groundwater. Depending on site conditions, reused equipment was then fully cleaned on site, or at a designated cleaning facility established in the study area. Except for the use of methanol, cleaning was performed in accordance with USGS NFM procedures for groundwater sampling (Wilde, 2004).

At selected monitoring and observation wells, qualitycontrol (QC) samples, including field blanks to assess potential sample contamination, and duplicate sequential groundwater samples to assess measurement precision, were collected for raw and dissolved constituents (appendix B, table B2). Additional duplicate sequential groundwater samples were collected for selected laboratory-analyzed samples, including pesticides or wastewater compounds, for laboratory spikes. Laboratory spikes were performed to assess whether any chemical precipitation [or other degradation] from sample oxidation during shipping or handling of samples in the laboratory reduced the recovery of these compounds. In addition, standard reference samples (SRSs), obtained from the USGS Branch of Quality Systems, Denver, Colorado, were submitted from the field to the NWQL to assess the accuracy of analysis for selected trace elements.

Chemical analysis of raw groundwater and qualitycontrol samples was conducted in the field or local USGS WSC laboratory depending upon the type of sample collected 
(appendix B, table B5). Analyses of samples for hydrogen sulfide were conducted on raw or whole-water samples in accordance with standard methods (appendix B, table B5), by the sampling team immediately, and no more than 5 to 10 minutes after the samples were collected. Analyses of duplicate samples for acid neutralization capacity also were conducted on whole-water samples in the field or the USGS WSC laboratory in Baltimore, Md., on the day of collection and in accordance with the USGS NFM (Rounds, 2006). Except for one modification, the analyses of samples for net acidity also were conducted on whole-water samples acidified to a $\mathrm{pH}$ of $4\left(\mathrm{H}_{2} \mathrm{SO}_{4}\right.$, titrant) within 24 hours of collection and then determined in the field or Baltimore USGS WSC laboratory in accordance with standard methods (appendix B, table B5). The modification was to increase the volume of hydrogen peroxide added to each sample from one-half to several milliliters to help ensure the oxidation of any hydrolyzed metals and DOC.

Samples analyzed by USGS laboratories other than the Baltimore USGS WSC were maintained until shipment, shipped, and then maintained by those laboratories under a formal chain of custody. With few exceptions, the analyses of groundwater and quality-control samples for total dissolved solids, dissolved inorganic constituents, dissolved carbon and 69 wastewater compounds were conducted with standard methods by the USGS NWQL in Denver, Colo. (appendix B, table B5). The exceptions are described below.

Although all samples submitted to USGS laboratories were initially filtered in the field, most samples were treated by these laboratories as whole-water samples. Thus, except for selected anions - ammonia-, nitrate-plus-nitrite-, and nitrite-nitrogen, sulfate, and halides (bromide, chloride, and fluoride) - chemical analyses were performed by the NWQL or USGS Minerals Program Laboratory (arsenic) as if the samples were raw or whole-water rather than dissolved (filtered) samples. As such, raw or whole-water samples were analyzed using standard reference methods that involved the appropriate digestion of the sample, including any suspended solids that formed as a result of sample oxidation (appendix B, table B5). Water-quality samples analyzed by the NWQL for ammonia-, nitrate-plus-nitrite-, and nitrite-nitrogen, sulfate, and halides (bromide, chloride, and fluoride), and for low-level pesticides by the USGS Organic Geochemistry Research Laboratory (OGRL), Lawrence, Kansas, were refiltered in each laboratory to remove any suspended solids in accordance with standard reference methods for the analysis of these compounds. In addition, duplicate sequential groundwater samples were collected at selected wells whose discharge during sample collection had a high specific conductance. These samples were then spiked by the receiving USGS laboratory for low-level pesticides or wastewater compounds immediately after the sample bottles were opened to determine if recoveries of these compounds were reduced by the formation of suspended solids following exposure of the sample to air.

The analysis of selected constituents required recently developed or modified standard reference methods, as follows:
1. The analysis of nitrate-nitrogen, which was conducted by the NWQL, employed a recently developed reductase method to circumvent low bias results for nitrate-nitrogen concentrations in groundwater samples with elevated iron concentrations associated with the standard cadmiumreduction method (Patton and Kryskalla, 2011; and appendix B);

2. The analysis of beryllium, which also was conducted by the NWQL, required the use of a modified standard whole-water recoverable method to reduce sample-matrix interferences (appendix B);

3. The analyses for arsenic were conducted by the USGS Minerals Program Laboratory, Denver, Colo. This analysis also utilized a modified standard whole-water recoverable method to reduce sample-matrix interferences (appendix B); and

4. The analysis of sulfate was conducted through a joint collaborative effort between the NWQL, which employed one standard reference method for most groundwater samples, and the Baltimore USGS WSC, which employed a second standard method, and regression analysis, to estimate sulfate concentrations for selected samples, which could not be analyzed by the NWQL method because of sample-matrix interferences (appendix B).

Analyses for approximately 50 low-level pesticide compounds in groundwater and surface-water samples obtained from selected wells and surface-water sites (appendix B, table B3) were conducted by the USGS OGRL in Lawrence, Kans. All samples were analyzed by the OGRL in accordance with standard recoverable methods for 22 triazine compounds or their metabolites and 32 acetanilide and acetanimide compounds or their metabolites at low levels (generally less than 0.020 or $0.025 \mu \mathrm{g} / \mathrm{L}$ (microgram per liter); appendix B, table B5).

Analyses of wastewater compounds only were conducted on samples obtained from selected wells and surface-water sites (appendix B, table B3), and by the NWQL in accordance with standard recoverable methods (appendix B, table B5). These analyses also included selected pesticides with relatively high laboratory reporting levels (approximately $0.2 \mu \mathrm{g} / \mathrm{L}$ or greater) compared to the OGRL laboratory reporting levels for similar compounds. Hereafter, this analysis or data from this analysis will be referred to as the NWQL highlevel pesticide method or data, respectively.

\section{Data Quality}

The quality of the surface and groundwater data collected in 2010-11 was determined on the basis of quality-control data obtained from field blanks and duplicate sequential groundwater samples, from laboratory recoveries of water-quality samples spiked with pesticides, wastewater, or surrogate compounds (appendix B). Laboratories were also sent SRSs 
marked as site environmental samples, as an additional quality control measure (appendix B). Additional laboratory qualitycontrol data also were obtained, analyzed, and summarized for those constituents whose concentrations were determined with modified analytical methods - nitrate-nitrogen, sulfate, beryllium, and arsenic (appendix B). The purpose of all these evaluations was to assess the quality of the groundwater data collected, and to ensure the data were of sufficient quality to address the purposes of the project and of this report. These data-quality evaluations are described in detail later in this report (appendix B), and are summarized below in relation to contamination bias, measurement precision, sample-matrix bias, and measurement accuracy.

\section{Contamination Bias: Field Blanks}

Inadvertent and routine contamination of water-quality samples during or after their collection can be identified with field blanks (Koterba and others, 1995). A review of fieldblank data collected during 2010-11 (appendix B) has been summarized (table 2). For most of the water-quality data collected in this study, including dissolved solids, major ions, and pesticides, there was no evidence of routine contamination of field blanks, and thus potentially of water-quality samples, during or after their collection. For both years of data collection, and except for occasional trace (detectable) amounts of selected major and minor ions, the concentrations of all groundwater constituents in field-blank samples generally were below the laboratory reporting levels (LRLs). In addition, no pesticide was detected in any field blank. Thus, no appreciable bias due to inadvertent contamination during the collection, processing, preservation, shipping, or analysis of groundwater samples in either year of data collection is evident that would warrant limiting the interpretation of the major ion, nutrient, or pesticide water-quality data.

For five wastewater compounds (1,4-dichlorobenzene, bis(2-ethylhexyl) phthalate, bisphenol A, diethyl phthalate, and phenol), the frequency, magnitude (generally less than $1 \mu \mathrm{g} / \mathrm{L}$ ), and timing of field-blank contamination does appear to correspond to the magnitude and timing of their occurrence in groundwater samples. In addition, triphenyl phosphate was detected in every field blank at concentrations below its LRL, but it was not detected in any water-quality sample. Determination of the source (or sources) of contamination was (were) beyond the scope of this report, but all these compounds are relatively ubiquitous in the environment due to their natural occurrence and (or) many anthropogenic uses. Given the consistency in low-level occurrence of these compounds in most if not all field blanks, with the co-occurrence of these same compounds in groundwater samples collected at similar times as the contaminated blanks, detections of these compounds in the groundwater samples are considered the result of contamination bias. These compounds were excluded from other interpretive analyses in this report, including evaluation of the USEPA SDWA standards.

\section{Measurement Uncertainty: Duplicate Samples}

The absolute relative difference between duplicate sample measurements for a given constituent, expressed in percent, and hereafter referred to as the relative sample difference (RSD) in this report, provides an indication of the general precision in measurement for that constituent. Given no bias in the sample values appeared in relation to their order of collection, the RSD for each constituent and duplicate sample was computed as follows:

$$
\operatorname{RSD}_{\mathrm{i}}=\operatorname{ABS}\left[\left(\mathrm{X}_{2}-\mathrm{X}_{1}\right) /\left(\operatorname{Mean}\left(\mathrm{X}_{1}+\mathrm{X}_{2}\right)\right)\right] * 100
$$

Where

RSD is the relative sample difference for a given constituent $\mathrm{X}$ and the $\mathrm{i}^{\text {th }}$ duplicate pair ( $i=1,2,3$, or 4 ), expressed in percent;

ABS is the absolute value of the entire subsequent calculation;

$\mathrm{X}_{2}-\mathrm{X}_{1} \quad$ is the difference in measurements between first sample collected $\left(\mathrm{X}_{1}\right)$ and the second sample $\left(\mathrm{X}_{2}\right)$ collected sequentially after $\mathrm{X}_{1}$; and

Mean $\left(\mathrm{X}_{2}+\mathrm{X}_{1}\right)$ is used to normalize their difference for comparative purposes.

RSD values were computed in the above manner for four pairs of duplicate sequential groundwater samples, and they were reviewed for each constituent and collectively summarized to reflect groups of constituents (appendix B).

The summary of RSD values obtained from sequential duplicate groundwater samples revealed that precision in measurement differed by constituent group (table 3 ). There were no differences in measurement precision for pesticide data obtained with either the low-level OGRL or high-level NWQL methods. This result reflects that only a few pesticides were detected in groundwater samples, and all detections reflect low-level concentrations above the LRLs for these pesticides. Precision results for total dissolved solids, major ions, and nutrients indicate little to modest variability between measurements from duplicate samples for most constituents. For these constituents, mean or median RSD values were less than 3 percent, and RSD values were generally less than 10 percent (table 3 ). Values in excess of approximately 10 percent corresponded to estimated sample concentrations below the LRLs, which generally have higher than normal uncertainty in their measurement. For trace elements, the uncertainty in measurement increases, with mean and median RSD values ranging from 4 to 10 percent, and individual constituent values as high as approximately 35 percent. RSD values derived from estimated (below LRL) concentrations for trace elements covered a similar range in values. Wastewater compounds had the greatest uncertainty in measurement (table 3). The mean RSD value for these compounds was approximately 20 percent, with individual RSD values as high as 45 percent - excluding two extreme outliers. The high degree of uncertainty in wastewater compound measurement 


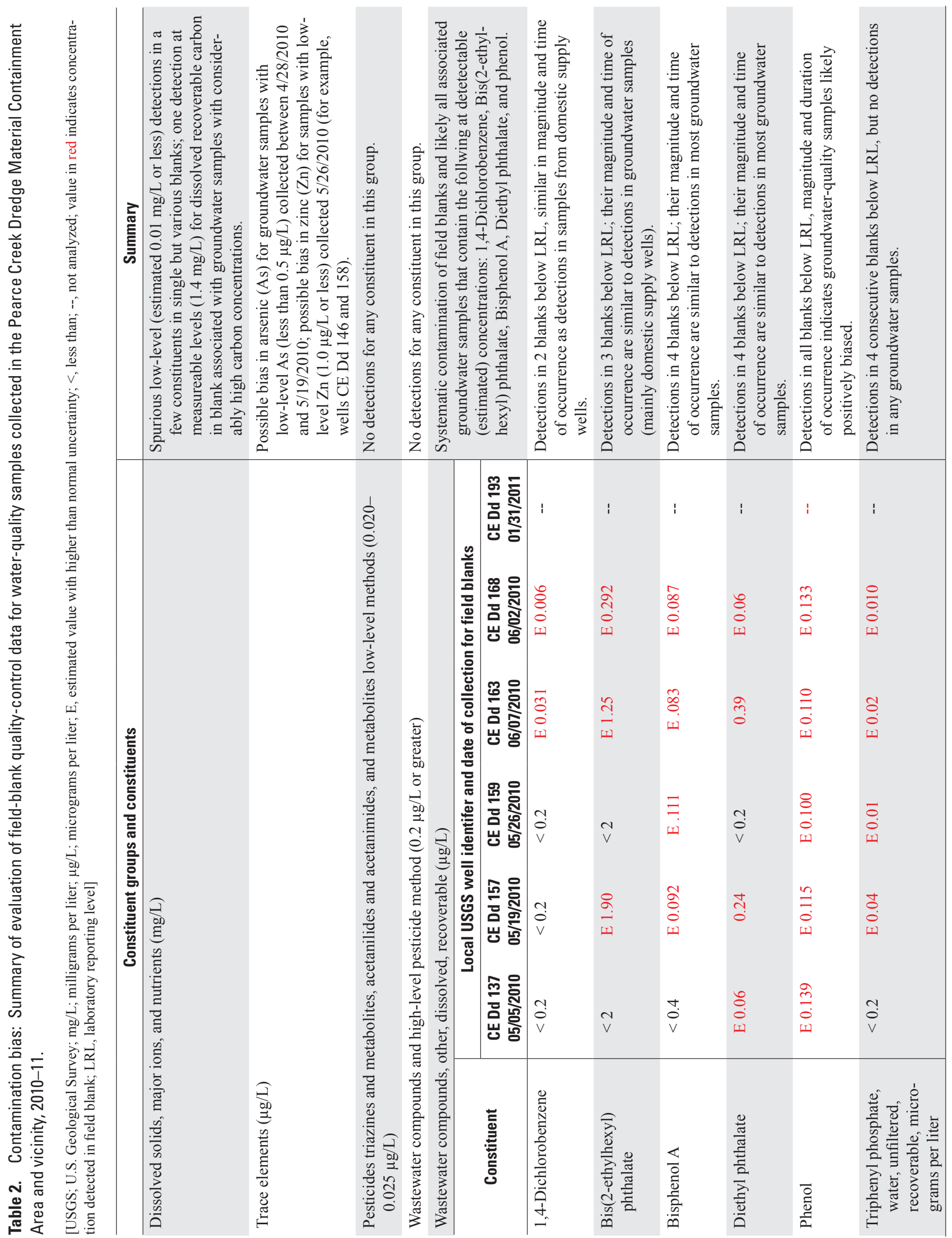


Table 3. Measurement precision: Summary statistics for the relative differences in measurements between duplicate samples, by constituent types, obtained from the analyses of sequential groundwater samples collected in the Pearce Creek Dredge Material Containment Area and vicinity, 2010.

[RSD, relative sample difference; E, estimated relative difference, in percent, determined from duplicate sequential samples, which each had a measureable concentrations below the laboratory reporting level for the constituent; ---, not quantified]

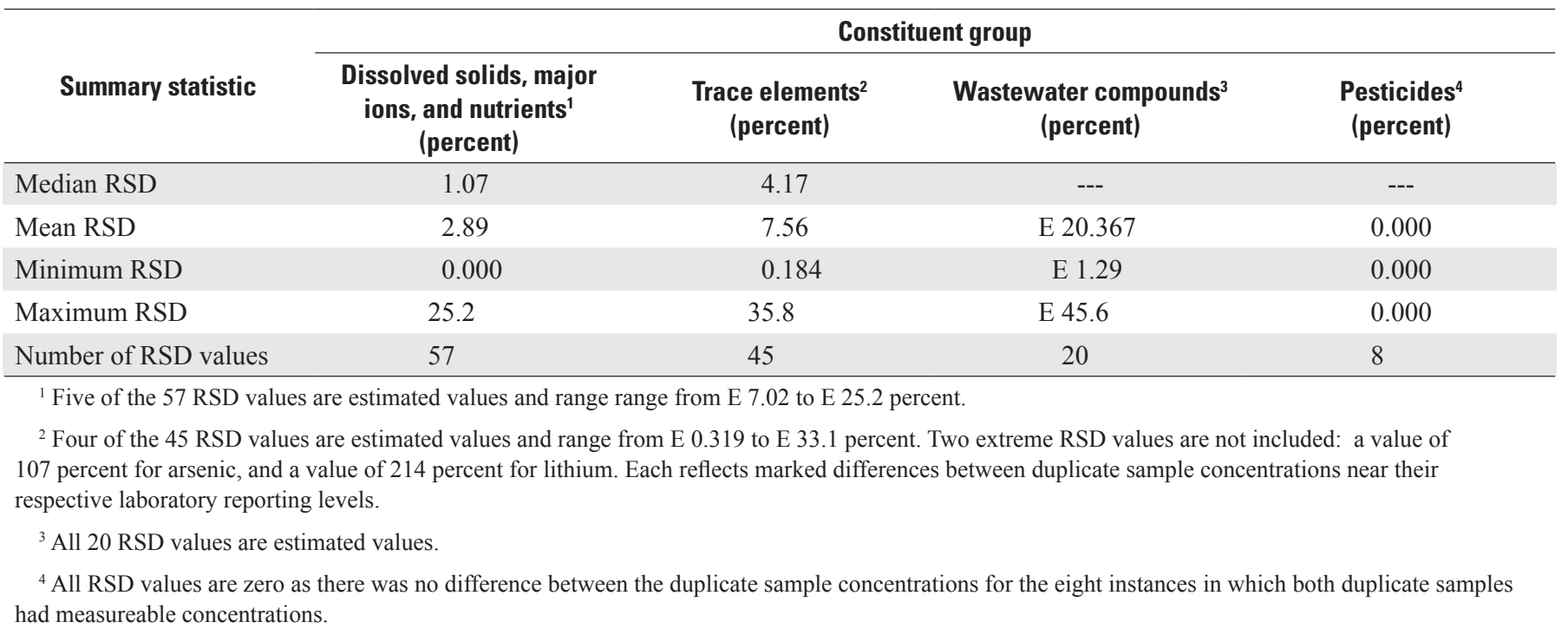

reflects concentrations that generally were below all the LRLs for these constituents.

The differences in measurement precision among constituent groups combined with differences in the frequency with which compounds were detected among constituent groups influenced how the data were interpreted for this report. For those constituents commonly detected and measurable above their LRLs with reasonably good precision-total dissolved solids, major ions, nutrients, and trace elements - the concentration data are used to describe patterns in the occurrence and distribution of these constituents in groundwater. For those constituents infrequently detected and (or) measured with a high degree of uncertainty - namely pesticides and wastewater compounds - simply their detections, either as individual compounds, or relative to grouping detected compounds by their chemical type or use, rather than their concentration, is used to describe simple patterns in the occurrence and distribution of either type of compound in groundwater.

\section{Matrix Bias: Spiked Groundwater Samples}

Given anticipated changes to the sample matrix that could result when suboxic (low dissolved oxygen) or anoxic (no measurable dissolved oxygen) samples were fully exposed to air (oxygen) in the USGS laboratories, it was necessary to determine whether such changes could influence the quality of the data collected. The potential for changes from dissolved to solid forms for redox-sensitive inorganic constituents, including major ions and trace elements, were for the most part addressed through the acidification of samples to a low $\mathrm{pH}$ ( 2 or less). Sample acidification to a $\mathrm{pH}$ of less than 2 proved sufficient to prevent solids from forming in samples for these constituents. In addition, the use of recoverable, rather than dissolved, laboratory analytical methods helped ensure any solids that did form were digested. However, potential changes in the sample matrix could affect the ability to accurately estimate concentrations of selected organic constituents, which were obtained from the analysis of dissolved samples that were not acidified - such as major anions, wastewater compounds, and pesticides. Also, although wastewater compounds and pesticides also were analyzed with recoverable methods, an additional assessment for possible matrix bias was conducted with the duplicate sequential groundwater samples whose collection was described earlier in this report. For pesticide and wastewater compounds, one of the duplicate samples was spiked by the OGRL or NWQL immediately upon opening in the laboratory. Both duplicate samples were then allowed time to oxidize; then they were analyzed with recoverable analytical methods, and the recovery of the spiked constituent was determined in accordance with standard laboratory procedures for spiked samples.

Data on the recoveries of low-level pesticides and wastewater compounds were reviewed with the OGRL and NWQL, respectively, and the results compiled for this report (appendix B). A summary of the recovery data for the OGRL low-level method for pesticides indicates that recoveries were within the normal ranges for most (46 of 53) compounds (table 4). Five compounds - cyanazine acid, deethyl cyanazine, linuron, flufenacet oxanilic acid, and propachlor oxanilic acid - had higher than normal recoveries; two compounds - 2-chloro-N-(2,6-diethylphenyl) acetamide and propachlor(ethane)sulfonic acid-had lower than normal recoveries. All pesticide compounds actually detected in 
Table 4. Matrix bias: Summary statistics for the recovery of pesticides on the basis of U.S. Geological Survey Organic Chemistry Research Laboratory low-level analytical methods and laboratory spikes for groundwater samples collected in the Pearce Creek Dredge Material Containment Area and vicinity, 2010.

[Rose-shaded background indicates compound recovery is greater (or less) than normal with normal (mean) recovery being generally between approximately 75 to 125 percent; Gray-shaded background indicates compounds that were detected in at least one groundwater sample; --, not applicable; <, less than]

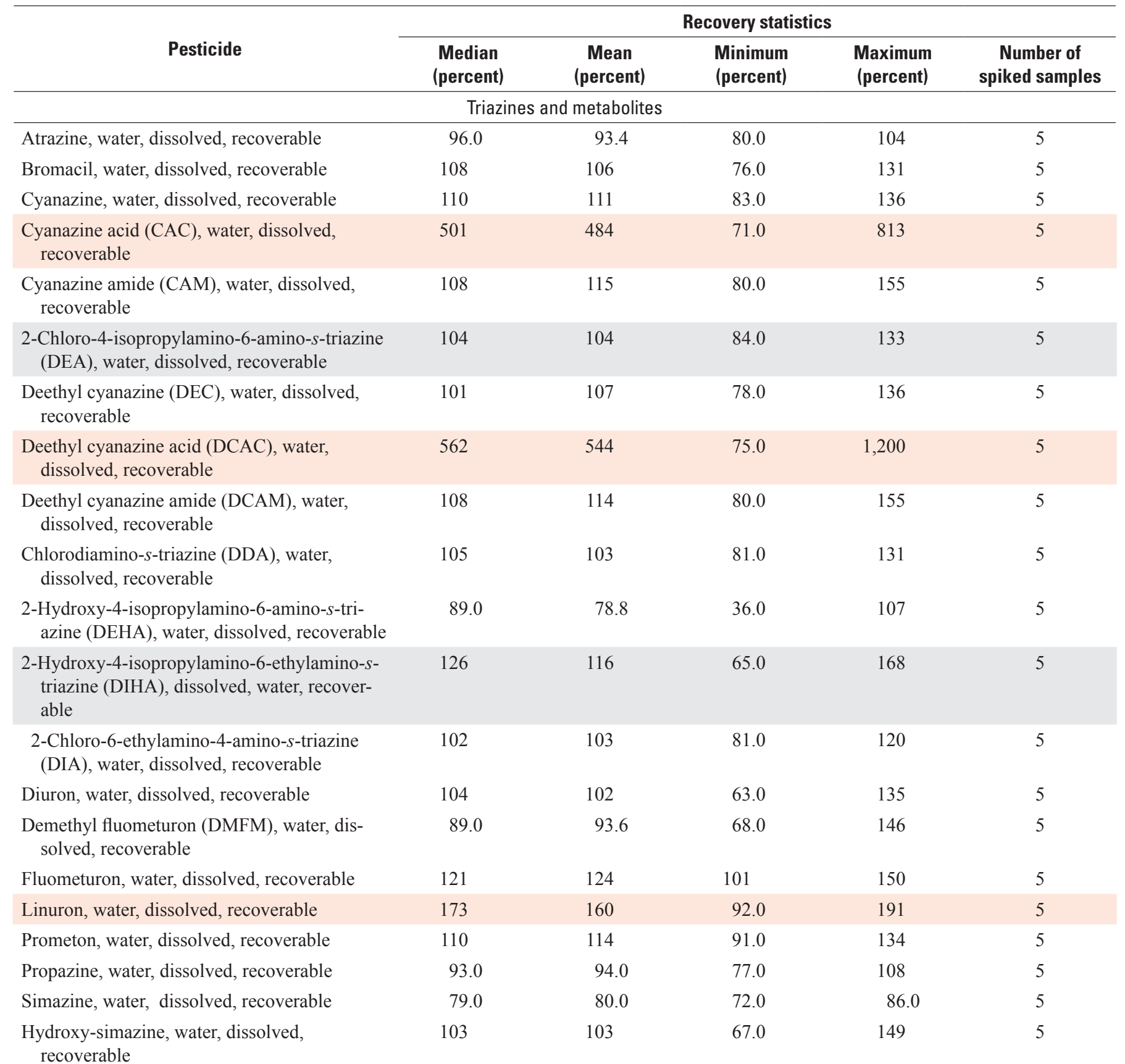


Table 4. Matrix bias: Summary statistics for the recovery of pesticides on the basis of U.S. Geological Survey Organic Chemistry Research Laboratory low-level analytical methods and laboratory spikes for groundwater samples collected in the Pearce Creek Dredge Material Containment Area and vicinity, 2010.-Continued

[Rose-shaded background indicates compound recovery is greater (or less) than normal with normal (mean) recovery being generally between approximately 75 to 125 percent; Gray-shaded background indicates compounds that were detected in at least one groundwater sample; --, not applicable; <, less than]

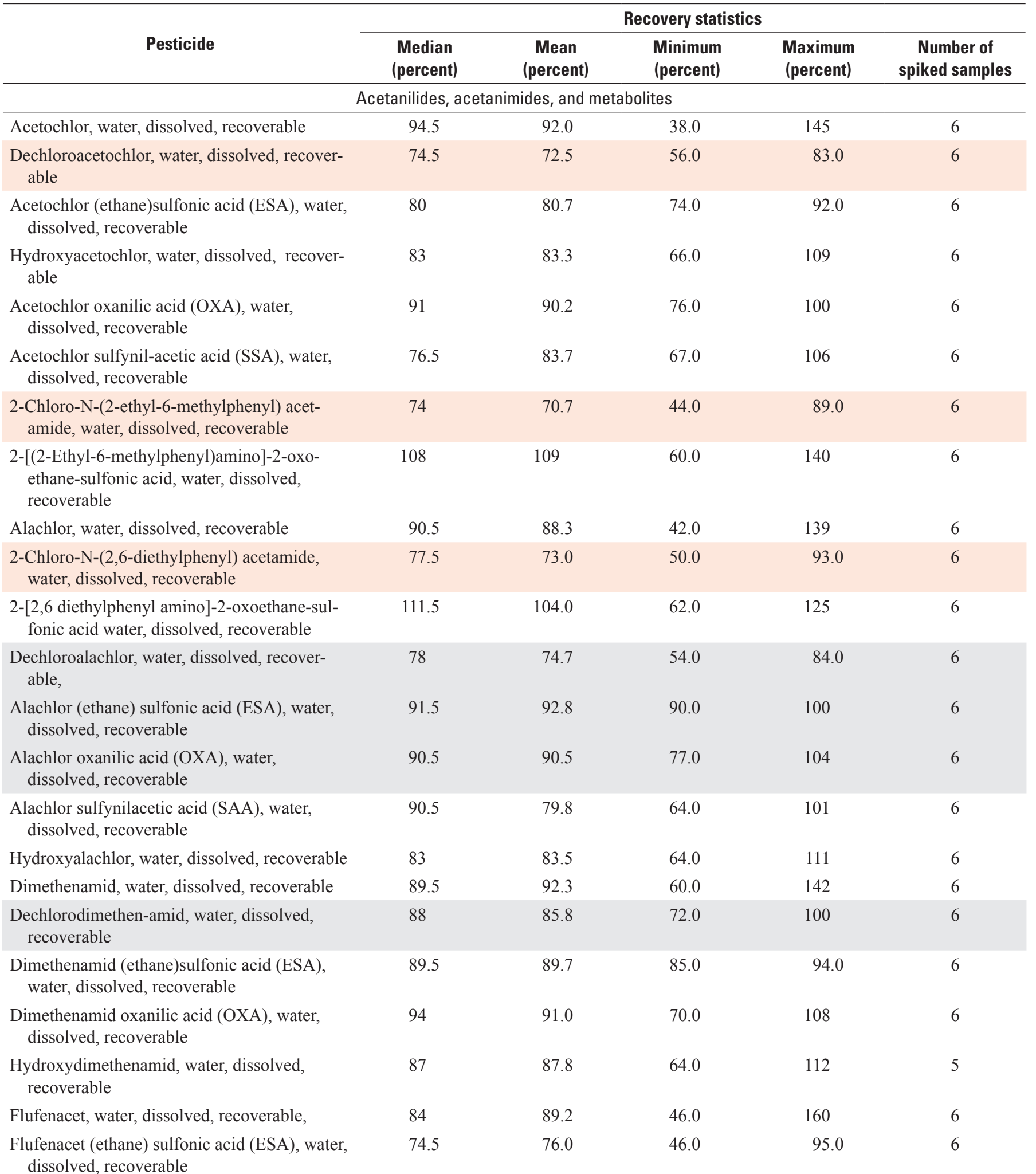


Table 4. Matrix bias: Summary statistics for the recovery of pesticides on the basis of U.S. Geological Survey Organic Chemistry Research Laboratory low-level analytical methods and laboratory spikes for groundwater samples collected in the Pearce Creek Dredge Material Containment Area and vicinity, 2010.-Continued

[Rose-shaded background indicates compound recovery is greater (or less) than normal with normal (mean) recovery being generally between approximately 75 to 125 percent; Gray-shaded background indicates compounds that were detected in at least one groundwater sample; --, not applicable; <, less than]

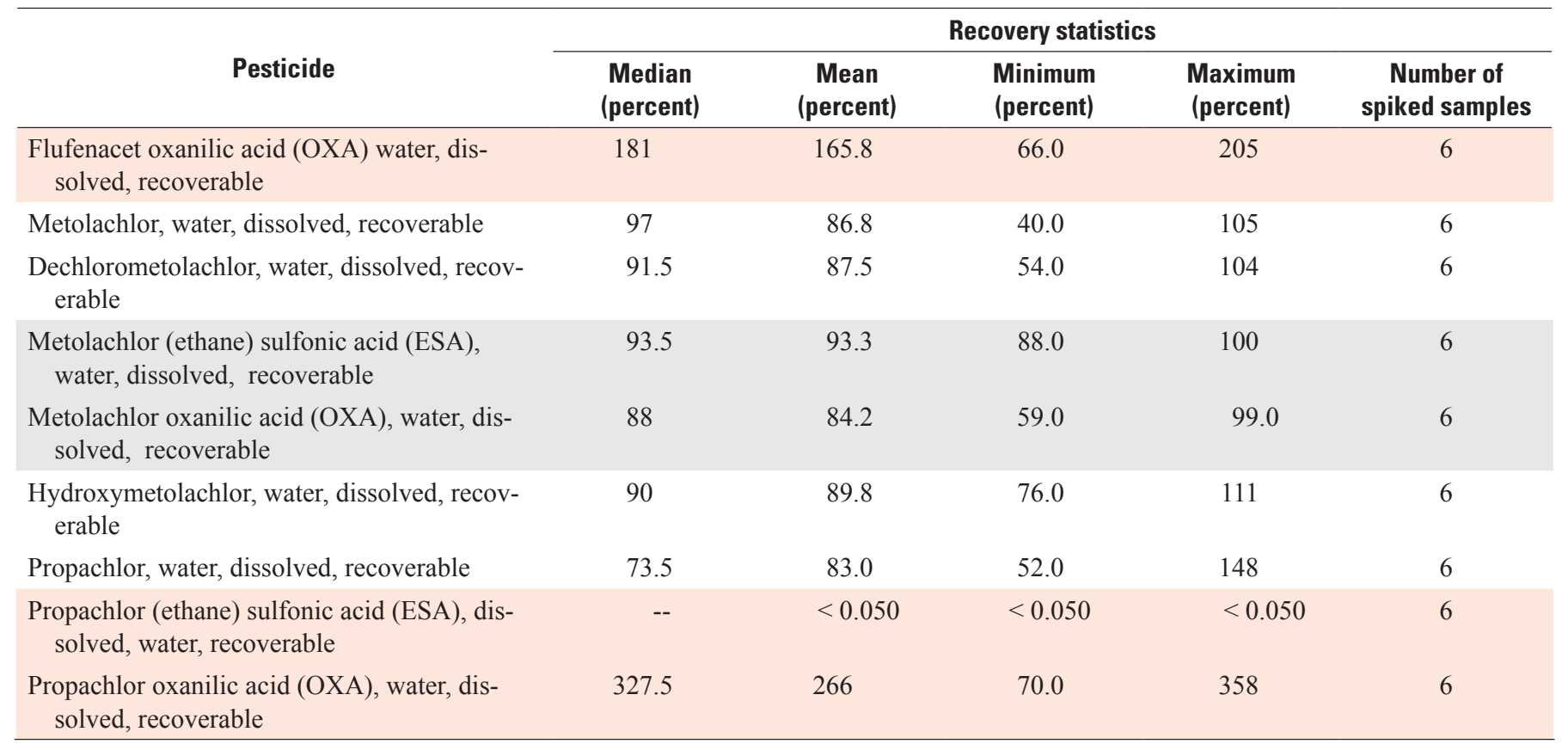

groundwater samples in the study area (table 4) had recoveries within the normal expected range. Therefore, the only limitation in relation to the interpretation of the pesticide data on the basis of detected compounds is that the lower than normal recoveries for 2-chloro-N-(2,6-diethylphenyl) acetamide and propachlor(ethane)sulfonic acid could have limited their detection in groundwater.

The NWQL determined recoveries on wastewater compounds and surrogate wastewater compounds from laboratoryspiked groundwater compounds. Whereas data on spiked groundwater samples for all constituents are limited, surrogate spikes, which involved four surrogate compounds, were used on all groundwater and surface-water samples. A compilation of these data (appendix B, table B8) is summarized (table 5), and, on the basis of a collaborative review with the NWQL, indicates that the pattern in recoveries in groundwater and surface-water samples essentially mimicked the pattern the NWQL observed in recent laboratory spiked reagent and other quality-control blanks. Namely, although recoveries of wastewater compounds generally are low compared to other analyses for trace organic constituents, the recoveries for most wastewater compounds in the spiked groundwater sample were similar to levels the NWQL has observed in other groundwater samples. In addition, wastewater compound surrogate recoveries (mean and range in recovery) from all the groundwater samples analyzed from the study area were similar to, or better than, the recoveries (mean and range in recovery) observed in a similar number of 2010 spiked reagent blanks (D. Damrau, USGS, written commun., 2011).

In relation to recoveries from laboratory spiked groundwater samples, and except for five wastewater compounds, recoveries for all other wastewater compounds from groundwater spiked samples were within acceptable ranges (generally 70 to 130 percent). However, the recovery for 3-beta-coprostanol was quite low (22 percent), and it was not detected in any groundwater sample. In addition, recoveries for four other compounds - beta-sitosterol, beta-stigmastanol, cholesterol, and cotinine - which ranged between 40 to 60 percent, although sufficient to detect each of these compounds in at least some groundwater samples, were considered too low to provide a reliable description of the occurrence of these compounds in groundwater samples in the study area. Thus, even detection data for these five compounds were excluded from interpretive analyses.

Recoveries from laboratory-spiked samples also were used to assess possible matrix bias effects on the analysis of nitrate-plus-nitrite nitrogen, arsenic, and beryllium, each of which was analyzed with modified standard methods. For these modified methods, laboratory-spiked samples included laboratory quality-control and (or) reagent blanks as well as groundwater and surface-water samples. For each method, recoveries from laboratory-spiked samples fell within the normal expected ranges (within approximately 75 to 125 percent of the expected theoretical spiked sample concentration) whether the spiked sample was a water-quality sample, or 
Table 5. Summary statistics for spike and surrogate recoveries for selected pesticides and other wastewater compounds in groundwater samples collected in the Pearce Creek Dredge Material Containment Area and vicinity, 2010-11.

[Recovery, in percent, determined from duplicate sequential samples, one of which was spiked with the actual wastewater compound (or surrogate) by the laboratory before analysis, and one of which was used to correct spiked-sample concentration for concentation of wastewater in sample before it was spiked; E, estimated, recovery with likely higher than normal uncertainty because of low concentrations - below laboratory reporting levels - in both duplicate samples]

\begin{tabular}{|c|c|c|c|c|c|c|c|}
\hline \multicolumn{3}{|c|}{$\begin{array}{l}\text { Recoveries for groundwater samples spiked with } \\
\text { actual wastewater compounds: summarized for all } \\
\text { recoveries for all compounds within the group }\end{array}$} & \multicolumn{5}{|c|}{$\begin{array}{l}\text { Recoveries for each of four laboratory surrogate wastewater compounds: summarized } \\
\text { for all groundwater samples spiked with all four compounds }\end{array}$} \\
\hline $\begin{array}{l}\text { Summary } \\
\text { statistics }\end{array}$ & \multicolumn{2}{|c|}{ Wastewater group } & $\begin{array}{l}\text { Summary } \\
\text { statistics }\end{array}$ & \multicolumn{4}{|c|}{ Wastewater surrogate compound } \\
\hline Mean & 106 & 90.69 & Mean & 100 & 74.8 & 56.6 & 79.7 \\
\hline Minimum & E 84.6 & E 48.00 & Minimum & 40.4 & 24.1 & 24.9 & 36.5 \\
\hline Maximum & E 126 & E 117.0 & Maximum & 147 & 105 & 79.5 & 106 \\
\hline $\begin{array}{l}\text { Number of re- } \\
\text { covery values }\end{array}$ & 11 & 56 & $\begin{array}{l}\text { Number of re- } \\
\text { covery values }\end{array}$ & 29 & 29 & 29 & 29 \\
\hline
\end{tabular}

reagent or other laboratory blank (appendix B). Thus, all data for nitrate-plus-nitrite nitrogen, arsenic, and beryllium were considered unbiased by sample-matrix effects and suitable for interpretation.

\section{Measurement Accuracy: Standard Reference Samples and Ionic Mass Balances}

Standard references samples (SRS), and the calculation of the mass balance (MB), as the sum of major cationic constituents minus sum of major anionic constituents, expressed in percent, for each groundwater and surface-water sample, provide independent checks on the quality of data for selected inorganic constituents (Koterba and others, 1995). Both SRSs and MBs were employed to assess the accuracy of measurements for the inorganic data collected.

The USGS Branch of Quality Service (BQS), Denver, Colo. provided SRSs that were submitted as blind waterquality samples from the field for trace elements (appendix B, table B4). Additional SRS samples also were employed by each of the USGS laboratories for the modified analytical methods for sulfate, arsenic, and beryllium.

Analytical results for the blind BQS SRS samples (appendix B) indicated that except for five trace elements, the concentrations of all other trace elements were within one (pseudo) standard deviation, and often within \pm (plus or minus) 20 percent or less of their most probable (median) value (MPMV) in either of two SRSs. Exceptions included copper, selenium, and uranium in one BQS SRS sample (sample TE-197), and thallium, boron, and selenium in another BQS SRS (sample TE-199). However, the concentrations for these trace elements generally also were acceptable, being within \pm 30 percent and (or) within two times the (pseudo) standard deviation from their MPMVs. For the modified analytical methods, all laboratories provided analytical results for all their internal SRSs (appendix B). The results indicate repeated measurements for all internal SRSs generally fell within standard laboratory acceptance criteria, namely within 80 to 120 percent of the most probable value for a variety of SRSs (appendix B). Thus, on the basis of all SRSs analyses, concentration data for sulfate and trace elements were considered sufficiently accurate for interpretive analyses.

Calculated results for MBs (appendix B, table B11) were reviewed and summarized (table 6). The MB values for groundwater samples indicate a negative bias from the theoretical value of zero and an excess of anions for most groundwater samples. For observation wells, the mean MB is $-5.41 \mathrm{meq} / \mathrm{L}$ (milliequivalents per liter) \pm 35 percent (variance), or in relative terms, approximately -15 percent \pm 30 percent. For domestic water-supply wells the bias is slightly less than that above for supply wells - the mean MB being $-1.26 \mathrm{meq} / \mathrm{L} \pm 2.70$ percent, or approximately -12 percent \pm 24 percent. The MB values for surface waters are similar in magnitude to $\mathrm{MB}$ values for domestic wells (appendix B, table B11).

The causes of the negative bias in the MB values are unknown, but they likely are multiple in nature. The laboratory analyses for most major anions, as well as most cations and trace elements, such as iron, manganese, and aluminum, 
Table 6. Measurement accuracy: Equivalence mass balance errors for groundwater samples collected in the Pearce Creek Dredge Material Containment Area and vicinity, 2010-11.

[meq/L, milliequivalents per liter]

\begin{tabular}{|c|c|c|c|c|c|}
\hline \multirow[b]{2}{*}{ Well type } & \multicolumn{5}{|c|}{ Mass balance error statistics (assuming iron is present as ferrous iron) } \\
\hline & $\begin{array}{l}\text { Mean difference } \\
\text { (meq/L) }\end{array}$ & Variance & $\begin{array}{l}\text { Mean difference } \\
\text { (percent) }\end{array}$ & Variance & Number of samples \\
\hline Domestic & -1.26 & 2.70 & -12.48 & 23.6 & 15 \\
\hline
\end{tabular}

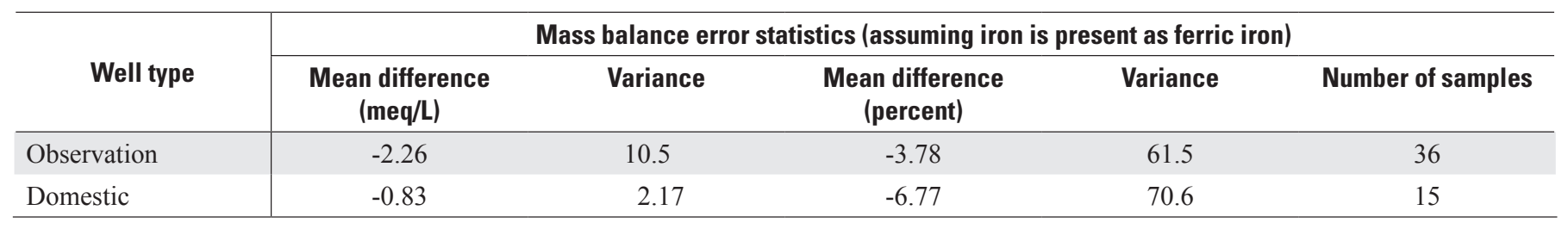

required a range of sample dilution rates be used to reduce sample matrix interferences in the analysis of samples for each constituent. Dilution rates for a given constituent often differed among samples-from as little as 2-fold to as high as 50- or 60-fold. Collectively, this could lead to one or more systematic biases - such as overestimating the concentrations of one or more major anions, or underestimating the concentrations of one or more cations. However, the MB bias also simply could be a function of the assumptions regarding the charge assigned to each cationic and anionic constituent. For example, in the case of iron, as with most other metals, only its concentration was determined. The mean MB error can be reduced assuming iron is present as $\mathrm{Fe}^{3+}$ rather than $\mathrm{Fe}^{2+}$ (table 6), but then variance also increases because the sole use of $\mathrm{Fe}^{3+}$ creates high outlier MB values. In actuality, both ionic forms of iron could be present and their ratios differ in groundwater associated with different well locations. However, determining the individual concentrations of multiple ionic species for major constituents such as iron, aluminum, and manganese, for each groundwater sample was beyond the scope of this report. In addition, the negative bias in MB could be the result of not including other possible cationic constituents in the MB calculation - such as organic acid or silica species associated with the high concentrations of dissolved recoverable organic carbon and dissolved silica $\left(\right.$ as $\left.\mathrm{SiO}_{2}\right)$ found in groundwater in the DMCA and vicinity (appendix B, table B3). Thus, although the MB results do indicate an imbalance in the electroneutrality of samples, it could be erroneous to assume and assign this imbalance solely to errors in laboratory measurements.

\section{Hydrogeologic Framework}

A hydrogeologic framework was developed to delineate the shallow groundwater system underlying the Pearce Creek DMCA and adjacent residential areas for the purpose of defining and understanding the groundwater flow system and water quality of the area. The main focus of the framework was the definition of the lateral and vertical distribution of the aquifers and confining units that ultimately contain and control the local groundwater supply.

\section{Well Network Design}

Previous geologic and hydrogeologic investigations were used to establish a preliminary hydrogeologic framework for the study area. These investigations included hydrogeologic data provided in Phase I and II groundwater investigations (Maryland Environmental Service, 1995; U.S. Army Corps of Engineers, 1996), and data from the following reports: Drummond (2007); Edwards and Hansen (1979); and Mack and Achmad (1986). Additionally, new borehole geophysics data were collected from existing monitoring wells in the study area, and were incorporated with well construction records for nearby domestic wells to refine the preliminary hydrogeologic framework. This framework was then used to delineate three water-bearing units within the top $250 \mathrm{ft}$ of sediments underlying the study area that are being tapped by local water-supply wells.

Findings of the Phase I and II groundwater investigations and subsequent review documents (Maryland Environmental Service, 1995; U.S. Army Corps of Engineers, 1996; R.F. Weston, Inc., 1998) stated the need for an expansion of the existing (prior to this study) 15-well monitoring network for further definition of groundwater flow directions, water chemistry, and the sources of degraded water in area wells. As part of the 2010-11 USGS study, 28 new monitoring wells were installed in the study area. Site selection was based on the need for (1) improved spatial and vertical distribution of geologic framework, water-level and water-quality data, and (2) replacement of 5 of the 15 existing monitoring wells determined to have structural or yield-related problems following video logging and redevelopment. 
The new monitoring wells mainly were installed to create nested well pairs or triplets to determine vertical as well as horizontal changes in the direction of groundwater flow and quality with depth in the targeted water-bearing units (fig. 7). Screen intervals for each well nest were determined by initially drilling and gamma-ray logging a deep borehole at each site. Screen intervals for the deep well and shallow well(s) at each nest were selected on the basis of the interpretation of gamma-ray logs and the lithological nature of core material retrieved for the same interval. Well construction data for existing and newly installed wells has been summarized (appendix A, table A1).

\section{Geologic Setting}

The study area is located in the upper Chesapeake Bay region approximately $12 \mathrm{mi}$ southeast of the Fall Line, which marks the western extent of the Atlantic Coastal Plain physiographic province. Coastal Plain sediments generally are classified as a southeast-dipping wedge of unconsolidated gravel, sand, silt, and clay that range in age from Cretaceous to Holocene. These sediments were deposited in non-marine, deltaic, and marine environments on a bedrock surface composed primarily of crystalline metamorphic and igneous rock of Cambrian and Precambrian age. Coastal Plain sediments in Cecil County range in thickness from a feather edge at the Fall Line, which approximately follows Interstate 95 in Maryland, to more than $1,500 \mathrm{ft}$ in the southeastern part of the county at the Maryland-Delaware border. The depth to crystalline bedrock underlying the Pearce Creek study area has been estimated at $900 \mathrm{ft}$ (Otton and others, 1988).

This study focused on the geologic units or parts of units that relate directly to the aquifers and confining units that comprise the shallow groundwater flow system underlying the DMCA and its vicinity. From oldest to youngest these units include sediments of the Patapsco Formation (the uppermost part of the Potomac Group), the Magothy Formation, and the Merchantville Formation of the Matawan Group, all of Cretaceous age. Overlying these are the Tertiary Pensauken Formation of Pliocene (?) to Miocene (?) age and the surficial deposits of Quaternary age. The stratigraphic relation of geologic and hydrogeologic units on the basis of the interpretation of the hydrogeologic framework and aquifer nomenclature used in this report is shown in table 7.

\section{Aquifers and Confining Units}

Aquifers, water-bearing zones within aquifers, and intervening confining units in the study area are described and delineated on the basis of stratigraphic correlations derived from existing geophysical data combined with collected geophysical data obtained from boreholes during the early stages of this study. The recent geophysical data were obtained from geophysical logs of existing and newly installed wells within the study area (appendix C).
The aquifers and confining units that form the basis for the determination of the groundwater flow system underlying the DMCA and its vicinity are illustrated in a series of structure contour and isopach maps (figs. 8 and 9). These maps along with five related hydrogeologic cross sections (figs. 10-15) show the vertical and horizontal relations among the hydrogeologic units. Structure contours and hydrogeologic-unit delineation were derived from the interpretation of natural gamma-ray logs. Distinctive signatures and patterns on gamma-ray logs provided an objective method to mark aquifer and confining unit boundaries and facilitate stratigraphic correlation of these units.

Gamma-ray logs are graphical plots of the rate of emission of gamma rays emitted by the formations penetrated by the borehole. In general, silt- and clay-bearing sediments show much higher natural gamma activity than do clean quartz sands and carbonates. This is because of the ability of clays to concentrate radioactive elements through ion exchange and adsorption. Feldspars and micas, which readily decompose into clay, also contain small proportions of the gammaemitting radioisotope potassium-40 (Keys and McCary, 1971). Gamma radiation increases to the right on the gamma-ray log. Therefore, relatively higher radioactive sediments, such as silts and clays, cause log deflections toward the right, whereas permeable sediments, such as sand and gravel, generally have low radioactivity and cause log deflections toward the left.

The aquifers described herein include the confined upper Patapsco aquifer where two distinct water-bearing zones, referred to hereafter as the shallow and deep water-bearing zones, are defined, and the shallower Magothy aquifer which functions in conjunction with overlying surficial deposits as either unconfined or confined depending on location. The confining units that are mapped include two within the Patapsco Formation: one that lies between the shallow and deep water-bearing zones of the upper Patapsco aquifer and another that lies between the upper Patapsco aquifer and the overlying Magothy aquifer. Confinement overlying the Magothy aquifer, which can include sediments of the Matawan Group and (or) fill material in the DMCA, forms the uppermost layer described in this framework.

\section{Potomac Group Aquifers}

The Potomac Group, which consists largely of a thick, complexly interbedded sequence of non-marine unconsolidated sand, silt, and clay, is the basal Coastal Plain unit in the study area. As is often characteristic of fluvial sediments, the Potomac Group exhibits great lateral variation, which makes lithostratigraphic correlation beyond a single outcrop or cluster of closely spaced boreholes difficult. In the upper Chesapeake Bay area south of Cecil County, the Potomac Group has been subdivided into three formations (Patuxent, Arundel, and Patapsco) (Higgins and Conant, 1990). The Patuxent and Patapsco are generally mapped as aquifers whereas the Arundel functions as a confining unit. Farther south in Maryland and the middle Eastern Shore, the Patapsco Formation has 


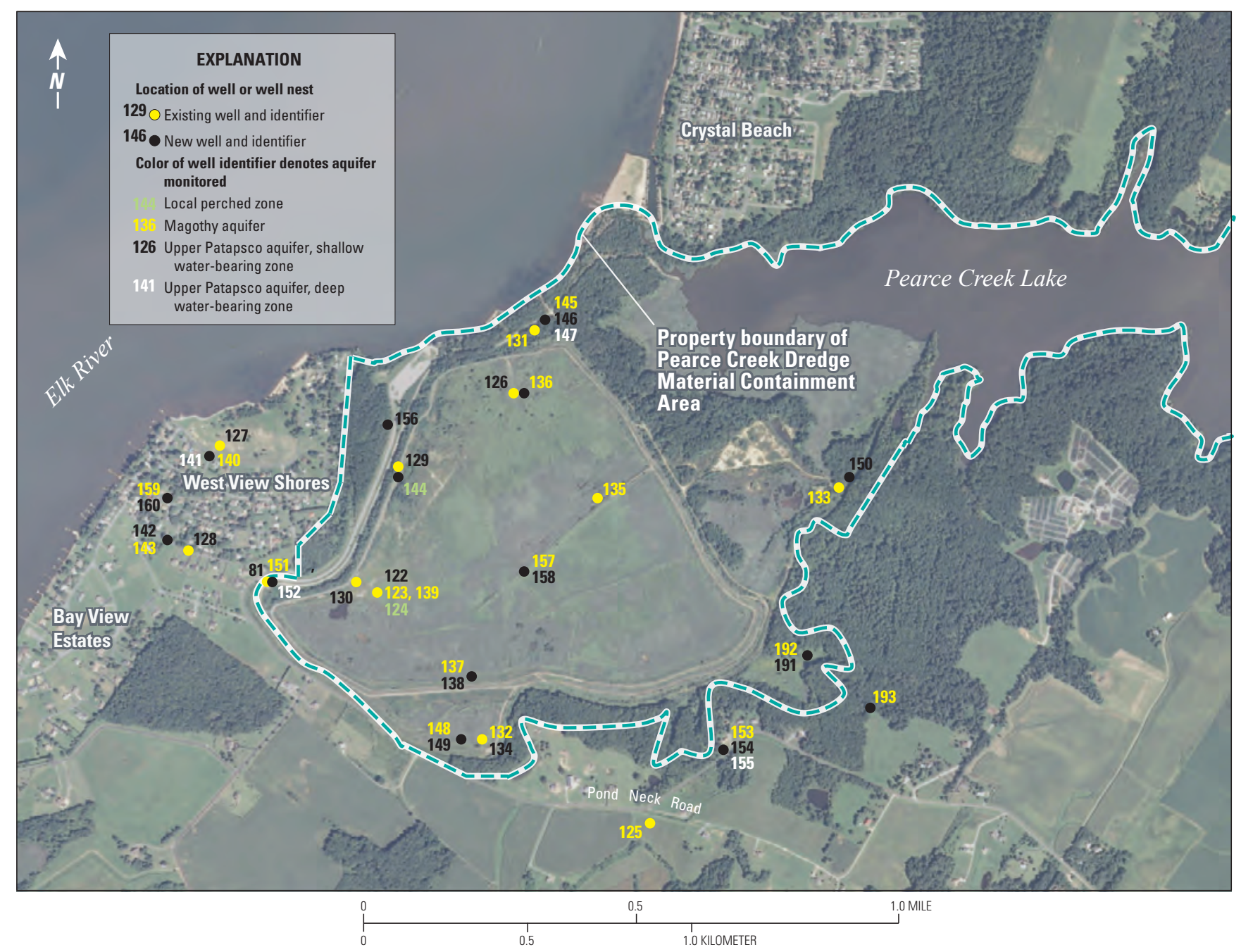

Figure 7. Monitoring well network, Pearce Creek Dredge Material Containment Area (DMCA) and vicinity, Cecil County, Maryland, 2010-11.

been subdivided into the lower Patapsco and upper Patapsco aquifers (Mack and Achmad, 1986; Drummond, 2007).

In Cecil County, the individual formations of the Potomac Group have been difficult to distinguish, particularly in outcrop, and are not differentiated on the geologic map of the county (Higgins and Conant, 1990). Otton and others (1988) in their study of the water resources of Cecil County, use borehole geophysics to broadly divide the Potomac Group into upper and lower Potomac aquifers using natural gamma-ray logs. The water-bearing zones of the upper Patapsco aquifer delineated in this report roughly correspond to permeable units within the upper Potomac aquifer shown in geologic cross sections by Otton and others (1988). Edwards and Hansen (1979) used borehole geophysics and pollen data to differentiate the formations of the Potomac Group in borehole CE Dc 2 near Turkey Point on Elk Neck and borehole CE Ec 17 at Grove Point, which are located approximately 2 mi west and southwest, respectively, of the Pearce Creek DMCA. The units they show as the "Elk Neck beds of the Patapsco Formation" (microfloral zone III) correlate well with the hydrogeologic units of the Patapsco Formation as subdivided for this study (J. Wilson, Maryland Geological Survey, written commun., 2010). Therefore, this report uses the terminology of the upper Patapsco aquifer in the description of hydrogeologic units delineated within the uppermost Potomac Group sediments underlying the study area.

\section{Upper Patapsco Aquifer}

In the study area, the upper Patapsco aquifer is mapped as a multi-layer aquifer system. Two distinct water-bearing zones (shallow and deep) separated by a clay/silt confining unit have been delineated (table 7; figs. 11-15). This multi-layer division is supported by natural gamma-ray log stratigraphy, water-level data, domestic well completion records and waterquality conditions. The high density of data made it possible to correlate these individual units in the study area. The waterbearing zones and confining units exhibit the fluvial nature of 
Table 7. Stratigraphic correlation chart of geologic and hydrogeologic units in the Pearce Creek Dredge Material Containment Area and vicinity.

[Geology from Higgins and Conant, 1990, and Edwards and Hansen, 1979; hydrogeology modified from Otton and others, 1988]

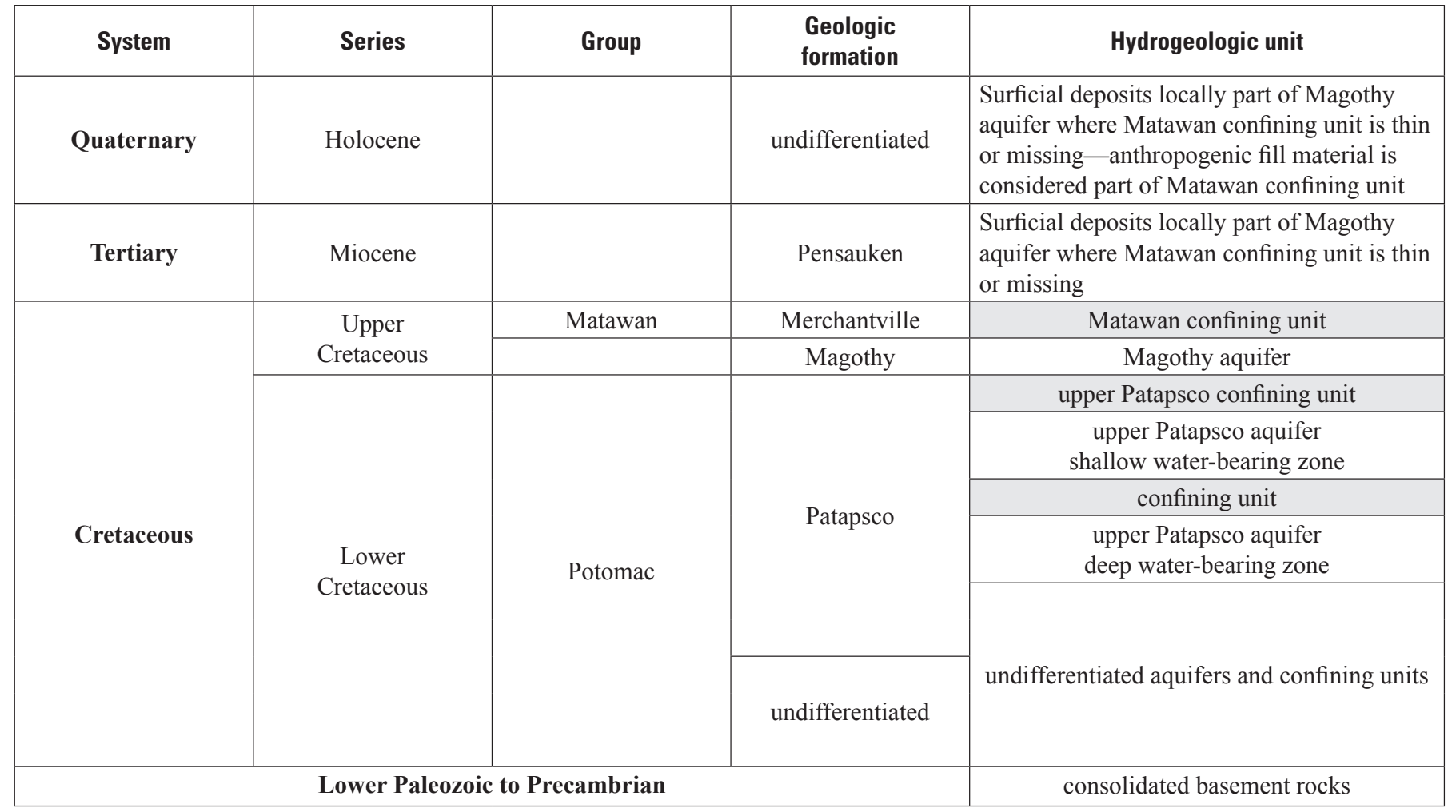

the deposition, which locally includes substantial changes of unit thickness and lithology over short distances, and fewer data points may have prevented the correlation of these units. These changes are characteristic of the riverine deposition of the Patapsco Formation in comparison to the broad sheet-like deposits characteristic of marine and marginal marine deposition of the overlying Magothy and Matawan units. Although the hydrogeologic units of the upper Patapsco Formation can be separated locally, at a regional scale these water-bearing zones could be connected to form a more extensive aquifer system.

\section{Upper Patapsco Aquifer Deep Water-Bearing Zone}

The upper Patapsco aquifer deep water-bearing zone is the deepest hydrogeologic unit penetrated in the study area and provides water for only a small number of homes in residential areas near the DMCA. Of the available well completion reports for the area it is estimated that the upper Patapsco aquifer deep water-bearing zone provides water for less than 8 percent of area wells.

Structure contours on the top of the upper Patapsco aquifer deep water-bearing zone reflect data obtained from seven boreholes (at six locations) that penetrate the top of this unit (fig. 8A). The altitude of the top of the unit ranges from a maximum of approximately $-150 \mathrm{ft}$ just north of the southern boundary of the perimeter dike to $-180 \mathrm{ft}$ NAVD 88 at the edges of the area. The upper Patapsco aquifer deep waterbearing zone ranges in thickness from 40 to $55 \mathrm{ft}$ at three sites where the entire unit was penetrated in the borehole. The predominant lithology based on continuous sediment core is medium to coarse-grained sand, well-sorted, and ranging in color from light tan to brown and gray.

\section{Confining Unit Between the Upper Patapsco Aquifer Shallow and Deep Water-Bearing Zones}

The thickness of this confining unit generally ranges from 40 to $50 \mathrm{ft}$ within the DMCA, increases to more than $80 \mathrm{ft}$ near the Elk River in WVS (West View Shores residential community), and decreases to approximately $25 \mathrm{ft}$ between the aquifers along the southeastern property boundary of the DMCA (fig. 8B). Dominant lithologies of the confining unit are gray to dark gray clay and silty clay, often with reddish mottling, with lignite and thin fine-grained sand lenses present. 

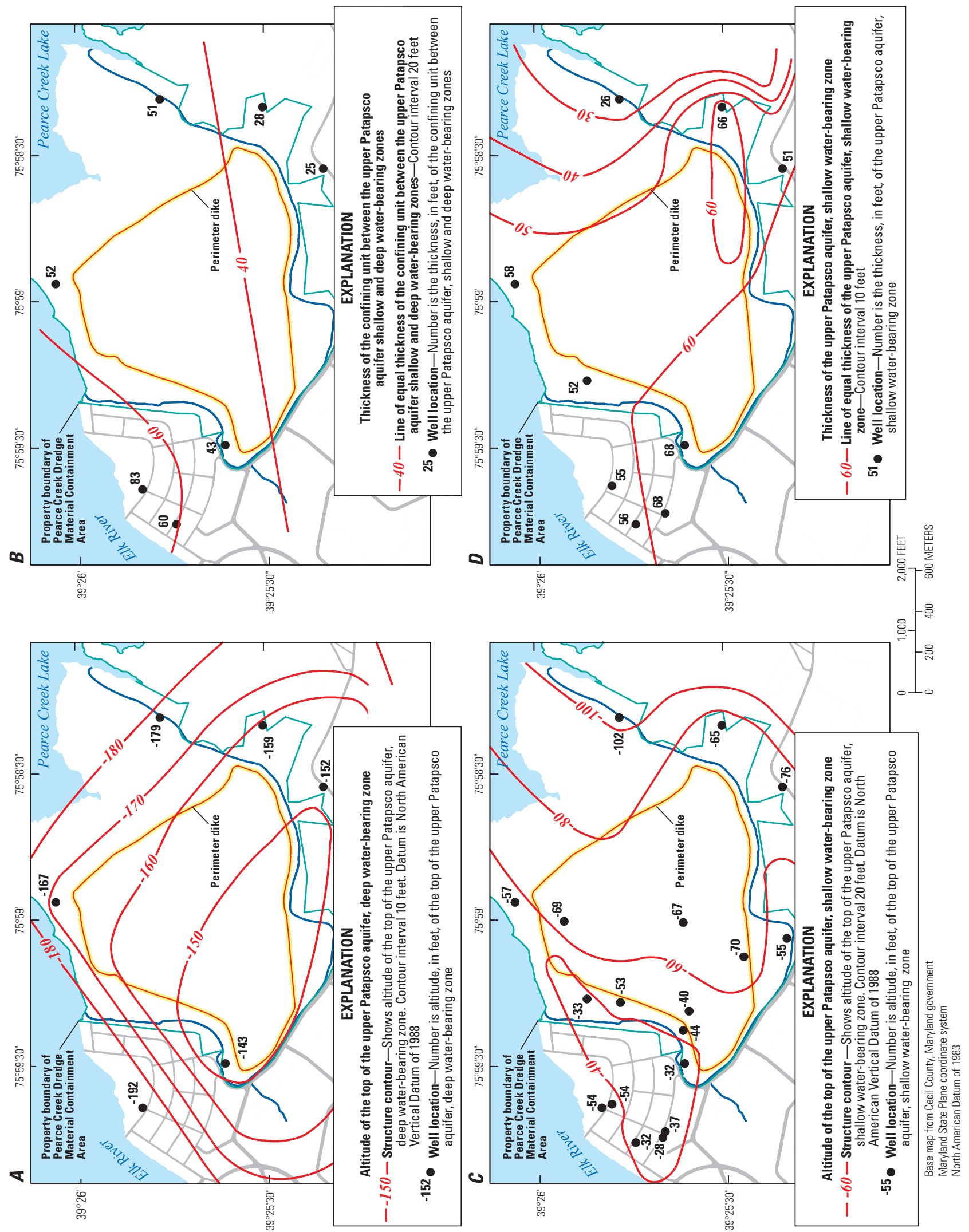

号

임잉

ॠँ

㐫妾

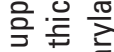

0

这

$\sum^{\infty}$

옹

.

离

语

○

추

菏 응

is

힝

曾喜迩

$\infty$ 웅

ه

恋

인응

즁 윽.

ब。

娄范交

응 융

\&

离吉

亏잉

$\circ$ 용

为

I. 0

음

品

음 홍

心 心

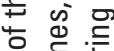

응 훙

안운

品

40

言

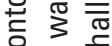

0 응

Ð 훙

늘 믐

के 30

ד 음

$\infty \frac{5}{5}$

言产 㐫 

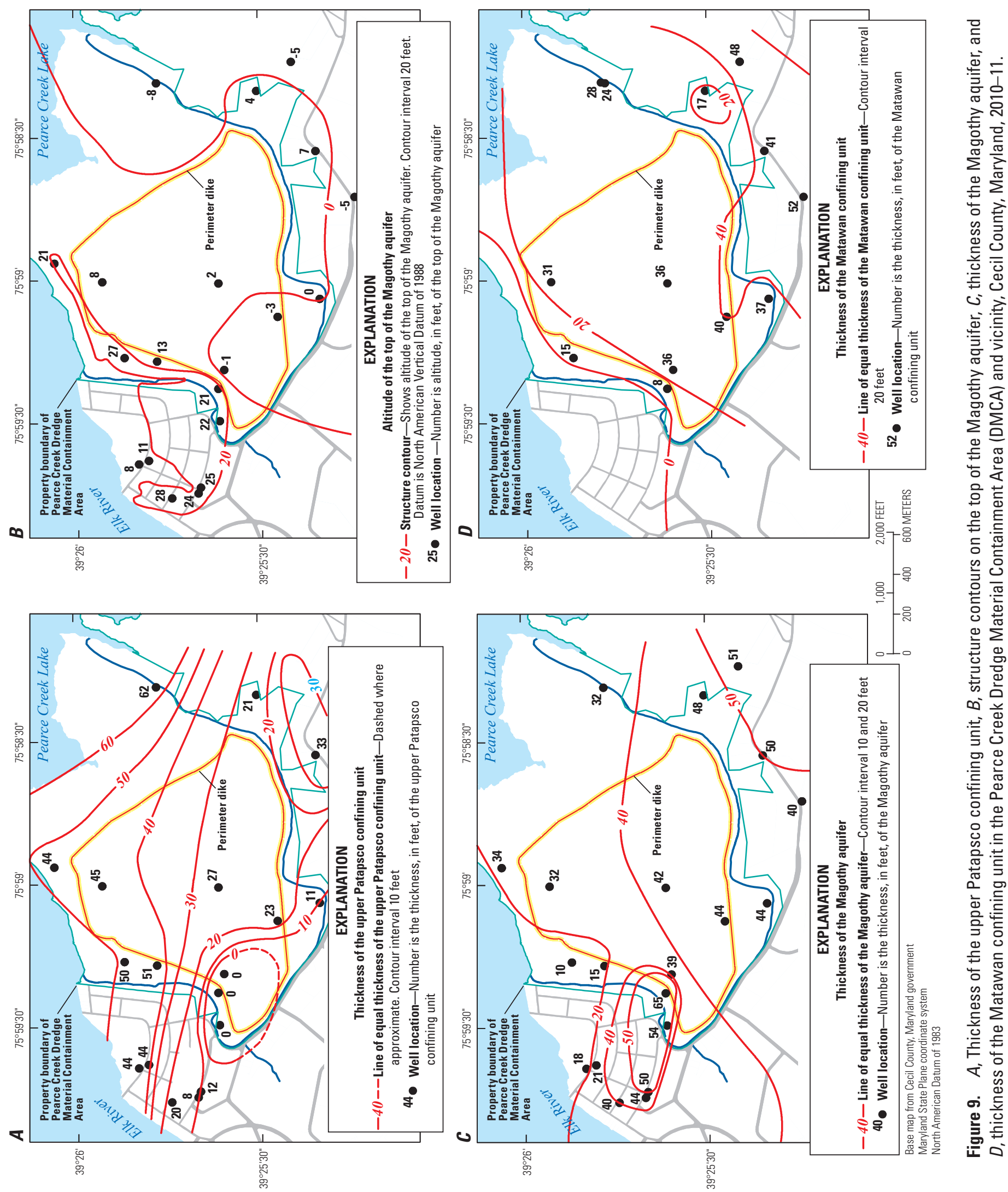


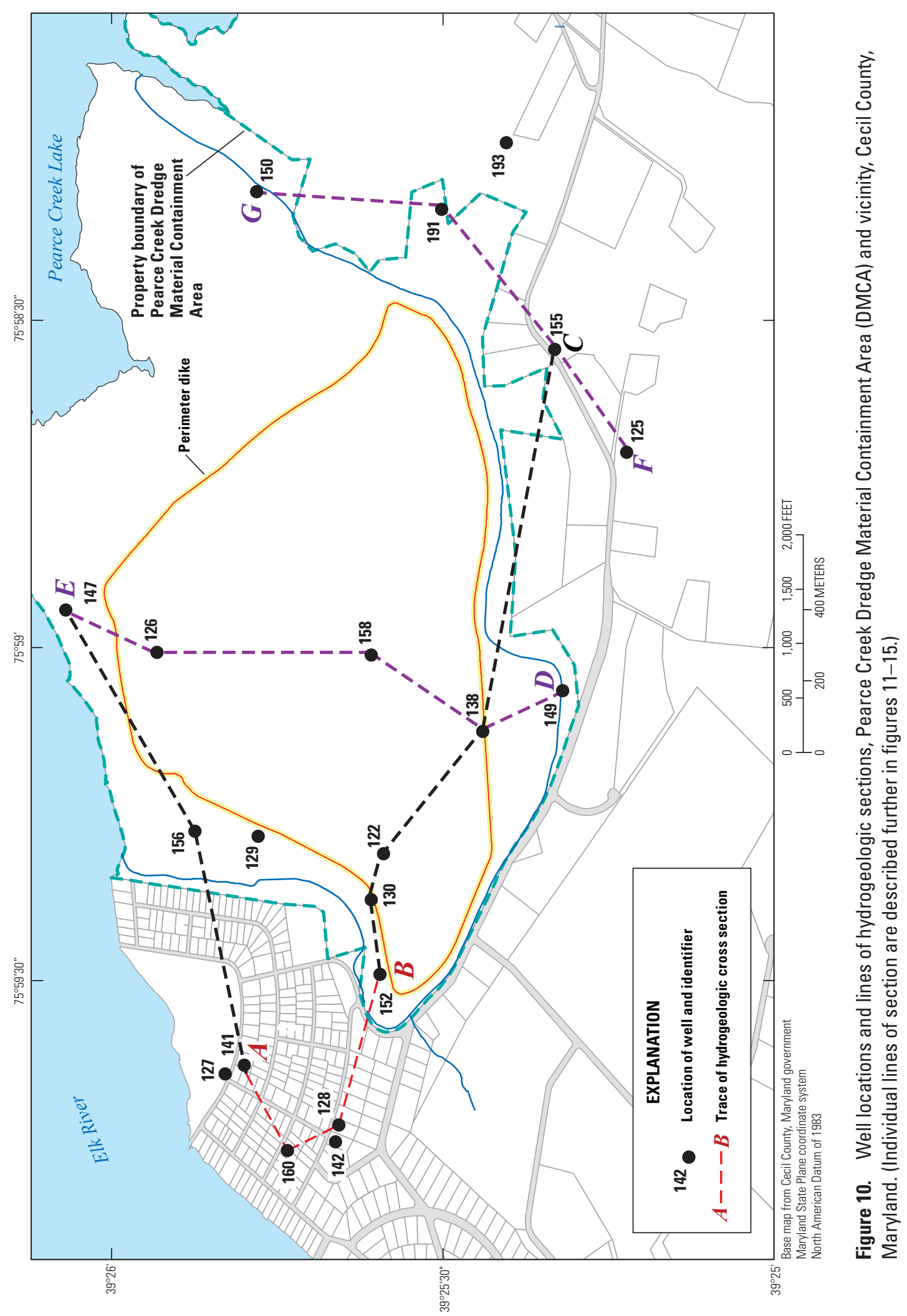




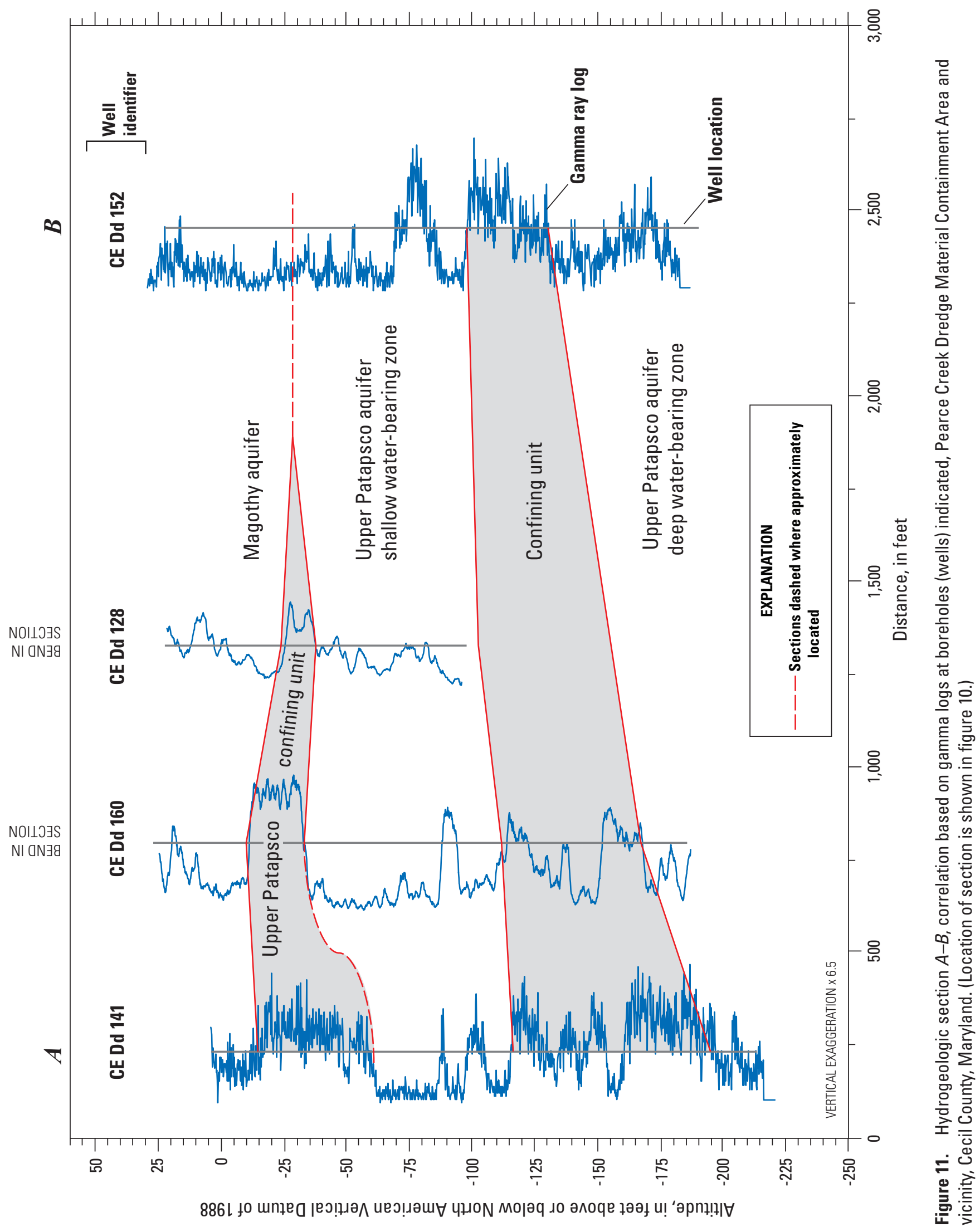




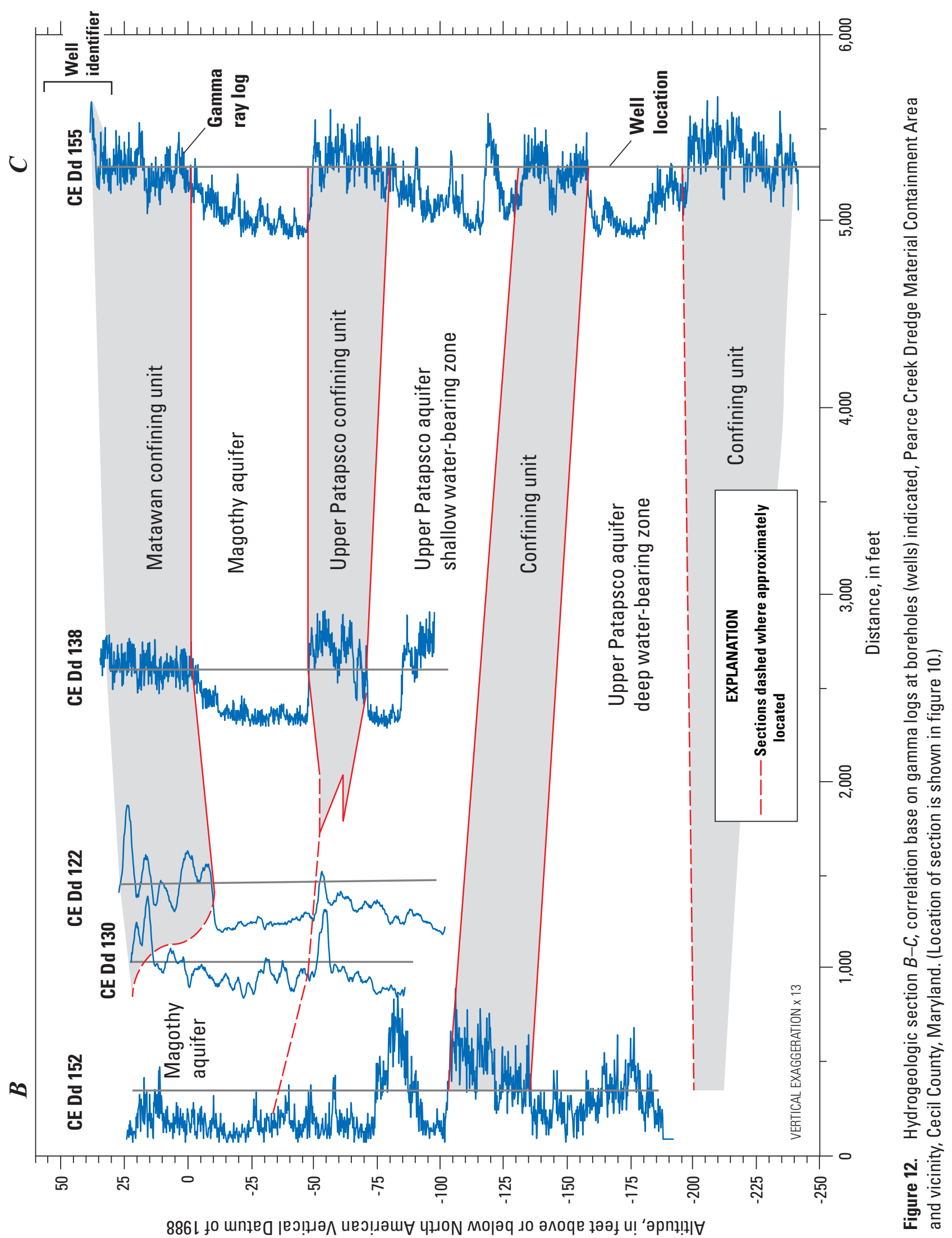




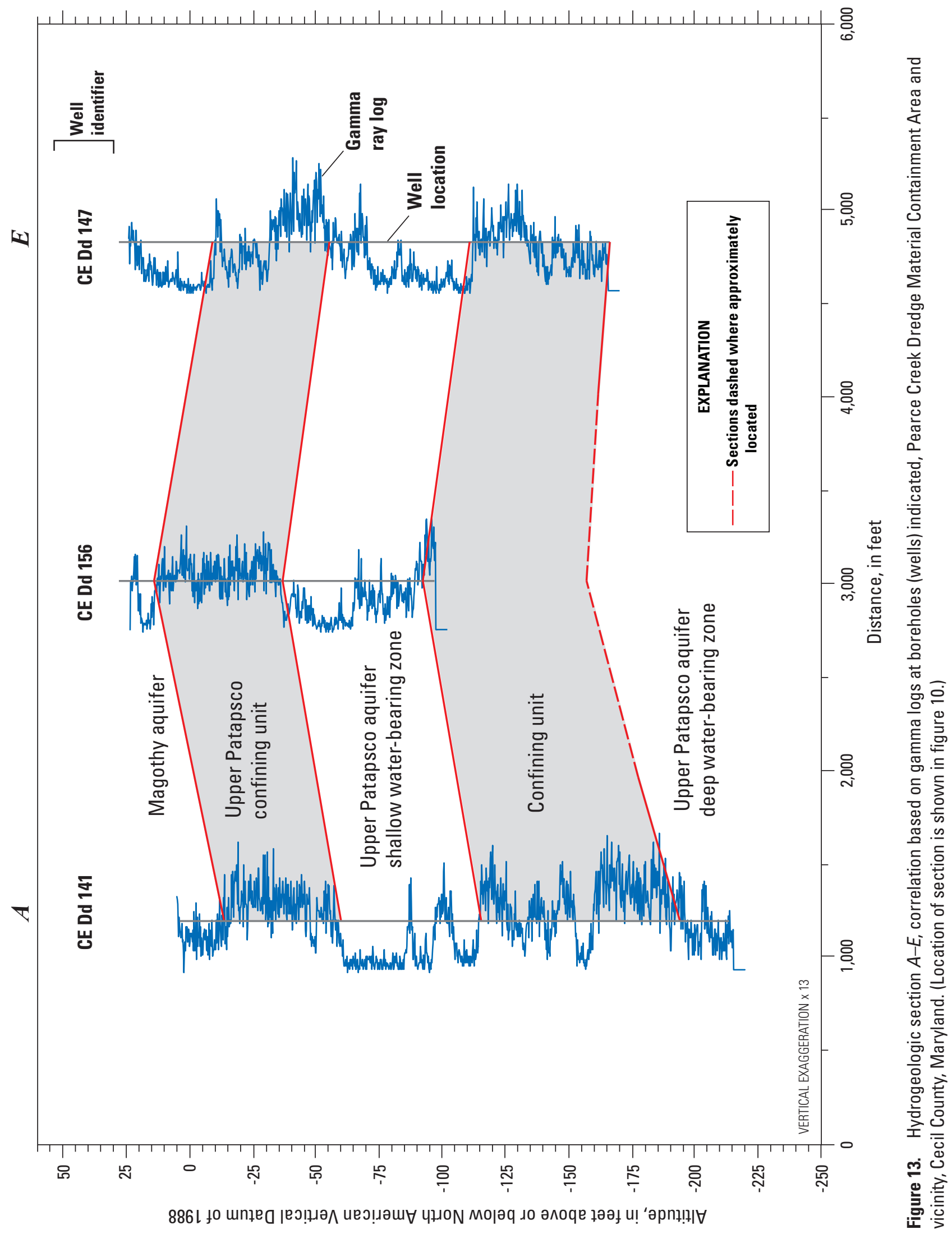




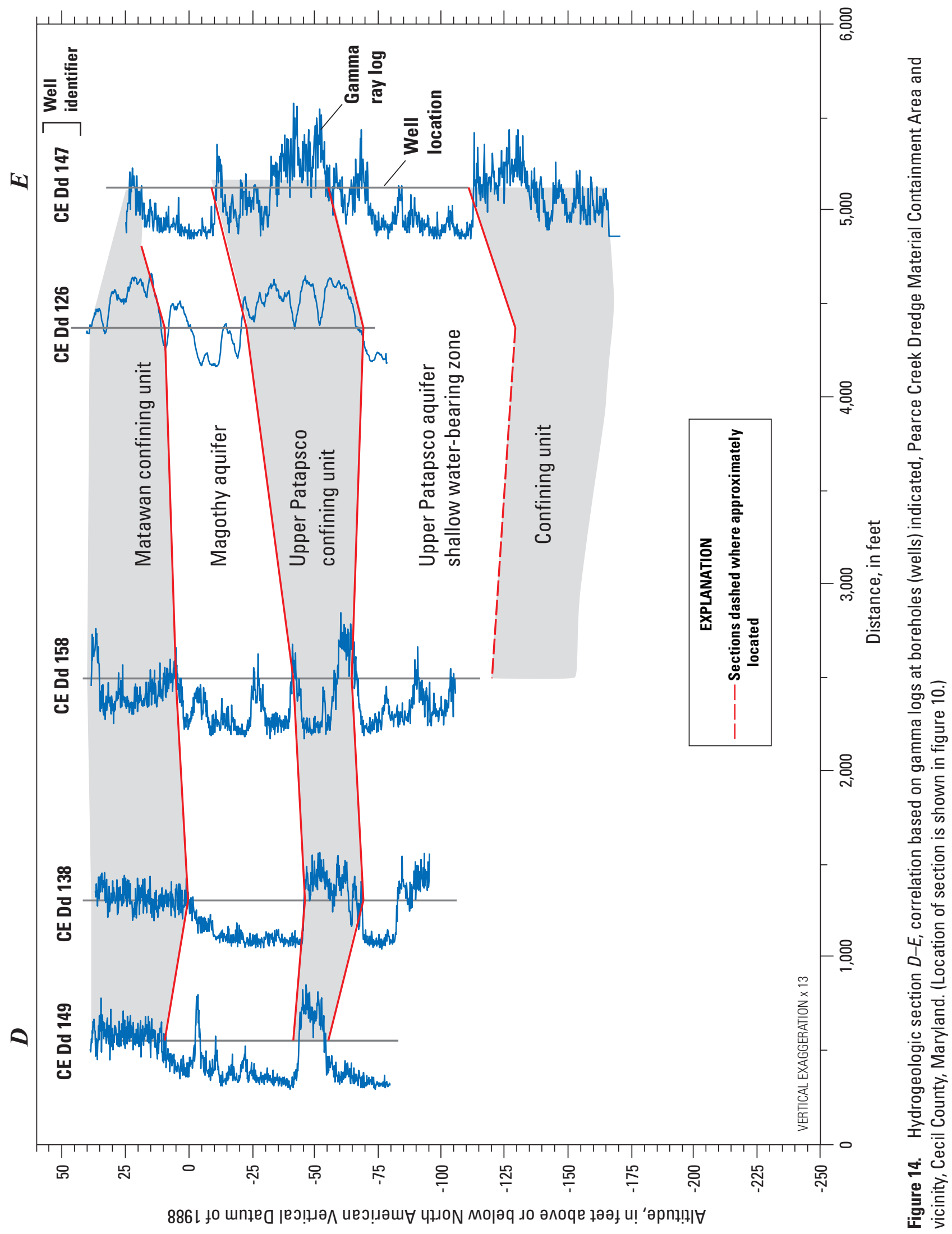




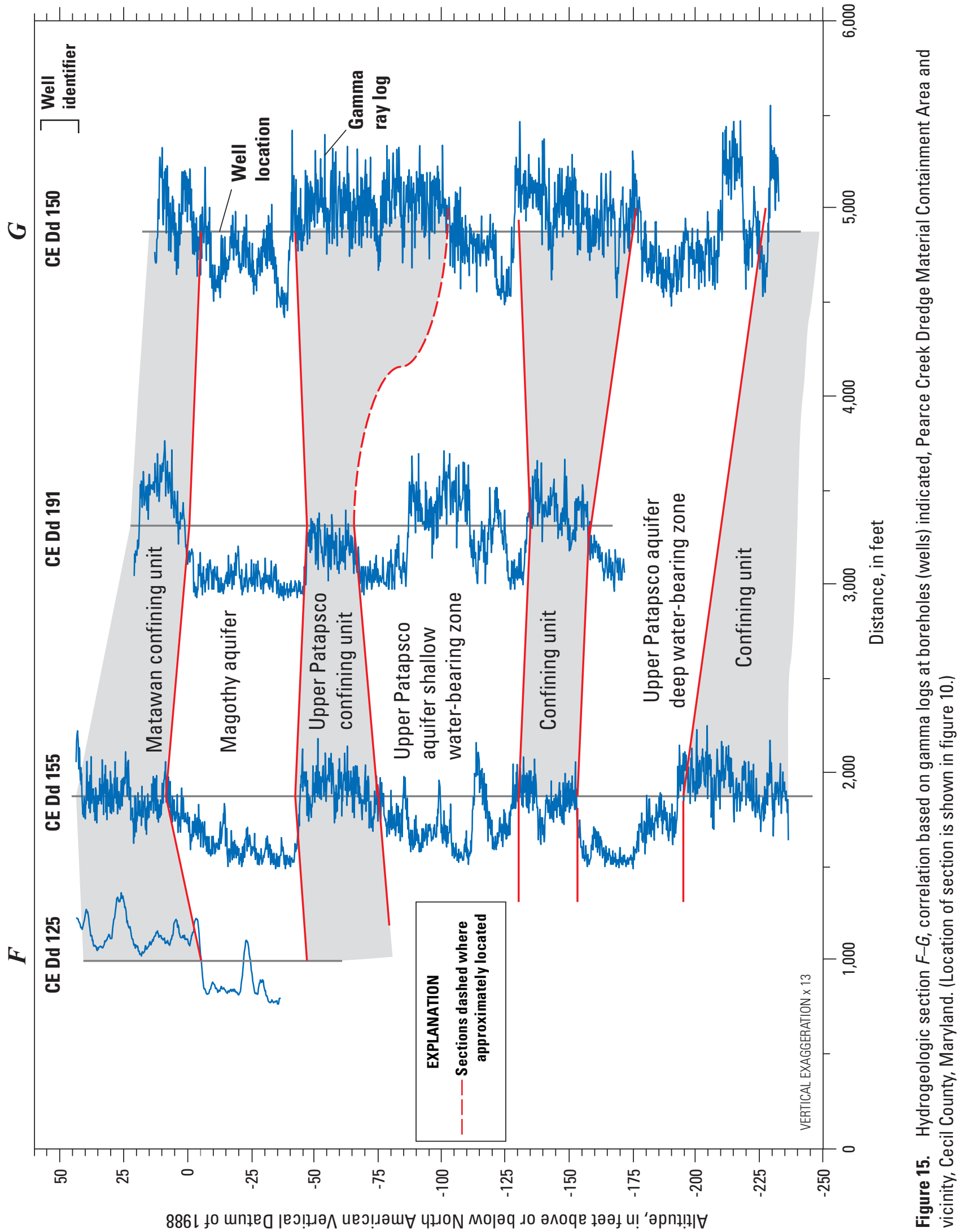




\section{Upper Patapsco Aquifer Shallow Water-Bearing Zone}

The upper Patapsco aquifer shallow water-bearing zone provides water for the majority of domestic wells along Pond Neck Road and the lower half of WVS nearer the Elk River. Of the available well-completion reports for the area, it is estimated that the upper Patapsco aquifer shallow water-bearing zone provides water for approximately 71 percent of area wells.

Structure contours of the top of the upper Patapsco aquifer shallow water-bearing zone indicate the altitude of the top of the unit ranges from approximately $-40 \mathrm{ft}$ NAVD 88 in the WVS area to $-102 \mathrm{ft}$ NAVD 88 at monitoring well CE Dd 150 located east of the DMCA perimeter dike (fig. $8 \mathrm{C}$ ). The thickness of the upper Patapsco aquifer shallow water-bearing zone ranges between 50 and $60 \mathrm{ft}$ for much of the DMCA and WVS (fig. 8D). The unit thins to less than $30 \mathrm{ft}$ in thickness near the eastern property boundary of the DMCA. Characteristic lithologies include fine to medium-grained gray, brown, tan, and locally orange sands with occasional thin beds of gravel. Clay and silt stringers within the unit are common, with some clay lenses as much as 5 to $10 \mathrm{ft}$ thick.

\section{Upper Patapsco Confining Unit}

The confining unit overlying the upper Patapsco aquifer shallow water-bearing zone increases in thickness from 30 to more than $60 \mathrm{ft}$ from the center of the DMCA north toward Elk River and Pearce Creek Lake (fig. 9A; section $D-E$, fig. 14; section $F-G$, fig. 15). The unit thins to the south and is missing in the southwestern corner of the DMCA near wells CE Dd 81, 130, 122, 123, and 124. The unit is also missing in the southeastern most part of WVS (fig. $9 \mathrm{~A}$; section $A-B$, figure 11; and section $B-C$, fig. 12), which places the upper Patapsco aquifer shallow water-bearing zone in direct hydraulic connection with the overlying Magothy aquifer. This hydraulic connection between the two aquifers in this area has direct implications on the groundwater flow system and water quality. The contact at the bottom of the Magothy aquifer and the top of the upper Patapsco aquifer shallow water-bearing zone on hydrogeologic sections where the upper Patapsco confining unit is missing is inferred and not meant to imply an exact boundary between geologic formations.

There is a substantial increase in the thickness of the upper Patapsco confining unit, and separation between the Magothy aquifer and upper Patapsco aquifer shallow waterbearing zone, from southeast to northwest through WVS and parallel to Elk River (section $A-B$, fig. 11; and section $A-E$, fig. 13, respectively). Continuous core retrieved during drilling for this study shows that the clays and silty clays of the upper Patapsco confining unit can be quite variable in color but are typically dark gray or red with lignite throughout.

\section{Magothy Aquifer}

The Magothy aquifer consists of sediments of the Cretaceous Magothy Formation. As defined herein, the aquifer can contain the overlying Tertiary Pensauken Formation and younger surficial Quaternary sands and gravels where unconfined. In the study area, the aquifer is composed predominantly of light colored white, yellow, tan, and gray medium to coarse-grained quartz sand and fine gravel. Beds of red brown iron stained sand and gravel are also present particularly near the top of the aquifer.

The Magothy aquifer is the uppermost aquifer encountered in the study area. Of the available well-completion reports for the area, it is estimated that the aquifer provides water for approximately 21 percent of area wells, most of which are located in the upper part of WVS near the DMCA property boundary.

The Magothy aquifer is unconfined from the Elk River eastward to near the western berm of the DMCA (figs. $9 B$ and $9 D$; section $A-B$, fig. 11). Therefore, the altitude of the top of the unit is land surface where the unit is exposed west of the berm. Across the DMCA, the top of the unit is encountered at approximately $0 \mathrm{ft}$ NAVD 88 . The aquifer generally ranges in thickness from 40 to $50 \mathrm{ft}$ throughout most of the study area except near the Elk River where the aquifer thins to less than $20 \mathrm{ft}$ and is likely composed predominantly of younger Tertiary and (or) Quaternary deposits (fig. $9 C$; section $A-B$, fig. 11; section $A-E$, fig. 13).

\section{Matawan Confining Unit and Fill}

Matawan Group sediments that overly the Magothy aquifer form a regional confining unit in the Maryland Coastal Plain (Otton and others, 1988). Higgins and Conant (1990) noted that the Merchantville Formation is the predominant component of Matawan Group sediments in the study area. Higgins and Conant also mapped a large area they refer to as spoil material indicated to be mixtures of soil, sand, clay, gravel, and debris from dredging operations. This fill material in part directly overlies the Magothy aquifer in the western part of the DMCA and overlies the Merchantville Formation in the eastern part of the DMCA. It is also likely that the fill material overlies the original wetland sediment, thus creating a buried layer of organic rich material. The Matawan confining unit is predominantly a dark gray to green clay and silty clay with lignite and organic detritus present. Because the fill imparts a degree of confinement, is locally as much as $25 \mathrm{ft}$ thick, and is difficult to distinguish hydrologically from the underlying Merchantville Formation sediments, both fill and Merchantville Formation sediments are included in the total thickness of the confining unit. Confinement overlying the Magothy aquifer increases from 0 to more than $40 \mathrm{ft}$ eastwardly across the DMCA as 20 to $30 \mathrm{ft}$ of fill is encountered and as the overlying Matawan Group sediments increase in thickness in the easterly down-dip direction (fig. 9D; section $B-C$, fig. 12). 


\section{Chemical Composition of Sediments}

For the purposes of this study, no data are available (or obtainable) on the chemical composition of the canal or Elk River sediments deposited in the DMCA during its use. Nor are there data on the chemical composition of native sediments in the area of the DMCA or vicinity that predate the creation and use of this facility. However, studies have been conducted on the composition of Chesapeake Bay sediments, which include the northern part of the Chesapeake Bay and Elk River Estuary. Limited data collected by the USACE after the closure of the DMCA also are available on the chemical composition of the surficial (fill-Matawan) sediments, and on sediments in the underlying aquifers and confining beds in the DMCA, as well as in the vicinity of the DMCA.

\section{Northern Chesapeake Bay Sediments}

The chemical composition of sediments in the Chesapeake Bay, hereafter referred to as bay sediments in this report, has been the subject of several studies. Early studies by Sinex and Helz (1981) describe the concentration and regional geochemistry of trace elements in bay sediments about the time the DMCA was in its final decade of use. Except for chromium, the authors found that bay sediments north of Baltimore, Md., are enriched 3 to 8 times relative to sediments in the remainder of the bay in the concentrations of most trace elements, including cobalt, copper, iron, manganese, nickel, and lead. Concentrations of metals in digested ${ }^{1}$ upper bay sediments were on the order of hundreds of milligrams per kilogram for cobalt, copper, nickel, and lead; thousands of milligrams per kilogram for manganese; and tens of thousands of milligrams per kilogram for iron. They also identified that the chief sources of the enriched metals are fine-grained (less than $63-\mu \mathrm{m}$ fraction) sediments, which are prevalent throughout the northern part of the bay. In a subsequent study, Marvin-DiPasquale and Capone (1998) found that greater than 50 percent of the sulfur, as labile sulfate $\left({ }^{35} \mathrm{SO}_{4}{ }^{2-}\right)$, annually introduced in in-situ surficial ( 0 - to 12 -cm depth) sediments in the upper bay was reduced to (ferrous) iron sulfide (FeS).

In a recent and broad comprehensive study of bay sediment contaminants, Hartwell and Hameedi (2007) examined the magnitude and extent of contaminants in recently deposited shallow (upper 2- to $3-\mathrm{cm}$ or upper 10-cm) bay sediments. For three sites on Elk River Estuary, sediments found at two of three sites - the mouth of the estuary near WVS and farther up river just above the C\&D Canal (Chesapeake and Delaware Canal) - were considered to be in the top 10th percentile of all contaminated sites. As for most sites in this percentile category, sediment samples from these two sites consisted of a relatively high percentage of fine-grained silts and clays, which as noted above, appear prone to the absorption and retention of inorganic and organic contaminants. In particular,

\footnotetext{
${ }^{1}$ Four-hour digestion with 90 percent nitric acid and 10 percent hydrochloric acid.
}

Hartwell and Hameedi (2007) provide data on the two Elk River estuary sites, which when compared to other middle and lower bay estuaries were:

1. High in most of the 15 extractable ${ }^{2}$ trace elements on the basis of their mean normalized total metal concentration, which was approximately 32 percent;

2. moderately high in selected insecticides, such as dichlorodiphenyltrichloroethane (DDT) and (or) DDT metabolites (approximately $4 \mu \mathrm{g} / \mathrm{kg}$ (micrograms per kilogram)), chlorpyrifos (approximately $0.4 \mu \mathrm{g} / \mathrm{kg}$ ), and chlordanes and related cyclodienes (approximately $2 \mu \mathrm{g} / \mathrm{kg}$ ), as well as total chlorinated benzenes (approximately $2-3 \mu \mathrm{g} / \mathrm{kg}$ );

3. moderate in levels of low-weight polyaromatic hydrocarbons (PAHs) (approximately 250-500 $\mu \mathrm{g} / \mathrm{kg}$ ), and polychlorinated biphenyls (about 10-20 $\mu \mathrm{g} / \mathrm{kg}$ ); and

4. moderately low to low in high-weight PAHs (500$1,000 \mu \mathrm{g} / \mathrm{kg}$ ) insecticides such as hexachlorcyclohexane $(\mathrm{HCH})$ (approximately $0.1 \mu \mathrm{g} / \mathrm{kg}$ ), butylins (approximately $5 \mu \mathrm{g} / \mathrm{kg}$ ), and total PAHs normalized for total organic carbon (approximately 1,000 or less $\mu \mathrm{g} / \mathrm{kg}$ ).

Hollweg and others (2009) also recently characterized the general chemical composition of bay sediments to assess rates of mercury methylation, which included sediment results from northern bay sites most applicable to Elk River Estuary (table 8). Because of the nature of their study, all sediment samples were collected, maintained, processed, and analyzed under anerobic (oxygen-free) conditions. Thus, their data reflect the in-situ chemical composition of bay sediments and sediment pore water. In comparison with middle and lower bay sediments, they concluded that upper bay sediments were low in bulk density, and high in total and organic carbon, sulfur, nitrogen, and iron (II). Extractable bulk-phase metallic monosulfides and polysulfides (table 8 , acid-volatile sulfide and chromium reduced sulfide, respectively) also were high and include, for example, ferrous sulfide (FeS) and pyrite $\left(\mathrm{FeS}_{2}\right)$. In addition, pore waters from these sediments as well as other bay sediments were highly alkaline in $\mathrm{pH}$ (a mean $\mathrm{pH}$ of 8.4, with a standard deviation of 0.2 ). Compared to middle and lower bay sediments, however, the authors noted that northern bay sediments contained little nitrate-plus-nitrite nitrogen, moderately low concentrations of sulfate, moderate concentrations of sulfide, and relatively high concentrations of total iron and total manganese (table 8).

\section{Dredge Material Containment Area and Vicinity Sediments}

Limited data are available on the chemical composition of surficial and underlying sediments in the DMCA. The readily available data reflect sediment samples taken and analyzed by the USACE after the closure of the facility in

\footnotetext{
${ }^{2}$ Extraction methods could not be documented.
} 
1992 (U.S. Army Corps of Engineers, 1996). The individual sediment-sample data from that report were categorized and grouped on the basis of their original location and depth of sampling to provide statistical summaries of the chemical data in relation to the hydrogeologic framework of the study area as described above in this report (tables 9 and 10).

As of 1995-96, when the sediment samples were collected, all sediments in and beneath the DMCA contained relatively high concentrations of iron, with the highest concentrations being associated with fill-Matawan sediments, which were of many types (table 9). The fill-Matawan sediments also contained relatively elevated concentrations of manganese, zinc, and copper. Slurry or pore waters ${ }^{3}$ associated with all sediments generally were acidic. Concentrations of sulfate were highest associated with the fill-Matawan sediments, but also occurred at elevated concentrations in water associated with the underlying Magothy aquifer sands, and the confininglayer silt, peat, and (or) clay. Sulfide also occurred at measurable concentrations in slurry or pore waters associated with at least some sediment samples from the fill-Matawan and underlying aquifer and confining unit sediments.

In the vicinity of the DMCA, all sediments except those associated with the Magothy aquifer contained relatively high concentrations of iron (table 10). Most other metals were at moderate to low concentrations, with metal concentrations associated with confining-unit sediments being higher than metal concentrations associated with sediments in either the Magothy aquifer or upper Patapsco aquifer shallow waterbearing zone. Slurry or pore waters associated with all sediments also generally were acidic. Sulfate concentrations appeared to be highest in sediments associated with the upper Patapsco aquifer shallow water-bearing zone. Sulfide concentrations also were measurable in sediments associated with both confining units and both aquifers; consistently high concentrations occurred in the confining unit sediments between the Magothy and upper Patapsco aquifers.

\section{Sediment Chemistry Comparisons}

Other than broad comparisons and contrasts, further interpretive analyses of the chemical composition of the bay and DMCA sediments are limited, in part by the fact that the sediment samples reflect two very different aquatic environments, and, in part, because the methodologies used to collect, preserve, and analyze samples associated with each of these environments differed appreciably. For example, it already was noted that the collection, preservation, and analysis of bay sediment samples were conducted excluding sample exposure to oxygen. It is unlikely that this condition could have been maintained during the collection, preservation, and analysis of sediment samples from the DMCA or its vicinity. Thus, results for redox-sensitive species, such as iron, manganese, nitrate and nitrite nitrogen, sulfide, and sulfate, could be biased if

\footnotetext{
${ }^{3}$ Unable to confirm whether analyses reflected pore waters or sediment slurries.
}

sediment samples were even partially oxidized during these procedures.

Despite the obvious differences, the bay sediment data indicate that these sediments contain appreciable amounts of carbon, nitrogen, and sulfur, as well as several trace elements such as iron and manganese. These sediments appear also to be quite alkaline ( $\mathrm{pH}$ approximately 8 ) and contain appreciable mono and poly sulfides and sulfate but little nitrateplus-nitrite nitrogen. Collectively, the above results indicate an environment that appears to be in a fairly reduced state. By comparison, sediments in the DMCA and its vicinity also exhibit many of the same chemical sediment characteristics as bay sediments, including elevated concentrations of iron and manganese, as well as sulfate and measurable sulfide, which could also reflect an environment that is possibly in a similar reduced state. There also is clearly one marked difference between bay and DMCA sediments: whereas the $\mathrm{pH}$ of the former appears distinctly alkaline (table $8, \mathrm{pH} 8.4$ (mean) \pm 0.2 (standard deviation)), the $\mathrm{pH}$ of the latter appears distinctly acidic (table 9, pH 3.0 to 6.2).

Because similar methods were used to collect, preserve, and analyze sediment samples in the DMCA and vicinity, one can compare and contrast their sediment chemical composition. For example, iron is highly abundant, and manganese moderately abundant, in sediments in and within the vicinity of the DMCA (tables 9 and 10, respectively). All other metals occur at relatively low concentrations in sediments in and within the vicinity of the DMCA. Slurry or pore water is acidic and contains measurable concentrations of sulfide in sediments in the DMCA and its vicinity.

There are differences in the concentrations of selected constituents in sediments in the DMCA and its vicinity. Concentrations of iron outside the DMCA generally are similar to iron concentrations in sediments in the DMCA, regardless of whether one is comparing these sediment concentrations between the surficial sediments, or the underlying Magothy aquifer, confining unit, or upper Patapsco aquifer shallow water-bearing zone. However, manganese and zinc concentrations occur at higher concentrations in the surficial fillMatawan sediments in the DMCA compared to the surficial Matawan sediments outside of the DMCA. The same pattern also occurs for the confining unit between the Magothy aquifer and upper Patapsco aquifer shallow water-bearing zone; but the order is reversed for sediments in the upper Patapsco aquifer shallow water-bearing zone. Sediments in this zone in the DMCA appear to contain more manganese and zinc than sediments in this zone outside of the DMCA.

The above information cannot be interpreted fully without knowing the patterns in groundwater flow in the study area and the geochemical processes that could occur within the groundwater flow system. For example, whether or not the chemical composition of sediments in the vicinity of the DMCA reflect native sediments, and thus a potential independent source area for recharge that influences the chemistry of groundwater in the area, depends on the answers to several 


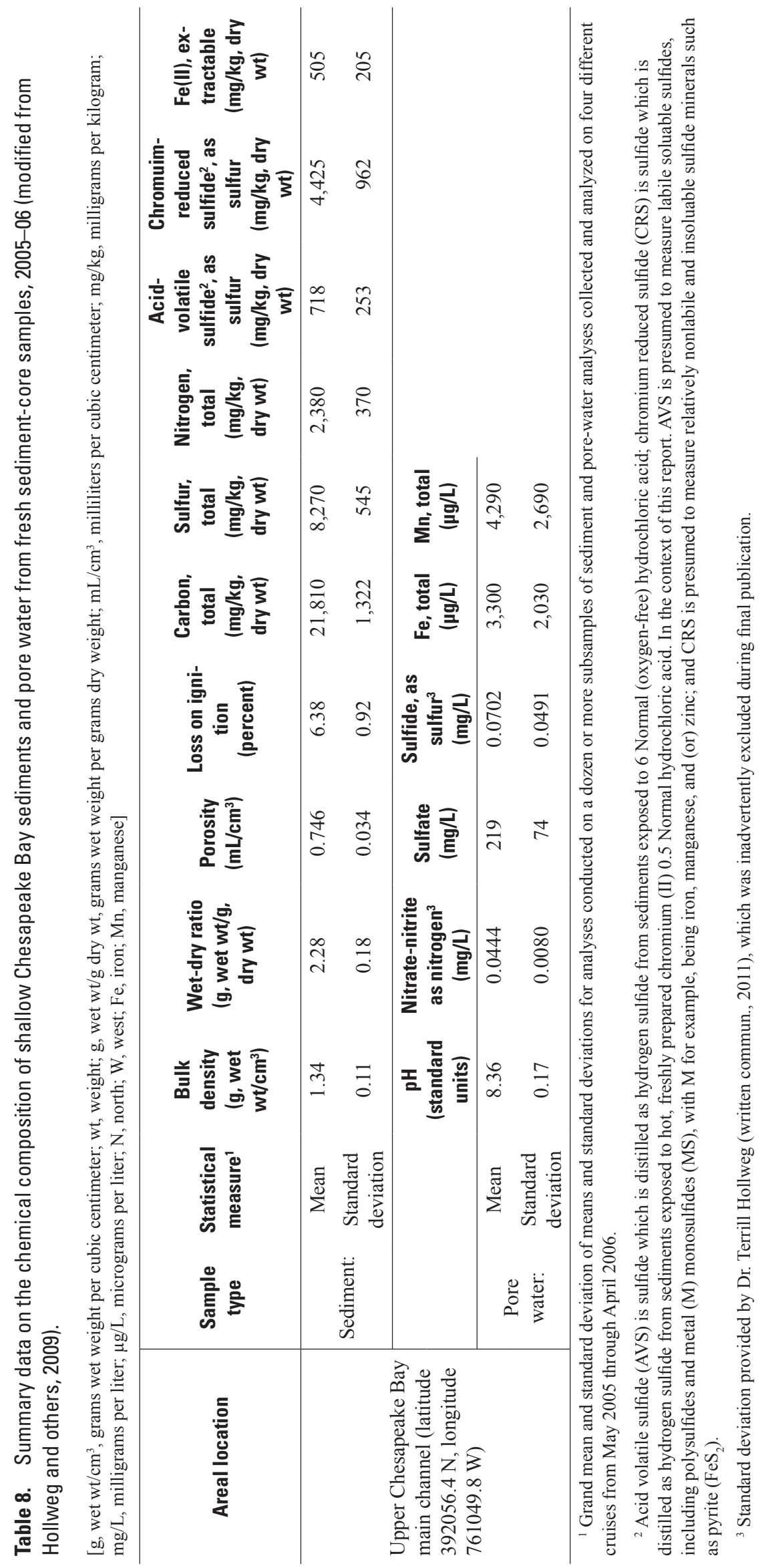



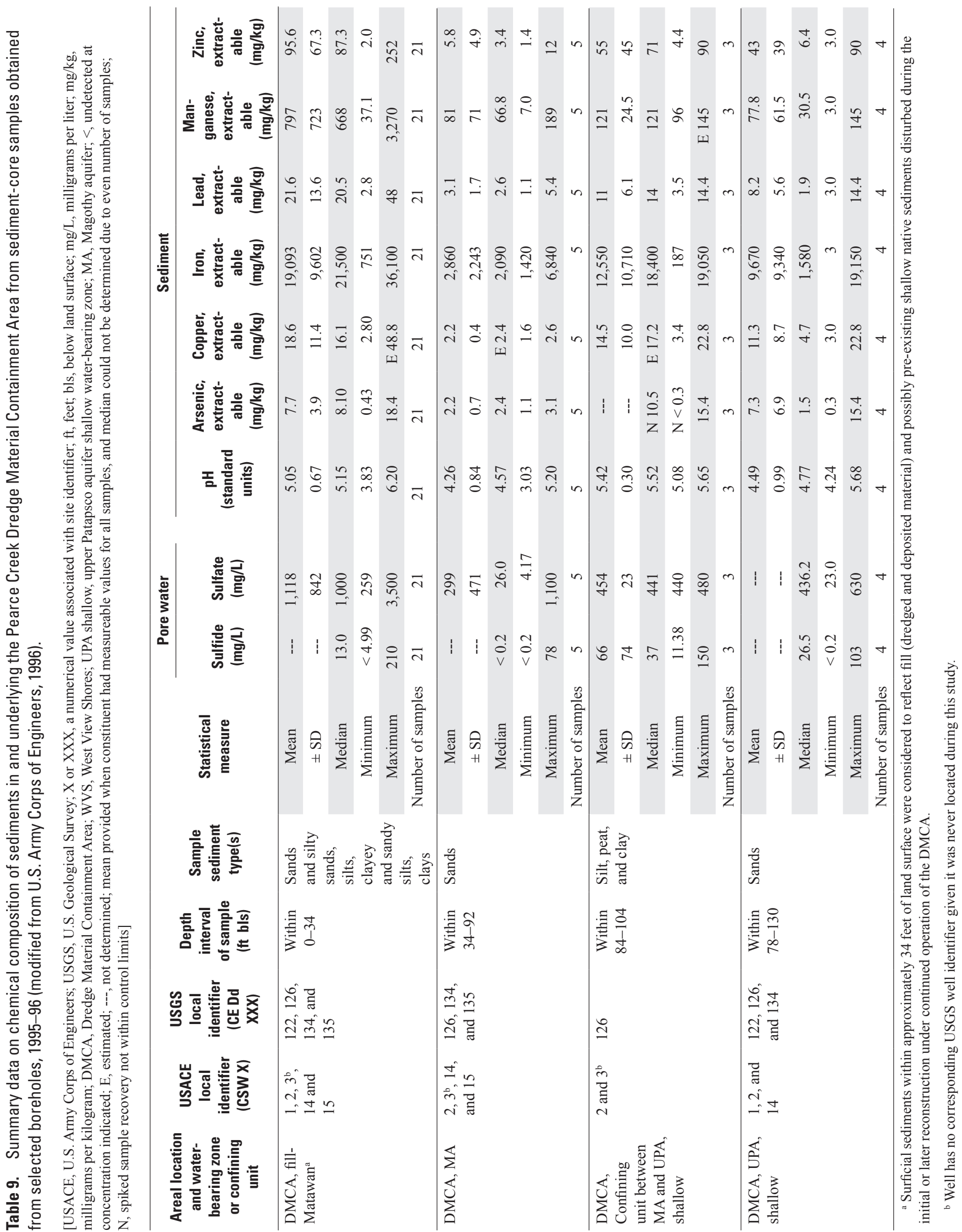


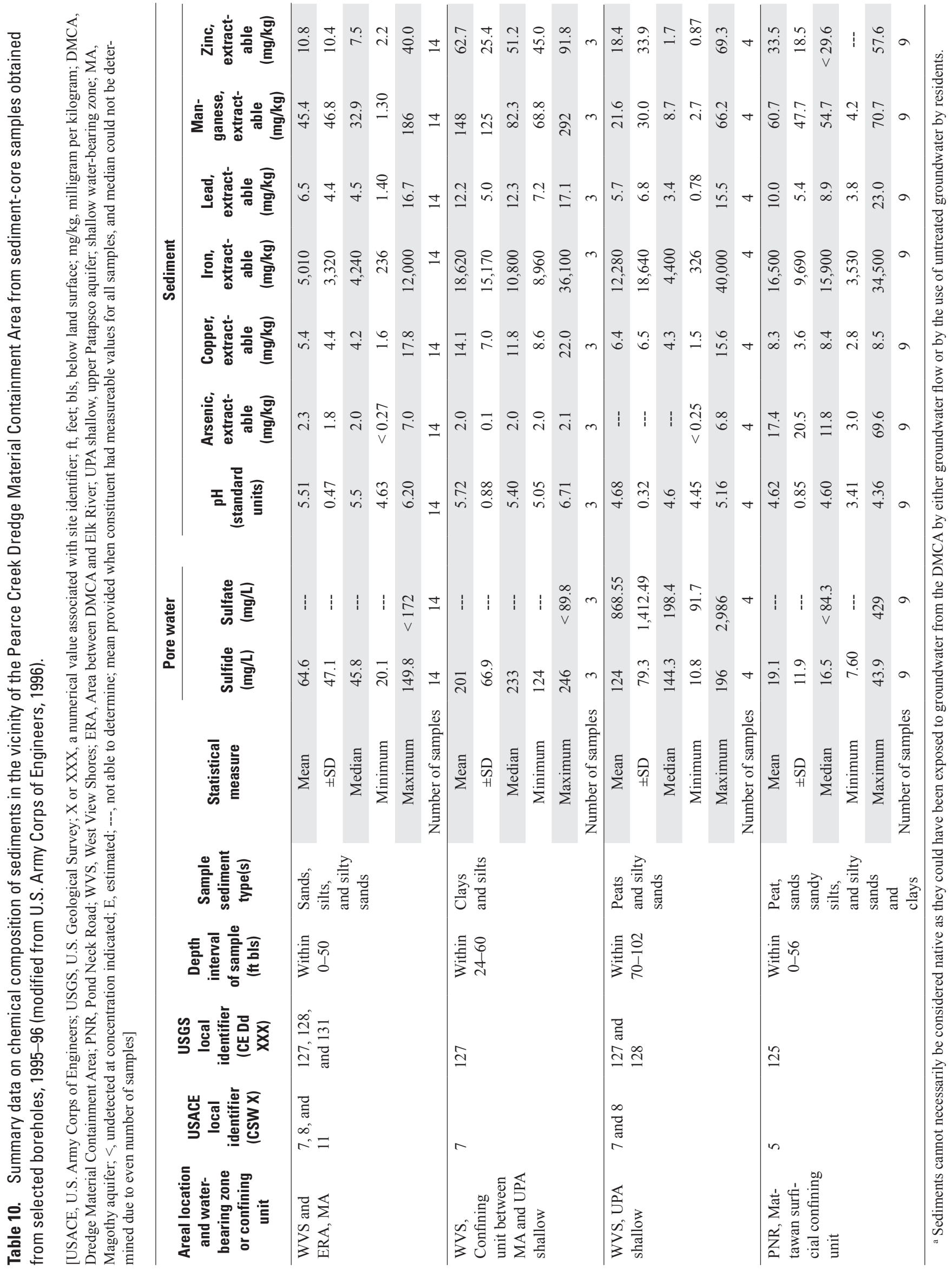


questions. Are these sediments in fact located in a recharge rather than a discharge zone? What is the redox state of the zone? What is the origin and chemical nature of the water entering the zone, and is it likely changing as water passes through the zone? Answers to these questions can be found by integrating hydrogeologic framework, hydrology, and waterquality information, and are described in later sections of this report.

\section{Hydrology}

Patterns in horizontal and vertical directions of groundwater flow within the Magothy and upper Patapsco aquifers were determined from synoptic water-level measurements made in May and August 2010 and March 2011. Continuous water-level data recorded during the period January 2010 through March 2011 from selected well nests provide information on daily and seasonal fluctuations and provide further information regarding vertical trends between aquifers. The derived patterns in groundwater flow associated with the May 2010 synoptic assessment are used as the basis for the interpretations of groundwater quality in the DMCA and vicinity given that most water-quality samples were collected within this general time frame. The changes in water levels between the three synoptics as well as the continuous water-level data provide additional information on how groundwater flow within and between aquifers changes through time in response to water use, recharge, precipitation, and tidal effects.

\section{Water-Level Synoptic Assessments and Continuous Data Collection}

Three synoptic assessments of groundwater levels were conducted in the study area. The first synoptic assessment was conducted during May 19-20, 2010; water-level data were obtained from 58 wells and calculated for 3 wells for a total of 61 data points from within the DMCA and vicinity (fig. 16; table 11). The second synoptic assessment was conducted from August 17-18, 2010; water-level data were obtained from 62 wells and calculated for 3 wells for a total of 65 data points from within the DMCA and vicinity (fig. 16; table 11). The May and August 2010 synoptic assessments included a combination of existing and newly installed project observation wells, neighboring domestic wells in WVS and along Pond Neck Road and a local irrigation well. Following the installation of three additional wells for the project in December 2010 (wells CE Dd 191, 192, and 193), a third more limited synoptic assessment using observation wells only (39 wells total) was conducted in March 2011 (table 11). The synoptic data were used to delineate the potentiometric surfaces of each aquifer in May and August 2010 and March 2011. The May and March synoptic assessments reflect a time in the spring when many of the seasonal residents of WVS generally are absent, and groundwater withdrawals for supplies are reduced leading to higher groundwater level altitudes. The August assessment reflects summer withdrawals and generally lower groundwater levels with most seasonal residents being present, and groundwater withdrawals for supplies presumably are greater than in the spring. Elevated evapotranspiration within the DMCA and vicinity also occurs during the summer.

The USACE (Atlantic City, New Jersey) surveyed the altitudes of land surface and measuring points at all observation wells and the altitude of land surface for domestic wells used for this study. From these surveyed altitudes, the altitude of a measuring point was determined for each well by the USGS.

For each water-level synoptic assessment, the depth to water in each well below the measuring point was measured by the USGS with a steel tape graduated to $0.01 \mathrm{ft}$. Water levels were adjusted to the altitude of the measuring point at each well to obtain the altitude of water level at each well. Accuracy of the altitude of groundwater levels is considered to be $0.01 \mathrm{ft}$ for the observation wells and $0.1 \mathrm{ft}$ for domestic wells.

Continuous water-level data, collected from 15 study area observation wells (fig. 17; appendix A, table A1) with installed transducers, provided additional information on how groundwater flow within and between aquifers changes through time, including long- and short-term responses to recharge, tidal effects and other stresses such as drought, and groundwater withdrawals. Transducer water-level data were collected from some wells starting January 26, 2010, and the last transducers were removed March 31, 2011. The period of record for water-level measurements ranged from about 3 to 14 months depending upon when the transducer was installed in the well. The transducers used were rated at either 15 or 30 psi (pounds per square inch), with an accuracy of altitude of water level of \pm 0.2 percent or less. The altitude of the water level was stored every 15 minutes on a data logger, and check measurements were made approximately every 30 days. Transducer water-level data were entered into the USGS National Water Information System (NWIS) database, where drift corrections based on check measurements, and (or) measuring point datum corrections were applied to the data when necessary.

Pearce Creek Lake, which is dammed at the northeastern limit of the DMCA property (fig. 17), receives streamflow from Pearce Creek and is a potential groundwater recharge source and (or) discharge area. The lake level was monitored with a staff gage and continuous gage; the transducer in the continuous gage recorded the lake level at 15-minute intervals. The transducer level was referenced to a surveyed reference point on the gage. To better understand groundwater and surface-water interaction within Pearce Creek Lake, 12 piezometers were driven into the lakebed during the May 2010 groundwater synoptic assessment. Each piezometer was connected to a manometer, and the difference between the lake and piezometer level was recorded. The piezometer difference then was converted to the altitude of water level using the altitude of lake level determined from the staff gage reading. 

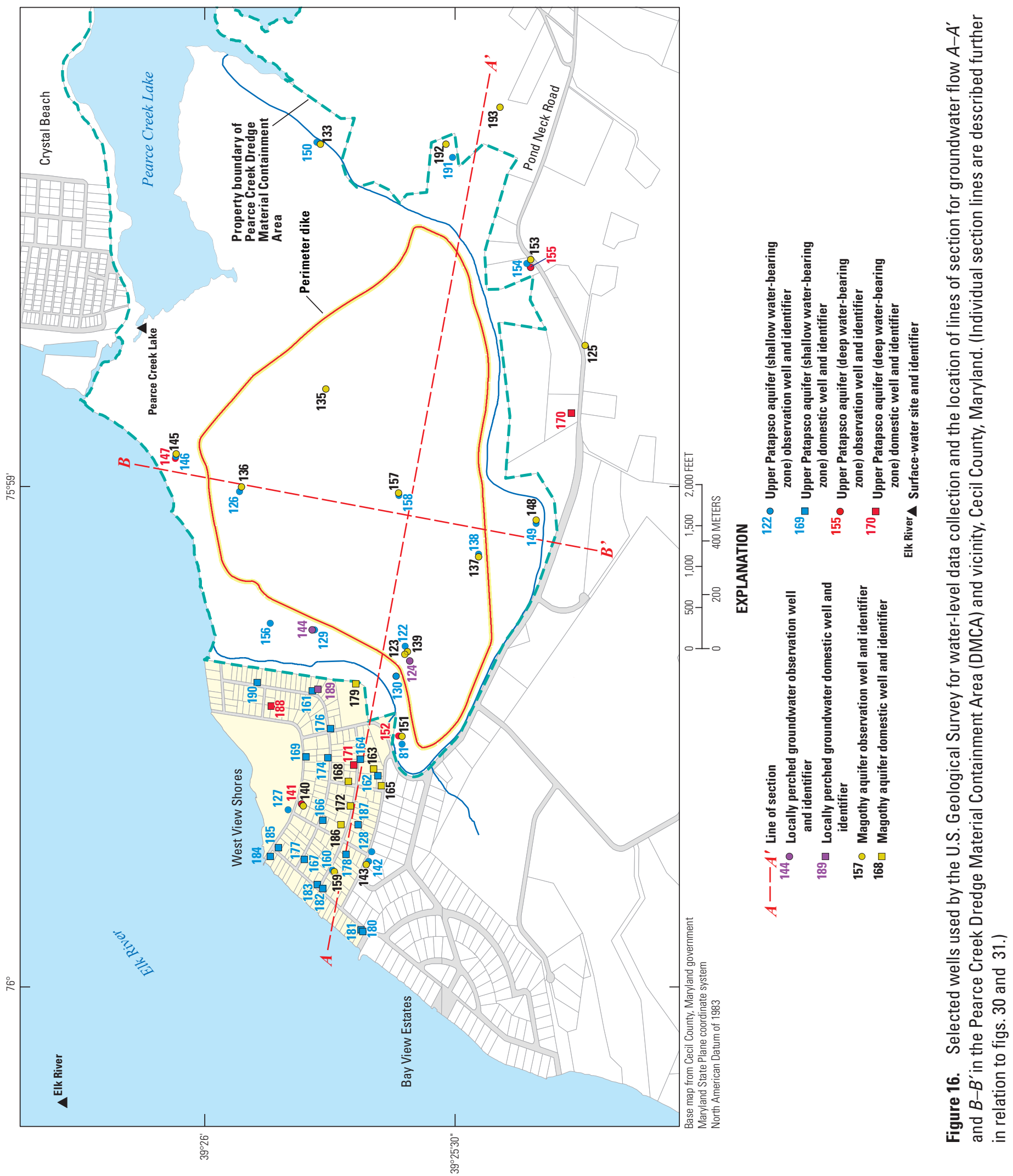


\section{Water Use}

Except for selected residences in the community of Crystal Beach, which is just north of Pearce Creek Lake (fig. 17), groundwater use in the study area is predominantly self-supplied by privately owned residential wells. Within Crystal Beach, a private water company, with a withdrawal permit from the Maryland Department of the Environment, pumps groundwater for public supplies. State-maintained records indicate the water company pumped an average of $0.295 \mathrm{Mgal} / \mathrm{d}$ (million gallons per day) in 2008 and $0.315 \mathrm{Mgal} / \mathrm{d}$ in 2009 from two wells completed in the upper Patapsco deep water-bearing zone. There also are permitted irrigation withdrawals from a farm to the east of the DMCA (fig. 17). Multiple irrigation wells on this property pumped an average of $0.672 \mathrm{Mgal} / \mathrm{d}$ in 2009 and $1.074 \mathrm{Mgal} / \mathrm{d}$ in 2008 from the Magothy aquifer. All other withdrawals in the area were from private non-permitted domestic wells. Maryland well completion reports were obtained for 107 wells in the area of WVS and Pond Neck Road. Of these, 23 wells were screened in the Magothy aquifer, 76 wells were screened in the upper Patapsco aquifer shallow water-bearing zone, and 8 wells were screened in the upper Patapsco aquifer deep water-bearing zone. Based on well completion reports, most withdrawals for supplies outside the DMCA property are from the upper Patapsco aquifer shallow water-bearing zone.

\section{Long-Term Water Levels}

Although there is a paucity of data on historical water levels in the study area, periodic measurements at one well, CE Dd 81, in the vicinity of the DMCA, are available beginning in 1983. This well is completed in the upper Patapsco aquifer shallow water-bearing zone, and is located near the entrance of the DMCA (fig. 17). Historical measurements at this well from March 1983 through March 2011, converted to water-level altitudes, ranged from $8.48 \mathrm{ft}$ NAVD 88 in July, 1983 to $1.26 \mathrm{ft}$ NAVD 88 in November 2002 (fig. 18). Waterlevel altitudes in this well also vary through time in response to changes in groundwater recharge. There does not appear to be a long-term decline in the altitude of water level in this well in response to groundwater withdrawals for the period of record.

\section{Short-Term Water Levels}

Average-daily water levels for the period of January 26, 2010, to March 31, 2011, were calculated from the 15-minute transducer water-level data. Average daily levels were calculated as altitudes for Pearce Creek Lake and selected wells, with the latter being grouped by water-bearing zone and similar approximate locations (fig. 19). The altitude of the surface of the lake is regulated at the outlet, with a rapid rise in lake level presumably the result of direct precipitation and runoff generated by precipitation. Among the monitored wells, the transducer data indicate the highest water-level altitude during the period of measurement occurred at well CE Dd 123, and the lowest occurred at well CE Dd 136. Both these wells are completed in the Magothy aquifer and are located within the bermed area of the DMCA.

Trends in water-level altitudes generally reflect seasonal patterns in evapotranspiration and water use (fig. 19). Waterlevel altitudes in the transducer wells generally increased during the winter to their highest recorded levels in early spring (January through May 2010). Both evapotranspiration and local water use (groundwater pumping) generally are low during this period. Water-level altitudes then around the end of May generally decreased through the summer to at least early fall in most wells, which generally corresponds to the time of reduced recharge, increased evapotranspiration, and increased local groundwater withdrawals. By early winter (January 2011), water-level altitudes generally increased until the time all transducers were removed from the observation wells (March 2011).

The altitudes of water levels collected at 15-minute intervals were examined in relation to Tropical Storm Nicole (fig. 20). This storm locally brought as much as 5 to 7 inches (in.) of rain to the study area during September 30-October 1, 2010. The water-level response to this tropical storm was greatest in Pearce Creek Lake; the transducer at the lake gage showed a 3 - $\mathrm{ft}$ increase in the altitude of the lake surface during this storm. The altitude of water level increased at most wells during the storm (fig. 20).

Increases in groundwater-level altitudes could reflect the net effects of (a) an increase in hydraulic head caused by the weight of the increased volume of river water on the underlying sediments from a storm surge on the Elk River, (b) a decrease in barometric pressure associated with the presence of the atmospheric low (depression) reflecting the remnants of Tropical Storm Nicole, and (c) an increase in the volume of water in the lake, coupled with ponding of water within the DMCA. Several wells that are relatively near the Elk River (e.g., CE Dd 81, 126, 127, 136, and 141) display semi-diurnal variations in water levels. The greatest tidal fluctuations average about $0.5 \mathrm{ft}$ per tidal cycle and occur in the upper Patapsco shallow water-bearing zone in observation well CE Dd 127 at the base of WVS near the Elk River. Tidal fluctuations are also noted in water levels in wells in and near the western most part of the DMCA where fluctuations are generally $0.2 \mathrm{ft}$ per tidal cycle or less. From September 30 into October 1, those wells show a heightened semi-diurnal response to greater than normal tides associated with storm surge in the upper Chesapeake Bay. Tidal fluctuations vary the load on confined aquifers near and beneath coastal water bodies. The relationship is direct, with water levels in wells increasing with tidal water levels. For barometric pressure fluctuations, the relationship is inverse; a decrease in barometric pressure would lead to an increase in water levels in wells in confined aquifers. Finally, an increase in the volume of water in the lake and infiltration of water ponded within the DMCA could provide a mechanism for recharging the groundwater. In relation to 
Table 11. Wells in the Pearce Creek Dredge Material Containment Area and vicinity in which water levels were measured during the May 2010, August 2010, and March 2011 synoptic assessments to delineate the potentiometric surface in three aquifers.

[ft, feet (referenced to North American Vertical Datum of 1988); UPA, upper Patapsco aquifer; shallow, shallow water-bearing zone; deep, deep water-bearing zone; ---, well not measured]

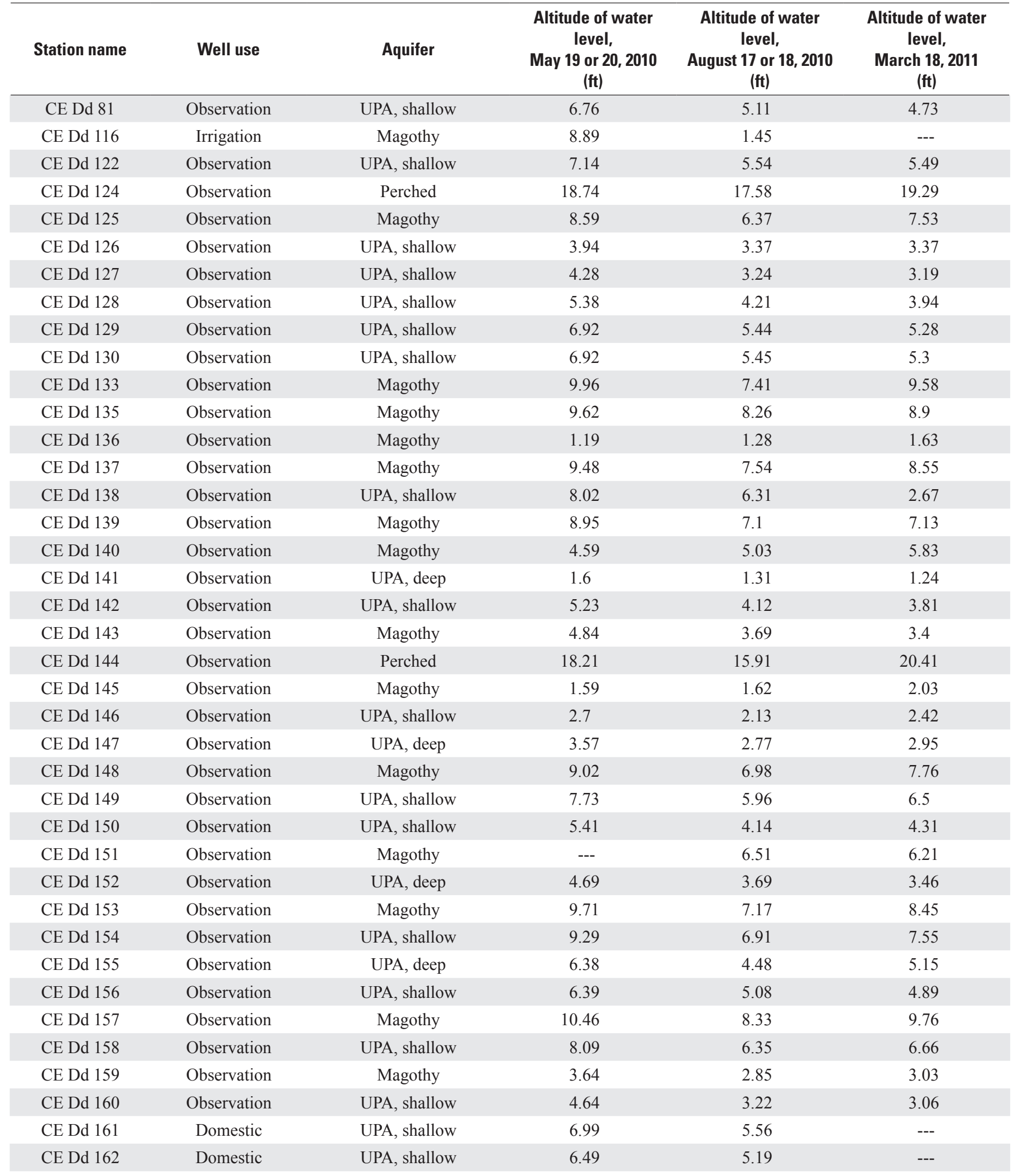


Table 11. Wells in the Pearce Creek Dredge Material Containment Area and vicinity in which water levels were measured during the May 2010, August 2010, and March 2011 synoptic assessments to delineate the potentiometric surface in three aquifers.-Continued

[ft, feet (referenced to North American Vertical Datum of 1988); UPA, upper Patapsco aquifer; shallow, shallow water-bearing zone; deep, deep water-bearing zone; ---, well not measured]

\begin{tabular}{|c|c|c|c|c|c|}
\hline Station name & Well use & Aquifer & $\begin{array}{c}\text { Altitude of water } \\
\text { level, } \\
\text { May } 19 \text { or 20, } 2010 \\
\text { (ft) }\end{array}$ & $\begin{array}{c}\text { Altitude of water } \\
\text { level, } \\
\text { August } 17 \text { or 18, } 2010 \\
\text { (ft) }\end{array}$ & $\begin{array}{c}\text { Altitude of wate } \\
\text { level, } \\
\text { March 18, } 2011 \\
\text { (ft) }\end{array}$ \\
\hline CE Dd 163 & Domestic & Magothy & 7.96 & 6.2 & --- \\
\hline CE Dd 164 & Domestic & UPA, shallow & 7.41 & 5.75 & --- \\
\hline CE Dd 165 & Domestic & Magothy & 8.13 & 6.34 & --- \\
\hline CE Dd 167 & Domestic & UPA, shallow & 3.67 & 2.85 & --- \\
\hline CE Dd 168 & Domestic & Magothy & 7.61 & 5.72 & --- \\
\hline CE Dd 169 & Domestic & UPA, shallow & 6.19 & 4.78 & --- \\
\hline CE Dd 170 & Domestic & UPA, deep & 6.79 & 5.01 & --- \\
\hline CE Dd 171 & Domestic & UPA, deep & 4.17 & 3.37 & --- \\
\hline CE Dd 174 & Domestic & UPA, shallow & --- & 5.48 & --- \\
\hline CE Dd 176 & Domestic & UPA, shallow & -- & 6.11 & --- \\
\hline CE Dd 177 & Domestic & UPA, shallow & 3.97 & --- & --- \\
\hline CE Dd 178 & Domestic & UPA, shallow & --- & 3.65 & -- \\
\hline CE Dd 179 & Domestic & Magothy & 8.24 & 6.43 & --- \\
\hline CE Dd 180 & Domestic & UPA, shallow & 3.18 & 2.19 & --- \\
\hline CE Dd 181 & Domestic & UPA, shallow & 3.12 & 2.15 & --- \\
\hline CE Dd 182 & Domestic & UPA, shallow & 3.83 & 2.63 & --- \\
\hline CE Dd 183 & Domestic & UPA, shallow & 3.98 & 2.58 & --- \\
\hline CE Dd 184 & Domestic & UPA, shallow & 3.55 & 2.03 & --- \\
\hline CE Dd 185 & Domestic & UPA, shallow & 4.33 & 2.84 & --- \\
\hline CE Dd 186 & Domestic & Magothy & 5.84 & 4.3 & --- \\
\hline CE Dd 187 & Domestic & UPA, shallow & 6.26 & 4.86 & --- \\
\hline CE Dd 188 & Domestic & UPA, deep & 3.26 & 2.88 & --- \\
\hline CE Dd 189 & Domestic & Perched & --- & 16.87 & --- \\
\hline CE Dd 190 & Domestic & UPA, shallow & 2.21 & 1.99 & --- \\
\hline CE Dd 191 & Observation & UPA, shallow & $6.11^{\mathrm{a}}$ & $4.18^{\mathrm{a}}$ & 5.21 \\
\hline CE Dd 192 & Observation & Magothy & $10.23^{\mathrm{a}}$ & $7.78^{\mathrm{a}}$ & 9.21 \\
\hline CE Dd 193 & Observation & Magothy & $9.85^{\mathrm{a}}$ & $7.59^{\mathrm{a}}$ & 8.92 \\
\hline
\end{tabular}

a Value was calculated.

the pre-storm water-level altitudes, post-storm water-level altitudes in several wells completed in the Magothy aquifer appear elevated and continued to rise thereafter (fig. 20).

Daily fluctuations in groundwater levels in the upper Patapsco aquifer shallow water-bearing zone are evident in well CE Dd 154 owing to nearby groundwater withdrawals. Well CE Dd 154 is part of a three-well nest where well CE Dd 153 is screened in the Magothy aquifer and CE Dd 155 is screened in the upper Patapsco aquifer deep water-bearing zone. The isolation of the three units from one another in this area is noted by the lack of any appreciable effect of nearby pumping as recorded in adjacent well CE Dd 154, screened in the upper Patapsco aquifer shallow water-bearing zone.

\section{Groundwater-Level Synoptic Assessments}

Groundwater flow directions in the Magothy and upper Patapsco aquifer shallow and deep water-bearing zones are based on potentiometric surface maps delineated using groundwater-level data collected during synoptic water-level assessments in May and August 2010 and March 2011 (table 11). May and August 2010 maps include estimated water levels for well 192 and well 193 screened in the Magothy aquifer and well 191 screened in the upper Patapsco aquifer shallow water-bearing zone. These wells were installed following the May and August synoptic assessments. The synoptic altitudes of water levels for wells 192 and 193 

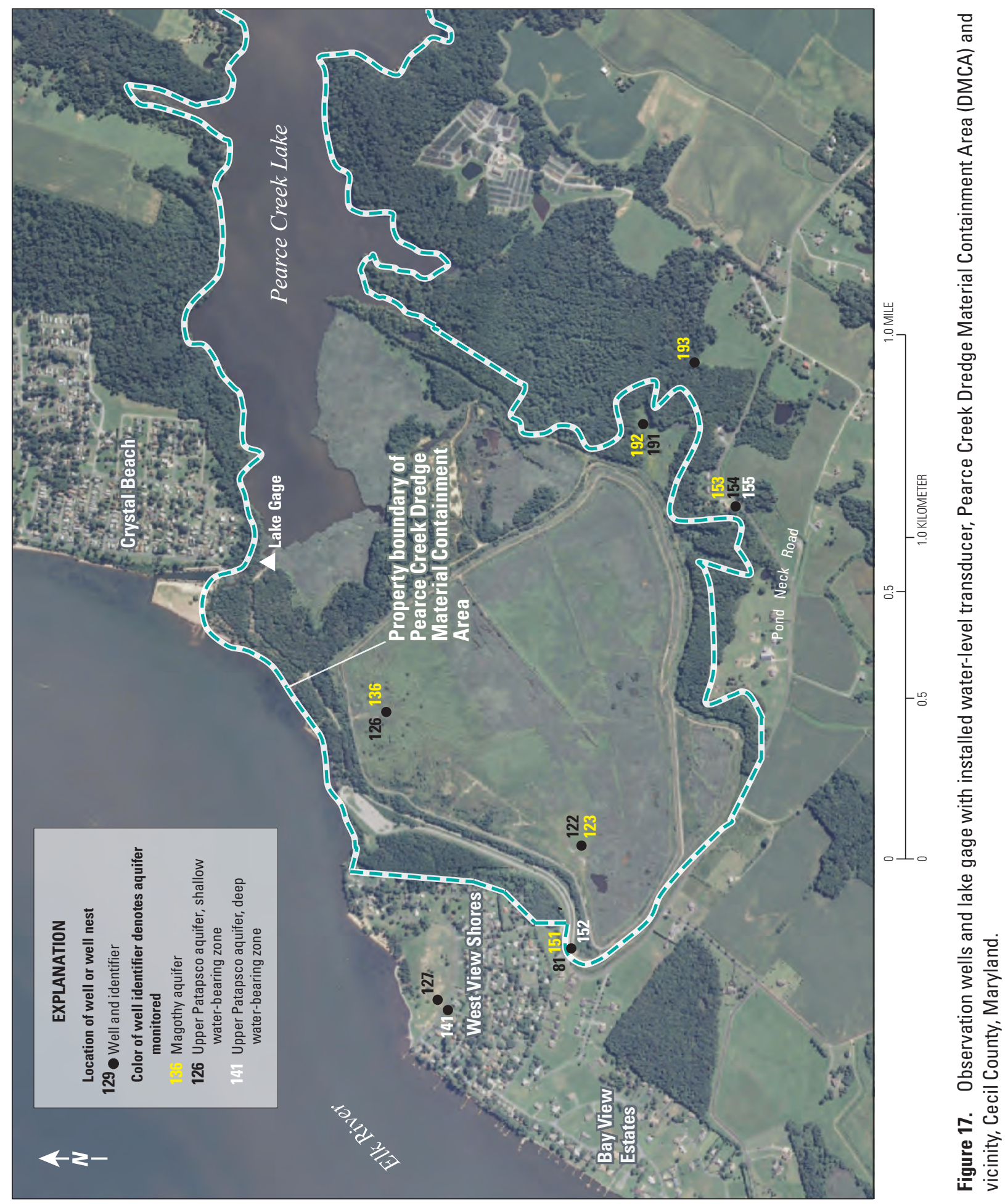


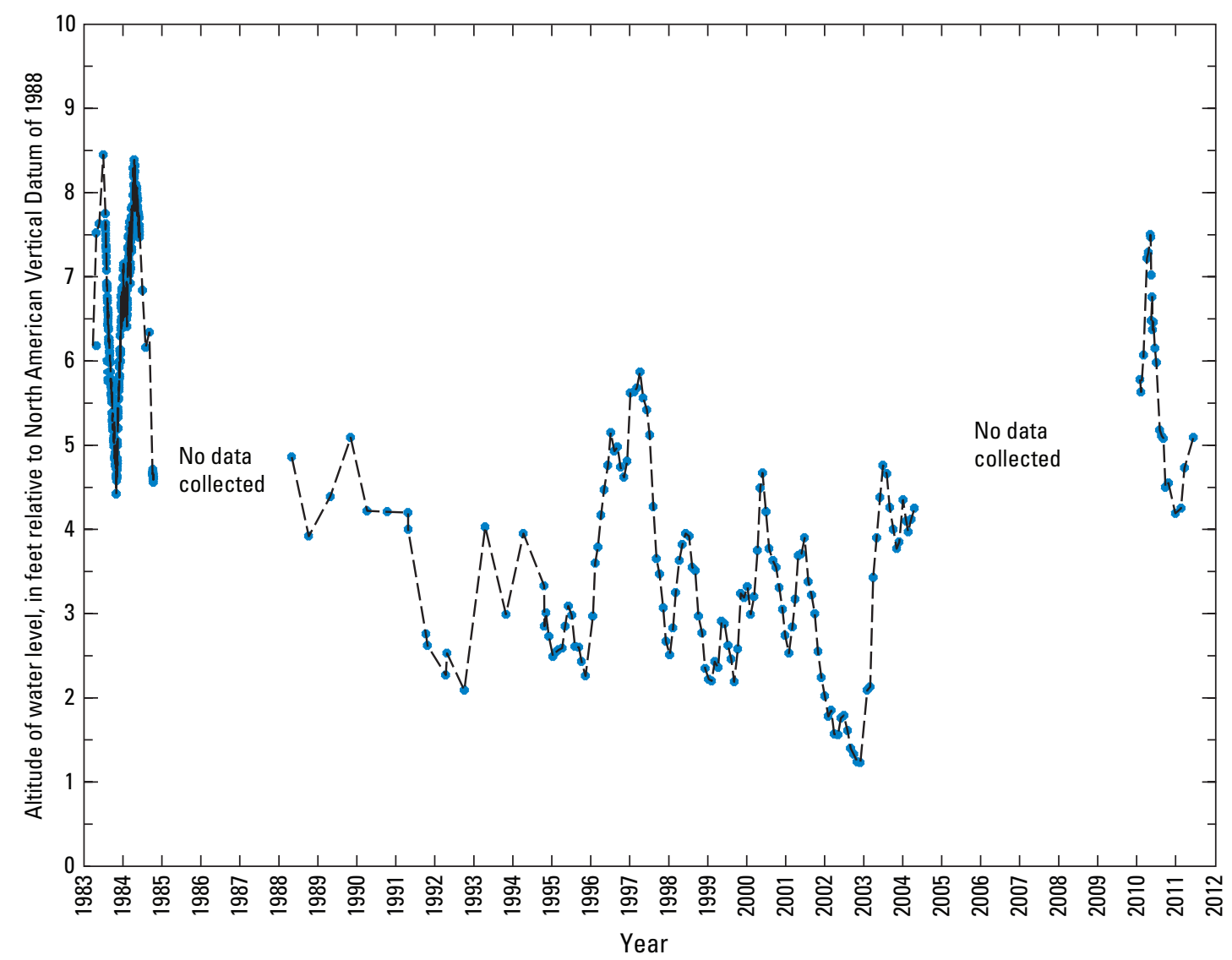

Figure 18. Altitude of water levels in well CE Dd 81 near Pearce Creek Dredge Material Containment Area (DMCA), Cecil County, Maryland, March 1983-June 2011.

were determined by estimating what the water levels would have been based on a simple linear regression of water levels in wells 192 and 193 with water-levels in well 153. (The coefficients of determination for the trend lines for wells 153 and 192, and for wells 153 and 193, were 0.983 and 0.991 , respectively.)

The comparable well for well 191 was well 154. Well 154, an upper Patapsco aquifer shallow water-bearing zone well, and well 153 are located on private property with a homeowner well that is also screened in the upper Patapsco aquifer shallow water-bearing zone. Withdrawals from the homeowner well cause declines in the altitude of water level in well 154-usually several times daily, with the altitude of water level recovering between withdrawal periods; this is clearly seen in figure 20. Because of the daily fluctuations in water level in well 154, the maximum daily altitudes of water levels for wells 154 and 191 were used for the linear regression. (The coefficient of determination value for this trend line was 0.9812 .) The maximum daily water-level altitude could differ from a synoptic level taken at a specific time during the day, but the difference is expected to be small; for example, the greatest daily difference recorded by the transducer in well 191 was $0.28 \mathrm{ft}$.

\section{Magothy Aquifer: May 19-20, 2010, Synoptic Assessment}

The altitude of groundwater levels was determined for the 16 observation wells, 5 domestic wells, and 1 irrigation well open to the Magothy aquifer from the groundwater-level measurements taken during May 19-20, 2010. The altitude of water levels in all Magothy aquifer wells and lake-bed piezometers measured during the May 19-20 synoptic assessment were used to develop the potentiometric-surface contours for the Magothy aquifer (fig. 21). Groundwater flow within the aquifer is interpreted as being perpendicular to the contours with flow in the direction of high groundwater altitude to low groundwater altitude. Areas of highest groundwater altitude generally occur in the southeastern part of the DMCA property. Groundwater flow is generally outward from this area, northward to Pearce Creek Lake, south toward Pond Neck Road, and northwest and westward toward WVS and the Elk River. A groundwater flow divide running in an easterly direction through the DMCA separates northerly and southerly flow components. The horizontal gradients are low to the east of the DMCA property, indicating little flow from the DMCA property toward the east, or from the east towards the DMCA property. 


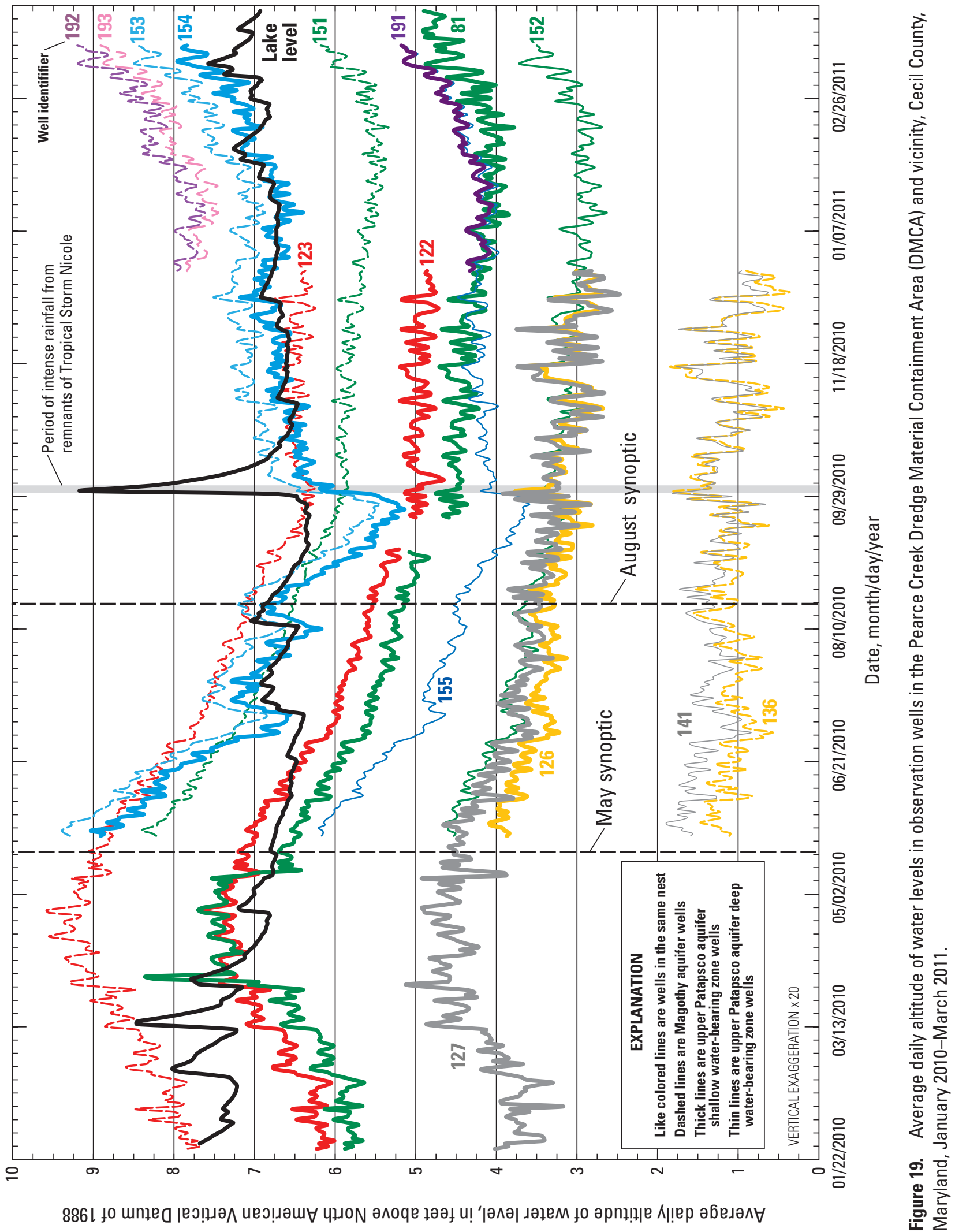




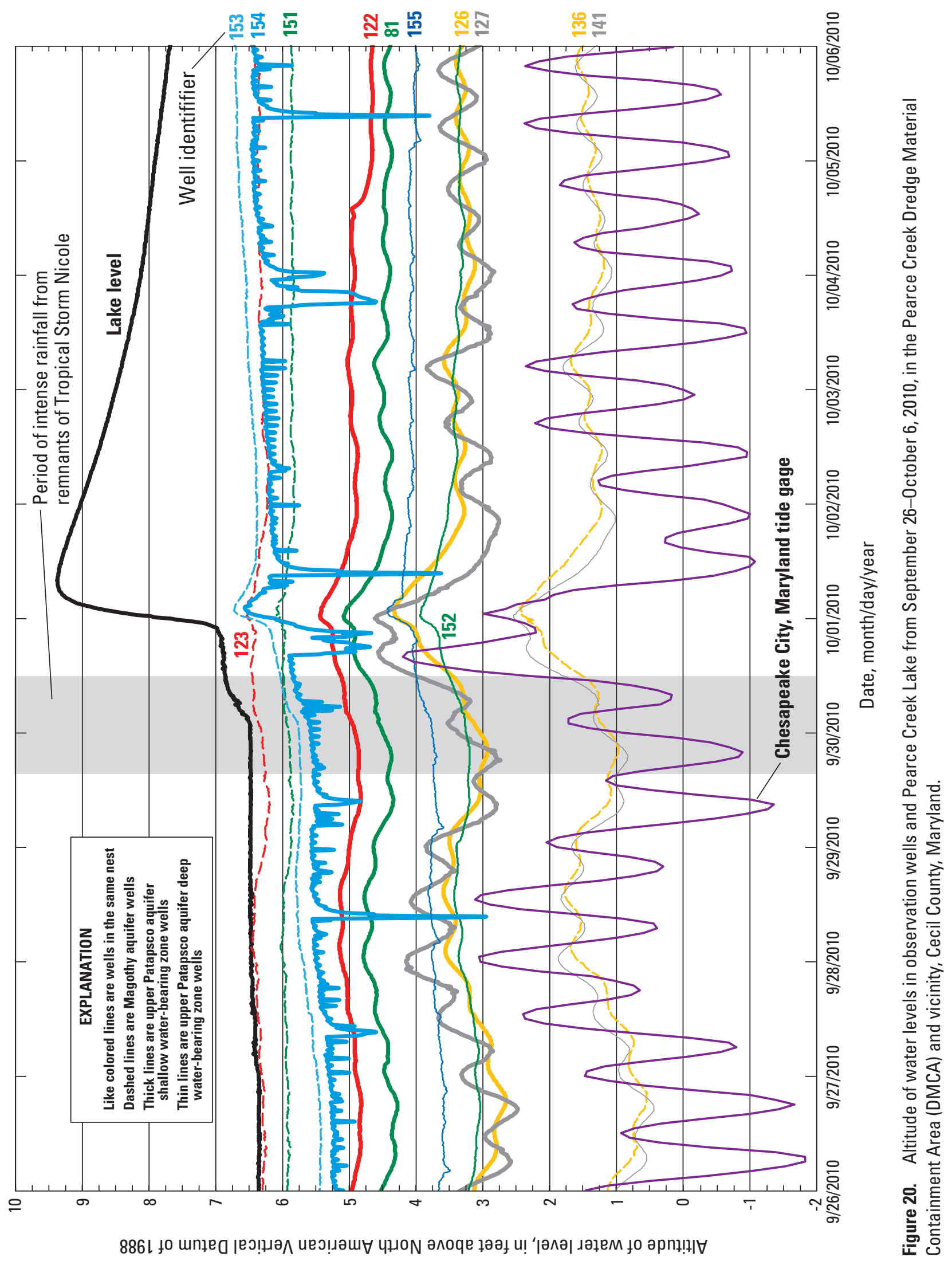


The potentiometric-surface contours in the area of Pearce Creek Lake during the May 2010 synoptic assessment were in part derived on the basis of the altitude of water levels obtained from the lake-bed piezometers (fig. 21). Except for areas of isolated clay or cemented sediments, most piezometer installations indicated that the lake-bed muck is hydraulically connected to underlying sands, implying that the Magothy aquifer subcrops beneath Pearce Creek Lake. Just to the east of the 6-ft potentiometric-surface contour, the altitude of the water level in the lake bed was the same as the lake level (fig. 21, P-11). When this piezometer was driven into the lake bed, solid clay was encountered immediately below the lake-bed deposits, and the piezometer was set into the lake-bed deposits. Thus, the altitude of the water level in this piezometer is that of the lake and not of the groundwater. Clay and iron-cemented sediments were encountered in the area between P-8 and P-9 (fig. 21); no water-level measurement could be made from a piezometer that was to be installed in this location. Cemented sediments also were encountered during initial attempts to install a third piezometer (fig. 21, P-4); however, this piezometer was eventually set in sand below the lake bottom.

During the May 2010 synoptic assessment, the altitude of the lake was calculated at $6.79 \mathrm{ft}$ on the basis of the lake staff gage reading on May 19, 2010. The continuous-gage lake-level data associated with this staff gage indicate that the lake level varied between 6.78 and $6.81 \mathrm{ft}$ during the 2-day synoptic assessment; thus variations between -0.01 and $0.02 \mathrm{ft}$ in the lake-bed piezometer measurements could be due to variations in the lake level. However, the lake-bed piezometers at the downstream end of the lake had an altitude of groundwater level in the Magothy aquifer that was $1.3 \mathrm{ft}$ less than the altitude of the lake (fig. 21, P-1 and P-7). This difference in water-level altitudes indicates that in the down-lake area in the vicinity of these two piezometers there is flow from the lake downward to the Magothy aquifer. Up-lake from these two piezometers, the vertical flow measurements indicate that during this synoptic assessment groundwater from the Magothy aquifer is discharging to the lake (fig. 21).

\section{Magothy Aquifer: August 17-18, 2010, Synoptic Assessment}

The altitude of groundwater levels was determined for the 16 observation wells, 5 domestic wells, and 1 irrigation well open to the Magothy aquifer from the groundwater-level measurements taken during August 17-18, 2010. The lake-bed piezometer at the downstream end of Pearce Creek Lake was reinstalled and an altitude of water level also was obtained at this piezometer. In general, the altitude of water levels in the remeasured wells and piezometer were lower than the altitude of water levels during the May 2012 synoptic assessment. Continuous altitude of water-level measurements confirm that between May and August 2010 there was a generally decreasing trend in the altitudes of water levels for the transducer wells open to the Magothy aquifer (fig. 19). The two exceptions were well 140 and well 145, which both are located near Elk River (fig. 17). Tidal influences could have caused the higher August level in well 145, but the consistently erratic levels in well 140 are indicative of a problem in well construction. The mean difference of the altitude of water level between the May and August levels, for all Magothy aquifer wells, was $1.82 \mathrm{ft}$. This includes one relatively large difference of $7.44 \mathrm{ft}$ for well 116, an active irrigation well to the east of the DMCA property; this difference is likely the result of local withdrawals from this and nearby irrigation wells.

The potentiometric-surface contours derived from the altitudes of water levels in the August 2010 synoptic assessment (fig. 22) generally resemble contours derived from the May 2010 synoptic assessment. Thus the pattern in groundwater flow within the Magothy aquifer during the late summer and spring synoptic assessments is similar despite the general decline in the altitude of water levels.

\section{Magothy Aquifer: March 18, 2011, Synoptic Assessment}

The altitude of groundwater levels was determined for the 16 observation wells open to the Magothy aquifer from the groundwater-level measurements taken on March 18, 2011. These late winter-early spring water levels are overall higher than those of August 2010 but generally not as high as those taken during May 2010 (table 11).

The potentiometric surface of the Magothy aquifer on March 18, 2010, is shown in figure 23. The pattern of horizontal flow in the Magothy aquifer within the study area is relatively consistent with previous synoptic results. Areas of highest groundwater altitude generally occur in the southeastern part of the DMCA. Groundwater flow is generally outward from this area, northward to Pearce Creek Lake, south toward Pond Neck Road and northwest and westward toward WVS and the Elk River. Horizontal gradients are low to the east of the DMCA property, indicating little flow from the DMCA property toward the east, or from the east toward the DMCA property.

\section{Upper Patapsco Aquifer Shallow Water-Bearing Zone: May 19-20, 2010, Synoptic Assessment}

The altitudes of groundwater levels were determined for 17 observation wells and 14 domestic wells open to the upper Patapsco aquifer shallow water-bearing zone from the groundwater-level measurements taken during the May 19-20, 2010, synoptic assessment. The altitudes of water levels in these wells from the May 19-20 synoptic assessment were used to derive the potentiometric-surface contours for this zone (fig. 24). The pattern of horizontal groundwater flow within this water-bearing zone during the May 2010 synoptic assessment was similar to the pattern of groundwater flow observed in the Magothy aquifer during this period. The potentiometric 


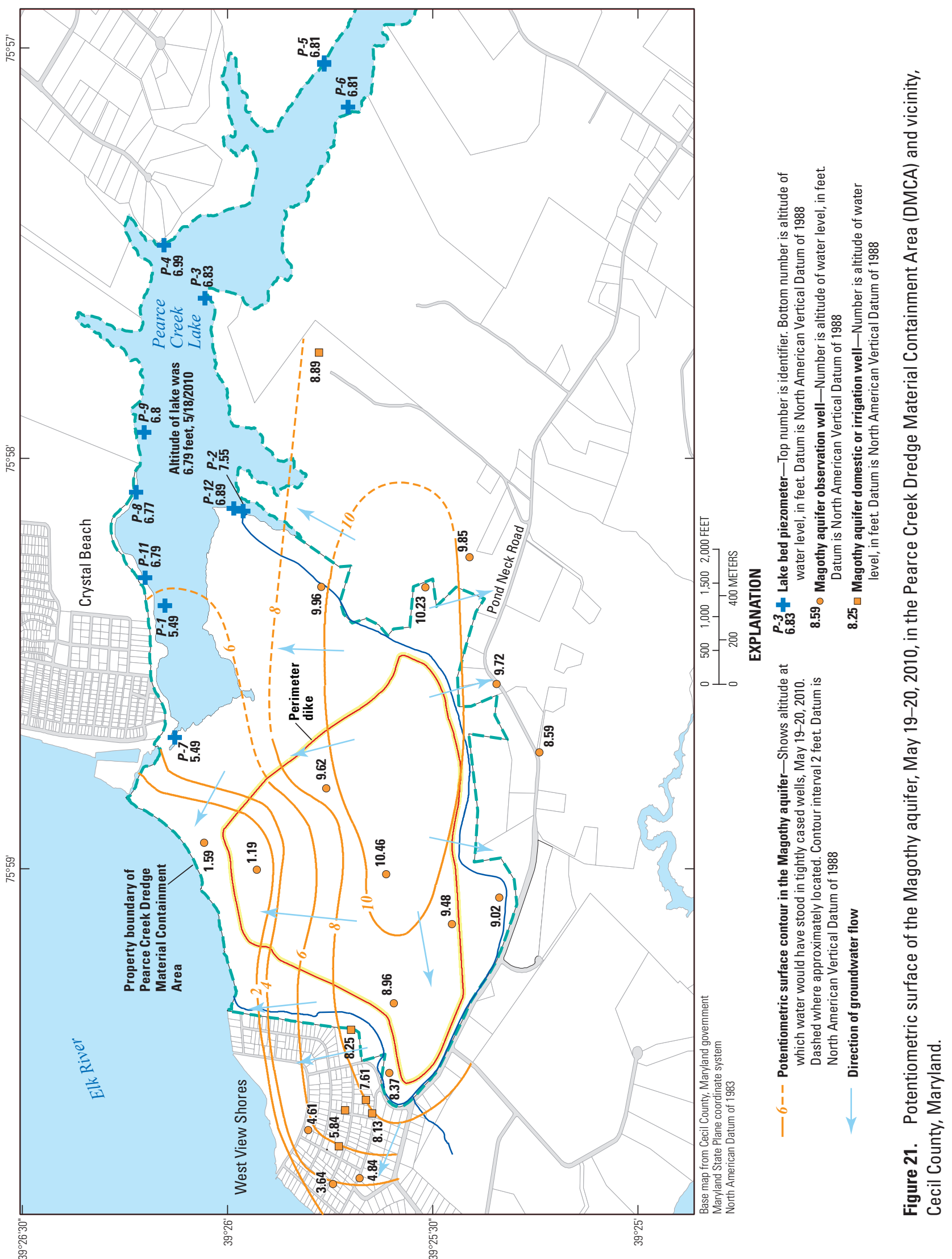


surface of the upper Patapsco aquifer shallow water-bearing zone has its highest altitudes in approximately the same location as the Magothy aquifer, but May 2010 upper Patapsco aquifer shallow heads are approximately 1 to $2 \mathrm{ft}$ lower than the highest altitudes of the Magothy potentiometric surface during the same time period. Similar to groundwater flow within the Magothy aquifer, groundwater flow within the upper Patapsco shallow water-bearing zone within the DMCA is interpreted to be northward and westward toward the Elk River and WVS. However, the horizontal gradients are low in the southeastern corner of the DMCA property and south along Pond Neck Road indicating little horizontal flow in this southern part of the study area.

\section{Upper Patapsco Aquifer Shallow Water-Bearing Zone: August 17-18, 2010, Synoptic Assessment}

The altitudes of groundwater levels were determined for 17 observation wells and 16 domestic wells open to the upper Patapsco aquifer shallow water-bearing zone from the groundwater-level measurements taken during the August 17-18, 2010, synoptic assessment. The altitudes of water levels in all wells completed in upper Patapsco aquifer shallow waterbearing zone from the August 17-18, 2010, synoptic assessment were used to derive potentiometric-surface contours for this time period (fig. 25). Synoptic results indicate the altitudes of water levels were lower during the August synoptic assessment compared to the May synoptic assessment (figs. 24 and 25). The decline in water-level altitudes between May and August 2010 is confirmed by the generally decreasing trend in continuous water-level altitudes for the wells open to the upper Patapsco aquifer shallow-water-bearing zone (fig. 19). The mean difference in altitude of water levels for this waterbearing zone between the May and August synoptic assessments was $1.34 \mathrm{ft}$.

The pattern of groundwater flow within the upper Patapsco aquifer shallow water-bearing zone, interpreted from the August synoptic levels, is similar to the pattern of flow observed on the basis of the May synoptic levels (figs. 24 and 25).

\section{Upper Patapsco Aquifer Shallow Water-Bearing Zone: March 18, 2011, Synoptic Assessment}

The altitudes of groundwater levels determined for 17 observation wells open to the upper Patapsco aquifer shallow water-bearing zone from the groundwater-level measurements taken during March 18, 2011, are contoured on the potentiometric map in figure 26. Groundwater flow directions during this period are essentially the same as described for the previous two synoptic measurements for this aquifer.

\section{Upper Patapsco Aquifer Deep Water-Bearing} Zone: May 19-20, 2010, Synoptic Assessment

The altitudes of groundwater levels were determined for four observation wells and three domestic wells open to the upper Patapsco aquifer deep water-bearing zone from the groundwater-level measurements taken during May 19-20, 2010. Although the paucity of data limits the accuracy of interpretation, potentiometric-surface contours for this waterbearing zone were derived from the water-level altitudes obtained from these 7 wells (fig. 27). The resultant contours indicate that groundwater in this zone generally follows the axis of the Pond Neck peninsula, and travels northwestward to the Elk River.

\section{Upper Patapsco Aquifer Deep Water-Bearing Zone: August 17-18, 2010, Synoptic Assessment}

All wells used for water-level measurements during the May 2010 synoptic assessment were reused during the August 2010 synoptic assessment. The altitudes of water levels in these wells were used to determine the potentiometric-surface contours for the upper Patapsco aquifer deep water-bearing zone (fig. 28). Similar to the synoptic results for the Magothy and upper Patapsco aquifer shallow water-bearing zone, the water-level altitudes in the upper Patapsco aquifer deep waterbearing zone were lower during the August synoptic assessment compared to their altitudes the May synoptic assessment. The mean decline in the altitudes of water levels between the two synoptic assessments was $1.07 \mathrm{ft}$. The general direction of groundwater flow in August remained northwestward toward the Elk River.

\section{Perched Groundwater Zone: August 17-18, 2010, Synoptic Assessment}

The altitude of groundwater determined for three shallow wells ( 22 to $27 \mathrm{ft}$ below land surface) located along the western property boundary of the DMCA and extending into WVS indicates a local zone of perched groundwater (fig. 29). These include wells 144 and 189, which are considered screened in part of the Magothy aquifer, and well 124, which is screened at the base of the dredge material (R.F. Weston, Inc., 1998). Water levels in these wells are approximately $10 \mathrm{ft}$ higher than surrounding wells screened deeper in the Magothy aquifer. R.F. Weston, Inc., (1998) also noted the perched water zone in well 124 based on water-level measurements taken in 1996 and 1997. The altitudes of water levels and associated potentiometric contours in figure 29 are approximate and generalized, given only three water-level altitudes form the basis of interpretation. The small unnamed stream along the western property boundary of the DMCA (fig. 29) is at approximately the same elevation as the potentiometric contours, and it is likely that the perched groundwater may be associated with, and discharges to, this unnamed stream. Water-quality data for 


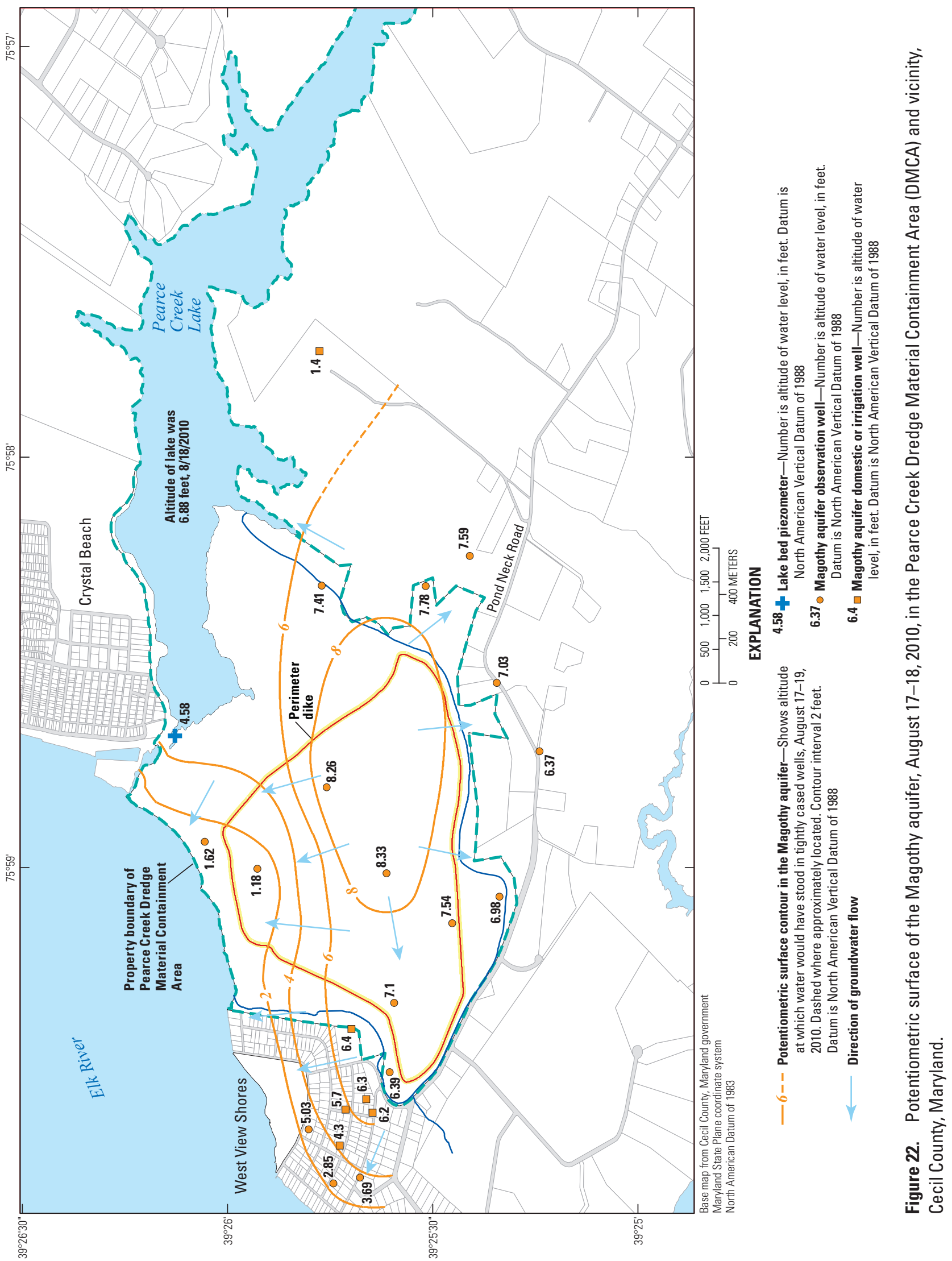




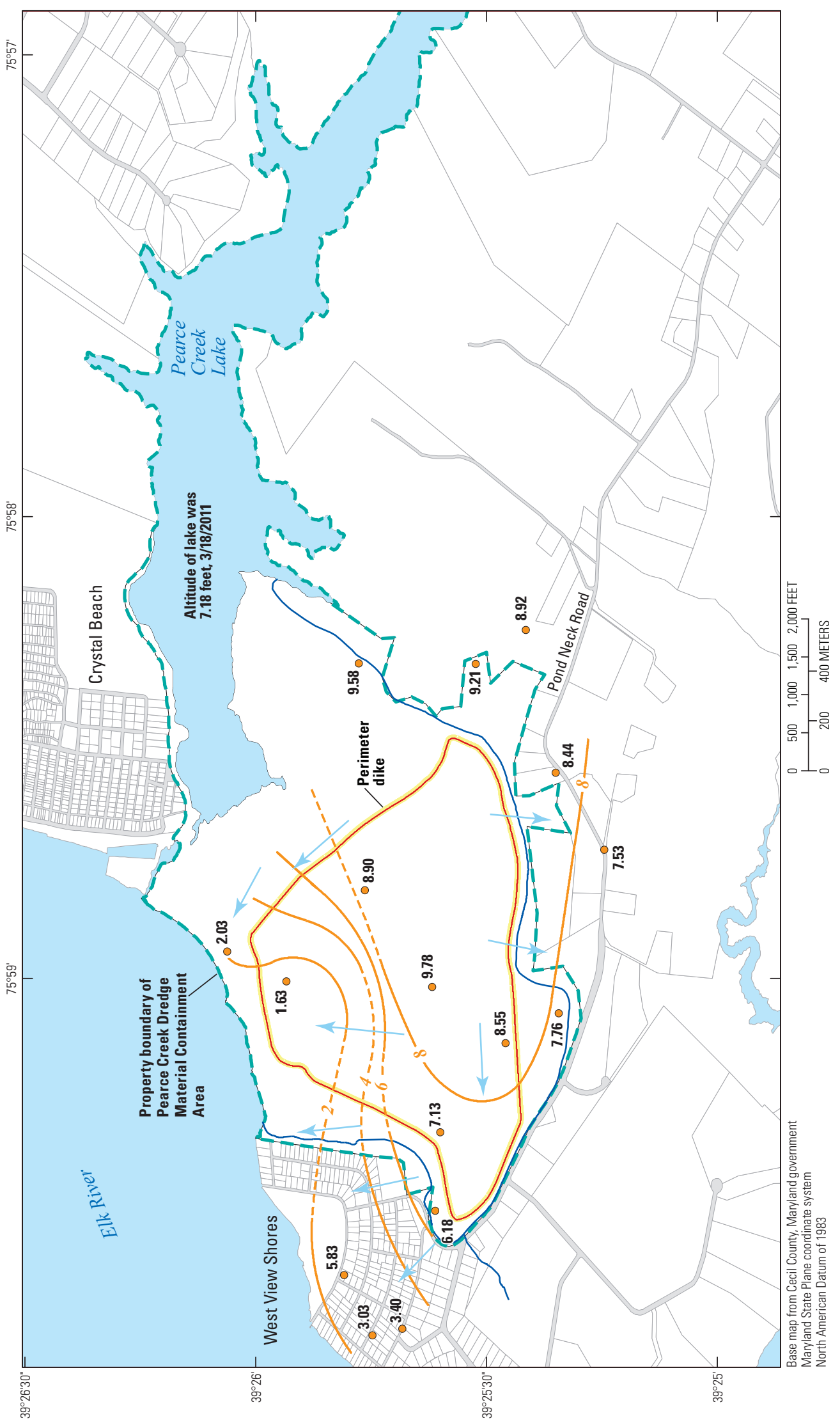

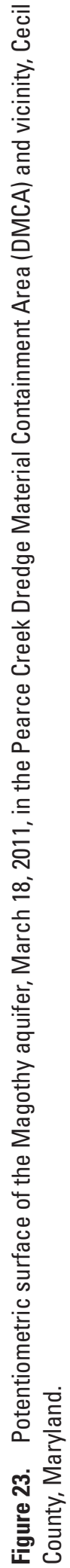



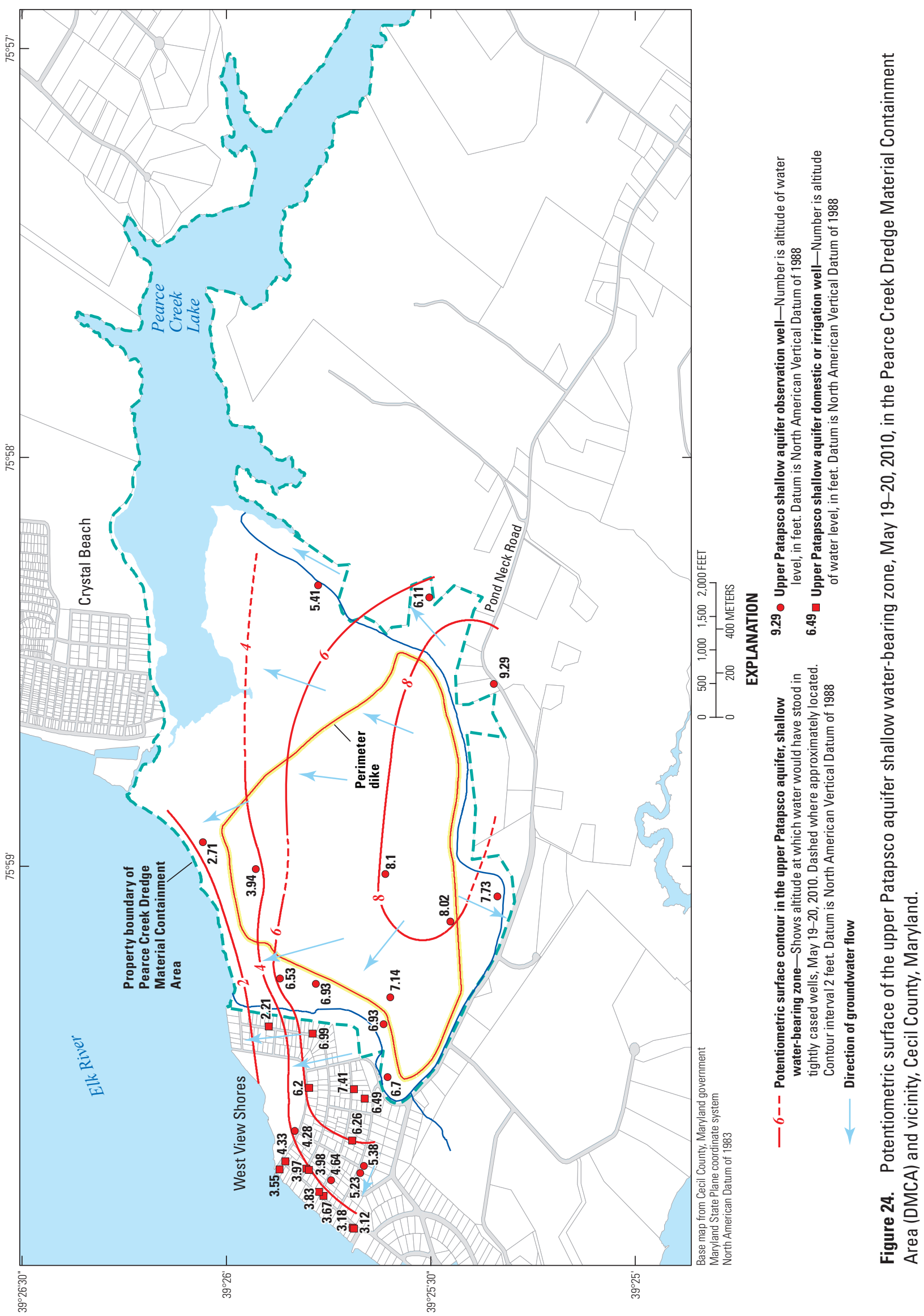


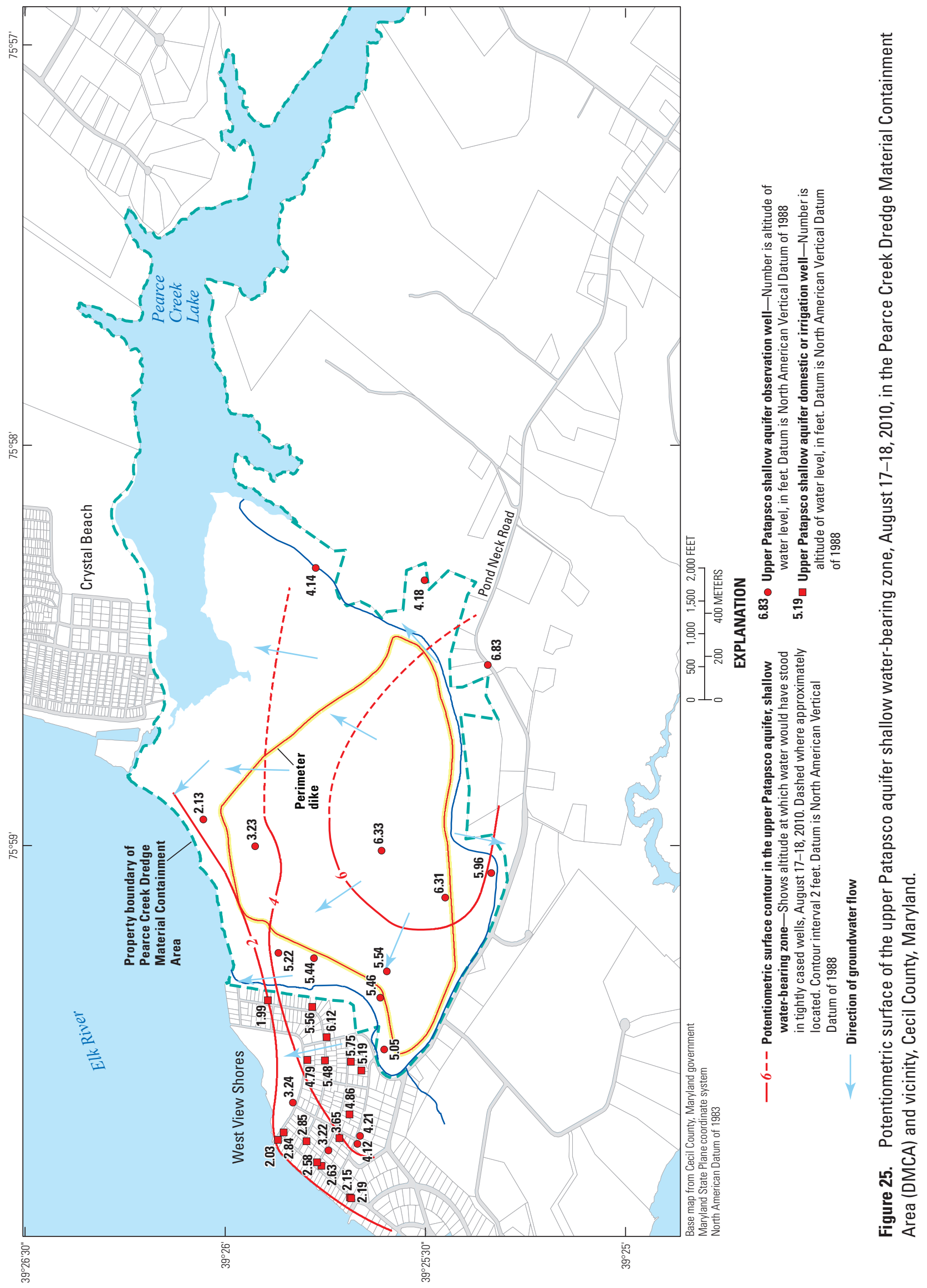




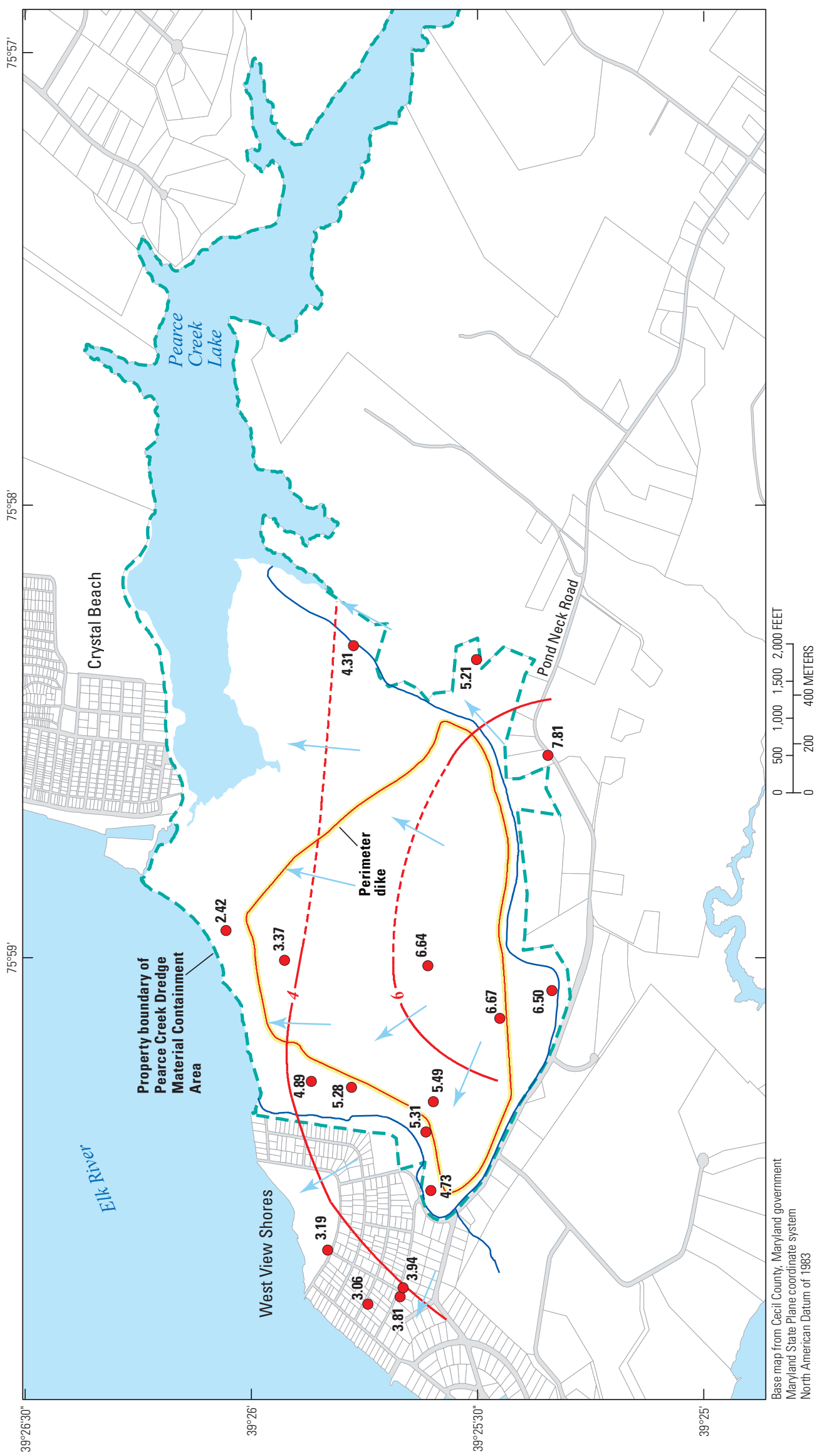

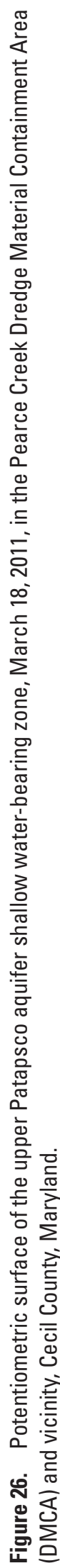



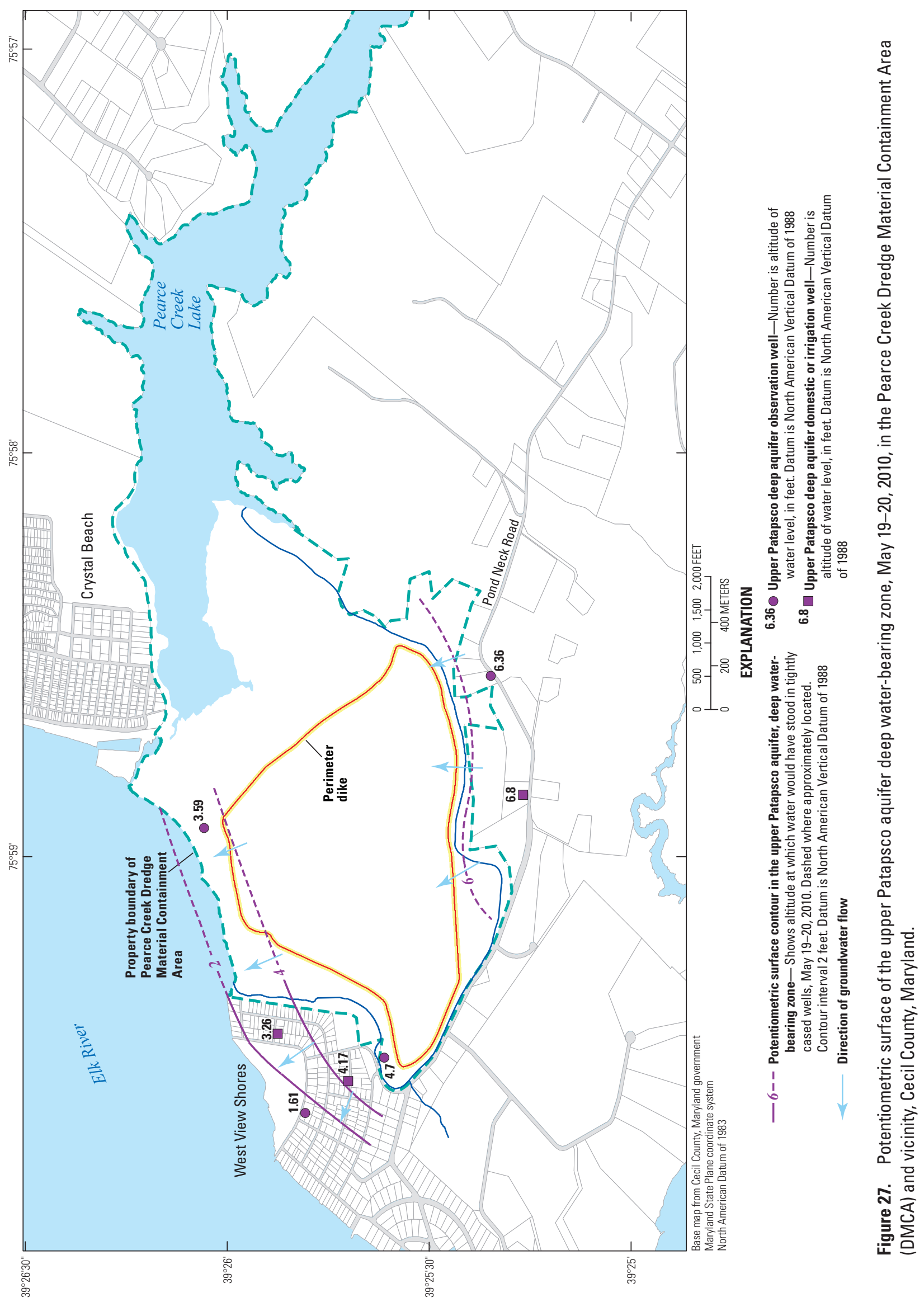


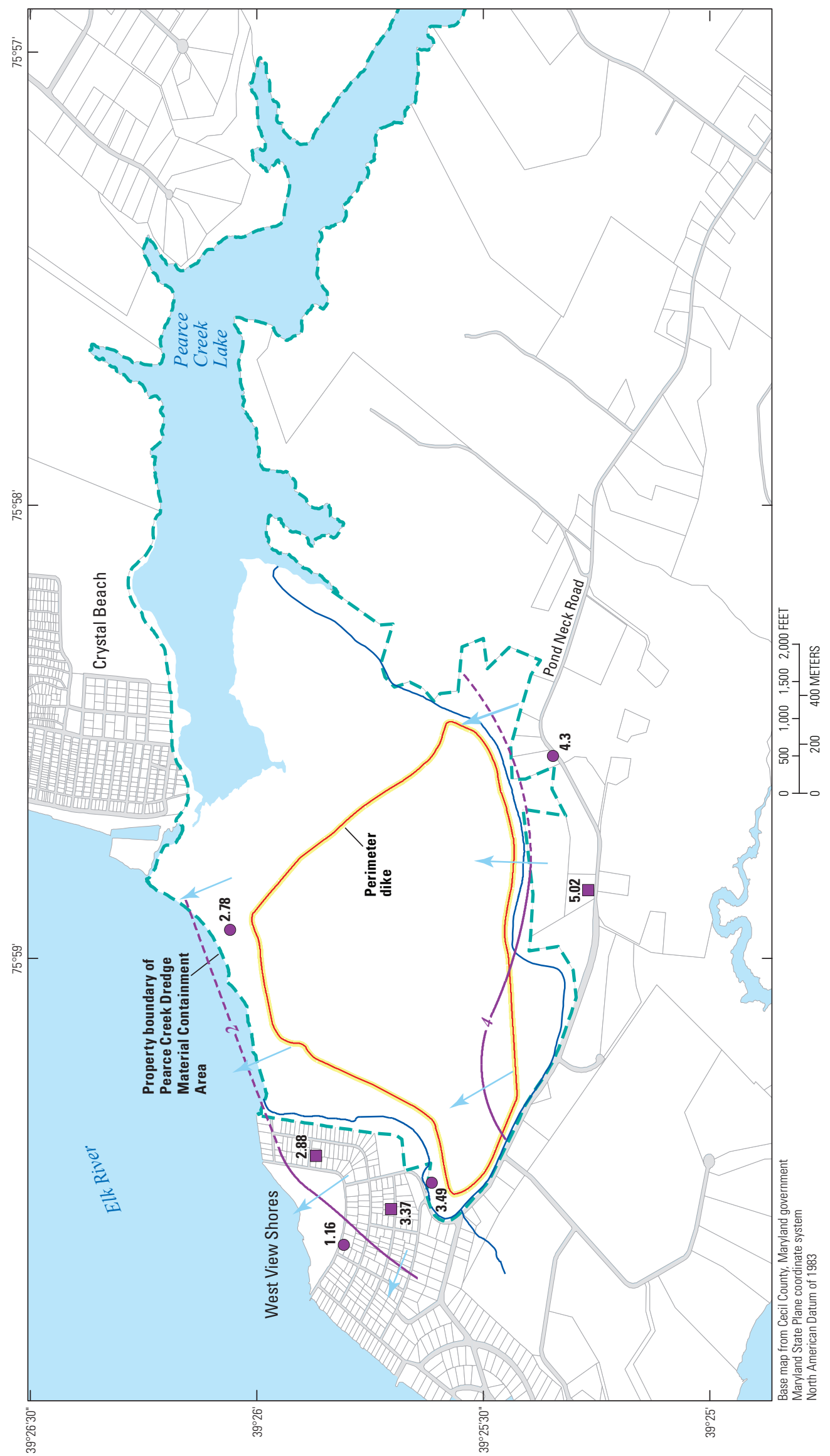

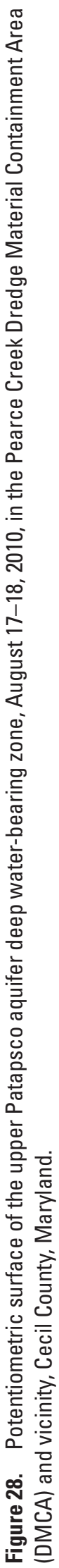


these shallow water table wells are included on maps of the Magothy aquifer.

\section{Cross-Sectional Flow}

In addition to potentiometric surfaces presented in map view, two-dimensional representations of groundwater flow along selected cross sections provide a perspective of vertical as well as horizontal groundwater flow within and between the three major water-bearing zones within the study area (fig. 30, section $A-A^{\prime}$ and fig. 31 , section $B-B^{\prime}$ ). Section $A-A^{\prime}$ (fig. 30) extends eastward from Elk River through WVS and the DMCA. Section $B-B^{\prime}$ (fig. 31) runs perpendicular to $A-A^{\prime}$ and in a north-south direction from Elk River to just beyond the southern property boundary of the DMCA. These sections have been generalized to show a vertical profile of well locations, screen intervals, contoured water-level data and flow directions in relation to the hydrogeologic framework. The sections extend vertically from land surface down to or through the upper Patapsco aquifer deep water-bearing zone. The potentiometric-surface contours from the May 19-20, 2010, synoptic assessment were projected onto each section and contours of equal value were connected across the confining units between the three water-bearing units.

Section $A-A^{\prime}$ (fig. 30) illustrates the direction of lateral and vertical components of flow as driven by the water-level altitudes among the hydrologic units. Downward flow at land surface implies recharge, which in the DMCA occurs mainly in response to precipitation since the DMCA's closure in the mid-1990s. Downward flow outside of the DMCA occurs in response to recharge from the lake, irrigation, and (or) septic effluent, as well as precipitation, depending on the local land use and human activities near the DMCA property.

Flow between aquifers is vertically downward over most of the area, and flow is generally impeded locally by the presence of confining units or zones of lower permeable material. However, groundwater flow along the line of section $A-A^{\prime}$ from the western part of the DMCA toward Elk River is relatively unimpeded and markedly downward where the Magothy aquifer is unconfined and hydraulically connected to the upper Patapsco aquifer shallow water-bearing zone. Ultimately, groundwater flow is vertically upward at the western end of section $A-A^{\prime}$ and discharges to the Elk River. Horizontal gradients are much lower in the eastern part of the DMCA property, indicating little flow from the DMCA property toward the east along section $A-A^{\prime}$.

Section $B-B^{\prime}$ (fig. 31) illustrates lateral flow of groundwater extending outward from the groundwater vertical divide, which is located approximately between well 138 and well 158. Along this line of section, and except in the vicinity of well 126 and well 147, vertical flow is predominantly downward through the hydrogeologic units. In the vicinity of well 126 and well 147, groundwater flow is upward as flow discharges to the Elk River. The cross-sectional patterns in groundwater flow described here form the basis for the discussion of water-quality conditions, and these patterns have direct bearing on the transport and quality of groundwater beneath the DMCA and vicinity as well as the quality of groundwater used for domestic water supplies (see Water Quality, this report).

\section{Historical Perspective}

There are no available groundwater-level data and, therefore, no interpreted directions of groundwater flow before or during the period of active disposal of dredge material at the DMCA. There are very few data for the period since the active disposal ceased at the DMCA until the 2010-11 study. This is a historical limitation in hydrologic data for this study. However, in general terms, and on the basis of topographic maps before, during, and after the DMCA was built, and hydrogeologic data collected during the 2010-11 study, the site was likely a low-elevation tidal wetland, which reflected regional groundwater discharge from the Magothy aquifer before the DMCA was constructed in the late 1930s. As is common in other coastal estuaries along the Chesapeake Bay, and on the basis of early (pre-1930s) topography of the study area, groundwater mainly would have discharged into the wetland. From this wetland, it (the former groundwater discharge) either flowed directly into the Elk River, or into Pearce Creek, and subsequently flowed into the Elk River. During the 1930s to 1990s, the construction of a land bridge limited the discharge of Pearce Creek into the Elk River and led to the creation of Pearce Creek Lake. This lake likely resulted in elevated water levels in local groundwater, particularly during the late fall through winter months. In addition, the initial construction and raising of berms used to create the DMCA, combined with an eventual rise in the land surface elevation within the DMCA of 20 to $30 \mathrm{ft}$ as a result the deposition of dredged sediments, combined with the large volumes of Elk River water that were used to transfer these sediments into the DMCA, likely contributed to a rise in water levels in local groundwater. Ultimately, the combined effects of all the above transitioned the site into an elevated local groundwater recharge area, which affected local groundwater flow patterns. Although much of the Elk River water pumped into the DMCA during sediment disposal was drained through a sluice and into Pearce Creek Lake after allowing sediments to settle over a several day period, net recharge within the DMCA as a result of sediment disposal exceeded that generally associated with the preexisting wetland under normal precipitation conditions.

Although there are no historical data that show the effects of depositing large volumes of recharge into the DMCA on groundwater levels during its use, the effects on groundwater levels could be similar to that observed from continuous water-level data in September and October 2010 from Tropical Storm Nicole, which deposited 5 to 7 in. of precipitation within a 48-hour period at the site. 


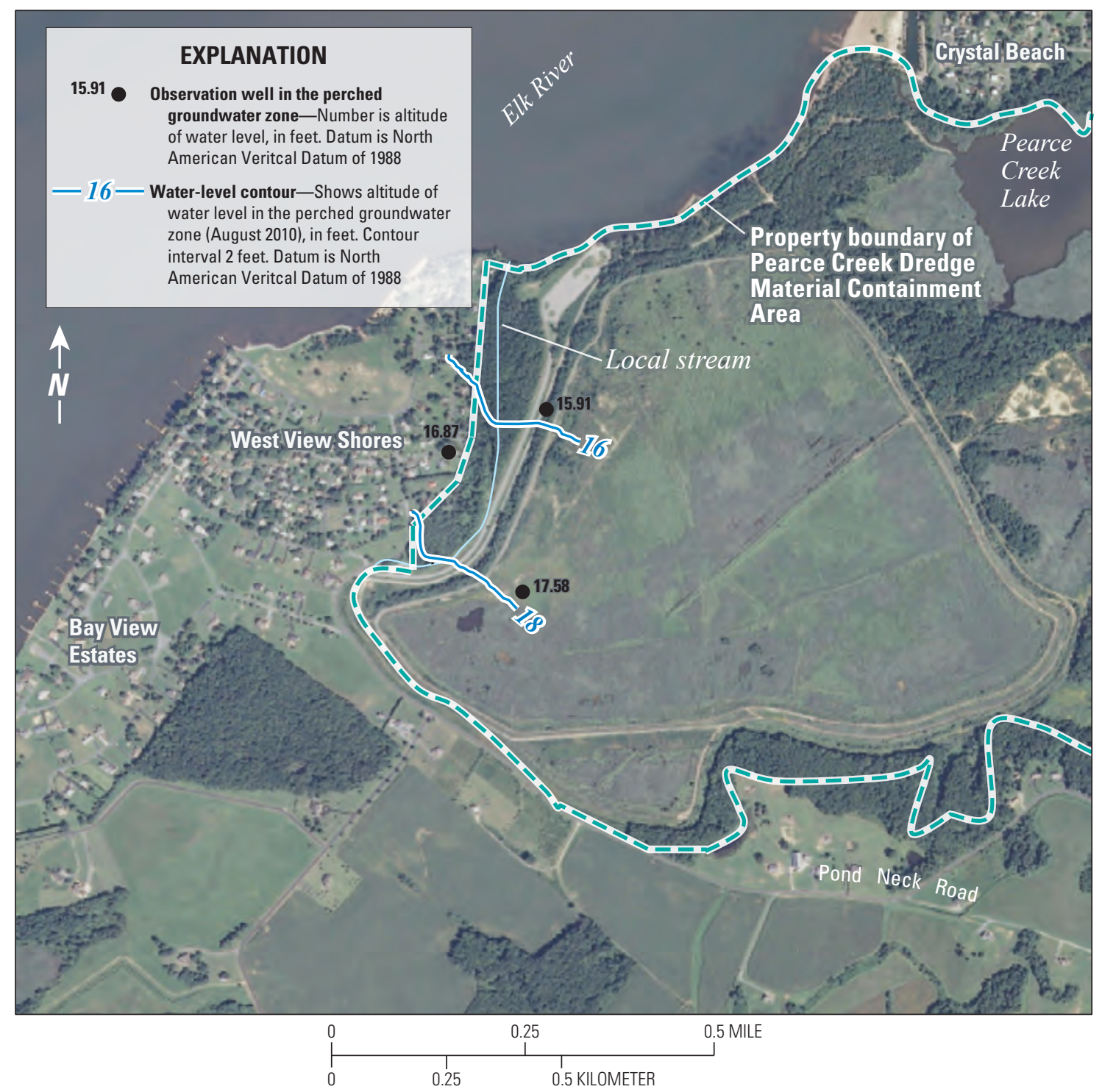

Figure 29. Potentiometric surface of a perched groundwater zone, August 17-18, 2010, in the Pearce Creek Dredge Material Containment Area (DMCA) and vicinity, Cecil County, Maryland.

Finally, despite no DMCA use during the past 2025 years, the maximum local water levels associated with the Magothy aquifer are centered over part of the DMCA. The water-level pattern is not entirely what would be expected solely from regional groundwater recharge and flow; the pattern indicates that recharge from precipitation is relatively high in the vicinity of the containment area.

\section{Water Quality}

The chemistry of regional and local surficial groundwater, both natural (or background) and that affected by human activities, of the Delmarva Peninsula has been described by Shedlock and others (1999). Natural surficial groundwater is moderately acidic, and low in total dissolved solids, specific conductance, alkalinity, nitrate as nitrogen, chloride, major cations (calcium, magnesium, sodium, and potassium), and, except in poorly draining sandy sediments with silt and organic matter, most trace elements (table 12). Under residential land use, groundwater in the surficial aquifer generally is slightly more acidic and moderately elevated in relation to most of the above properties or constituents. In the northern and inner coastal section of the Delmarva Peninsula, which includes the general area near the DMCA, Shedlock and others (1999) note that sediments typically are fine grained and low in permeability. However, their study did not specifically characterize water quality along coastal areas in the northernmost part of the Delmarva Peninsula, probably because of a paucity of historical data.

Historical data to describe the quality of local groundwater without the effects from human development in the vicinity 


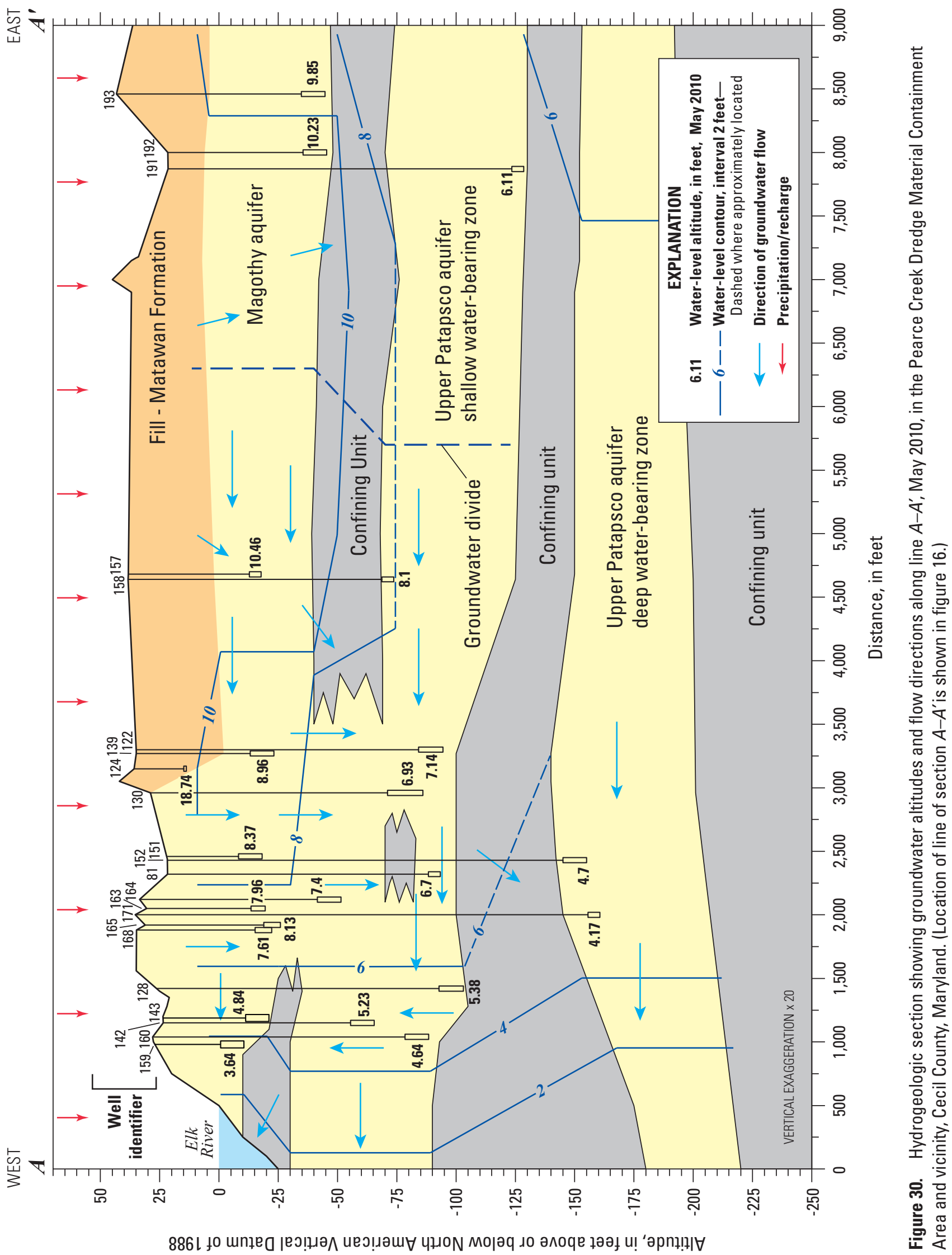




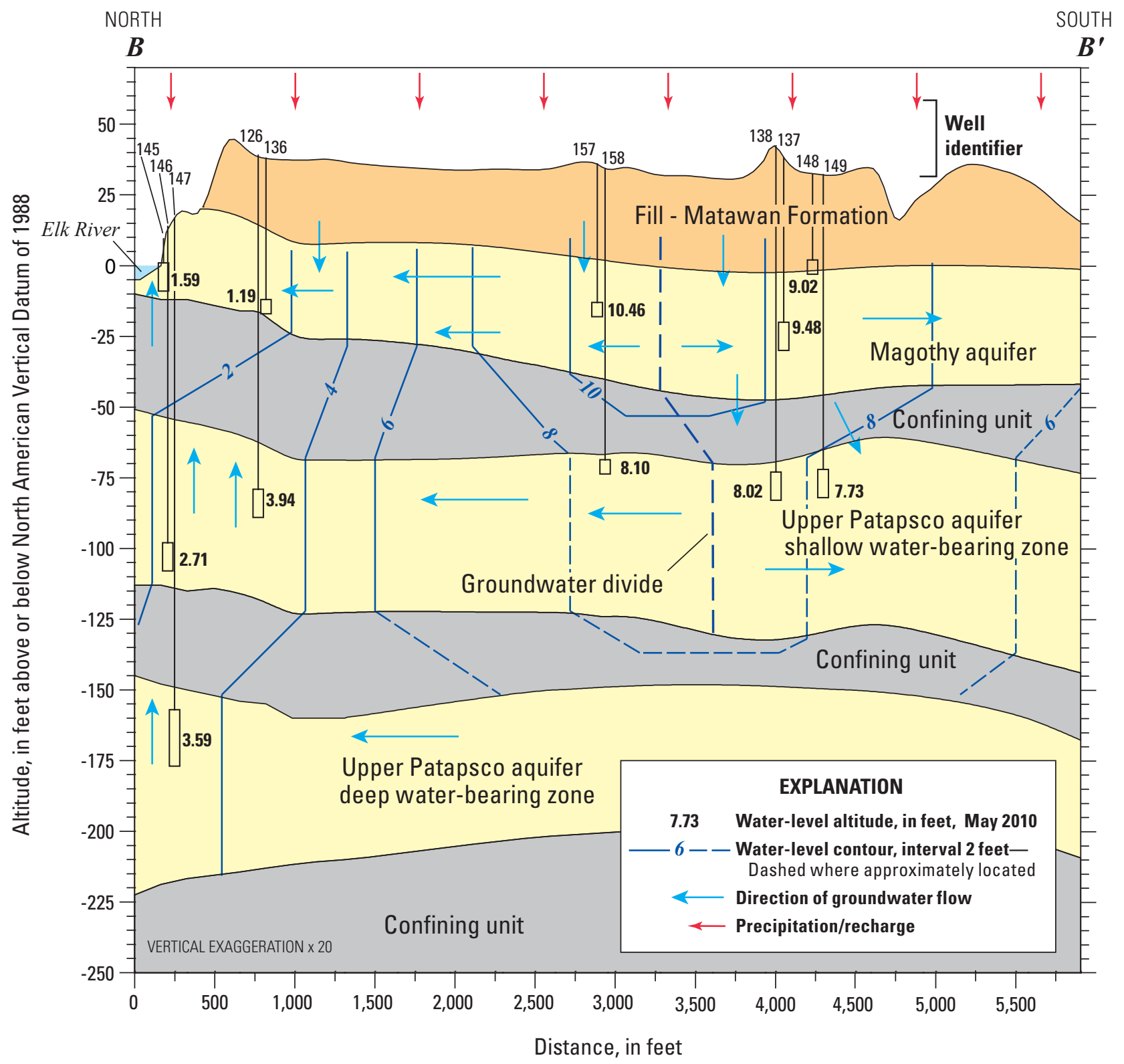

Figure 31. Hydrogeologic section showing groundwater altitudes and flow directions along line $B-B^{\prime}$, May 2010, in the Pearce Creek Dredge Material Containment Area and vicinity, Cecil County, Maryland. (Location of line of section $B-B$ 'is shown in figure 16.)

of the DMCA are limited: however, there are some groundwater-quality conditions from nearby sites (outside of the DMCA) that are available from various other studies (19832003) (table 13, fig. 32). Whereas the data are insufficient to warrant a definitive discussion of "natural or background" water-quality conditions for the study area, they are used for comparative purposes in subsequent discussions in this report as the best representation available of those conditions.

The quality of groundwater beneath the study area differed spatially within the Magothy aquifer, and within the upper Patapsco aquifer deep and shallow water-bearing zones. In part, the differences in the general chemical composition of groundwater can be linked to the previously described patterns in groundwater flow. In part, the differences also reflect differences in geochemical conditions associated with groundwater-including redox conditions and acidity - that also appear to relate to the DMCA and its influence on groundwater quality beneath and in the vicinity of the DMCA.

\section{General Water-Quality Characteristics}

The general quality of groundwater in the study area can be described in relation to the occurrence, distribution, and chemistry of total dissolved solids (TDS). Both the quantity and quality, which is presented on trilinear diagrams, of TDS are discussed in relation to the probable patterns in recharge 
and groundwater flow from the DMCA in each of the major aquifers in the study area. Collectively, these descriptions provide the basis for subsequent discussions of the redox states and acidity of groundwater and help illustrate the influence of the DMCA on the quality of groundwater in the study area, including that used for domestic drinking-water supplies.

Trilinear (Piper) diagrams provide a useful tool for the visualization of geochemical data. By plotting percentages of major ions, similarities and differences in the chemical composition of the samples can be easily illustrated. Figure 33 shows the anionic and cationic composition of groundwater and surface waters in the study area. The waters are grouped into two different categories: low TDS (less than $300 \mathrm{mg} / \mathrm{L}$ ), and high TDS (greater than $300 \mathrm{mg} / \mathrm{L}$ ) (fig. $33 A$ and $33 B$, respectively).

\section{Total Dissolved Solids and Major lons}

The concentrations of TDS in the two predominant surface waters in the vicinity of the DMCA were markedly different (fig. 34). The concentration of TDS was relatively low $(89 \mathrm{mg} / \mathrm{L})$ at the controlled discharge outlet for the landlocked Pearce Creek Lake in comparison to the concentration of TDS at the main channel of the nearby Elk River tidal estuary $(1,960 \mathrm{mg} / \mathrm{L})$. Differences between the two waters were also observed in their major ion chemistries. Sodium and chloride were the predominant ions measured in the Elk River tidal estuary, whereas mixtures of calcium and sodium cations and sulfate and chloride anions were observed in the Pearce Creek Lake water (fig. 33).

The concentration and chemistry of TDS in groundwater is heterogeneous, both spatially and vertically, amongst and within different aquifers in the study area. In the Magothy aquifer (fig. 34), concentrations of TDS ranged from 45 to $5,700 \mathrm{mg} / \mathrm{L}$. Within the DMCA property boundary, all but two of the wells sampled (135 and 145) had TDS concentrations greater than $500 \mathrm{mg} / \mathrm{L}$, the Federal Secondary Drinking Water Regulation (SDWR) for public drinking-water supplies. The two wells with the highest concentrations (greater than $5,500 \mathrm{mg} / \mathrm{L}$ ) of TDS are located just south of the DMCA property boundary along Pond Neck Road. Low TDS concentrations (less than $200 \mathrm{mg} / \mathrm{L}$ ) in the Magothy aquifer mainly occurred in the WVS community, and specifically in the topographically elevated residential area that lies just northwest of the DMCA property boundary. The lowest concentration of TDS (45 mg/L) in the Magothy aquifer occurred southeast of the DMCA and its property boundary and just north of Pond Neck Road in well CE Dd 193, which had a TDS concentration similar to natural water (tables 12 and 13).

The chemistry of the Magothy aquifer also varied greatly within the study area. Wells with TDS concentrations under $300 \mathrm{mg} / \mathrm{L}$, slightly greater than level found in natural water, showed different chemistries than those with TDS concentrations greater than $300 \mathrm{mg} / \mathrm{L}$. The main difference in chemistry was the proportion of sulfate in the samples. Sulfate was the most prevalent anion (typically greater than 50 percent of the total anion composition) in waters that had concentrations of TDS greater than $300 \mathrm{mg} / \mathrm{L}$ (fig. 33B; appendix B, table B3). This pattern was observed primarily in wells within the DMCA boundary. Wells within the WVS community with TDS under $300 \mathrm{mg} / \mathrm{L}$ had very low proportions of ferrous iron and manganese and a mixture of chloride and sulfate anions (fig. 33A). The higher percentages of chloride found in the wells under WVS may show some impact from Elk River water, in which chloride made up greater than 80 percent of the total anions (fig. 33).

In the upper Patapsco aquifer shallow water-bearing zone, as in the case of the Magothy aquifer, the concentrations of TDS also varied greatly, ranging from 75 to $6,080 \mathrm{mg} / \mathrm{L}$

(fig. 35). Elevated TDS concentrations occur along the southern and western parts of the DMCA (either within the DMCA or at its property boundary), just beyond the southeastern property boundary of the DMCA near Pond Neck Road, and west of the DMCA into WVS. Within WVS, elevated concentrations of TDS occurred peripheral to low concentrations of TDS (above and below but near $500 \mathrm{mg} / \mathrm{L}$ ) in wells located in the central part of this residential area northwest of the DMCA. The lowest concentrations of TDS occurred in this water-bearing zone throughout most of the southeastern half of the DMCA. The lowest concentration in TDS $(75 \mathrm{mg} / \mathrm{L})$ occurred in the upper Patapsco aquifer shallow water-bearing zone at the easternmost edge of the DMCA property boundary (well CE Dd 191), and may indicate

Table 12. Chemical characteristics of natural water and water affected by residential activities in the surficial aquifer of the Delmarva Peninsula (modified from Shedlock and others, 1993, 1999).

$\left[\mathrm{mg} / \mathrm{L}\right.$; milligrams per liter; $\mu \mathrm{S} / \mathrm{cm}$ at $25^{\circ} \mathrm{C}$; microsiemens per centimeter at 25 degrees Celsius; $\mathrm{CaCO}_{3}$, calcium carbonate; $\mu \mathrm{g} / \mathrm{L}$, micrograms per liter; $<$, less than; ---, not available]

\begin{tabular}{|c|c|c|c|c|c|c|c|c|c|c|c|c|c|}
\hline \multirow[b]{2}{*}{$\begin{array}{l}\text { Predominant } \\
\text { land use }\end{array}$} & \multicolumn{4}{|c|}{ Properties } & \multicolumn{9}{|c|}{ Dissolved constituents } \\
\hline & $\begin{array}{l}\text { Total } \\
\text { dis- } \\
\text { solved } \\
\text { solids } \\
\text { (mg/L) }\end{array}$ & $\begin{array}{c}\text { Specific } \\
\text { conduc- } \\
\text { tance } \\
(\mu \mathrm{S} / \mathrm{cm})\end{array}$ & $\begin{array}{l}\text { pH } \\
\text { (stan- } \\
\text { dard } \\
\text { units) }\end{array}$ & $\begin{array}{c}\text { Alka- } \\
\text { linity } \\
\text { (mg/L } \\
\text { as } \\
\mathrm{CaCO}_{3} \text { ) }\end{array}$ & $\begin{array}{c}\text { Cal- } \\
\text { cium } \\
\text { (mg/L) }\end{array}$ & $\begin{array}{l}\text { Magne- } \\
\text { sium } \\
\text { (mg/L) }\end{array}$ & $\begin{array}{c}\text { So- } \\
\text { dium } \\
\text { (mg/L) }\end{array}$ & $\begin{array}{l}\text { Potas- } \\
\text { sium } \\
(\mathrm{mg} / \mathrm{L})\end{array}$ & $\begin{array}{l}\text { Chlo- } \\
\text { ride } \\
\text { (mg/L) }\end{array}$ & $\begin{array}{c}\text { Sul- } \\
\text { fate } \\
(\mathrm{mg} / \mathrm{L})\end{array}$ & $\begin{array}{l}\text { Nitrate } \\
\text { as } \\
\text { nitrogen } \\
\text { (mg/L) }\end{array}$ & $\begin{array}{l}\text { Silica } \\
\text { (mg/L) }\end{array}$ & $\begin{array}{l}\text { Iron } \\
\text { ( } \mu \mathrm{g} / \mathrm{L})\end{array}$ \\
\hline Undeveloped & $<200$ & 115 & 5.8 & 26 & 4.8 & 1.7 & 9.4 & 1.1 & 9.1 & 6.6 & $<0.4$ & 24 & 1,800 \\
\hline
\end{tabular}




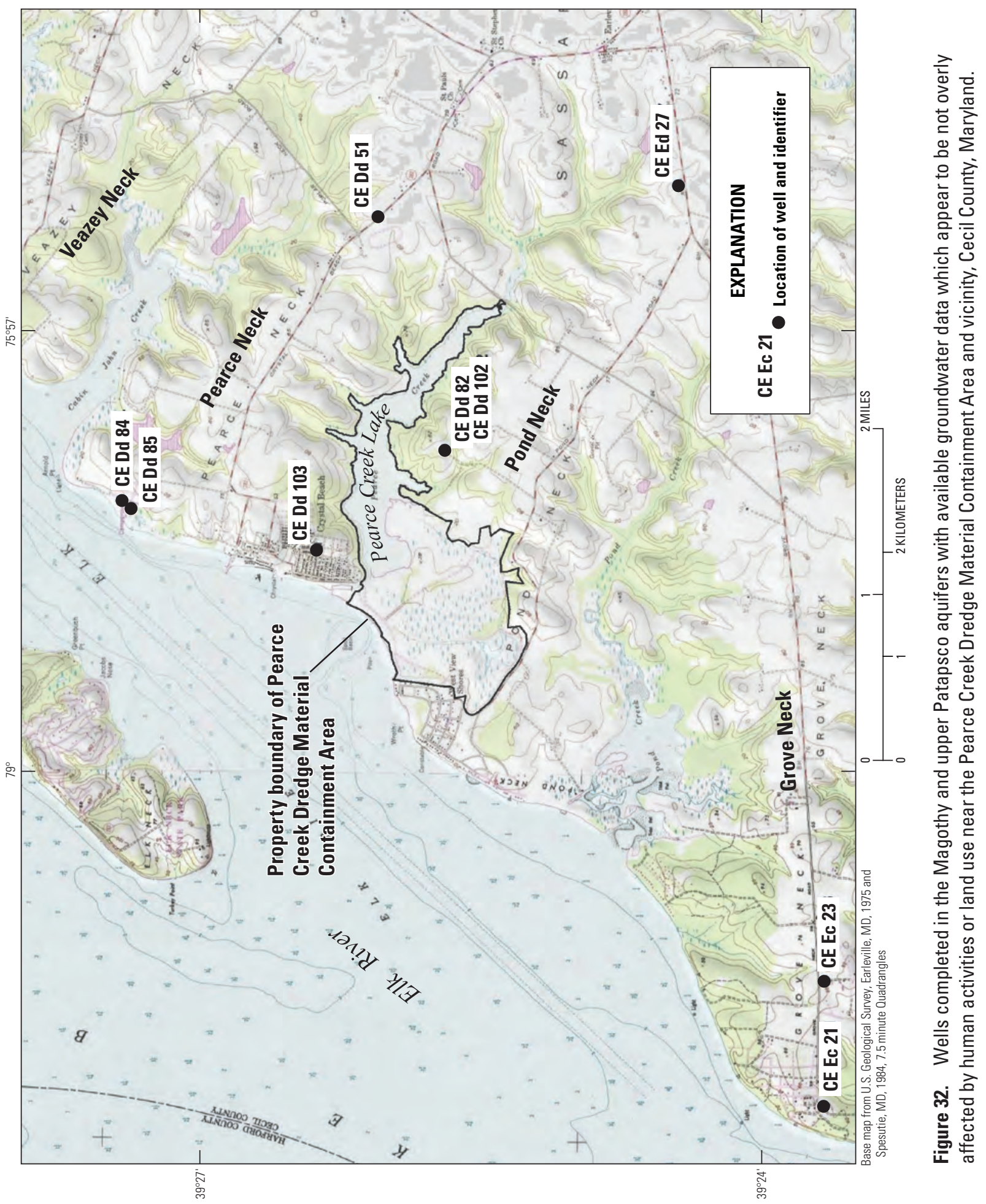




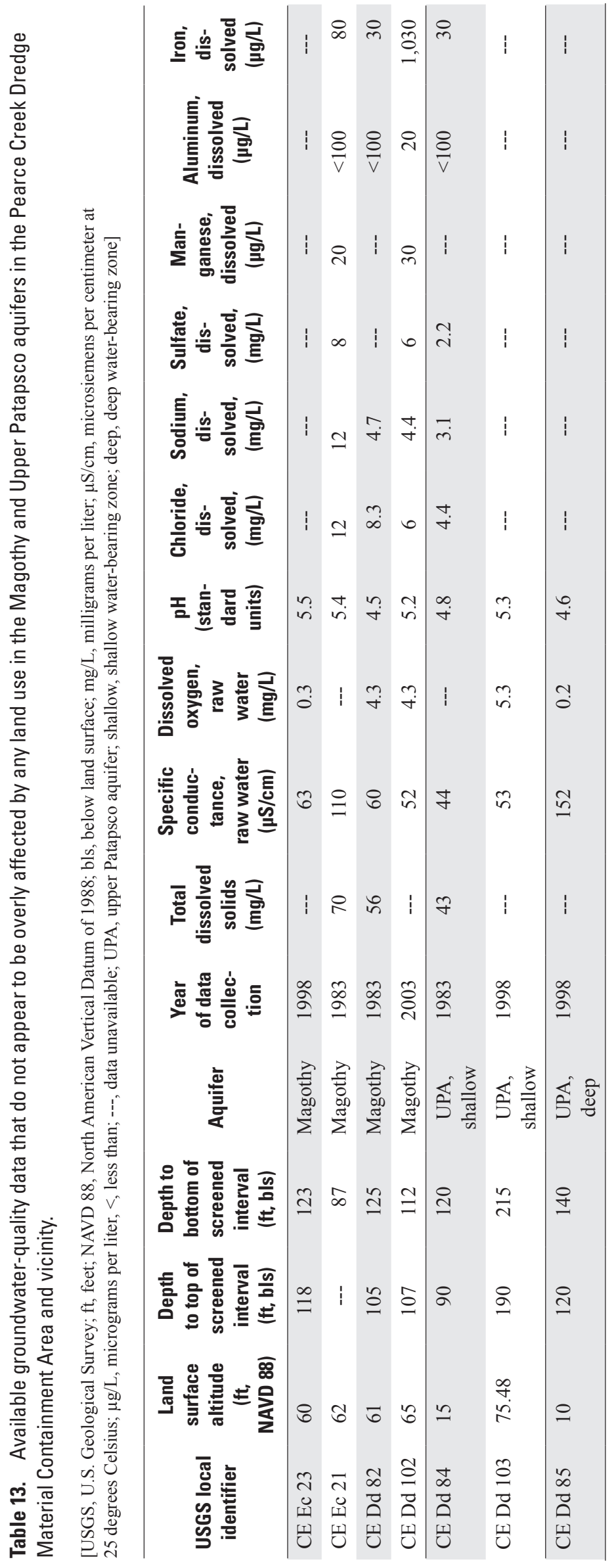


$\boldsymbol{A}$ TOTAL DISSOLVED SOLIDS LESS THAN 300 MILLIGRAMS PER LITER

EXPLANATION

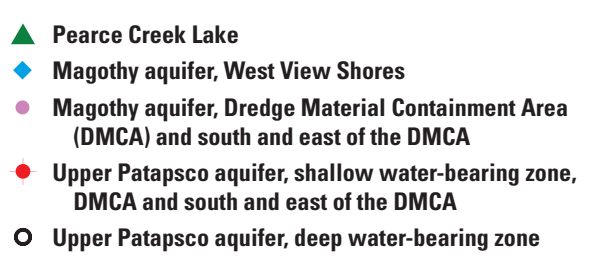

Patapsco aquifer, deep water-bearing zone

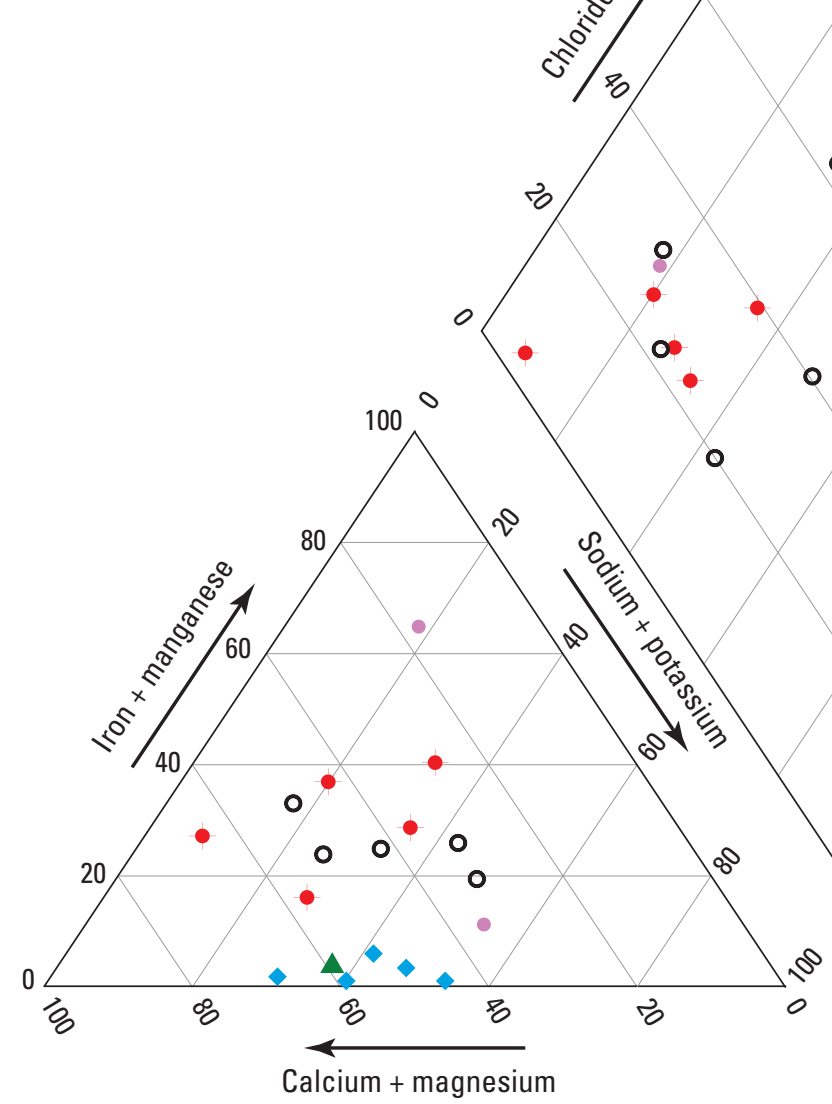

PERCENTAGE OF TOTAL MILLIEQUIVALENTS PER LITER

Figure 33. Trilinear diagram for samples with $A$, total dissolved solids less than 300 milligrams per liter $(\mathrm{mg} / \mathrm{L})$ and $B$, total dissolved solids greater than $300 \mathrm{mg} / \mathrm{L}$ collected in the Pearce Creek Dredge Material Containment Area and vicinity, Cecil County, Maryland.

background concentrations (natural water) for this aquifer (see tables 12 and 13).

The upper Patapsco aquifer shallow water-bearing zone displayed similar major ion chemistry to the Magothy aquifer for wells with TDS concentrations greater than $300 \mathrm{mg} / \mathrm{L}$. Regardless of geographic position, sulfate was the most prevalent anion (greater than 50 percent) in samples with high TDS (greater than $300 \mathrm{mg} / \mathrm{L}$ ). For wells with less than $300 \mathrm{mg} / \mathrm{L}$ of TDS, which were only located within the DMCA property boundary, bicarbonate was the predominant (greater than 75 percent) anion in the water; in contrast, proportions of chloride and sulfate were very low. Although the low TDS wells were located in the DMCA, they were located in areas where the confining unit between the Magothy and upper Patapsco aquifer shallow water-bearing zone is present.

In the upper Patapsco aquifer deep water-bearing zone, the concentrations of TDS were relatively low, ranging from 60 to $137 \mathrm{mg} / \mathrm{L}$ (fig. 36). The TDS concentrations in this aquifer were slightly higher along the Elk River shoreline (74 and $137 \mathrm{mg} / \mathrm{L}$ ) than inland and southeast of the DMCA in this aquifer (60 and $101 \mathrm{mg} / \mathrm{L})$. Locations with TDS concentrations less than $100 \mathrm{mg} / \mathrm{L}$ are similar to concentrations found in natural groundwater in this aquifer (tables 12 and 13). Well CE Dd 152 had a concentration of 2,100 mg/L TDS, however, the integrity of the sample/well may have been compromised during installation and was not used for groundwater flow 
EXPLANATION

$\Delta$ Elk River

- Fill

- Magothy aquifer, West View Shores

- Magothy aquifer, Dredge Material Containment Area (DMCA) and south and east of the DMCA

- Upper Patapsco aquifer, shallow water-bearing zone, West View Shores

- Upper Patapsco aquifer, shallow water-bearing zone, DMCA and south and east of the DMCA

○ Upper Patapsco aquifer, deep water-bearing zone
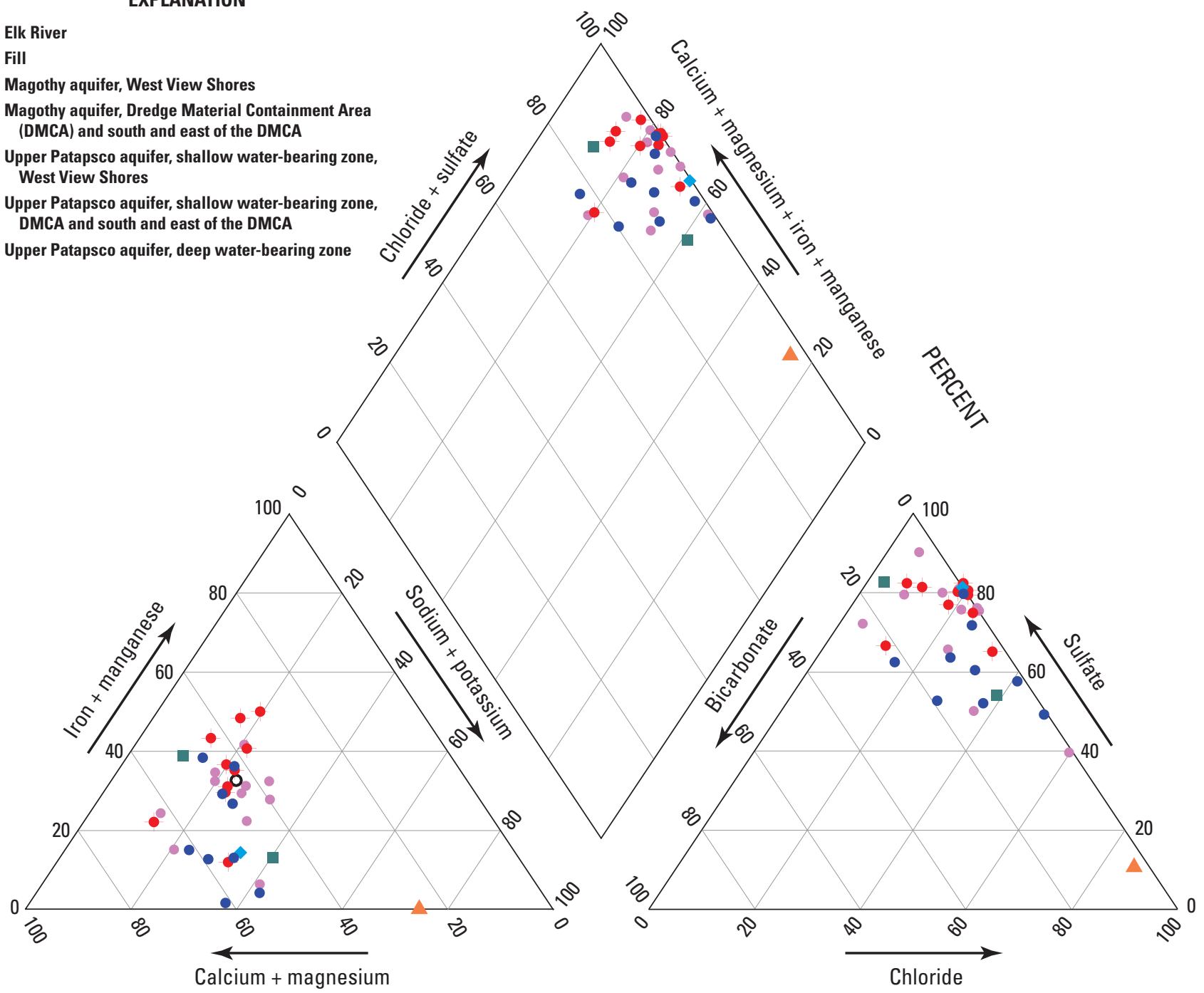

PERCENTAGE OF TOTAL MILLIEQUIVALENTS PER LITER

Figure 33. Trilinear diagram for samples with $A$, total dissolved solids less than 300 milligrams per liter $(\mathrm{mg} / \mathrm{L})$ and $B$, total dissolved solids greater than $300 \mathrm{mg} / \mathrm{L}$ collected in the Pearce Creek Dredge Material Containment Area and vicinity, Cecil County, Maryland.-Continued

interpretations in this report. The complete set of data for well CE Dd 152 is available in appendix B, table B3 and is presented on water-quality figures in the main part of the report.

The major ion chemistry of the upper Patapsco aquifer deep water-bearing zone was very similar to the chemistry of the upper Patapsco aquifer shallow water-bearing zone with similar TDS concentrations. Bicarbonate was the predominant anion; in contrast, proportions of chloride and sulfate were very low. The proportions of cations were relatively mixed and similar to those for water from other aquifers.

\section{Bromide-Chloride Ratios}

Mass ratios of bromide to chloride $(\mathrm{Br}: \mathrm{Cl}, \mathrm{mg} / \mathrm{L}$ to $\mathrm{mg} / \mathrm{L}$ ) have been used to identify seawater intrusion into groundwater (Richter and Kreitler, 1993). They also have been used to differentiate groundwater affected by road salt and from other land uses (Snow and others, 1990), and brackish water from urban land uses (Andreasen and Fleck, 1997). In addition, R.F. Weston, Inc., (1998) used these ratios in an attempt to identify potential sources of recharge to WVS community groundwater supplies.

In particular, R.F. Weston, Inc., (1998) utilized statistical and graphical analyses of water quality data, including $\mathrm{Br}: \mathrm{Cl}$ ratios (fig. 37), to argue that the groundwater used for supplies 

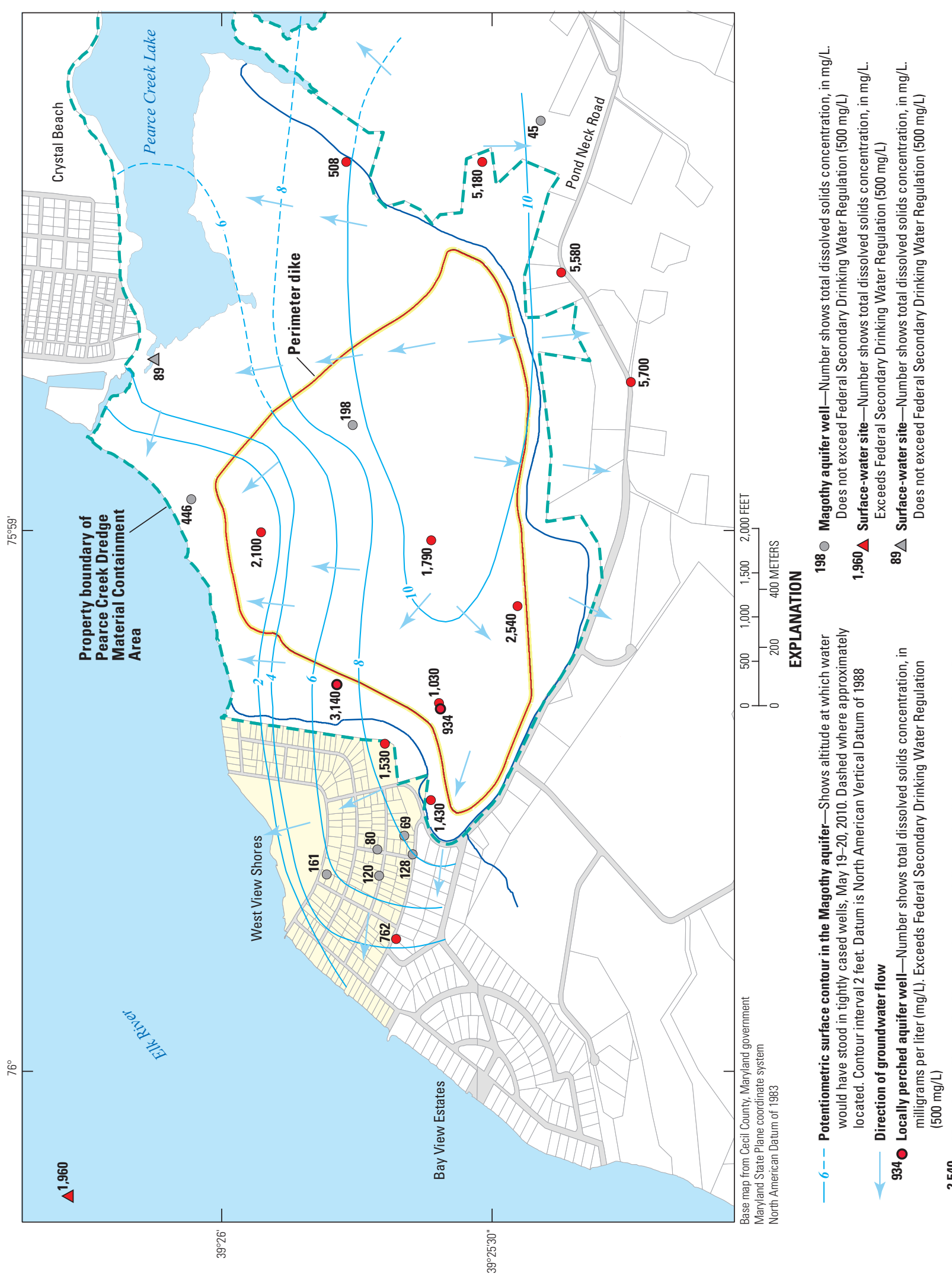

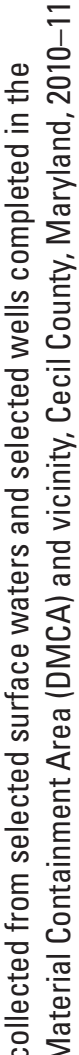

离

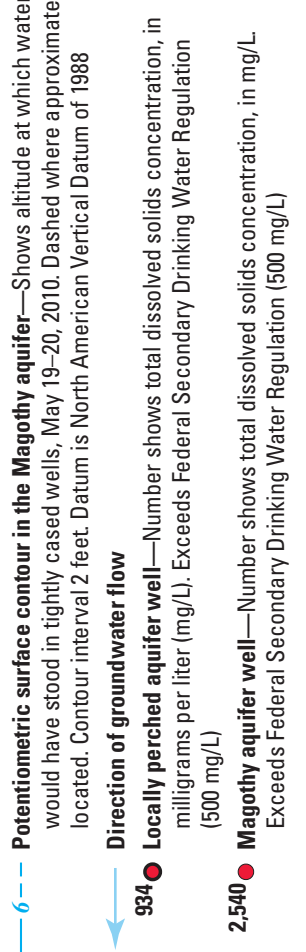

\& 욤

हิ

힝

전

인

d

30

일

음.

के

음

它 $\overrightarrow{\underline{I}}$

흠

要 $\sum^{\pi}$

잉

ธิ ธำ

휸

징

인

c.

लें

논

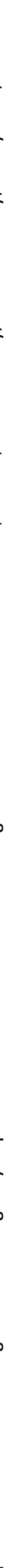



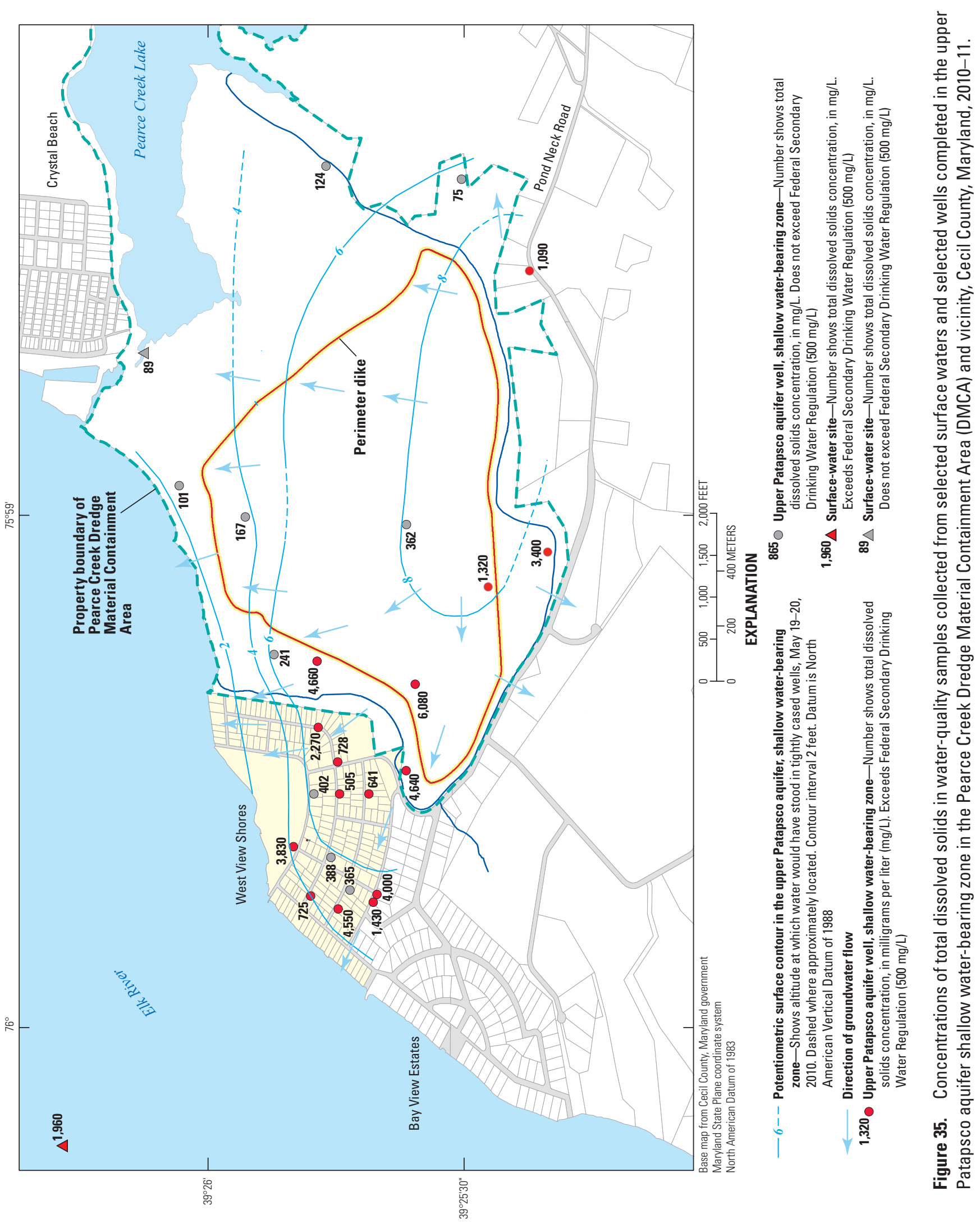

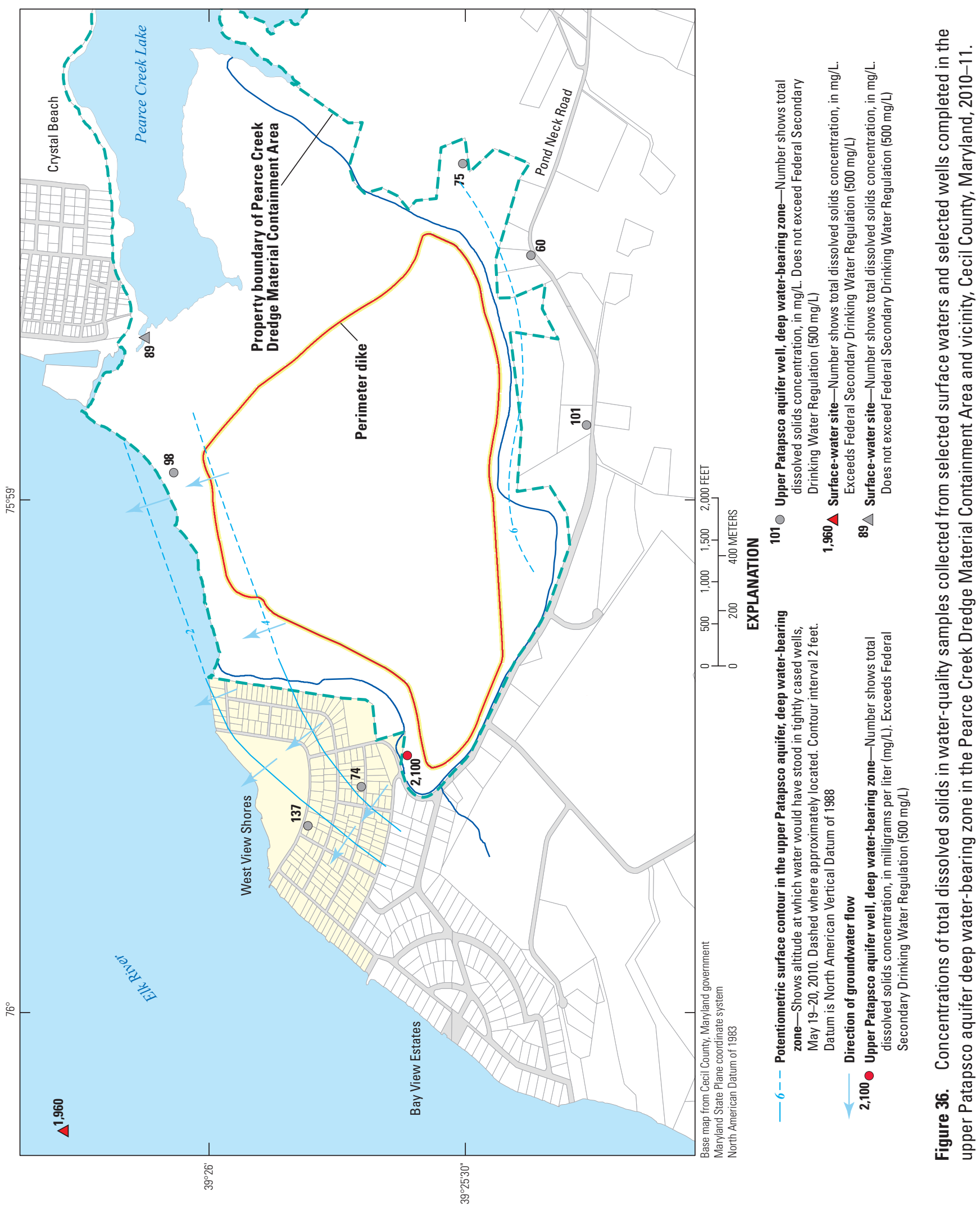


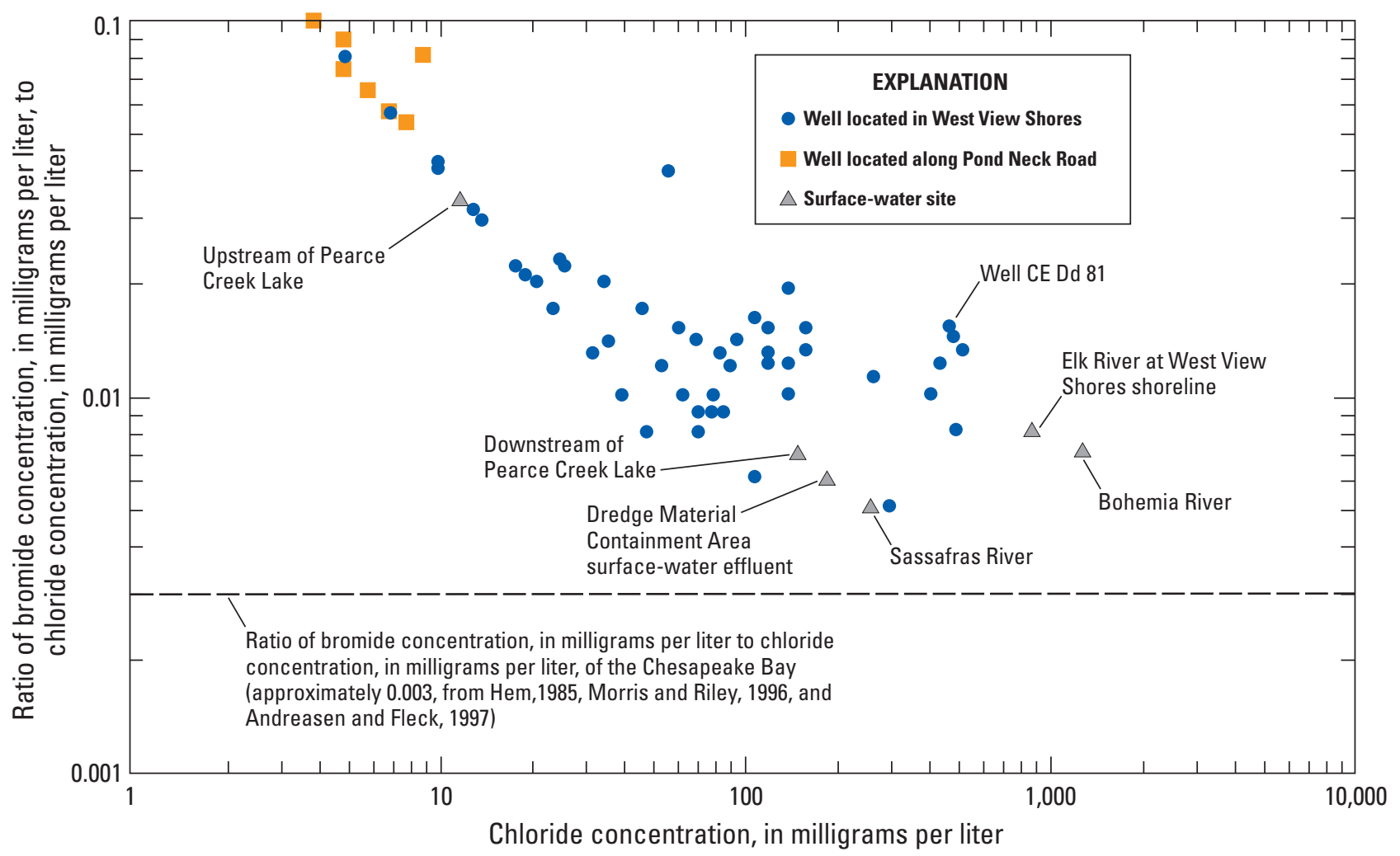

Figure 37. Ratios of the concentration of bromide to the concentration of chloride as a function of the concentration of chloride for selected surface- and groundwater samples collected in the Pearce Creek Dredge Material Containment Area (DMCA) and vicinity, Cecil County, Maryland, 1995-96 (modified from R.F. Weston, Inc.,1998).

by WVS residents likely reflected multiple different sourcesintruded Elk River water, local recharge, including possibly that from an local unknown dump area, and (or) groundwater flow from the DMCA. However, absent sufficient information on the hydrogeologic framework and actual patterns in groundwater flow, R.F. Weston, Inc., indicated it was not possible to determine the actual sources of groundwater supplies beneath the community.

Revisiting these ratios on the basis of the 2010-11 data (appendix B, table B3), the ratio values for selected surface waters and groundwater in the study area are diverse (fig. 38). There does still appear to be an elevated ratio (greater than surface-water ratios) in groundwater associated with most supply and observation wells. However, groundwater associated with selected wells has ratios that are either similar in value to the ratio for Pearce Creek Lake, or to the ratio for Elk River water.

Vertical cross sections (locations shown in figure 39) illustrate the relations between $\mathrm{Br}: \mathrm{Cl}$ values and groundwater flow patterns. For example, anoxic groundwater in the western part of the DMCA in the perched water-bearing zone, and in the Magothy aquifer just beyond the DMCA property boundary near WVS, is highly enriched in bromide relative to chloride (fig. 40). The opposite is true for groundwater in the shallow oxygen-bearing zone in the Magothy aquifer beneath WVS, which have the lowest $\mathrm{Br}: \mathrm{Cl}$ values for groundwater in the area. At depth beneath WVS, the $\mathrm{Br}: \mathrm{Cl}$ values for groundwater in the upper Patapsco aquifer shallow water-bearing zone are intermediate in value in relation to their shallow water and DMCA (likely) sources, which is to be expected if water in this zone reflects a mixture of water from both sources. Furthermore, these ratios also are generally greater than the $\mathrm{Br}: \mathrm{Cl}$ value for Elk River water, or for the oxygen-bearing groundwater much farther east in the Magothy aquifer, which reflect two different sources of groundwater. Hence, without knowledge of the hydrogeologic framework and patterns and chemistry of groundwater flow, it would be a challenge to interpret the influence of the DMCA on the quality of groundwater supplies in WVS solely on the basis of $\mathrm{Br}: \mathrm{Cl}$ ratios.

\section{Total Dissolved Solids and General Patterns in Groundwater Flow}

Differences in the concentrations of TDS can be related to the general patterns in groundwater flow within and between the Magothy and upper Patapsco aquifers. This relation is best illustrated through visual (aerial and sectional), rather than statistical, comparisons of the concentrations of TDS at selected wells along the general and probable directions of groundwater flow. The latter are inferred from the potentiometric surface maps and sectional flow diagrams 


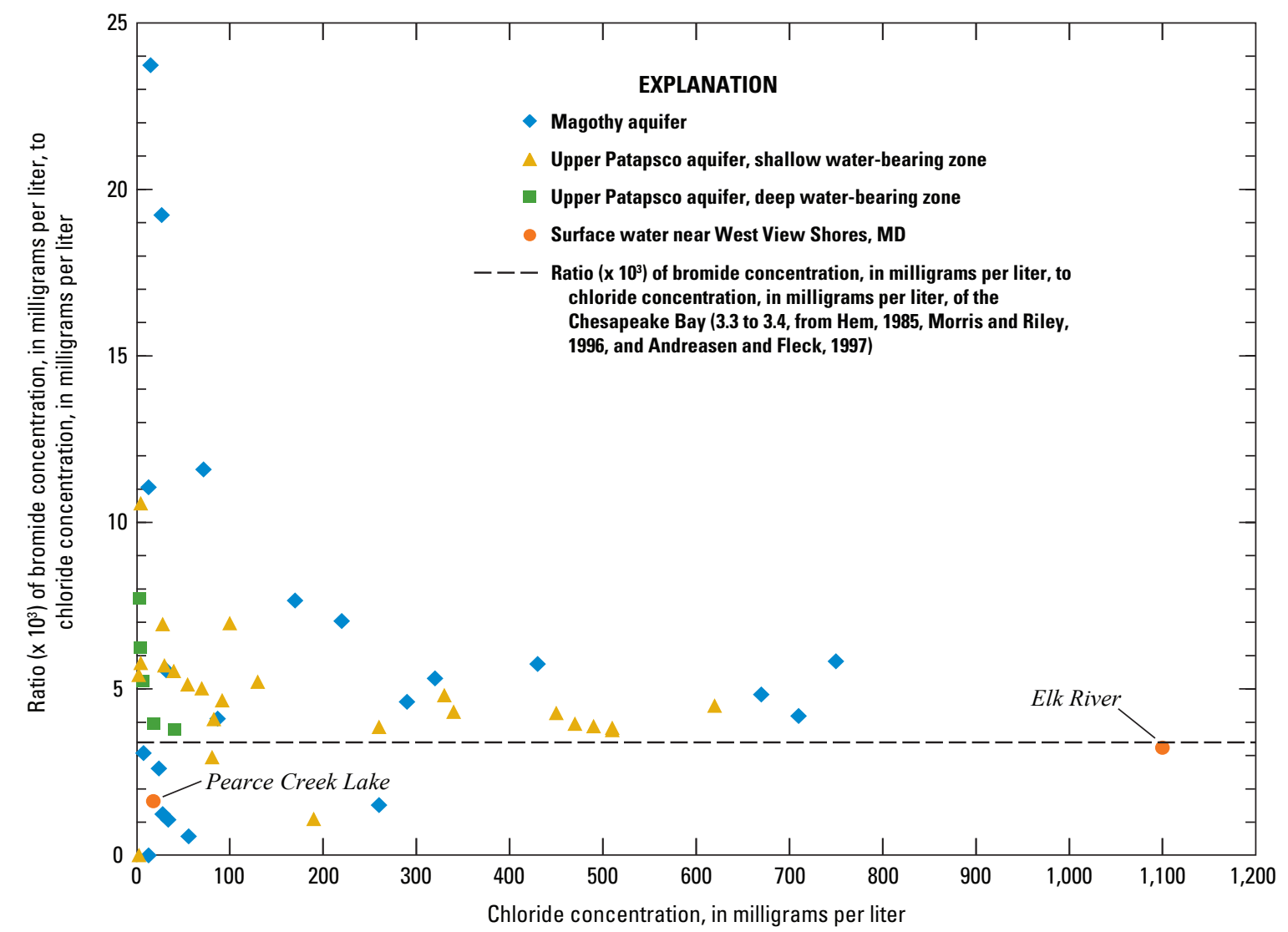

Figure 38. Ratios of the concentration of bromide to the concentration of chloride as a function of the concentration of chloride for selected surface- and groundwater samples collected in the Pearce Creek Dredge Material Containment Area (DMCA) and vicinity, Cecil County, Maryland, 2010-11.

described earlier in this report (see Hydrology, this report). Because most of the groundwater-quality samples were collected close in time to the May 2010 synoptic assessment, the potentiometric surface and flow lines presented on the waterquality figures are interpreted from the May synoptic assessment presented in figures 21, 24, and 27.

For the sectional comparisons, only those wells in the vicinity of each line of section are used to illustrate vertical patterns in groundwater flow (fig. 39). In addition, in the resulting composite TDS-groundwater-flow sections, only the general directions of groundwater flow are shown within and between aquifers, without the accompanying water-level potentiometric contours, to facilitate visualization of the TDS concentrations along the probable paths of groundwater flow.

From both the aerial (fig. 34) and the vertical section $A-A^{\prime}$ (fig. 41) perspectives, groundwater in the shallow perched zone, shown by well CE Dd 124 and (or) CE Dd 144, on the west side of the DMCA, is elevated in TDS (CE Dd 124, 934 mg/L; CE Dd 144, 3,140 mg/L). The occurrence of elevated concentrations of TDS in this shallow perched groundwater demonstrates that the surficial sediments in the DMCA remain a source for elevated TDS in groundwater more than 20 years after the cessation in use of the DMCA in the early 1990s. As to the fate of these TDS, groundwater in this perched zone likely discharges to the local stream that lies between the DMCA berm and property boundary farther west (see Hydrology, this report). Although water-quality data associated with this perched groundwater are provided throughout later discussions of specific water-quality constituents in this report, the fate of each dissolved constituent likely is determined when this groundwater discharges into the local stream, and (or) in the stream during its flow to Elk River, which are beyond the scope of this report.

To the north of the perched groundwater, the DMCA is fairly close to Elk River. Groundwater beneath this northern section of the DMCA in both the Magothy aquifer (fig. 34) and the upper Patapsco aquifer shallow water-bearing zone (fig. 35) reflect the northerly flow of groundwater from the central interior of the DMCA. The TDS concentrations associated with this northerly flow are best illustrated in section $B-B^{\prime}$ (fig. 42). Beneath the DMCA and just west of the groundwater divide, groundwater that flows north in the Magothy aquifer contains elevated concentrations of TDS

(fig. 42, well 157, 1,790 mg/L). This TDS concentration is over 30 times greater than the TDS concentration for natural water found nearby in this aquifer (table 13, Magothy aquifer, TDS, 43, 56, and $70 \mathrm{mg} / \mathrm{L}$ ). The high concentration of TDS in this part of the Magothy aquifer likely reflects vertical 

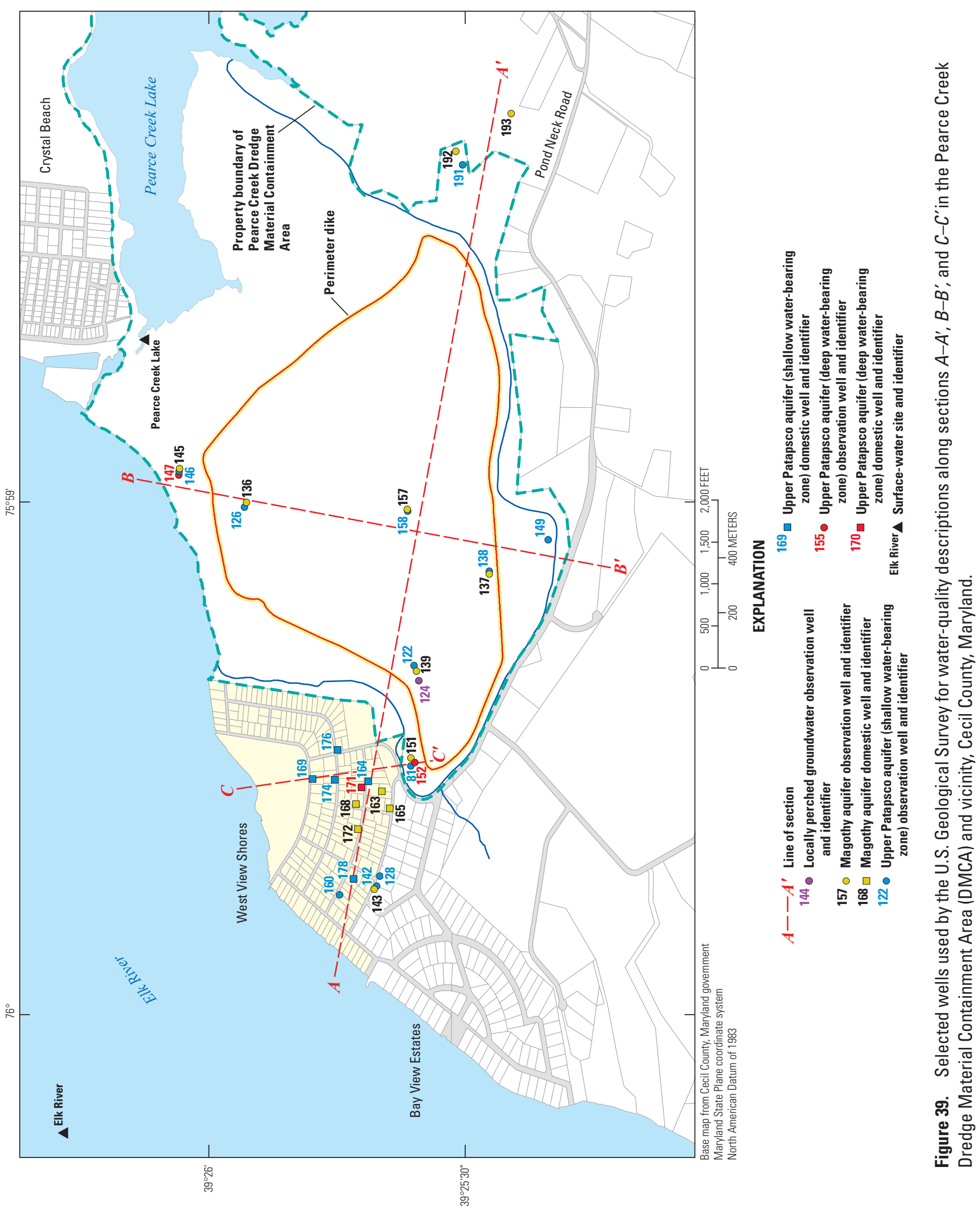


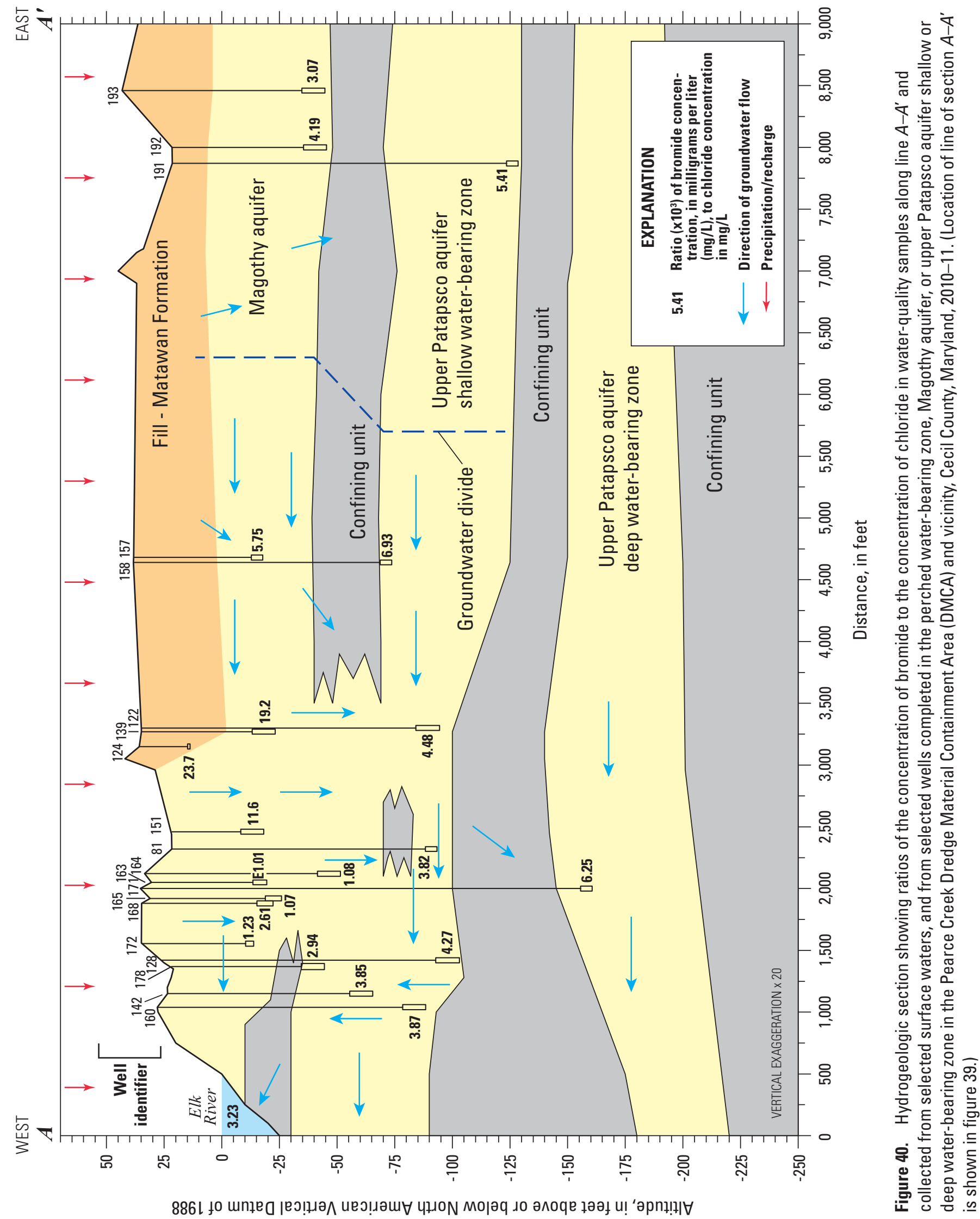




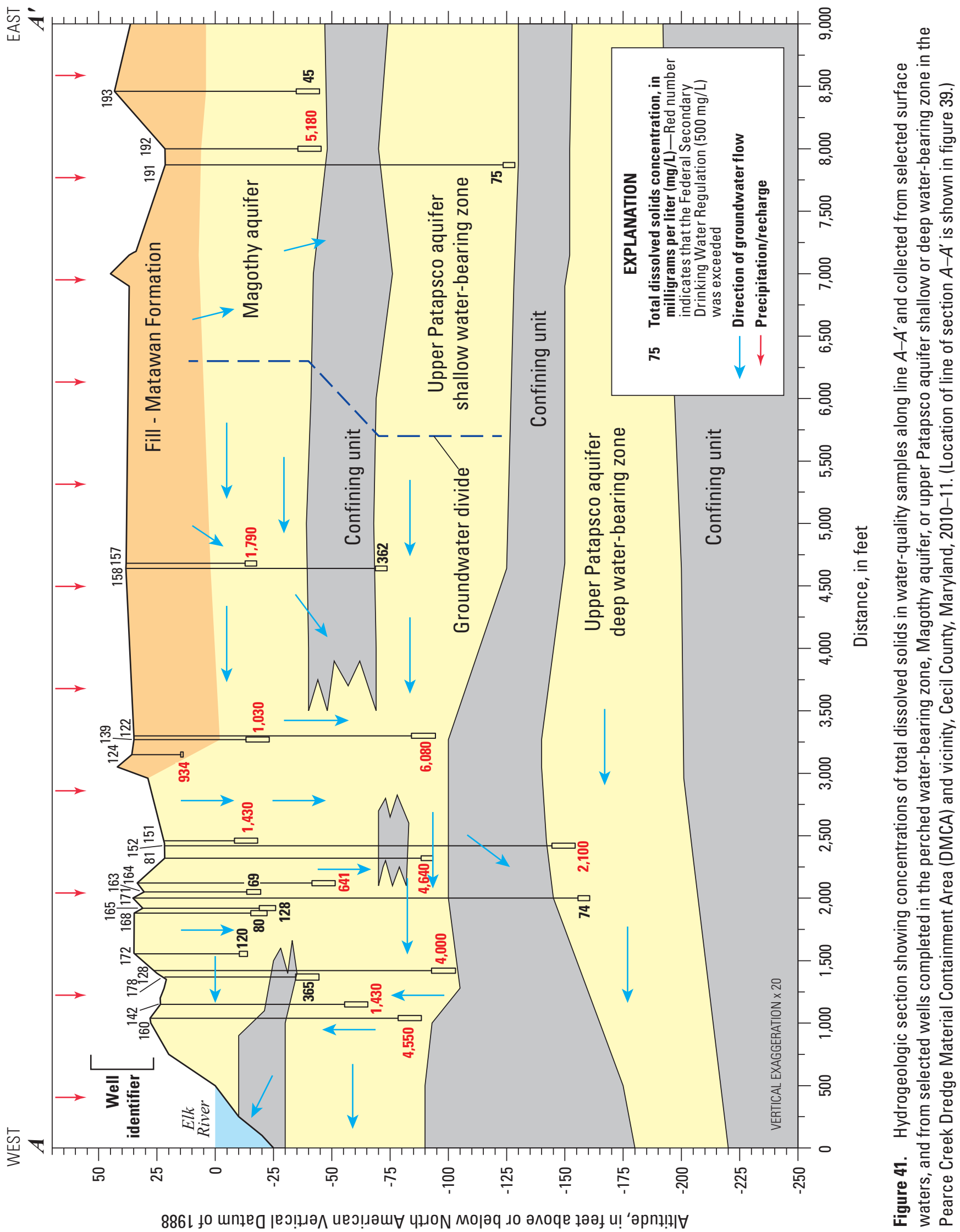




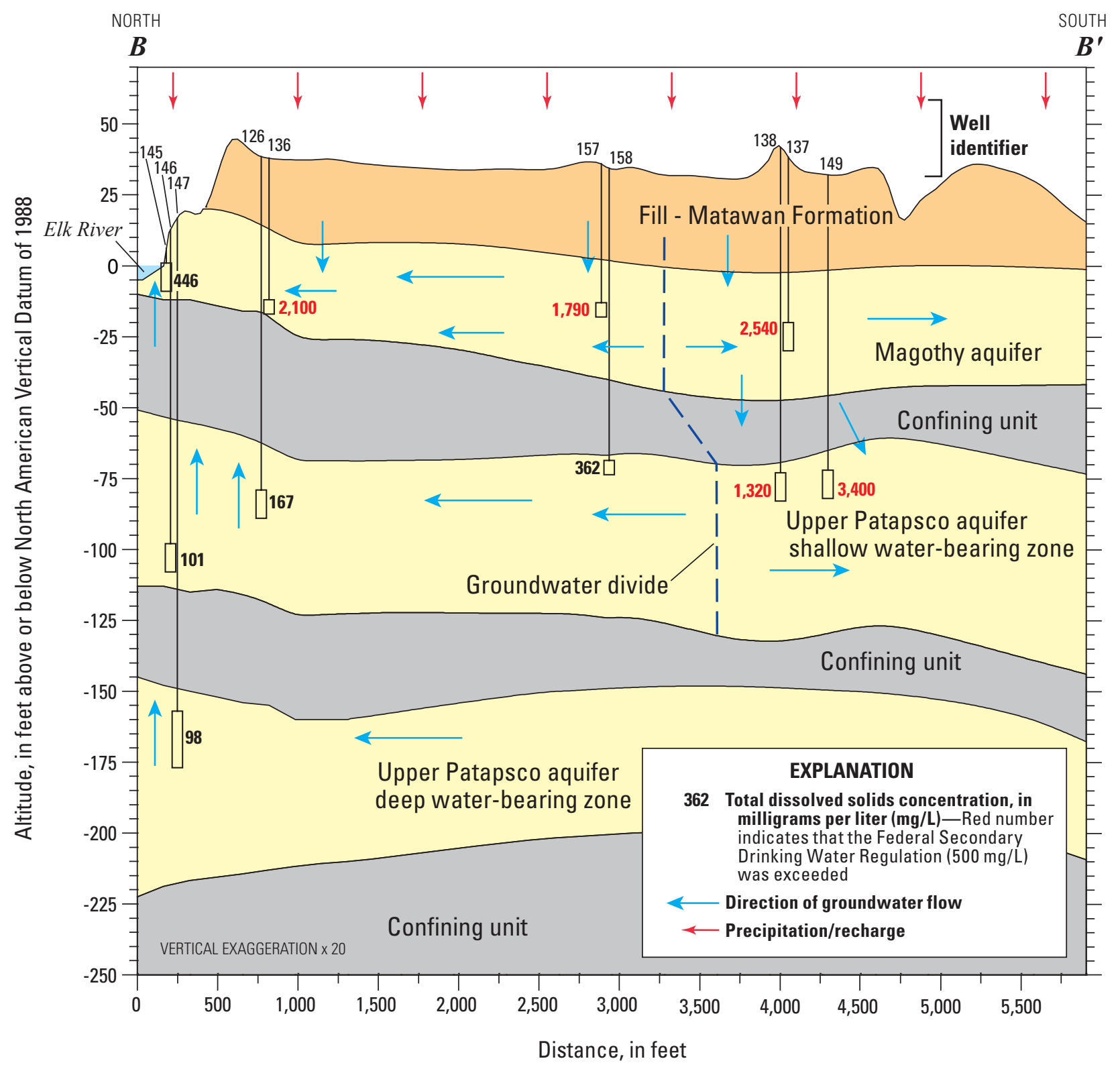

Figure 42. Hydrogeologic section showing concentrations of total dissolved solids in water-quality samples along line $B-B^{\prime}$ and collected from selected wells completed in the Magothy aquifer or upper Patapsco aquifer shallow or deep water-bearing zone in the Pearce Creek Dredge Material Containment Area (DMCA) and vicinity, Cecil County, Maryland, 2010-11. (Location of line of section $B-B^{\prime}$ is shown in figure 39.)

recharge through overlying DMCA sediments. Flow at this location also continues vertically downward to the upper Patapsco aquifer shallow water-bearing zone through the confining layer, which is relatively thin, and consists of sandy and silty clay sediments (see Hydrogeologic Framework, this report). Leakage through this confining layer of groundwater elevated in TDS likely accounts for the occurrence of the moderately elevated concentration of TDS in this water-bearing zone (fig. 42, CE Dd 158, $362 \mathrm{mg} / \mathrm{L}$ ). This TDS concentration is about 5 times greater than the TDS concentration in natural water in this aquifer (table 13, upper Patapsco aquifer, shallow water-bearing zone, TDS, $53 \mathrm{mg} / \mathrm{L}$ ). The chemistry of CE Dd 158 (fig. 33), despite its moderate TDS concentrations, was very similar to the chemistry of those wells with much higher concentrations of TDS. The similarities in major ion content, specifically a high percentage of sulfate, also indicated a vertical influence from the Magothy aquifer.

Groundwater in both the Magothy aquifer and upper Patapsco aquifer shallow water-bearing zone at the groundwater divide and beneath the DMCA flows laterally to the north (figs. 34 and 42). In the northern part of the DMCA, the concentration of TDS in the Magothy aquifer is elevated (figs. 42 and, CE Dd 136, 2,100 mg/L). However, this concentration is not much greater than the concentration of TDS observed in this aquifer upgradient and in the interior of the DMCA. 
By way of contrast, the concentration of TDS is relatively low in the underlying upper Patapsco aquifer shallow waterbearing zone in this northern section of the DMCA (fig. 42, CE Dd 126, $167 \mathrm{mg} / \mathrm{L}$ ). It is only about half the concentration of TDS observed in this water-bearing zone generally upgradient and in the interior of the DMCA (fig. 42, CE Dd 158, $362 \mathrm{mg} / \mathrm{L}$ ). This decline in TDS implies the leakage observed through the confining layer into this zone in the DMCA interior is not extensive, and is consistent with the increasing thickness of the overlying upper Patapsco confining layer along $B-B^{\prime}$ to the north (see Hydrogeologic Framework, this report).

The quality of the TDS also indicates that leakage through the confining zone in the northern section of the DMCA area is not extensive. As mentioned previously, despite only moderate TDS concentrations, water from CE Dd 158 is chemically similar to water from wells with much higher concentrations of TDS, particularly those with a high percentage of sulfate (fig. 33). In contrast, water from CE Dd 126 is chemically very different; this water was dominated by bicarbonate but had very low percentages of sulfate (fig. 33).

Farther north beyond the DMCA berm, but within the DMCA property boundary, along $B-B^{\prime}$, the Magothy aquifer crops out beneath the shoreline and Elk River (fig. 42). Here groundwater flow from this shallow aquifer and upgradient flow from the underlying upper Patapsco aquifer shallow water-bearing zone converge and discharge either into Pearce Creek (downstream of the lake outlet), or along the shoreline or beneath the Elk River (fig. 42, CE Dd 145, 146, and 147). The concentration of TDS in the Magothy aquifer at this northerly location is notably lower (fig. 42, CE Dd 145, $446 \mathrm{mg} / \mathrm{L}$ ) compared to the elevated TDS concentration observed in the Magothy aquifer upgradient and interior to the DMCA (fig. 42, CE Dd 136, 2,100 mg/L). The chemistry of water from CE Dd 145 is typical of water from wells with TDS greater than $300 \mathrm{mg} / \mathrm{L}$, specifically the high percentage of sulfate (fig. 33). The reduced TDS concentration in the Magothy aquifer at this location could reflect groundwater recharge from Pearce Creek Lake, which has a similar chemistry, although a lower percentage of sulfate (fig. 34, TDS equals $89 \mathrm{mg} / \mathrm{L}$ ). Recharge likely occurs seasonally when lake levels are high along the lower part of the lake (see Hydrology, this report).

Well CE Dd 145 can be used as a TDS point of reference to evaluate the possible effect of DMCA discharge on the Elk River. The TDS concentration in the Magothy aquifer near the northern DMCA property boundary (fig. 42, CE Dd 145, $446 \mathrm{mg} / \mathrm{L}$ ) is about 7 to 8 times greater than the concentration of TDS in natural water for this aquifer (table 13, Magothy aquifer). Whether or not this concentration of TDS in the Magothy aquifer at this location is of concern depends in part upon the nature of the TDS, which is predominantly sulfate. However, the transport and fate of the individual dissolved constituents as this groundwater discharges along the shoreline, or directly through bed sediments into the Elk River, are beyond the scope of this report. In addition, consideration needs to be given to the water quality of the receiving body, the Elk River, which has a TDS concentration of $1,960 \mathrm{mg} / \mathrm{L}$ (fig. 34) and chemistry that is predominantly made up of sodium and chloride ions.

In the eastern and southern parts of the DMCA and vicinity, from an aerial perspective (figs. 34 and 35), elevated concentrations of TDS (greater than $500 \mathrm{mg} / \mathrm{L}$ ) occur downgradient of the groundwater divides in the Magothy aquifer and in the upper Patapsco aquifer shallow water-bearing zone at all but the most easterly sites. From a vertical perspective to the east along $A-A^{\prime}$ (fig. 41), in the Magothy aquifer in the interior of the DMCA, elevated TDS concentrations, composed mainly of sulfate, occurred near the groundwater divide (CE Dd 157, 1,790 mg/L) and likely reflect vertical recharge through overlying DMCA sediments. Farther to the east near the DMCA property boundary, and just south of the groundwater divide, the concentrations of TDS were quite high (CE Dd $192,5,180 \mathrm{mg} / \mathrm{L}$ ). Absent additional information, it is unlikely that the elevated TDS at depth in the Magothy aquifer at this location reflect groundwater flow into the DMCA area from farther to the east, or through the confining unit from above. Either source of water is extremely low in TDS (fig. 41, CE Dd 193, 45 mg/L; CE Dd 191, 75 mg/L).

The extremely high concentration of TDS in the Magothy aquifer at CE Dd 192 could reflect groundwater flow from the southeastern part of the DMCA. Similar elevated concentrations of TDS with high proportions of sulfate occur in the Magothy aquifer south and downgradient of the groundwater divide within the DMCA property boundary and along Pond Neck Road (fig. 34, CE Dd 125 and 153; 5,700 and 5,580 $\mathrm{mg} / \mathrm{L}$, respectively). In addition, elevated concentrations of TDS also occur in the upper Patapsco aquifer shallow waterbearing zone south and downgradient of its groundwater divide - within the DMCA, within the DMCA property boundary, and outside the DMCA property boundary (fig. 35, CE Dd 138, 149, and 154; 1,320, 3,400, and 1,090 mg/L, respectively). These elevated TDS concentrations also reflect leakage through the relatively thin and permeable confining layer described earlier, but reflect southerly rather than northerly groundwater flow (fig. 42).

The elevated concentrations of TDS in both of these aquifers, which are attributed to groundwater flow from the DMCA, are considerable. The TDS concentrations in excess of $5,000 \mathrm{mg} / \mathrm{L}$ in the Magothy aquifer in the eastern and southern locations described above are 90-100 times greater than the concentration of TDS in natural water in this aquifer (table 13, Magothy aquifer). The TDS concentrations in the upper Patapsco aquifer shallow water-bearing zone in the southern locations described above are approximately 14 to 48 times greater than the concentration of TDS in natural water for this aquifer (table 13, upper Patapsco aquifer shallow water-bearing zone).

Along the western part of the DMCA, elevated TDS concentrations occur within the DMCA, at its property boundary, and beyond into WVS in both the Magothy aquifer (fig. 34) and the upper Patapsco aquifer shallow water-bearing 
zone (fig. 35). In the Magothy aquifer (fig. 34), westward groundwater flow begins in the interior southern half of the DMCA, and from there moves through the lower western part of the DMCA to its property boundary with WVS. Elevated concentrations of TDS associated with westward flow within the DMCA property boundary are between 1,000 and 2,000 $\mathrm{mg} / \mathrm{L}$ in the Magothy aquifer (fig. 34). Concentrations of TDS in the underlying upper Patapsco aquifer shallow water-bearing zone were lower than or similar to those in the Magothy aquifer at two wells near the central interior of the DMCA but are markedly elevated $(4,000$ to $6,000 \mathrm{mg} / \mathrm{L})$ near the westernmost point in the DMCA (fig. 35). Toward the west (toward WVS) along $A-A^{\prime}$ (fig. 41), groundwater flow with elevated TDS in the Magothy aquifer beneath the DMCA likely travels beyond the berm, and at least to well CE Dd 152. However, along this part of the groundwater flow system, and farther west into WVS, the following patterns in groundwater flow and TDS concentrations were observed (fig. 41):

(1) Elevated concentrations of TDS occurred in the deeper Magothy aquifer groundwater just beyond the DMCA dike in WVS (CE Dd 151, 1,430 mg/L), concomitant with a vertically downward gradient where local recharge occurs through this elevated part of WVS; and

(2) Highly elevated concentrations of TDS $(4,000$ $6,000 \mathrm{mg} / \mathrm{L}$ ) occurred beneath the WVS community in the upper Patapsco aquifer shallow water-bearing zone, where the confining unit between the Magothy and upper Patapsco aquifers is absent and flow is vertically downward.

In the Magothy aquifer in the WVS area (fig. 41), shallow groundwater flow is determined by vertical recharge - both from precipitation and residential land use. The latter includes outdoor water uses such as irrigation and effluents from individual septic systems for every residence. Nevertheless, shallow groundwater in the Magothy aquifer in the elevated central part of WVS contained relatively low TDS (less than approximately $130 \mathrm{mg} / \mathrm{L}$ ) and had a chloride dominated chemistry.

Groundwater flow with elevated TDS from the western end of the DMCA that travels vertically downward into the upper Patapsco aquifer shallow water-bearing zone can travel farther north in this zone and beneath the confining layer before possibly discharging vertically upwards and eventually into Elk River (fig. 43). As observed in section $A-A^{\prime}$, shallow groundwater in the Magothy aquifer in section $C-C^{\prime}$ contains low concentrations of TDS (CE Dd 163, $69 \mathrm{mg} / \mathrm{L}$ ), which likely reflect local recharge from precipitation and residential use.

The patterns in groundwater flow and the low TDS concentrations beneath the WVS community indicate that it is unlikely that the community is responsible for the elevated TDS concentrations found at depth beneath their community. The chemistry of the water from Magothy wells under WVS was different from that at other wells with TDS concentrations less than $300 \mathrm{mg} / \mathrm{L}$ (fig. 33). Chloride and sulfate accounted for the majority of the anions in water from the WVS Magothy wells, whereas, other waters with TDS concentrations less than $300 \mathrm{mg} / \mathrm{L}$ had a higher proportion of bicarbonate.

The patterns in the TDS concentrations and groundwater flow beneath and in the vicinity of the DMCA indicate that the DMCA is the most likely source of elevated concentrations of TDS in groundwater in the Magothy aquifer and upper Patapsco aquifer shallow water-bearing zone. There was also a clear distinction in the chemistry of water based on the concentration of TDS. For those waters with greater than $300 \mathrm{mg} / \mathrm{L}$ of TDS, sulfate was the most prevalent ion, regardless of aquifer or well location. For those wells with TDS concentrations less than $300 \mathrm{mg} / \mathrm{L}$, closer to levels found in natural groundwater for the aquifer, the chemistry was not dominated by sulfate and varied between location.

\section{Electromagnetic-Induction Logging}

Electromagnetic-induction logs support the use of waterquality sampling from wells screened at discrete intervals to describe groundwater quality in each aquifer. These logs are obtained by running an induction probe inside a well and simultaneously recording the conductivity of the water outside the borehole as the probe is lowered and then raised through the entire length of the well. The major hydrogeologic factors that affect induction logs in sand and gravel aquifers are the TDS concentration in the groundwater and the silt and clay content of the aquifer (Williams and others, 1993). Lithologic information from sediment-core descriptions and natural gamma-ray logs were used in combination to determine whether the increased conductivity of a given zone is related to the TDS concentration or to the silt and clay content.

A vertical profile of the concentrations of TDS and the induction logs for selected wells within the Magothy aquifer and upper Patapsco aquifer shallow and deep water-bearing zones was constructed along the line of section $A-B$ (fig. 44). Conductivity increases toward the right on the induction logs with a scale ranging from 0 to 100 millisiemens per meter. The induction logs clearly mark the extent of the poorest quality water in relation to TDS content of groundwater. The largest deflections to the right are noted on the section and generally correspond to 100 millisiemens per meter on the log scale. Also shown on section $A-B$ are the location of the sampled intervals of wells within each nested site and the concentration of TDS in $\mathrm{mg} / \mathrm{L}$ obtained from those intervals. Zones of highest conductivity marked by signatures on the induction logs are consistent with high concentrations of TDS recorded in sampled wells. Thus, section $A-B$ shows that the extent of poor quality water containing high TDS concentrations is greatest in vertical thickness in the upper Patapsco aquifer shallow water-bearing zone in the most upgradient well of the section (CE Dd 152), namely near the DMCA beginning at an elevation of approximately $-30 \mathrm{ft}$ NAVD 88. Induction-log signatures show zones of highest conductivity downgradient toward the Elk River and mainly are situated in the bottom $30 \mathrm{ft}$ of this zone beginning at elevations of -70 to $-80 \mathrm{ft}$ 
NAVD 88. Similar TDS-conductivity log relations constructed for wells along the western side of the DMCA (line of section $B-C$, figure 45 , which includes wells CE Dd 130, 122, and 152) show signatures which also confirm relatively thick zones of high conductivity water occur at shallow depths, and at the base of the Magothy aquifer where confined, inside the DMCA.

The downward and downgradient movement of highconductivity water representative of high TDS concentration is consistent with groundwater flow conditions that indicate recharge to the unconfined system, strong downward gradients of flow, and movement of water downgradient to the Elk River.

As shown in the above examples, TDS concentrations in sand and gravel aquifers can differ by more than an order of magnitude within a vertical distance of a 5 to $10 \mathrm{ft}$. At a single location, the water quality sampled from monitoring wells can markedly change, depending on the vertical placement of screened intervals. However, in the case of this study, the occurrence of highly elevated concentrations of TDS and high log-conductance do frequently co-occur and reflect high TDS and thick water-bearing zones. The induction logs also indicate that the vertical extent of the aquifer with high TDS water likely is greater in and near the western side of the DMCA than indicated solely by groundwater sampling (figs. 44 and 45; circled high-conductance areas in log sections without well locations). In addition, as the downgradient distance from the DMCA through WVS increases, both the concentrations of TDS and log-conductance patterns indicate the poorest quality groundwater occurs at depth within the upper Patapsco aquifer shallow water-bearing zone, which is consistent with the flow of groundwater from the DMCA to beneath WVS.

\section{Reduction-0xidation Processes}

\section{Historical Influences on Reduction-0xidation Processes}

The topographic map from 1900 indicates that the area upon which the DMCA was built was a natural, inner-coastal, tidal wetland, which drained into the Elk River directly, or Pearce Creek, which, in turn, drained into the Elk River (fig. 3; see Hydrology, this report). Prior to construction of the DMCA, the 1900 topography combined with the hydrogeologic framework for this area indicate that this wetland likely was a discharge area for shallow groundwater, flowing from topographic highs on the peninsula uplands towards the topographically low wetlands, as well as discharge from parts of the Magothy aquifer. Given the descriptions of groundwater quality for wetlands overlying similar stratigraphy, groundwater flow to this wetland likely would have been slow, and the chemistry of groundwater would have been governed by reducing conditions (Shedlock and others, 1993, 1999; Speiran, 1996). Under such reducing conditions, and given natural groundwater conditions in the area, groundwater associated with the original wetland likely would have contained little to no dissolved oxygen or nitrate-nitrogen and possibly elevated concentrations of metals such as iron. However, as groundwater discharged into and from this wetland, redox-sensitive metals, such as iron and manganese, and minerals, such as iron sulfide, likely would have oxidized, precipitated, and accumulated in wetland sediments.

Construction of the DMCA likely changed this wetland area over time from a groundwater discharge area to a local groundwater recharge area. Construction of the DMCA berms, placement of dredge materials, and resulting increases in land surface, Pearce Creek Lake levels, and groundwater levels reversed the natural flow directions. The construction of the DMCA would have also caused the native wetland sediments, typically high in organic material, to be buried under the dredge materials.

During the use of the DMCA, Elk River water was mixed with sediments, and the slurry was pumped into the bermed area of the DMCA. This process likely resulted in an appreciable increase in recharge compared to recharge from normal amounts of precipitation. Up to several feet of standing water were drained from the DMCA, primarily through a sluice, over the course of several days after each batch of sediment slurry was deposited (D. Sirkis, USACE, written commun., 2010). The effects on hydraulic head from adding Elk River water are illustrated by the rise in water levels associated with the recharge from Tropical Storm Nicole, which reflects less than $0.5 \mathrm{ft}$ of water being deposited over the DMCA (see Hydrology, this report). The mixing of anoxic bay sediments with oxic Elk River water also likely would result in the temporary oxidation of shallow dredged sediments, which contain minerals such as ferrous sulfide and pyrite. The oxidation of these minerals could lead to acidic conditions and the mobilization of metals during and initially following sediment deposition concomitant with recharge. Similar oxidizing, acidic, and mobilizing conditions could arise in surficial deposited sediments during annual drying (summer) and wetting (winter) cycles within the DMCA, which also could promote the mobilization of metals; whereas deep sediments likely remained under reduced conditions.

Repetition of the above dredged-sediment disposal process over time has raised the level of deposited sediments (fill) in the DMCA by $30 \mathrm{ft}$ or more (see Hydrogeologic Framework, this report). This is a substantial increase in material enriched in carbon, nitrogen, sulfur, and metals (see Northern Chesapeake Bay Sediments, this report). Also because deposited dredged material contained an abundance of fine-grained organic and silty sediments, drainage conditions in the DMCA have remained poor.

Current (2010-11) groundwater levels in the DMCA and vicinity and a seasonal dense Phragmites (species unknown) cover indicate the containment area has become an elevated recharging artificial wetland (fig. 5, see Hydrology, this report). As such, the DMCA's historical influence on groundwater could not only be as a source of elevated concentrations of TDS, but also as a geochemical driver of redox processes 


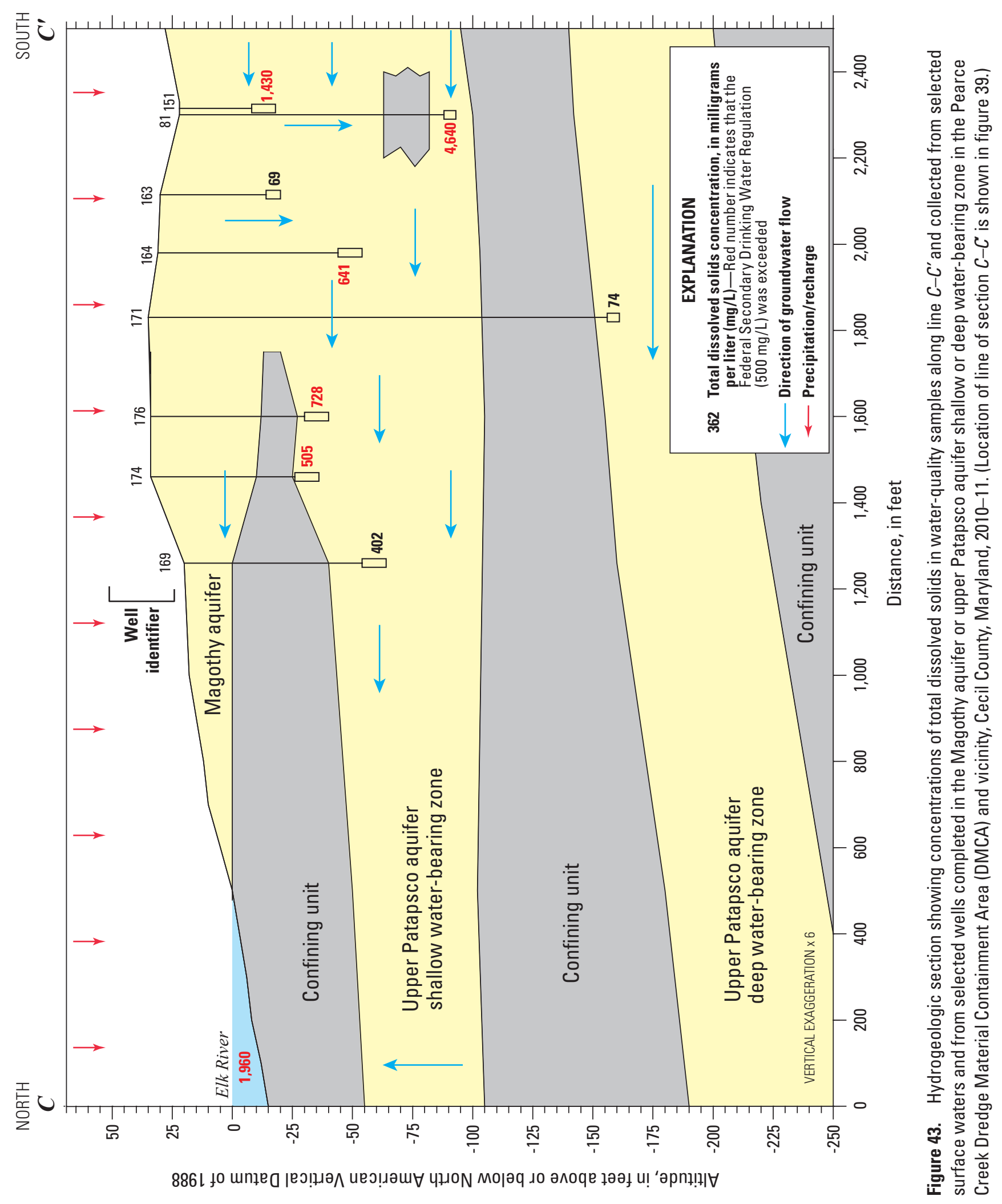




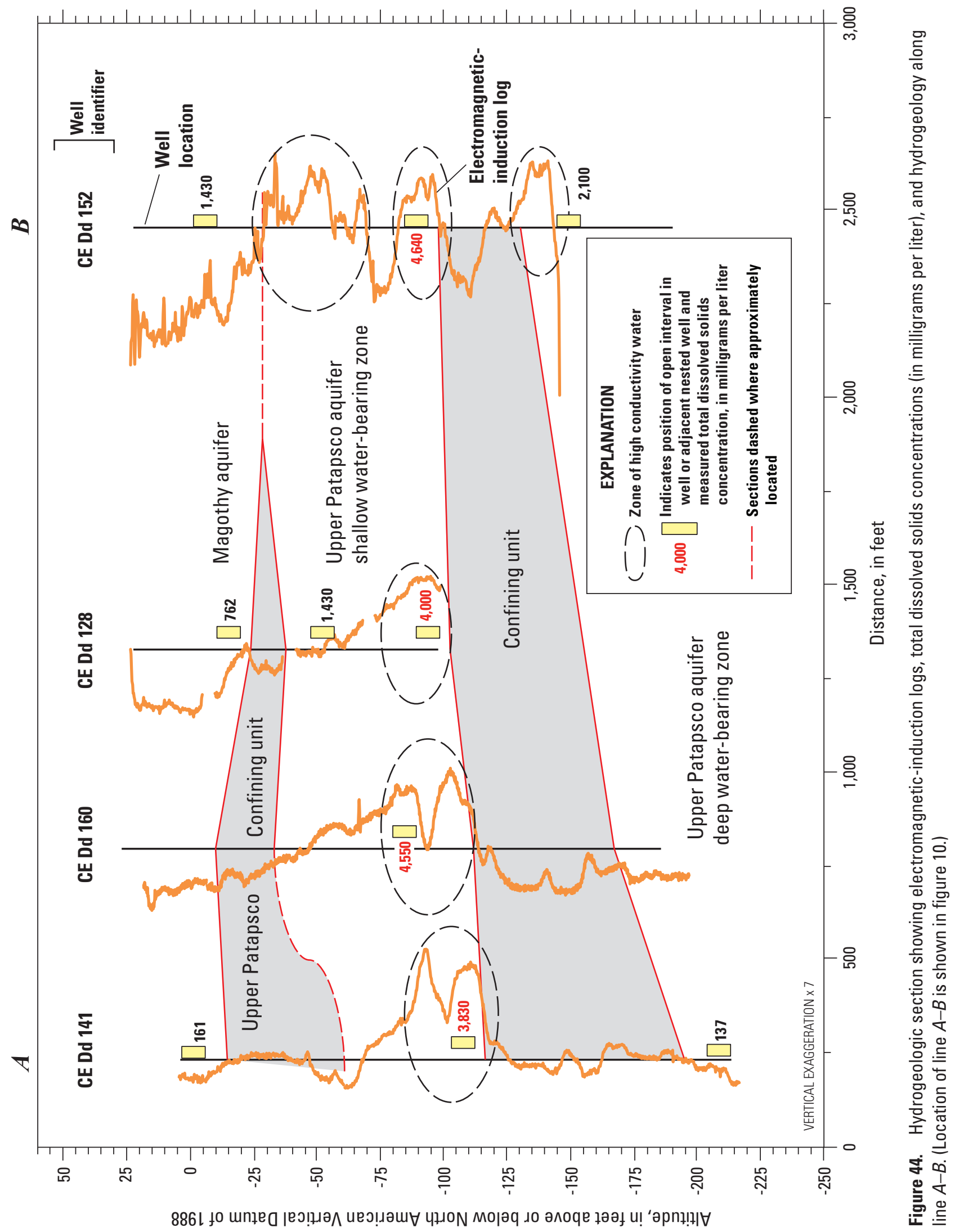




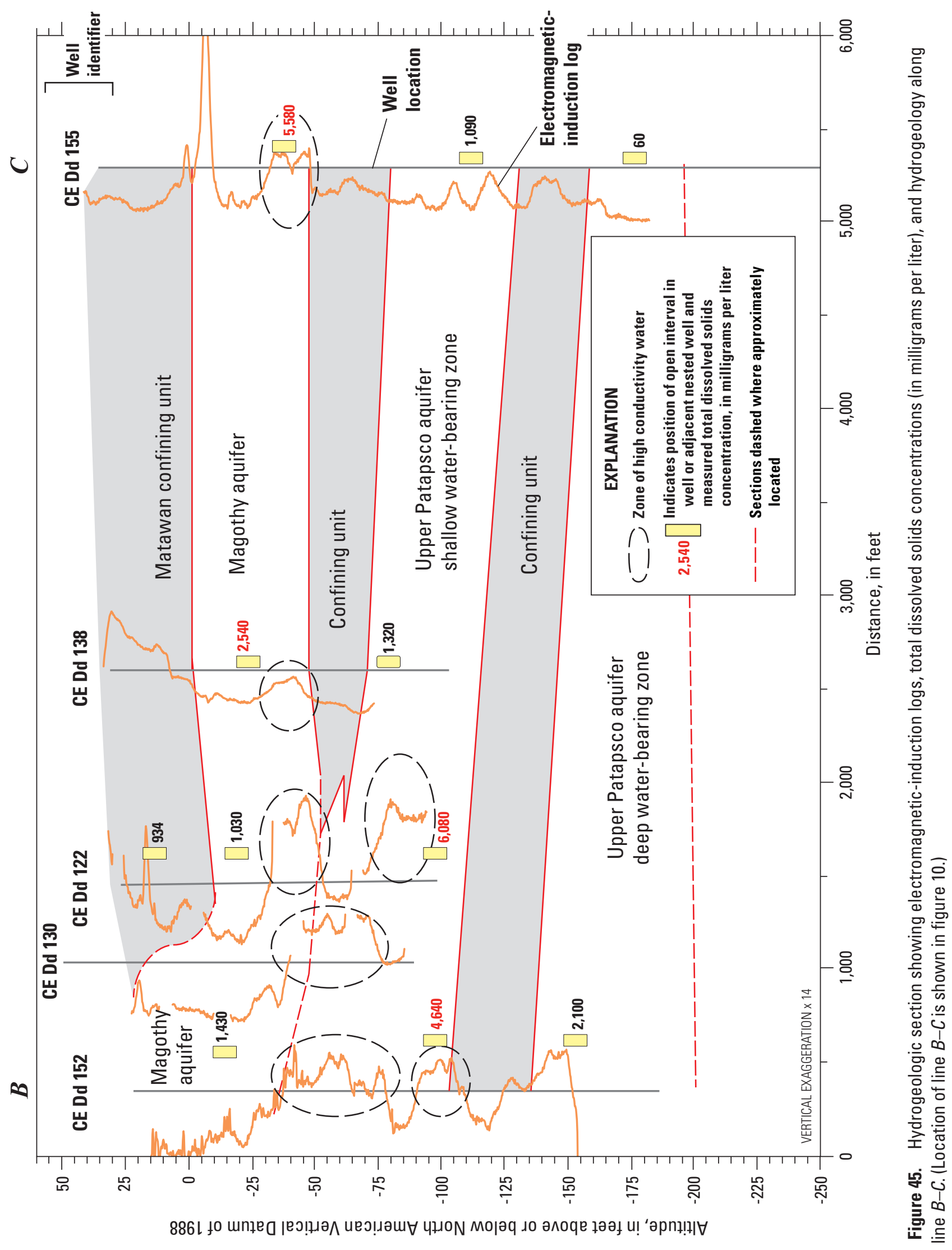


that enhance the mobilization and transport of redox-sensitive metals and nutrients in the DMCA fill-Matawan sediments as well as in the underlying aquifers.

\section{Terminal Electron Acceptor Process Analysis}

Redox processes can markedly affect the quality of groundwater in an aquifer. These processes have been shown to immobilize or mobilize potentially toxic metals in natural aquifers (Lovely and others, 1991; Smedley and Kinniburgh, 2002; McMahon and Chapelle, 2008); and generate undesirable byproducts, including ferrous iron, hydrogen sulfide, and methane (Back and Barnes, 1965; Baedecker and Back, 1979; Chapelle and Lovley, 1992).

McMahon and Chapelle (2008) developed a terminal electron acceptor process (TEAP) methodology to help identify the dominant redox conditions and predominant redox processes in groundwater for 15 principal aquifers in the United States. This analytical and systematic framework was developed on the basis of frequently observed ecological patterns in the sequential reduction of dissolved oxygen, nitrate, and sulfate in groundwater, and the threshold concentrations of these substrates to support microbial populations, combined with the utilization of manganese and iron as solid-phase electron acceptors to indicate the production of dissolved manganese and iron.

The method of Jurgens and others (2009), which automated the TEAP analytical approach and framework developed by McMahon and Chapelle (2008), was used in this report to help identify the dominant redox conditions and processes for the study area. For the purposes of this report, their automated method was used to compare the dominant redox conditions and processes with the probable patterns in groundwater flow, TDS, and other indicators of water quality to help determine the probable influence of the DMCA on groundwater in the study area.

In the Jurgens and others (2009) method, it is assumed that $\mathrm{pH}$ is moderate (6.8-8.6), that there is sufficient total dissolved carbon to meet microbial demands, and that the total (recoverable) dissolved concentrations of iron and manganese accurately reflect the concentrations of the bivalent metals $\mathrm{Fe}^{2+}$ and $\mathrm{Mn}^{2+}$, respectively (McMahon and Chapelle, 2008; Chapelle and others, 2008). However, if the system contains an abundance of total dissolved carbon, it is possible have multiple, simultaneous reduction processes occurring. If the proper microorganisms are present, iron, manganese and sulfate reduction, as well as methanogenesis can occur simultaneously when there is no competition for an organic donor.

Measurement of the concentrations of dissolved oxygen, nitrate, sulfate, sulfide, and dissolved methane gas are recommended by Jurgens and others (2009) for the TEAP analyses. All these constituents were directly measured for groundwater in the DMCA and vicinity, except nitrate and methane. Because concentrations of nitrite occurred at no more than trace levels in groundwater (appendix B, table B3), the concentration of nitrate plus nitrite was used to estimate nitrate nitrogen.

The TEAP analysis reflects redox conditions generally facilitated by microorganisms that obtain energy by transferring electrons from donors (usually organic carbon) to acceptors (usually inorganic species). Because some electron acceptors provide more energy than others, electron acceptors are utilized by these microorganisms in the order of energy provided by the acceptors, from most to least in energy gain. With sufficient, but not excess, carbon sources, the order of progression in the reduction of inorganic species usually is as follows: dissolved oxygen $\left(\mathrm{O}_{2}\right)$, nitrate $\left(\mathrm{NO}_{3}^{-}\right)$, manganese $(\mathrm{Mn}(\mathrm{IV}))$, iron $(\mathrm{Fe}(\mathrm{III}))$, sulfate $\left(\mathrm{SO}_{4}{ }^{2-}\right)$, and carbon dioxide $\left(\mathrm{CO}_{2}(\mathrm{~g})\right)$. Hence, the concentrations of the soluble electron acceptors- $\left(\mathrm{O}_{2}\right)$, nitrate $\left(\mathrm{NO}_{3}{ }^{-}\right)$, and sulfate $\left(\mathrm{SO}_{4}{ }^{2-}\right)$ - and of the TEAP end products - manganese $\left(\mathrm{Mn}^{2+}\right)$, iron $\left(\mathrm{Fe}^{2+}\right)$, ammonia, sulfide $\left[\mathrm{H}_{2} \mathrm{~S}_{\text {Total }}\right.$ the sum of dihydrogen sulfide $\left(\mathrm{H}_{2} \mathrm{~S}\right)$, hydrogen sulfide $\left(\mathrm{HS}^{-}\right)$, and sulfide $\left.\left(\mathrm{S}^{2-}\right)\right]$, and methane $\left(\mathrm{CH}_{4}(\mathrm{~g})\right)$ - can be used to identify the dominant redox conditions and processes in groundwater within, beneath, and in the vicinity of the DMCA.

Dissolved $\mathrm{CH}_{4}(\mathrm{~g})$ was not measured, as it was not sampled in past studies, nor were there any indications of its occurrence base on interpretation in past studies (U.S. Army Corps of Engineers, 1996; R.F. Weston, Inc., 1998). Because groundwater in the DMCA and vicinity generally is more acidic (appendix B, table B3, pH 4.0 - 6.6) than groundwater considered by McMahon and Chapelle (2008, pH 6.5-8.5), the use of the dissolved recoverable concentrations of iron for the concentrations of $\mathrm{Fe}^{2+}$ warrants explanation. At the low end of the $\mathrm{pH}$ range for groundwater in the DMCA and its vicinity, the concentration of dissolved recoverable metals such as iron likely reflects ferric $\left(\mathrm{Fe}^{3+}\right)$ as well as ferrous $\left(\mathrm{Fe}^{2+}\right)$ iron. Except for groundwater with measurable dissolved oxygen, the concentrations of dissolved recoverable metals in groundwater are highly elevated, and in most cases, orders of magnitude above the TEAP threshold concentration necessary to support microbial-reducing conditions for these metals. Thus, it was assumed that the actual concentrations of $\mathrm{Fe}^{2+}$, even if not equal to the dissolved recoverable concentration of iron, would still be in excess of that needed to support microbial reduction requirements (table 14, Individual half-reaction, concentration of $\left.\mathrm{Fe}^{2+} \geq 0.1 \mathrm{mg} / \mathrm{L}\right)$.

Chapelle and others (2008) note that anoxic groundwater systems also can be dominated by sulfate-reducing conditions. To distinguish between iron- and sulfate-reducing conditions, they observed that concentrations of ferrous iron and hydrogen sulfide in groundwater systems tend to be inversely (hyperbolically) related. The authors determined that measurements of dissolved (ferrous) iron, sulfate, and hydrogen sulfide could be used to distinguish which, if either, of these two reduction processes likely is dominant. For iron reduction to be the dominant process, the iron-to-hydrogen sulfide mass ratio must exceed 10 (table 14 , iron $\left(\mathrm{Fe}^{2+}\right) \geq 0.1 \mathrm{mg} / \mathrm{L}$; sulfate $\geq 0.5 \mathrm{mg} / \mathrm{L}$; and iron-to-hydrogen sulfide mass ratio [(mg/L)/ $(\mathrm{mg} / \mathrm{L}) \geq 10]$. For sulfate reduction to be the dominant 
process, the iron-to-hydrogen sulfide ratio cannot exceed 3. For ratios between 3 and 10, both processes could be occurring simultaneously, and (or) in close proximity with reduced waters mixing in the well borehole.

\section{Dissolved Organic Carbon}

DOC concentrations appeared more than adequate for microbial reduction. Concentrations of dissolved (recoverable) carbon generally were one to two orders of magnitude greater than the dissolved carbon concentrations found in surficial or confined natural groundwater on the Delmarva Peninsula (Shedlock and others, 1993, 1999). Higher dissolved carbon concentrations also occurred in conjunction with high TDS concentrations.

Bay sediments contain abundant amounts of organic carbon (table 8 , carbon, $21,810 \mathrm{mg} / \mathrm{kg}$ ). The DMCA fill also likely contains abundant organic carbon from deposited bay sediments. In addition, the original wetland sediment, buried by DMCA fill, may have been a significant source of organic carbon. Seasonal Phragmites vegetation within the DMCA continues to provide an additional source of organic carbon to the containment area.

Groundwater in both the perched water-bearing zone and the Magothy aquifer within the DMCA property boundary contained elevated concentrations of DOC (fig. 46). Concentrations of DOC range from approximately 3 to $13 \mathrm{mg} / \mathrm{L}$. By way of contrast, concentrations in shallow groundwater in Magothy aquifer beneath WVS are no more than $2 \mathrm{mg} / \mathrm{L}$ and are generally less than $1 \mathrm{mg} / \mathrm{L}$. To the east beyond the DMCA property boundary, the concentration of DOC in groundwater not overly affected by anthropogenic activities is less than $0.3 \mathrm{mg} / \mathrm{L}$ (fig. 46; appendix B, table B3).

Groundwater in the upper Patapsco aquifer shallow water-bearing zone and along the southwestern part of the DMCA and property boundary contains elevated concentrations of DOC - approximately 4-11 mg/L (fig. 47). Beneath WVS, concentrations of carbon also are elevated and are approximately $1-7 \mathrm{mg} / \mathrm{L}$. The lowest concentrations of DOC occur along the eastern property boundary of the DMCA and are less than $0.6 \mathrm{mg} / \mathrm{L}$. Similar low concentrations are found in the upper Patapsco aquifer deep water-bearing zone (appendix B, table B3).

Elevated concentrations of DOC may have been a major cause of the reducing conditions found in groundwater associated with groundwater flow from the DMCA (for example, figure 48). The occurrence of DOC at elevated levels in groundwater flow from the DMCA into the Magothy aquifer and ultimately into the upper Patapsco aquifer shallow water-bearing zone beneath WVS is significant. Elevated concentrations of DOC from the DMCA provide an abundance of carbon to support microbial reduction and mobilization of metals in the upper Patapsco aquifer shallow water-bearing zone beneath WVS.

\section{Reduction-0xidation Conditions and Processes}

Summary results for the TEAP analysis identified five general redox categories and corresponding reduction processes characterizing groundwater in the DMCA and its vicinity (table 14). Also included in this summary are the corresponding individual half-cell reactions and threshold conditions for each individual reduction process. The TEAP results can be characterized on the basis of the dominant condition and predominant reduction process identified for each well (table 15).

The five major redox categories and corresponding reduction reaction processes indicate groundwater in the DMCA and vicinity include oxic $\left(\mathrm{O}_{2}\right.$ reducing condition), mixed oxicanoxic $\left(\mathrm{O}_{2}-\mathrm{Mn}(\mathrm{IV})\right.$ or $\mathrm{O}_{2}-\mathrm{Fe}(\mathrm{III})$ reducing condition), mixed anoxic ( $\mathrm{NO}_{3}-\mathrm{Fe}$ (III) reducing conditions), anoxic (( $\mathrm{Fe}(\mathrm{III})$ reducing), and $\mathrm{CH}_{4}(\mathrm{~g})$ generating conditions (table 15$)$. The oxic or anoxic categories reflect a single species predominant in the redox condition, whereas the mixed reducing conditions $\left(\mathrm{O}_{2}-\mathrm{Fe}(\mathrm{III}), \mathrm{O}_{2}-\mathrm{Mn}(\mathrm{IV})\right.$, or $\left.\mathrm{NO}_{3}-\mathrm{Fe}(\mathrm{III})\right)$ warrant explanation. Mixed categories reflect groundwater associated with different reducing processes. Mixed conditions could reflect: (a) two reduction processes occurring simultaneously in the sediment, with neither process fully dominating, (b) borehole mixing of groundwater undergoing different reduction processes at different depths along, or different distances from, the well screen (Jurgens and others, 2009; McMahon and Chapelle, 2008), or (c) simultaneous reactions occurring due to the abundance of DOC found in the majority of the waters.

With the potential causes in mind, the TEAP analysis can be used to describe redox conditions and processes in different parts of the surface-water and groundwater system in the study area. Redox conditions differed for surface waters. At the Pearce Creek Lake outlet, lake discharge reflected a slightly reduced, mixed oxic-anoxic condition (fig. 49, $\mathrm{O}_{2}-\mathrm{Mn}$ ); whereas Elk River water was found to be oxic (fig. 49, $\mathrm{O}_{2}$ ). Groundwater in the perched zone and the Magothy aquifer within the DMCA property boundary, and along Pond Neck Road, are anoxic, and, except for well CE Dd 135, reflect groundwater where ferric $\left(\mathrm{Fe}^{3+}\right)$ iron likely is being reduced (fig. 49, Fe(III)). Groundwater associated with well CE Dd 135 is classified as under anoxic conditions and potentially generating methane (fig. 49, $\mathrm{CH}_{4}(\mathrm{~g}), \mathrm{NC}$ ).

By way of contrast, except for groundwater associated with well CE Dd 143, shallow groundwater in the Magothy aquifer and surface waters in the vicinity, but beyond the property boundary of the DMCA, exhibit a variety of different but generally less severe reducing conditions-either oxic $\left(\mathrm{O}_{2}\right)$ or mixed oxic-anoxic conditions (fig. 49, $\mathrm{O}_{2}-\mathrm{Mn}$ (IV) or $\mathrm{Fe}(\mathrm{III})$ ), indicating that oxygen and either $\mathrm{Mn}(\mathrm{IV})$ or $\mathrm{Fe}(\mathrm{III})$ are being reduced. The chemistry of the groundwater from well CE Dd 143 reflects a mixed anoxic condition associated with nitrate $\left(\mathrm{NO}_{3}^{-}\right)$and ferric iron reduction (fig. 49, $\mathrm{NO}_{3}^{-}-\mathrm{Fe}$ ). The variety of redox conditions and reducing processes associated with groundwater in the Magothy aquifer beneath WVS could reflect pumping-induced mixing of groundwater with different 


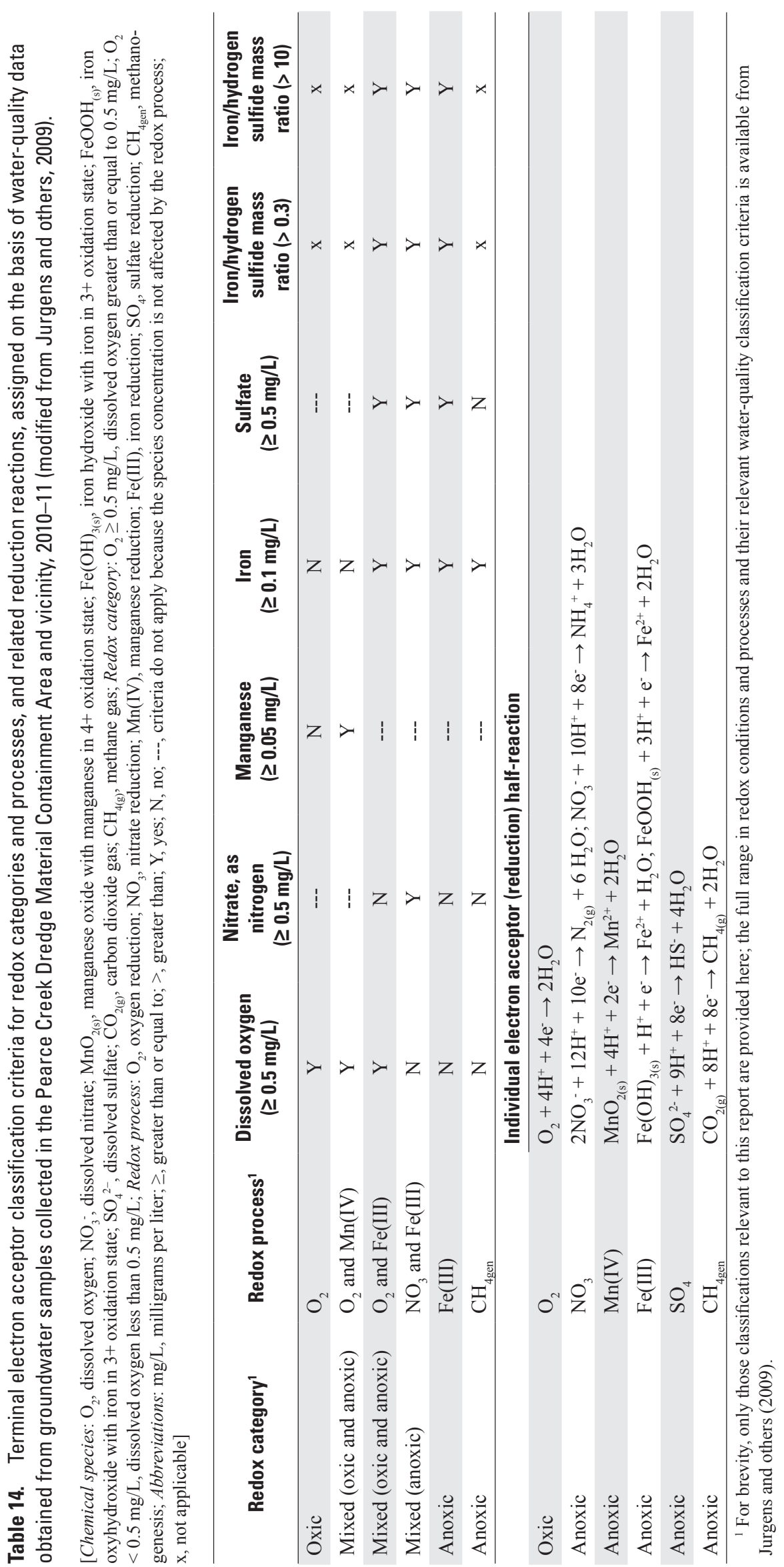


Table 15. Classification of redox categories and processes assigned on the basis of water-quality data obtained from groundwater and surface-water samples collected in the Pearce Creek Dredge Material Containment Area and vicinity, 2010-11.

[USGS, U.S. Geological Survey; Redox process: $\mathrm{O}_{2}$, oxygen reduction; $\mathrm{NO}_{3}$, nitrate reduction; $\mathrm{Mn}(\mathrm{IV})$, manganese reduction; $\mathrm{Fe}(\mathrm{III})$, iron reduction; $\mathrm{SO}_{4}$, sulfate reduction; $\mathrm{CH}_{4 \mathrm{gen}}$, methanogenesis]

\begin{tabular}{|c|c|c|}
\hline $\begin{array}{l}\text { USGS local } \\
\text { identifier }\end{array}$ & $\begin{array}{l}\text { General redox } \\
\text { category }\end{array}$ & Redox process \\
\hline \multicolumn{3}{|c|}{ Observation wells } \\
\hline CE Dd 81 & Anoxic & $\mathrm{Fe}(\mathrm{III})$ \\
\hline CE Dd 122 & Anoxic & $\mathrm{Fe}(\mathrm{III})$ \\
\hline CE Dd 124 & Anoxic & $\mathrm{Fe}(\mathrm{III})$ \\
\hline CE Dd 125 & Anoxic & $\mathrm{Fe}(\mathrm{III})$ \\
\hline CE Dd 126 & Anoxic & $\mathrm{Fe}(\mathrm{III})$ \\
\hline CE Dd 127 & Anoxic & $\mathrm{Fe}(\mathrm{III})$ \\
\hline CE Dd 128 & Anoxic & $\mathrm{Fe}(\mathrm{III})$ \\
\hline CE Dd 129 & Anoxic & $\mathrm{Fe}(\mathrm{III})$ \\
\hline CE Dd 133 & Anoxic & $\mathrm{Fe}(\mathrm{III})$ \\
\hline CE Dd 135 & Anoxic & $\mathrm{CH}_{4 \mathrm{gen}}$ \\
\hline CE Dd 136 & Anoxic & $\mathrm{Fe}(\mathrm{III})$ \\
\hline CE Dd 137 & Anoxic & $\mathrm{Fe}(\mathrm{III})$ \\
\hline CE Dd 138 & Anoxic & $\mathrm{Fe}(\mathrm{III})$ \\
\hline CE Dd 139 & Anoxic & $\mathrm{Fe}(\mathrm{III})$ \\
\hline CE Dd 140 & Mixed (oxic-anoxic) & $\mathrm{O}_{2}-\mathrm{Fe}(\mathrm{III})$ \\
\hline CE Dd 141 & Anoxic & $\mathrm{Fe}(\mathrm{III})$ \\
\hline CE Dd 142 & Anoxic & $\mathrm{Fe}(\mathrm{III})$ \\
\hline CE Dd 143 & Mixed (anoxic) & $\mathrm{NO}_{3}-\mathrm{Fe}(\mathrm{III})$ \\
\hline CE Dd 144 & Anoxic & $\mathrm{Fe}(\mathrm{III})$ \\
\hline CE Dd 145 & Anoxic & $\mathrm{Fe}(\mathrm{III})$ \\
\hline CE Dd 146 & Anoxic & $\mathrm{Fe}(\mathrm{III})$ \\
\hline CE Dd 147 & Anoxic & $\mathrm{Fe}(\mathrm{III})$ \\
\hline CE Dd 149 & Anoxic & $\mathrm{Fe}(\mathrm{III})$ \\
\hline CE Dd 150 & Anoxic & $\mathrm{Fe}(\mathrm{III})$ \\
\hline CE Dd 151 & Anoxic & $\mathrm{Fe}(\mathrm{III})$ \\
\hline CE Dd 153 & Anoxic & $\mathrm{Fe}(\mathrm{III})$ \\
\hline CE Dd 154 & Anoxic & $\mathrm{Fe}(\mathrm{III})$ \\
\hline CE Dd 155 & Mixed (oxic-anoxic) & $\mathrm{O}_{2}-\mathrm{Fe}(\mathrm{III})$ \\
\hline CE Dd 156 & Anoxic & $\mathrm{CH}_{4 \mathrm{gen}}$ \\
\hline CE Dd 157 & Anoxic & $\mathrm{Fe}(\mathrm{III})$ \\
\hline CE Dd 158 & Anoxic & $\mathrm{Fe}(\mathrm{III})$ \\
\hline CE Dd 160 & Anoxic & $\mathrm{Fe}(\mathrm{III})$ \\
\hline CE Dd 191 & Anoxic & $\mathrm{Fe}(\mathrm{III})$ \\
\hline CE Dd 192 & Anoxic & $\mathrm{Fe}(\mathrm{III})$ \\
\hline CE Dd 193 & Mixed (oxic-anoxic) & $\mathrm{O}_{2}-\mathrm{Fe}(\mathrm{III})$ \\
\hline
\end{tabular}

Table 15. Classification of redox categories and processes assigned on the basis of water-quality data obtained from groundwater and surface-water samples collected in the Pearce Creek Dredge Material Containment Area and vicinity, 2010-11.-Continued

[USGS, U.S. Geological Survey; Redox process: $\mathrm{O}_{2}$, oxygen reduction; $\mathrm{NO}_{3}$, nitrate reduction; $\mathrm{Mn}(\mathrm{IV})$, manganese reduction; $\mathrm{Fe}(\mathrm{III})$, iron reduction; $\mathrm{SO}_{4}$, sulfate reduction; $\mathrm{CH}_{4 \mathrm{gen}}$, methanogenesis]

\begin{tabular}{|c|c|c|}
\hline $\begin{array}{l}\text { USGS local } \\
\text { identifier }\end{array}$ & $\begin{array}{c}\text { General redox } \\
\text { category }\end{array}$ & Redox process \\
\hline \multicolumn{3}{|c|}{ Domestic wells } \\
\hline CE Dd 161 & Anoxic & $\mathrm{Fe}(\mathrm{III})$ \\
\hline CE Dd 163 & Mixed (oxic-anoxic) & $\mathrm{O}_{2}-\mathrm{Mn}(\mathrm{IV})$ \\
\hline CE Dd 164 & Mixed (oxic-anoxic) & $\mathrm{O}_{2}-\mathrm{Mn}(\mathrm{IV})$ \\
\hline CE Dd 165 & Mixed (oxic-anoxic) & $\mathrm{O}_{2}-\mathrm{Fe}(\mathrm{III})$ \\
\hline CE Dd 166 & Mixed (anoxic) & $\mathrm{NO}_{3}-\mathrm{Fe}(\mathrm{III})$ \\
\hline CE Dd 168 & Oxic & $\mathrm{O}_{2}$ \\
\hline CE Dd 169 & Anoxic & $\mathrm{Fe}(\mathrm{III})$ \\
\hline CE Dd 170 & Anoxic & $\mathrm{Fe}(\mathrm{III})$ \\
\hline CE Dd 171 & Mixed (oxic-anoxic) & $\mathrm{O}_{2}-\mathrm{Fe}(\mathrm{III})$ \\
\hline CE Dd 172 & Mixed (oxic-anoxic) & $\mathrm{O}_{2}-\mathrm{Mn}(\mathrm{IV})$ \\
\hline CE Dd 174 & Anoxic & $\mathrm{Fe}(\mathrm{III})$ \\
\hline CE Dd 176 & Anoxic & $\mathrm{Fe}(\mathrm{III})$ \\
\hline CE Dd 177 & Anoxic & $\mathrm{Fe}(\mathrm{III})$ \\
\hline CE Dd 178 & Mixed (oxic-anoxic) & $\mathrm{O}_{2}-\mathrm{Mn}(\mathrm{IV})$ \\
\hline CE Dd 179 & Anoxic & $\mathrm{Fe}(\mathrm{III})$ \\
\hline \multicolumn{3}{|c|}{ Surface waters } \\
\hline $\begin{array}{l}\text { Elk River at mouth } \\
\text { near Crystal Beach, } \\
\text { Md. }\end{array}$ & Oxic & $\mathrm{O}_{2}$ \\
\hline $\begin{array}{l}\text { Pearce Creek at } \\
\text { Crystal Beach, Md. }\end{array}$ & Mixed (oxic-anoxic) & $\mathrm{O}_{2}-\mathrm{Mn}(\mathrm{IV})$ \\
\hline
\end{tabular}

redox conditions and (or) simultaneous but different redox conditions occurring in groundwater in close proximity to the well screens.

Redox conditions and processes influence the occurrence and distribution of individual redox-sensitive species in groundwater in the DMCA and vicinity. The affected redoxsensitive species include dissolved oxygen, dissolved inorganic nitrogen compounds (nitrate-plus-nitrite and ammonianitrogen), total recoverable manganese and iron, and dissolved sulfur compounds (sulfide or sulfate).

On the basis of concentrations of dissolved oxygen above the TEAP threshold (table $14, \mathrm{O}_{2} \geq 0.50 \mathrm{mg} / \mathrm{L}$ ), only shallow groundwater in the Magothy aquifer beneath WVS (fig. 50), and in the Magothy aquifer east of the DMCA property boundary (fig. 50, well CE Dd 193) are considered to be in an oxygen-bearing zone. 

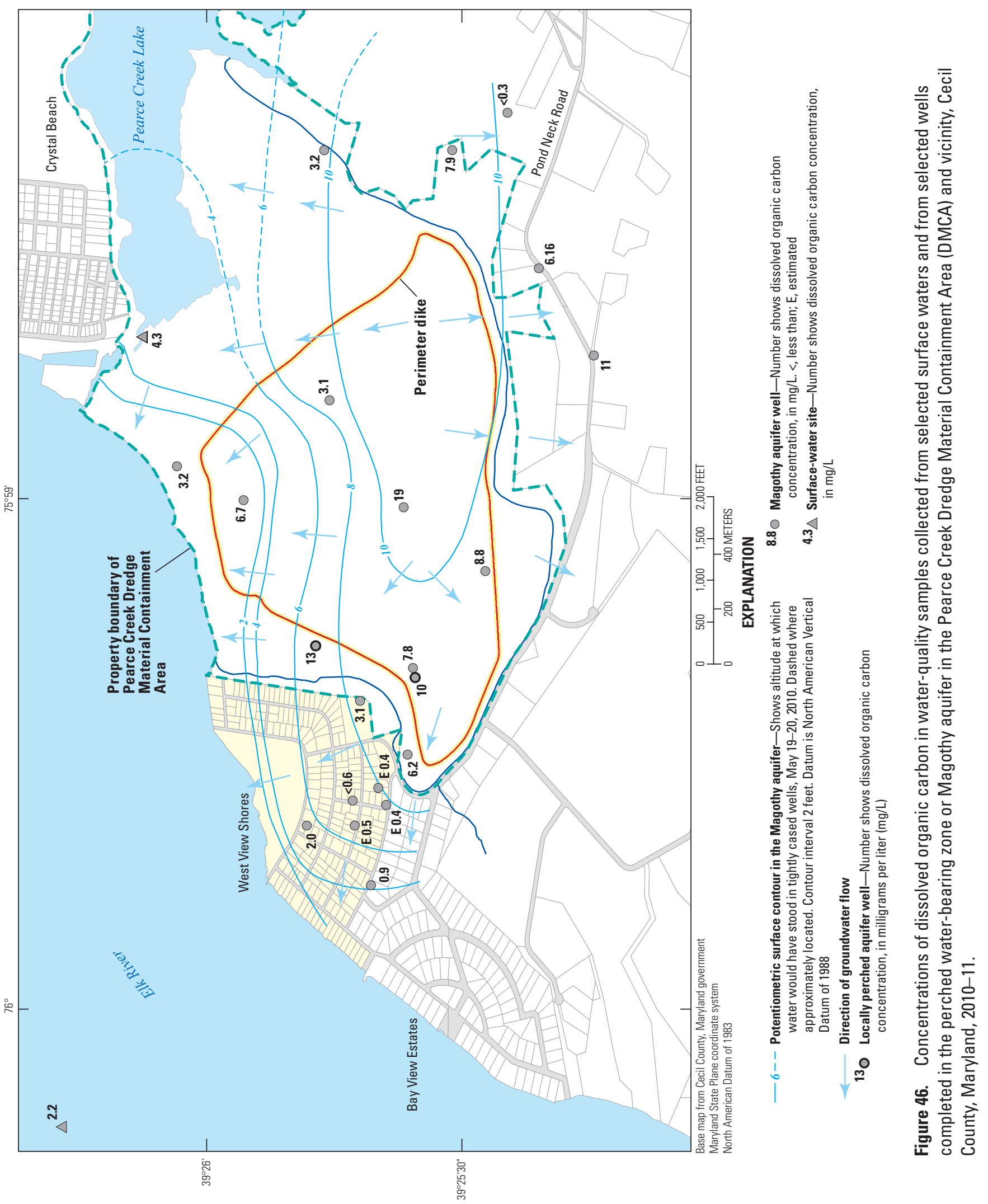

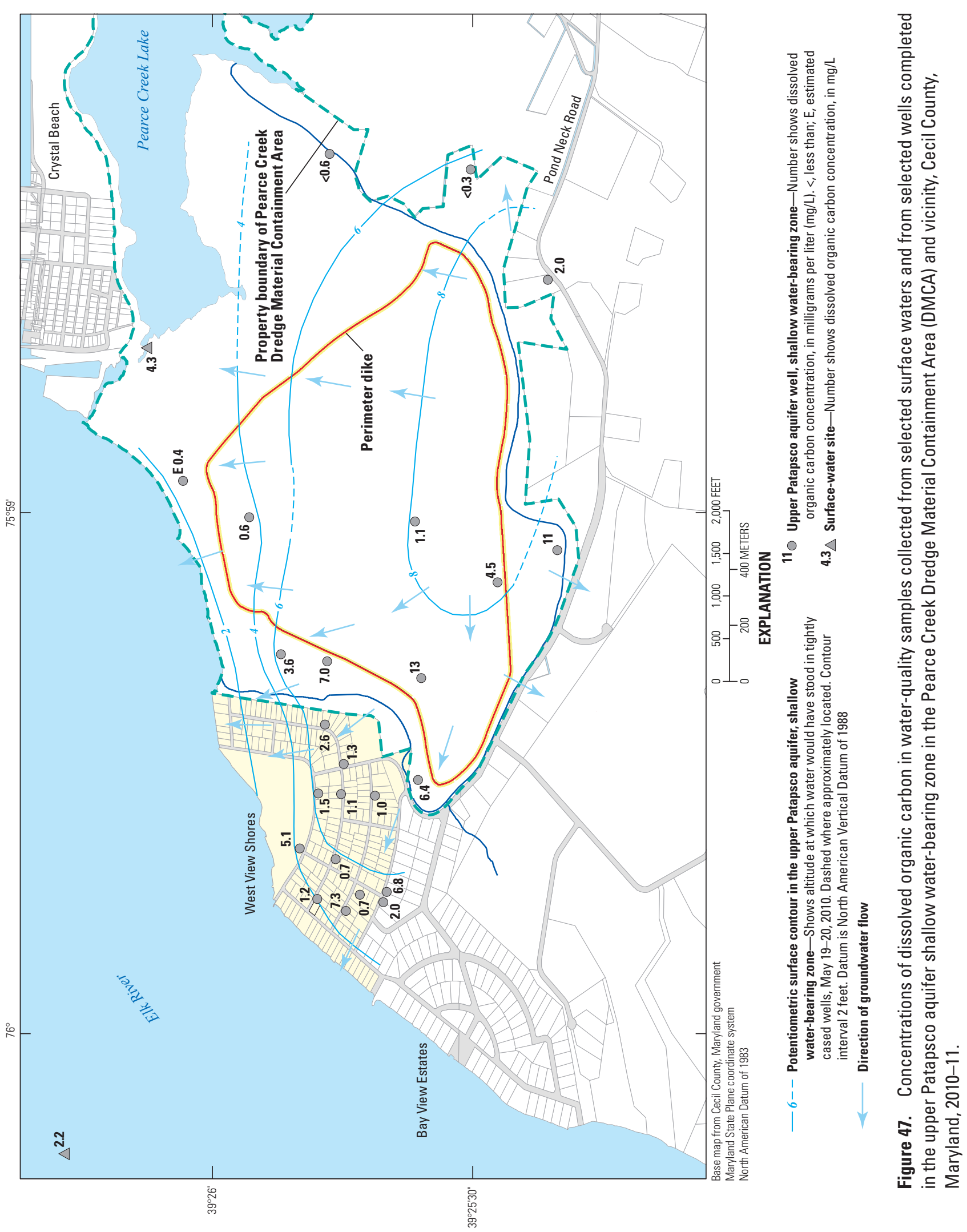


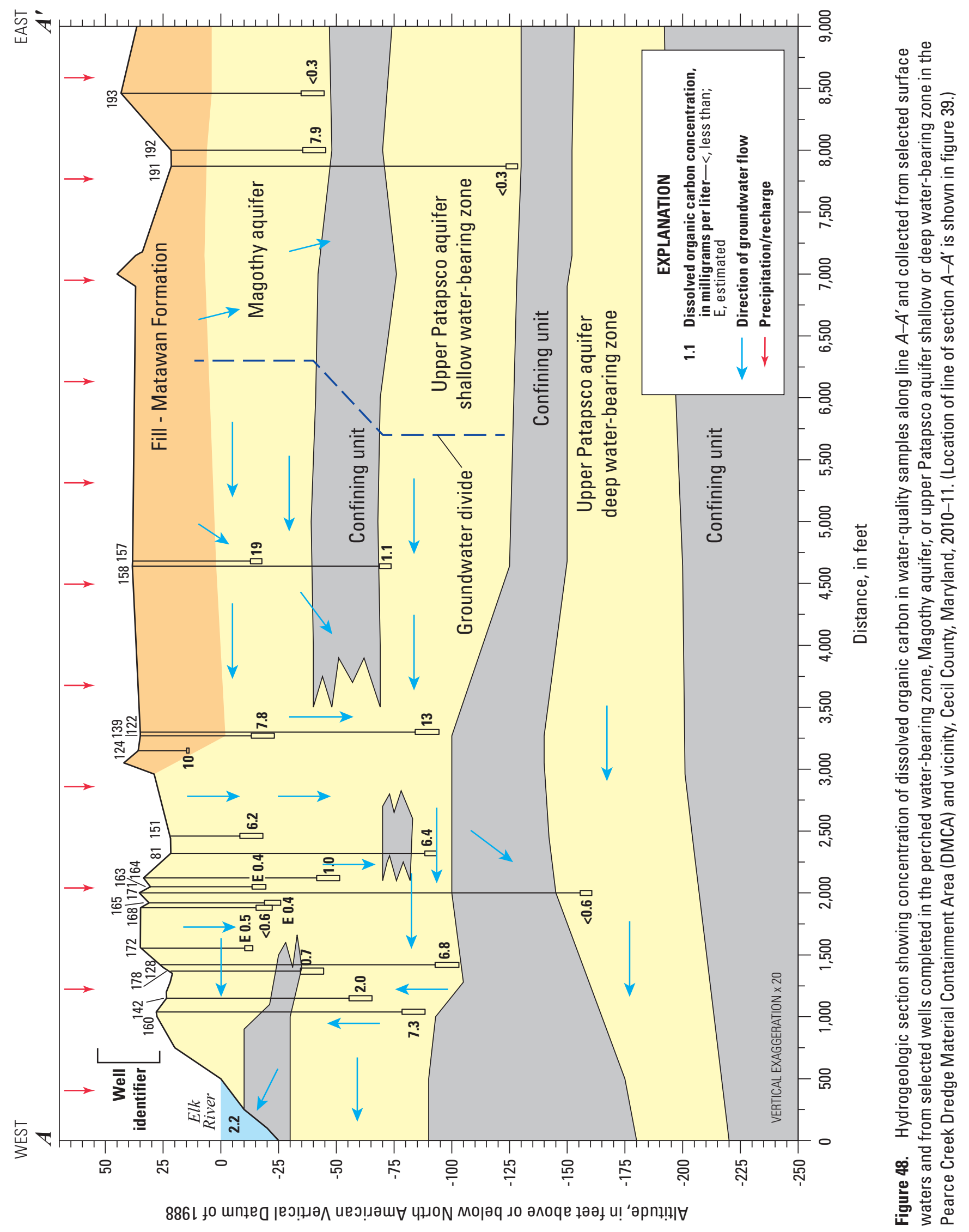



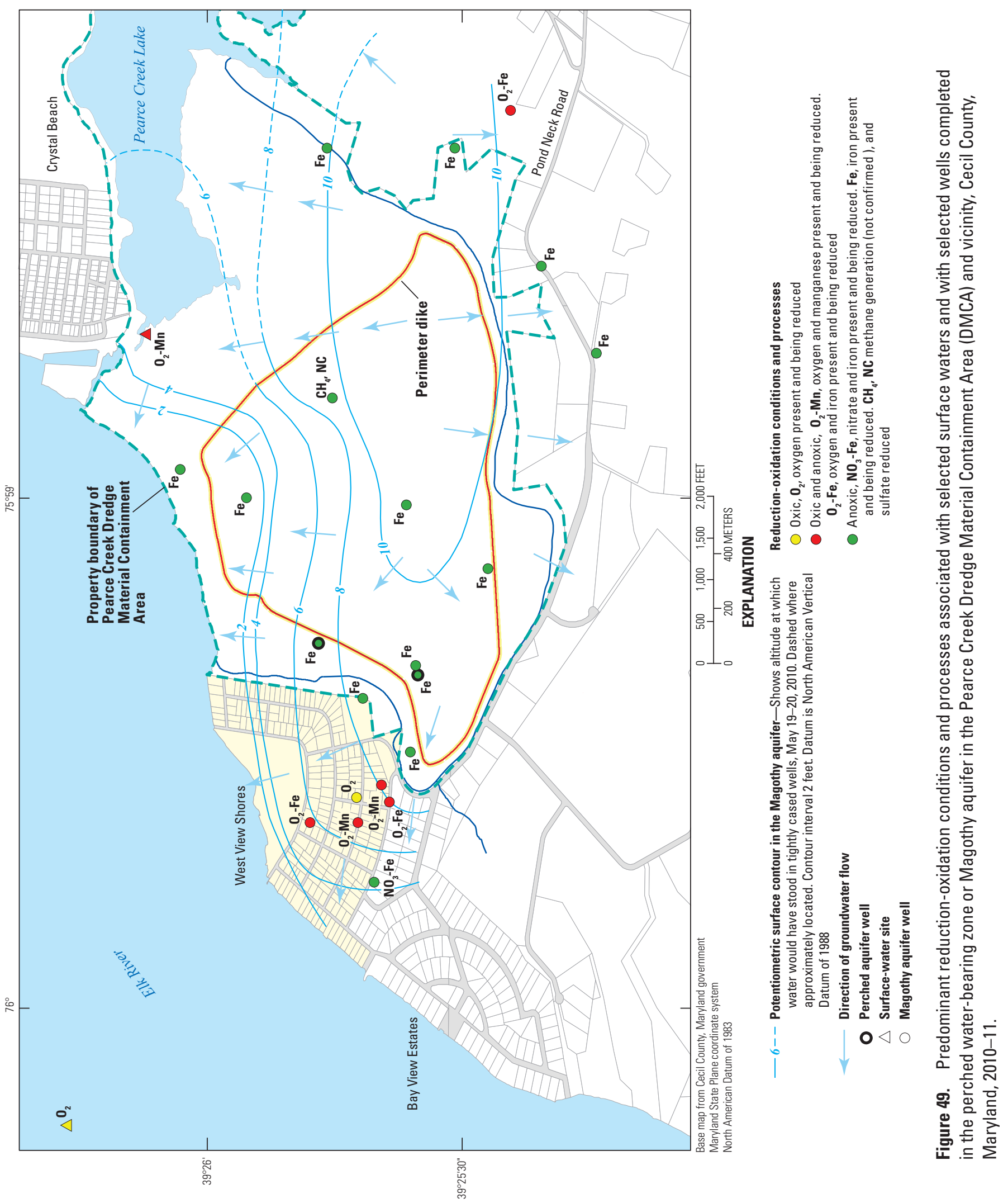
Concentrations of nitrate-plus-nitrite nitrogen above the TEAP threshold (table $14, \mathrm{NO}_{3}^{-} \geq 0.5 \mathrm{mg} / \mathrm{L}$ ) only occur in shallow groundwater in the Magothy aquifer beneath part of WVS and east of the DMCA property boundary (fig. 51). Elsewhere nitrate-plus-nitrite nitrogen only occurs at low concentrations (approximately $0.15 \mathrm{mg} / \mathrm{L}$ or less). The pattern in the occurrence of nitrate plus nitrite nitrogen at elevated concentrations is consistent with elevated concentrations of dissolved oxygen described above. The occurrence of nitrate plus nitrite nitrogen is also similar to other groundwater samples from residential areas elsewhere on the Delmarva Peninsula, where oxic shallow groundwater has higher concentrations of nitrate plus nitrite nitrogen than anoxic groundwater (table 12).

The major dissolved inorganic form of nitrogen in groundwater under reduced conditions is ammonia nitrogen (fig. 52). The highest concentrations in ammonia nitrogen in groundwater under reduced conditions occur beneath the DMCA, or within or near the DMCA property boundary, in the perched groundwater zone and Magothy aquifer (figs. 52 and 53). On the basis of patterns in groundwater flow, groundwater in the Magothy aquifer with elevated concentrations of ammonia nitrogen travels south at least to Pond Neck Road and west from the DMCA (fig. 52) before flowing laterally and vertically downward into the upper Patapsco shallow water-bearing zone beneath WVS (fig. 54).

Concentrations of dissolved manganese are less than the TEAP threshold (table $14, \mathrm{Mn}^{2+}, 0.05 \mathrm{mg} / \mathrm{L}$, or $50 \mu \mathrm{g} / \mathrm{L}$ ) in groundwater at one well in the Magothy aquifer beneath WVS (fig. 55). The occurrence of moderately elevated manganese concentrations just below the oxygen-bearing zone in WVS could reflect solid-phase $\mathrm{Mn}(\mathrm{IV})$ reduction and mobilization in conjunction with groundwater moving vertically downward from this oxygen-bearing zone. Manganese was abundant and well above the TEAP threshold throughout the remainder of the Magothy aquifer (fig. 55). High manganese concentrations in this aquifer occurred beneath the southern and western parts of the DMCA. To the south, the highest concentrations occurred along Pond Neck Road and reflected groundwater flow from the DMCA to this aquifer. Given this flow path occurs in entirely anoxic iron-reducing conditions, the high manganese concentrations along Pond Neck Road could reflect solid-phase $\mathrm{Mn}(\mathrm{IV})$ reduction and mobilization not only in the DMCA, but throughout the anoxic aquifer (fig. 56).

Chapelle and others (2008) note that anoxic groundwater systems can be dominated by iron- or sulfate-reducing conditions, or both. Groundwater throughout most of the DMCA and vicinity is under redox conditions where iron likely is being reduced. Concentrations of iron below $<0.01 \mathrm{mg} / \mathrm{L}$ only are approached in oxygen-bearing shallow groundwater in the Magothy aquifer beneath WVS (fig. 57). Iron concentrations are considerably above the TEAP threshold in the perched water-bearing zone and the Magothy aquifer, as well as the upper Patapsco aquifer shallow water-bearing zone (figs. 58 and 59). As in the case of manganese, high concentrations of iron generally correspond to groundwater flow within and from the DMCA. Concentrations of iron also tend to increase with depth and distance along the groundwater flow paths from the DMCA (for example, figure 57), in what are mainly anoxic iron-reducing conditions. The highest concentrations of iron correspond to areas where groundwater flow from the DMCA potentially could be in contact with oxygen-bearing or mixed oxic-anoxic groundwater from other source areasfor example, to the west of the DMCA in the upper Patapsco aquifer beneath WVS or to the east of the DMCA property boundary (fig. 59). The high concentrations of iron also correspond to elevated levels of DOC found in the samples. These elevated concentrations of iron are also considerably greater than concentrations of iron in groundwater elsewhere in the vicinity of the study area that are considered not overly affected by human activities (table 13).

Groundwater unaffected by flow from the DMCA has concentrations of iron higher than the TEAP threshold of $0.01 \mathrm{mg} / \mathrm{L}$. Native sediments throughout most of the area have high iron concentrations, which likely reflect iron's abundance in native aquifer sediments as well as in the DMCA fill (see Chemical Composition of Sediments, this report). Iron is more abundant than manganese in DMCA fill-Matawan sediments and other sediments in the study area (table 9). The relative abundance of iron and manganese in the sediments, iron being greater than manganese, is likely related to the relative abundance of those elements in the Earth's outer crust: this could explain why iron concentrations generally exceed manganese concentrations in groundwater in the study area and vicinity that are not overly affected by human activities (table 13).

As noted in the previous section (see Total Dissolved Solids and Major Ions, this report) the proportion of sulfate within a particular sample was an important factor for distinguishing groundwater flow patterns. Dredge material and buried wetland sediments were likely the largest source of sulfur within the study area. The addition of oxic Elk River water may have oxidized the ferrous sulfide minerals to form sulfate, which is mobile. The sulfate can then be reduced, under the proper conditions, to hydrogen sulfide. However, sulfate generally is not undergoing appreciable reduction in this groundwater flow system. The iron-to-hydrogen sulfide mass ratios all exceeded 10, indicating the flow system was predominately iron-reducing. Except for groundwater associated with two wells within the DMCA property boundary, concentrations of sulfate occurred at measurable (exceeding approximately $0.2 \mathrm{mg} / \mathrm{L}$ ) to extremely elevated (thousands of milligrams per liter) concentrations throughout the Magothy aquifer (fig. 60) and the upper Patapsco aquifer shallow waterbearing zone (fig. 61).

Groundwater associated with two wells within the DMCA property boundary (fig. 6, wells CE Dd 156 and CE Dd 135) and screened in the Magothy aquifer had low levels of dissolved oxygen (less than $0.5 \mathrm{mg} / \mathrm{L}$ ), low to moderate levels of levels of ammonia-nitrogen (less than $4 \mathrm{mg} / \mathrm{L}$ ), moderately elevated levels of dissolved iron (up to hundreds of milligrams per liter), low levels of sulfide $(0.015 \mu \mathrm{g} / \mathrm{L})$, and sulfate concentrations reported as less than the LRL $(19 \mathrm{mg} / \mathrm{L})$. On the 


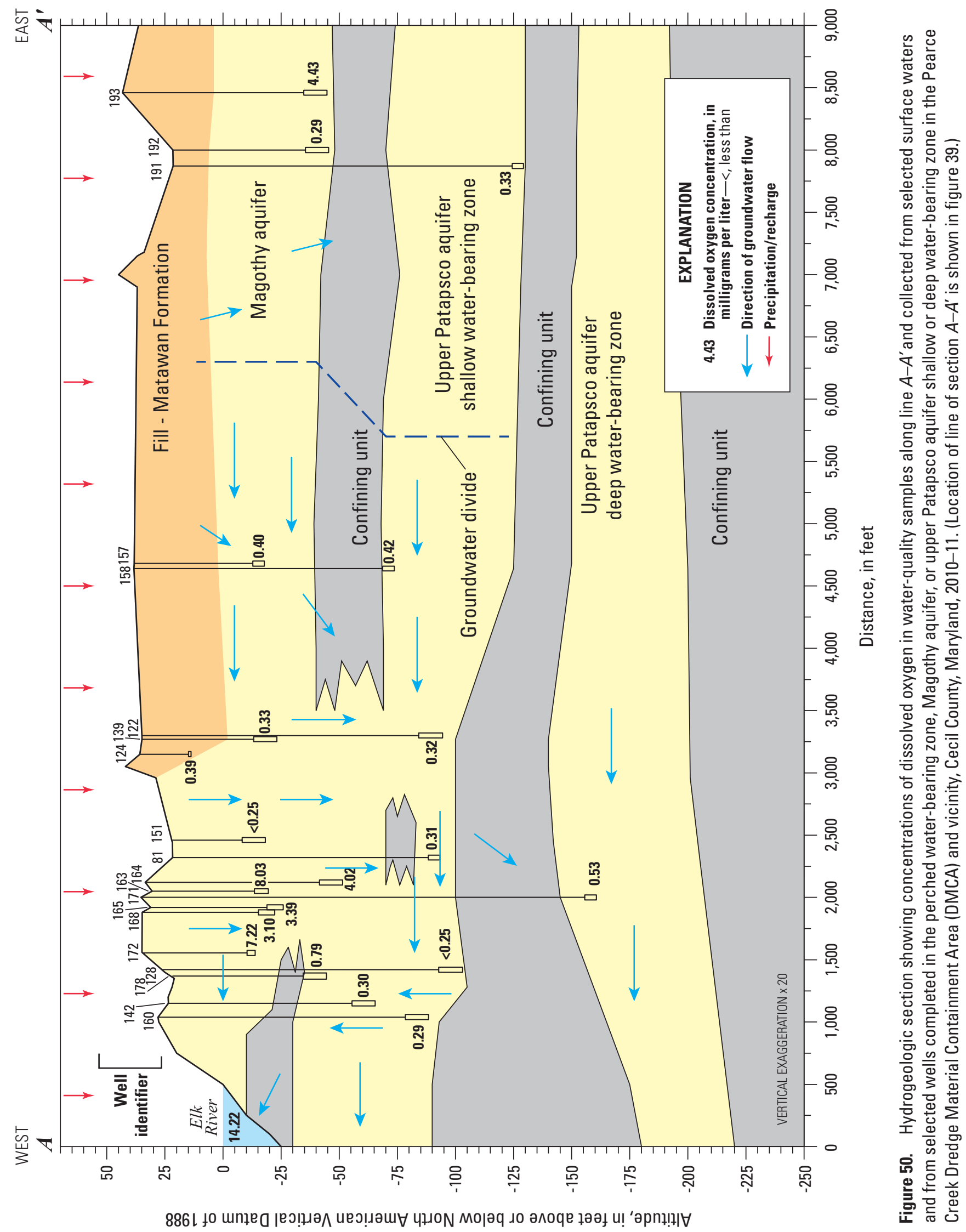




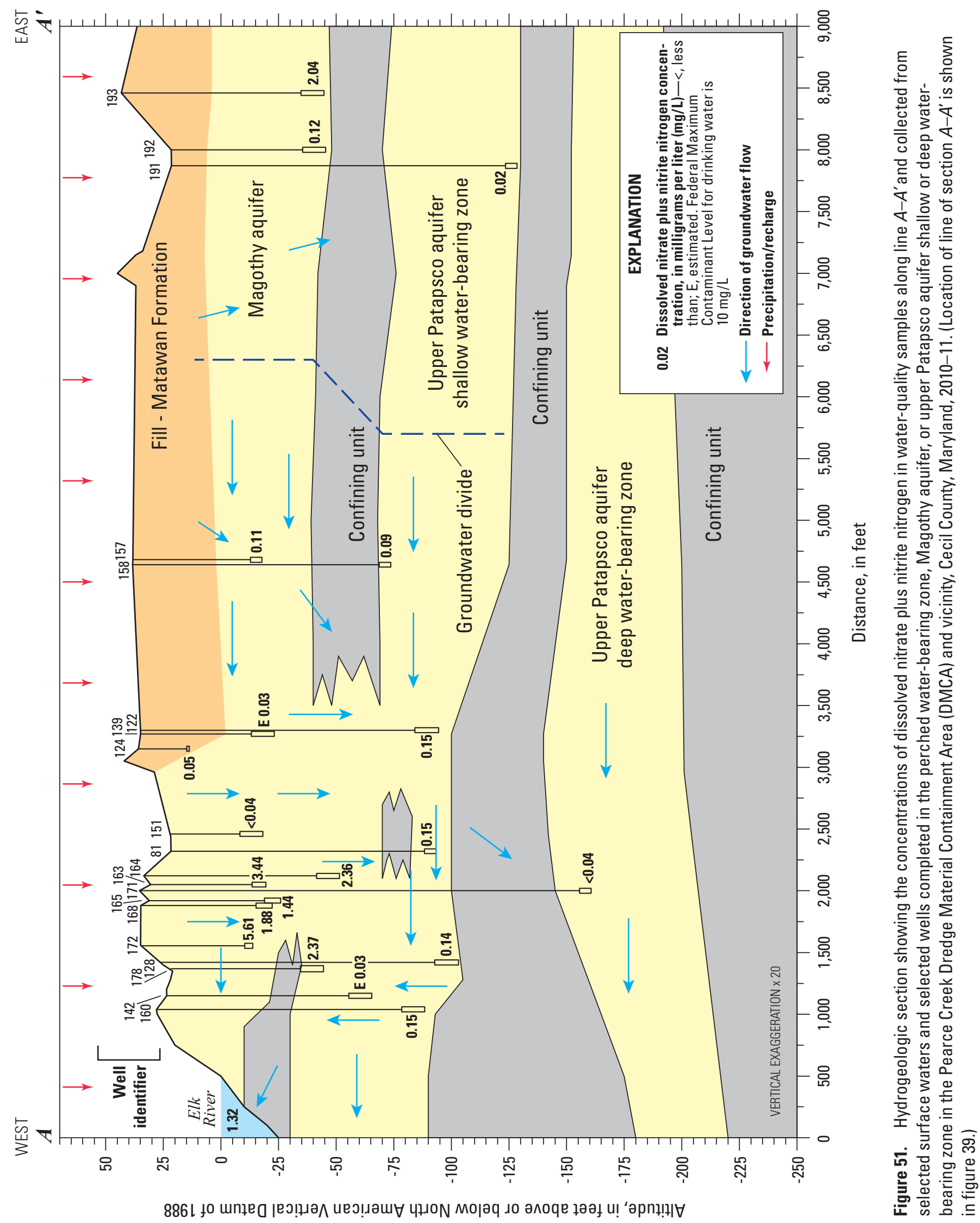




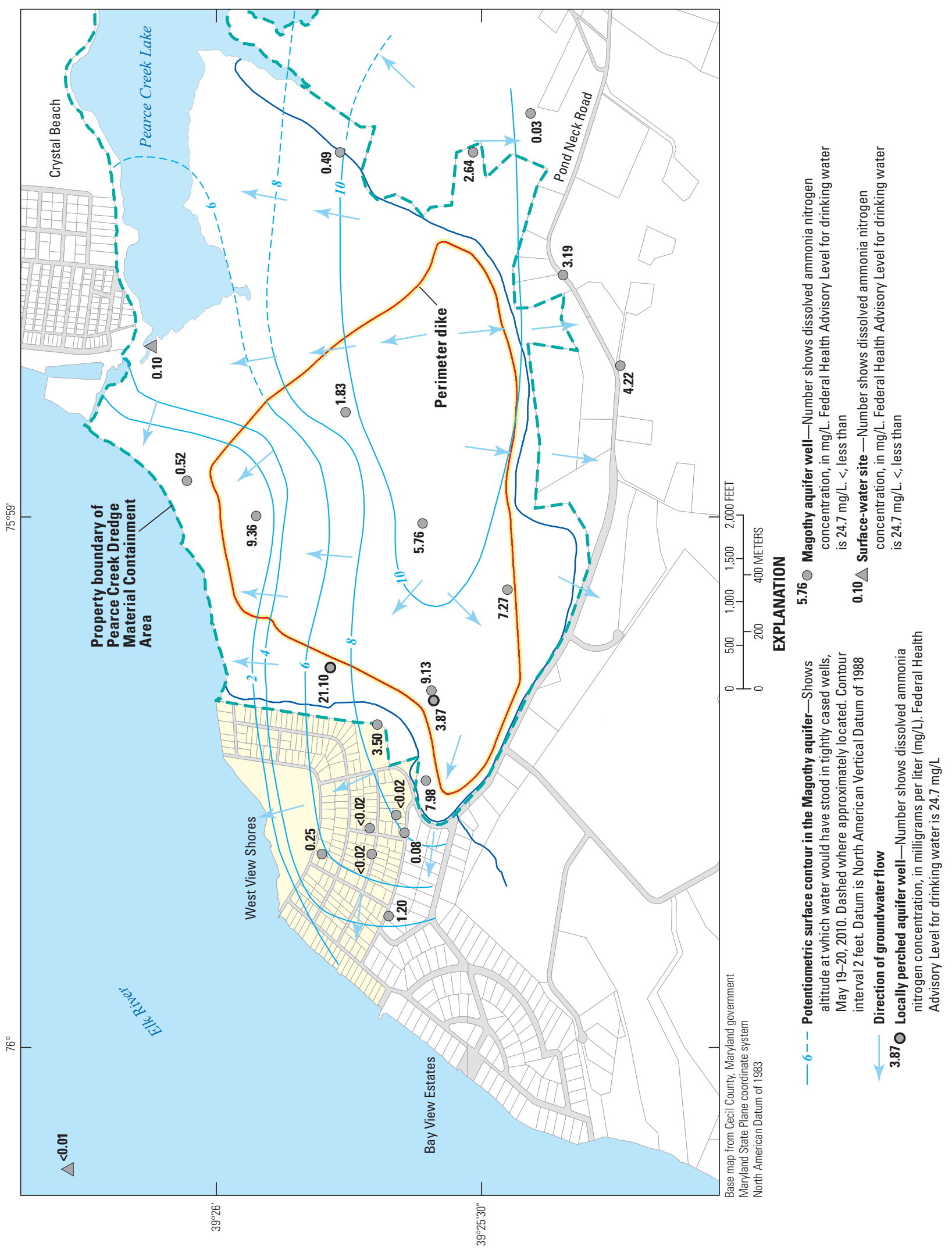

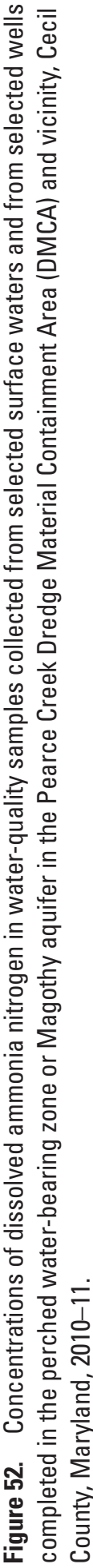



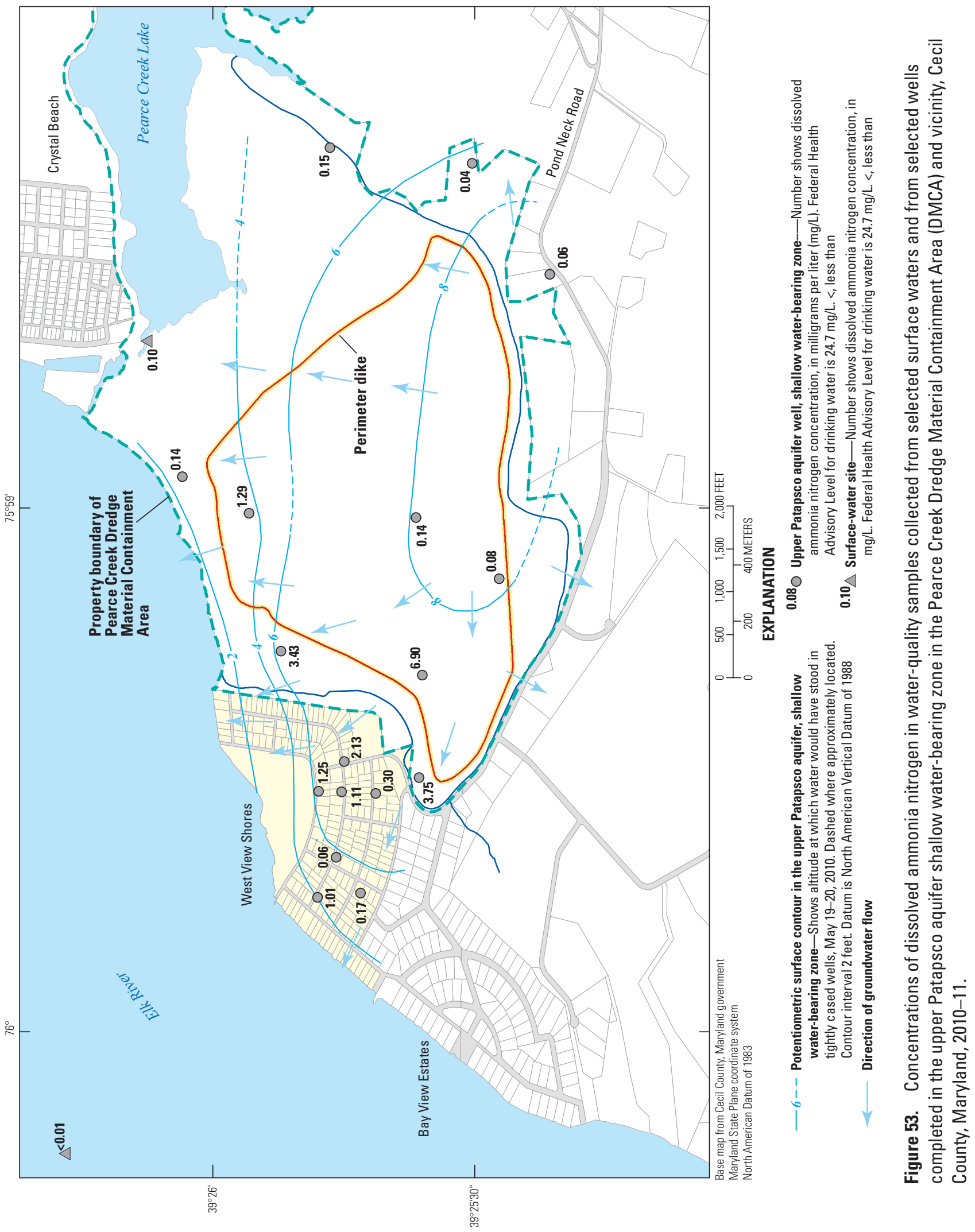


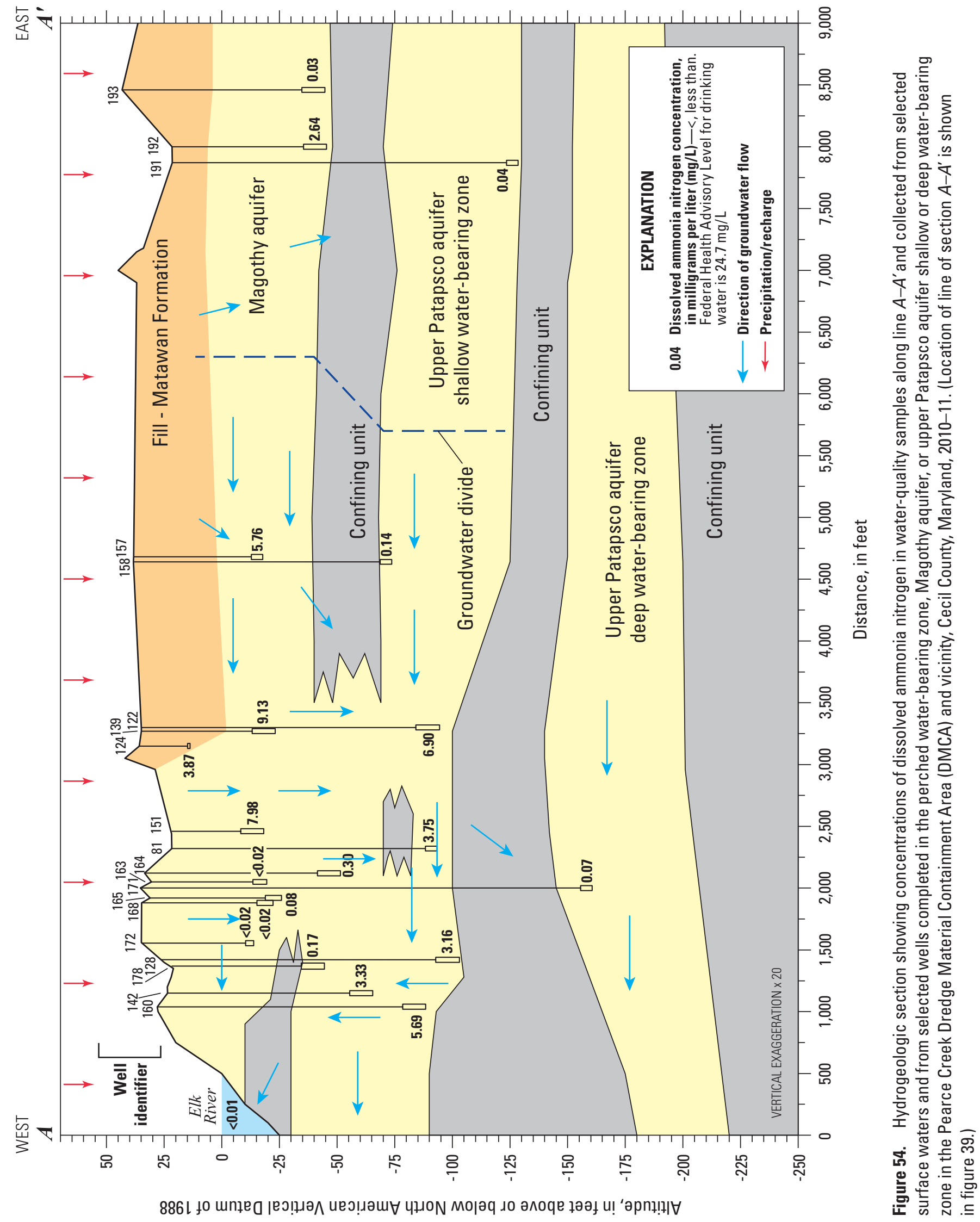




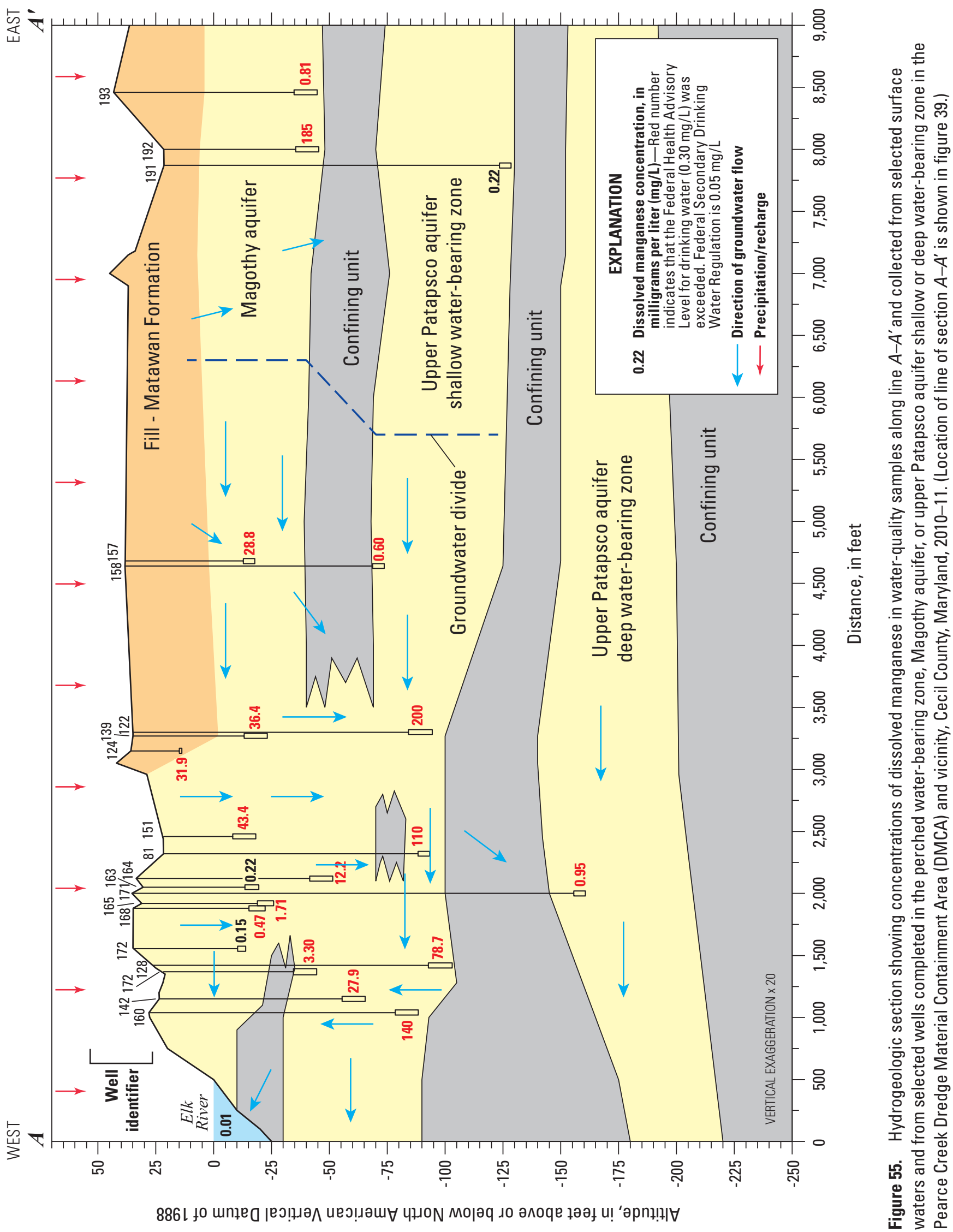



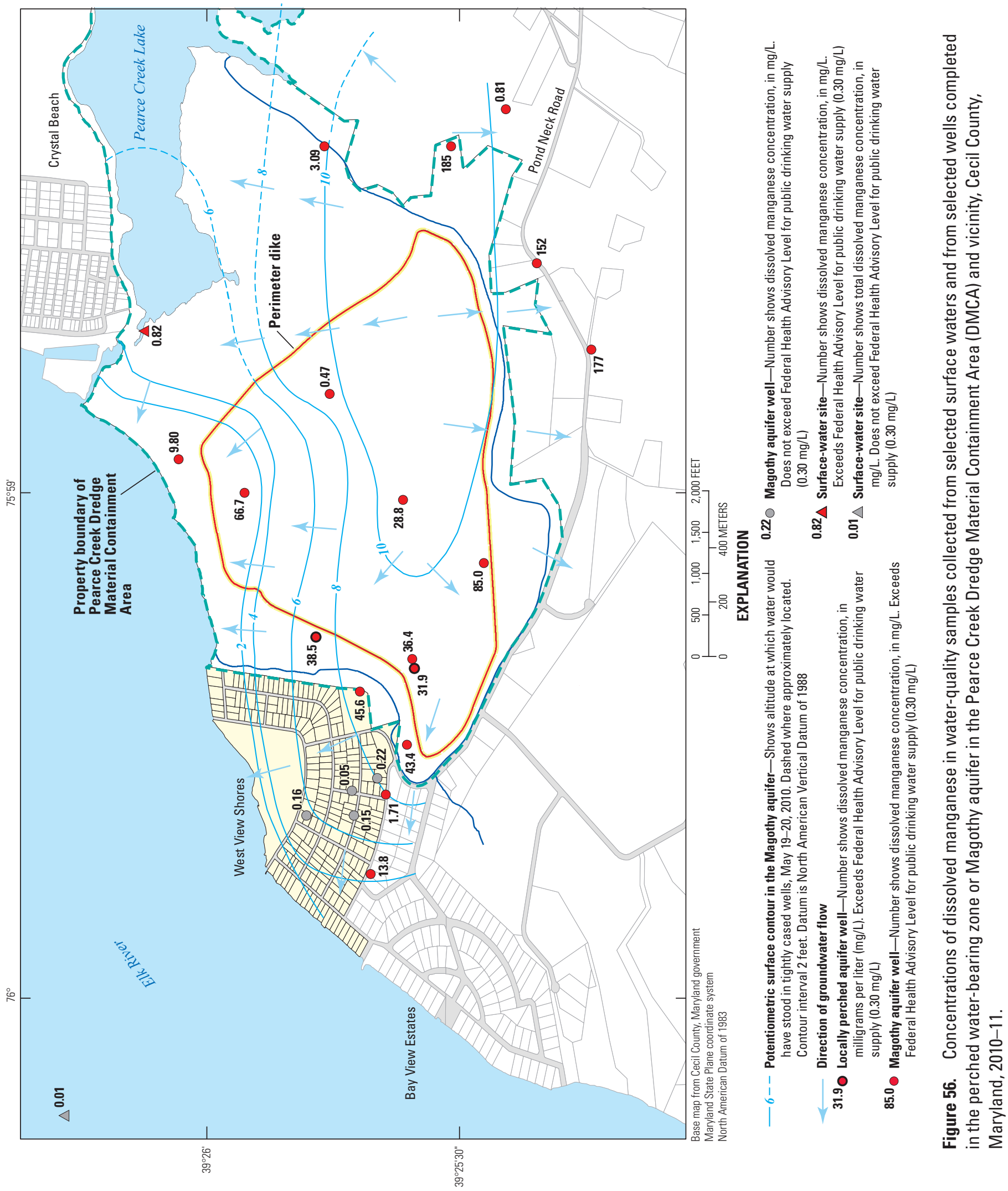


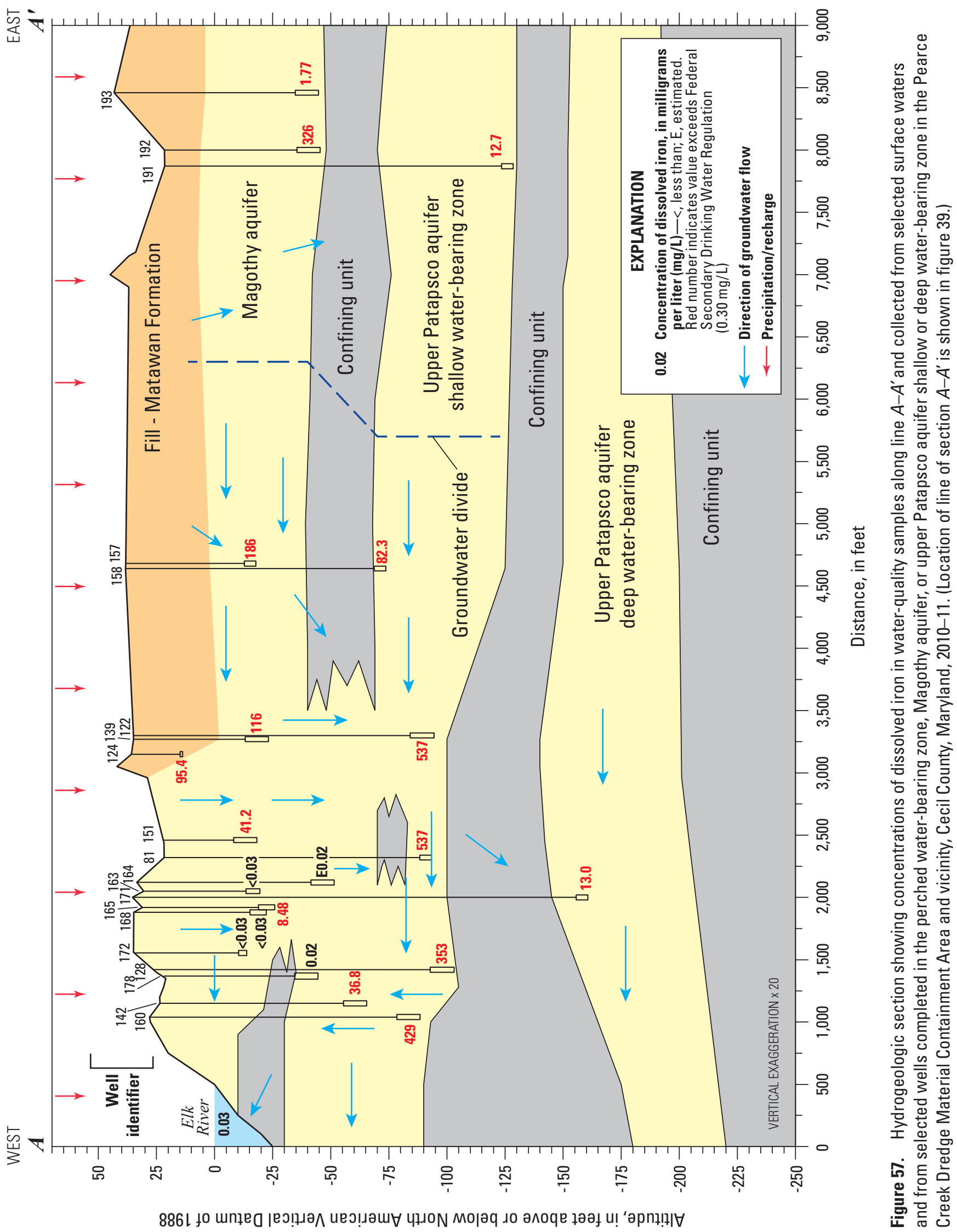



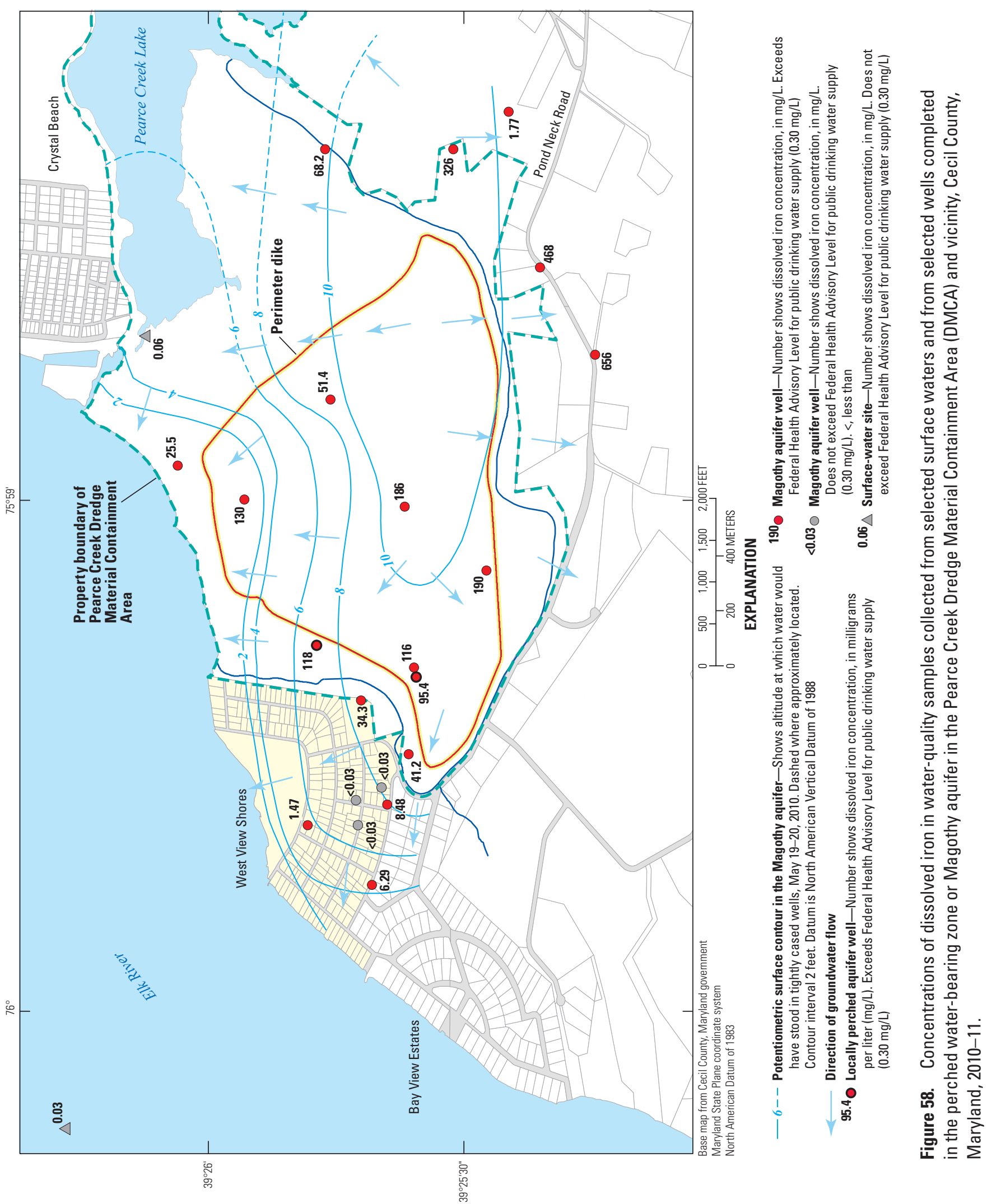

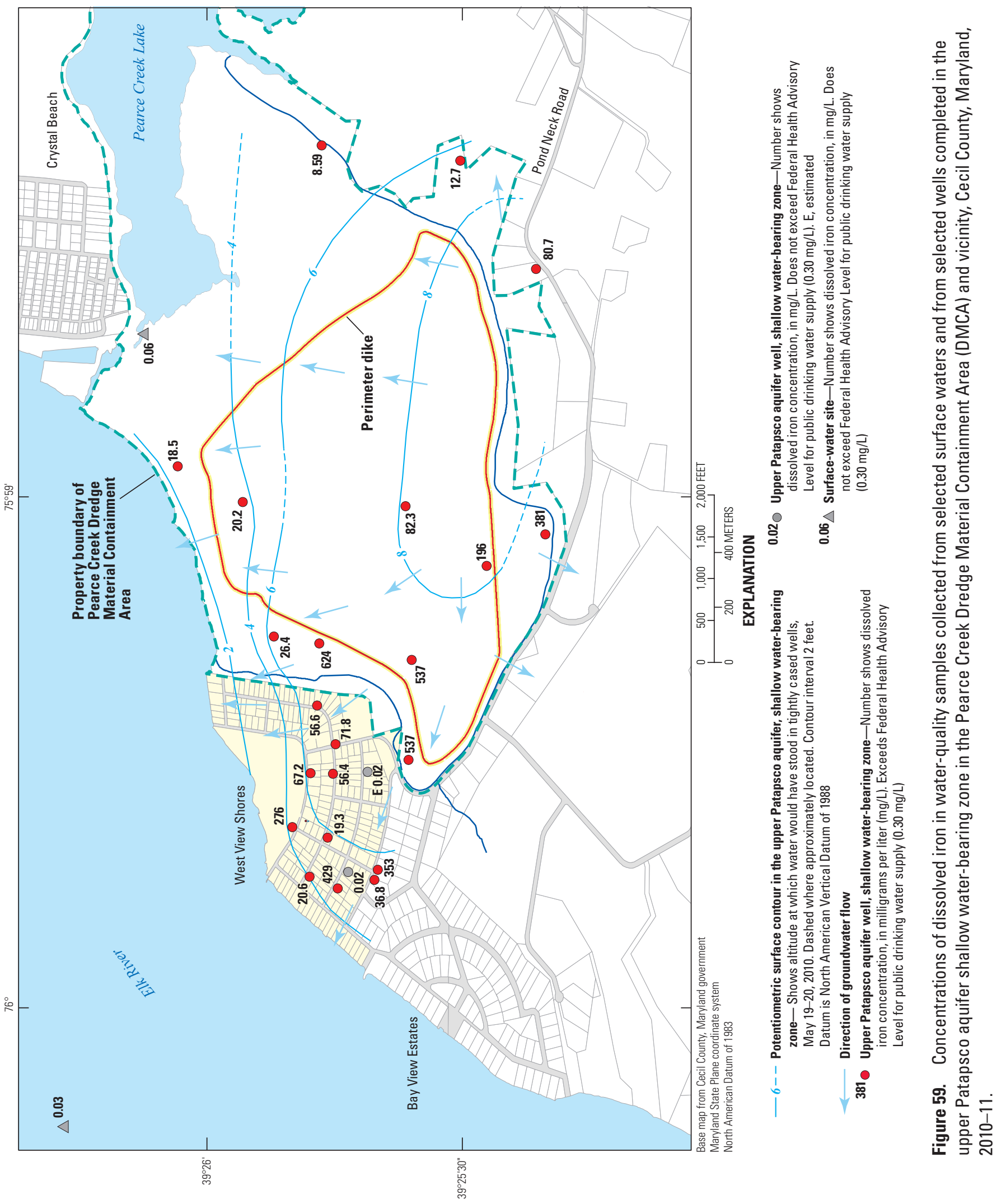

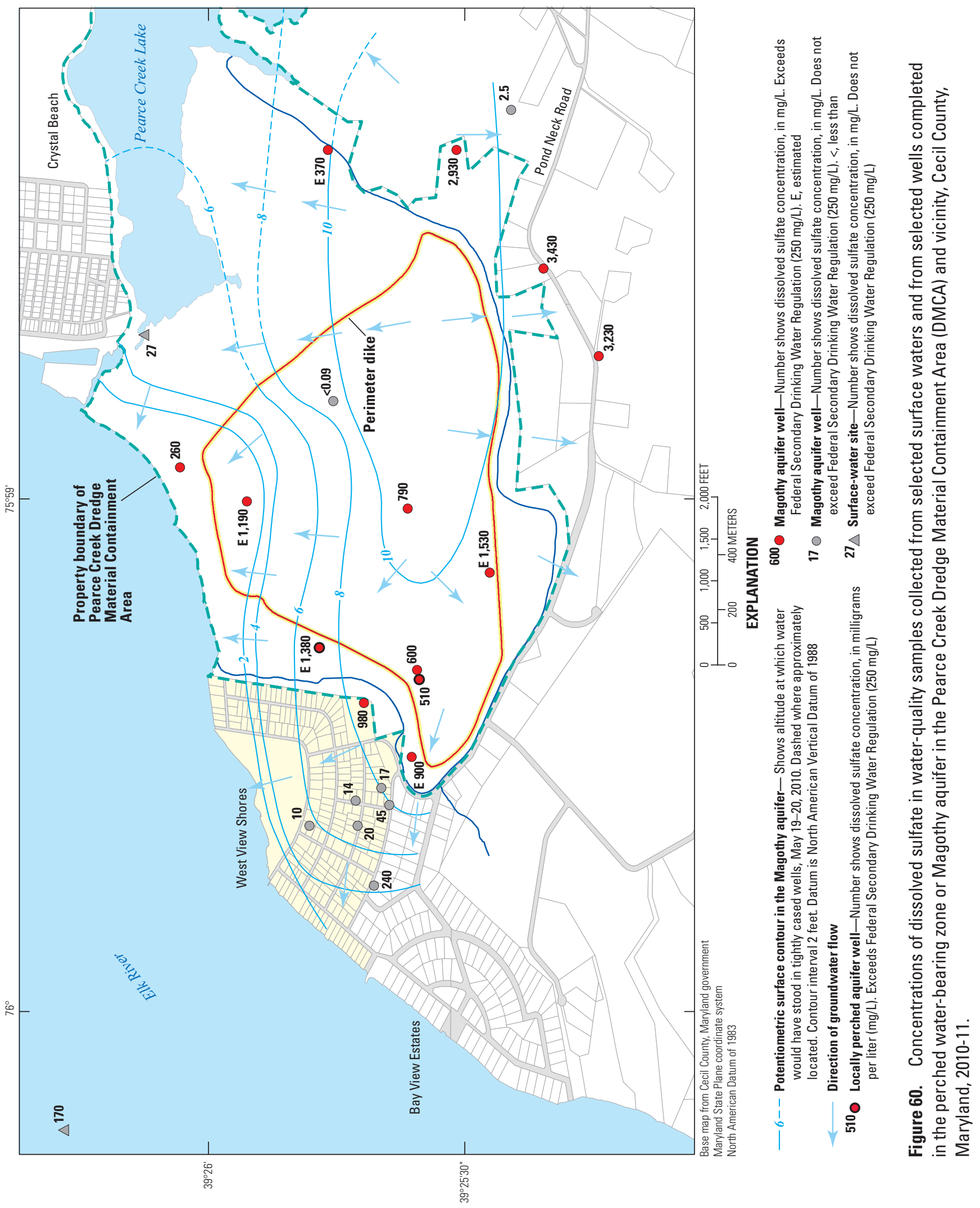


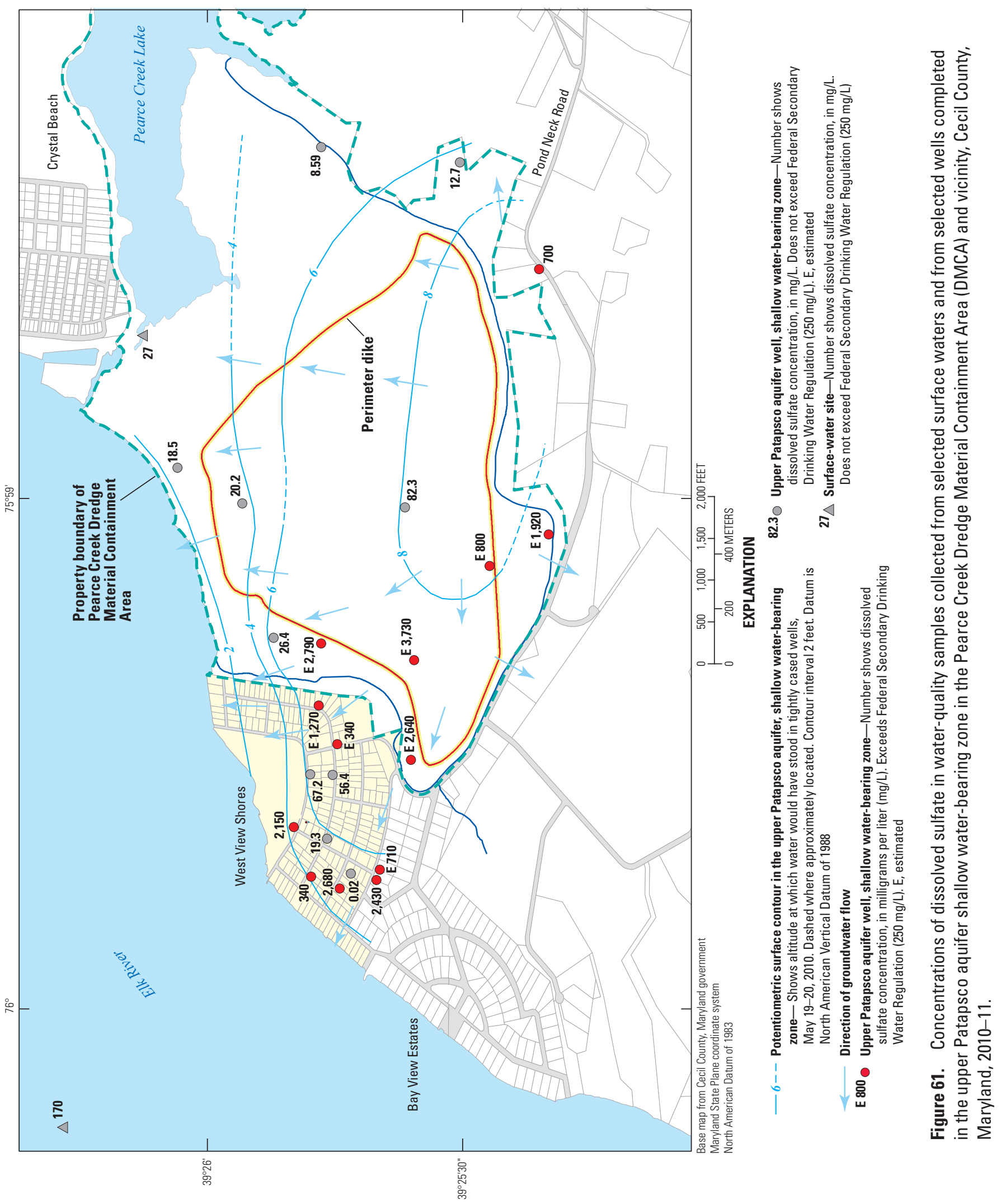


basis of the TEAP threshold criteria (table 14), groundwater at both wells was classified as anoxic and the predominant reduction process as methane generation (table 15). Since dissolved methane (gas) was not determined, this classification could not be confirmed. But both wells contain unusually low levels of TDS-less than $250 \mathrm{mg} / \mathrm{L}$ (appendix B, table B3). Groundwater from both wells exhibit water-quality conditions that would indicate conditions are anoxic and have reducing conditions that indicate at least sulfate is being reduced.

Redox conditions in the upper Patapsco aquifer shallow water-bearing zone beneath the DMCA and within or just beyond the DMCA property boundary are similar to the conditions in the overlying Magothy aquifer. Except for well CE Dd 156, groundwater conditions generally are anoxic, with $\mathrm{Fe}(\mathrm{III})$ reduction being the dominant process (fig. 62, $\mathrm{Fe}(\mathrm{III})$ ). Groundwater associated with well CE Dd 156 also is anoxic, but it is in a severely reduced state and possibly generating methane (fig. 62, $\mathrm{CH}_{4}$ (g), not confirmed). Beneath WVS, water in the upper Patapsco shallow water-bearing zone exhibits reducing conditions, which generally are almost as severe as conditions associated with this water-bearing zone within and near the DMCA (fig. 62, Fe(III) dominates), and more severe than the redox conditions in the overlying Magothy aquifer (fig. 49), with anoxic (Fe(III)) or mixed anoxic $\left(\mathrm{NO}_{3}-\mathrm{Fe}\right)$ conditions dominating (fig. 62).

In the upper Patapsco aquifer shallow water-bearing zone, elevated manganese concentrations occurred above the TEAP threshold in the southern and western parts of the DMCA and its vicinity (fig. 63). In the south, elevated manganese concentrations occurred beneath the DMCA, and beyond along Pond Neck Road. The elevated concentrations of manganese along Pond Neck Road correspond to flow initially from the DMCA and into the Magothy aquifer, which eventually leaked through the confining layer into the upper Patapsco aquifer shallow water-bearing zone (fig. 42). In the west, the pattern and process is similar, but rather than leakage, the confining layer between the aquifers is absent (fig. 42). Groundwater in the Magothy aquifer beneath the DMCA contained elevated manganese concentrations above the TEAP threshold and the concentration of manganese increased along the western flow path from the DMCA groundwater divide to the base of the upper Patapsco aquifer shallow water-bearing zone. This increase in manganese could reflect solid-phase $\mathrm{Mn}(\mathrm{IV})$ reduction and mobilization not only in the DMCA, but also along the groundwater flow path, and particularly at the base of the upper Patapsco aquifer shallow water-bearing zone.

In the upper Patapsco aquifer deep water-bearing zone, groundwater reflects mixed oxic-anoxic conditions (fig. 64, $\mathrm{O}_{2}-\mathrm{Fe}(\mathrm{III})$, wells CE Dd 155 and CE Dd 171) and anoxic conditions (fig. 64, Fe(III)). In this zone, however, the mixed oxic-anoxic conditions reflect low concentrations of dissolved oxygen, 0.55 and $0.53 \mathrm{mg} / \mathrm{L}$ at wells CE Dd 155 and CE Dd 171 , respectively, which are just above the $0.50 \mathrm{mg} / \mathrm{L}$ TEAP threshold that identifies oxic waters (table 14).
In the upper Patapsco aquifer deep water-bearing zone, and except for one well (CE Dd 170, $\mathrm{Mn}^{2+}, 1.17 \mathrm{mg} / \mathrm{L}$ ), concentrations of manganese range from approximately 0.07 to $0.13 \mathrm{mg} / \mathrm{L}$ (appendix B, table B3). There likely is little solidphase reduction and mobilization of $\mathrm{Mn}(\mathrm{IV})$ in this aquifer despite the anoxic conditions. The low manganese concentrations could reflect the lack of availability of solid-phase $\mathrm{Mn}(\mathrm{IV})$ in this aquifer (see below).

The upper Patapsco aquifer deep water-bearing zone had low sulfate concentrations (appendix B, table B3, range from 8 to $22 \mathrm{mg} / \mathrm{L}$ ), when compared to other parts of the study area. Elevated concentrations of sulfate, at levels of hundreds to thousands of milligrams per liter, mainly occurred in anoxic groundwater in the DMCA, or were associated with groundwater flow from the DMCA (fig. 65). The elevated concentrations of sulfate associated with groundwater flow within and from the DMCA appreciably exceeded concentrations of sulfate in groundwater associated with either aquifer within (figs. 60, 61, and 65) or near the study area where that groundwater does not appear to be overly affected by human activities (table 13).

The different patterns observed in $t$ he dominant redox categories and predominant reduction processes can be related to the quality of groundwater and, in particular, concentrations of TDS in groundwater in the study area, as well as land use, through patterns in groundwater flow. To illustrate, groundwater flow and the redox conditions associated with that flow from DMCA recharge into the Magothy aquifer to either the east or west of the groundwater divide along $A-A^{\prime}$ are anoxic; $\mathrm{Fe}(\mathrm{III})$ reduction is the dominant process (fig. 66). This anoxic groundwater also contains highly elevated concentrations of TDS (fig. 41). However, to the east and beyond the DMCA property boundary, less-severe mixed oxic-anoxic conditions occur (fig. 66, $\mathrm{O}_{2}-\mathrm{Fe}(\mathrm{III})$, well CE Dd 193). Although the sources of the water sampled in this area are not entirely known, they are unlikely to include recharge from the DMCA, as the concentration of TDS associated with this well more aptly reflects groundwater that has not been overly affected by any human activities or land use (fig. 41; table 12).

Along the western end of the DMCA property boundary and $A-A^{\prime}$ (fig. 66), the pattern in redox conditions and processes also appears related to the source of the groundwater and previously described patterns in groundwater flow and TDS (fig. 41). The most severe reducing condition - that of $\mathrm{Fe}(\mathrm{III})$ reduction - corresponds to groundwater from DMCA recharge to the Magothy aquifer that flows beneath the western half of the DMCA. The reducing conditions then occur farther westward and vertically downward to the base of the upper Patapsco aquifer shallow water-bearing zone. Finally, the reducing conditions are found farther along the flow path, to the west, or along the flow path that goes upwards or discharges along the western end of WVS or the Elk River (fig. 66). This flow also contains the highest concentrations of TDS in either aquifer in this area (fig. 41). However, groundwater at shallow depths beneath the WVS community is under less severe and often mixed oxic-anoxic conditions (fig. 66, 

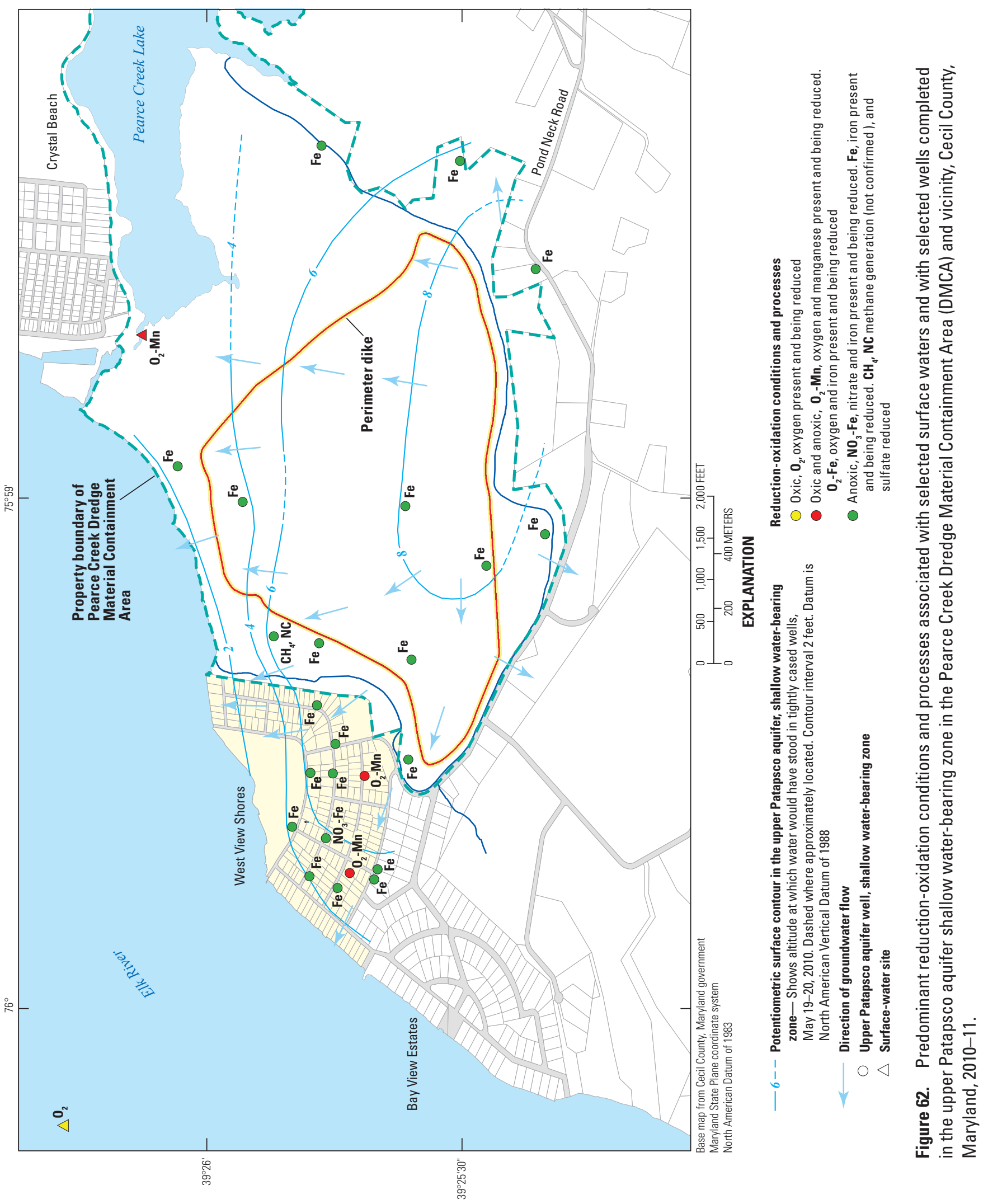

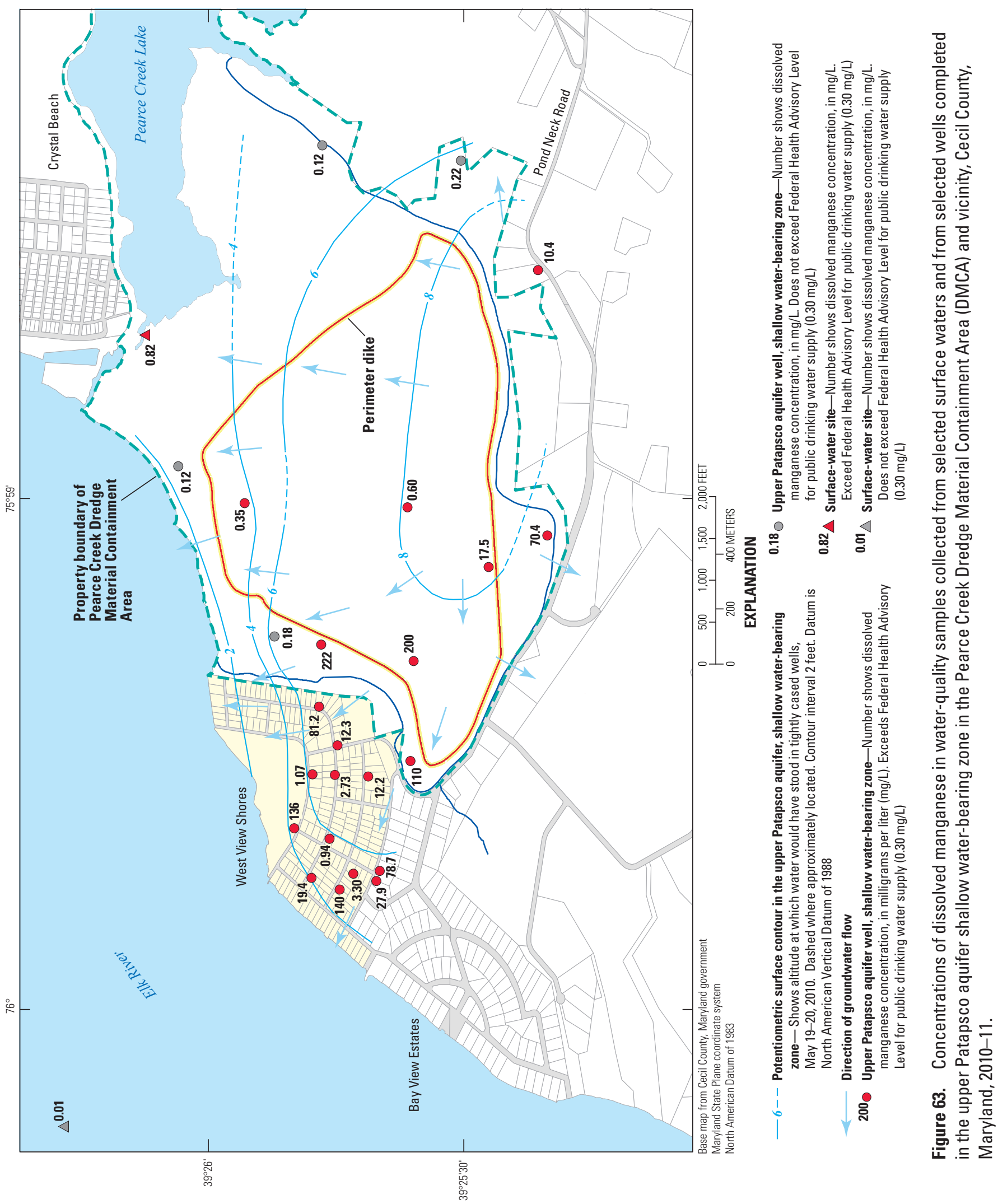

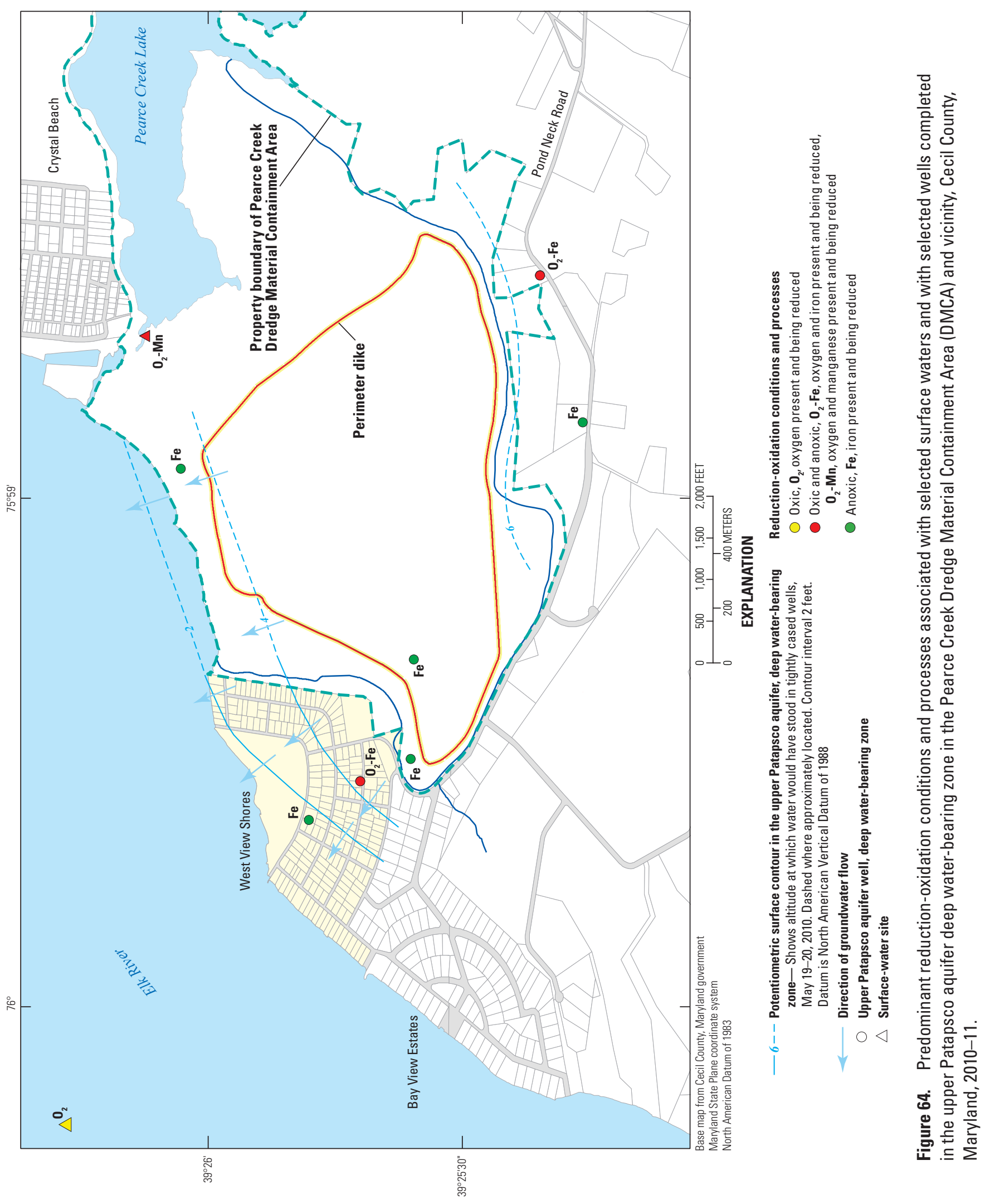


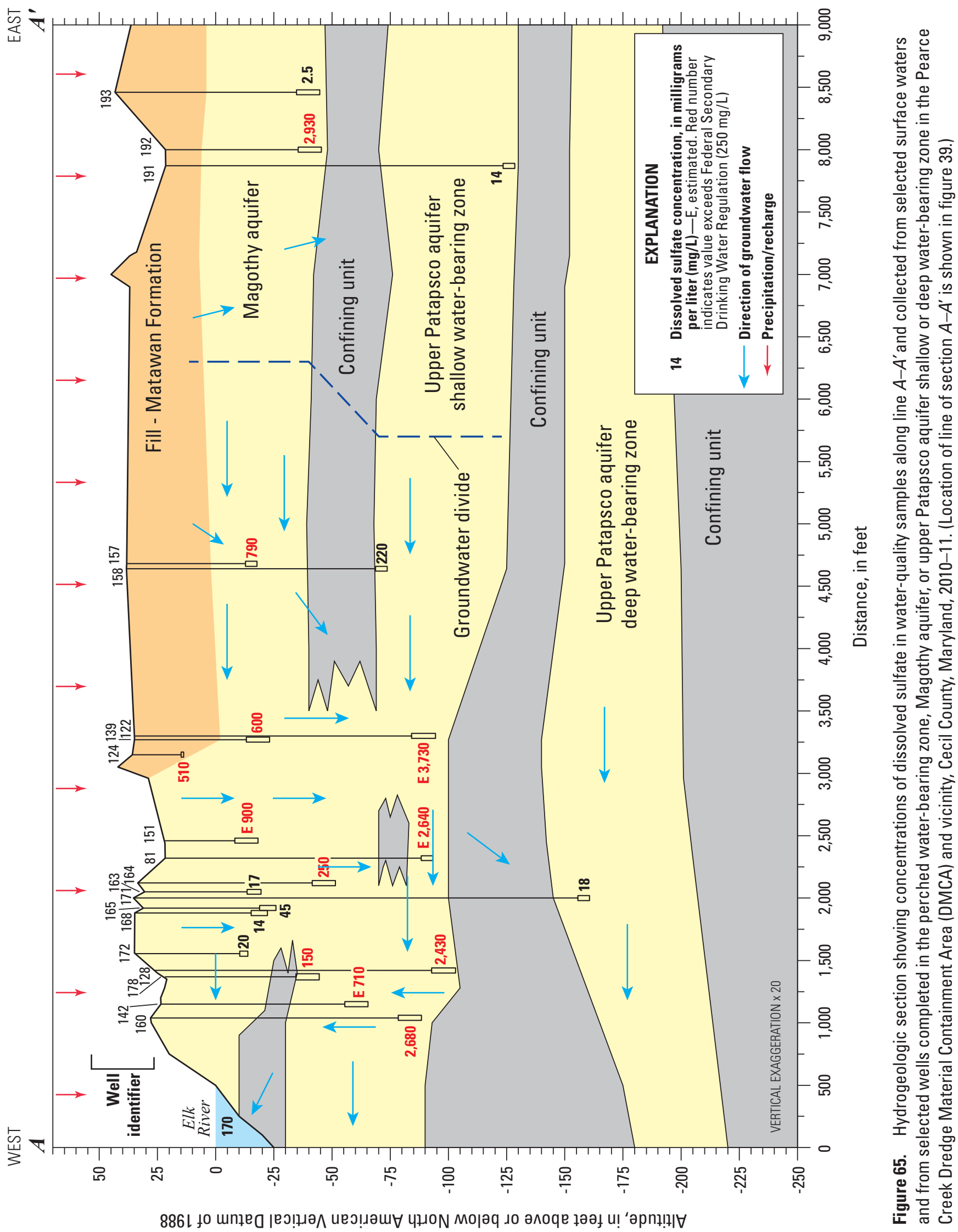




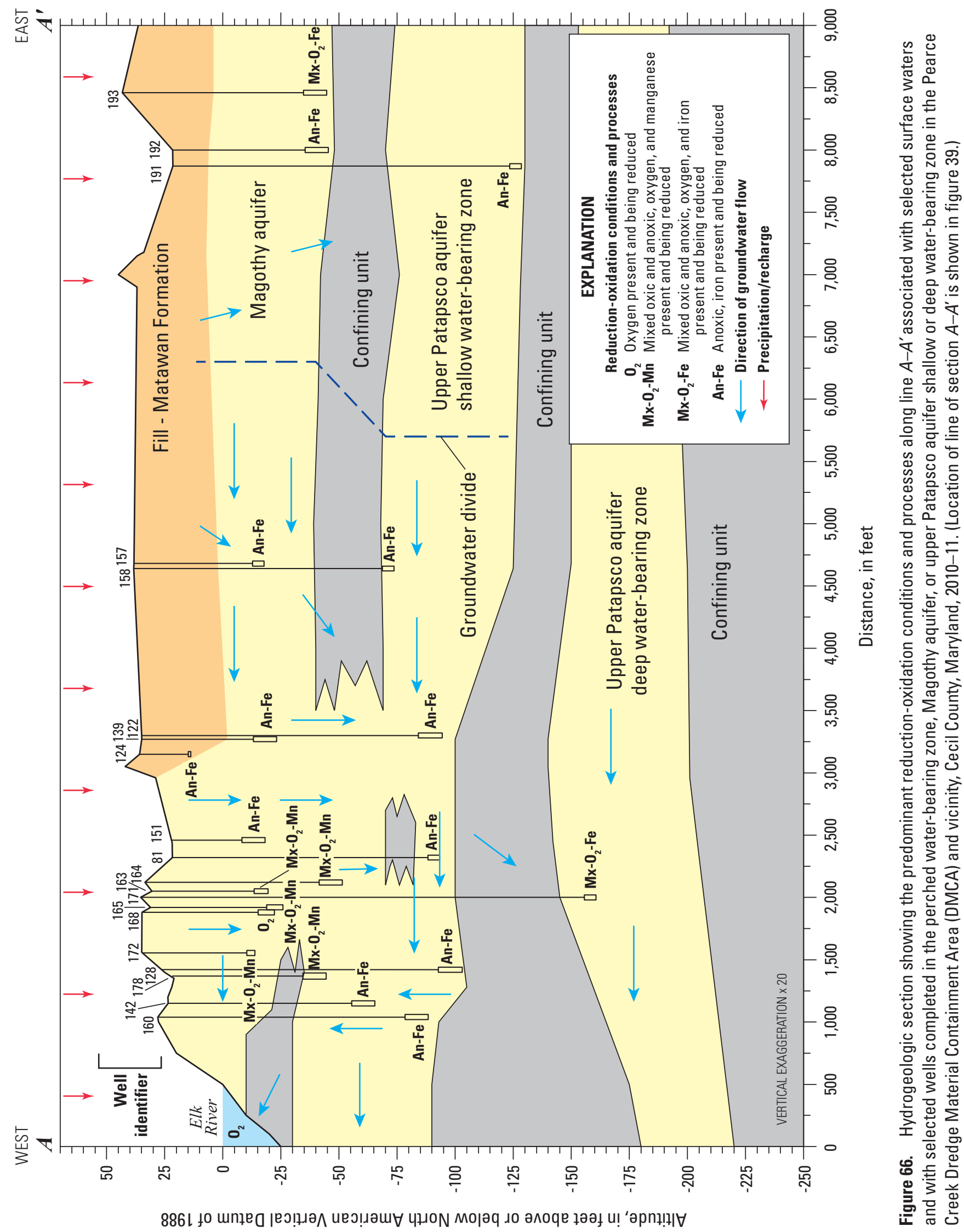


$\mathrm{O}_{2}-\mathrm{Fe}(\mathrm{III})$ or $\left.\mathrm{O}_{2}-\mathrm{Mn}\right)$. In part, these redox conditions and processes likely reflect local recharge - precipitation and residential use (irrigation and septic effluents), where human uses reflect groundwater that generally has been treated to remove TDS before use. Thus, local recharge and shallow groundwater likely is a mixture of oxic (precipitation or surface irrigation) and mixed oxic-anoxic (for example, septic system effluent) (figs. 43, 49, and 66), with relatively low concentrations of TDS (fig. 41).

A pattern similar to that described among redox conditions and processes, TDS, and groundwater described above for $A-A^{\prime}$, also occurs along $C-C^{\prime}$ through the WVS community (fig. 67). Groundwater in the Magothy aquifer beneath the DMCA is under anoxic and Fe(III)-reducing conditions and associated with high concentrations of TDS (fig. 43). Both these attributes persist as this water flows north into WVS and then downward into the upper Patapsco aquifer shallow water-bearing zone beneath the community. However, as in the case of $A-A^{\prime}$, groundwater at shallow depths beneath the community along $C-C^{\prime}$ also is under mixed oxic-anoxic conditions (fig. $67, \mathrm{O}_{2}-\mathrm{Mn}$ ) and likely reflects the relatively oxic to mixed oxic-anoxic nature of local recharge that contains low to intermediate concentrations of TDS (fig. 43).

It should be noted that anoxic iron-reducing groundwater conditions are not solely the result of the DMCA. For example, along $B-B^{\prime}$, anoxic iron-reducing conditions occur throughout the groundwater flow system, including the upper Patapsco aquifer deep water-bearing zone. Despite the anoxic iron-reducing conditions, concentrations of TDS and major ion distributions indicated that the groundwater in the upper Patapsco aquifer deep water-bearing zone has not been impacted by the DMCA (fig. 68).

Given the dominant redox conditions and predominant redox processes and their relation to patterns in groundwater flow and TDS, the effect of the DMCA appears to be the recharging of groundwater under reduced conditions that is elevated in TDS, which could be expected to contain elevated concentrations of reduced forms of redox-sensitive species. The primary areas affected by this DMCA recharge are the perched water-bearing zone and the Magothy aquifer within and at least along to the DMCA property boundary, and where leakage occurs into the upper Patapsco aquifer shallow waterbearing zone - along Pond Neck Road, and into WVS. This conclusion is consistent with the concept that the DMCA is an elevated and artificial groundwater-recharging wetland that was created on a natural discharging wetland. However, whether or not groundwater flow from the DMCA is the sole source of poor quality water farther along groundwater flow paths from the DMCA cannot be fully determined on the basis of this analysis of groundwater flow, redox conditions, and TDS.

\section{Mixed Reduction-0xidation Processes and pH}

Groundwater in the DMCA and vicinity with the highest levels of TDS (fig. 41), and high or the highest levels of sulfate (fig. 65), and reduced metals - manganese (fig. 63), and ferrous iron (fig. 57) - generally corresponds to parts of the groundwater flow system where anoxic iron-reducing groundwater from the DMCA potentially come into contact with oxygen-bearing groundwater from other source areas. Two such areas are the local Magothy aquifer-upper Patapsco aquifer shallow water-bearing zone beneath WVS and the local Magothy aquifer just east of the DMCA.

Whether groundwater in these two areas simply represents a downgradient plume of older contaminated groundwater from the DMCA - for example, the migration of groundwater recharge from the DMCA when it was in use- or reflects another unique redox condition outside of the DMCA is critical to understanding what factors influence the quality of water in these areas. However, no information is available on the ages of groundwater in the study area since its time of recharge, or from hydrogeochemical modeling, which could help determine the above. In the case of the local WVS flow system, there are sufficient data and knowledge about the area to indicate that the quality of the groundwater in this area could reflect a localized interaction between oxygen-bearing and anoxic groundwater that leads to a unique redox environment, which further affects the quality of groundwater beneath the community.

Redox conditions in the groundwater beneath WVS indicate groundwater at shallow depth is oxygen bearing, at intermediate depths reflects mixed oxic-anoxic conditions, and at even deeper depths is anoxic (figs. 66 and 67). Absent any influence from the DMCA, this description could be considered a natural groundwater phenomenon; it generally could be expected to result in groundwater whose quality with depth would be expected to reflect that found in local aquifers in the study area that are not overly affected by human activities (tables 12 and 13).

Hamilton and others (1993) describe typical changes in the $\mathrm{pH}$ associated with redox conditions for groundwater in the surficial aquifer and updip confined aquifers of the Delmarva Peninsula. Rainfall on the Peninsula typically is oxic and acidic ( $\mathrm{pH} 4-5$ standard units), but low in TDS, and not highly buffered. However, upon infiltration and with increasing depth, the $\mathrm{pH}$ in most shallow groundwater increases (pH 5-6) and is weakly buffered as a result of reactions with silicate minerals. In updip aquifers such as the Magothy aquifer, or possibly in areas such as in WVS, where there no longer is a confining layer, groundwater flow is not impeded and can continue downward. Hamilton and others (1993) indicate the $\mathrm{pH}$ could again increase (6-8) with depth of flow as a result of iron and possibly sulfate reduction. The results of this process absent considerable anthropogenic influence are reflected in the $\mathrm{pH}$ of groundwater in the upper Patapsco aquifer shallow water-bearing zone in the study area (table 13; wells CE Dd 146 and CE Dd 191). Overall, the general pattern of declines in $\mathrm{pH}$ with depth and from shallow to deep aquifers also appears in groundwater in the vicinity of the study area not overly affected by human activities (table 13).

Differences in the $\mathrm{pH}$ of groundwater with depth beneath WVS are not similar to the pattern with depth described above for groundwater relatively unaffected by human activities 


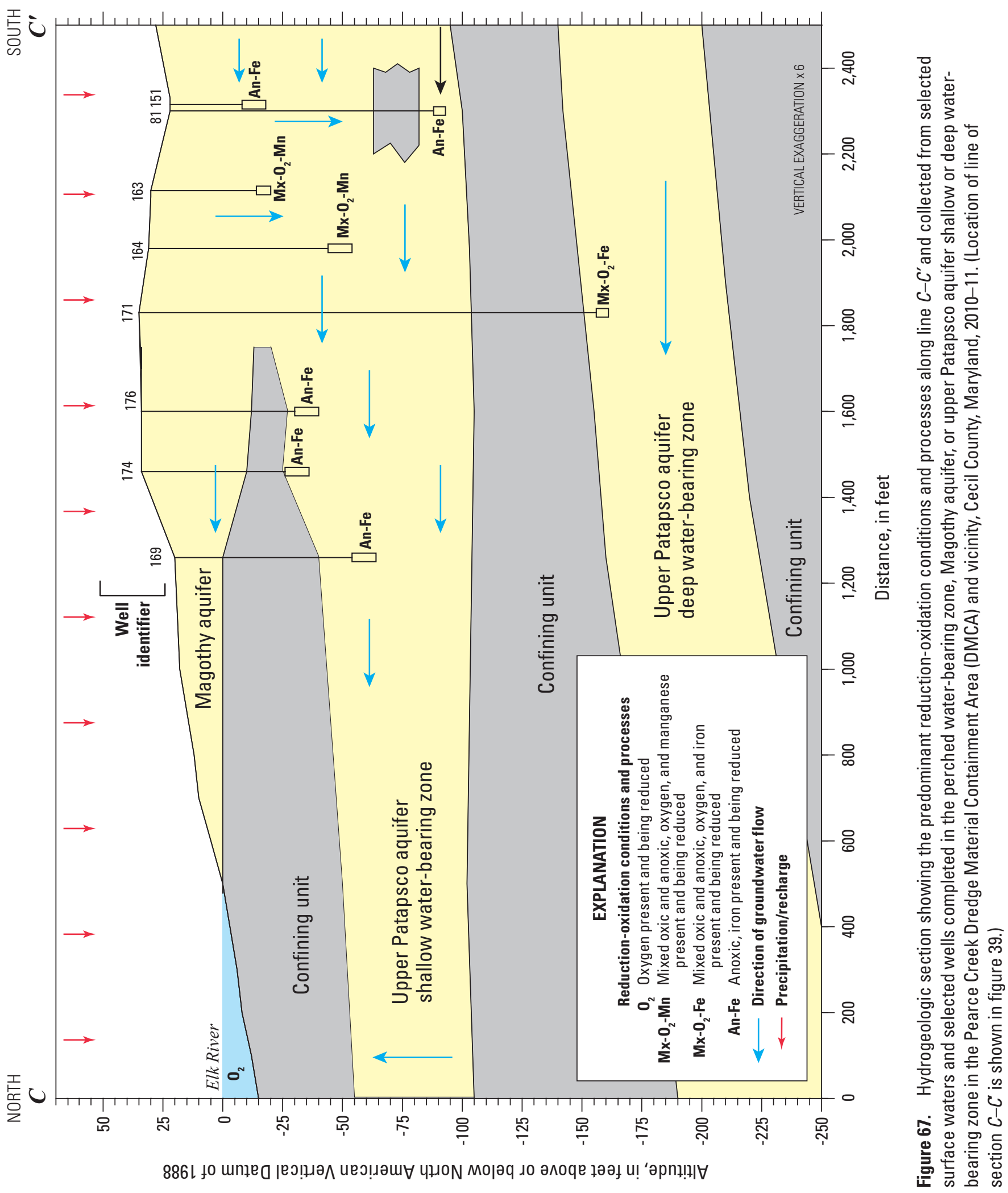




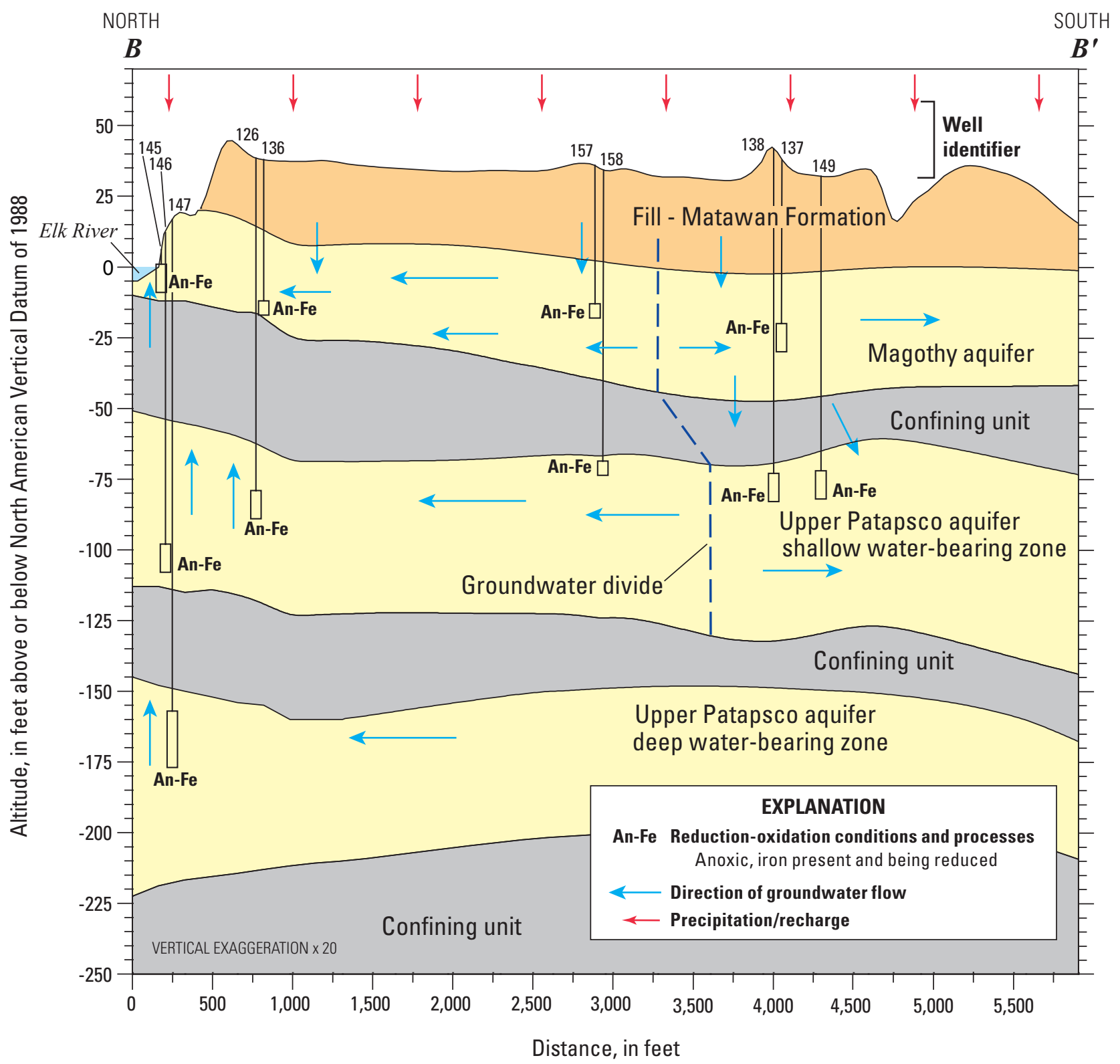

Figure 68. Hydrogeologic section showing the predominant reduction-oxidation conditions and processes along line $B-B^{\prime}$ associated with selected wells completed in the Magothy aquifer or in the upper Patapsco aquifer shallow or deep waterbearing zone in the Pearce Creek Dredge Material Containment Area (DMCA) and vicinity, Cecil County, Maryland, $2010-11$. (Location of line of section $B-B^{\prime}$ is shown in figure 39.)

(figs. 69 and 70). Shallow oxygen-bearing groundwater beneath WVS is acidic (fig. 69; approximately pH 4.5 to 5.0 standard units). In part, this acidity likely reflects recharge from precipitation. In part, it also reflects recharge from residential use.

The $\mathrm{pH}$ of residential recharge in WVS could differ considerably. Historical surveys (Maryland Environmental Service, 1995) indicate that most WVS residents treat their water to remove most but not all metals. However, these historical surveys, as well as recent surveys conducted by the USGS during the canvassing of this area to select wells and by the Cecil County Health Department (A. Scramlin, Cecil County Health Department, written commun., 2010), suggested at least some but not all residents also treat their water to increase the $\mathrm{pH}$ to approximately 6 standard units. Thus, depending on the depth water is withdrawn (fig. 69), and the subsequent level of treatment, the $\mathrm{pH}$ of residential supply water, and, thus, initial recharge water associated with its use, could range from approximately 4.2 to 6 standard units. This range in $\mathrm{pH}$ is considerably broader than the range in $\mathrm{pH}$ in groundwater recharge typically associated with precipitation. Ultimately, despite the possible range in the initial $\mathrm{pH}$ of residential recharge, it likely is weakly buffered, as the $\mathrm{pH}$ in oxygen-bearing shallow groundwater beneath WVS ranges from of approximately 4.5 to 5 standard units and is typically less than $\mathrm{pH}$ associated with groundwater in the Magothy 


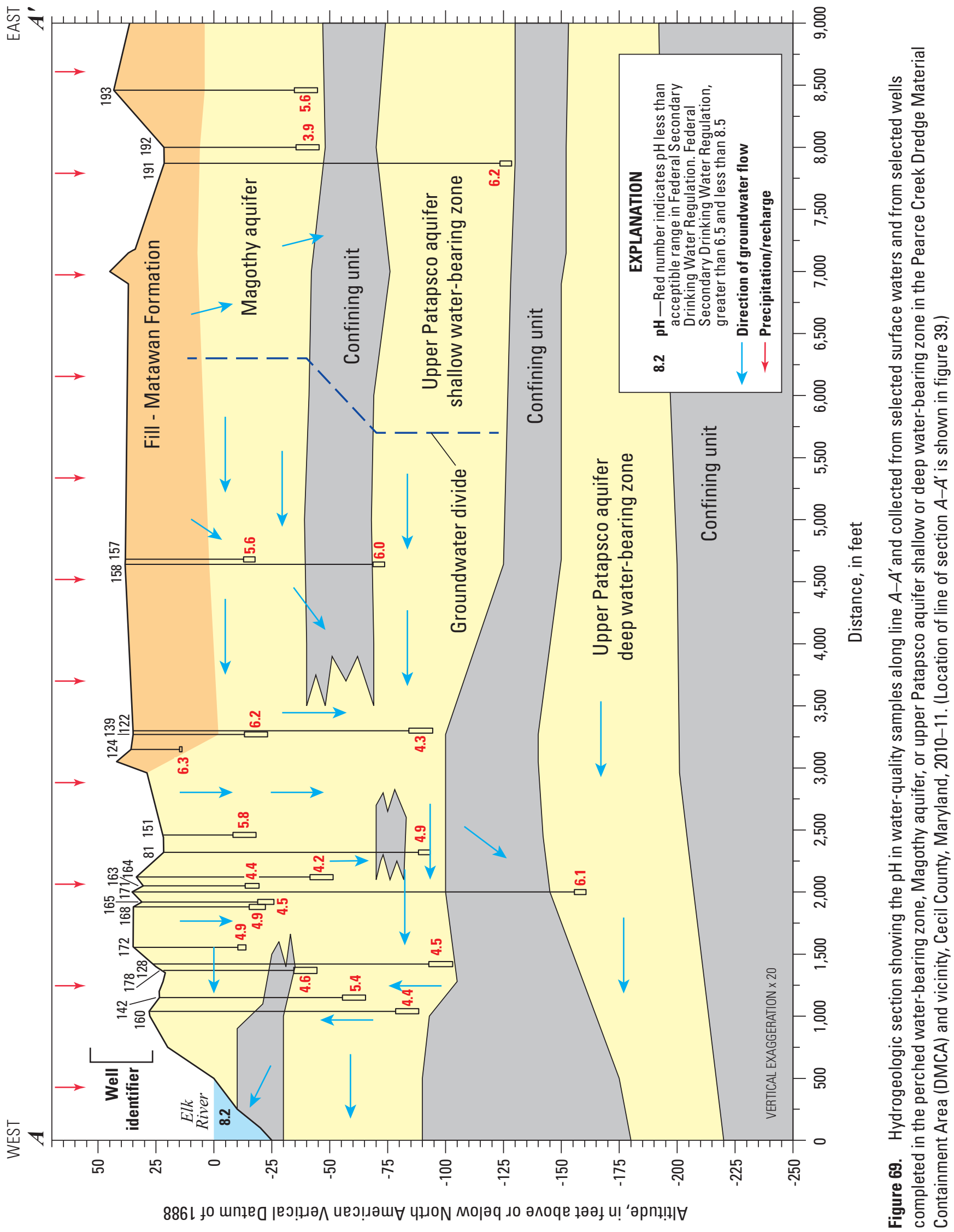




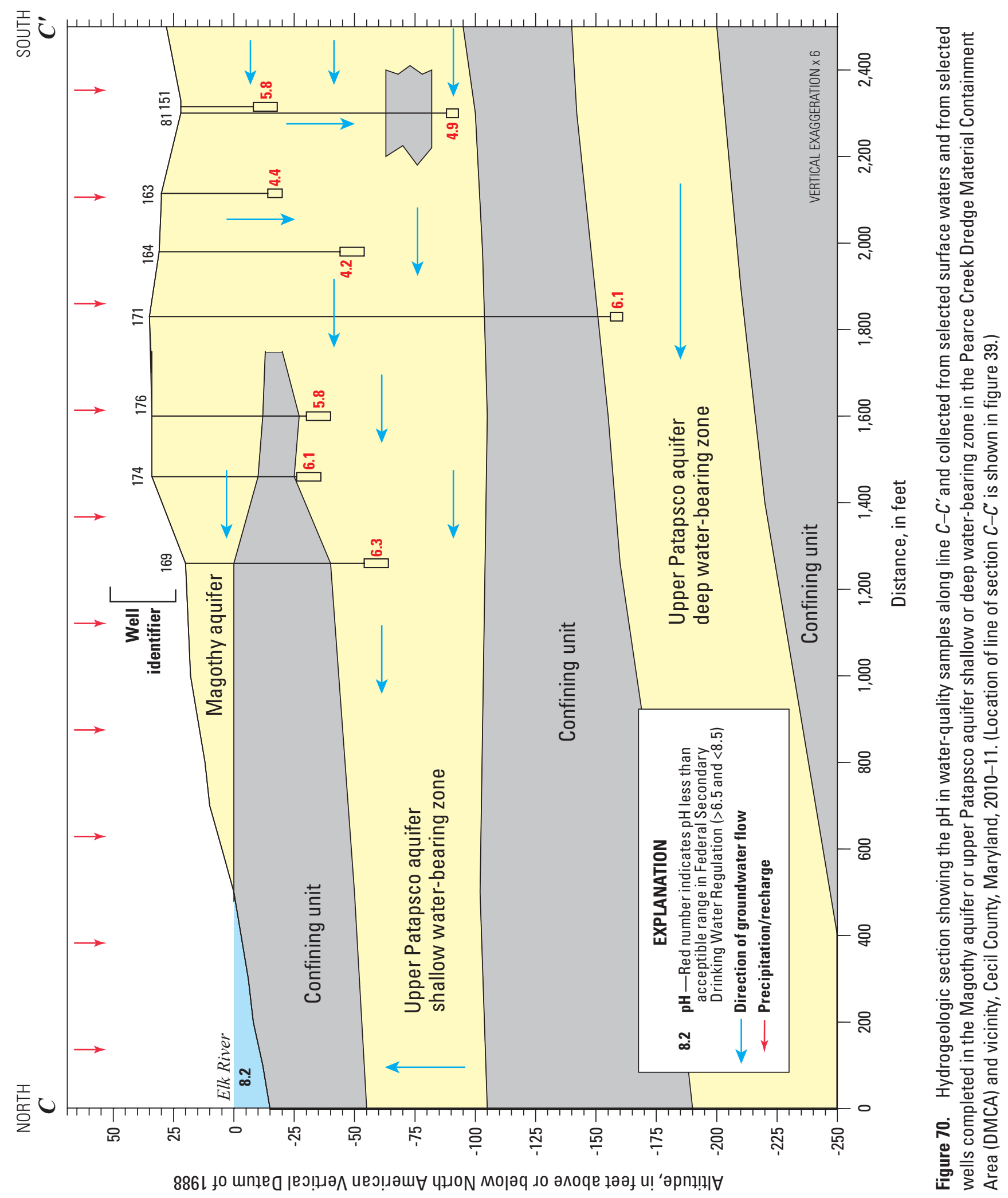


aquifer in the vicinity of the study area which appear not overly affected by human activities (table 13).

Beneath the oxygen-bearing zone in WVS, and under natural conditions, as described above, it would be expected that there would be an increase in $\mathrm{pH}$ downgradient. However, the $\mathrm{pH}$ of groundwater beneath the oxygen-bearing zone in the Magothy-upper Patapsco aquifers slightly decreases, ranging from 4.2 to 4.9 standard units (fig. 69). In addition, the low $\mathrm{pH}$ at depth in the upper Patapsco aquifer shallow water-bearing zone appears to be local in character, and is not evident either upgradient or downgradient in this zone (fig. 70). Below the shallow oxygen-bearing zone, groundwater at intermediate depths also reflects mixed oxic and anoxic conditions, and, at the base of the upper Patapsco aquifer shallow water-bearing zone, anoxic (iron-reducing) conditions (figs. 66 and 67). The overall trend in $\mathrm{pH}$ of progressively acidic conditions with depth could be directly related to the progression from oxygen-bearing to mixed oxic and anoxic and ultimately anoxic conditions. Both progressive conditions could reflect the effects of residential supply-well withdrawals, which draw anoxic groundwater coming from the DMCA into what initially is relatively oxygen-bearing groundwater associated with local recharge. If anoxic groundwater is drawn into predominately oxygen-bearing groundwater, then the former will undergo oxidation. One notable outcome of oxidation would be the production of acidity $\left(\mathrm{H}^{+}\right)$, and corresponding decline in $\mathrm{pH}$, through the oxidation of reduced iron, and the local formation of ferric hydroxide precipitates, as follows:

$$
\begin{gathered}
\mathrm{Fe}^{2+}+0.25 \mathrm{O}_{2}+\mathrm{H}^{+}=\mathrm{Fe}^{3+}+0.5 \mathrm{H}_{2} \mathrm{O} \\
\mathrm{Fe}^{3+}+3 \mathrm{H}_{2} \mathrm{O}=\mathrm{Fe}(\mathrm{OH})_{3(\mathrm{~s})}+3 \mathrm{H}^{+}
\end{gathered}
$$

The oxidation of iron sulfide minerals would also lead to the production of acidity. The oxidation reaction of iron sulfide is as follows:

$$
2 \mathrm{FeS}+4.5 \mathrm{O}_{2}+2 \mathrm{H}_{2} \mathrm{O}=\mathrm{Fe}_{2} \mathrm{O}_{3}+4 \mathrm{H}^{+}+2 \mathrm{SO}_{4}^{2-}
$$

The initial low $\mathrm{pH}$ of shallow groundwater in the Magothy aquifer beneath WVS, and the resulting increase in $\mathrm{pH}$ with depth in groundwater in the Magothy - upper Patapsco aquifers beneath WVS, would provide acidic conditions well suited for hydrolysis and mobilization of metals from native sediments. The groundwater flow from the DMCA also contains abundant levels of organic carbon (see Dissolved

Organic Carbon, this report), which are necessary to support microbial reducing conditions (table 14, reduction reactions). The return to relatively severe (iron-reducing) anoxic conditions at depth in the upper Patapsco aquifer shallow waterbearing zone beneath WVS, combined with the low $\mathrm{pH}$ and elevated concentrations of organic carbon, imply groundwater conditions at depth in the upper Patapsco aquifer beneath the WVS community are ideally suited for the increased microbial reduction and mobilization of metals. The overall expected result would be a localized increase in the concentration of TDS, which in combination with the major inflow of anoxic groundwater of similar quality from the DMCA would account for the local and highly elevated concentrations of TDS and reduced metals at depth in the upper Patapsco aquifer shallow water-bearing zone directly beneath the WVS community and described in earlier sections of this report. Similar redox reactions could occur elsewhere in the vicinity of the DMCA where local groundwater withdrawals for supplies draw highly reduced anoxic groundwater from the DMCA into areas where local groundwater generally is oxygen-bearing.

\section{Extended Implications of Reduction-0xidation Processes on Groundwater Quality}

Groundwater in the DMCA and vicinity that is not affected by the DMCA include: (a) in the Magothy aquifer, the shallow oxygen-bearing groundwater beneath WVS to the west of the DMCA and to the east of the DMCA, (b) in the anoxic upper Patapsco aquifer shallow water-bearing zone, except where leakage has occurred through the confining layer from the Magothy aquifer beneath the DMCA, or where the confining layer is absent to the west of the DMCA beneath WVS, and (c) in the anoxic upper Patapsco aquifer deep water-bearing zone. Despite differences in redox conditions, groundwater in these areas has been shown to contain relatively low concentrations of TDS and the forms of redoxsensitive constituents reflecting the redox condition.

Groundwater affected by the DMCA is predominately anoxic and mainly reflects iron-reducing conditions. These redox conditions correspond to the virtual absence of dissolved oxygen but an abundance of the reduced forms of nitrogen (ammonia) and metals (manganese and iron). Given iron is reduced instead of sulfate, sulfate occurs at elevated concentrations. The resultant anoxic groundwater occurs in the Magothy aquifer beneath the DMCA, and bordering the DMCA property boundary, as well as beyond its boundary. The anoxic groundwater also occurs in the upper Patapsco aquifer shallow water-bearing zone to the west of the DMCA beneath WVS where the confining layer between the Magothy aquifer and the upper Patapsco aquifer shallow water-bearing zone is absent, and beneath the DMCA where leakage occurs through the confining layer between these two aquifers.

The implications of the potential effects of the DMCA on groundwater quality beyond its boundaries extend to other trace elements and not just iron and manganese. McMahon and Chapelle (2008) recently examined high concentrations of naturally occurring arsenic in the principal aquifers of the United States. They found that regardless of aquifer sediment type, elevated concentrations of arsenic concentrations were found in groundwater under reduced (Mn(IV)- or $\left.\mathrm{Fe}(\mathrm{III})-\mathrm{SO}_{4}{ }^{2-}\right)$ compared to oxic conditions. In particular, the occurrence and distribution of three additional trace elements - aluminum, beryllium, and arsenic - appear similarly governed for groundwater in the DMCA and vicinity. Elevated 
concentrations of these trace elements mainly occur at high concentrations in groundwater where reducing conditions could be enhanced by the mixing of anoxic water from the DMCA and oxygen-bearing water from another source. The three areas where these conditions possibly occur are in the Magothy aquifer just east of the DMCA property boundary, in the Magothy aquifer west of the DMCA property boundary and beneath WVS, and in the Magothy aquifer to the north where it potentially co-discharges with groundwater from the upper Patapsco aquifer shallow water-bearing zone and possibly groundwater recharge from Pearce Creek Lake. For brevity, the following discussion focuses on groundwater flow along $C-C^{\prime}$ with an emphasis on groundwater flow in the Magothy aquifer to WVS.

After iron and manganese, the next most abundant trace element in groundwater is aluminum (appendix B, table B3). Concentrations of aluminum in groundwater in the DMCA and vicinity range from less than 0.01 to $58 \mathrm{mg} / \mathrm{L}$. Along section line $A-A^{\prime}$ (fig. 71), the highest concentrations of aluminum occur at depth in the upper Patapsco aquifer shallow waterbearing zone west of the DMCA and beneath WVS, and in the Magothy aquifer east of the DMCA property boundary. In each case, anoxic groundwater from the DMCA is in proximity to oxic waters from another source. In WVS, the concentrations of aluminum begin increasing with depth, acidity, and severity in redox conditions below the oxygen-bearing zone, and they are highest at the base of the upper Patapsco aquifer shallow water-bearing zone. The solubility of aluminum can increase with elevated concentrations of sulfate and DOC, which were also observed at the base of the upper Patapsco aquifer shallow water-bearing zone. Elsewhere, in the study area (fig. 71), or near the study area (table 13), groundwater has relatively low concentrations of dissolved aluminum.

Concentrations of dissolved beryllium in groundwater in the DMCA and vicinity range from less than 0.4 to $18 \mu \mathrm{g} / \mathrm{L}$ (appendix B, table B3). Elevated concentrations of beryllium mainly are associated with groundwater at depth in the upper Patapsco aquifer shallow water-bearing zone beneath the western end of the DMCA and into WVS (fig. 72). As in the case of aluminum, concentrations of beryllium increase with depth below the oxygen-bearing zone beneath the community and are highest under the extreme reducing conditions at the base of the upper Patapsco aquifer shallow water-bearing zone (fig. 73).

Concentrations of arsenic in groundwater in the DMCA and vicinity range from less than 0.10 to $58.7 \mu \mathrm{g} / \mathrm{L}$ (appendix B, table B3). The highest concentrations of arsenic occurred in samples taken in 2010 and 2011 at well CE Dd 122, which is completed in the upper Patapsco aquifer shallow water-bearing zone beneath perched water-bearing zone and Magothy aquifer at the western end of the DMCA (fig. 74). Lower but still elevated concentrations of arsenic occur in water-supply wells completed in this same water-bearing zone directly downgradient and west-northwest of well CE Dd 122. All of these wells are completed at depth in this water-bearing zone and under highly reducing conditions.

\section{Additional Water-Quality Indicators Illustrate Effect of Dredge Material Containment Area on Local Groundwater Quality}

The influence of the DMCA on the quality of groundwater is apparent in relation to water-quality conditions not directly related to redox conditions and redox-sensitive waterquality constituents. The DMCA's influence also is apparent in the occurrence and distribution of detectable pesticides and wastewater compounds in groundwater in the DMCA and vicinity.

\section{Pesticides and Wastewater Compounds}

Occurrence and distribution surveys for pesticides in groundwater in the Mid-Atlantic Coastal Plain generally have been conducted to determine their fate and transport following their use in agricultural, residential, and (or) urban settings (Koterba and others, 2010). Fewer surveys have been conducted for wastewater compounds in groundwater in this setting, but they too generally have been conducted to determine the fate and transport of these compounds in groundwater.

Only within the last decade have surveys been done to determine the fate and transport of these and other organic compounds in bay sediments (see Chemical Composition of Sediments, this report). Bay sediments contain pesticides and wastewater compounds that generally are resistant to complete degradation. The source of most of these compounds typically is related to their use in terrestrial settings, but the occurrence of these compounds in bay sediments implies they generally have been exposed to both oxic and anoxic environments, and still persist, albeit often in a metabolite, rather than parent, compound form.

For the purposes of this report, occurrence and distribution surveys for these compounds mainly were conducted to (a) determine if groundwater in WVS used for water supplies, and relatively shallow groundwater elsewhere in the study area, contained residues of these compounds, and (b) determine the source of local recharge or groundwater flow such as agricultural areas, residential areas, and (or) the DMCA. Because most pesticides and wastewater compounds of anthropogenic origin are of relatively recent origin, the surveys are limited in aerial and vertical extent in relation to the shallow groundwater flow system in the DMCA and its vicinity. Thus deeper groundwater in the study area (such as from the upper Patapsco aquifer deep water-bearing zone and some groundwater from the upper Patapsco aquifer shallow water-bearing zone) was not analyzed for pesticides or wastewater compounds. In this report, the term pesticide includes both pesticides and their metabolites for which samples were analyzed. 


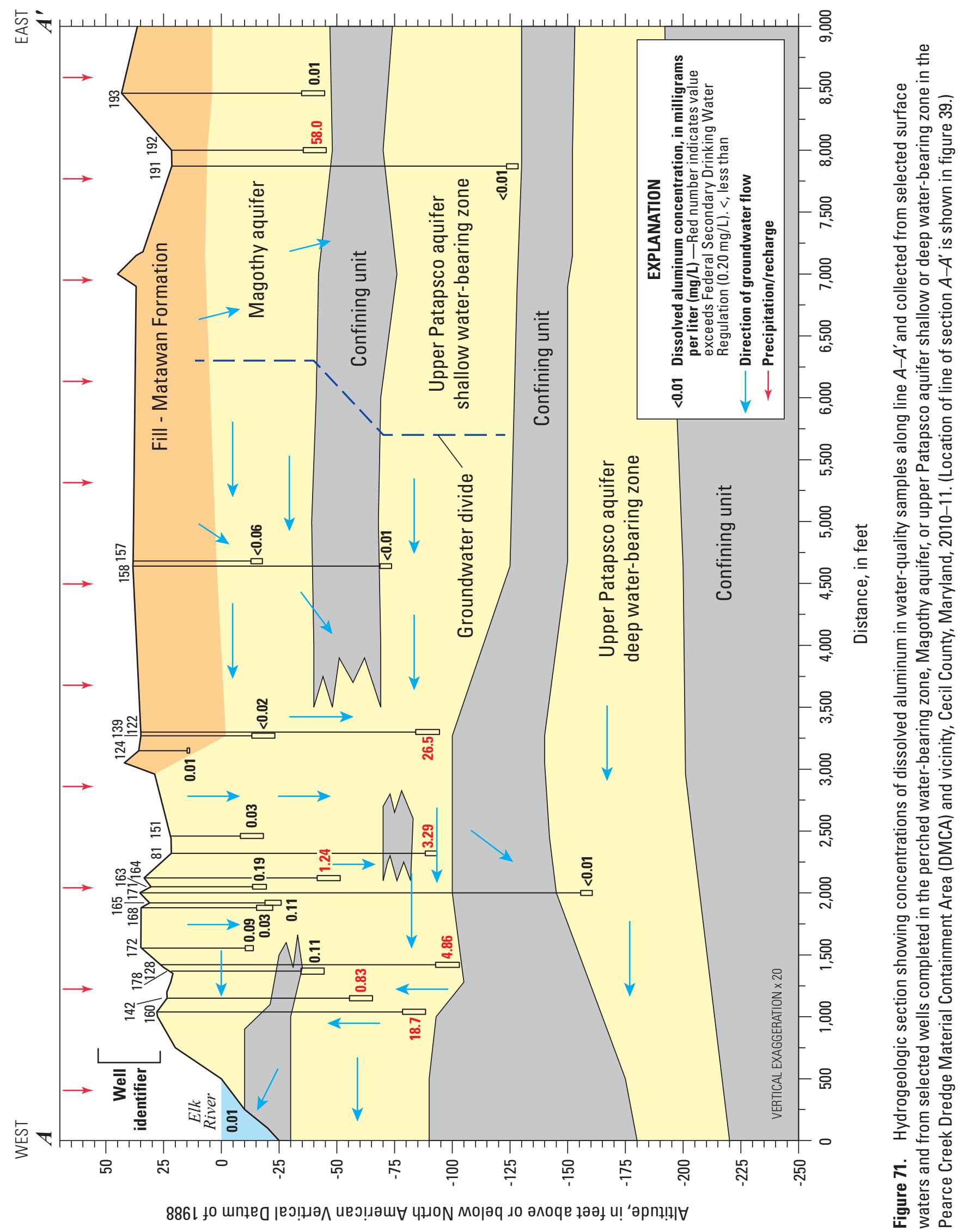



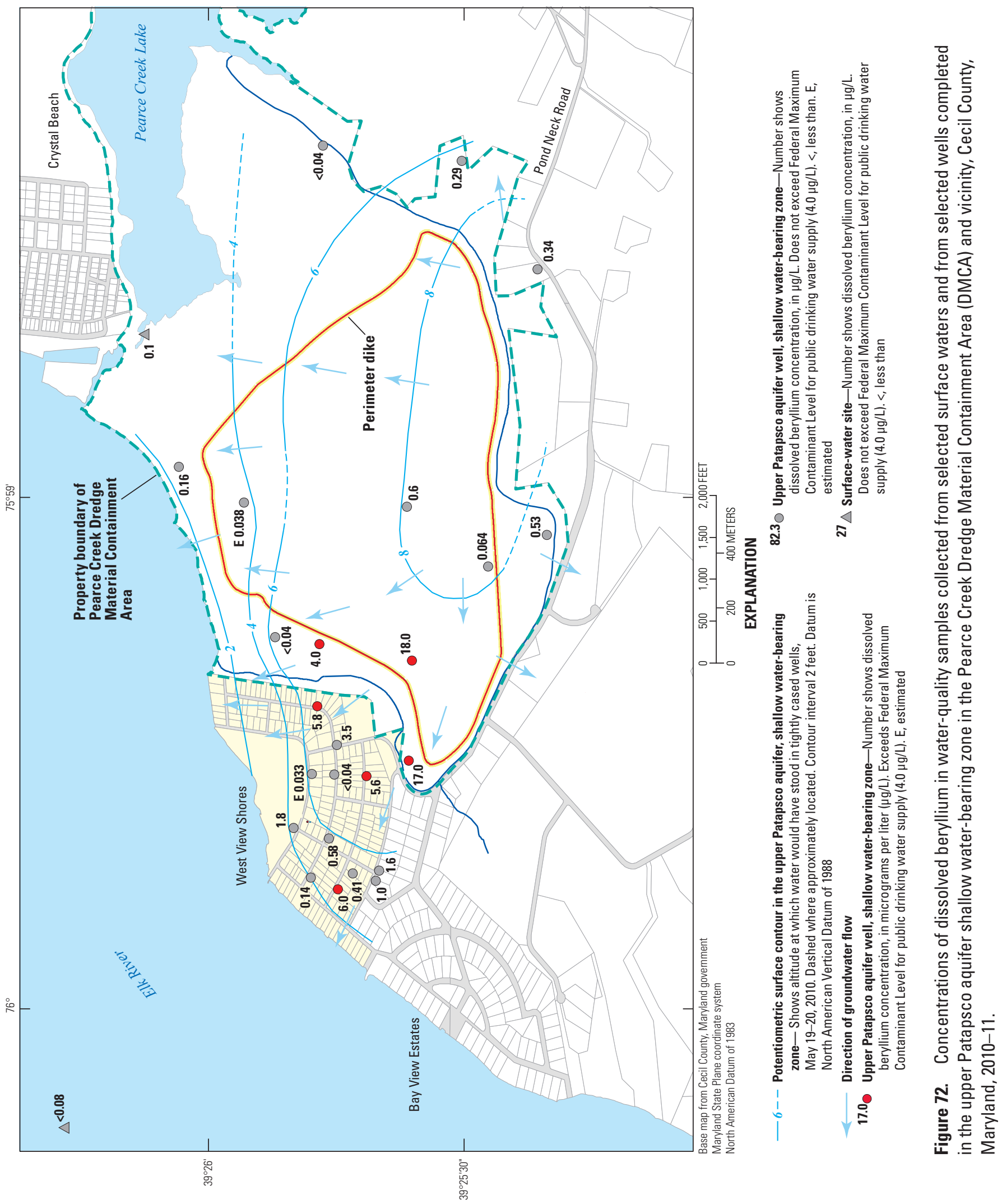


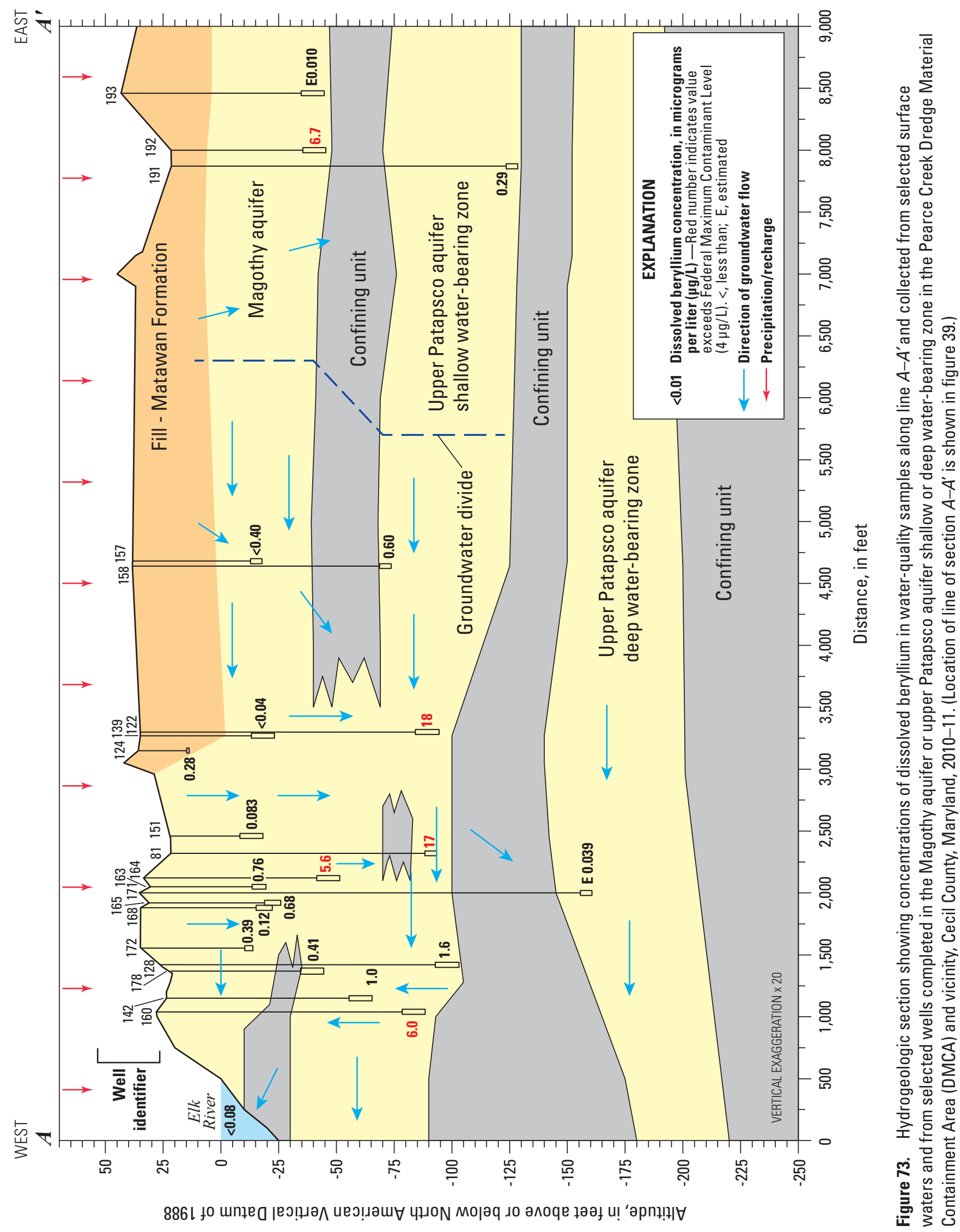



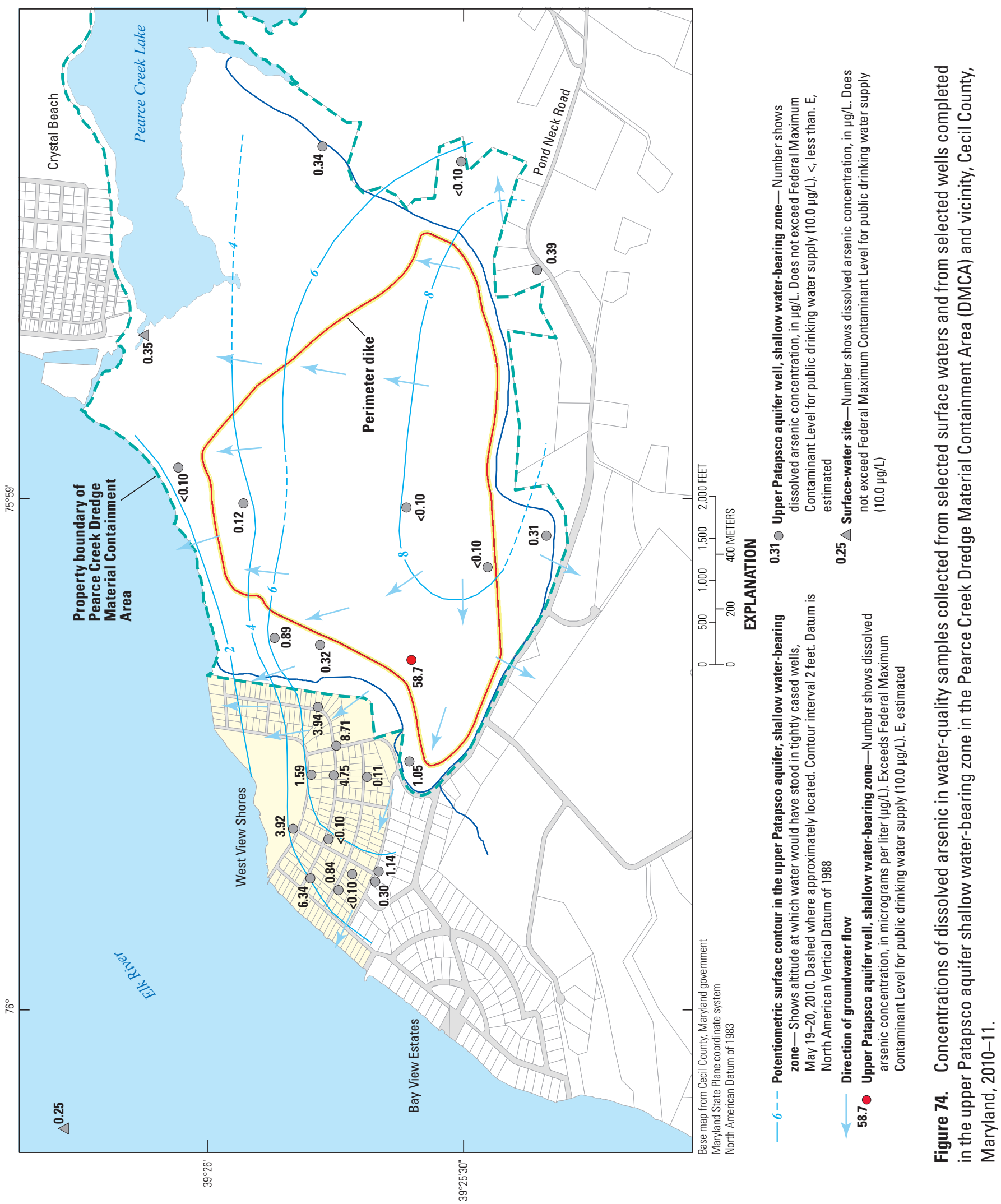
Table 16. Summary of pesticides detected with low-level analytical methods in groundwater and surface-water samples collected in the Pearce Creek Dredge Material Containment Area and vicinity, 2010-11.

$[\mu \mathrm{g} / \mathrm{L}$, micrograms per liter; $<$, less than; $\mathrm{X}$, number of wells with detectable concentrations]

\begin{tabular}{|c|c|c|c|c|c|}
\hline \multirow[b]{2}{*}{ Analyte } & \multirow{2}{*}{$\begin{array}{c}\text { Laboratory } \\
\text { reporting } \\
\text { level ( } \mu \mathrm{g} / \mathrm{L})\end{array}$} & \multicolumn{3}{|c|}{ Number of detections and range in detected concentrations $(\mu \mathrm{g} / \mathrm{L})$} & \multirow[b]{2}{*}{ Comments } \\
\hline & & $\begin{array}{l}\text { Observation wells } \\
\text { (X/20) }\end{array}$ & $\begin{array}{c}\text { Domestic wells } \\
(X / 15)\end{array}$ & All wells $(X / 35)$ & \\
\hline $\begin{array}{l}\text { 2-chloro-4-isopropyl-amino- } \\
\text { 6-amino-s-triazine (DEA) }\end{array}$ & $<0.025$ & $1 / 20,0.050$ & $0 / 15$ & $1 / 35,0.50$ & \\
\hline $\begin{array}{l}\text { 2-hydroxy-4-isopropyl- } \\
\text { amino-6-ethylamino-s- } \\
\text { triazine (HA) }\end{array}$ & $<0.025$ & $1 / 20,0.050$ & $0 / 15$ & $1 / 35,0.050$ & $\begin{array}{l}\text { Also detected } \\
\qquad(0.070 \mu \mathrm{g} / \mathrm{L}) \text { in } \\
\text { Pearce Creek Lake }\end{array}$ \\
\hline \multicolumn{6}{|c|}{ Acetanilides, acetanimides, and metabolites } \\
\hline $\begin{array}{l}\text { Alachlor ethane sulfonic } \\
\text { acid (ESA) }\end{array}$ & $<0.020$ & $9 / 20,0.020$ to 0.160 & $2 / 15,0.020$ to 0.030 & $11 / 35,0.020$ to 0.160 & \\
\hline $\begin{array}{l}\text { Alachlor oxanilic acid } \\
\text { (OXA) }\end{array}$ & $<0.020$ & $9 / 20,0.040$ to 0.250 & $3 / 15,0.030$ to 0.100 & $12 / 35,0.030$ to 0.250 & \\
\hline Metolachlor & $<0.020$ & $1 / 20,0.030$ & $0 / 15$ & $1 / 35,0.030$ & \\
\hline Dechlorometolachlor & $<0.020$ & $0 / 20$ & $1 / 15,0.020$ & $1 / 35,0.020$ & \\
\hline $\begin{array}{l}\text { Metolachlor oxanilic acid } \\
\text { (OXA) }\end{array}$ & $<0.020$ & $10 / 20,0.030$ to 0.100 & $3 / 15,0.030$ to 0.090 & $13 / 35,0.030$ to 0.100 & $\begin{array}{l}\text { Also detected } \\
\qquad(0.090 \mu \mathrm{g} / \mathrm{L}) \text { in } \\
\text { Pearce Creek Lake }\end{array}$ \\
\hline Dimethenamid & $<0.020$ & $0 / 20$ & $0 / 15$ & $0 / 35$ & $\begin{array}{l}\text { Detected }(0.040 \mu \mathrm{g} / \mathrm{L}) \\
\text { only in Pearce Creek } \\
\text { Lake }\end{array}$ \\
\hline
\end{tabular}

\section{Low Level of Detection Pesticide Survey}

An occurrence and distribution survey to detect pesticides at low levels was conducted with 20 observation and 15 domestic-supply wells (appendix A, table A1; appendix B, table B1) in the DMCA and its vicinity to provide information on the distribution of 54 pesticides or their metabolites in the shallow groundwater in the study area (primarily the Magothy aquifer and upper Patapsco aquifer shallow waterbearing zone). These pesticides and metabolites commonly are detected in shallow groundwater in Mid-Atlantic Coastal Plain settings and associated with agricultural, residential, and (or) urban land use (Koterba and others, 2010).

The purpose of this pesticide survey was to help determine the potential sources of groundwater used for domestic water supplies in the vicinity of the DMCA. Most (44 of 54) pesticide or metabolite compounds were not detected (concentrations reported as less than their respective LRLs) in any groundwater samples from observation or domestic wells (appendix B, table B3, LCEA and LCPD pesticides and metabolites).

Ten of the 54 different pesticides were detected in observation and (or) domestic water-supply wells at generally low (less than $0.50 \mu \mathrm{g} / \mathrm{L}$ ) concentrations (table 16). Compounds detected with the highest frequency were the metabolites of metolachlor and alachlor, and included metolachlor ethane sulfonic acid (ESA) (15 of 35 wells), metolachlor oxanilic acid (OXA) (13 of 35 wells), alachlor oxanilic acid (OXA) (12 of 35 wells), and alachlor ethane sulfonic acid (ESA) (11 of 35 wells). Other than these four compounds, only six other compounds were each detected once-dechloroalachlor, dechlorometolachlor, metolachlor, the triazine metabolites 2-chloro-4-isopropyl-amino-6-amino-s-triazine (DEA) and 2-hydroxy-4-isopropyl-amino-6-ethylamino-s-triazine (HA), and dimethenamid, with the latter only being detected at the Pearce Creek Lake outlet (table 16).

The occurrence of mainly the ESA and OXA metabolites of alachlor and metolachlor, compared to other pesticide residues in groundwater in the study area, is consistent with patterns of pesticide occurrence observed in other nearby Coastal Plain settings (Koterba and others, 2010) and likely relates to their resistance to further degradation once in the soil and no longer exposed to photochemical degradation (J. Barbash, USGS, written commun., 2011).

Multiple pesticide detections occurred in groundwater at two wells screened in the local perched water table 
(wells CE Dd 124, 2 pesticide detections; and CE Dd 144, 4 pesticide detections) and in 11 wells screened in the Magothy aquifer primarily located along the southern part of the study area along Pond Neck Road (fig. 75) in the central part of the DMCA (wells CE Dd 137 and 144, 3 pesticides detected at each well; well CE Dd 157, 2 detections), and in WVS just beyond the DMCA property boundary (domestic well CE Dd 179, 5 pesticides detected). Only one pesticide, metolachlor ethane sulfonic acid, was detected in one of the six other wells (used in this survey) located in WVS and completed in shallow oxic water in the Magothy aquifer (well CE Dd 172). Thus, most pesticide detections occur in wells completed beneath the DMCA, beneath its property boundary, or just beyond its property boundary, and are associated with anoxic groundwater flow within or from the DMCA (figs. 76 and 77). Notably, five detections occurred in well CE Dd 193, which is completed in the oxic water east of the DMCA. Despite having 5 detections, other water quality parameters in CE Dd 193 did not appear to be overly affected by any land use.

The co-occurrence of similar pesticides (mainly ESA and OXA metabolites of metolachlor and alachlor) in the wells sampled along Pond Neck Road could indicate that shallow oxic groundwater east of the DMCA is mixing with anoxic groundwater flowing south from the DMCA along the southern and southeastern border of the DMCA property boundary. It also could be that the co-occurrence of similar pesticides in both anoxic groundwater from the DMCA and oxic water to the east of the DMCA simply reflect the ubiquitous and long-term use of these compounds and their resistance to degradation. During DMCA use, these compounds could have been introduced into the DMCA in either dredged sediment or Elk River water, and they simply have remained detectable in older groundwater flowing from the DMCA; whereas their occurrence in oxic groundwater from the east of the DMCA simply reflects their long-term use in agricultural areas to the east and (or) south of the DMCA. That the latter is most likely supported by the fact that pesticide detections in the Magothy aquifer beneath the DMCA or along its property boundary to the north and northwest (figs. 75 and 76) also had detections of these same compounds, and this groundwater is mainly associated with recharge and groundwater flow from the DMCA.

In only one sample, domestic-supply well CE Dd 172, which involves a single pesticide detection, does the source of Magothy groundwater possibly reflect solely local recharge in WVS (figs. 75 and 76), as supported by other water-quality data. The remainder of the pesticides detected in groundwater beneath the WVS community reflect groundwater flowing from the DMCA or mixed DMCA-anoxic and WVS-oxic groundwater at depth (figs. 76 and 77).

The majority of wells screened in the upper Patapsco aquifer shallow water-bearing zone from which samples were analyzed for low-level pesticide detections were located in WVS; two other wells were located in the southeastern part of the study area. Most of the low-level pesticide detections in the upper Patapsco aquifer shallow water-bearing zone are associated with groundwater flow from the DMCA, or mixed
DMCA anoxic and WVS oxic groundwater. With one exception, multiple metabolite detections in the upper Patapsco aquifer shallow water-bearing zone are most prevalent beneath the northwestern part of WVS, where wells are completed in the deep part of this water-bearing zone (fig. 78). The one exception is domestic well CE Dd 161, which is located on the eastern edge of WVS and just west of the DMCA. Four pesticides were detected in this well (metolachlor and alachlor ESA and OXA metabolites). Absent the confining layer between the Magothy and upper Patapsco aquifers, the most likely source of water for this well is groundwater flow from the DMCA.

Of the two wells in this pesticide survey that were completed in the upper Patapsco aquifer outside of the WVS community (fig. 78) only one pesticide (metolachlor-ESA) was detected in one of these wells (CE Dd 192). The source of this groundwater is flow from the DMCA.

\section{Wastewater Compound Survey}

An occurrence and distribution survey for wastewater compounds was conducted for 14 selected observation wells, mainly in the western half of the DMCA, and 15 domestic water-supply wells in the vicinity of the DMCA (appendix A, table A1; appendix B, table B1). Approximately 69 wastewater compounds (table 17), classified according to common sources or uses, were included and reflect selected fossil fuel and combustion byproducts (11), biogenic sterols (4), detergent components and their metabolites (8), solvents (4), pesticides (15), fragrances and flavorants (9), pharmaceuticals (5), plasticizers (7), flame retardants (3), anti-oxidants (2), and chlorination byproducts (1). Data for five wastewater compounds appeared unsuitable for source-water or spatial interpretation because of issues related to the quality of data (table 17, DQI; and appendix B, table B9), and included the pesticide 1,4-dichlorobenzene, the plasticizers bisphenol A, and bis(2-ethylhexyl) and diethyl phthalates, and the ubiquitous use and source compound phenol. Of the remaining 64 wastewater compounds, 35 were not detected (reported as less than their respective LRLs) in groundwater samples from observation or domestic wells (appendix B, table B9).

Twenty-nine of the 64 wastewater compounds were detected at low concentrations (less than $1 \mu \mathrm{g} / \mathrm{L}$ ), which generally were below the LRLs, but above the long-term method detection limit (table 17; appendix B, table B3). Therefore, most concentrations are estimated values with higher than normal uncertainty, and hereafter they are referred to as simply detections in this report. Individual compounds detected with the highest frequency were the biogenic sterols cholesterol (11 of 29 wells) and $\beta$-sitosterol ( 9 of 29 wells), the detergent isomers of 4-nonylphenol ( 8 of 29 wells), and the solvent isophorone (10 of 29 wells).

The most frequently detected wastewater compounds grouped according to potential source and (or) use and the number of different compounds detected within each group were fossil fuel components and combustion byproducts (10 of 11 compounds), biogenic sterols (4 of 4 compounds), 
Table 17. Characteristics and summary of detections of organic wastewater compounds associated with groundwater samples collected from selected wells in the Pearce Creek Dredge Material Containment Area and vicinity, 2010.

$[\mathrm{NO}$, naturally occurring source; CMAR, commercial, manufacturing, agricultural, and (or) residential source(s); PAH, polycyclic aromatic hydrocarbon; $\mu \mathrm{g} / \mathrm{L}$, micrograms per liter; E, estimated concentration with greater than normal uncertainty; <, less than; DQI, data-quality issues preclude interpretation of data, see text for in-depth discussion; wastewater compound analytical method described in Zaugg and others (2002)]

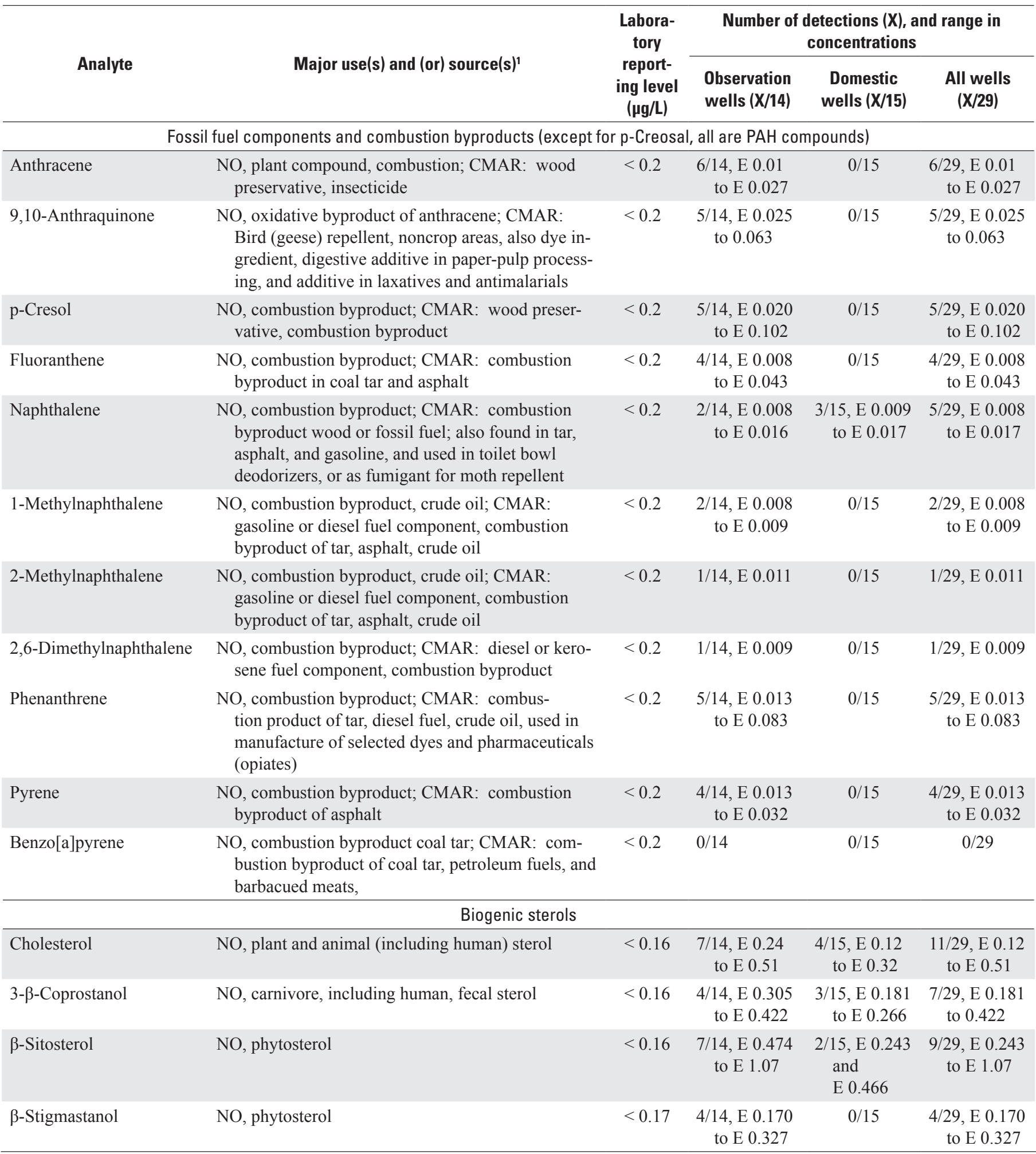


Table 17. Characteristics and summary of detections of organic wastewater compounds associated with groundwater samples collected from selected wells in the Pearce Creek Dredge Material Containment Area and vicinity, 2010. - Continued

[NO, naturally occurring source; CMAR, commercial, manufacturing, agricultural, and (or) residential source(s); PAH, polycyclic aromatic hydrocarbon; $\mu \mathrm{g} / \mathrm{L}$, micrograms per liter; E, estimated concentration with greater than normal uncertainty; <, less than; DQI, data-quality issues preclude interpretation of data, see text for in-depth discussion; wastewater compound analytical method described in Zaugg and others (2002)]

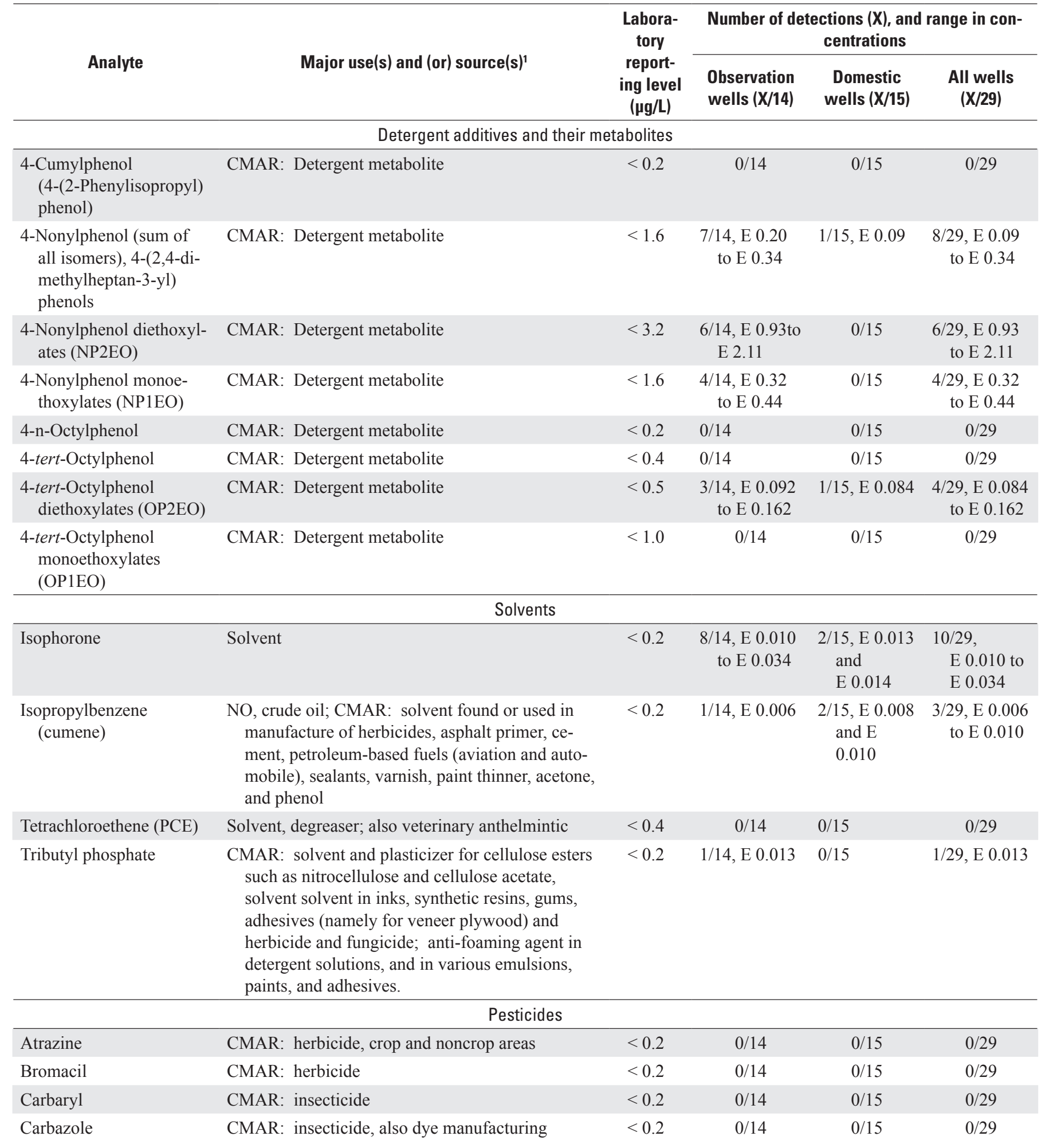


Table 17. Characteristics and summary of detections of organic wastewater compounds associated with groundwater samples collected from selected wells in the Pearce Creek Dredge Material Containment Area and vicinity, 2010.-Continued

[NO, naturally occurring source; CMAR, commercial, manufacturing, agricultural, and (or) residential source(s); PAH, polycyclic aromatic hydrocarbon; $\mu \mathrm{g} / \mathrm{L}$, micrograms per liter; E, estimated concentration with greater than normal uncertainty; $<$, less than; DQI, data-quality issues preclude interpretation of data, see text for in-depth discussion; wastewater compound analytical method described in Zaugg and others (2002)]

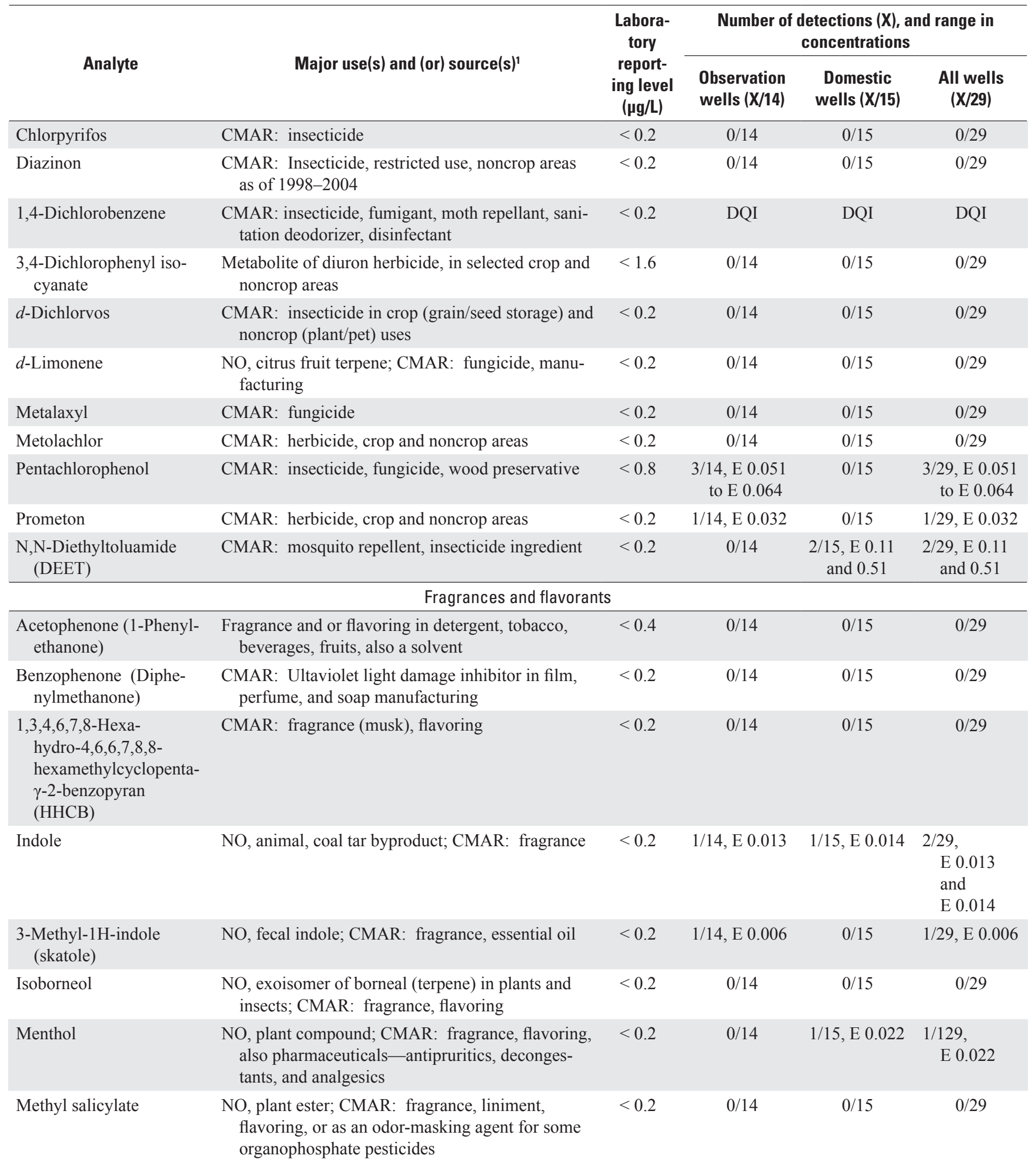


Table 17. Characteristics and summary of detections of organic wastewater compounds associated with groundwater samples collected from selected wells in the Pearce Creek Dredge Material Containment Area and vicinity, 2010. - Continued

[NO, naturally occurring source; CMAR, commercial, manufacturing, agricultural, and (or) residential source(s); PAH, polycyclic aromatic hydrocarbon; $\mu \mathrm{g} / \mathrm{L}$, micrograms per liter; E, estimated concentration with greater than normal uncertainty; <, less than; DQI, data-quality issues preclude interpretation of data, see text for in-depth discussion; wastewater compound analytical method described in Zaugg and others (2002)]

\begin{tabular}{|c|c|c|c|c|c|}
\hline \multirow{2}{*}{ Analyte } & \multirow{2}{*}{ Major use(s) and (or) source(s) ${ }^{1}$} & \multirow{2}{*}{$\begin{array}{l}\text { Labora- } \\
\text { tory } \\
\text { report- } \\
\text { ing level } \\
(\mu \mathrm{g} / \mathrm{L})\end{array}$} & \multicolumn{3}{|c|}{$\begin{array}{l}\text { Number of detections }(X) \text {, and range in } \\
\text { concentrations }\end{array}$} \\
\hline & & & $\begin{array}{l}\text { Observation } \\
\text { wells }(\mathrm{X} / 14)\end{array}$ & $\begin{array}{c}\text { Domestic } \\
\text { wells (X/15) }\end{array}$ & $\begin{array}{l}\text { All wells } \\
\text { (X/29) }\end{array}$ \\
\hline $\begin{array}{l}\text { 7-Acetyl-1,1,3,4,4,6- } \\
\text { hexamethyl-1,2,3,4- } \\
\text { tetrahydro-naphthalene } \\
\text { (AHTN) }\end{array}$ & CMAR: fragrance (musk) & $<0.2$ & $0 / 14$ & $0 / 15$ & $0 / 29$ \\
\hline \multicolumn{6}{|c|}{ Plasticizers } \\
\hline $\begin{array}{l}\text { Bis(2-ethylhexyl) phthal- } \\
\text { ate }\end{array}$ & CMAR: plasticizer, antioxidant & $<0.2$ & DQI & DQI & DQI \\
\hline Bisphenol A & CMAR: plasticizer, antioxidant & $<0.4$ & DQI & DQI & DQI \\
\hline Diethyl phthalate & CMAR: plasticizer for polymers and resins & $<0.2$ & DQI & DQI & DQI \\
\hline $\begin{array}{l}\text { Triethyl citrate (ethyl } \\
\text { citrate) }\end{array}$ & $\begin{array}{l}\text { Plasticizer, cosmetics, food additive, food contact } \\
\text { material, medical, and pharmaceutical uses; } \\
\text { cigarette filters, cosmetics, lacquers }\end{array}$ & $<0.2$ & $0 / 14$ & $0 / 15$ & $0 / 29$ \\
\hline Triphenyl phosphate & $\begin{array}{l}\text { Platicizer, also used as antioxidant flame retardant } \\
\text { in resin, wax, and roofing paper }\end{array}$ & $<0.2$ & $0 / 14$ & $0 / 15$ & $0 / 29$ \\
\hline $\begin{array}{l}\text { Tri(2-butoxyethyl) phos- } \\
\text { phate }\end{array}$ & Plasticizer & $<0.320$ & $0 / 14$ & 1/15, E 0.145 & $1 / 29$, E 0.145 \\
\hline \multicolumn{6}{|c|}{ Pharmaceuticals } \\
\hline Camphor & $\begin{array}{l}\text { NO, plant terpenoid; CMAR: Pharmaceutical } \\
\text { (ointments), also flavoring, fragrance, and moth } \\
\text { repellent }\end{array}$ & $<0.2$ & $\begin{array}{l}2 / 14, \text { E } 0.018 \\
\text { and E } 0.021\end{array}$ & $0 / 15$ & $\begin{array}{l}2 / 29 \\
\text { E } 0.018 \\
\text { and } \\
\text { E } 0.021\end{array}$ \\
\hline Caffeine & $\begin{array}{l}\text { NO: plant insecticide; CMAR: psychoactive } \\
\text { stimulant }\end{array}$ & $<0.8$ & $0 / 14$ & $0 / 15$ & $0 / 29$ \\
\hline Cotinine & NO, Nicotine metabolite and biomarker & $<0.2$ & $0 / 9$ & $0 / 15$ & $0 / 24$ \\
\hline Isoquinoline & $\begin{array}{l}\text { CMAR: used in manufacture of antifungals and } \\
\text { insectidies, as well as in dyes, paints, and rubber } \\
\text { products; also extraction solvent for resins and } \\
\text { terpenes, and corrosion inhibitor }\end{array}$ & $<0.2$ & $0 / 14$ & $0 / 15$ & $0 / 29$ \\
\hline Triclosan & $\begin{array}{l}\text { CMAR: antimicrobial disinfectant used in deodor- } \\
\text { ants, toothpastes, shaving creams, mouth washes, } \\
\text { and cleaning supplies }\end{array}$ & $<0.2$ & $0 / 14$ & $0 / 15$ & $0 / 29$ \\
\hline \multicolumn{6}{|c|}{ Flame retardants } \\
\hline $\begin{array}{l}2,2^{\prime}, 4,4^{\prime} \text {-tetrabromodi- } \\
\text { phenyl ether (BDE } 47)\end{array}$ & CMAR: flame retardent & $<0.3$ & $0 / 14$ & $0 / 15$ & $0 / 29$ \\
\hline $\begin{array}{l}\text { Tri(2-chloroethyl) phos- } \\
\text { phate (FYROL CEF) }\end{array}$ & CMAR: flame retardant & $<0.2$ & $0 / 14$ & $0 / 15$ & $0 / 29$ \\
\hline $\begin{array}{l}\text { Tri(dichloroisopropyl) } \\
\text { phosphate (FYROL } \\
\text { PCF) }\end{array}$ & CMAR: flame retardant & $<0.2$ & $0 / 14$ & $0 / 15$ & $0 / 29$ \\
\hline
\end{tabular}


Table 17. Characteristics and summary of detections of organic wastewater compounds associated with groundwater samples collected from selected wells in the Pearce Creek Dredge Material Containment Area and vicinity, 2010. - Continued

$[\mathrm{NO}$, naturally occurring source; CMAR, commercial, manufacturing, agricultural, and (or) residential source(s); PAH, polycyclic aromatic hydrocarbon; $\mu \mathrm{g} / \mathrm{L}$, micrograms per liter; E, estimated concentration with greater than normal uncertainty; <, less than; DQI, data-quality issues preclude interpretation of data, see text for in-depth discussion; wastewater compound analytical method described in Zaugg and others (2002)]

\begin{tabular}{|c|c|c|c|c|c|}
\hline \multirow{2}{*}{ Analyte } & \multirow{2}{*}{ Major use(s) and (or) source(s) $)^{1}$} & \multirow{2}{*}{$\begin{array}{l}\text { Labora- } \\
\text { tory } \\
\text { report- } \\
\text { ing level } \\
\text { ( } \mu \mathrm{g} / \mathrm{L})\end{array}$} & \multicolumn{3}{|c|}{$\begin{array}{l}\text { Number of detections }(X) \text {, and range in con- } \\
\text { centrations }\end{array}$} \\
\hline & & & $\begin{array}{l}\text { Observation } \\
\text { wells }(X / 14)\end{array}$ & $\begin{array}{c}\text { Domestic } \\
\text { wells (X/15) }\end{array}$ & $\begin{array}{l}\text { All wells } \\
\text { (X/29) }\end{array}$ \\
\hline \multicolumn{6}{|c|}{ Antioxidants } \\
\hline $\begin{array}{l}\text { 3-t-Butyl-4-hydroxyani- } \\
\text { sole (BHA) }\end{array}$ & CMAR: antioxidant, food preservative & $<0.2$ & $0 / 14$ & $0 / 15$ & $0 / 29$ \\
\hline \multicolumn{6}{|c|}{ Chlorination byproducts } \\
\hline $\begin{array}{l}\text { Bromoform (tribromo- } \\
\text { methane) }\end{array}$ & CMAR: water-chlorination byproduct & $<0.2$ & $0 / 14$ & $0 / 15$ & $0 / 29$ \\
\hline \multicolumn{6}{|c|}{ Ubiquitous (multiple) source and use } \\
\hline
\end{tabular}

\footnotetext{
${ }^{1}$ Modified from similar source and use categorizations from Buxton and Kolpin (2002), Kolpin and others (2002), Focazio and others (2008), Ferrell (2009), and Tertuliani and others (2008).
}

detergent additives and (or) their metabolites (4 of 8 compounds), and solvents ( 3 of 4 compounds). Few pesticides and fragrances or flavorants, plasticizers, or pharmaceuticals, and no flame retardants or antioxidants were detected.

Most of the detected wastewater compounds have natural as well as synthetic origins (table 17), and a number of these compounds have been shown to occur in organic-rich siltyclay sediments such as those found in the upper bay (Hartwell and Hameedi, 2007). As such, they also reflect compounds which generally are resistant to degradation, and thus, could still be emanating from the sediment and Elk River water initially deposited in the DMCA during the time of operation.

Wastewater compounds were minimally detected in 5 of the 7 surveyed wells in the Magothy aquifer in WVS. Two of the 7 wells had zero compounds detected, 2 wells had 1 compound detected, 2 wells had 3 compounds detected, and 1 well had 4 compounds detected (fig. 79). Wastewater compounds were detected in 7 of 8 wells screened in the Magothy aquifer and surveyed within the property boundary of the DMCA. Three to five compounds were detected in three wells. The highest number of detections of wastewater compounds in the Magothy aquifer occurred in the western and central part of the DMCA at well 137 (7 compounds detected), well 139 (13 compounds detected), well 157 (14 compounds detected), and well 144 (18 compounds detected) (fig. 79). Southeast of the DMCA property boundary, three compounds were detected in well CE Dd 153, which is screened in the Magothy aquifer.
In the upper Patapsco aquifer shallow water-bearing zone (fig. 80), all but one surveyed well (CE Dd 154) was located in WVS. Of the eleven surveyed wells, 5 had zero detections of wastewater compounds; 5 wells had between 1 and 3 detections, and 1 well (CE Dd 160) had 12 detections. Wastewater compounds detected in the Magothy aquifer in the western half of the DMCA may have been transported within the anoxic flow from the DMCA west beneath WVS and vertically downward to the upper Patapsco aquifer shallow waterbearing zone (fig. 81); this may account for the high number of wastewater compounds detected in groundwater analyzed from well CE Dd 160.

Groundwater contaminated by residential wastewater treatment, landfill, or septic effluents in other shallow aquifers, often includes measurable or detectable concentrations of wastewater compounds associated with human consumption and residential land-use activities - for example, pharmaceuticals or residential pesticide use (Barnes and others, 2008; Focazio and others, 2008; Standley and others, 2008). However, with the exception of N,N-diethyltoluamide (DEET) and menthol found in the groundwater sample from domestic well CE Dd 165, and a relatively high concentration of DEET found in the groundwater sample from domestic well CE Dd 172, few of these types of wastewater compounds were detected in shallow domestic wells in WVS. The two human-use wastewater compounds detected in groundwater at well CE Dd 165 could reflect local use because the well 

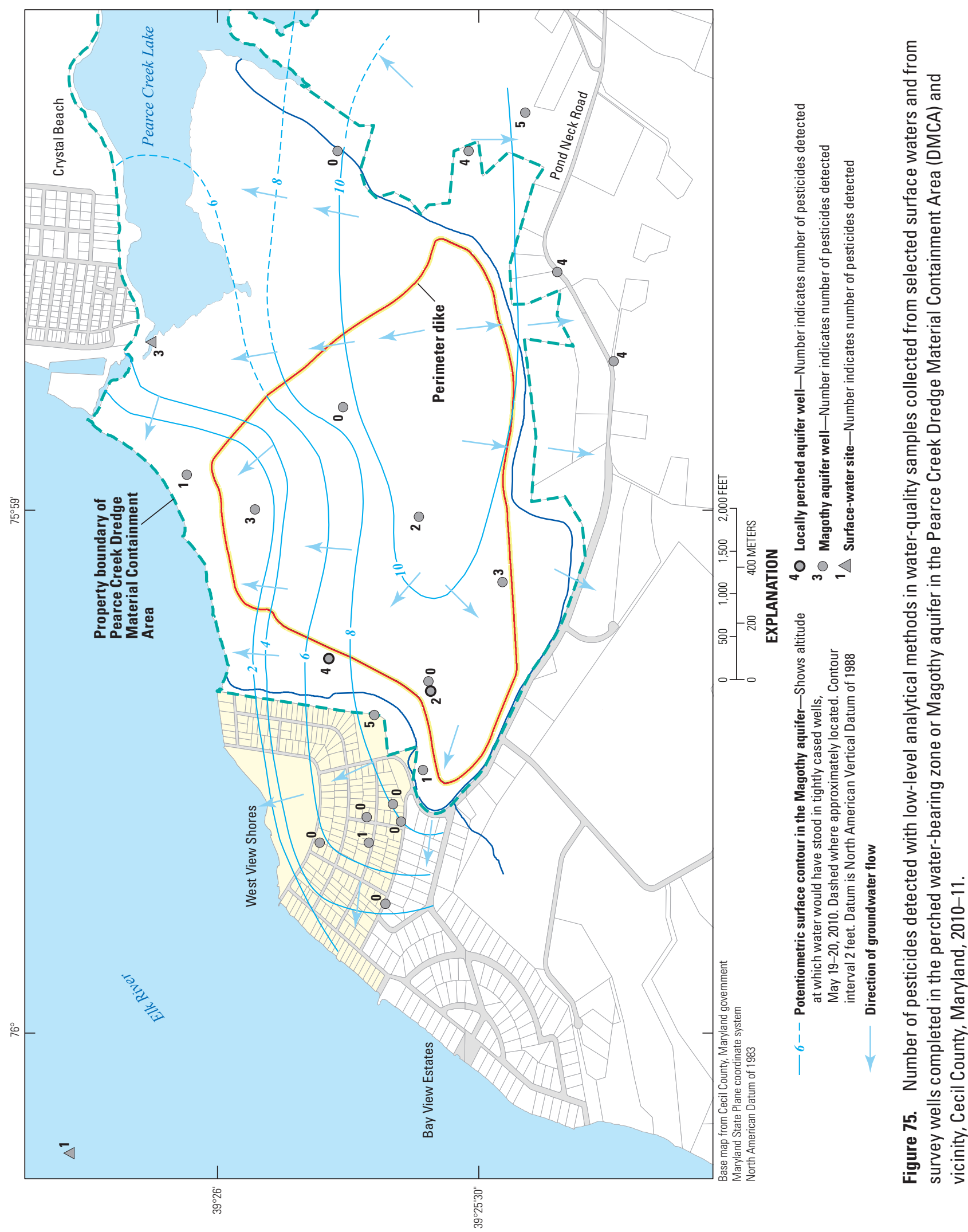


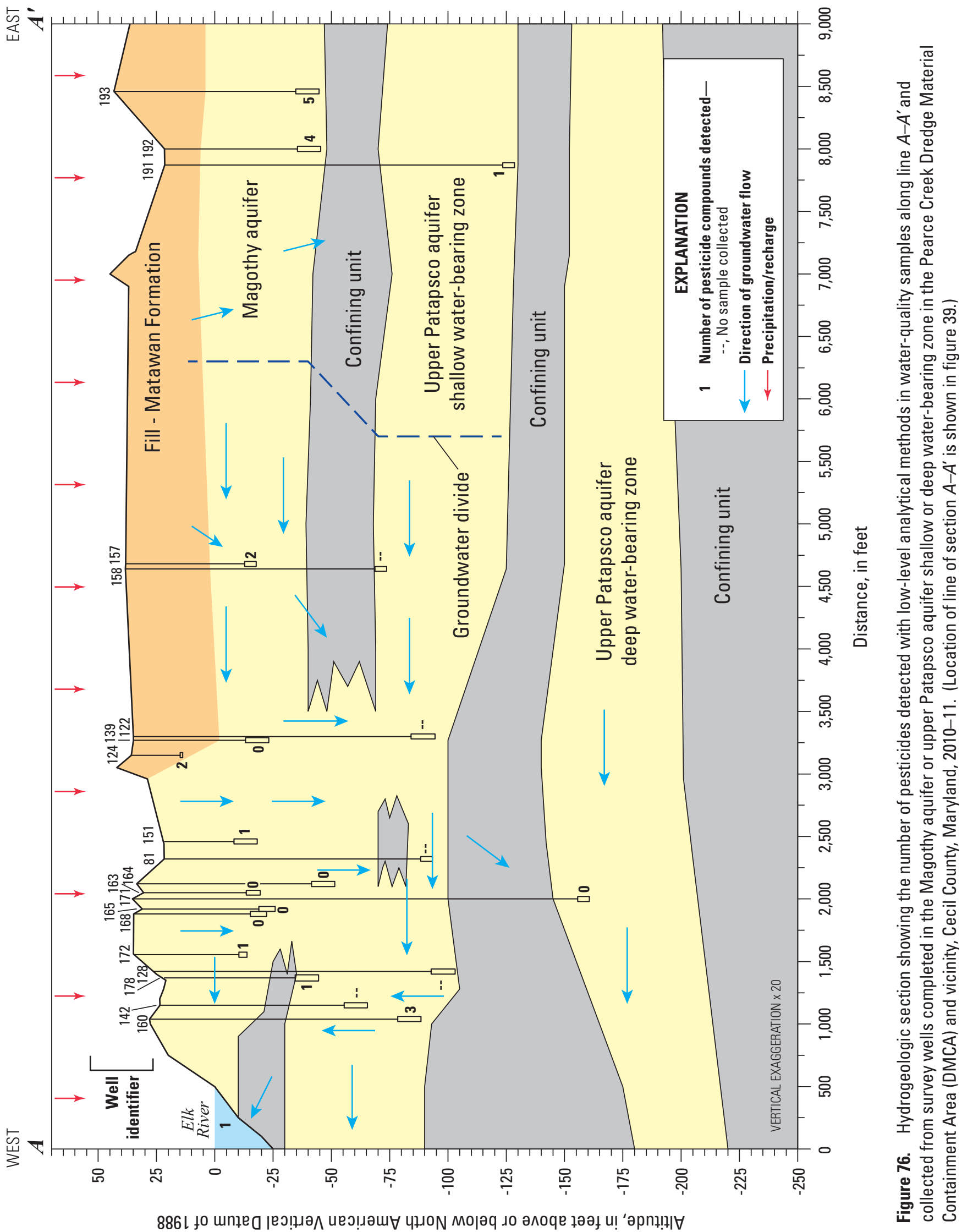




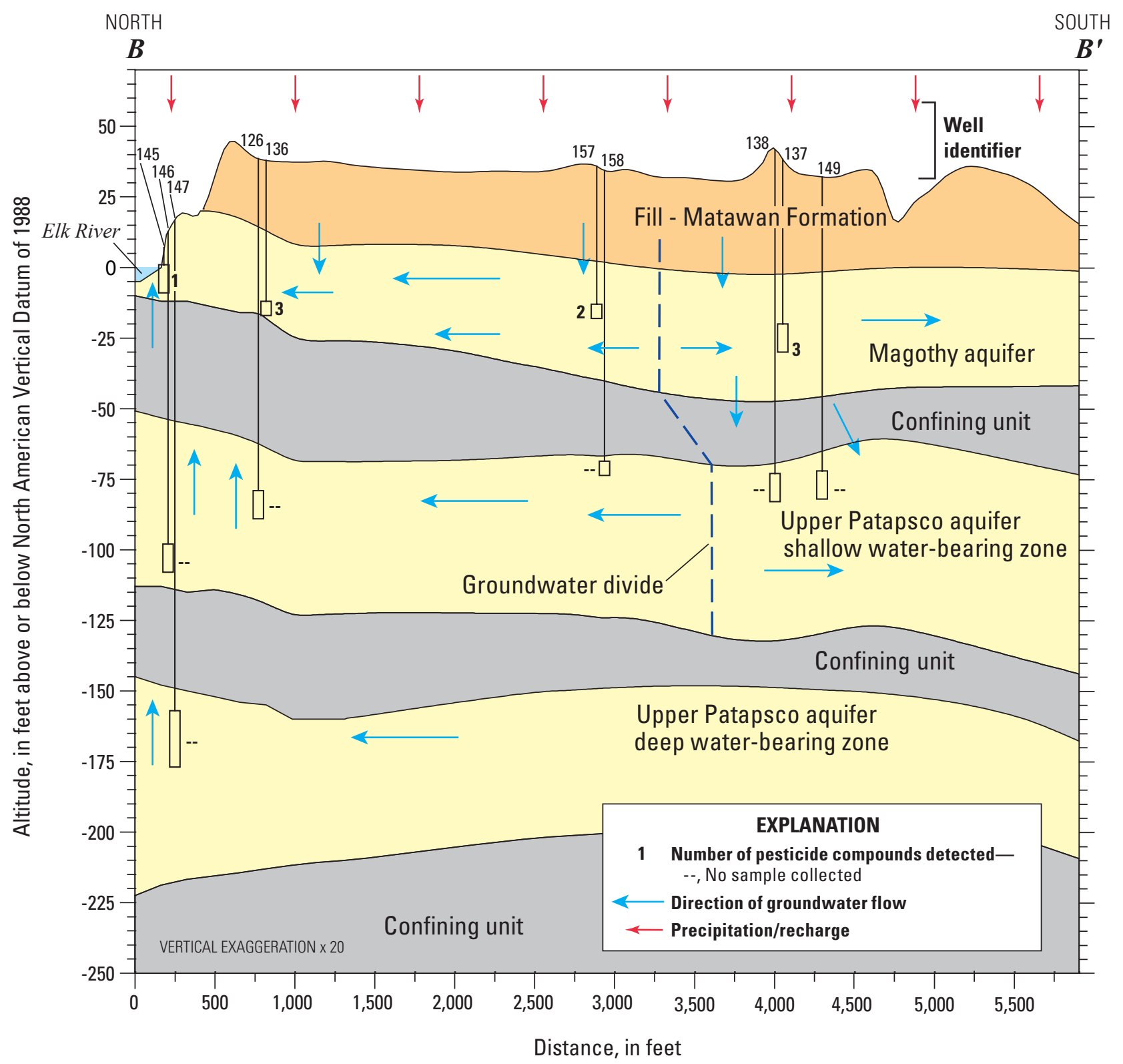

Figure 77. Hydrogeologic section showing the number of pesticides detected with low-level methods in water-quality samples along line $B-B^{\prime}$ and collected from survey wells completed in the Magothy aquifer in the Pearce Creek Dredge Material Containment Area (DMCA) and vicnity, Cecil County, Maryland, 2010-11. (Location of line of section $B-B^{\prime}$ is shown in figure 39.)

pit is located inside the house and was flooded by an internal water-supply line break in 2008. The high concentration of DEET found in domestic well CE Dd 172 also could reflect local residential use. DEET was the only wastewater compound detected in groundwater from this well. DEET was only detected in wells CE Dd 165 and CE Dd 172; DEET was not detected in any wells in the DMCA.

Other than DEET and menthol, all other wastewater compounds detected in groundwater from domestic wells in the WVS also were detected in groundwater from DMCA observation wells. In addition, they were detected at a greater frequency and (or) often-higher concentration in samples from
DMCA wells compared to samples from domestic-supply wells (table 17).

In the upper Patapsco aquifer deep water-bearing zone only one well (CE Dd 170) was included in the survey. Two wastewater compounds were detected in well CE Dd 170. In summary, the wastewater compound results indicate the occurrence of a high number of similar compounds in and beneath the DMCA and in the upper Patapsco aquifer shallow water-bearing zone along the groundwater flow path from the DMCA to WVS, which is consistent with the patterns observed for many other water-quality constituents in this study. Thus, detections of wastewater compounds also support 


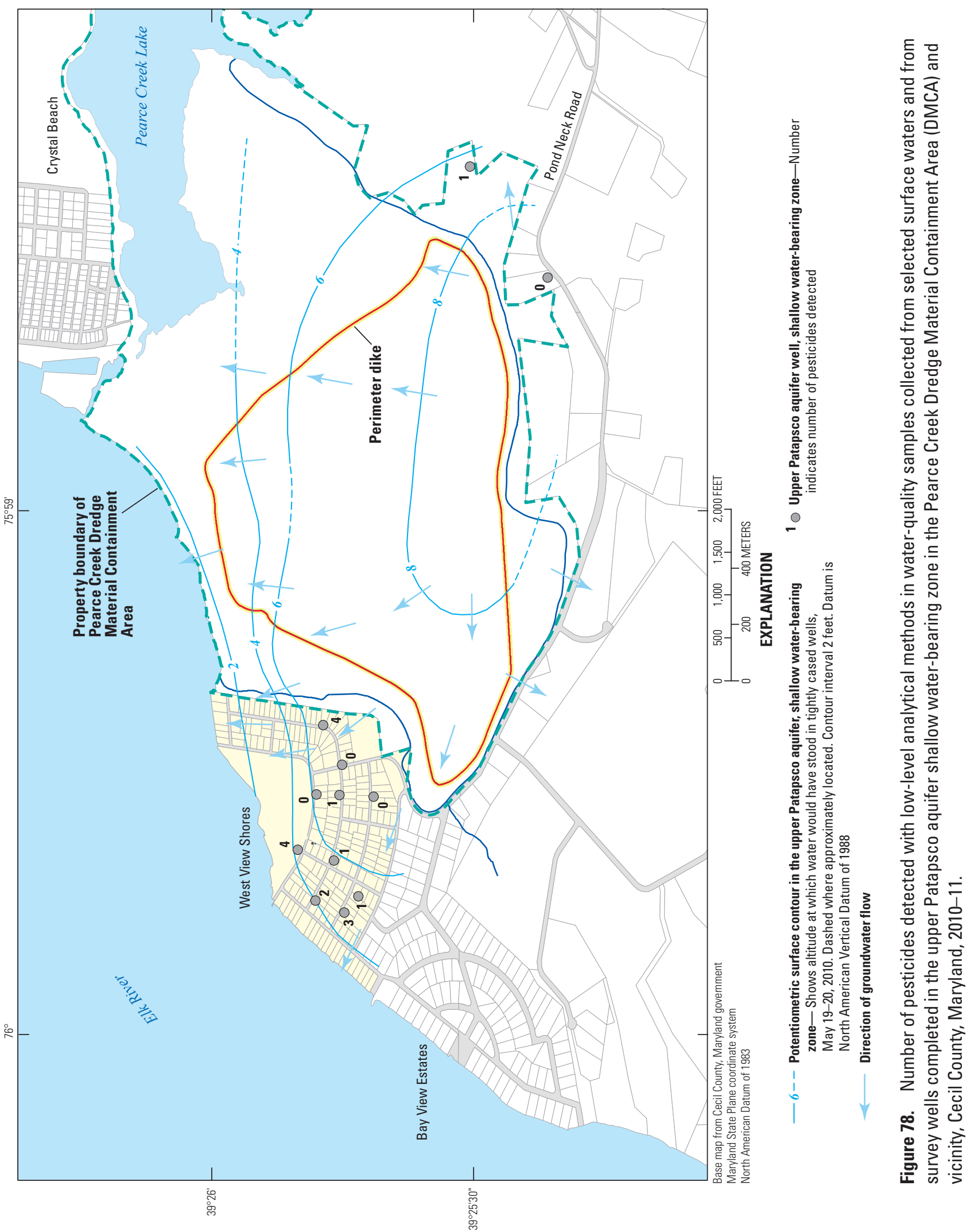




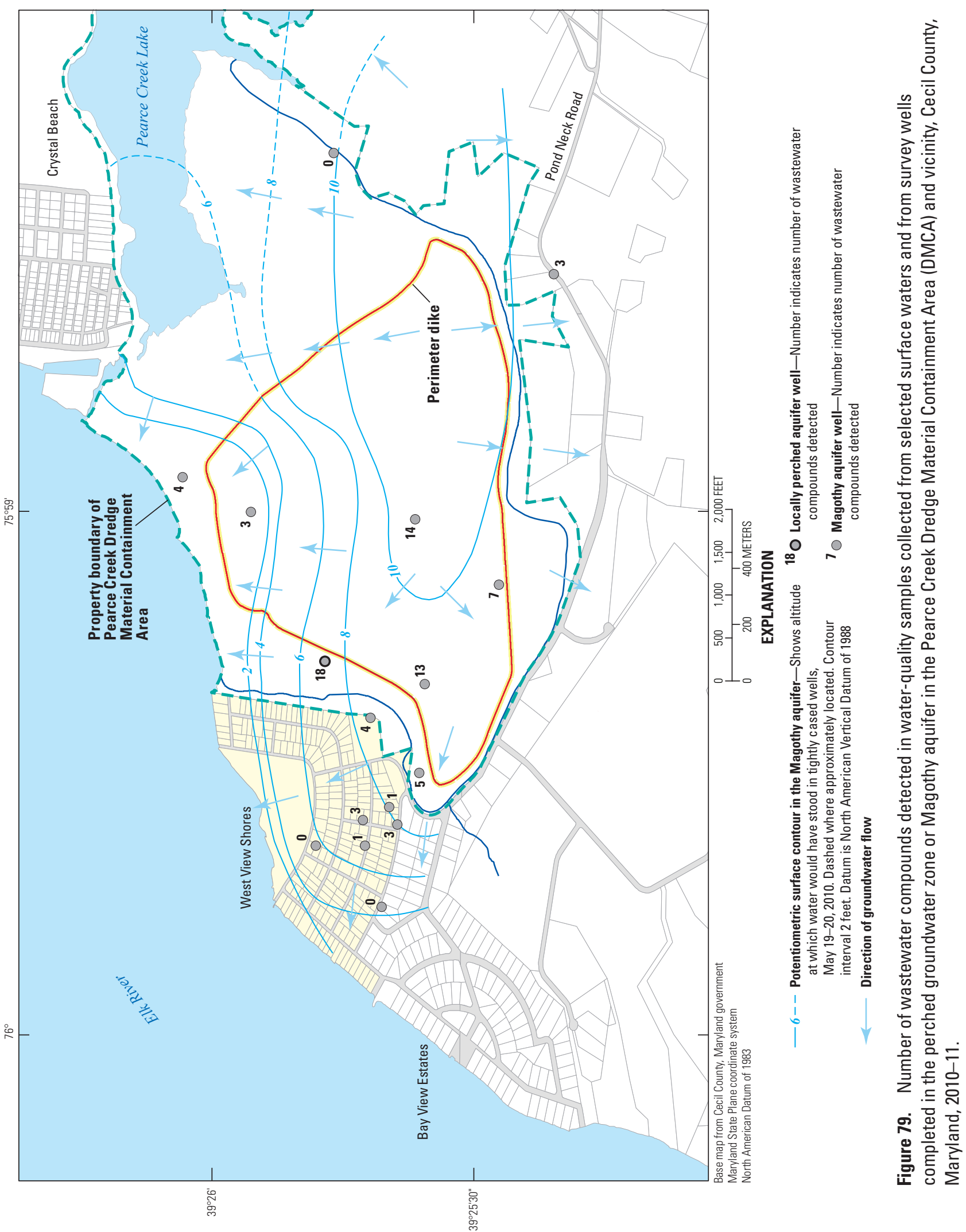



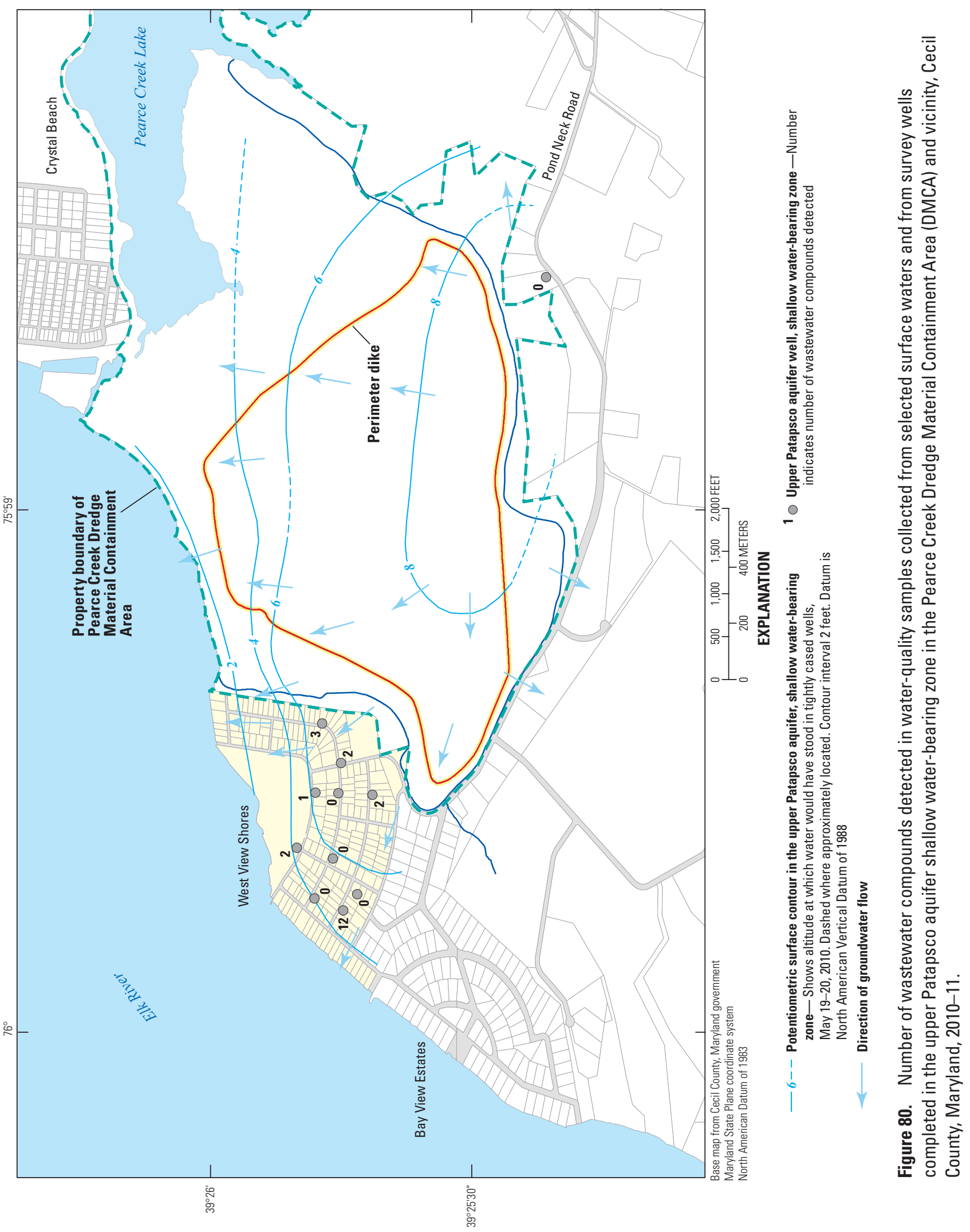


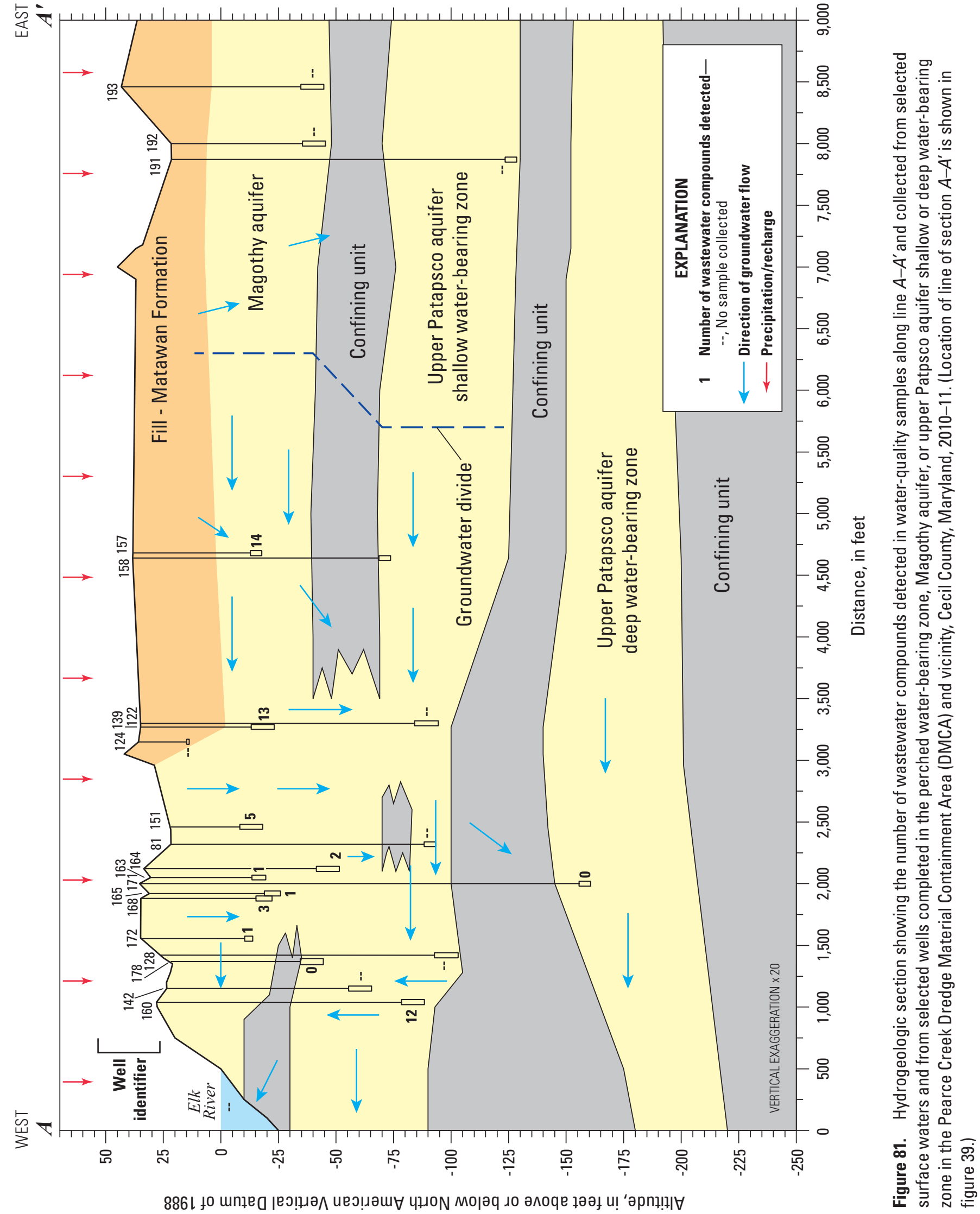


the conclusion that groundwater flow from the DMCA affects the quality of groundwater at depths used for domestic supplies beneath WVS.

\section{Quality of Water for Drinking-Water Supplies}

Single-residential domestic water supplies such as those in WVS are not regulated under the Federal Safe Drinking Water Act (SDWA). ${ }^{4}$ However, local groundwater is the major source of domestic-well water supplies in vicinity of the DMCA. Thus, although the USEPA SDWA standards have no regulatory bearing on the use of private residential wells for drinking or other household purposes, they can be used as a guide to indicate whether or not local groundwater supplies are impaired.

The 2009 Edition of the U.S. Environmental Protection Agency Drinking Water Standards and Health Advisories (U.S. Environmental Protection Agency, 2009) was used to evaluate the quality of the groundwater in drinking-water supplies. All USEPA SDWA standards and advisories, including Maximum Contaminant Levels (MCLs), Health Advisory Levels (HALs), and Secondary Drinking Water Regulations (SDWRs), were considered, provided the data were collected. The MCL, HAL, or SDWR is included with the collected water-quality data for every constituent that has a Federal standard (appendix B, table B3). The term "standard" as used hereafter in the report will be a generic reference to refer to one or all three of the sets of standards above. For brevity, results are provided in general terms for those constituents that were less than the maximum allowable or recommended levels, and only those water-quality constituents with concentrations that were greater than maximum allowable or recommended levels (MCLs, HALs, or SDWR), are discussed below.

Fifty-eight water-quality constituents measured as part of this study have a 2009 SDWA standard (U.S. Environmental Protection Agency, 2009), which was used to evaluate the suitability of sampled water for potable use (appendix B, table B3). Concentrations of forty-two of these constituents were measured at concentrations below the maximum allowable or recommended levels in all samples collected for this study, thus they did not exceed the USEPA SDWA standards. The majority of these 42 constituents were either regulated pesticides or wastewater compounds, which generally were detected at concentrations below their individual LRLs. Included in this group are five wastewater compounds whose concentrations in groundwater samples possibly were positively biased by contamination during or after sample collection (see Data Quality, this report). However, as with the other 37 constituents in this group, their concentrations were less than the maximum allowable or recommended levels for their respective 2009 USEPA SDWA standards.

\footnotetext{
${ }^{4}$ Serves fewer than 25 individuals and (or) has fewer than 15 service connections (Federal Register, 1998).
}

Sixteen constituents had concentrations in groundwater and (or) surface-water samples that were greater than the maximum allowable or recommended levels for a 2009 USEPA SDWA standard (table 18). These constituents include the general physical or chemical characteristics common to groundwater-for example, TDS and $\mathrm{pH}-$ as well as selected inorganic constituents that generally are less than the maximum allowable or recommended levels for the standards in most groundwater-for example, the trace elements beryllium, thallium, nickel, and arsenic. Measured concentrations greater than the allowable or recommended levels established in standards, are hereafter termed exceedances, these include MCLs, HALs, and SDWR criteria, and form an initial basis for the following discussion.

\section{Maximum Contaminant Levels}

Groundwater concentrations for four trace elementsarsenic, beryllium, cadmium, and thallium — were greater than their respective MCLs at one or more observation or domestic wells (table 18). A brief summary for each of these trace elements follows.

Arsenic (MCL $10 \mu \mathrm{g} / \mathrm{L}$ ): Only one observation well, (CE Dd 122) located in the DMCA, yielded a sample with a concentration of arsenic greater than the MCL. The concentration of arsenic was $58.7 \mu \mathrm{g} / \mathrm{L}$ and was confirmed and replicated. Concentrations of arsenic, ranging from approximately 4 to $9 \mu \mathrm{g} / \mathrm{L}$, were measured in wells downgradient from this well in the upper Patapsco aquifer shallow water-bearing zone beyond the western side of the DMCA and in domestic-supply wells in WVS (fig. 74). These concentrations (ranging from 4 to $9 \mu \mathrm{g} / \mathrm{L}$ ) are below the MCL for arsenic, but they are greater than concentrations found in natural groundwater for the aquifer.

Beryllium (MCL $4 \mu \mathrm{g} / \mathrm{L}$ ): Six observation wells (CE Dd $81,122,133,145,160$ and 192) and two domestic-supply wells (CE Dd 161 and CE Dd 164) had concentrations of beryllium greater than the MCL. In addition, one observation well (CE Dd 129) and one domestic-supply well (CE Dd 176) had beryllium concentrations at or within 10 percent of the MCL (appendix B, table B3). Beryllium concentrations also appeared to be higher - than concentrations common in natural groundwater near the study area - in the upper Patapsco aquifer shallow water-bearing zone beneath the DMCA and downgradient in groundwater beneath WVS (fig. 72, beryllium concentrations of approximately 4-18 $\mu \mathrm{g} / \mathrm{L})$.

Cadmium (MCL $5 \mu \mathrm{g} / \mathrm{L}$ ) and thallium (MCL $2 \mu \mathrm{g} / \mathrm{L}$ ): One observation well (CE Dd 192) had concentrations of cadmium $(5.12 \mu \mathrm{g} / \mathrm{L})$ and thallium $(2.56 \mu \mathrm{g} / \mathrm{L})$ (as well as beryllium, $6.7 \mu \mathrm{g} / \mathrm{L}$ ) above their respective MCLs.

Exceedances of the MCLs for beryllium, cadmium, and thallium and elevated concentrations of arsenic (compared to natural groundwater) could reflect enhanced reduction and their release from sediments within the DMCA. The occurrence of concentrations of beryllium and arsenic greater than or near the MCLs in groundwater in the study area were 
shown to be highly localized (generally the western part of the DMCA and WVS), and related to Fe(III)-reducing conditions associated with the mixing of anoxic DMCA-source waters and oxic (other source) groundwater (see Extended Implications of Reduction-Oxidation Processes on Groundwater Quality, this report). Cadmium and thallium concentrations greater than the MCLs occurred simultaneously with beryllium concentration greater than the MCL in one observation well-CE Dd 122. This well is completed at the base of the upper Patapsco aquifer shallow water-bearing zone, where extreme reducing conditions occurred.

\section{Health Advisory Levels}

Six constituents, manganese, nickel, sodium, sulfate, strontium, and zinc, exceeded (were greater than recommended levels) USEPA SDWA HALs (table 18) in some wells. Strontium, zinc, and nickel exceeded their respective HALs in 2,4 , and 22 percent of the 50 wells sampled, respectively. In contrast, sulfate, sodium, and manganese exceeded the HAL in 44,66 , and 72 percent of the 50 wells sampled (table 18; appendix B, table B3).

\section{Secondary Drinking-Water Regulations}

Eight constituents (or properties), aluminum, chloride, iron, manganese, $\mathrm{pH}$, sulfate, TDS, and turbidity, exceeded SDWRs in some wells (table 18). Iron, manganese, and $\mathrm{pH}$ values exceeded the SDWR in 90, 90, and 92 percent of the sampled wells respectively (table 18; appendix B, table B3). Aluminum, chloride, TDS, and sulfate concentrations exceeded the SDWR in fewer wells $(32,32,56$, and 52 percent, respectively) than iron, manganese, and $\mathrm{pH}$. Samples from 10 percent of the sampled wells exceeded the SWDR for turbidity; which likely is an artifact of sampling rather than an in-situ condition of groundwater (table 18).

The evaluation of the quality of groundwater in the DMCA and vicinity based on USEPA SDWA standards indicates that the $\mathrm{pH}$, metals (numerous, but notably iron and manganese), and TDS are of concern (table 18). To improve the understanding of the effect of reduced (chemically) groundwater on the quality of drinking water currently (2010-11) used for WVS supplies, the exceedance data for domestic wells (table 18) was combined with their TEAP classification (table 15). In combination, the data indicate the effects of reduced groundwater on domestic supplies depend upon the degree of reduction (table 19). As the degree of reduction in groundwater increased-from oxic to mixed to anoxic - the number and type of impairments and number of chemical constituents that exceeded the USEPA SDWA standards increased. The concentration of TDS in water used for domestic supplies was greater than the USEAP SDWA standard mainly when that water is anoxic because there is then sufficient dissolved manganese, iron, and (or) sulfate concentrations greater than maximum allowable or recommended levels. Other metals, such as aluminum, beryllium, and nickel (table 19), also were greater than their respective USEPA SDWA standards when groundwater is withdrawn for supplies from wells completed in a mixed anoxic-oxic zone (fig. 66, well CE Dd 164, $\mathrm{Mn}-\mathrm{O}_{2}-\mathrm{Fe}$ (III), or downgradient of an anoxic zone (fig. 67, well CE Dd 176, anoxic Fe(III)). Data were not collected from any supply well in the highest or most severe reduction zone (anoxic-Fe) because most deep supply wells in WVS appear to have been abandoned and no longer exist. However, groundwater from observation wells completed in or downgradient from the anoxic-Fe zone (fig. 66, wells CE Dd 81, and CE Dd 128,142 , and 160) contained elevated concentrations of other metals, in addition to iron and manganese, at concentrations that exceed their USEPA SDWA standards (appendix B, table B3).

\section{Acidity of Groundwater}

Whereas the effect of the DMCA on groundwater quality used for domestic supplies could be addressed, the effect of the DMCA on Elk River is only partially addressed. Information on the quality of groundwater that discharges into streams before they enter Elk River, or that eventually directly discharges through bed sediments into Elk River, is unavailable as groundwater samples were not collected in stream or riverbed. The quality of domestic supplies or Elk River water can be defined and compared through an accurate determination of the net acidity of groundwater, where the latter is derived on the basis of the $\mathrm{pH}$, the concentrations of total dissolved redox-sensitive metals (iron- $\left(\mathrm{Fe}^{2+}\right.$ and $\mathrm{Fe}^{3+}$ ), manganese$\mathrm{Mn}^{2+}$, aluminum- $\mathrm{Al}^{3+}$ ), and if the $\mathrm{pH}$ exceeds 4.3 , alkalinity (bicarbonate, $\mathrm{HCO}_{3}^{-}$, and carbonate $\mathrm{CO}_{3}^{2-}$ ) of groundwater and surface water.

\section{Influence on the Elk River}

On the basis of data collected in this study, groundwater likely to either be discharging through bed sediments to streams, which then discharge to Elk River, or that likely discharges into bed sediments into Elk River, is anoxic. The implications of the possible effects of DMCA groundwater discharge on either local streams or the Elk River will differ depending on the redox condition of the stream or river and bed-sediment redox conditions. If the stream or river becomes anoxic for an extended period of time, reduced metals that have accumulated in underlying sediments likely will be released into the river. However, if the stream or river maintains a generally oxic state throughout, then reduced metals being transported in groundwater will oxidize upon exposure to oxic sediments or river water, form insoluble precipitates, and accumulate in the river bed sediments.

Whereas verifying either the oxic or anoxic scenario for groundwater discharge into the local stream or Elk River as described above was beyond the scope of this study, verifying 
Table 18. Summary of water-quality constituents with concentrations exceeding 2009 U.S. Environmental Protection Agency (USEPA) Safe Drinking Water Act (SDWA) standards for at least one groundwater or surface-water site in the Pearce Creek Dredge Material Containment Area and vicinity, 2010-11.

[NTRU, nephelometric turbidity ratio unit; $\mathrm{mg} / \mathrm{L}$, milligrams per liter; dissolved, sample filtered through an encapsulated and pleated 0.2 -micron effective pore size, polysulfonyl filter; $\mu \mathrm{g} / \mathrm{L}$, micrograms per liter; SDWR, Secondary Drinking Water Standard (aesthetic — generally color, odor, and (or) taste);

HAL, Health Advisory Level; MCL, Maximum Contaminant Level; LRL, laboratory reporting level; <, less than; E, estimated]

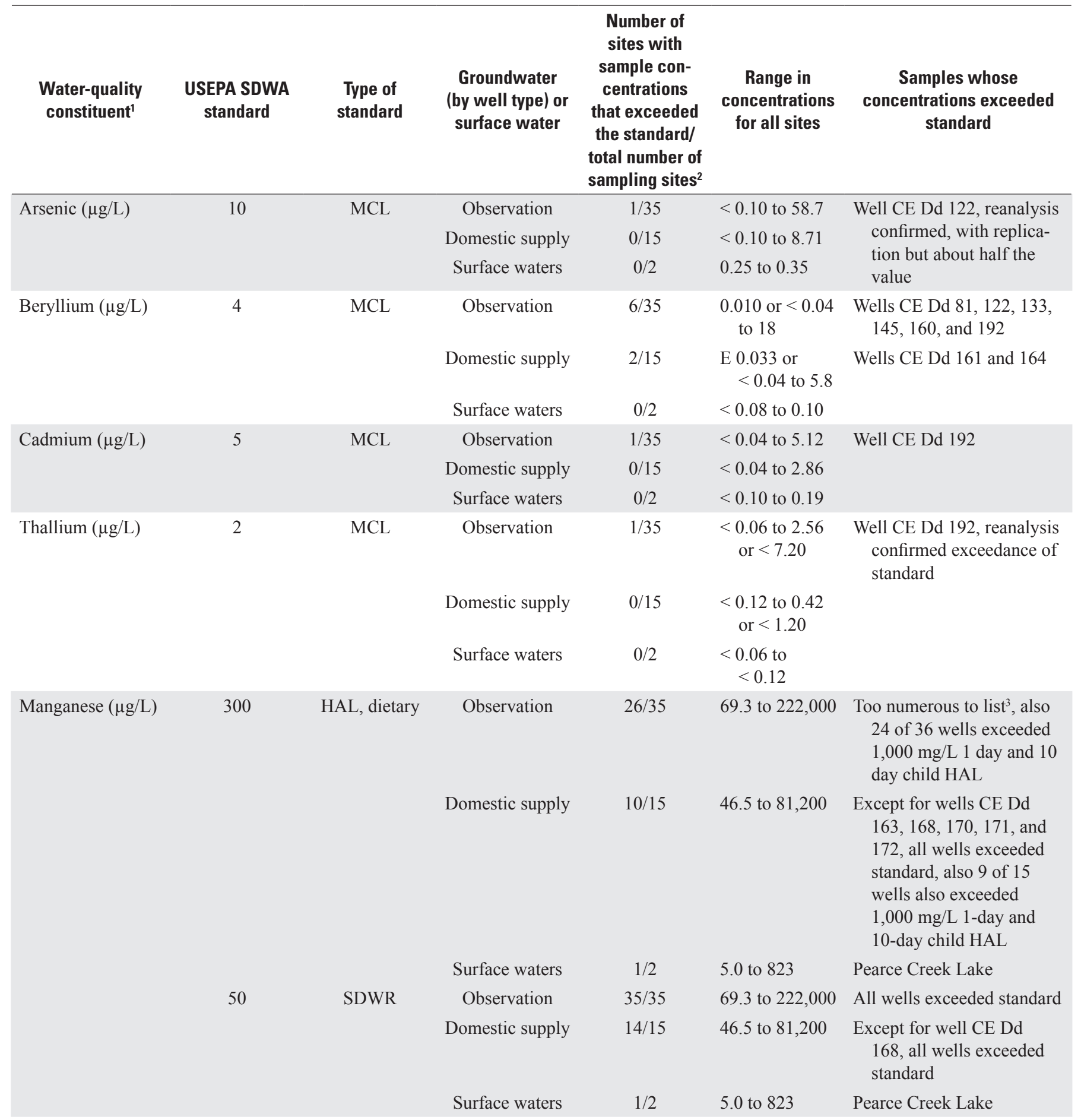


Table 18. Summary of water-quality constituents with concentrations exceeding 2009 U.S. Environmental Protection Agency Safe Drinking Water Act standards for at least one groundwater or surface-water site in the Pearce Creek Dredge Material Containment Area and vicinity, 2010-11.-Continued

[NTRU, nephelometric turbidity ratio unit; mg/L, milligrams per liter; dissolved, sample filtered through an encapsulated and pleated 0.2-micron effective pore size, polysulfonyl filter; $\mu \mathrm{g} / \mathrm{L}$, micrograms per liter; SDWR, Secondary Drinking Water Standard (aesthetic-generally color, odor, and (or) taste); HAL, Health Advisory Level; MCL, Maximum Contaminant Level; LRL, laboratory reporting level; <, less than; E, estimated]

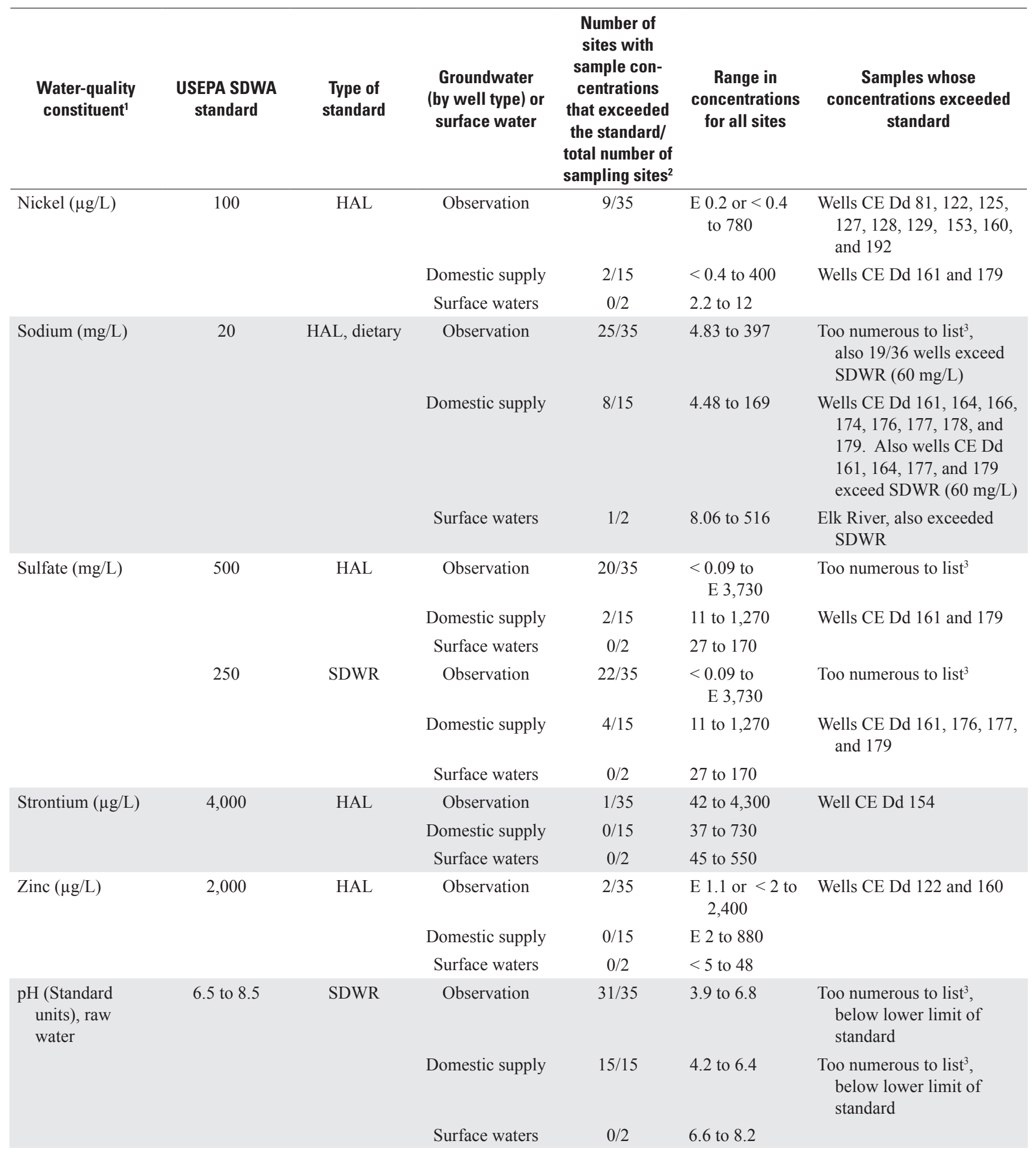


Table 18. Summary of water-quality constituents with concentrations exceeding 2009 U.S. Environmental Protection Agency Safe Drinking Water Act standards for at least one groundwater or surface-water site in the Pearce Creek Dredge Material Containment Area and vicinity, 2010-11.-Continued

[NTRU, nephelometric turbidity ratio unit; $\mathrm{mg} / \mathrm{L}$, milligrams per liter; dissolved, sample filtered through an encapsulated and pleated 0.2-micron effective pore size, polysulfonyl filter; $\mu \mathrm{g} / \mathrm{L}$, micrograms per liter; SDWR, Secondary Drinking Water Standard (aesthetic — generally color, odor, and (or) taste); HAL, Health Advisory Level; MCL, Maximum Contaminant Level; LRL, laboratory reporting level; <, less than; E, estimated]

\begin{tabular}{|c|c|c|c|c|c|c|}
\hline $\begin{array}{l}\text { Water-quality } \\
\text { constituent }^{1}\end{array}$ & $\begin{array}{l}\text { USEPA SDWA } \\
\text { standard }\end{array}$ & $\begin{array}{l}\text { Type of } \\
\text { standard }\end{array}$ & $\begin{array}{l}\text { Groundwater } \\
\text { (by well type) or } \\
\text { surface water }\end{array}$ & $\begin{array}{l}\text { Number of } \\
\text { sites with } \\
\text { sample con- } \\
\text { centrations } \\
\text { that exceeded } \\
\text { the standard/ } \\
\text { total number of } \\
\text { sampling sites }\end{array}$ & $\begin{array}{l}\text { Range in } \\
\text { concentrations } \\
\text { for all sites }\end{array}$ & $\begin{array}{c}\text { Samples whose } \\
\text { concentrations exceeded } \\
\text { standard }\end{array}$ \\
\hline \multirow{2}{*}{$\begin{array}{l}\text { Turbidity (NTRU), } \\
\text { raw water }\end{array}$} & & & Domestic supply & $2 / 15$ & 0.2 to 16 & Wells CE Dd 161 and 166 \\
\hline & & & Surface waters & $2 / 2$ & 8.6 to 20 & $\begin{array}{l}\text { Elk River and Pearce Creek } \\
\text { Lake }\end{array}$ \\
\hline $\begin{array}{l}\text { Total dissolved } \\
\text { solids }(\mathrm{mg} / \mathrm{L})\end{array}$ & 500 & SDWR & Observation & $22 / 35$ & 45 to 6,080 & Too numerous to list ${ }^{3}$ \\
\hline \multirow[t]{3}{*}{ Chloride (mg/L) } & 250 & SDWR & Observation & $15 / 35$ & 2.7 to 750 & Too numerous to list ${ }^{3}$ \\
\hline & & & Domestic supply & $1 / 15$ & 3.8 to 330 & Well CE Dd 161 \\
\hline & & & Surface waters & $1 / 2$ & 18 to 1,100 & Elk River \\
\hline \multirow[t]{3}{*}{ Aluminum $(\mu \mathrm{g} / \mathrm{L})$} & 50 to 200 & SDWR & Observation & $13 / 35$ & $<3$ to 58,000 & Too numerous to list ${ }^{3}$ \\
\hline & & & Domestic supply & $3 / 15$ & $<6$ to 1,990 & Wells CE Dd 164, 176, 179 \\
\hline & & & Surface waters & $0 / 2$ & 9 to 34 & \\
\hline \multirow[t]{2}{*}{ Iron $(\mu \mathrm{g} / \mathrm{L})$} & 300 & SDWR & Observation & $35 / 35$ & $\begin{array}{l}1,170 \text { to } \\
656,000\end{array}$ & All wells exceeded standard \\
\hline & & & Domestic supply & $10 / 15$ & $\begin{array}{c}19 \text { or }<28 \text { to } \\
71,800\end{array}$ & $\begin{array}{l}\text { Except for wells CE Dd } \\
\text { 163, 164, 168, 172, and } \\
\text { 178, all wells exceeded } \\
\text { standard }\end{array}$ \\
\hline
\end{tabular}

${ }^{1}$ Except for $\mathrm{pH}$ and turbidity, all other constituents reflect dissolved concentrations.

${ }^{2}$ Well CE Dd 152 not included in analysis. Additional details are provided in the Total Dissolved Solids and Major Ions section of this report.

${ }^{3}$ Additional information on wells that exceeded standard is provided in appendix B, table B3.

that the DMCA is a potential contributing element in either scenario is within the scope of this study

Groundwater flow to the local unnamed stream near the western DMCA property boundary from the perched waterbearing zone in the western end of the DMCA is anoxic (fig. 41), moderately elevated in TDS (fig. 34), moderately to highly elevated in dissolved ammonia-nitrogen and sulfate, and extremely elevated in the concentrations of dissolved metals (Mn(II), Fe(II/III)). This local unnamed stream, in turn, discharges to the Elk River (fig. 34).

Pearce Creek Lake discharges to the tidal part of Pearce Creek (downstream of the lake outlet). However, during seasonally high levels, the lake also provides groundwater recharge along its lower third, which also could discharge to the stream, and possibly directly to Elk River (see Hydrology, this report). On the basis of data collected in February 2011; whereas Elk River water is highly oxic, the quality of lake water was mixed oxic-anoxic and undergoing oxygen and manganese reduction (table 15). Thus, at a time when lake turnover in the region likely already had occurred, and the lake water should have been well oxygenated, it was discharging manganese downstream (appendix B, table B3, Pearce Creek Lake, dissolved manganese, $823 \mu \mathrm{g} / \mathrm{L}$ ). 


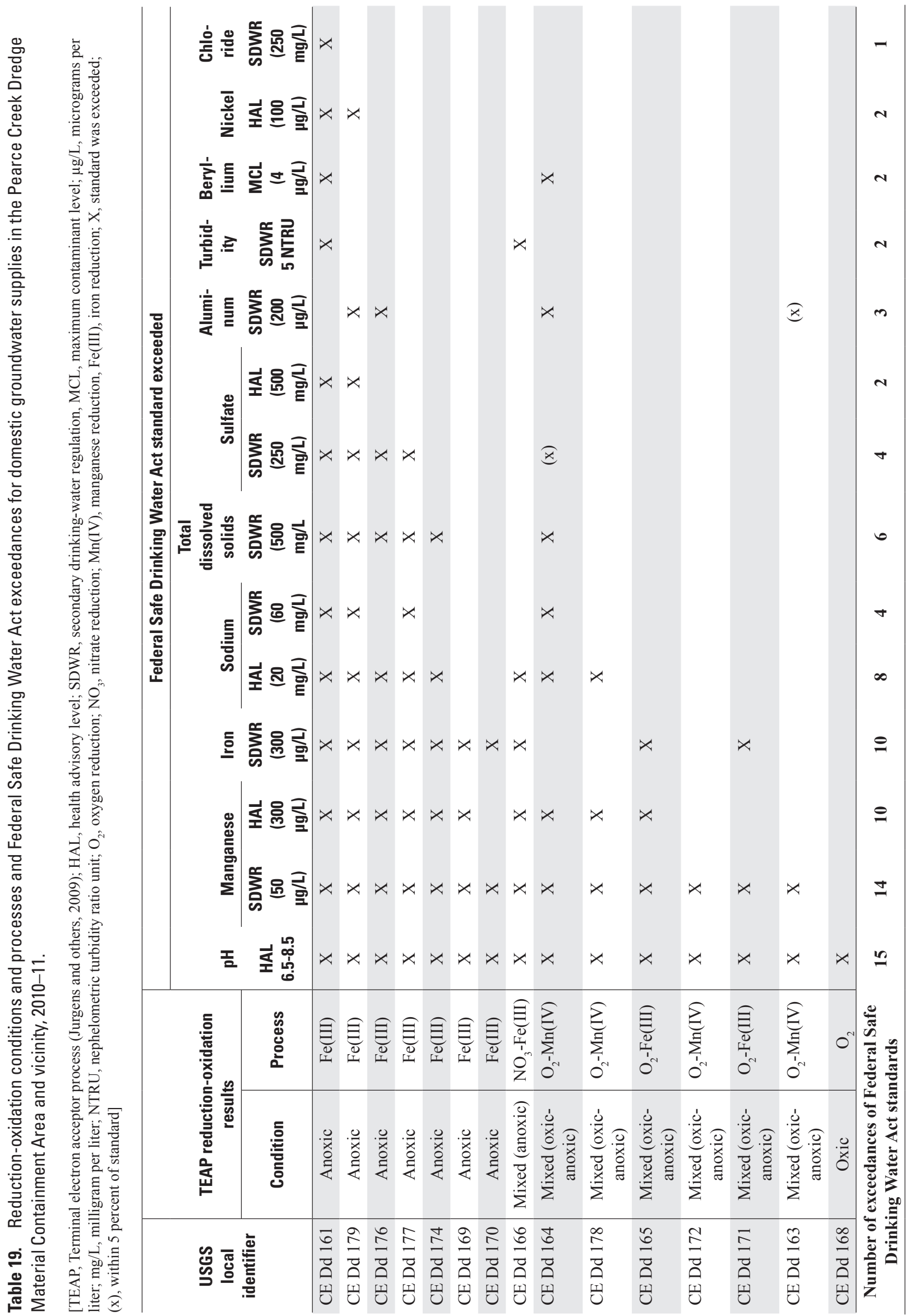


Pearce Creek Lake also was recharging groundwater along the lower third of the lake in May 2010 (see Hydrology, this report). Groundwater downstream of Pearce Creek Lake also was discharging from the DMCA through the Magothy aquifer to Pearce Creek downstream of the lake discharge and likely farther along the shoreline and into the Elk River. This groundwater north of the DMCA is moderately elevated in TDS and, on the basis of the samples from the shallowest well in the Magothy aquifer (appendix B, table B3, well CE Dd $145)$, is anoxic. However, the groundwater is low in ammonianitrogen and sulfate and is only moderately elevated in metals.

Farther south and along the western edge of the DMCA, groundwater from the DMCA flows west into WVS and travels vertically downward into the upper Patapsco aquifer shallow water-bearing zone into what is a highly-reducing zone. Then the groundwater moves upward and discharges along the western WVS shoreline or into bed sediments beneath the Elk River. In the area of upward flow, groundwater is anoxic (figs. 66 and 67), contains moderate to low levels of ammonianitrogen, and has high levels of manganese and iron.

At the time of this study, the Elk River was highly oxic (dissolved oxygen, $14.2 \mathrm{mg} / \mathrm{L}$ ). The composite sample from the river (taken at 133 -ft intervals) was collected soon after high tide, and in the winter. Field measurements indicated the concentration of dissolved oxygen was vertically uniform throughout the river profile (L. Myers, USGS, written commun., 2010). The USGS field crew also observed the river from the shore of WVS at an unusually low tide, and they noted an abrupt transition in river bed sediments, which went from light brown near shore to extremely dark black color offshore (J. Teunis, USGS, written commun., 2010). Both observations support the concept that metals are accumulating in the sediments offshore from WVS.

Furthermore, the effect of generally oxic river conditions on the fate of elevated metal concentrations in groundwater discharge in this area of Elk River could already be known. The recent study by Hartwell and Hameedi (2007; also see Chemical Composition of Sediments, this report) identified the lower Elk River Estuary as in the top tenth percentile among all bay estuary sites for toxics accumulation, largely on the basis of metals. DMCA use covers an extended period from the 1930s to the 1990s (six decades) in this part of the river.

\section{Net Acidity}

Groundwater and surface waters governed by redox conditions in the DMCA and its vicinity can be compared on the basis of acidity, provided the latter is not just the acidity associated with the $\mathrm{pH}$ (free hydrogen ion, $\mathrm{H}^{+}$) of water. Accurate measurement of the acidity of groundwater governed by redox conditions requires including the additional acidity associated with hydrolyzed dissolved metal species such as iron, manganese, and aluminum, if they occur in groundwater that is governed by redox conditions (Kirby and Cravotta, 2005a,b).
Acidity calculations can provide a single value that reflects the $\mathrm{pH}$ and all major redox-sensitive metal species to characterize and compare water quality. Acidity also can be used to assess potential changes in the quality of any surface water receiving direct discharge of anoxic water.

Net acidity can be determined as follows (Kirby and Cravotta, 2005b):

$$
\text { Acidity }_{\text {Net }}=\text { Acidity }_{\text {Calculated }}-\text { Alkalinity }_{\text {StdMthd }}
$$

where:

Each of the above terms is expressed in milligrams per liter as calcium carbonate $\left(\mathrm{CaCO}_{3}\right)$,

Alkalinity $_{\text {StdMthd }}$ is determined by standard methods, Acidity $_{\text {Calculated }}$ is $50\left(1000 \times\left(10^{-\mathrm{pH}}\right)+2\left(\mathrm{Fe}^{2+}\right) / 56+3\left(\mathrm{Fe}^{3+}\right)\right.$ $\left./ 56+2\left(\mathrm{Mn}^{2+}\right) / 55+3\left(\mathrm{Al}^{3+}\right) / 27\right)$

and where the $\mathrm{pH}$ is measured and expressed in standard units, the total dissolved metal $\left(\mathrm{Fe}^{2+}\right.$, $\mathrm{Fe}^{3+}, \mathrm{Mn}^{2+}$, and $\mathrm{Al}^{3+}$ ) concentrations are in milligrams per liter, each converted to milliequivalents per liter, using their valences and formula weights, and the entire expression then converted to milligrams per liter as $\mathrm{CaCO}_{3}$.

For groundwater in the DMCA and its vicinity, Acidi$\mathrm{ty}_{\mathrm{Net}}$ was determined from equations (5) and (6) with selected modifications (appendix B). In brief, Alkalinity StdMthd $_{\text {(ALK, }}$ hereafter) was estimated by Acid Neutralization Capacity (ANC, hereafter; see appendix B, table B3), as it was similar in value to ALK, on the basis of duplicate titrations of raw- and dissolved-groundwater samples. Concentrations of aluminum $\left(\mathrm{Al}^{3+}\right)$, manganese $\left(\mathrm{Mn}^{2+}\right)$, and iron $\left(\mathrm{Fe}^{2+}\right)$ were estimated with the dissolved recoverable concentrations of these metals (appendix B, table B3, dissolved iron, manganese, and aluminum). The assumption that all iron was present as ferrous $\left(\mathrm{Fe}^{2+}\right)$ iron could underestimate Acidity ${ }_{\text {Calculated }}$ (equation 6), and thus Acidity ${ }_{\text {Net }}$ (equation 5). Although this potential bias was investigated, and this bias was not apparent (appendix B), Acidity $_{\mathrm{Net}}$ should be considered a conservative estimate. For interpretation of Acidity ${ }_{\mathrm{Net}}$ calculation, large negative values imply waters whose ALK exceeds Acidity Calculated $_{\text {, and thus }}$ generally reflect oxic conditions with Acidity ${ }_{\text {Net }}$ mainly governed by bicarbonate and carbonate alkalinity. Large positive values generally imply anoxic waters with Acidity $_{\mathrm{Net}}$ mainly governed by dissolved metals. For either case, the measured $\mathrm{pH}$ may be nearly identical, but Acidity $_{\mathrm{Net}}$ values can differ markedly and range from positive to highly negative. Thus, the interpretive value in using Acidity $_{\text {Net }}$ to describe and compare the quality of groundwater governed by changes in redox conditions is apparent.

The most oxic and ALK-governed water in the study area is Elk River, whose Acidity $_{\mathrm{Net}}$ equals $-63 \mathrm{mg} / \mathrm{L}$ as $\mathrm{CaCO}_{3}$ (fig. 82). In the Magothy aquifer beneath and in the vicinity of the DMCA (fig. 82), Acidity ${ }_{\mathrm{Net}}$ ranges from values of 
approximately $-10 \mathrm{mg} / \mathrm{L}$ as $\mathrm{CaCO}_{3}$ to over $1,100 \mathrm{mg} / \mathrm{L}$ as $\mathrm{CaCO}_{3}$, reflecting natural groundwater and DMCA dischargeaffected groundwaters, respectively. The most oxic and weakly ALK-governed water in the Magothy aquifer occurs in the recharge area in WVS (Acidity ${ }_{\mathrm{Net}}$ equals approximately -6 to $-3 \mathrm{mg} / \mathrm{L}$ as $\mathrm{CaCO}_{3}$ ) and in the Pearce Creek Lake discharge area (Acidity ${ }_{\text {Net }}$ equals approximately $-5 \mathrm{mg} / \mathrm{L}$ as $\mathrm{CaCO}_{3}$ ). Acidity $_{\text {Net }}$ values throughout the remainder of the DMCA and WVS in the Magothy aquifer and perched-water zone are governed by moderate $\mathrm{pH}$ and moderate to high concentrations of reduced metals.

In the upper Patapsco aquifer shallow water-bearing zone (fig. 83), the general trend in Acidity ${ }_{\mathrm{Net}}$ is for low negative values to occur in the very eastern part of the study area. Moving to the west, and south along the DMCA, Acidity ${ }_{\text {Net }}$ values (227 and $656 \mathrm{mg} / \mathrm{L}$ as $\mathrm{CaCO}_{3}$ ) reflect leakage from the Magothy aquifer through the confining layer. Farther west, the Acidity ${ }_{\mathrm{Net}}$ values (thousands of $\mathrm{mg} / \mathrm{L}$ as $\mathrm{CaCO}_{3}$ ) increase, reflecting downward flow from the Magothy aquifer of moderate-pH waters with very high reduced metals and no ALK, except for one deep well (Acidity ${ }_{\mathrm{Net}}$ of 1,130 as $\mathrm{CaCO}_{3}$ ), and, the Acidi$\mathrm{ty}_{\mathrm{Net}}$ values decrease in intermediate depth wells (Acidity ${ }_{\mathrm{Net}}$ values of approximately 5 to $90 \mathrm{mg} / \mathrm{L}$ as $\mathrm{CaCO}_{3}$, respectively) a short distance farther west into WVS, where mixing occurs with recharging water from the Magothy aquifer. Toward the

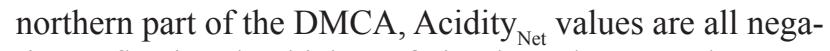
tive, reflecting the thick confining layer between the Magothy aquifer and upper Patapsco aquifer, and again groundwater that is ALK-governed with moderate $\mathrm{pH}$ and relatively low redox-metals content.

The contrast between groundwater unaffected by human activity and groundwater affected by the DMCA and WVS is striking in cross-sectional views. Along line $A-A^{\prime}$ (fig. 84), natural or relatively unaffected waters have Acidity $_{\text {Net }}$ values ranging from -10 to $-30 \mathrm{mg} / \mathrm{L}$ as $\mathrm{CaCO}_{3}$. DMCA-affected groundwater Acidity $_{\mathrm{Net}}$ values range from approximately 89 to $1,250 \mathrm{mg} / \mathrm{L}$ as $\mathrm{CaCO}_{3}$ in the Magothy aquifer. Beneath WVS, Acidity ${ }_{\mathrm{Net}}$ values in the shallow oxic zone are -3 to $3 \mathrm{mg} / \mathrm{L}$ as $\mathrm{CaCO}_{3}$, and it increases to approximately $30 \mathrm{mg} / \mathrm{L}$ as $\mathrm{CaCO}_{3}$ at intermediate depths. However, in the low pH (highly acidic) and highly reducing upper Patapsco shallow water-bearing zone, Acidity ${ }_{\mathrm{Net}}$ values range from 800 to 1,480 $\mathrm{mg} / \mathrm{L}$ as $\mathrm{CaCO}_{3}$. Along line $C-C^{\prime}$ (fig. 85), the pattern in Acidity $_{\text {Net }}$ values is similar to that observed in WVS along line $A-A^{\prime}$. However, the replication indicates this pattern occurs beneath a major part of the community.

The influence of the DMCA on Acidity ${ }_{\mathrm{Net}}$ concentrations in groundwater also is apparent along $B-B^{\prime}$ (fig. 86). Concentrations in Acidity $_{\mathrm{Net}}$ in the upper Patapsco aquifer shallow water-bearing zone are approximately $-40 \mathrm{mg} / \mathrm{L}$ as $\mathrm{CaCO}_{3}$, where groundwater is relatively unaffected by human activities. In contrast, Acidity ${ }_{\mathrm{Net}}$ values range from approximately 90 to $400 \mathrm{mg} / \mathrm{L}$ as $\mathrm{CaCO}_{3}$ beneath the DMCA, downgradient from the DMCA along its borders, or where leakage of DMCAaffected groundwater occurs between the Magothy aquifer and upper Patapsco aquifer shallow water-bearing zone.

\section{Integration of Findings}

The water-quality conditions currently (2010-11) present in the study area are directly related to a number of contributing factors. These factors include: historical changes in land use and landscape, the distribution and composition of permeable and relatively impermeable sediments, the groundwater flow system, and the chemical reactions that occur as water moves from areas of groundwater recharge to groundwater discharge.

Development of the DMCA has significantly changed the hydrology of the site. Once an area of low-lying swamp and marsh deposits, with surface elevations only several feet above sea level (fig. 3), repetition of the disposal process over time has raised the level of deposited sediments (fill). The DMCA now stands at an average elevation of between 35 to $40 \mathrm{ft}$ NAVD 88 (EA Engineering, Science, and Technology, Inc., 2009). Berms and dikes surrounding the containment area are substantially higher in elevation. The developed site functions as a large retention basin, not only during former times of dredge-material emplacement, but also during substantial precipitation events once placement of dredge materials ceased. Formerly an area of groundwater discharge, the site is now an area of groundwater mounding and recharge, allowing for the slow percolation of water downward through the fill material.

Limited existing data are available on the chemical composition of the fill material within the DMCA. Sediment data collected in 1995-96 during the Phase II study (U.S. Army Corps of Engineers, 1996) indicate elevated concentrations of some metals - particularly manganese, zinc, lead, and copper - as compared to deeper naturally deposited formation sediments (table 9). Numerous studies of bay sediments from the upper Chesapeake Bay (a source of dredged material) have been made. These studies indicate that northern bay sediments - including sediments in the lower Elk River near the DMCA - are enriched in trace elements such as iron, manganese, zinc, and aluminum; have appreciable amounts of carbon, nitrogen, and sulfur; and include anthropogenic organic compounds such as pesticides and wastewater compounds.

Although groundwater of poor quality in the DMCA and vicinity has been documented in previous studies with samples collected in 1991-96 (Maryland Environmental Service, 1995; R.F. Weston, Inc., 1998), the results were inconclusive in identifying the source (or sources) of poor quality groundwater in nearby domestic wells. On the basis of the recommendations of these earlier studies, a more comprehensive monitoringwell network (fig. 6) was designed for this 2010-11 USGS study with the purpose of collecting the data necessary to define the underlying hydrogeologic framework, groundwaterflow system, the source(s) of water to supply wells, and the impact, if any, the DMCA has on water quality underlying the facility and in adjacent residential areas.

Synoptic groundwater-level measurements collected in May and August 2010 in the study area show that groundwater 


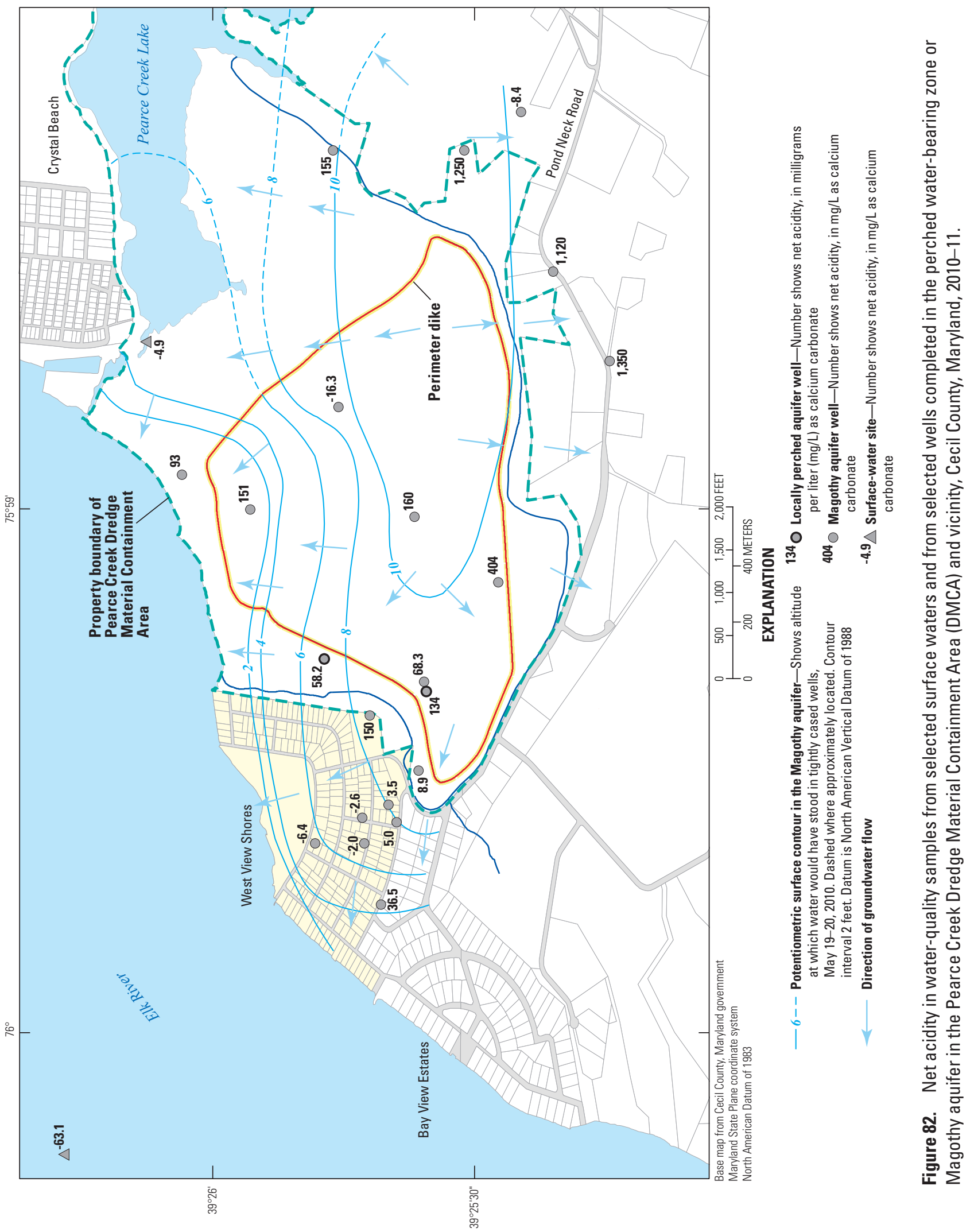




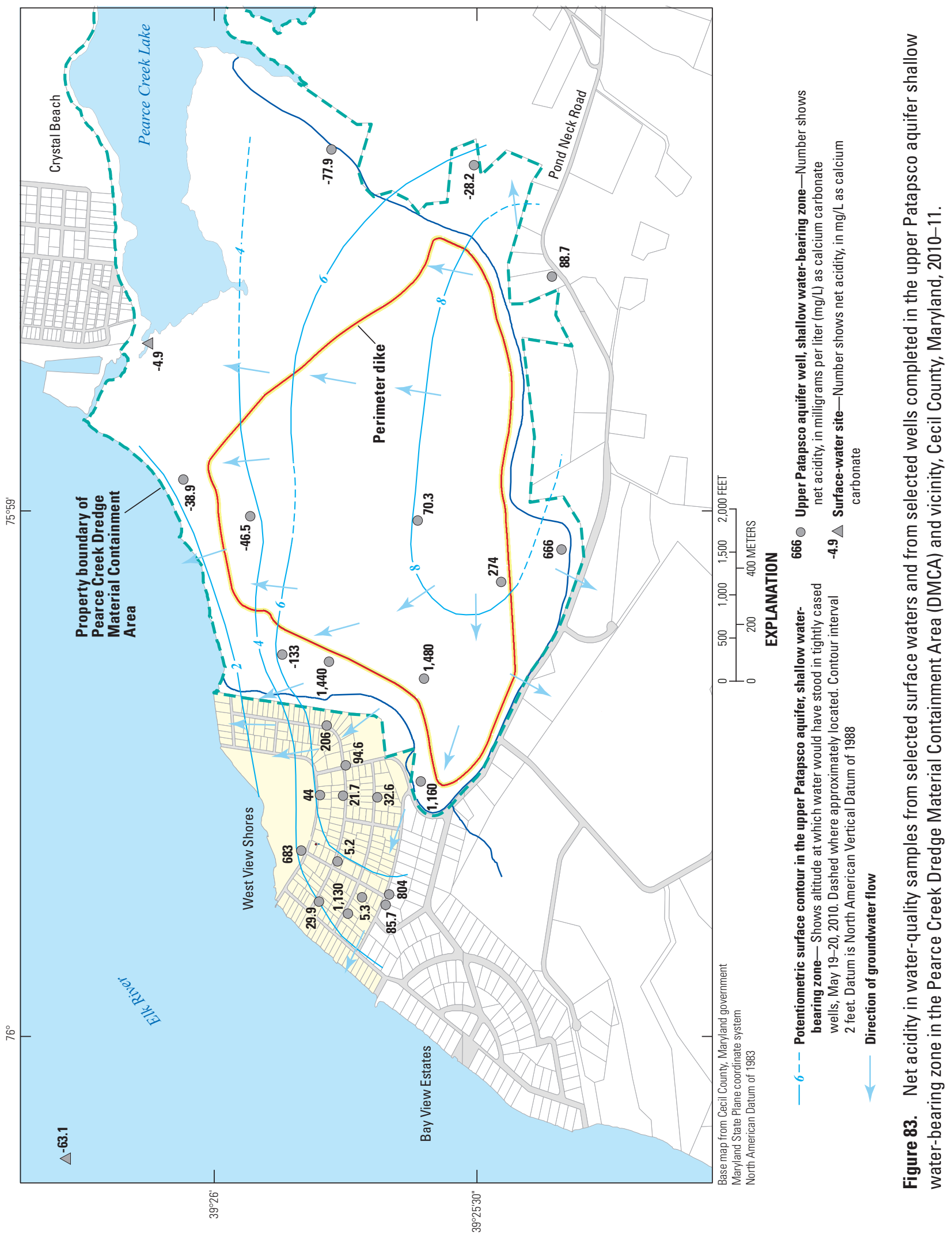




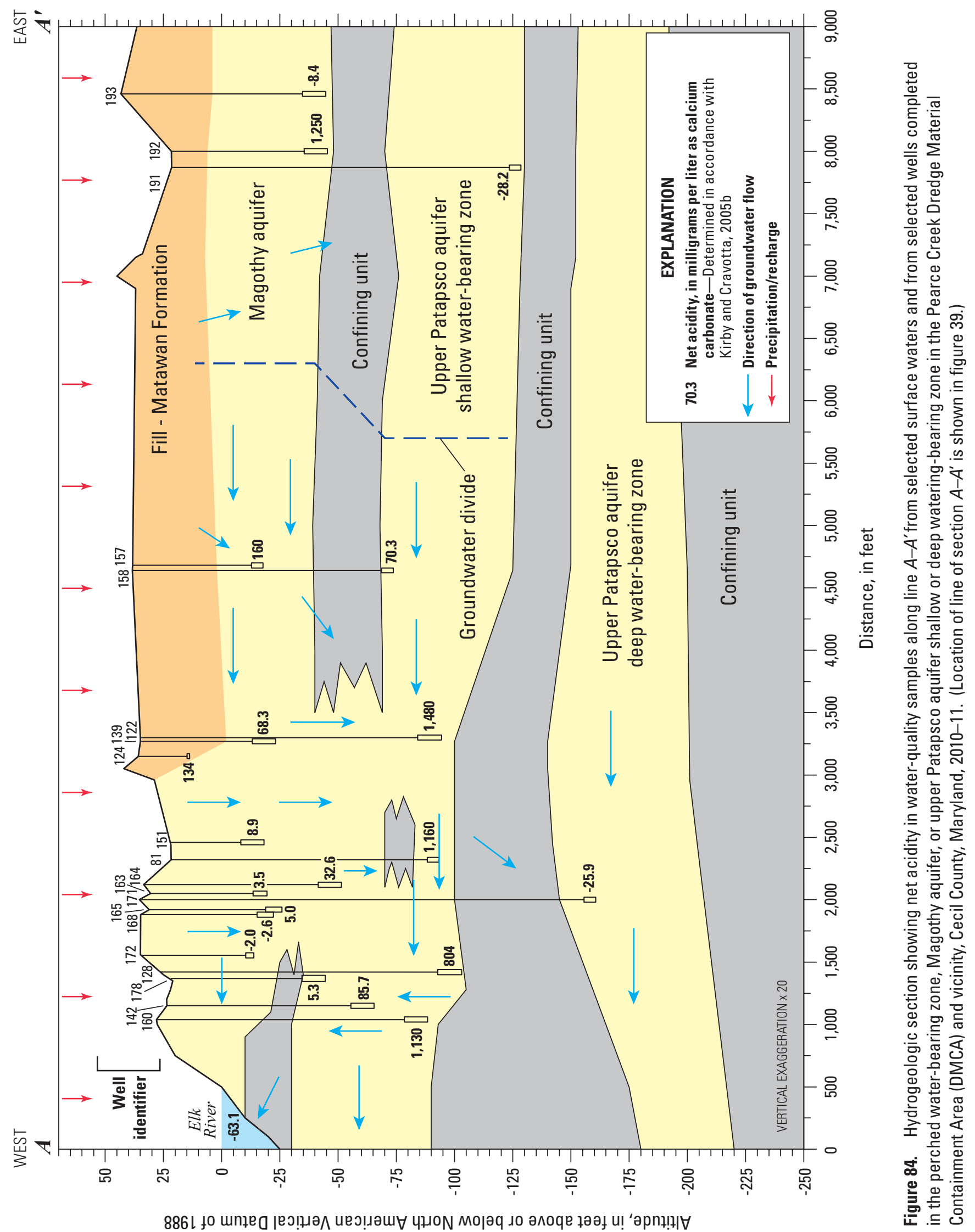




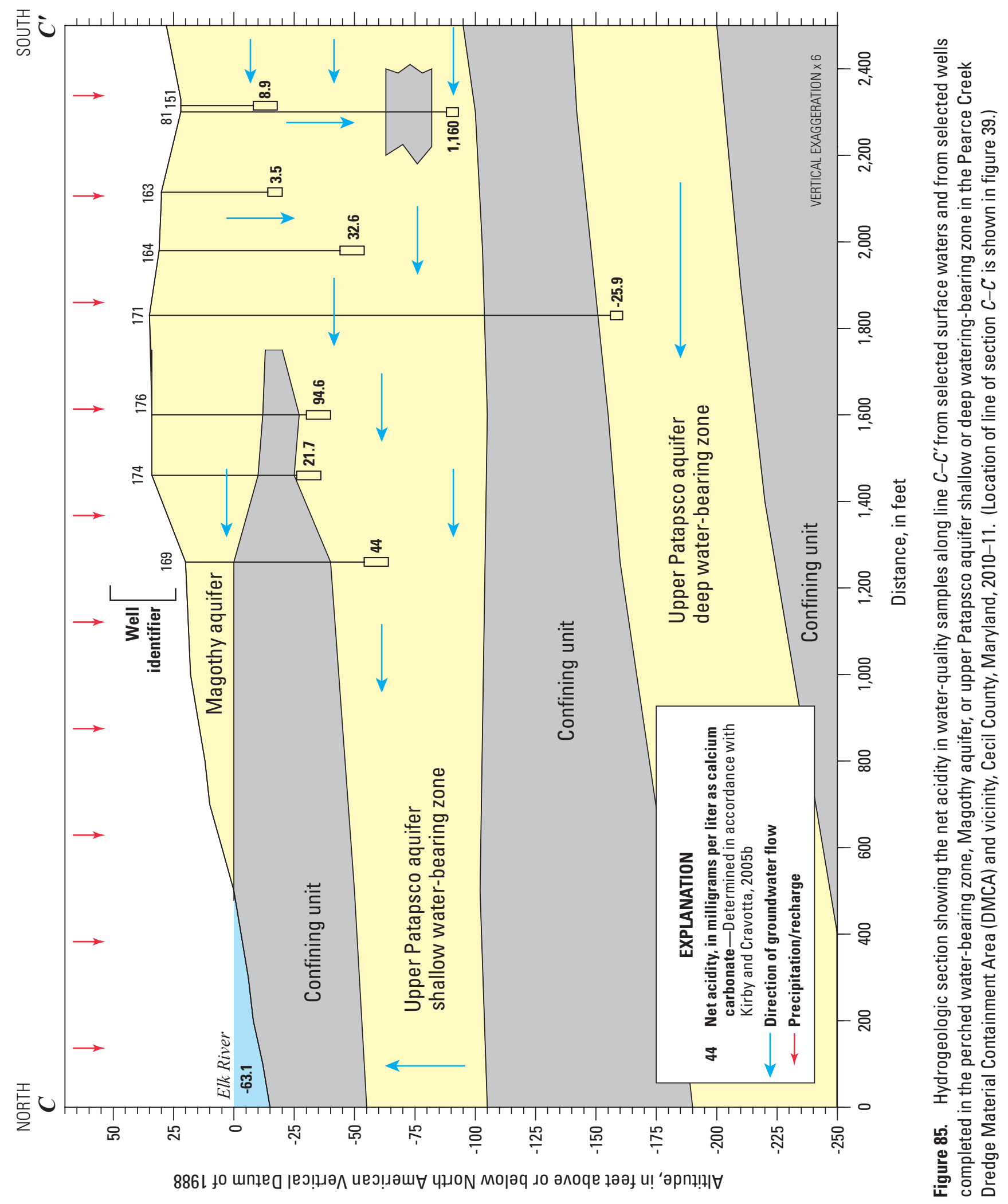




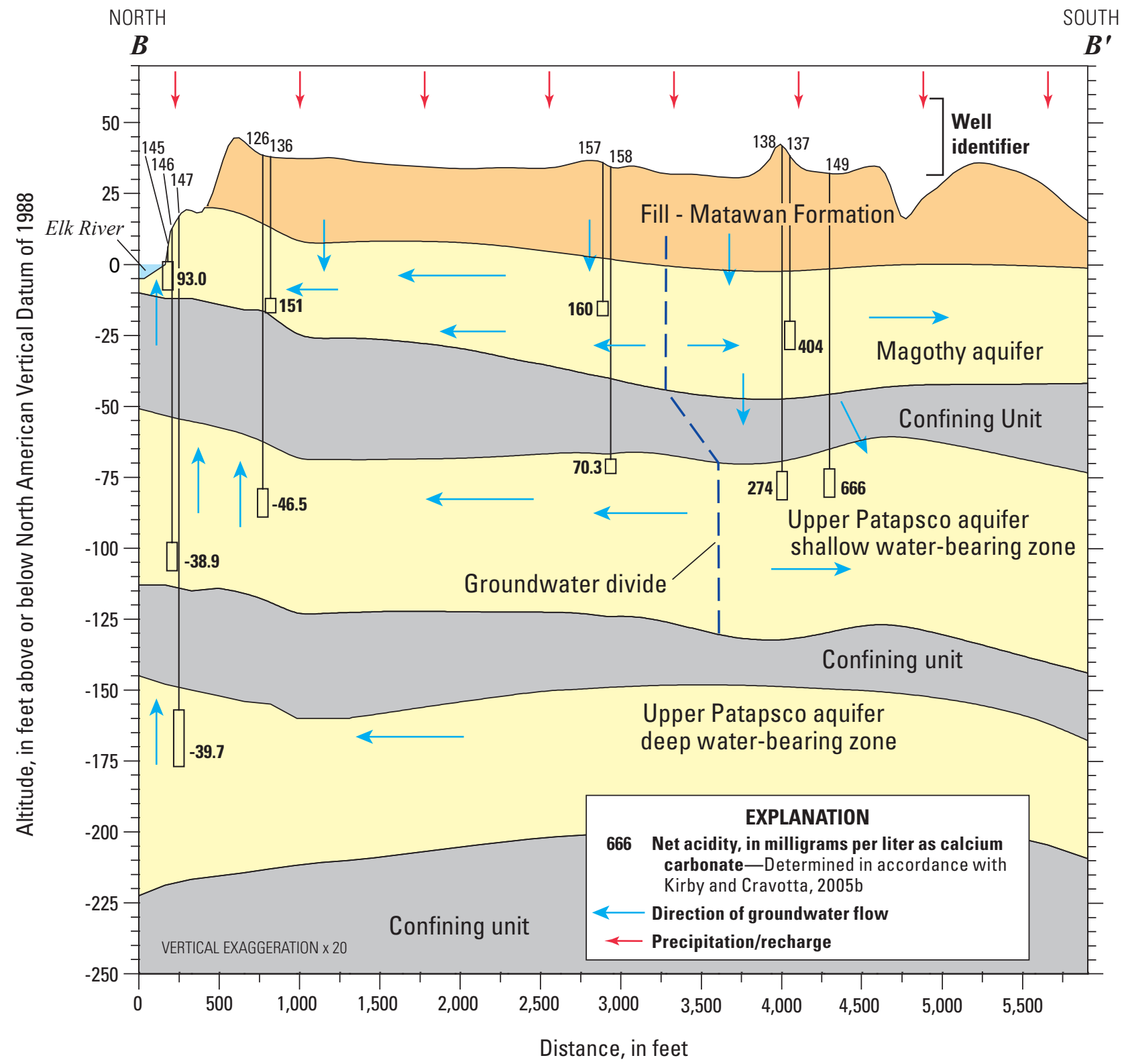

Figure 86. Hydrogeologic section showing the net acidity in water-quality samples along line $B-B^{\prime}$ and from selected wells completed in the Magothy aquifer or upper Patapsco aquifer shallow or deep watering-bearing zone in the Pearce Creek Dredge Material Containment Area (DMCA) and vicinity, Cecil County, Maryland, 2010-11. (Location of line of section $B-B^{\prime}$ is shown in figure 39.)

flow in the two primary aquifers used for local supplies - the Magothy aquifer and upper Patapsco aquifer (shallow waterbearing zone) - is radially outward from the DMCA toward discharge areas, including WVS, Elk River and Pearce Creek Lake (figs. 21-25). In addition to horizontal flow outward from the DMCA, vertical gradients primarily are downward in most of the study area, and upward near the Elk River on the north side of the DMCA property, and the western part of West View Shores. Vertical mixing of waters occurs between the two aquifers particularly where the Magothy aquifer and upper Patapsco aquifer shallow water-bearing zone are in hydraulic connection in areas where confinement between the aquifers is thin or missing (figs. 9, 11, 12, and 30).

Given this understanding of the groundwater flow system, it is clear that water that falls on the DMCA as precipitation or is deposited along with dredge-fill material will eventually seep into the underlying Magothy aquifer and flow from that aquifer into parts of the upper Patapsco aquifer shallow water-bearing zone. Potentiometric-contour maps and vertical profiles of the groundwater flow system in cross section show that the DMCA is the major upgradient source area of water to wells completed in the Magothy aquifer and the upper Patapsco aquifer shallow water-bearing zone and located in WVS 
and along part of Long Neck Road. Other important sources of groundwater recharge to the area and particularly to domestic wells located at higher elevations in WVS and completed at shallow depths in the Magothy aquifer are precipitation that falls directly on this area and local residential recharge from landscape irrigation and septic effluents (fig. 30).

Results of water-quality analyses and the occurrence and distribution of specific water-quality constituents are consistent with the hydrogeologic framework, directions of groundwater flow, and identification of the DMCA as a source area that has impacted local groundwater quality. The distribution of TDS in groundwater is used as a measure of the general quality of groundwater beneath the DMCA and its vicinity. TDS content is a measure of the combined content of all dissolved inorganic and organic substances contained in the water sample. It is not generally considered a primary pollutant associated with health effects; rather it is used as an indication of aesthetic characteristics of drinking water and as an aggregate indicator of the presence of a broad array of chemical constituents. The Federal SDWR for TDS is $500 \mathrm{mg} / \mathrm{L}$ or less in public drinking-water supplies.

During the use of the DMCA, brackish Elk River water was mixed with sediments, and the slurry would have been pumped into the DMCA, adding an additional major source of TDS, including chloride and sodium. Concentrations measured in area wells in the Magothy and upper Patapsco aquifers not influenced by the DMCA, or located just outside the study area, have TDS concentrations of less than $100 \mathrm{mg} / \mathrm{L}$, typical of natural groundwater for the aquifers. In contrast, TDS concentrations in the Magothy aquifer directly under the DMCA are an order of magnitude greater; several Magothy aquifer and upper Patapsco aquifer shallow water-bearing zone wells yielded groundwater samples with TDS in the 4,000 to $6,000 \mathrm{mg} / \mathrm{L}$ range (appendix B; and figs. 32, 34, and 35). Individual constituents such as chloride, sodium, sulfate, manganese, iron, and aluminum are also orders of magnitude higher in aquifers underlying the DMCA and vicinity than in either aquifer within or near the study area where human activities have not overly influenced groundwater quality (table 13; appendix B). The latter also reflect conditions consistent with water-quality information and analysis provided by Otton and others (1988) and Willey and others (1987) for Potomac Group and Magothy aquifers throughout Cecil County, Md. In fact, Otton and others (1988) make a point of not using analytical results from a 1983 sample of groundwater from well CE Dd 81 located just outside the DMCA berm in the southwestern corner of the DMCA, owing to the fact that the water does not represent natural water in the aquifer.

Given the groundwater flow system and groundwater geochemistry of the study area, the influence of the DMCA is not only as a source of TDS but also a geochemical driver of redox processes that enhance the mobilization and transport of redox-sensitive metals and nutrients. Groundwater affected by the DMCA is predominately anoxic and mainly reflects ironreducing conditions. These redox conditions are characterized by the absence of dissolved oxygen, and an abundance of the reduced forms of nitrogen (ammonia) and metals (manganese and iron). Compounding factors that elevate the concentrations of dissolved constituents include the presence of organic carbon, the mixing of anoxic and oxic waters, and the acidity of groundwater.

Creation of reduced groundwater conditions generally is facilitated by microorganisms that depend on the presence of organic carbon. Sources of organic carbon dissolved in groundwater include fill composed of bay sediments that are known to contain abundant amounts of carbon (table 8, carbon, $21.8 \mathrm{mg} / \mathrm{kg}$ ). Other substantial sources of carbon to the groundwater flow system are the seasonal Phragmites vegetation within the DMCA; the abundance of lignite in naturally deposited sediments including the Matawan, Magothy, and Patapsco Formations; and wetland sediments that were buried during the construction of the DMCA. The elevated concentrations of dissolved organic carbon support microbial activity that leads to anoxic conditions in groundwater.

Groundwater in the study area with the highest levels of TDS, manganese, ferrous iron, and sulfate generally correspond to parts of the groundwater flow system under highly anoxic iron-reducing conditions that possibly reflect the mixing of anoxic groundwater from the DMCA with oxic groundwater from other source areas. This occurs predominantly where the Magothy aquifer is unconfined, allowing hydraulic connection with the underlying upper Patapsco aquifer shallow water-bearing zone. Here, direct recharge from precipitation provides oxygenated water to the groundwater flow system, and groundwater pumping for water supplies aids mixing (figs. 30 and 66).

As anoxic groundwater is drawn into or flows into areas such as WVS, which contain predominately oxic water, the anoxic water undergoes oxidation. The outcome of this process is the production of acidity $\left(\mathrm{H}^{+}\right)$through the oxidation of reduced iron, and the formation of ferric hydroxide precipitates. The low $\mathrm{pH}$ of groundwater throughout the Magothy aquifer and upper Patapsco aquifer shallow water-bearing zone beneath WVS provides an abundance of acidity for metal hydrolysis. This acidity is locally increased with depth beneath oxic zones in WVS. The result is a localized increase in the concentration of TDS (and likely reduced metals and sulfate) which, in combination with the major inflow of anoxic groundwater of similar quality from the DMCA, accounts for the local and highly elevated concentrations of TDS and other reduced species in the upper Patapsco aquifer shallow waterbearing zone. The most severe reducing condition - that of $\mathrm{Fe}(\mathrm{III})$ reduction - corresponds to groundwater from DMCA recharging the Magothy aquifer, flowing beneath the western half of the DMCA, then moving farther westward and vertically downward to the base of the upper Patapsco aquifer shallow water-bearing zone, and ultimately either continuing farther west in this zone, or moving vertically upward to discharge along the western end of WVS or Elk River (fig. 66). This flow also contains the highest concentrations of 
TDS in either aquifer in this area (fig. 41). However, groundwater at shallow depths beneath the community is under less severe mixed oxic-anoxic conditions (fig. 66, $\mathrm{O}_{2}-\mathrm{Fe}(\mathrm{III})$ ).

Whereas groundwater at depth beneath WVS is poor in quality, shallow groundwater in elevated areas of this community is of relatively good quality. Shallow groundwater in the Magothy aquifer initially reflects local recharge, precipitation, and residential use, and contains relatively low concentrations of TDS (fig. 41). The improved water quality is due in part to recharge from precipitation (low in TDS) and in part to residential use of groundwater that has been treated to reduce TDS. Use of this limited zone of generally oxic water that is low in TDS is consistent with the large percentage of wells that have been installed within the shallow unconfined Magothy aquifer in WVS since 1985, as opposed to deeper depths where poor quality water is present.

In addition to water-quality analyses of discrete intervals within aquifers, electromagnetic-induction logging provided a continuous profile of the vertical extent of high conductivity water representative of high TDS concentration (figs. 44 and 45). The downward and downgradient movement of water with high TDS concentrations emanating from the DMCA is consistent with groundwater flow patterns, recharge to the unconfined system, strong downward gradients of flow, and movement of water downgradient to Elk River as described above.

The influence of the DMCA on the quality of groundwater is apparent in relation to more than just TDS and redoxsensitive species. This influence has also been demonstrated in relation to the low-level detections of pesticides and in particular wastewater compounds. Multiple detections of pesticides and wastewater compounds occur within the Magothy aquifer, primarily within the DMCA, and are attributed to dredged sediment and Elk River water pumped into the DMCA during the active time period of the DMCA.

Other hydrogeologic and groundwater flow conditions within the DMCA that have an impact on local water quality are the integrity of confining units associated with the aquifers and upward or horizontal flow to streams. The lack of confinement and hydraulic connection of the Magothy aquifer and upper Patapsco aquifer shallow water-bearing zone and its implication to flow and quality of groundwater has already been discussed. Also important is the structure of the upper Patapsco confining unit as it spans the DMCA. This confining unit thickens substantially in the northern half of the DMCA, north of well 158 . The confining unit thins to the south of well 158 , with local sandy zones interfingering with the clays that decrease the effectiveness of the confining unit in restricting downward flow from the Magothy aquifer to the upper Patapsco aquifer shallow water-bearing zone (figs. $9 A$ and 14). This is consistent with the elevated TDS concentrations found in both aquifers south of well 158 (fig. 42). Upward flow of groundwater at well nests near wells 126 and 145 effectively keep water with high concentrations of TDS contained in the Magothy aquifer in the northwestern part of the DMCA.
Water-quality sampling and analysis of wells completed in the upper Patapsco aquifer deep water-bearing zone indicate that groundwater throughout this zone is under anoxic conditions but is relatively low in TDS content. Based on minimal data, the water quality in the upper Patapsco aquifer deep water-bearing zone does not seem to have been impacted by the DMCA.

The groundwater flow (as determined by this study) combined with multiple aspects of the groundwater quality data and analysis indicate that the high TDS and sulfate waters beneath and beyond the DMCA, both vertically and laterally, are the result of past use and recharge as a result of past operation of the DMCA. The groundwater-quality data and analysis that support this conclusion include the redox distribution, concentration distributions of TDS, sulfate, iron, chloride, dissolved oxygen, $\mathrm{pH}$, nitrogen, groundwater types (as shown on trilinear diagrams), and the correlation of TDS to multiple anions and cations. Specifically,

1. TDS concentrations in the Magothy aquifer under the DMCA and vicinity range from 45 to more than $5,000 \mathrm{mg} / \mathrm{L}$.

2. TDS concentrations toward the high end of this range generally correspond to the westerly thinning of the Matawan confining unit and eventual outcrop of the sediments of the Magothy aquifer in the western part of the DMCA and in WVS. The high TDS values in the southeastern part of the study area likely reflect historical flows outward from the DMCA during the site's operation. Substantial overlying confinement and slow horizontal flow in this area of the Magothy aquifer hinder the dilution of high TDS water.

3. Concentrations of TDS in the Magothy aquifer beneath the northern or northeastern part of the study area are generally $500 \mathrm{mg} / \mathrm{L}$ or less and reflect the occurrence and increased thickness of the Matawan confining unit above the Magothy aquifer, which likely reduced recharge from the DMCA. In addition, there is upward flow of low TDS water from the upper Patapsco aquifer shallow waterbearing zone, and (or) recharge from Pearce Creek Lake (also low TDS water) into the Magothy aquifer.

4. Waters with concentrations of TDS less than $170 \mathrm{mg} / \mathrm{L}$ occur in the shallow Magothy aquifer beneath WVS. These moderately low concentrations of TDS reflect recharge through the residential area from precipitation combined with septic system recharge and (or) local residential irrigation.

5. In the upper Patapsco shallow water-bearing zone in the northeastern part of the study area, TDS concentrations are less than $170 \mathrm{mg} / \mathrm{L}$ and reflect concentrations found in natural waters. In contrast, TDS concentrations exceed $6,000 \mathrm{mg} / \mathrm{L}$ under the southwestern part of the DMCA. The latter likely reflects older groundwater recharge from 
the DMCA under past hydrologic conditions (that may not be represented by current $2010-11$ hydrogeologic data).

6. Under WVS, TDS concentrations in the deep part of the upper Patapsco shallow water-bearing zone are 4,000 to $5,000 \mathrm{mg} / \mathrm{L}$. These concentrations in part reflect groundwater with high TDS concentrations that flowed from the Magothy aquifer from the east and then downward into this zone.

7. The distribution of major ions was very similar for wells with TDS concentrations greater than $300 \mathrm{mg} / \mathrm{L}$. Sulfate accounted for the majority of the anions present in the water. The ion distribution was similar regardless of geographic position or aquifer.

8. The distribution of major ions was heterogeneous for wells with TDS concentrations less than $300 \mathrm{mg} / \mathrm{L}$.

However, patterns in ion distribution varied depending on aquifer or geographic position.

- In general, where water-bearing zones are well confined, groundwater beneath the study area is anoxic regardless of the aquifer or water-bearing zone. Anoxic waters were also found in several wells that were not affected by the DMCA.

- Conditions in the Magothy aquifer and upper Patapsco shallow water-bearing zone beneath WVS are oxic at the shallowest depths, oxic to anoxic or anoxic mixtures at intermediate depths, and anoxic in the deepest part of the upper Patapsco shallow water-bearing zone. The only other area where oxic groundwater conditions occur is east of the DMCA property boundary (well 193).

- Within the DMCA, the reduced sediments and oxic Elk River water deposition could have led to the initial oxidation of sulfur, the formation of sulfate, a decrease in $\mathrm{pH}$, and hydrolyzation of trace elements such as iron, manganese, and aluminum from the deposited and (or) native sediments exposed to the recharged water from the DMCA. As this water returns to reduced conditions, elevated nitrogen (organic and (or) ammonia) and carbon, as well as elevated calcium, magnesium, sodium, and chloride would all have generally been present in groundwater beneath the DMCA, in areas where the confining layer is absent or thin (i.e., southcentral, southwest, and southeast of the boundary of the DMCA).

There are very little data to support alternative hypotheses for a different or additional source of high TDS, sulfate, iron, and chloride and low $\mathrm{pH}$ groundwater. The overwhelming evidence is that the DMCA has affected the groundwater. Human activities potentially upgradient of the DMCA to the east, and (or) including extensive agriculture, or potential local point sources such as ponds or landfills are unlikely sources of the high TDS groundwater observed beneath and in the southeast part of the study area for several reasons.

First, TDS concentrations in the Magothy aquifer (which one could hypothesize are possibly associated with regional groundwater flow towards the DMCA) are low (less than $170 \mathrm{mg} / \mathrm{L}$ ) and are similar to natural waters unaffected by anthropogenic activities in the aquifer. The concentrations of TDS in wells nearby, but outside the study area of this report, are also less than $100 \mathrm{mg} / \mathrm{L}$. These low concentrations of TDS are consistent with this aquifer being overlain by the Matawan confining unit (50 to $60 \mathrm{ft}$ thick). Groundwater has distinctly different major ion chemistry in areas with low TDS than in areas with higher TDS (greater than $300 \mathrm{mg} / \mathrm{L}$ ).

Second, one could hypothesize that human activities near the land surface (agriculture, landfills) could be the source of the high TDS and sulfate water. There are three problems with this hypothesis: (a) concentrations of TDS, sulfate, and iron beneath other agricultural areas of the Eastern Shore of Maryland are orders of magnitude lower than measured in samples beneath the DMCA and vicinity; (b) the source necessary to generate the mass of TDS, sulfate, and iron as measured in samples beneath the DMCA and vicinity would need to be extremely large; and (c) the Magothy aquifer to the east and south, where human activities predominate (for example, agriculture, nurseries, local surface landfill), is overlain by 50 to $60 \mathrm{ft}$ of the Matawan confining unit, which would retard the flow of high TDS and sulfate water from the land surface to the Magothy aquifer. Potential loading from point sources likely would not be able to generate the mass of source necessary.

Third, there is no evidence that Elk River water intrusion is directly responsible for the occurrence of high TDS and sulfate waters. In contrast, several lines of evidence suggest that it is not a direct source. General patterns in groundwater flow in both the Magothy aquifer and upper Patapsco shallow water-bearing zone all are east to west, not west to east; groundwater from both aquifers discharges into the Elk River bed sediments. Trilinear (Piper) diagrams indicate that Elk River water is a chemically unique type (predominately sodium chloride and low sulfate). Previous (R.F. Weston, Inc.,1998) and current (2010-11) analyses of the bromide to chloride ratios collectively show that the ratios for Elk River water appear similar to ratios in groundwater, but they are not indicative of the Elk River being the source of the groundwater.

There are selected limitations in the available data for groundwater flow and quality at several locations throughout the extent and thickness of the Magothy aquifer and upper Patapsco shallow water-bearing zone within the perimeter dike of the DMCA. Borehole geophysical logs indicate that high conductance water occurs in several locations where wells have not been screened and indicate that the low conductance water occurs at other locations. Water level and geochemical 
data at the following locations would address gaps in the current data set regarding both groundwater flow and quality as water flows through the DMCA sediments, and through the Magothy aquifer beneath the DMCA: midway between wells CE Dd 139 and CE Dd 157 at the base of the Magothy aquifer, near well CE Dd 157 at the base of the Magothy aquifer, near well CE Dd 139 screened at a depth midway between the screened intervals of wells CE Dd 122 and 139, near well CE Dd 193 in the top of the Magothy aquifer, near well CE Dd 193 in the upper Patapsco shallow water-bearing zone.

Data gaps also exist outside the DMCA perimeter dike. Water level and geochemical data south and east of wells CE Dd 125, 153, and 193 would be useful in further delineation of the groundwater flow system and geochemistry of groundwater south and east of the DMCA. These additional data may provide information that further corroborate the conclusions presented in this report - namely that the DMCA is the major source of the high TDS type groundwater found beneath and in the vicinity of the DMCA, or they could indicate that groundwater east and (or) south of the DMCA contributes to the high TDS type groundwater beneath and along the southern and eastern parts of the DMCA and study area. However, without the additional data, the latter is largely speculative; whereas there are sufficient data and multiple lines of evidence on the basis of the analyses of current (2010-11) and historical data to suggest that the DMCA use led to the occurrence of the high TDS type groundwater in the study area.

\section{Conclusions}

The integration of the hydrogeologic, hydrologic, and water-quality information developed as part of this study provides an improved understanding of the impact of the U.S. Army Corps of Engineers Pearce Creek Dredge Material Containment Area (DMCA) in Cecil County, Maryland on the groundwater flow system in the DMCA and the immediate vicinity. Before the DMCA was constructed, the site was a low-lying, natural wetland that freely drained to the tidal Elk River, or freely drained to the adjacent Pearce Creek, which in turn drained into the tidal Elk River. The bermed area of the DMCA now rises more than $30 \mathrm{ft}$ above pre-DMCA low-lying topographic position on the Chesapeake Bay coast, making it a recharge area for the underlying aquifers, as demonstrated by potentiometric maps of the Magothy aquifer and upper Patapsco shallow and deep water-bearing zones. Vertical gradients have resulted in downward groundwater flow from the DMCA sediments into the underlying Magothy aquifer, and then downward into the upper Patapsco shallow water-bearing zone where the intervening confining unit is thin or missing. The chemical composition of the dredged bay sediments that were mixed with oxic, brackish Elk River water and emplaced within the berms of the DMCA has influenced the quality of groundwater recharging the underlying aquifers, creating a complex chemical matrix discernible in groundwater throughout the local groundwater flow system. Water-quality data of numerous types are consistent with the hydrogeologic and hydrologic interpretation that the DMCA has degraded local groundwater quality. The water is considered degraded in part as a result of concentrations of some chemical constituents at levels greater than maximum allowable or recommended levels established in the U.S. Environmental Protection Agency Safe Drinking Water Act Secondary Drinking Water Regulations, Health Advisory Levels, and Maximum Contaminant Levels. Data for TDS concentrations, major ion content, redox-sensitive species (dissolved oxygen, nitrogen, manganese, iron, and sulfate), DOC, pesticides, wastewater compounds, and acidity support the finding that the DMCA is the primary source of the poor quality of water found in the aquifers underlying it. The migration of groundwater impacted by the DMCA into the upper Patapsco shallow water-bearing zone where the overlying confining unit is absent is a source of the poor quality groundwater that supplies some domestic wells in the West View Shores residential community.

\section{Acknowledgments}

The authors would like to thank the U.S. Army Corps of Engineers for support of this study, and providing technical background on the site and previous studies, especially Timothy Kelly, Daniel Sirkis, and J. Mark Chamberlain.

The authors thank the following USGS colleagues for thorough reviews that helped to improve this report: Matthew Pajerowski, Douglas Chambers, Jeff Raffensperger, J. Stephen Schindler, David Pollock, and Michelle Lorah. The authors thank Charles Cravotta for his assistance in the determination and review of acidity titrations and calculations. The authors would like to thank the following USGS colleagues who were instrumental in the completion of this study: Michael Brayton, Deborah Bringman, Michael Brownley, Roberto Cruz, William Davies, Megan Dustin, Andrew LaMotte, Peter Lapa-Lilly, Brenda Majedi, Luke Myers, Andrew Reid, Jessica Teunis, Jason Sorenson, Andrew Massey, Pierre Lacombe, and Robert Rosman. Finally, the authors appreciate the help of Larry Slack, Valerie Gaine, Michael Kemppainen and Timothy Auer for editorial review, illustration preparation, and publication of this report. 


\section{References Cited}

American Public Health Association (APHA), 1998, Sulfide method 4500-S ${ }^{2-}(\mathrm{D})$, in Clesceri, L.S., and others, eds., Standard methods for the examination of water and wastewater, 20th ed.: American Public Health Association, American Water Works Association, and Water Environment Federation, Washington, D.C., 1,325 p.

Anderson, C.W., 2005, Turbidity (ver. 2.1): U.S. Geological Survey Techniques of Water-Resources Investigations, book 9, chap. A6, sec.6.7, 55 p., accessed April 5, 2010, at http://pubs.water.usgs.gov/twri9A6/.

Andreasen, D.C., and Fleck, W.B, 1997, Use of bromide: chloride ratios to differentiate potential sources of chloride in a shallow unconfined aquifer affected by brackish-water intrusion: Hydrogeological Journal, v. 5, no. 2, p. 17-26.

Back, William, and Barnes, Ivan, 1965, Relation of electrochemical potentials and iron content to ground-water flow patterns: U.S. Geological Survey Professional Paper 498-C, $16 \mathrm{p}$.

Baedecker, M.J., and Back, William, 1979, Hydrogeological processes and chemical reactions at a landfill: Ground Water, v. 17 , no. 5, p. 429-437.

Barnes, K.K., Kolpin, D.W, Furlong, E.T., Zaugg, S.D., Meyer, M.T., and Barber, L.B., 2008, A national reconnaissance of pharmaceuticals and other organic wastewater contaminants in the United States-I) groundwater: Science of the Total Environment, v. 402, no. 2-3, p. 192-200.

Black and Veatch Special Projects Corp., 1996, Final report, subsurface investigation, Pearce Creek Disposal Area, Pearce Creek, Maryland, prepared for U.S. Army Corps of Engineers, Philadelphia District: Philadelphia, Pa., [variously paged].

Buxton, H.T., and Kolpin, D.W., 2002, Pharmaceuticals, hormones, and other organic wastewater contaminants in U.S. streams: U.S. Geological Survey Fact Sheet FS-027-02, $2 \mathrm{p}$.

Chapelle, F.H., Bradley, P.M., Thomas, M.A., and McMahon, P.B., 2008, Distinguishing iron-reducing from sulfate-reducing conditions: Ground Water, v. 47, no. 2, p. 300-305.

Chapelle, F.H., and Lovley, D.R., 1992, Competitive exclusion of sulfate reduction by Fe(III)-reducing bacteria: A mechanism for producing discrete zones of high-iron ground water: Ground Water, v. 30, no. 1, p. 29-36.
Drummond, D.D., 2007, Water-supply potential of the coastal plain aquifers in Calvert, Charles, and St. Mary's Counties, Maryland, with emphasis on the Upper Patapsco and Lower Patapsco aquifers: Maryland Geological Survey Report of Investigations No. 76, 48 p.

EA Engineering, Science, and Technology, Inc., 2009, Sampling report for soil sampling at Pearce Creek Dredged Material Containment Area, Pearce Creek, Maryland: EA Engineering, Science, and Technology, Baltimore, Md., [variously paged].

Edwards, J., and Hansen, Harry J., 1979, New data bearing on the structural significance of the upper Chesapeake Bay magnetic anomaly: Maryland Geological Survey Report of Investigations No. 30, 44 p.

Federal Register, 1998, Part IV, Environmental Protection Agency, Safe Drinking Water Act, Section 1401(4) Public Water System Definition as Amended by 1996 Safe Drinking Water Act, v. 63, no. 150, p. 41940-41946, accessed April 5, 2010,at http://frwebgate.access.gpo.gov/cgi-bin/ getdoc.cgi? dbname $=1998$ register\&docid $=$ fro5au98-138. $p d f$.

Ferrell, G.M., 2009, Occurrence of selected pharmaceutical and organic wastewater compounds in effluent and water samples from municipal wastewater and drinking-water treatment facilities in the Tar and Cape Fear River basins, North Carolina, 2003-2005: U.S. Geological Survey OpenFile Report 2009-1046, 45 p.

Focazio, M.J., Kolpin, D.W., Barnes, K.K., Furlong, E.T., Meyer, M.T., Zaugg, S.D., Barber, L.B., and Thurman, E.M., 2008, A national reconnaissance for pharmaceuticals and other organic wastewater contaminants in the United States-II) untreated drinking-water sources: Science of the Total Environment, v. 402, no. 2-3, p. 201-216. (Abstract and ordering information available at $h t t p: / / w w w$. sciencedirect.com/science/article/pii/S004896970800154X [September 3, 2012].)

Garbarino, J.R., and Struzeski, T.M., 1998, Methods of analysis by the U.S. Geological Survey National Water Quality Laboratory-Determination of elements in whole-water digests using inductively coupled plasma-optical emission spectrometry and inductively coupled plasma-mass spectrometry: U.S. Geological Survey Open-File Report 98-165, $101 \mathrm{p}$.

Gibs, Jacob, Wilde, F.D., and Heckathorn, H.A., 2007, Use of multiparameter instruments for routine field measurements (ver. 1.1): U.S. Geological Survey Techniques of Water-Resources Investigations, book 9, chap. A6, sec. 6.8, August, accessed April 5, 2010, at http://pubs.water.usgs. gov/twri9A/. 
Hamilton, P.A., Denver, J.M., Phillips, P.J., and Shedlock, R.J., 1993, Water-quality assessment of the Delmarva Peninsula, Delaware, Maryland, and Virginia-Effects of agricultural activities on and distribution of nitrate and other inorganic constituents in the surficial aquifer: U.S. Geological Survey Open-File Report 93-40, 87 p.

Hartwell, S.I., and Hameedi, J., 2007, Magnitude and extent of contaminated sediment and toxicity in Chesapeake Bay: National Oceanic and Atmospheric Administration Technical Memorandum NOS NCCOS 47: Silver Spring, Md., 215 p., accessed April 27, 2012, at http://ccma.nos.noaa. gov/publications/NCCOSTM47.pdf.

Hem, J.D., 1985, Study and interpretation of the chemical characteristics of natural water (3rd ed.): U.S. Geological Survey Water-Supply Paper 2254, 263 p.

Higgins, M.W., and Conant, L.B., 1990, The geology of Cecil County, Maryland: Maryland Geological Survey Bulletin $37,183 \mathrm{p}$.

Hollweg, T.A., Gilmour, C.C., and Mason, R.P., 2009, Methylmercury production in sediments of Chesapeake Bay and the mid-Atlantic continental margin: Marine Chemistry, v. 114 , p. 86-101.

Jurgens, B.C., McMahon, P.B., Chapelle, F.H., and Eberts, S.M., 2009, An Excel ${ }^{\circledR}$ workbook for identifying redox processes in ground water: U.S. Geological Survey OpenFile Report 2009-1004, 8 p., accessed August 25, 2010, at http://pubs.usgs.gov/of/2009/1004/.

Keys, W.S., and McCary, L.M., 1971, Applications of borehole geophysics to water-resources investigations: U.S. Geological Survey Techniques of Water-Resources Investigations, book 2, chap., E1, $126 \mathrm{p}$.

Kirby, C.S., and Cravotta, C.A., III, 2005a, Net alkalinity and net acidity 1: Theoretical considerations: Applied Geochemistry, v. 20, no. 10, p. 1920-1940. (Also available at $h t t p: / / w w w . s c i e n c e d i r e c t . c o m / s c i e n c e / a r t i c l e / p i i /$ S088329270500137X.)

Kirby, C.S., and Cravotta, C.A., III, 2005b, Net alkalinity and net acidity 2: Practical considerations: Applied Geochemistry, v. 20, no. 10, p. 1940-1964. (Also available at $h t t p: / / w w w . s c i e n c e d i r e c t . c o m / s c i e n c e / a r t i c l e / p i i /$ S0883292705001381.)

Kolpin, D.W., Furlong, E.T., Meyer, M.T., Thurman, E.M., Zaugg, S.D., Barber, L.B., and Buxton, H.T., 2002, Pharmaceuticals, hormones, and other organic wastewater contaminants in U.S. streams, 1999-2000: A national reconnaissance: Environmental Science and Technology, v. 36, no. 6, p. $1202-1211$.
Koterba, M.T., Dieter, C.A., and Miller, C.V., 2010, Pesticides in groundwater in the Anacostia River and Rock Creek watersheds in Washington, D.C., 2005 and 2008: U.S. Geological Survey Scientific Investigations Report 2010-5130, $90 \mathrm{p}$.

Koterba, M.T., Wilde, F.D., and Lapham, W.W., 1995, Ground-water data-collection protocols and procedures for the National Water-Quality Assessment Program-Collection and documentation of water-quality samples and related data: U.S. Geological Survey Open-File Report 95-399, $113 \mathrm{p}$.

LaMotte, A.E., 2010, Groundwater site identification indexes for Washington, D.C., Baltimore City, and the counties of Maryland: U.S. Geological Survey Digital Data Series 576, available at http://water.usgs.gov/GIS/metadata/usgswrd/ $X M L / m d d c$ indexes.xml.

Lane, S.L., Flanagan, Sarah, and Wilde, F.D., 2003, Selection of equipment for water sampling (ver. 2.0): U.S. Geological Survey Techniques of Water-Resources Investigations, book 9, chap. A2, March 2003, accessed April 5, 2010, at http://pubs.water.usgs.gov/twri9A2/.

Lovley, D.R., Phillips, E.J.P., Gorby, Y.A., and Landa, E.R., 1991, Microbial reduction of uranium: Nature, v. 350, p. 413-415. (Also available at http://www.wipp.energy. gov/library/cra/2009_cra/references/Others/Lovley_et al_1991_Microbial_Reduction_of_Uranium.pdf.)

Mack, F.K., and Achmad, G., 1986, Evaluation of the water supply potential of aquifers of the Potomac Group of Anne Arundel County, Maryland: Maryland Geological Survey Report of Investigations No. 46, 111 p.

Marvin-DiPasquale, M.C., and Capone, D.G., 1998, Benthic sulfate reduction along the Chesapeake Bay central channel-Spatial trends and controls: Marine Ecology Progress Series, v. 168, p. 213-228.

Maryland Environmental Service, 1995, Pearce Creek upland dredged material placement site, Phase I Groundwater Study: Maryland Environmental Service Report of Findings for the Maryland Port Administration and the U.S. Army Corps of Engineers, 27 p. with 7 additional apps.

McMahon, P.B., and Chapelle, F.H., 2008, Redox processes and the water quality of selected principal aquifer systems of the United States: Ground Water, v. 44, no. 2, p. 259-271.

Morris, A.W., and Riley, J.P., 1996, The bromide/chlorinity and bromide/salinity ratio in sea water: Deep-Sea Research, v. 13 , p. $695-705$. 
Nordstrom, D.K., and Wilde, F.D., 2005, Reduction-oxidation potential (electrode method) (ver. 1.2): U.S. Geological Survey Techniques of Water-Resources Investigations, book 9 , chap. A6, sec. 6.5, p. 20, September, accessed April 5, 2010, at http://pubs.water.usgs.gov/twri9A/.

Otton, E.G., Willey, R.E., McGregor, R.A., Achmad, G., Hiortdahl, S.N., and Gerhart, J.M., 1988, Water resources and estimated effects of ground-water development, Cecil County, Maryland: Maryland Geological Survey Bulletin $34,133 \mathrm{p}$.

Patton, C.J., and Kryskalla, J.R., 2011, Colorimetric determination of nitrate plus nitrite in water by enzymatic reduction, automated discrete analyzer methods: U.S. Geological Survey Techniques and Methods, book 5, chap. B8, 34 p.

Radtke, D.B., Horowitz, A.J., and Sandstrom, M.W., 2002, Filtered samples (ver. 2.0): U.S. Geological Survey Techniques of Water-Resources Investigations, book 9, chap. A5, sec. 5.2, April, accessed April 5, 2010, at http://pubs.water. usgs.gov/twri9A/.

Richter, B.C., and Kreitler, C.W., 1993, Geochemical techniques for identifying sources of ground-water salinization: Boca Raton, Fla., C.K. Smoley (CRC Press), 272 p.

Rounds, S.A., 2006, Alkalinity and acid neutralizing capacity (ver. 3.0): U.S. Geological Survey Techniques of WaterResources Investigations, book 9, chap. A6., sec. 6.6, July, accessed April 5, 2010, at http://pubs.water.usgs.gov/ twri9A6/.

Shedlock, R.J., Denver, J.M., Hayes, M.A., Hamilton, P.A., Koterba, M.T., Bachman, L.J., Phillips, P.J., and Banks, W.S.L., 1999, Water-quality assessment of the Delmarva Peninsula, Delaware, Maryland, and Virginia: Results of investigations, 1987-91: U.S. Geological Survey WaterSupply Paper 2355-A, 41 p.

Shedlock, R.J., Hamilton, P.A., Denver, J.M., and Phillips, P.J., 1993, Multiscale approach to regional ground-waterquality assessment of the Delmarva Peninsula, in Alley, W.M., ed., Regional ground-water quality: New York, Van Nostrand Reinhold, p. 563-587.

Sinex, S.A., and Helz, G.R., 1981, Regional geochemistry of trace elements in Chesapeake Bay sediments: Environmental Geolology, v. 3, p. 315-323.

Smedley, P.L., and Kinniburgh, D.G., 2002, A review of the source, behavior, and distribution of arsenic in natural waters: Applied Geochemistry, v. 17, no. 5, p. 517-568.
Snow, M.S., Kahl, J.S., Norton, S.A., and Olsen, C., 1990, Geochemical determination of salinity sources in ground water wells in Maine, in Proceedings of the FOCUS Conference on Eastern Regional Groundwater Issues, Ground water Management Book, 1990, National Well Water Association, Springfield, Mass., no. 3, p. 313-327.

Speiran, G.K., 1996, Geohydrology and geochemistry near coastal ground-water-discharge areas of the Eastern Shore, Virginia: U.S. Geological Survey Water-Supply Paper 2479, $73 \mathrm{p}$.

Standley, L.J., Rudel, R.A., Swartz, C.H., Attfield, K.R., Christian, J., Erickson, M., and Brody, J.G., 2008, Wastewater-contaminated groundwater as a source of endogenous hormones and pharmaceuticals to surface water ecosystems: Environmental Toxicology and Chemistry, v. 12, p. 2457-2468.

Tertuliani, J.S., Alvarez, D.A., Furlong, E.T., Meyer, M.T., Zaugg, S.D., and Koltun, G.F., 2008, Occurrence of organic wastewater compounds in the Tinkers Creek watershed and two other tributaries to the Cuyahoga River, Northeast Ohio: U.S. Geological Survey Scientific Investigations Report 2008-5173, 60 p.

U.S. Army Corps of Engineers, 1996, Pearce Creek Disposal Area Groundwater Investigation, Pearce Creek, Maryland, Phase II Report: U.S. Army Corps of Engineers, Philadelphia District, Philadelphia, Pa., 240 p. including 5 apps.

U.S. Environmental Protection Agency, 2009, 2009 Edition of drinking water standards and health advisories: Washington, D.C. Office of Water, U.S. Environmental Protection Agency Report 822-R-09-011, 12 p., accessed October 25, 2012 at http://water.epa.gov/action/advisories/drinking/ upload/dwstandards2009.pdf

U.S. Geological Survey, variously dated, chaps. A1-A9, National field manual for the collection of water-quality data: U.S. Geological Survey Techniques of WaterResources Investigations, book 9, accessed April 5, 2010, at http://pubs.water.usgs.gov/twri9A/.

U.S. Geological Survey, September 2006, Collection of water samples (ver. 2.0): U.S. Geological Survey Techniques of Water-Resources Investigations, book 9, chap. A4, accessed April 5, 2010, at http://pubs.water.usgs.gov/twri9A.

Weston, R.F., Inc., 1998, Review of groundwater investigations for the Pearce Creek Dredge Disposal Containment Area, Final report to the U.S. Army Corps of EngineersPhiladelphia District: Weston, R.F., Inc., West Chester, Pa., 73 p. with 2 additional apps. 
Wilde, F.W., 2004, Equipment cleaning (ver. 2.0): U.S. Geological Survey Techniques of Water-Resources Investigations, book 9, chap. A3, April, accessed April 5, 2010, at http://pubs.water.usgs.gov/twri9A/.

Wilde, F.D., Radtke, D.B., Gibs, Jacob, and Iwatsubo, R.T., eds., 2004 with updates through 2009, Processing of water samples (ver. 2.2): U.S. Geological Survey Techniques of Water-Resources Investigations, book 9, chap. A5, April, accessed April 5, 2010, at http://pubs.water.usgs.gov/ twri9A5/.

Willey, R.E., McGregor, R.A., de Grouchy, J., and Tompkins, M.D., 1987, Hydrologic data for Cecil County, Maryland: Maryland Geological Survey, Basic Data Report No. 16, $150 \mathrm{p}$.
Williams, J.H., Lapham, W.W., and Barringer, T.H., 1993, Application of electromagnetic logging to contamination investigations in glacial sand-and-gravel aquifers: Groundwater Monitoring and Remediation Review, v. 13, no. 3, p. 129-138.

Zaugg, S.D., Smith, S.G., Schroeder, M.P., Barber, L.B., and Burkhardt, M.R., 2002, Methods of analysis by the U.S. Geological Survey National Water Quality LaboratoryDetermination of wastewater compounds by polystyrenedivinylbenzene solid-phase extraction and capillary-column gas chromatography/mass spectrometry: U.S. Geological Survey Water-Resources Investigations Report 01-4186, $37 \mathrm{p}$. 

Appendixes A-C 


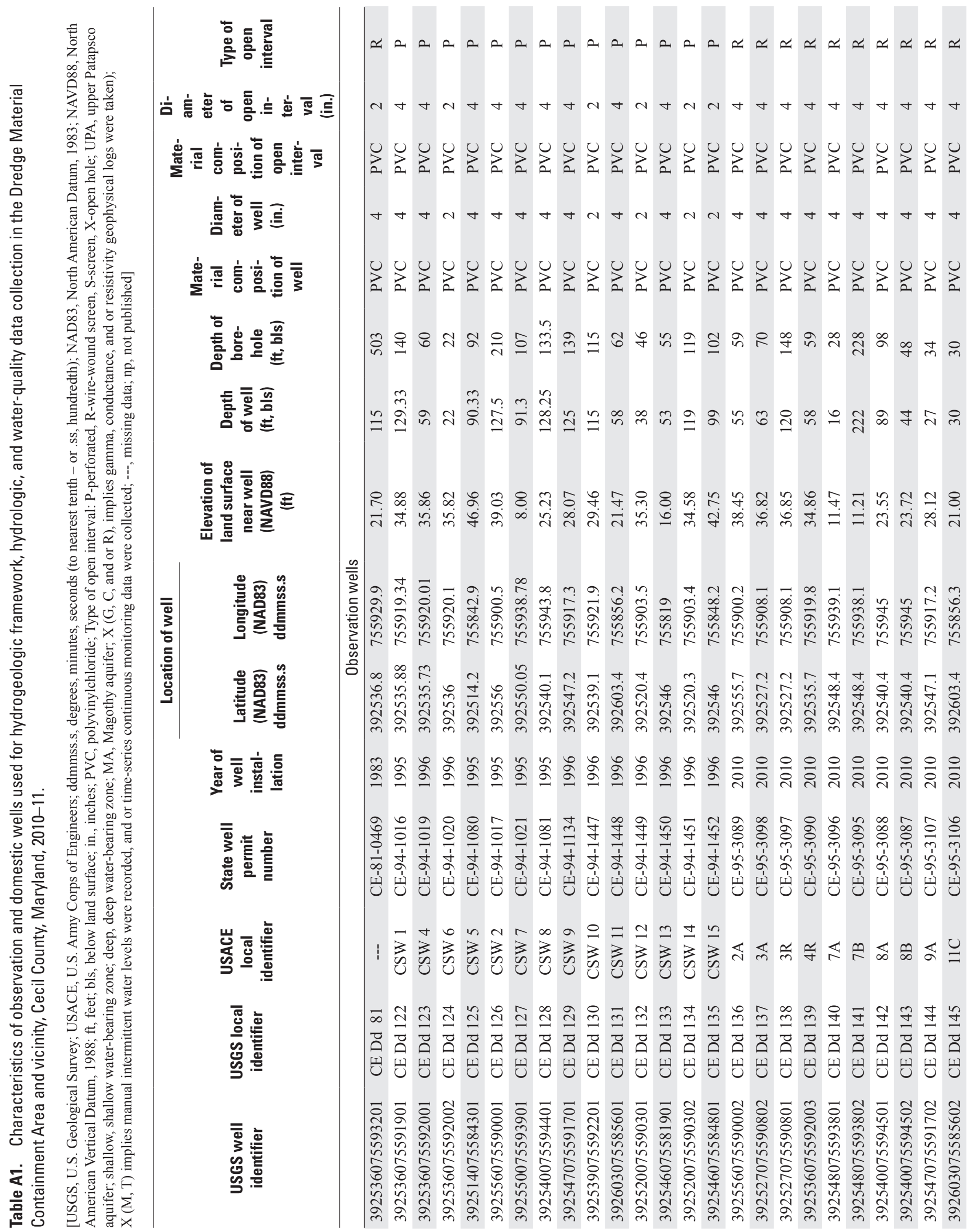




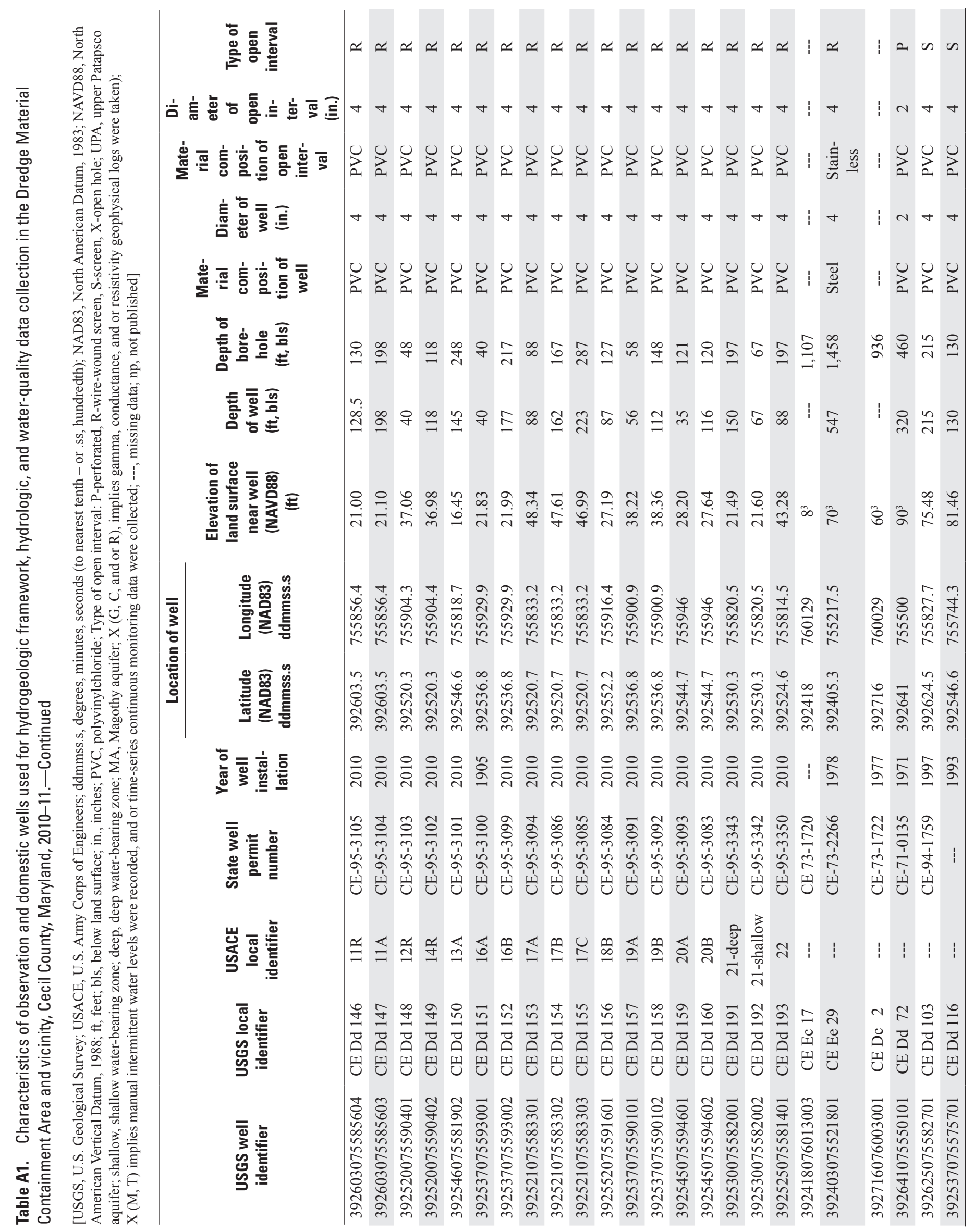




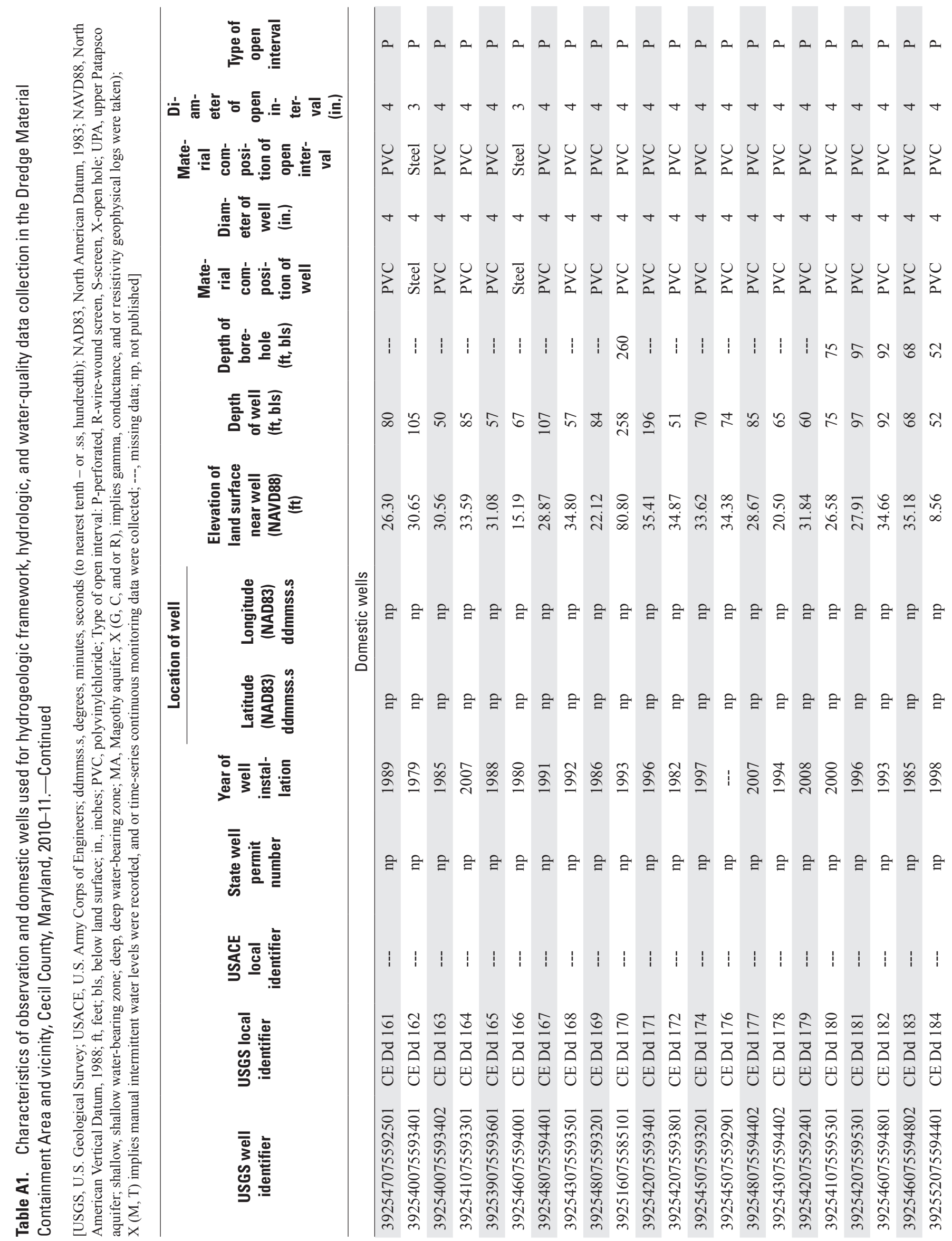




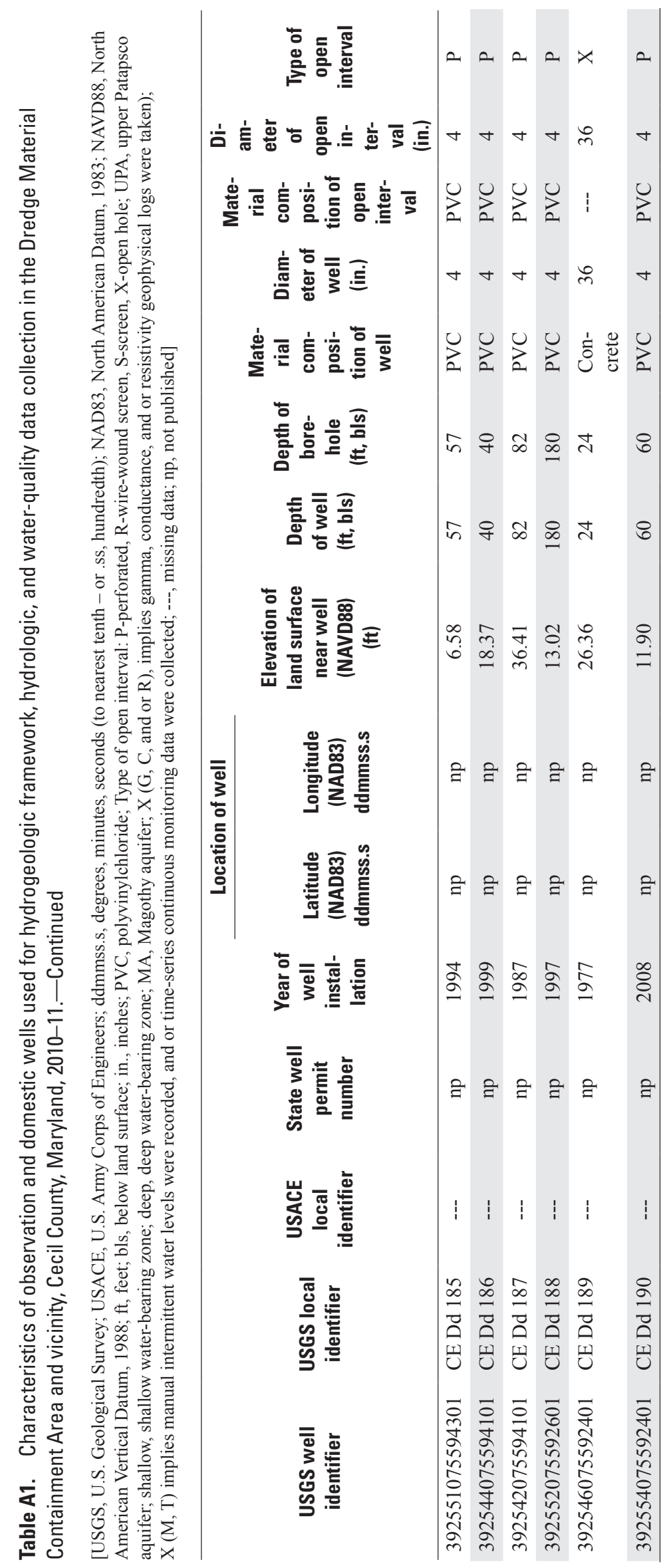




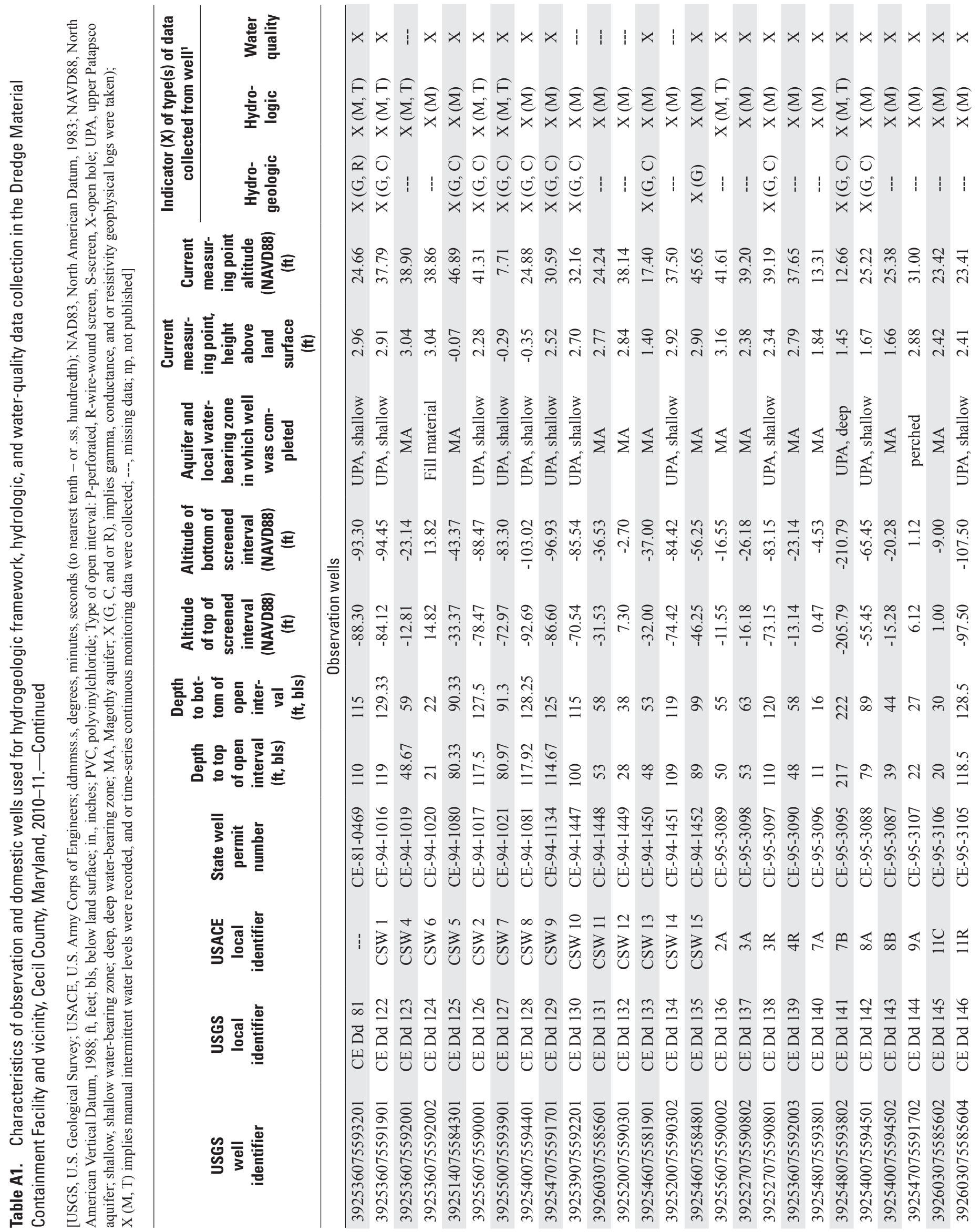




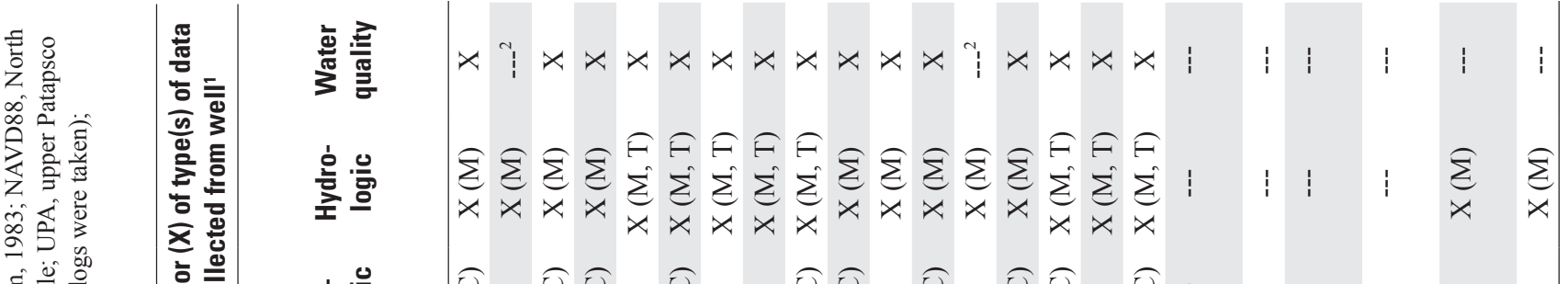

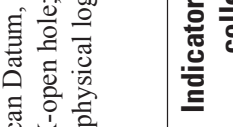

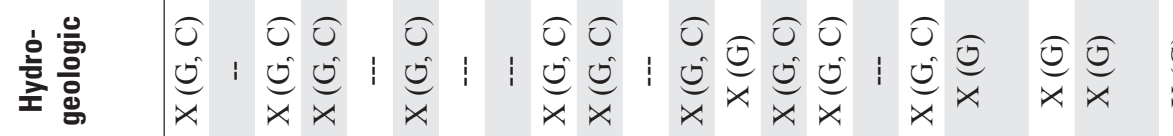

焉离离

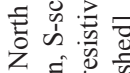

ली

它要焉

乙. छ

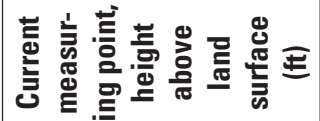

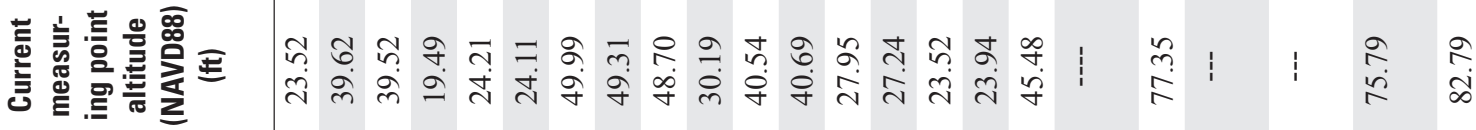

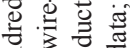

表完驾

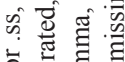

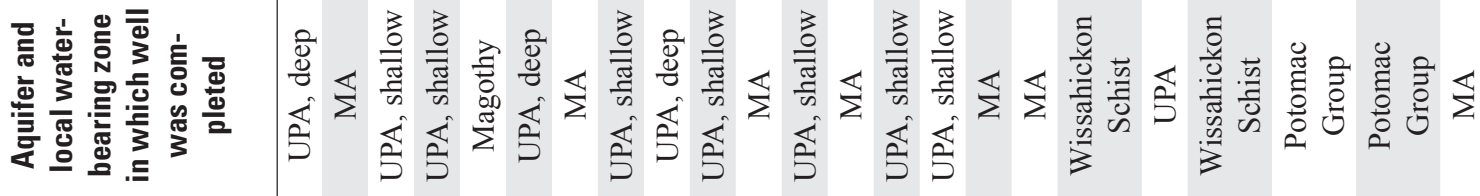

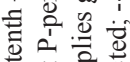

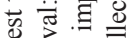

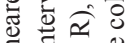

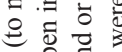

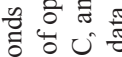

递过.

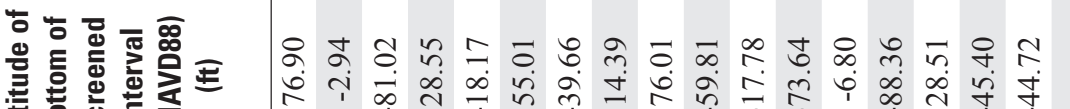

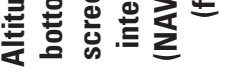

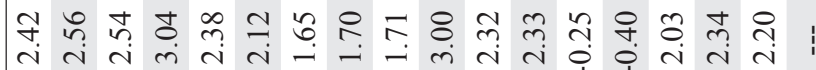

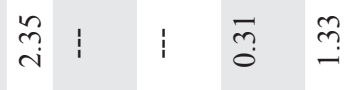

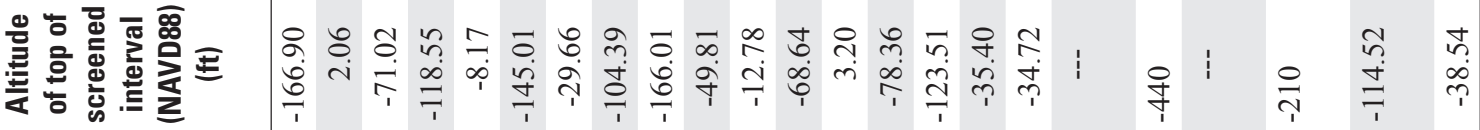

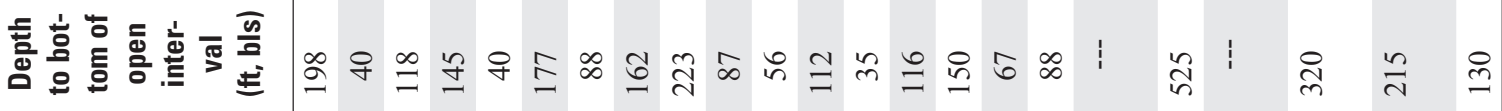

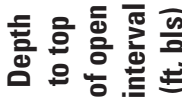

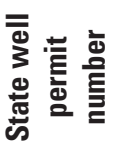

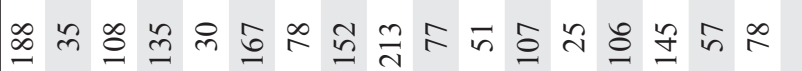

in 8 \&

क्ष

必

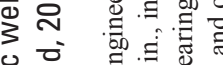

फ

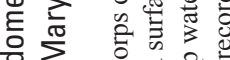

言离焉

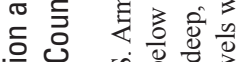

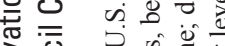

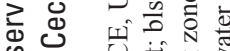

定蓆

证

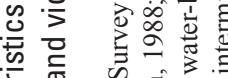

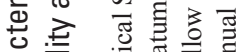

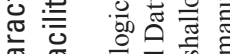

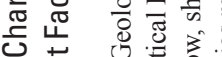

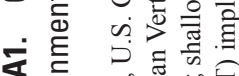

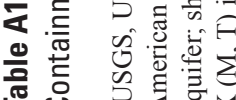

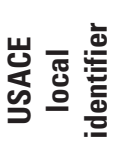

屯

ऊूँ

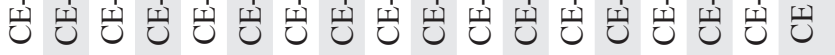

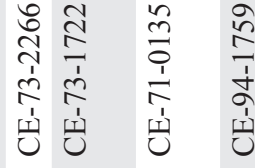

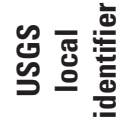

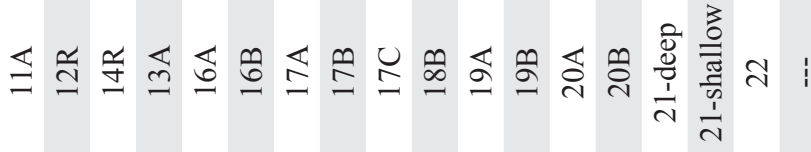

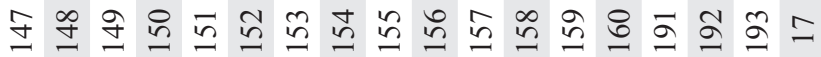

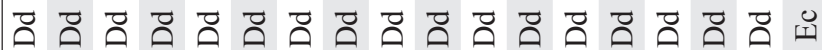

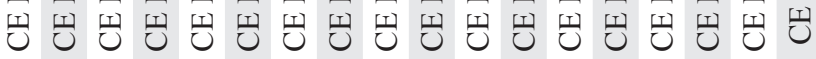

ते $\mathrm{N}$

i

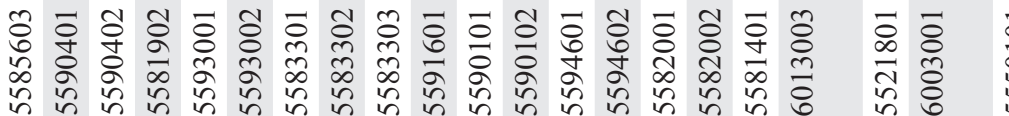

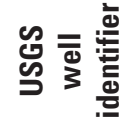

ôे

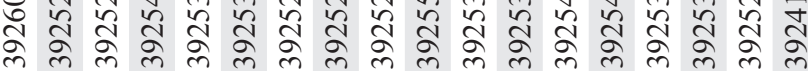

容

古范

ूू ूू ूू

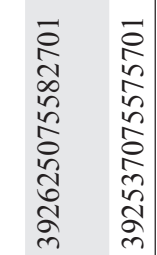




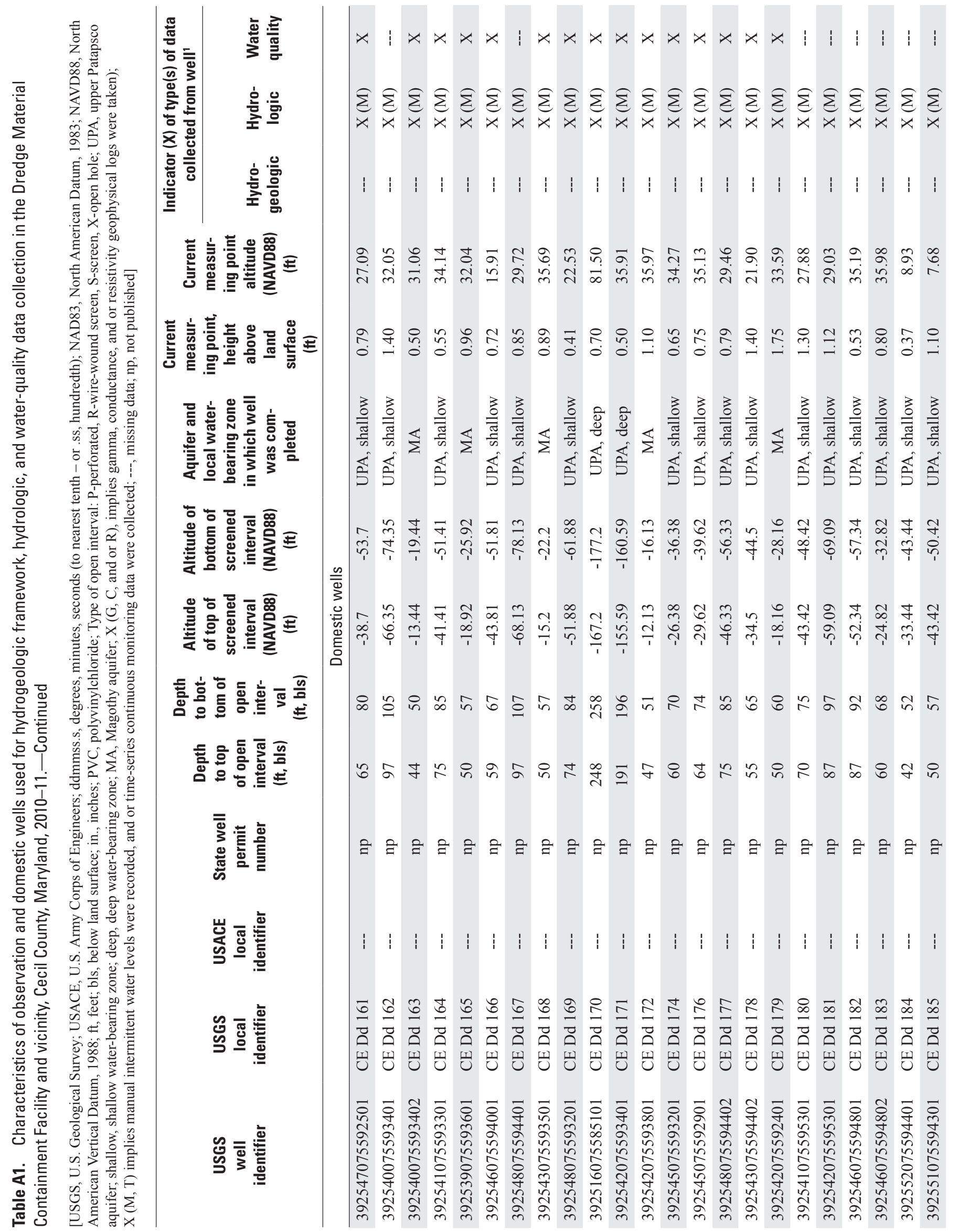




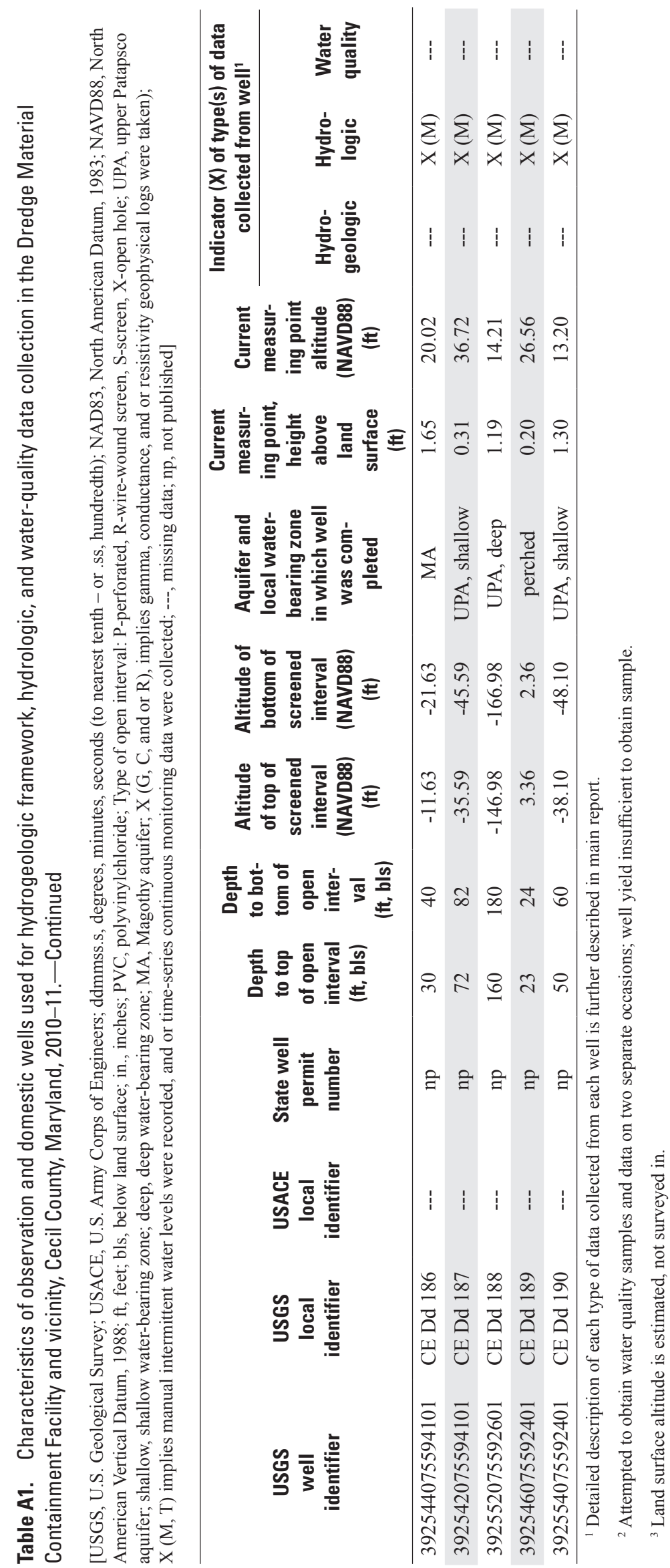




\section{Appendix B: Water-Quality and Quality-Control Data and Custom Methods Used in the Investigation of the Pearce Creek Dredge Material Containment Area and Vicinity, Cecil County, Maryland, 2010-11}

\section{Introduction}

Water-quality field measurements and laboratory analyses were conducted in 2010-11 to provide data on the physical and chemical characteristics of groundwater and surface water in the Pearce Creek Dredge Material Containment Area (DMCA) and vicinity, Cecil County, Maryland. The data collected included quality-control (QC) samples and measurements at selected groundwater and surface-water sites to help determine the accuracy and comparability of the water-quality data. Modified laboratory methods also were used to obtain data for selected water-quality constituents because of samplematrix interferences likely associated with the high dissolvedsolids concentrations of groundwater in the study area. All tables referenced in this appendix are linked to an Excel file.

\section{Extent and Types of Data Collected}

Water-quality measurements and samples were collected at 36 observation wells, 15 domestic water-supply wells, and two surface-water sites during 2010-11. A broad variety of data were collected at each site on general water-quality characteristics, major ions, trace elements, pesticides, and wastewater compounds. However, survey (occurrence and distribution) data for pesticides and wastewater compounds in groundwater and surface waters were obtained from only shallow observation wells, in addition to all domestic supply wells, and both surface-water sites. The types of water-quality data collected have been summarized by category or type for each groundwater or surface-water site (table B1, link to Excel file).

Quality-control samples and measurements were obtained at selected groundwater and surface-water sites to help determine the accuracy and comparability of the water-quality data. At selected monitoring and observation wells, field blanks were collected on site to assess potential sample contamination, and duplicate sequential groundwater samples were obtained to assess measurement precision. At selected sites, additional replicate sequential groundwater samples were collected for selected laboratory-analyzed samples, including pesticide or wastewater compounds, for laboratory spikes. Laboratory spikes were performed to assess whether any chemical precipitation from sample oxidation during shipping or handling of samples in the laboratory reduced the recovery of these compounds. In addition, standard reference samples, obtained from the U.S. Geological Survey (USGS) Branch of Quality Systems (BQS), Denver, Colorado, were submitted from the field to the National Water Quality Laboratory (NWQL) to assess the accuracy of analysis for selected trace elements. Table B2 (link to Excel file) summarizes the different types of field QC samples collected, their site of collection, and the types and categories of water-quality constituents assessed in relation to that QC sample.

\section{Water-Quality and Quality-Control Data}

Water-quality data from most observation wells (30 of 36 ) and all domestic supply wells (15) were obtained during April through mid-June, 2010. Data for five additional monitoring wells installed late in 2010, and from two nearby surface-water sites - the Elk River and Pearce Creek Lakewere obtained February 9-10, 2011. The data for both periods of data collection are summarized by general water-quality category or type (table B3, link to Excel file). The associated QC data have been summarized in a manner consistent with their use to address the objectives of this report (table B4, link to Excel file).

In relation to both the water-quality and $\mathrm{QC}$ data, the nomenclature regarding the types of data warrants discussion. References to constituent results for raw water, for example, "pH, raw water," imply a measurement [analysis] made on unaltered groundwater discharge from the well. References to results for constituents dissolved in water, for example, "Chloride, dissolved water," a measurement made on a sample of groundwater being discharged from the well, was filtered in the field when collected, and may have been filtered again in the laboratory before analysis. Major anions fall into this category, including bromide, chloride, and fluoride, as well as sulfate, and ammonia-, nitrite, and nitrate-plus-nitrite nitrogen.

The majority of the inorganic water-quality data are expressed as "dissolved recoverable," which implies a measurement obtained from a sample of groundwater being discharged from the well that was filtered in the field when collected, then if inorganic in nature, also preserved with acid in the field, but ultimately analyzed by a USGS laboratory after an initial in-bottle digestion with nitric acid — as if it were a whole-water recoverable sample. The digestion procedure was essential to ensure any colloidal precipitates, which formed after collection and because of oxidation of the sample, were dissolved and incorporated into the original dissolved sample. In the case of other dissolved recoverable constituents, including organic carbon, and ammonia-plus-organic 
nitrogen, which also initially were chemically preserved with acids, other and more rigorous digestion procedures were used to ensure results reflected the original dissolved samples. In the case of pesticides and wastewater compounds, which were preserved by chilling, rather than acidification, representative samples of water and any suspended material were extracted rather than digested to ensure the results reflected the original dissolved samples. Details of the specific digestion or extraction procedure used, which were conducted in accordance with standard reference methods, are provided in the laboratory reference for each inorganic constituent (table B5, link to Excel file).

Overall, whole-water recoverable methods reflect the constituents in solution after a representative water-suspendedsediment sample is digested or extracted. In the case of this study, complete dissolution of any colloidal material likely was achieved, as field-acidified samples did not appear to form visible colloidal precipitates after samples were oxidized and the digested samples for inorganics, organic carbon, and ammonia-plus-organic nitrogen, have remained clear for months following their initial oxidation (D. Damrau, USGS, written commun., 2011). Suspensions did form in selected pesticide and wastewater samples after their oxidation in the laboratory. However, the efficiency of the extractions for pesticide and wastewater compounds was assessed to determine if the suspensions biased the recovery of these compounds (see below).

For selected constituents - nitrate-plus-nitrite nitrogen, beryllium, arsenic, and sulfate - data reference the use of a "modified method." Historical or preliminary QC data for each of these constituents indicated that the standard method for these constituents was inadequate to obtain accurate measurements, mainly because of sample-matrix interferences that could not be addressed without some modification to the standard method. These water-quality constituents were analyzed with modified standard methods, which are described later in this appendix.

\section{Quality-Control Data Tables for Interpretation}

Tables used to create summary QC data and determine the quality of groundwater and surface-water data as described in the main body of this report are as follows:

To assess the potential contamination of water-quality samples during or after their collection from field blanks (table B6, link to Excel file); a summary table of these data are discussed in the main report (table 2);

To assess the precision of measurement of commonly measureable water-quality constituents from sequential replicate groundwater samples (table B7, link to Excel file); a summary table of these data are discussed in main report (table 3);

To assess the potential influence of sample matrix bias on the recovery of pesticide compounds from low-level $(0.2$ to $0.8 \mu \mathrm{g} / \mathrm{L}$, micrograms per liter) analytical methods used by the USGS Organic Geochemistry Research Laboratory, from spiked groundwater samples and surrogate constituents in all samples (table B8, link to Excel file); a summary table of these data is discussed in the main report (table 4);

To assess the potential influence of sample matrix bias on the recovery of wastewater compounds from analytical methods used by the USGS NWQL from spiked groundwater samples and surrogate constituents in all samples (table B9, link to Excel file); a summary table of these data is discussed in the main report (table 5); and

To assess measurement accuracy, standard reference samples, from USGS BQS, for trace elements were sent as blind water-quality samples from the field (table B10, link to Excel file); these data are discussed in the main report.

In addition, mass equivalent balances were computed for major ionic constituents in milliequivalents per liter (table B11, link to Excel file); a summary table of these data is discussed in the main report (table 6).

In addition, all pesticides detected in groundwater samples with low-level detection methods are summarized (table B12, link to Excel file) to facilitate their interpretation and discussion in the main report. Within the context of each of the above tables, QC as well as water-quality data for selected constituents were obtained with modified standard methods for four water-quality constituents - nitrate-plusnitrite nitrogen, arsenic, beryllium, and sulfate. The modified standard method for each of these constituents is described below.

\section{Modified Standard Laboratory Methods for the Analysis of Selected Water- Quality Constituents}

Modified laboratory methods were employed by the USGS laboratories to obtain accurate measurements of four water-quality constituents - nitrate-plus-nitrite nitrogen, arsenic, beryllium, and sulfate. A description of the modified method and the associated field and laboratory control data to support the validation of the resultant water-quality data for interpretive use in this report are provided below.

\section{Nitrate-plus-Nitrite Nitrogen}

Historical data indicated there was little to no measureable nitrate and nitrite but highly elevated concentrations of dissolved iron in groundwater in the DMCA and vicinity (U.S. Army Corps of Engineers, 1996; Weston, Inc., 1998). Given elevated concentrations of dissolved iron in the form of ferrous iron, the latter can be preferentially reduced instead of nitrate using the standard cadmium-reduction method for nitrate analysis, and lead to low-biased or immeasurable concentrations of nitrate-plus-nitrite nitrogen (Patton and Kryskalla, 
2011). To avoid this potential bias, the USGS NWQL recently developed a nitrate reductase method, which reduces nitrate to nitrite (Patton and Kryskalla, 2011). The nitrite concentration is then determined using the standard spectrophotometric (colorimetric) phosphomolybdenum-blue complex analytical method.

With few exceptions, all laboratory QC data were within acceptable limits (table B13, link to Excel file). Laboratory blanks contained trace $(0.01-0.05 \mathrm{mg} / \mathrm{L})$ to undetectable (or less than the laboratory reporting level of $<0.04 \mathrm{mg} / \mathrm{L}$ ) concentrations of nitrate-plus-nitrite nitrogen. Except for three water-quality samples, recoveries on spiked samples of all types-laboratory blanks, field blanks, duplicate sequential samples, and water-quality samples-were similar, and generally within the acceptable control range for standard NWQL methods - 85-115 percent. High recoveries (124, 147, and 162 percent) occurred on the water-quality sample for wells CE Dd 163, CE Dd 168 duplicate sequential sample, and CE Dd 172, respectively. CE Dd 172, which required dilution, and thus concentrations of nitrate-plus-nitrite nitrogen would be expected to have a higher or lower than normal variability in recovery.

\section{Beryllium}

Concentrations of beryllium were determined by the USGS NWQL using a modified standard inductively coupled plasma-mass spectrometry (ICP-MS) method. Whole-water recoverable beryllium is routinely determined along with other trace elements simultaneously on a single sample by using ICP-MS (Garbarino and Struzeski, 1998) ${ }^{1}$. An aerosol of the sample solution is produced by using a high-dissolved-solids tolerant nebulizer. The aerosol is introduced into the argon plasma where it undergoes desolvation, atomization, and ionization. Ions are sampled through multiple orifices into the quadrupole mass spectrometer where they are separated on the basis of their mass-to-charge ratios. An electron multiplier detects the ions by generating a current that is directly proportional to the concentration of the element present in the sample. The effects of sample transport, instrumental drift, and matrix-induced fluctuations in plasma characteristics are reduced by using the ratio of elemental ion intensity to the internal standard element ion intensity for calibration. The described method is for the determination of multiple elements in a sample. The standard optimization procedure consists of maximizing the signal for three elements spanning the entire mass spectrum $\left({ }^{7} \mathrm{Li},{ }^{89} \mathrm{Y}\right.$, and $\left.{ }^{205} \mathrm{Tl}\right)$ while maintaining ion doubly-charged and oxide levels below pre-determined values. Optimization is achieved through the adjustment of argon gas flows, electrical lenses, quadrupole electrical settings, and electron multiplier settings.

Preliminary QC information for beryllium determinations conducted with the standard method described above indicated that concentrations of beryllium could be biased

${ }^{1}$ See table B5. and underestimated (Mark R. Hill, USGS, written commun., 2011). Minimal modifications were made to the standard method optimization procedures to enhance the ICP-MS determinations of beryllium. Also, an alternate internal standard was used for beryllium, which is permissible under the NWQL ICP-MS methodology. In routine analyses at the NWQL, concentrations of beryllium generally are determined by ratios to germanium-72, ${ }^{72} \mathrm{Ge}$. However, for water-quality samples analyzed in this study, the most accurate determination of beryllium was obtained with beryllium ratios to rhodium-103, ${ }^{103} \mathrm{Rh}$. The latter was determined on the basis of recoveries of beryllium from laboratory spikes of reagent blanks, field blanks, and groundwater samples, as well as internal beryllium standard-reference samples, whose spiked or reference concentrations were similar to the range in beryllium concentrations found in groundwater samples from the study area.

All laboratory control data indicated that the beryllium water-quality data are suitable for interpretation. Laboratory QC data for beryllium were within acceptable limits (table B14, link to Excel file). All laboratory (and field) blanks contained immeasurable $(<0.04 \mu \mathrm{g} / \mathrm{L})$ concentrations of beryllium. The beryllium concentrations in the spiked and reference samples were similar to the range of arsenic values found in groundwater and surface-water samples from the study area. Despite considerable differences in the range of dilution rates among samples, recoveries (beryllium) on spiked samples of all types-laboratory blanks, field blanks, duplicate sequential samples, and water-quality samples-were similar, and all within the generally acceptable control range for standard NWQL ICP-MS methods for trace elements-80-120 percent. A high recovery (146 percent) occurred on the water-quality sample for well CE Dd 146, which was the only sample that required dilution, and thus concentrations of beryllium would be expected to have a higher or lower than normal variability in recovery. Concentrations for three standard reference samples, each analyzed multiple times, all fell within plus or minus $( \pm) 30$ percent, and, in most cases were within \pm 2 SD (standard deviations) of the most probable value (MPV), and within the acceptable QC range.

\section{Arsenic}

Preliminary QC information indicated that the analysis of arsenic with standard ICP-MS methods used by the NWQL failed to pass laboratory quality controls due to sample-matrix interferences. An alternative standard method for the analysis of arsenic is through conversion of arsenic to arsenic hydride (arsine) and analysis of arsenic hydride by atomic fluorescence spectrometry (Hageman and others, 2002).

The determination of total arsenic requires that all the arsenic be in the inorganic As(III) state. Organic and inorganic forms of arsenic are first oxidized to $\mathrm{As}(\mathrm{V})$ by digestion with a mixture of saturated potassium persulfate and concentrated hydrochloric acid in open polychlorofluorocarbon vessels. The $\mathrm{As}(\mathrm{V})$ is then quantitatively reduced to As(III) by adding a 
potassium iodide/ascorbic acid reagent. Sodium borohydride is added to the solution, which results in rapid formation of the arsenic hydride as illustrated by:

$$
3 \mathrm{NaBH}_{4}+4 \mathrm{H}_{3} \mathrm{AsO}_{3} \rightarrow 4 \mathrm{AsH}_{3}(g)+3 \mathrm{H}_{3} \mathrm{BO}_{3}+3 \mathrm{NaOH}
$$

The gaseous arsine is phase separated from the analytical solution stream and transported with argon gas to the atomizer (a hydrogen flame) of the atomic fluorescence spectrometer. The sodium borohydride reducing agent, by rapid generation of the elemental hydride in the reaction cell, minimizes dilution of the arsine by the carrier gas and provides rapid, sensitive determinations of arsenic.

Concentrations of arsenic in the samples are quantified using calibration standards in solutions of a similar matrix. QC information for arsenic determinations was obtained by digesting, and subsequently analyzing, water reference samples purchased from the National Research Council, Canada (NASS-5 seawater and SLEW-3 estuarine water) that have certified values for their arsenic concentrations in highly saline media. QC data were also obtained by digesting and determining the total arsenic content of four different aqueous standard reference samples ("T" standards) produced by the USGS's BQS, and on the basis of recoveries obtained from laboratory spikes of reagent blanks, field blanks, and groundwater samples.

All laboratory control data indicated that the arsenic water-quality data are suitable for interpretation. Laboratory QC data for arsenic were within acceptable limits (table B15, link to Excel file). All laboratory (and field) blanks contained trace $(0.10-0.15 \mu \mathrm{g} / \mathrm{L})$, or immeasurable $(<0.10 \mu \mathrm{g} / \mathrm{L})$, concentrations of arsenic. Thus, trace levels of arsenic in groundwater and surface-water samples could reflect a very low level contamination bias. Despite considerable differences in the range of dilution rates among samples, recoveries on spiked samples of all types - laboratory blanks, field blanks, duplicate sequential samples, and water-quality samples - were similar, and all were within the generally acceptable control range for standard NWQL ICP-MS methods for trace elements (80-120 percent). In addition, all standard reference sample concentrations fell within the acceptable range of being within $\pm 3 \mathrm{SD}$ of the MPV, and in most cases were within $\pm 2 \mathrm{SD}$ of the MPV. The arsenic concentrations in the spiked and reference samples were similar to the range of arsenic values found in groundwater and surface-water samples from the study area.

\section{Sulfate}

The analysis of sulfate in water is routinely conducted by the USGS NWQL with a standard ICP method (Garbarino and Struzeski, 1998). Preliminary QC information for selected samples repeatedly failed to pass laboratory quality controls due to sample-matrix interferences - generally related to samples with elevated concentrations of dissolved recoverable solids. An alternative standard method for the analysis of sulfate is to convert sulfate (ion) to barium sulfate (solid)

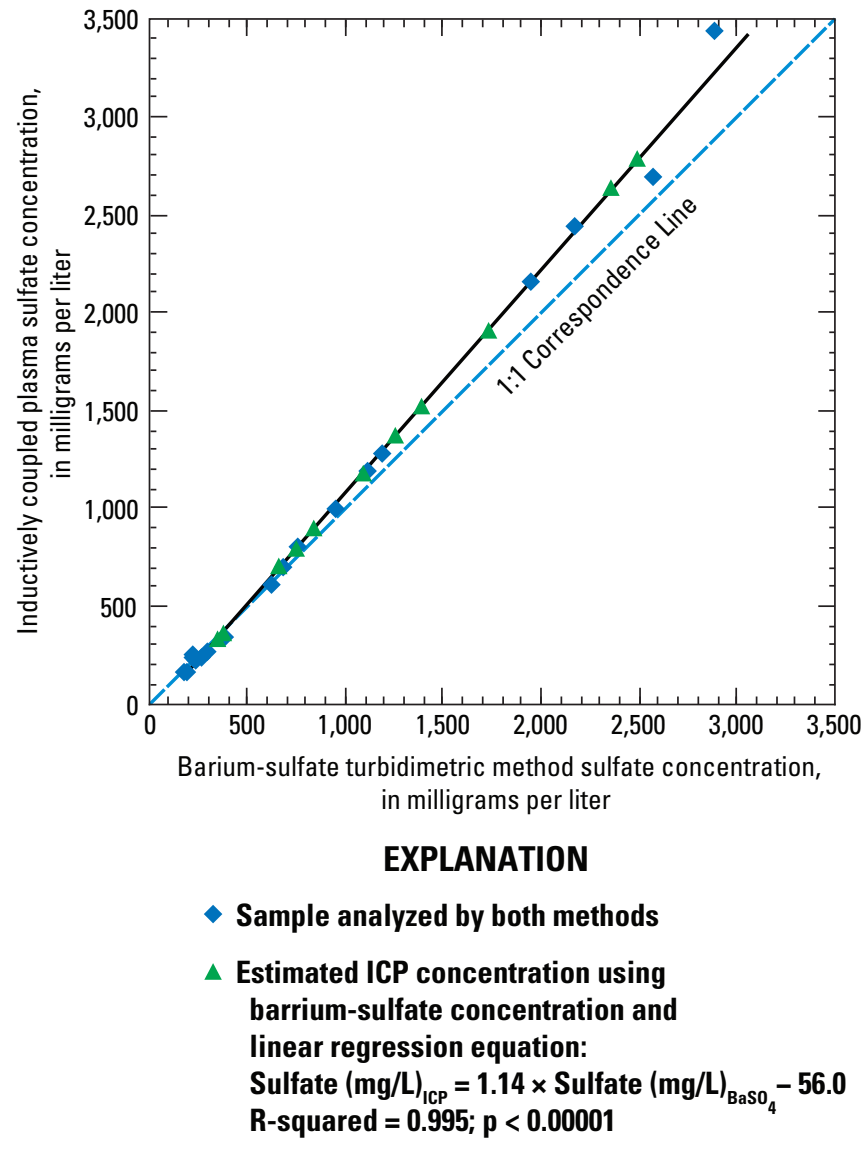

Figure B1. Relation between sulfate concentration in milligrams per liter (mg/L) determined with the barium-sulfate method and the inductively coupled plasma (ICP) method for samples collected in the Pearce Creek Dredge Material Containment Area and vicinity, Cecil County, Maryland, 2010-11.

and measure a colloidal dispersion of the barium sulfate with a nephelometric turbidimeter (U.S. Environmental Protection Agency, 2005, Method 375.4). The concentration of sulfate in the sample is determined as a ratio against similarly prepared and analyzed barium-sulfate standards. General comparisons between these two methods have shown that they provide similar results given low dilution rates are maintained for the barium-sulfate analyses (Reisman and others, 2007).

For the purposes of this report-and the analysis and interpretation of sulfate data-we employed a nephelometric turbidity ratio unit spectrophotometer and the Hach, Inc. $(2008 \mathrm{a}, \mathrm{b})$ methods for barium-sulfate analyses. Limitations in this method are twofold. First, the method reporting level for the barium-sulfate method $(40 \mathrm{mg} / \mathrm{L})$ is higher than the method reporting level for the ICP method $(10 \mathrm{mg} / \mathrm{L})$. Second, the dilution rate for the barium-sulfate method had to be generally less than 5:1 to avoid bias in measurements related to the use of high dilution rates (Reisman and others, 2007).

Because of limitations in dilution rates and a high method reporting level, data from the barium-sulfate method were correlated to data from the ICP method on the basis of samples 
analyzed with both methods. The established linear relation between sulfate concentrations then was used to estimate the concentration of sulfate relative to the ICP method on the basis of the concentration of sulfate determined with the bariumsulfate method for those groundwater samples with sulfate concentrations that could not be determined with the ICP method.

The relation between sulfate concentrations on the basis of samples analyzed with both methods was linear, positive, and highly significant (fig. B1, correlation coefficient (R-squared) equal to 0.995 , and power of test, $\mathrm{p}$, less than 0.00001). In addition, results were consistent between the two methods in relation to field blanks - the barium-sulfate method reporting as $<40 \mathrm{mg} / \mathrm{L}$ and the ICP method reporting as $<0.18 \mathrm{mg} / \mathrm{L}$ (table B16, link to Excel file).

\section{Validation of Net Acidity with Hot Acidity Titrations}

Kirby and Cravotta (2005b) recommended that net acidity be determined as follows:

$$
\text { Acidity }_{\text {Net }}=\text { Acidity }_{\text {Calculated }}-\text { Alkalinity }_{\text {StdMthd }}
$$

Where each of the above terms is expressed in milligrams per liter as calcium carbonate $\left(\mathrm{CaCO}_{3}\right)$, Alkalinity ${ }_{\text {StdMthd }}$ is determined by standard methods, and Acidity ${ }_{\text {Calculated }}$ is given by:

$$
\begin{aligned}
\text { Acidity }_{\text {Calculated }} & 50\left\{1,000\left(10^{-\mathrm{pH}}\right)+\left[2\left(\mathrm{Fe}^{2+}\right)+3\left(\mathrm{Fe}^{3+}\right)\right] / 56+\right. \\
& \left.2\left(\mathrm{Mn}^{2+}\right) / 55+3\left(\mathrm{Al}^{++}\right) / 27\right\}
\end{aligned}
$$

Where the $\mathrm{pH}$ is measured and expressed in standard units, the total dissolved metal $\left(\mathrm{Fe}^{2+}, \mathrm{Fe}^{3+}, \mathrm{Mn}^{2+}\right.$ and $\left.\mathrm{Al}^{3+}\right)$ concentrations are in milligrams per liter, each converted to milliequivalents per liter, using their valences and formula weights, and the entire expression then converted to $\mathrm{mg} / \mathrm{L}$ as $\mathrm{CaCO}_{3}$.

Kirby and Cravotta (2005b) also recommend validation of Acidity ${ }_{\text {Net }}$ be conducted by direct measurements obtained through hot acidity titrations. These titrations were performed in accordance with Kirby and Cravotta (2005b), and equivalent on selected groundwater samples reflecting the range in Acidity $_{\text {Net }}$ as determined above. In brief, titrations were performed on groundwater samples after initially reducing their $\mathrm{pH}$ to 4 within 24 hours to preserve samples (Kirby and Cravotta, 2005b). Preserved samples were digested with 30 percent hydrogen peroxide with heating to drive off carbon dioxide, and then titrated to a $\mathrm{pH}$ of approximately 8.2. The acidity of the sample in milligrams per liter as $\mathrm{CaCO}_{3}$ was determined in accordance with procedures described by Kirby and Cravotta (2005b), which hereafter, is referred to as Acidity $_{\text {hot }}$ in this appendix.
On the basis of theoretical considerations and empirical studies, Kirby and Cravotta (2005b) have shown that Acidity $_{\mathrm{Net}}$ is equal to Acidty ${ }_{\text {hot }}$. Therefore, the two measurements should be linearly and positively correlated. Comparisons of Acidity ${ }_{\text {Net }}$ with Acidity $_{\text {hot }}$ - a direct measure of Acidity Calculated $_{\text {- Alkalinity }}$ StdMthd $_{\text {, }}$, were conducted using standard methods (Kirby and Cravotta, 2005b). The two measures were highly, positively, and linearly related (fig. B2, correlation coefficient (R-squared) equal to 0.997 , and power of test, $p$, less than 0.00001). Acidity ${ }_{\text {hot }}$ values were biased low at high acidity concentrations. The values for CE Dd 127 and 160 are considered outliers, with potential low bias in Acidity hot $_{\text {. }}$ The cause of this bias was investigated but remains unknown (C. Cravotta, III, USGS, written commun., 2010). It possibly could be related to the slow hydrolization of manganese, which has been found to occur in acid-mine drainage waters with elevated concentrations of manganese and dissolved organic carbon (Tewalt, 2004). Most groundwater samples in the DMCA and vicinity with elevated dissolved solids also contain elevated concentrations of dissolved recoverable organic carbon (see Dissolved Recoverable Organic Carbon, main report). Thus, Acidity ${ }_{\text {Net }}$ values as determined by equations (B2) and (B3) likely are accurate with Acidity hot $_{\text {likely }}$ being underestimated.

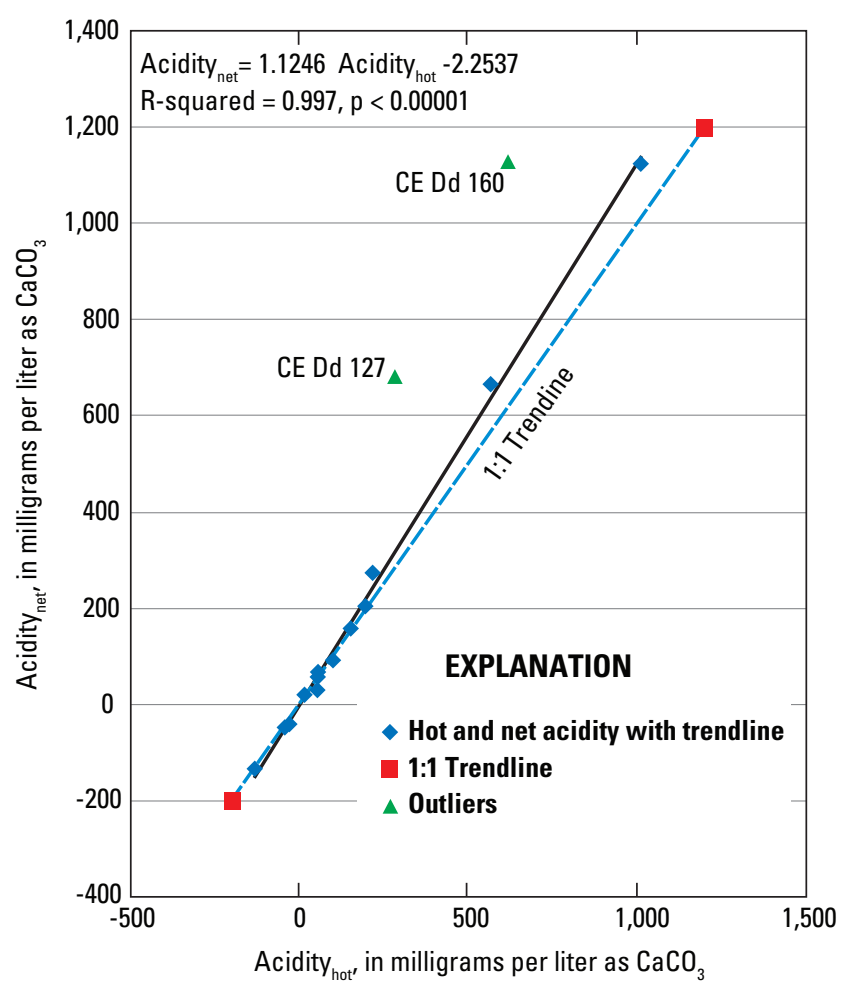

Figure B2. Relation between Acidity ${ }_{\text {Net }}$ and Acidity ${ }_{\text {hot }}$ (both in milligrams per liter (mg/L) as $\mathrm{CaCO}_{3}$ ) for selected groundwater samples collected in the Pearce Creek Dredge Material Containment Area and vicinity, 2010. 


\section{Acknowledgments}

The authors would like to thank the following chemists for their collaborative efforts to develop modified standard methods that were used to analyze the water samples for arsenic and beryllium, their thorough summaries of method modifications, and their reviews of the resultant data: Donna Damrau, Supervisory Chemist, and Mark Hill, Research Chemist, USGS NWQL, Denver, Colorado, Paul Lamothe, Research Chemist, USGS Geologic Discipline Mineral Resources Program Laboratory, Denver, Colorado; and Anthony Bednar, Research Chemist, USACE Environmental Laboratory, Engineer Research and Development Center, Vicksburg, Mississippi.

\section{References Cited}

American Public Health Association (APHA), 1998a, Acidity titration method 2310, in Standard methods for the examination of water and wastewater, 20th ed.: American Public Health Association, American Water Works Association, and Water Environment Federation, Washington, D.C., $1,325 \mathrm{p}$.

American Public Health Association (APHA), 1998b, Sulfide method 4500-S2-(D), in Standard methods for the examination of water and wastewater, 20th ed.: American Public Health Association, American Water Works Association, and Water Environment Federation, Washington, D.C., $1,325 \mathrm{p}$.

Anderson, C.W., 2005, Turbidity (ver. 2.1): U.S. Geological Survey Techniques of Water-Resources Investigations, book 9, chap. A6, sec. 6.7, 55 p., accessed September 28, 2010, at http://pubs.water.usgs.gov/twri9A/.

Clesceri, L.S., Greenberg, A.E., and Eaton, A.D., ed., 1998, Standard methods for the examination of water and wastewater, 20th ed.: ISBN: 0875532357, American Public Health Association, Washington, D.C., 1,325 p.

Fishman, M.J., ed., 1993, Methods of analysis by the U.S. Geological Survey National Water Quality LaboratoryDetermination of inorganic and organic constituents in water and fluvial sediments: U.S. Geological Survey OpenFile Report 93-125, $217 \mathrm{p}$.

Fishman, M.J., and Friedman, L.C., eds., 1989, Methods for determination of inorganic substances in water and fluvial sediments: U.S. Geological Survey Techniques of WaterResources Investigations, book 5, chap. A1, 545 p.
Garbarino, J.R., 1999, Methods of analysis by the U.S. Geological Survey National Water Quality LaboratoryDetermination of dissolved arsenic, boron, lithium, selenium, strontium, thallium, and vanadium using inductively coupled plasma-mass spectrometry: U.S. Geological Survey Open-File Report 99-093, 31 p.

Garbarino, J.R., 2000, Methods of analysis by the U.S. Geological Survey, National Water Quality LaboratoryDetermination of whole-water recoverable arsenic, boron, and vanadium using inductively coupled plasmamass spectrometry: U.S. Geological Survey Open-File Report 99-464, 15 p.

Garbarino, J.R., and Hoffman, G.L., 1999, Methods of analysis by the U.S. Geological Survey National Water Quality Laboratory-Comparison of a nitric acid in-bottle digestion procedure to other whole-water digestion procedures: U.S. Geological Survey Open-File Report 99-094, 23 p.

Garbarino, J.R., Kanagy, L.K., and Cree, M.E., 2006, Determination of elements in natural-water, biota, sediment and soil samples using collision/reaction cell inductively coupled plasma-mass spectrometry: U.S. Geological Survey Techniques and Methods, book 5, chap. 1, sec. B, 88 p.

Garbarino, J.R., and Struzeski, T.M., 1998, Methods of analysis by the U.S. Geological Survey National Water Quality Laboratory-Determination of elements in whole-water digests using inductively coupled plasma-optical emission spectrometry and inductively coupled plasmamass spectrometry: U.S. Geological Survey Open-File Report 98-165, 101 p.

Gibs, J., Wilde, F.D., and Heckathorn, H.A., 2007, Use of multiparameter instruments for routine field measurements (ver. 1.1): U.S. Geological Survey Techniques of Water-Resources Investigations, book 9, chap. A6, sec. 6.8, August, accessed September 28, 2010, at http://pubs.water. usgs.gov/twri9A6/.

Hach, Inc, 2008a, Sulfate, turbidimetric method 10227 TNTplus 864 low range (40 to $150 \mathrm{mg} / \mathrm{L} \mathrm{SO} 42-$ ) for drinking water, wastewater, raw water, and process control, 5 th ed.: Hach Company, Incorporated, Loveland, Colo., 4 p.

Hach, Inc, 2008b, Sulfate, turbidimetric method 10227 TNTplus 865 high range (150 to $900 \mathrm{mg} / \mathrm{L} \mathrm{SO42-)}$ for drinking water, wastewater, raw water, and process control, 5 th ed.: Hach Company, Incorporated, Loveland, Colo., 4 p.

Hageman, P.L., Brown, Z.A., and Welsch, E., 2002, Arsenic and selenium by flow injection or continuous flow-hydride generation-atomic absorption spectrometry, in Taggart, J.E., ed., Analytical methods for chemical analysis of geologic and other materials, U.S. Geological Survey: U.S. Geological Survey Open-File Report 02-223, Chapter L, 7 p. 
Hoffman, G.L., Fishman, M.J., and Garbarino, J.R., 1996, Methods of analysis by the U.S. Geological Survey National Water Quality Laboratory-In-bottle acid digestion of whole-water samples: U.S. Geological Survey, Open-File Report 96-225, $28 \mathrm{p}$.

Kirby, C.S., and Cravotta, C.A., III, 2005a, Net alkalinity and net acidity 1: Theoretical considerations: Applied Geochemistry, v. 20, no. 10, p. 1920-1940. (Also available at $h t t p: / / w w w . s c i e n c e d i r e c t . c o m / s c i e n c e / a r t i c l e / p i i /$ S088329270500137X.)

Kirby, C.S., and Cravotta, C.A., III, 2005b. Net alkalinity and net acidity 2: Practical considerations: Applied Geochemistry, v. 20, no. 10, p. 1,941-1,964. (Also available at $h t t p: / / w w w . s c i e n c e d i r e c t . c o m / s c i e n c e / a r t i c l e / p i i /$ S0883292705001381.)

Lee, E.A., Kish, J.L., Zimmerman, L.R., and Thurman, E.M., 2001, Methods of analysis by the U.S. Geological Survey Organic Geochemistry Research Group-Update and additions to the determination of chloroacetanilide herbicide degradation compounds in water using high-performance liquid chromatography/mass spectrometry: U.S. Geological Survey Open-File Report 01-10, 17 p.

Lee, E.A., Strahan, A.P., and Thurman, E.M., 2002, Methods of analysis by the U.S. Geological Survey Organic Geochemistry Research Group-Determination of triazine and phenylurea herbicides and their degradation products in water using solid-phase extraction and liquid chromatography/mass spectrometry: U.S. Geological Survey Open-File Report 02-436, 26 p. (Also available at http://ks.water.usgs. gov/pubs/reports/of.02-436.pdf.)

Lewis, M.E., 2006, Dissolved-oxygen concentration (ver. 2.1): U.S. Geological Survey Techniques of Water-Resources Investigations, book 9, chap. A6, sec. 6.2, June, accessed September 28, 2010, at http://pubs.water.usgs.gov/twri9A6/.

Nordstrom, D.K., and Wilde, F.D., 2005, Reduction-oxidation potential (ver. 1.2): U.S. Geological Survey Techniques of Water-Resources Investigations, book 9, chap. A6, sec. 6.5, September, accessed September 28, 2010, at $h t t p: / / p u b s$. water.usgs.gov/twri9A6/.

Patton, C.J., and Kryskalla, J.R., 2011, Colorimetric determination of nitrate plus nitrite in water by enzymatic reduction, automated discrete analyzer methods: U.S. Geological Survey Techniques and Methods, book 5, chap. B8, 34 p.
Patton, C.J., and Truitt, E.P., 1992, Methods of analysis by the U.S. Geological Survey National Water Quality Laboratory-Determination of total phosphorus by a Kjeldahl digestion method and an automated colorimetric finish that includes dialysis: U.S. Geological Survey Open-File Report 92-146, 39 p.

Patton, C.J., and Truitt, E.P., 2000, Methods of analysis by the U.S. Geological Survey National Water Quality Laboratory-Determination of ammonium plus organic nitrogen by a Kjeldahl digestion method and an automated photometric finish that includes digest cleanup by gas diffusion: U.S. Geological Survey Open-File Report 00-170, 31 p.

Radtke, D.B., Davis, J.V., and Wilde, F.D., 2005, Specific electrical conductance (ver. 1.2): U.S. Geological Survey Techniques of Water-Resources Investigations, book 9, chap. A6, sec. 6.3, August, accessed September 28, 2010, at http://pubs.water.usgs.gov/twri9A6/.

Reisman, D.J., Sundaram, V., Al-Abed, S.R., and Allen, D., 2007, Statistical validation of sulfate quantification methods used for analysis of acid mine drainage: Talanta, v. 71, p. 303-311.

Ritz, G.F., and Collins, J.A., 2008, pH (ver. 2.0): U.S. Geological Survey Techniques of Water-Resources Investigations, book 9, chap. A6, sec. 6.4, October, accessed September 28, 2010, at http://pubs.water.usgs.gov/twri9A6/.

Tewalt, S.J., 2004, The use of ozone to remediate dissolved manganese from coal mine drainage, abs., in Northeastern Section (39th Annual) and Southeastern Section (53rd Annual) Joint Meeting March 25-27, 2004, McLean, Va., Geological Society of America, Abstracts, v. 36. no. 2, p. 82 .

U.S. Army Corps of Engineers, 1996, Pearce Creek Disposal Area Groundwater Investigation, Pearce Creek, Maryland, Phase II Report: U.S. Army Corp of Engineers, Philadelphia District, Philadelphia, Penn., 240 p. including 5 apps.

U.S. Environmental Protection Agency, 2005, B.3.11 EPA Methods 375.3 and 375.4 (Sulfate), p. B9, in U.S. Environmental Protection Agency Aquiculture Guide, Appendix B: 508 Analytical methods and nominal quantification limits, 15 p., accessed May 5, 2010, at http://water.epa.gov/scitech/ wastetech/guide/aquaculture/upload/2005_09_01_guide_ aquaculture_add_appendixb_508.pdf.

Weston, R.F., Inc., 1998, Review of groundwater investigations for the Pearce Creek Dredge Disposal Containment Area, Final report to the U.S. Army Corps of EngineersPhiladelphia District, Weston, R.F., Inc. Westchester, Penn., 73 p. with 2 additional apps. 
Wilde, F.D., 2006, Temperature (ver. 2.0): U.S. Geological Survey Techniques of Water-Resources Investigations, book 9, chap. A6, sec. 6.1, March, accessed September 28, 2010, at http://pubs.water.usgs.gov/twri9A6/.

Zaugg, S.D., Smith, S.G., and Schroeder, M.P., 2006, Methods of analysis by the U.S. Geological Survey National Water Quality Laboratory-Determination of wastewater compounds in whole water by continuous liquid-liquid extraction and capillary-column gas chromatography/mass spectrometry: U.S. Geological Survey Techniques and Methods, book 5, chap. B4, 30 p. 


\section{Appendix C: Descriptive Logs of Boreholes in the Pearce Creek Dredge Material Containment Area and Vicinity, Cecil County, Maryland, 2010-11}

\begin{tabular}{ll}
\multicolumn{2}{l}{ List of boreholes } \\
\hline CE Dd 136 & CE Dd 150 \\
CE Dd 137 & CE Dd 151 \\
CE Dd 138 & CE Dd 152 \\
CE Dd 139 & CE Dd 153 \\
CE Dd 140 & CE Dd 154 \\
CE Dd 141 & CE Dd 155 \\
CE Dd 142 & CE Dd 156 \\
CE Dd 143 & CE Dd 157 \\
CE Dd 144 & CE Dd 158 \\
CE Dd 145 & CE Dd 159 \\
CE Dd 146 & CE Dd 160 \\
CE Dd 147 & CE Dd 191 \\
CE Dd 148 & CE Dd 192 \\
CE Dd 149 & CE Dd 193
\end{tabular}

Conversion factors

Inch/Pound to SI

\begin{tabular}{|c|c|c|}
\hline Multiply & By & To obtain \\
\hline \multicolumn{3}{|c|}{ Length } \\
\hline inch (in.) & 2.54 & centimeter $(\mathrm{cm})$ \\
\hline inch (in.) & 25.4 & millimeter (mm) \\
\hline foot $(\mathrm{ft})$ & 0.3048 & meter $(\mathrm{m})$ \\
\hline mile (mi) & 1.609 & kilometer (km) \\
\hline
\end{tabular}

Vertical coordinate information is referenced to the North American Vertical Datum of 1988 (NAVD 88).

Horizontal coordinate information is referenced to the North American Datum of 1983 (NAD 83).

Altitude, as used in this report, refers to distance above the vertical datum.

Apparent conductivity (AP-COND) is given in millimhos per meter, which is equivalent to milliSiemens per meter.

Gamma logs are given in units of American Petroleum Institute gamma ray units (API-GR). 


\section{Abbreviations and acronyms}

$\begin{array}{ll}\text { AP-COND } & \text { apparent conductivity (from borehole geophysical log) } \\ \text { API-GR } & \text { American Petroleum Institute gamma ray units } \\ \text { DMCA } & \text { dredge material containment area } \\ \text { GAMMA } & \text { natural gamma radiation (from borehole geophysical log) } \\ \text { NAVD 88 } & \text { North American Vertical Datum of 1988 } \\ \text { NGVD29 } & \text { National Geodetic Vertical Datum of 1929 } \\ \text { UPA, deep } & \text { upper Patapsco aquifer, deep water-bearing zone } \\ \text { UPA, shallow } & \text { upper Patapsco aquifer, shallow water-bearing zone } \\ \text { USACE } & \text { U.S. Army Corps of Engineers } \\ \text { USGS } & \text { U.S. Geological Survey } \\ \text { WSC } & \text { Water Science Center of the U.S. Geological Survey } \\ \text { WVS } & \text { West View Shores residential community }\end{array}$




\section{EXPLANATION}

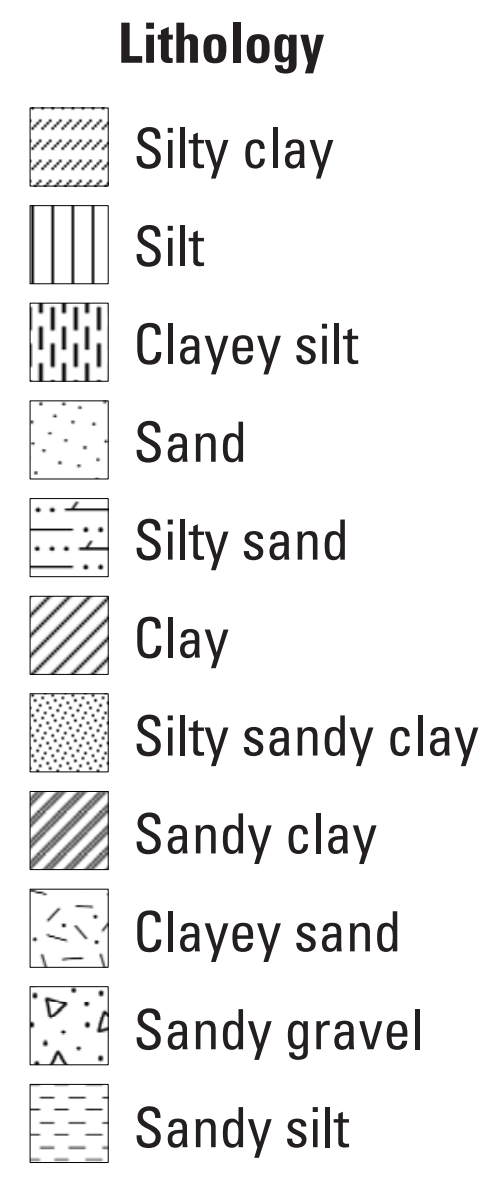

Aquifer

$\square$ Magothy
$\square$ UPA, shallow
$\square$ UPA, deep
$\square$ Matawan confining unit
Confining unit

Well construction Cement with grout

Bentonite

Sand \#00

$\because$ Sand \#01

Casing Screen 


\begin{tabular}{|c|c|c|c|}
\hline $\begin{array}{l}\text { Station ID: } 392556075590002 \\
\text { Date Began: } 3 / 31 / 2010 \\
\text { Date Completed: } 3 / 31 / 2010 \\
\text { Logged By: J. Sorenson }\end{array}$ & $\begin{array}{l}\text { Boring Depth (Feet): } 59 \\
\text { Well Depth (Feet): } 55 \\
\text { Screen Size (Inches): } 0.02 \\
\text { Drilling Method: Sonic } \\
\text { Driller: Boart Longyear }\end{array}$ & $\begin{array}{l}\text { Latitude } 39^{\circ} 25^{\prime} 55.7^{\prime \prime} \mathrm{N} \\
\text { (NAD 83): } \\
\text { Longitude } 75^{\circ} 59^{\prime} 00.2^{\prime \prime} \mathrm{W} \\
\text { (NAD 83): } \\
\text { Land Surface Elevation } 38.45 \\
\text { (NAVD 88): }\end{array}$ & $\begin{array}{c}\text { CE Dd } 136 \\
\text { Pearce Creek } \\
\text { Dredge Material Containment Area } \\
\text { Cecil County, Maryland }\end{array}$ \\
\hline $\begin{array}{lc}\text { Scale } & \text { Lithologic } \\
\text { (Feet) } & \text { Log }\end{array}$ & & Lithologic Description & Aquifer \\
\hline
\end{tabular}

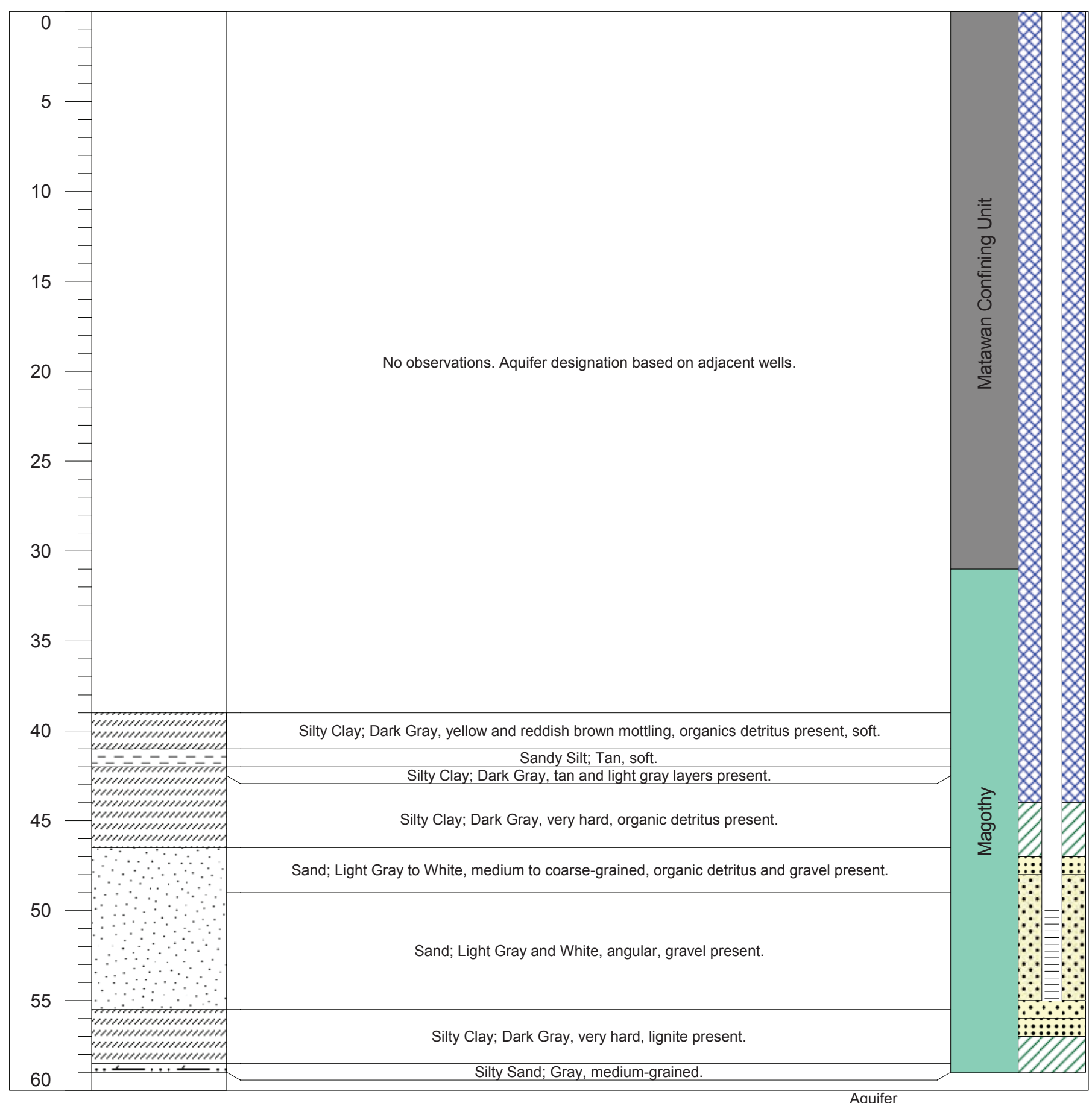

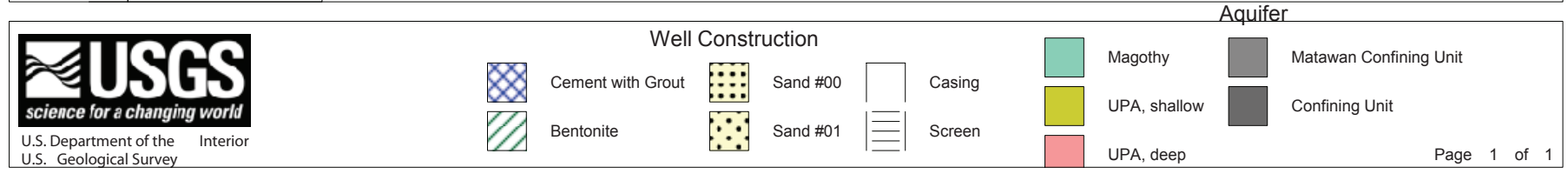




\begin{tabular}{|c|c|c|c|}
\hline $\begin{array}{l}\text { Station ID: } 392527075590802 \\
\text { Date Began: 4/6/2010 } \\
\text { Date Completed: 4/7/2010 } \\
\text { Logged By: A. Massey }\end{array}$ & $\begin{array}{l}\text { Boring Depth (Feet): } 70 \\
\text { Well Depth (Feet): } 63 \\
\text { Screen Size (Inches): } 0.015 \\
\text { Drilling Method: Sonic } \\
\text { Driller: Boart Longyear }\end{array}$ & $\begin{array}{l}\text { Latitude } \\
\text { (NAD 83): } 39^{\circ} 25^{\prime} 27.2^{\prime \prime} \mathrm{N} \\
\text { Longitude } 75^{\circ} 59^{\prime} 08.1^{\prime \prime} \mathrm{W} \\
\text { (NAD 83): } \\
\text { Land Surface Elevation } 36.82 \\
\text { (NAVD 88): }\end{array}$ & $\begin{array}{c}\text { CE Dd 137 } \\
\text { Pearce Creek } \\
\text { Dredge Material Containment Area } \\
\text { Cecil County, Maryland }\end{array}$ \\
\hline $\begin{array}{lc}\text { Scale } & \text { Lithologic } \\
\text { (Feet) } & \text { Log }\end{array}$ & & jic Description & Aquifer \\
\hline
\end{tabular}

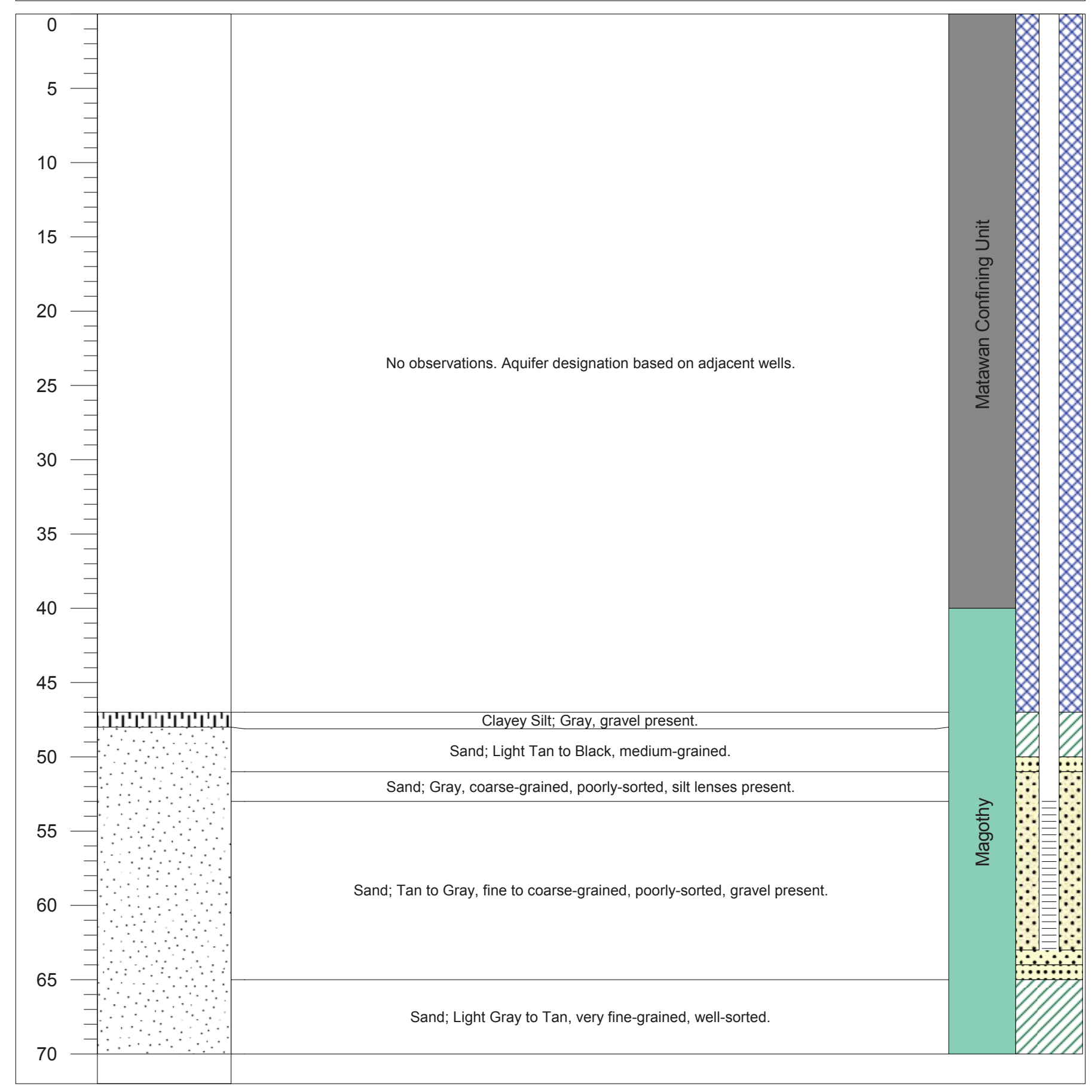

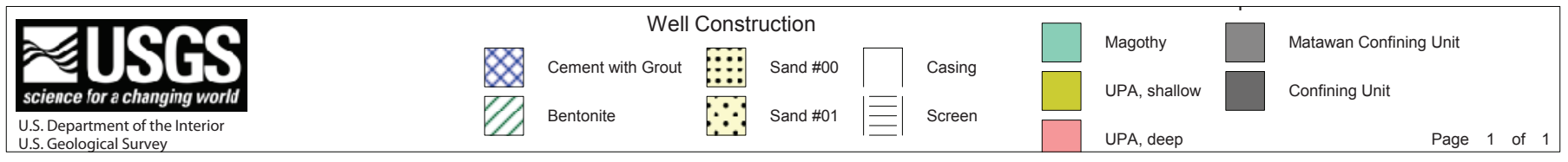




\begin{tabular}{|c|c|c|c|}
\hline $\begin{array}{l}\text { Depth } \\
\text { AP-COND }\end{array}$ & $\begin{array}{l}\text { Lithologic } \\
\quad \text { Log }\end{array}$ & Lithologic Description & Aquifer \\
\hline
\end{tabular}

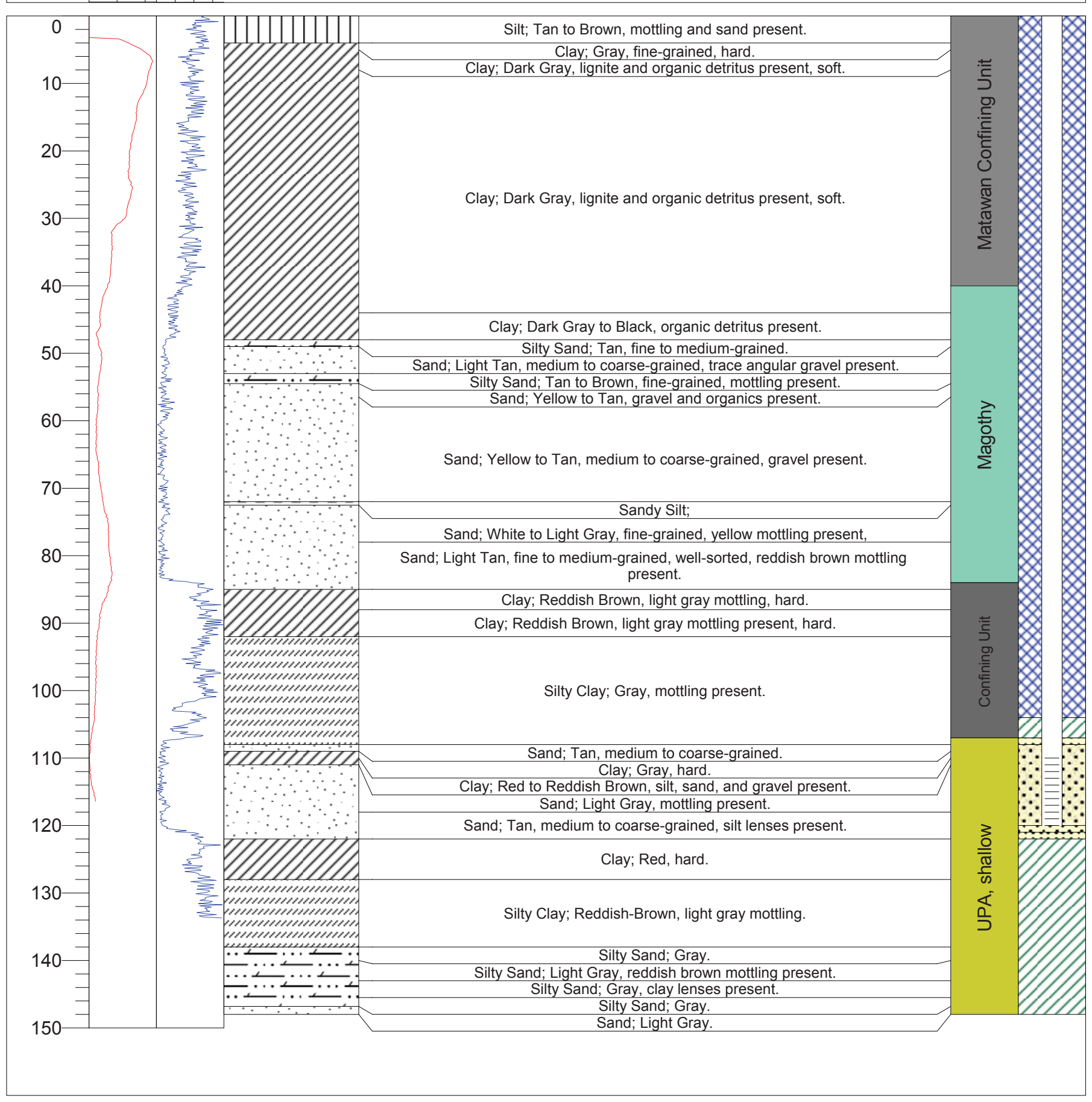

\section{EUSGS}

U.S. Department of the Interior

U.S. Geological Survey

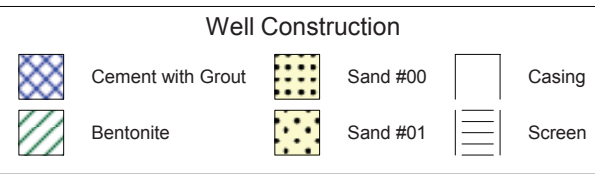

$\square$ Magothy
$\square$ UPA, shallow
$\square$ UPA, deep

Matawan Confining Unit

Confining Unit

Page 1 of 1 


\begin{tabular}{|c|c|c|c|}
\hline $\begin{array}{l}\text { Station ID: } 392536075592003 \\
\text { Date Began: } 3 / 30 / 2010 \\
\text { Date Completed: } 3 / 30 / 2010 \\
\text { Logged By: A. Massey }\end{array}$ & $\begin{array}{l}\text { Boring Depth (Feet): } 59 \\
\text { Well Depth (Feet): } 58 \\
\text { Screen Size (Inches): } 0.02 \\
\text { Drilling Method: Sonic } \\
\text { Driller: Boart Longyear }\end{array}$ & $\begin{array}{l}\text { Latitude } \\
\text { (NAD 83): } 39^{\circ} 25^{\prime} 35.7^{\prime \prime} \mathrm{N} \\
\text { Longitude } 75^{\circ} 59^{\prime} 19.8^{\prime \prime} \mathrm{W} \\
\text { (NAD 83): } \\
\text { Land Surface Elevation } 34.86 \\
\text { (NAVD 88): }\end{array}$ & $\begin{array}{c}\text { CE Dd 139 } \\
\text { Pearce Creek } \\
\text { Dredge Material Containment Area } \\
\text { Cecil County, Maryland }\end{array}$ \\
\hline $\begin{array}{lc}\text { Depth } & \text { Lithologic } \\
\text { (Feet) } & \text { Log }\end{array}$ & & Lithologic Description & Aquifer \\
\hline
\end{tabular}

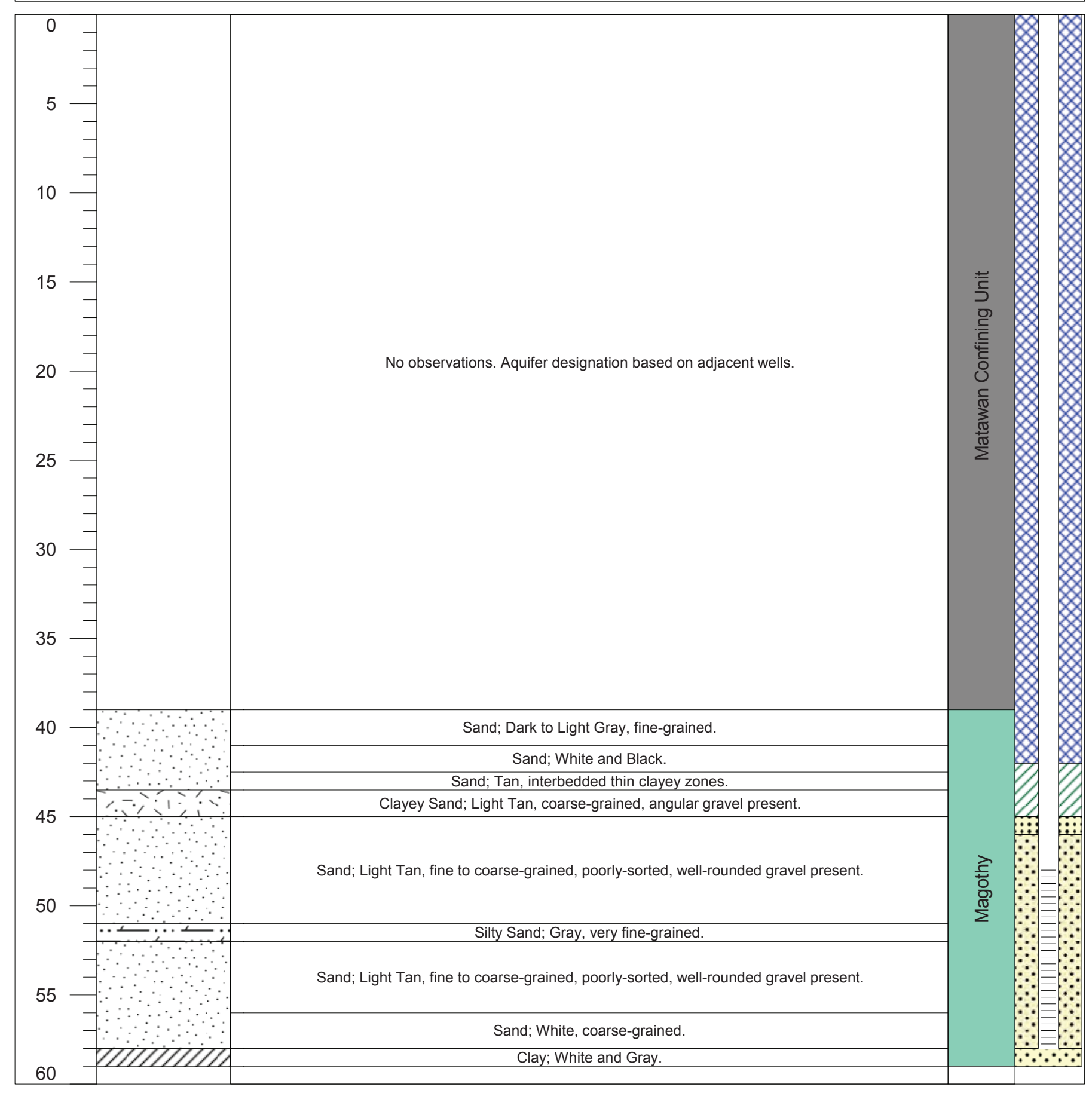

Q




\begin{tabular}{|c|c|c|c|}
\hline $\begin{array}{l}\text { Station ID: } 392548075593801 \\
\text { Date Began: 4/10/2010 } \\
\text { Date Completed: 4/10/2010 } \\
\text { Logged By: A. Massey }\end{array}$ & $\begin{array}{l}\text { Boring Depth (Feet): } 28 \\
\text { Well Depth (Feet): } 16 \\
\text { Screen Size (Inches): } 0.02 \\
\text { Drilling Method: Sonic } \\
\text { Driller: Boart Longyear }\end{array}$ & $\begin{array}{l}\text { Latitude } 39^{\circ} 25^{\prime} 48.4^{\prime \prime} \mathrm{N} \\
\text { (NAD 83): } \\
\text { Longitude } 75^{\circ} 59^{\prime} 39.1 \mathrm{~W} \\
\text { (NAD 83): } \\
\text { Land Surface Elevation } \\
\text { (NAVD 88): }\end{array}$ & $\begin{array}{c}\text { CE Dd } 140 \\
\text { Pearce Creek } \\
\text { Dredge Material Containment Area } \\
\text { Cecil County, Maryland }\end{array}$ \\
\hline $\begin{array}{lc}\text { Depth } & \text { Lithologic } \\
\text { (Feet) } & \text { Log }\end{array}$ & & Lithologic Description & Aquifer \\
\hline
\end{tabular}

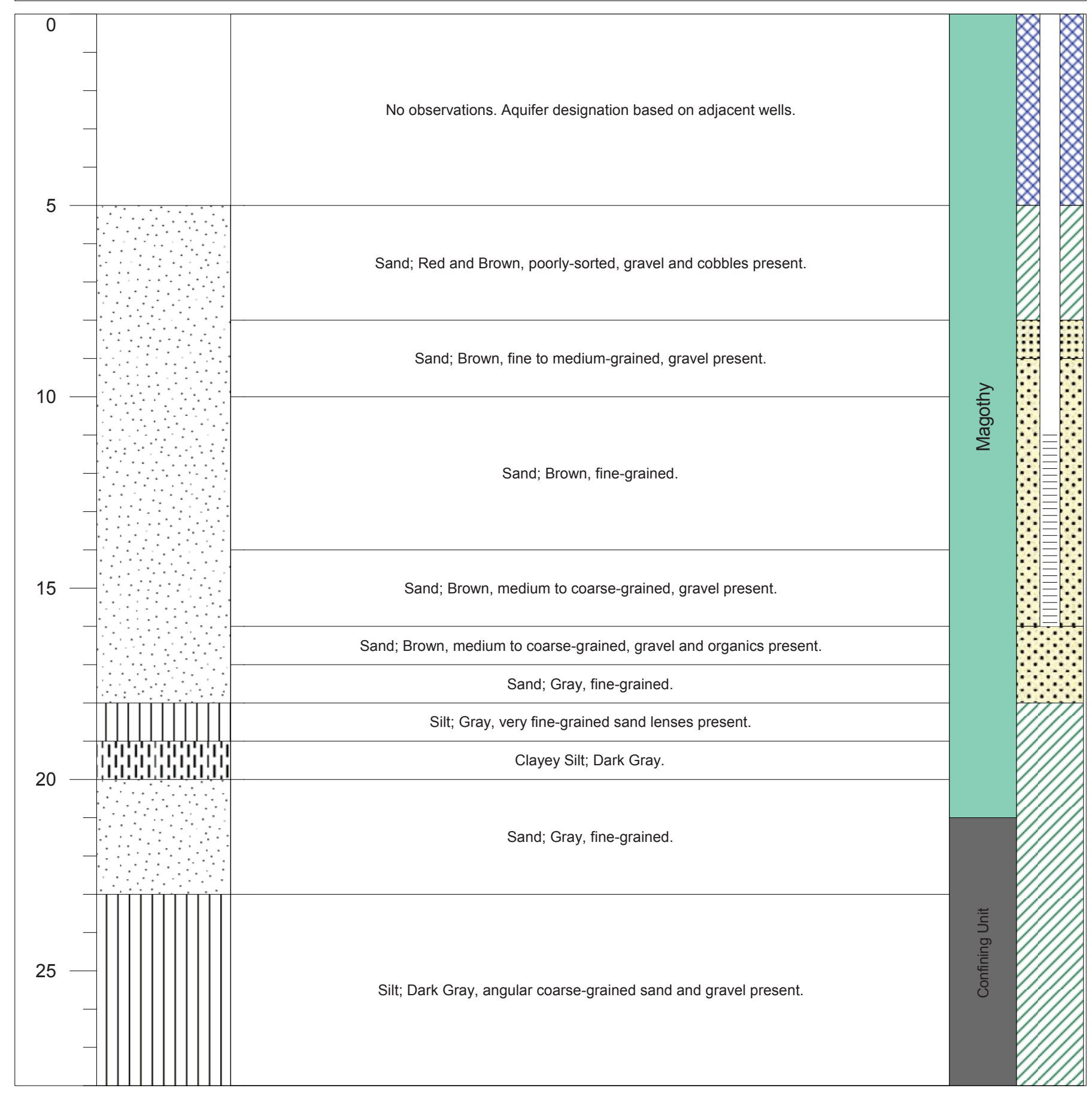

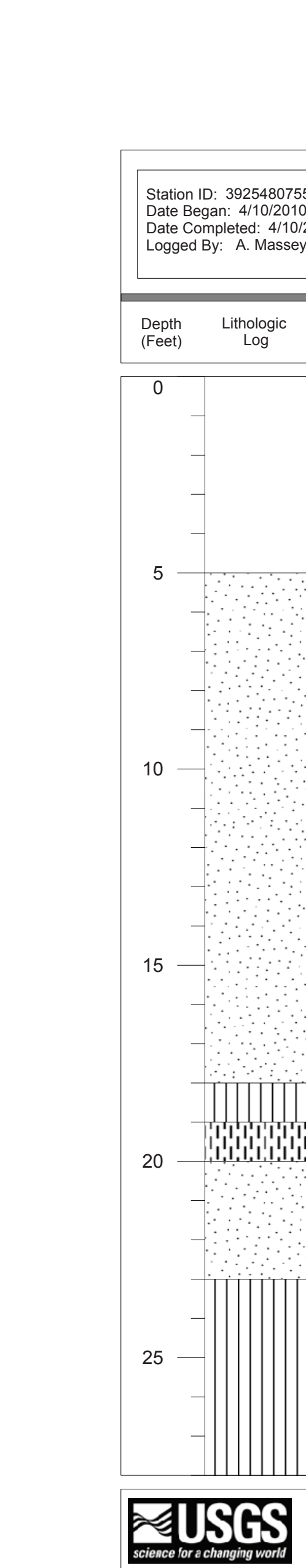

\begin{tabular}{|c|c|c|c|c|c|}
\hline \multirow{2}{*}{8} & \multicolumn{4}{|c|}{ Well Construction } & \\
\hline & Cement with Grout & $:::$ & Sand \#00 & & Casing \\
\hline$B$ & Bentonite & $\because \because$ & Sand \#01 & $\equiv$ & Screen \\
\hline
\end{tabular}

$\square$ Magothy
$\square$ UPA, shallow
$\square$ UPA, deep

Matawan Confining Unit

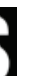

Q Bentonite

(Feet). 16

Drilling Method: Sonic

Longitude $75^{\circ} 59^{\prime} 39.1 " W$

(NAD 83):

Land Surface Elevation $\quad 11.47$

Cecil County, Maryland 


\begin{tabular}{|c|c|c|c|}
\hline $\begin{array}{l}\text { Station ID: } 392548075593802 \\
\text { Date Began: } 4 / 8 / 2010 \\
\text { Date Completed: } 4 / 9 / 2010 \\
\text { Logged By: A. Massey }\end{array}$ & $\begin{array}{l}\text { Boring Depth (Feet): } 228 \\
\text { Well Depth (Feet): } 222 \\
\text { Screen Size (Inches): } 0.02 \\
\text { Drilling Method: Sonic } \\
\text { Driller: Boart Longyear }\end{array}$ & $\begin{array}{l}\text { Latitude } \\
\text { (NAD 83): } 39^{\circ} 25^{\prime} 48.4^{\prime \prime N} \\
\text { Longitude } \\
\text { (NAD 83): } 75^{\circ} 59^{\prime} 38.1 " \mathrm{~W} \\
\text { Land Surface Elevation } 11.21 \\
\text { (NAVD 88): }\end{array}$ & $\begin{array}{c}\text { CE Dd 141 } \\
\text { Pearce Creek } \\
\text { Dredge Material Containment Area } \\
\text { Cecil County, Maryland }\end{array}$ \\
\hline $\begin{array}{l}\text { Depth } \\
\text { AP-COND }\end{array}$ & $\begin{array}{l}\text { Lithologic } \\
\text { Log }\end{array}$ & Lithologic Description & Aquifer \\
\hline
\end{tabular}

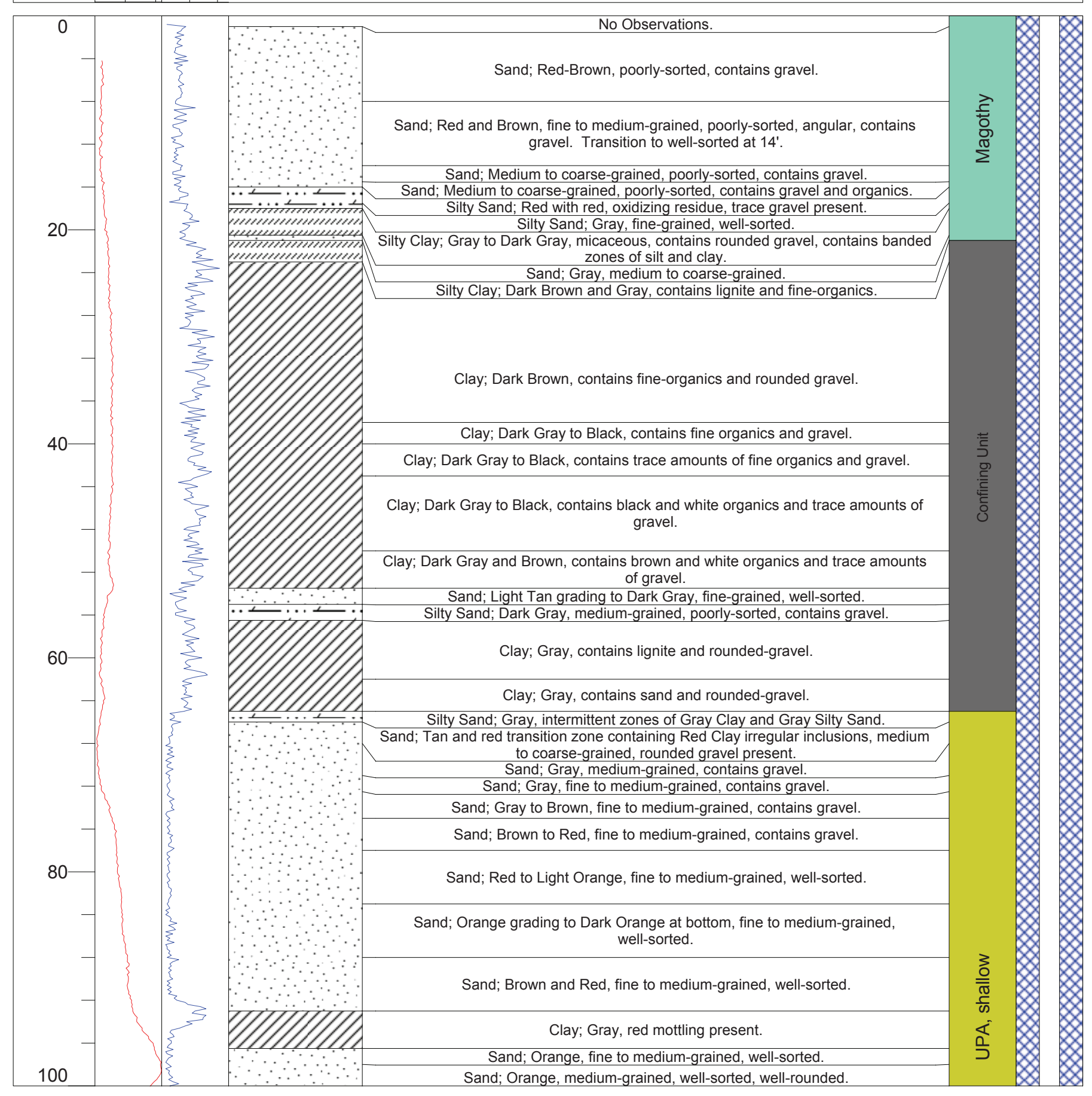

Well Construction
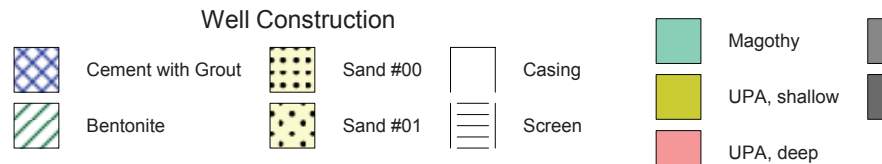

Matawan Confining Unit Confining Unit UPA, deep 


\begin{tabular}{|c|c|c|c|}
\hline $\begin{array}{l}\text { Station ID: } 392548075593802 \\
\text { Date Began: } 4 / 8 / 2010 \\
\text { Date Completed: } 4 / 9 / 2010 \\
\text { Logged By: A. Massey }\end{array}$ & $\begin{array}{l}\text { Boring Depth (Feet): } 228 \\
\text { Well Depth (Feet): } 222 \\
\text { Screen Size (Inches): } 0.02 \\
\text { Drilling Method: Sonic } \\
\text { Driller: Boart Longyear }\end{array}$ & $\begin{array}{l}\text { Latitude } 39^{\circ} 25^{\prime} 48.4 " \mathrm{~N} \\
\text { (NAD 83): } \\
\text { Longitude } 75^{\circ} 59^{\prime} 38.1 " \mathrm{~W} \\
\text { (NAD 83): } \\
\text { Land Surface Elevation } 11.21 \\
\text { (NAVD 88): }\end{array}$ & $\begin{array}{c}\text { CE Dd 141 } \\
\text { Pearce Creek } \\
\text { Dredge Material Containment Area } \\
\text { Cecil County, Maryland }\end{array}$ \\
\hline 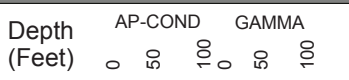 & $\begin{array}{l}\text { Lithologic } \\
\text { Log }\end{array}$ & Lithologic Description & Aquifer \\
\hline
\end{tabular}

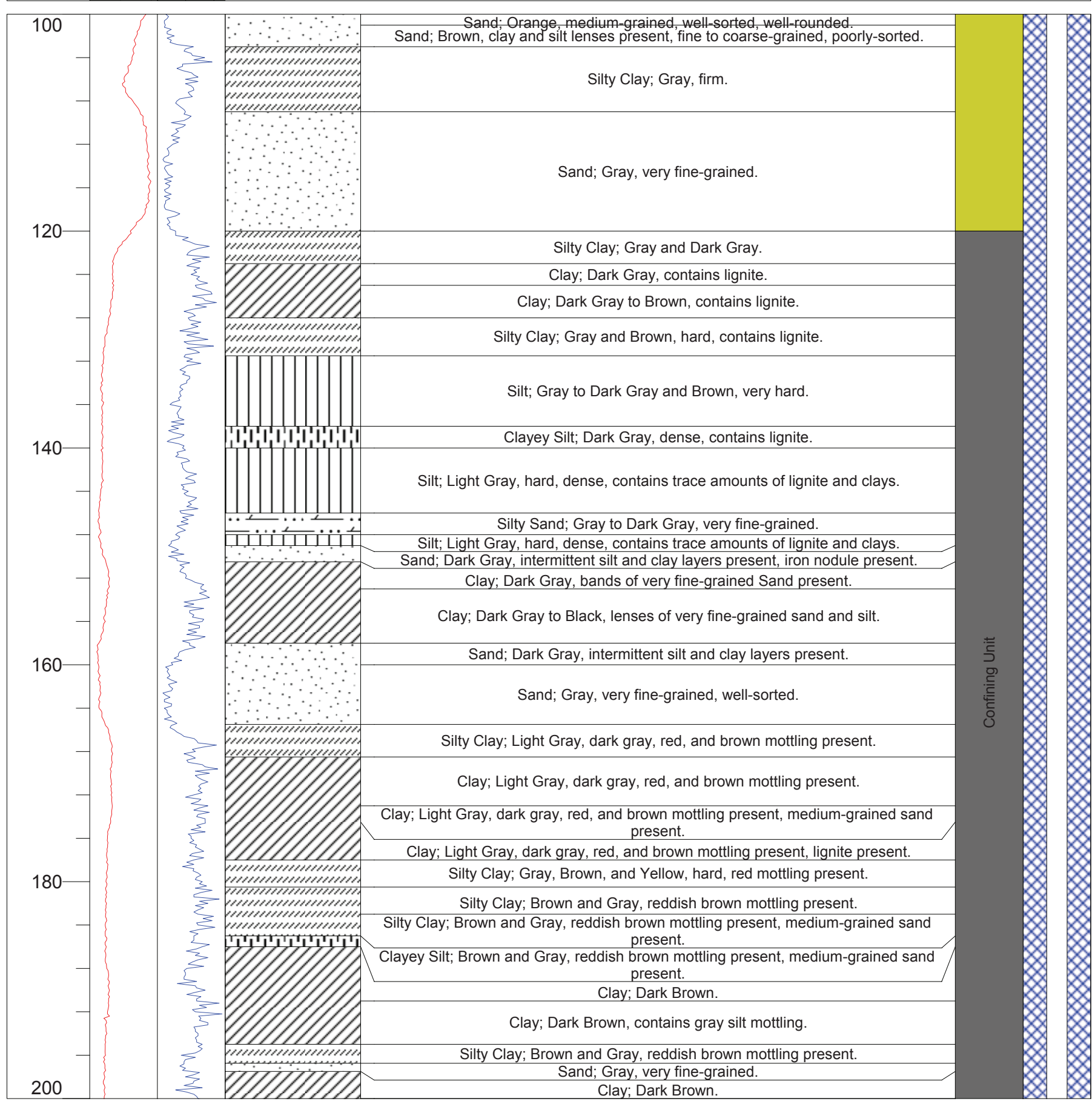

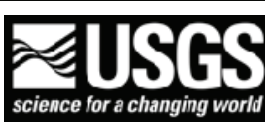

U.S. Department of the Interior U.S. Geological Survey

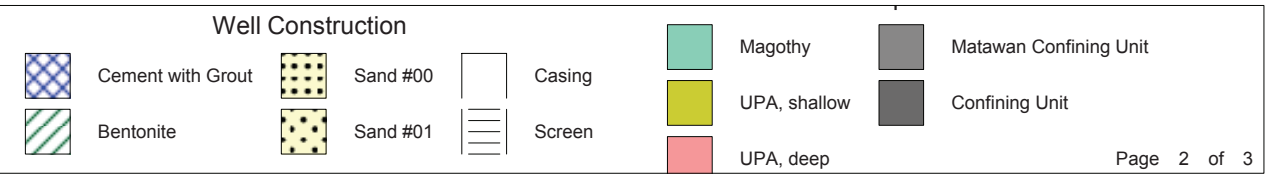




\begin{tabular}{|c|c|c|c|}
\hline $\begin{array}{l}\text { Station ID: } 392548075593802 \\
\text { Date Began: 4/8/2010 } \\
\text { Date Completed: 4/9/2010 } \\
\text { Logged By: A. Massey }\end{array}$ & $\begin{array}{l}\text { Boring Depth (Feet): } 228 \\
\text { Well Depth (Feet): } 222 \\
\text { Screen Size (Inches): } 0.02 \\
\text { Drilling Method: Sonic } \\
\text { Driller: Boart Longyear }\end{array}$ & $\begin{array}{l}\text { Latitude } 39^{\circ} 25^{\prime} 48.4^{\prime \prime} \mathrm{N} \\
\text { (NAD 83): } \\
\text { Longitude } 75^{\circ} 59^{\prime} 38.1^{\prime \prime} \mathrm{W} \\
\text { (NAD 83): } \\
\text { Land Surface Elevation } 11.21 \\
\text { (NAVD 88): }\end{array}$ & $\begin{array}{c}\text { CE Dd 141 } \\
\text { Pearce Creek } \\
\text { Dredge Material Containment Area } \\
\text { Cecil County, Maryland }\end{array}$ \\
\hline 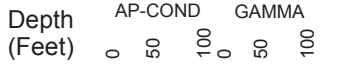 & $\begin{array}{l}\text { Lithologic } \\
\quad \text { Log }\end{array}$ & Lithologic Description & Aquifer \\
\hline
\end{tabular}

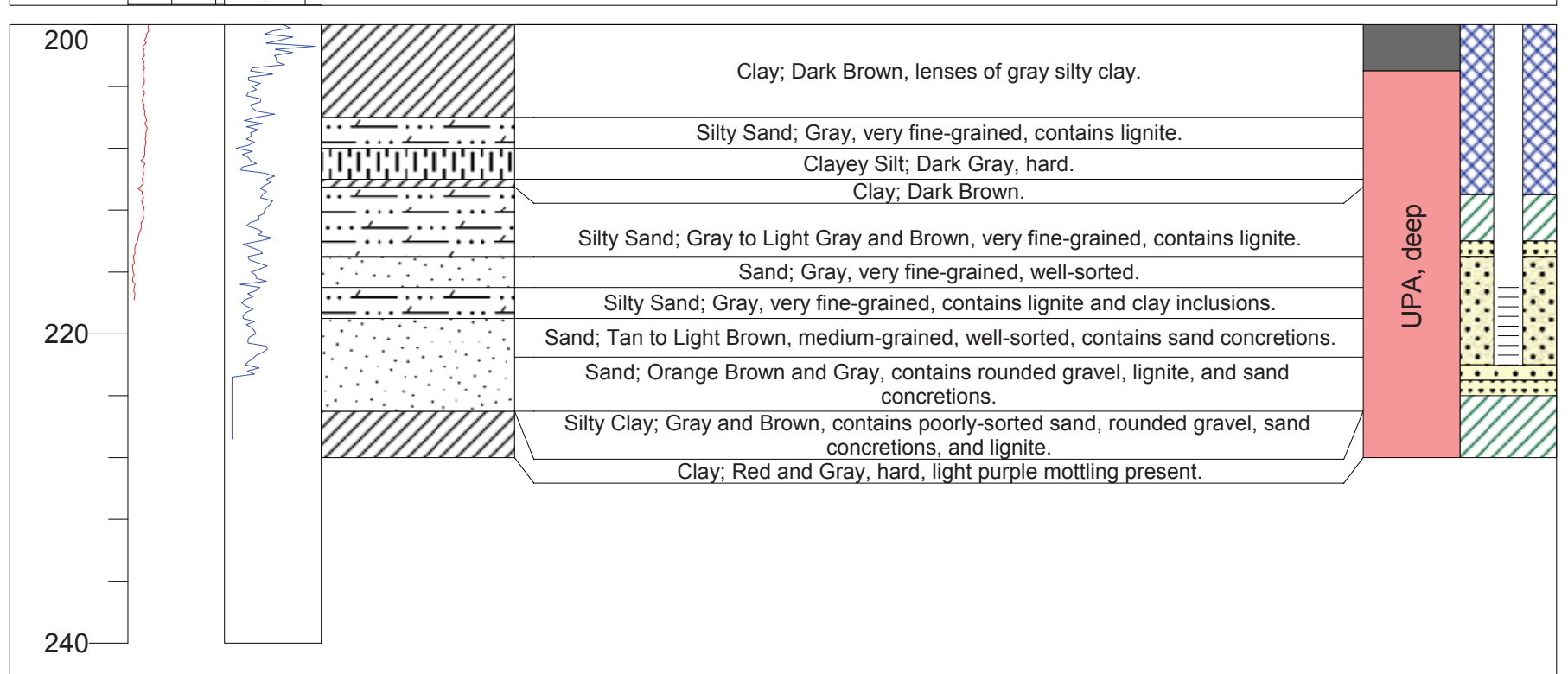

Q




\begin{tabular}{|c|c|c|c|}
\hline $\begin{array}{l}\text { Station ID: } 392540075594501 \\
\text { Date Began: } 4 / 11 / 2010 \\
\text { Date Completed: } 4 / 11 / 2010 \\
\text { Logged By: A. Massey }\end{array}$ & $\begin{array}{l}\text { Boring Depth (Feet): } 98 \\
\text { Well Depth (Feet): } 89 \\
\text { Screen Size (Inches): } 0.02 \\
\text { Drilling Method: Sonic } \\
\text { Driller: Boart Longyear }\end{array}$ & $\begin{array}{l}\text { Latitude } \\
\text { (NAD 83): } 39^{\circ} 25^{\prime} 40.4^{\prime \prime} \mathrm{N} \\
\text { Longitude } \\
\text { (NAD 83): } 75^{\circ} 59^{\prime} 45.0^{\prime} \mathrm{W} \\
\text { Land Surface Elevation } 23.55 \\
\text { (NAVD 88): }\end{array}$ & $\begin{array}{c}\text { CE Dd } 142 \\
\text { Pearce Creek } \\
\text { Dredge Material Containment Area } \\
\text { Cecil County, Maryland }\end{array}$ \\
\hline 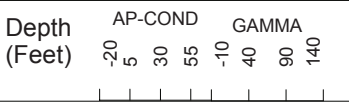 & $\begin{array}{l}\text { Lithologic } \\
\text { Log }\end{array}$ & Lithologic Description & Aquifer \\
\hline
\end{tabular}

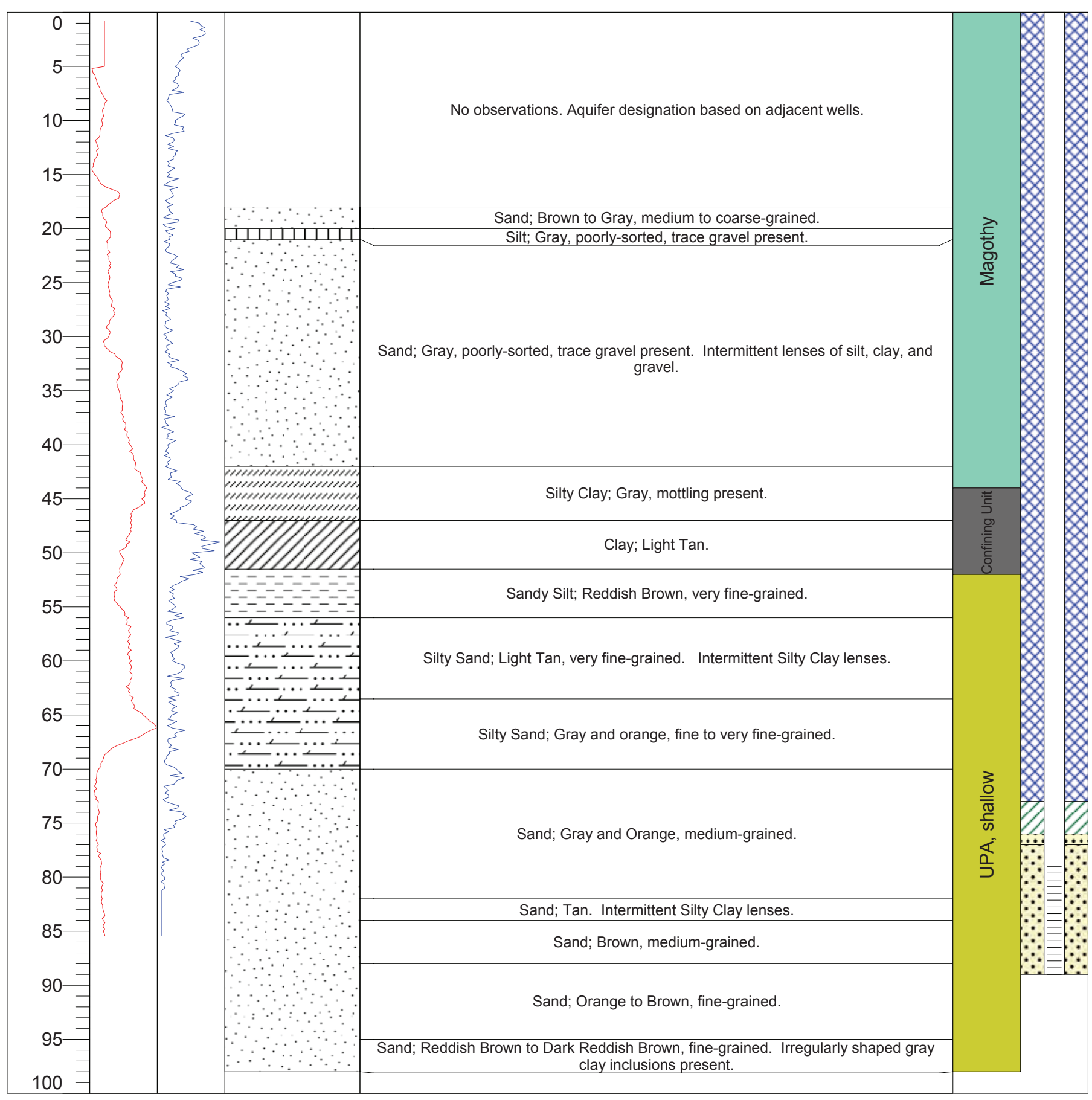
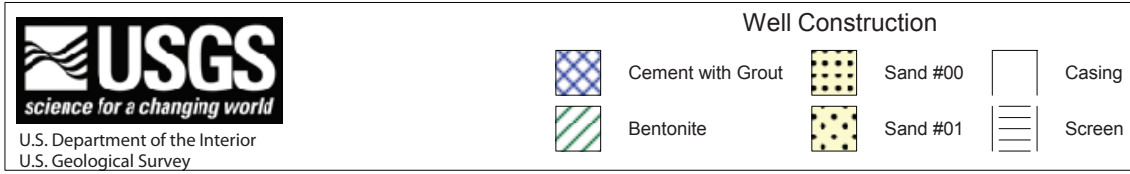

\begin{tabular}{|c|c|}
\hline Magothy & Matawan Confining Unit \\
\hline UPA, shallow & Confining Unit \\
\hline UF & Page \\
\hline
\end{tabular}




\begin{tabular}{|c|c|c|c|}
\hline $\begin{array}{l}\text { Station ID: } 392540075594502 \\
\text { Date Began: 4/12/2010 } \\
\text { Date Completed: 4/12/2010 } \\
\text { Logged By: A. Massey }\end{array}$ & $\begin{array}{l}\text { Boring Depth (Feet): } 48 \\
\text { Well Depth (Feet): } 44 \\
\text { Screen Size (Inches): } 0.02 \\
\text { Drilling Method: Sonic } \\
\text { Driller: Boart Longyear }\end{array}$ & $\begin{array}{l}\text { Latitude } \\
\text { (NAD 83): } 39^{\circ} 25^{\prime} 40.4 " \mathrm{~N} \\
\text { Longitude } 75^{\circ} 59^{\prime} 45.0^{\prime} \mathrm{W} \\
\text { (NAD 83): } \\
\text { Land Surface Elevation } 23.72 \\
\text { (NAVD 88): }\end{array}$ & $\begin{array}{c}\text { CE Dd 143 } \\
\text { Pearce Creek } \\
\text { Dredge Material Containment Area } \\
\text { Cecil County, Maryland }\end{array}$ \\
\hline $\begin{array}{lc}\text { Depth } & \text { Lithologic } \\
\text { (Feet) } & \text { Log }\end{array}$ & & Lithologic Description & Aquifer \\
\hline
\end{tabular}

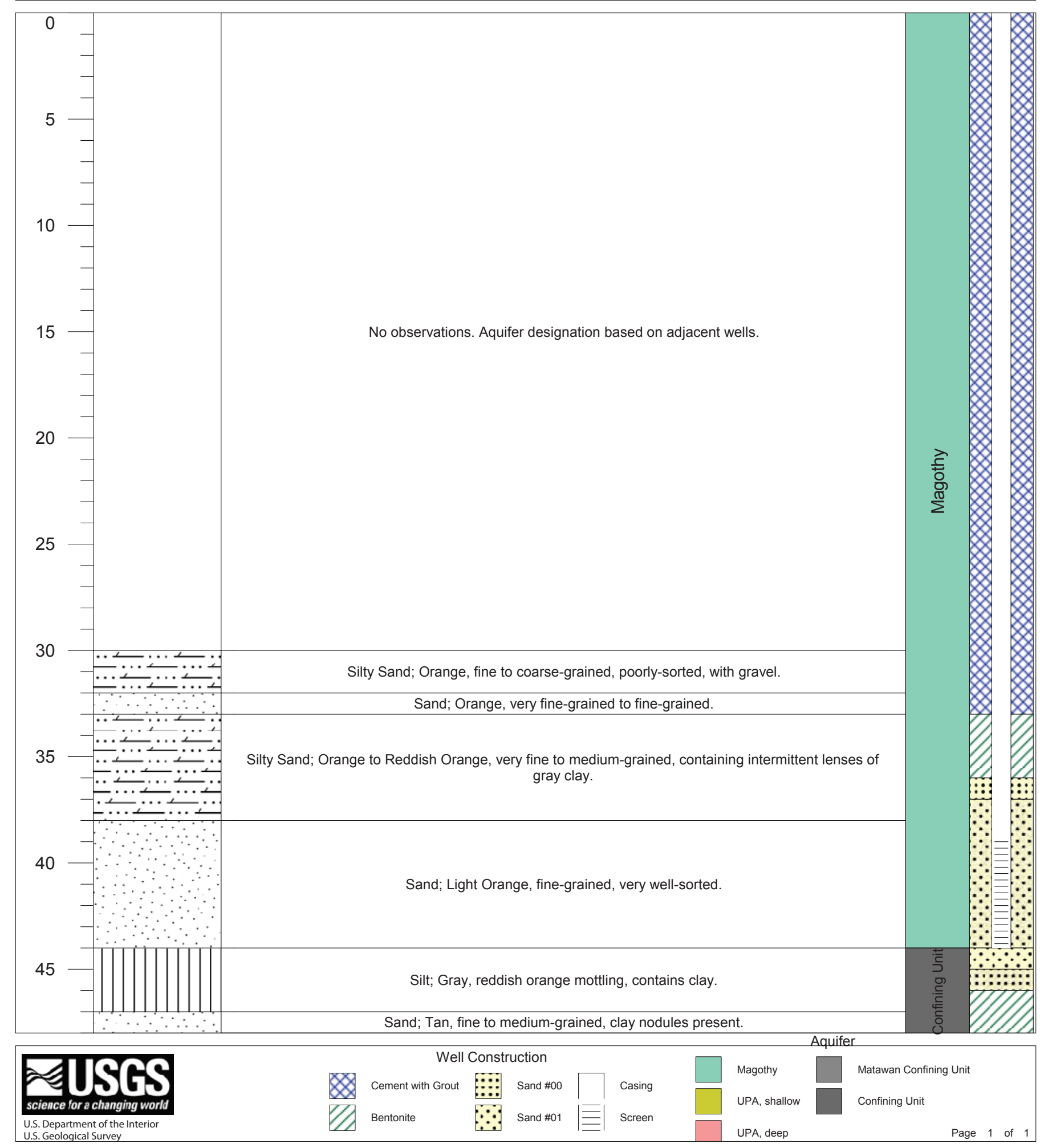




\begin{tabular}{|c|c|c|c|}
\hline $\begin{array}{l}\text { Station ID: } 392547075591702 \\
\text { Date Began: } 3 / 29 / 2010 \\
\text { Date Completed: } 3 / 29 / 2010 \\
\text { Logged By: C. Dieter }\end{array}$ & $\begin{array}{l}\text { Boring Depth (Feet): } 34 \\
\text { Well Depth (Feet): } 27 \\
\text { Screen Size (Inches): } 0.02 \\
\text { Drilling Method: Sonic } \\
\text { Driller: Boart Longyear }\end{array}$ & $\begin{array}{l}\text { Latitude } \\
\text { (NAD 83): } 39^{\circ} 25^{\prime} 47.1^{\prime \prime} \mathrm{N} \\
\text { Longitude } 75^{\circ} 59^{\prime} 17.2^{\prime \prime} \mathrm{W} \\
\text { (NAD 83): } \\
\text { Land Surface Elevation } 28.12 \\
\text { (NAVD 88): }\end{array}$ & $\begin{array}{c}\text { CE Dd 144 } \\
\text { Pearce Creek } \\
\text { Dredge Material Containment Area } \\
\text { Cecil County, Maryland }\end{array}$ \\
\hline $\begin{array}{lc}\text { Depth } & \text { Lithologic } \\
\text { (Feet) } & \text { Log }\end{array}$ & & Lithologic Description & Aquifer \\
\hline
\end{tabular}

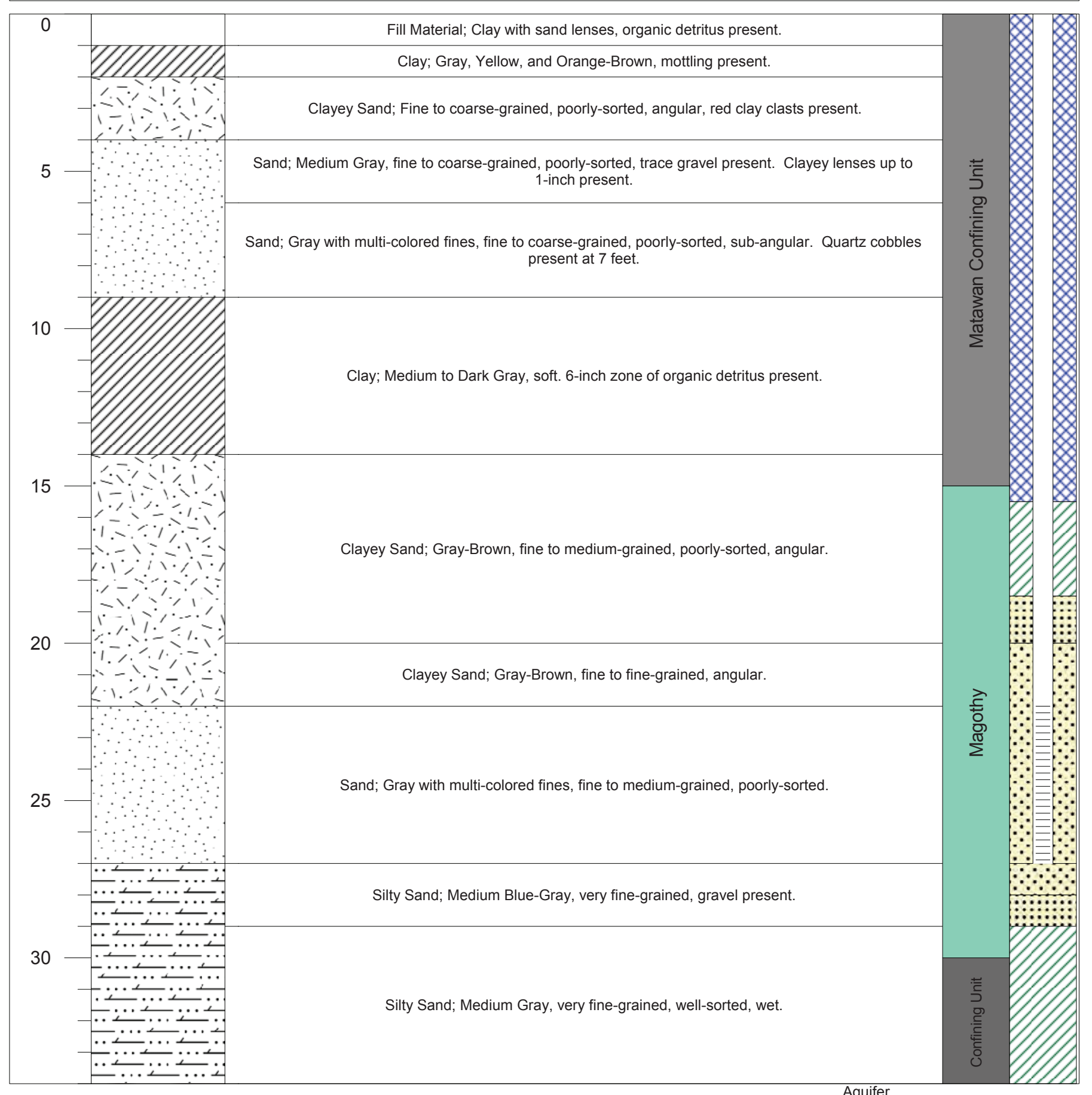

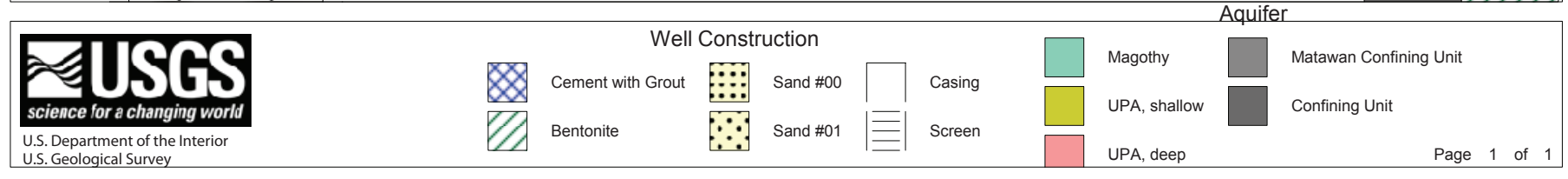




\begin{tabular}{|c|c|c|c|}
\hline $\begin{array}{l}\text { Station ID: } 392603075585602 \\
\text { Date Began: 3/28/2010 } \\
\text { Date Completed: } 3 / 28 / 2010 \\
\text { Logged By: A. Massey }\end{array}$ & $\begin{array}{l}\text { Boring Depth (Feet): } 30 \\
\text { Well Depth (Feet): } 30 \\
\text { Screen Size (Inches): } 0.02 \\
\text { Drilling Method: Sonic } \\
\text { Driller: Boart Longyear }\end{array}$ & $\begin{array}{l}\text { Latitude } \\
\text { (NAD 83): } 39^{\circ} 266^{\prime} 03.4^{\prime \prime} \mathrm{N} \\
\text { Longitude } 75^{\circ} 58^{\prime} 56.3^{\prime \prime} \mathrm{W} \\
\text { (NAD 83): } \\
\text { Land Surface Elevation } 21.00 \\
\text { (NAVD 88): }\end{array}$ & $\begin{array}{c}\text { CE Dd 145 } \\
\text { Pearce Creek } \\
\text { Dredge Material Containment Area } \\
\text { Cecil County, Maryland }\end{array}$ \\
\hline $\begin{array}{lc}\text { Depth } & \text { Lithologic } \\
\text { (Feet) } & \text { Log }\end{array}$ & & Lithologic Description & Aquifer \\
\hline
\end{tabular}

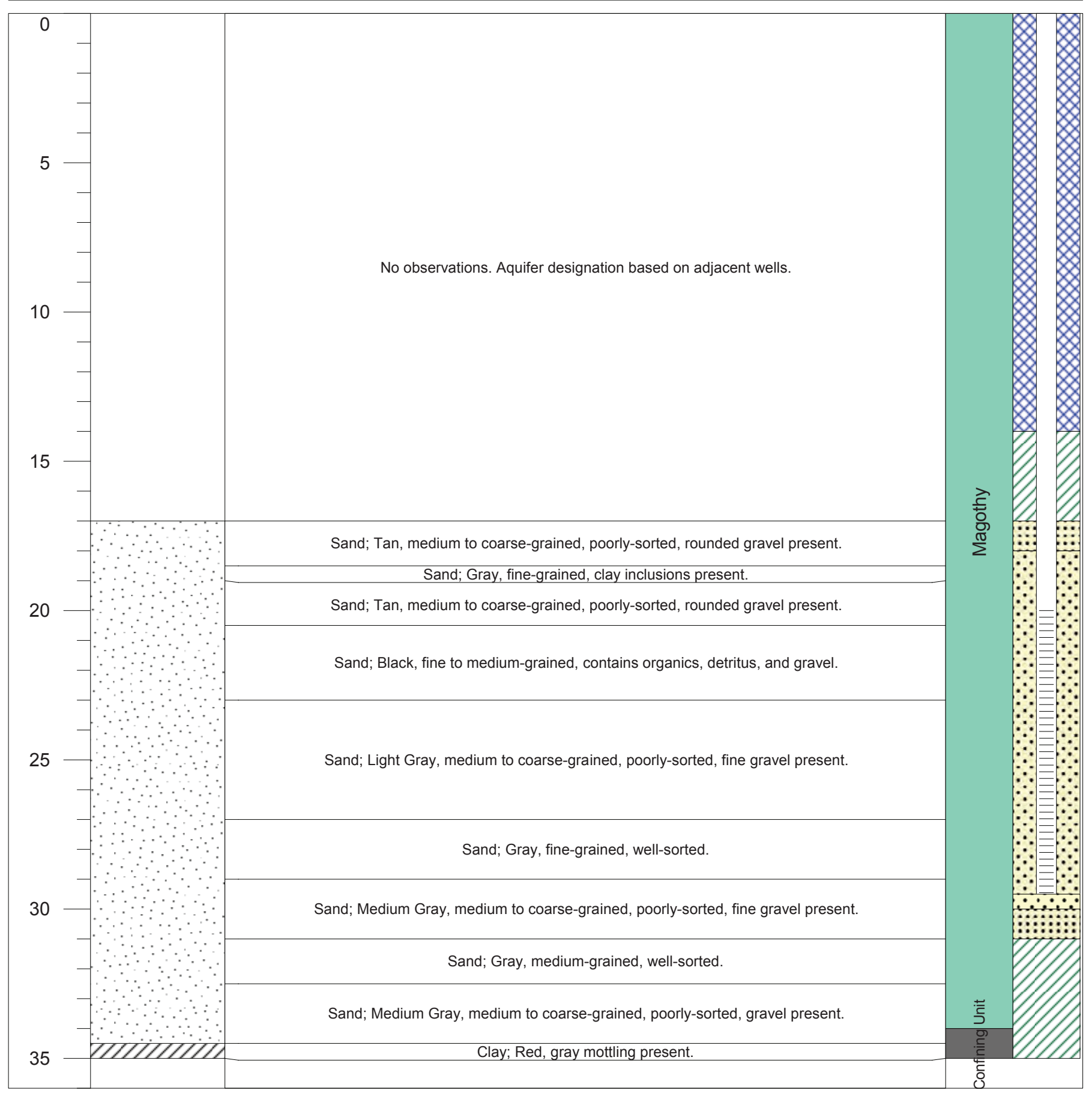

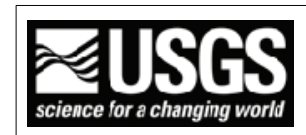

U.S. Department of the Interior

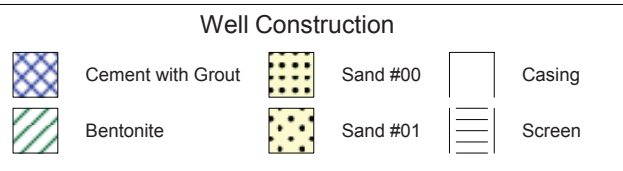

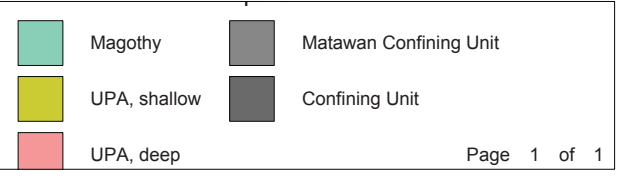




\begin{tabular}{|c|c|c|c|}
\hline $\begin{array}{l}\text { Station ID: } 392603075585604 \\
\text { Date Began: } 3 / 28 / 2010 \\
\text { Date Completed: } 3 / 28 / 2010 \\
\text { Logged By: A. Massey }\end{array}$ & $\begin{array}{l}\text { Boring Depth (Feet): } 129.5 \\
\text { Well Depth (Feet): } 128.5 \\
\text { Screen Size (Inches): } 0.02 \\
\text { Drilling Method: Sonic } \\
\text { Driller: Boart Longyear }\end{array}$ & $\begin{array}{l}\text { Latitude } \\
\text { (NAD 83): } 39^{\circ} 26^{\prime} 03.5^{\prime \prime} \mathrm{N} \\
\text { Longitude } 75^{\circ} 58^{\prime} 56.4 " \mathrm{~W} \\
\text { (NAD 83): } \\
\text { Land Surface Elevation } 21.00 \\
\text { (NAVD 88): }\end{array}$ & $\begin{array}{c}\text { CE Dd 146 } \\
\text { Pearce Creek } \\
\text { Dredge Material Containment Area } \\
\text { Cecil County, Maryland }\end{array}$ \\
\hline $\begin{array}{lc}\text { Depth } & \text { Lithologic } \\
\text { (Feet) } & \text { Log }\end{array}$ & & Lithologic Description & Aquifer \\
\hline
\end{tabular}

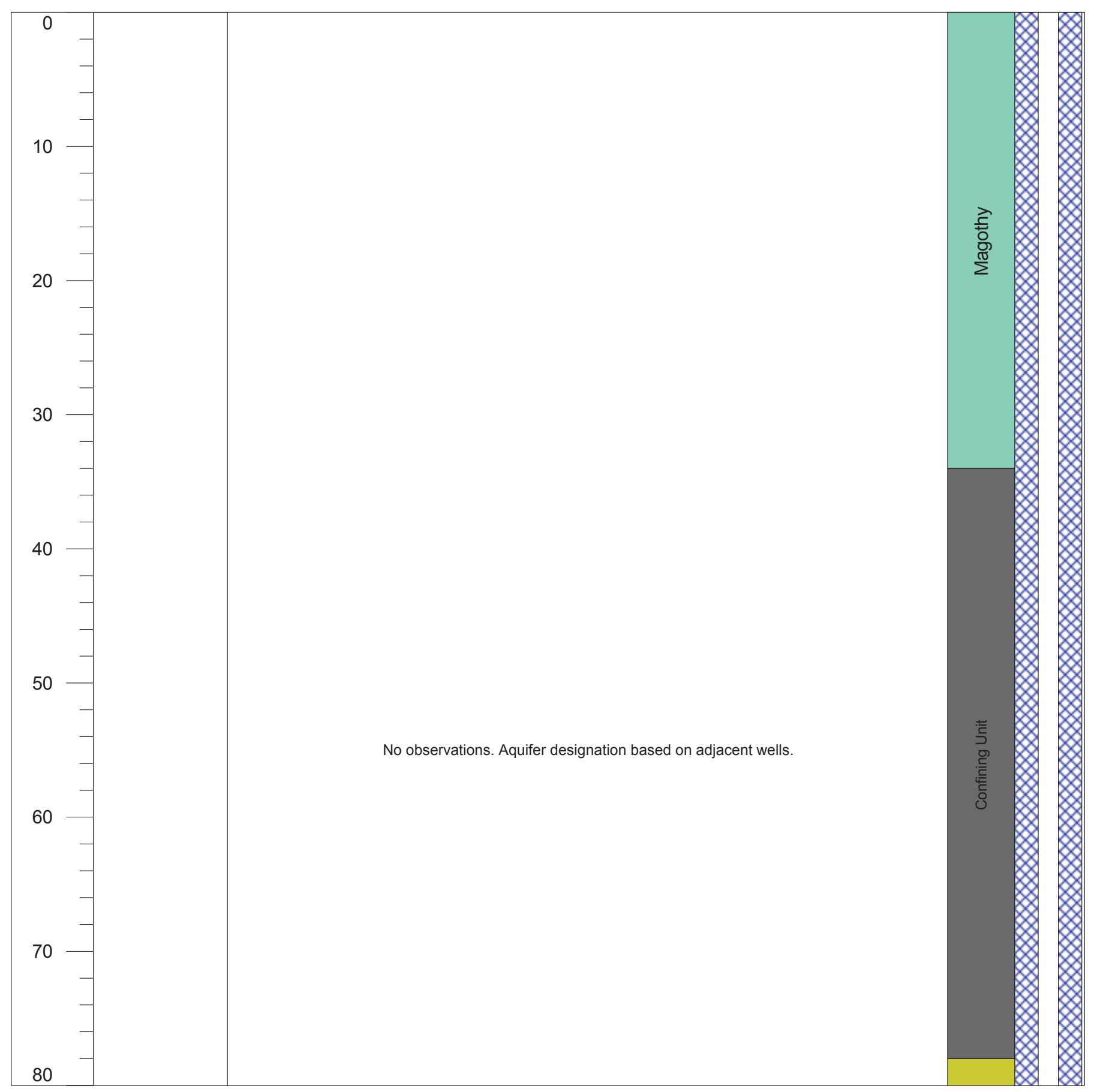

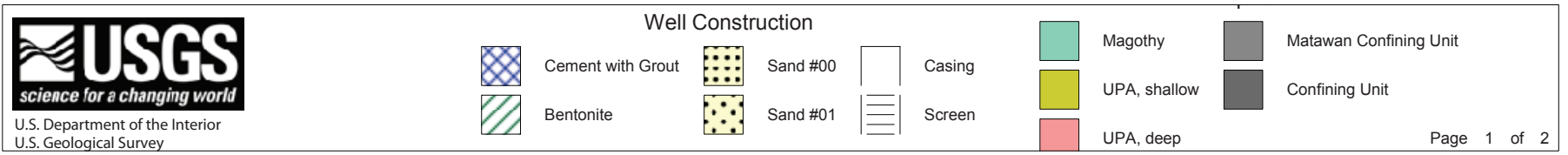




\begin{tabular}{|c|c|c|c|}
\hline $\begin{array}{l}\text { Station ID: } 392603075585604 \\
\text { Date Began: } 3 / 28 / 2010 \\
\text { Date Completed: } 3 / 28 / 2010 \\
\text { Logged By: A. Massey }\end{array}$ & $\begin{array}{l}\text { Boring Depth (Feet): } 129.5 \\
\text { Well Depth (Feet): } 128.5 \\
\text { Screen Size (Inches): } 0.02 \\
\text { Drilling Method: Sonic } \\
\text { Driller: Boart Longyear }\end{array}$ & $\begin{array}{l}\text { Latitude } 39^{\circ} 26^{\prime} 03.5^{\prime \prime} \mathrm{N} \\
\text { (NAD 83): } \\
\text { Longitude } 75^{\circ} 58^{\prime} 56.4^{\prime \prime} \mathrm{W} \\
\text { (NAD 83): } \\
\text { Land Surface Elevation } 21.00 \\
\text { (NAVD 88): }\end{array}$ & $\begin{array}{c}\text { CE Dd } 146 \\
\text { Pearce Creek } \\
\text { Dredge Material Containment Area } \\
\text { Cecil County, Maryland }\end{array}$ \\
\hline $\begin{array}{lc}\text { Depth } & \text { Lithologic } \\
\text { (Feet) } & \text { Log }\end{array}$ & & Lithologic Description & Aquifer \\
\hline
\end{tabular}

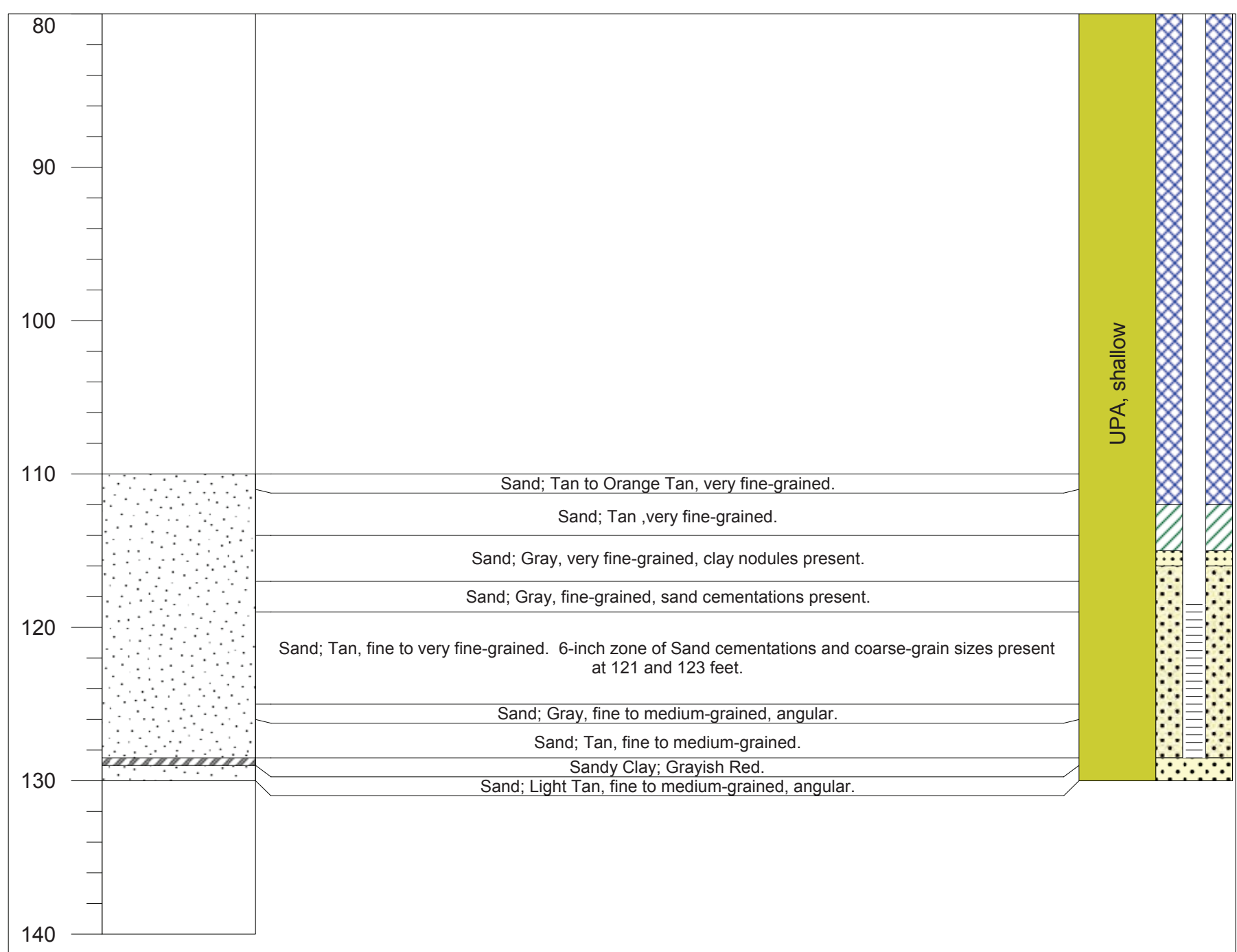

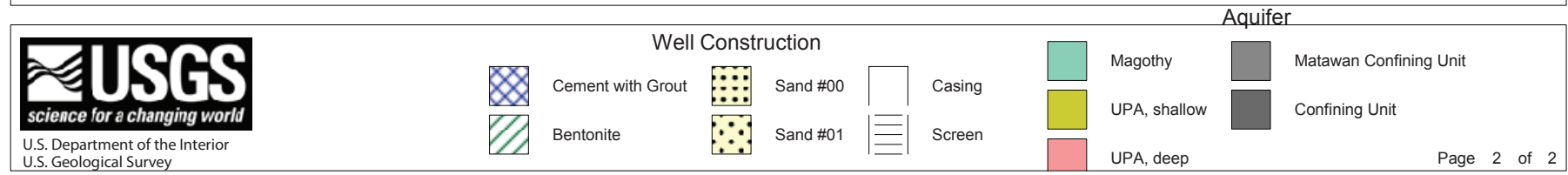




\begin{tabular}{|c|c|c|c|}
\hline $\begin{array}{l}\text { Station ID: } 392603075585603 \\
\text { Date Began: } 3 / 27 / 2010 \\
\text { Date Completed: } 3 / 27 / 2010 \\
\text { Logged By: A. Massey }\end{array}$ & $\begin{array}{l}\text { Boring Depth (Feet): } 198 \\
\text { Well Depth (Feet): } 198 \\
\text { Screen Size (Inches): } 0.02 \\
\text { Drilling Method: Sonic } \\
\text { Driller: Boart Longyear }\end{array}$ & $\begin{array}{l}\text { Latitude } \\
\text { (NAD 83): } 39^{\circ} 26^{\prime} 03.5^{\prime \prime} \mathrm{N} \\
\text { Longitude } \\
\text { (NAD 83): } 75^{\circ} 58^{\prime} 56.4^{\prime \prime} \mathrm{W} \\
\text { Land Surface Elevation } 21.10 \\
\text { (NAVD 88): }\end{array}$ & $\begin{array}{c}\text { CE Dd } 147 \\
\text { Pearce Creek } \\
\text { Dredge Material Containment Area } \\
\text { Cecil County, Maryland }\end{array}$ \\
\hline 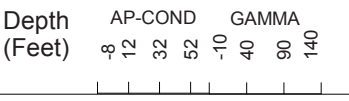 & $\begin{array}{l}\text { Lithologic } \\
\text { Log }\end{array}$ & Lithologic Description & Aquifer \\
\hline
\end{tabular}

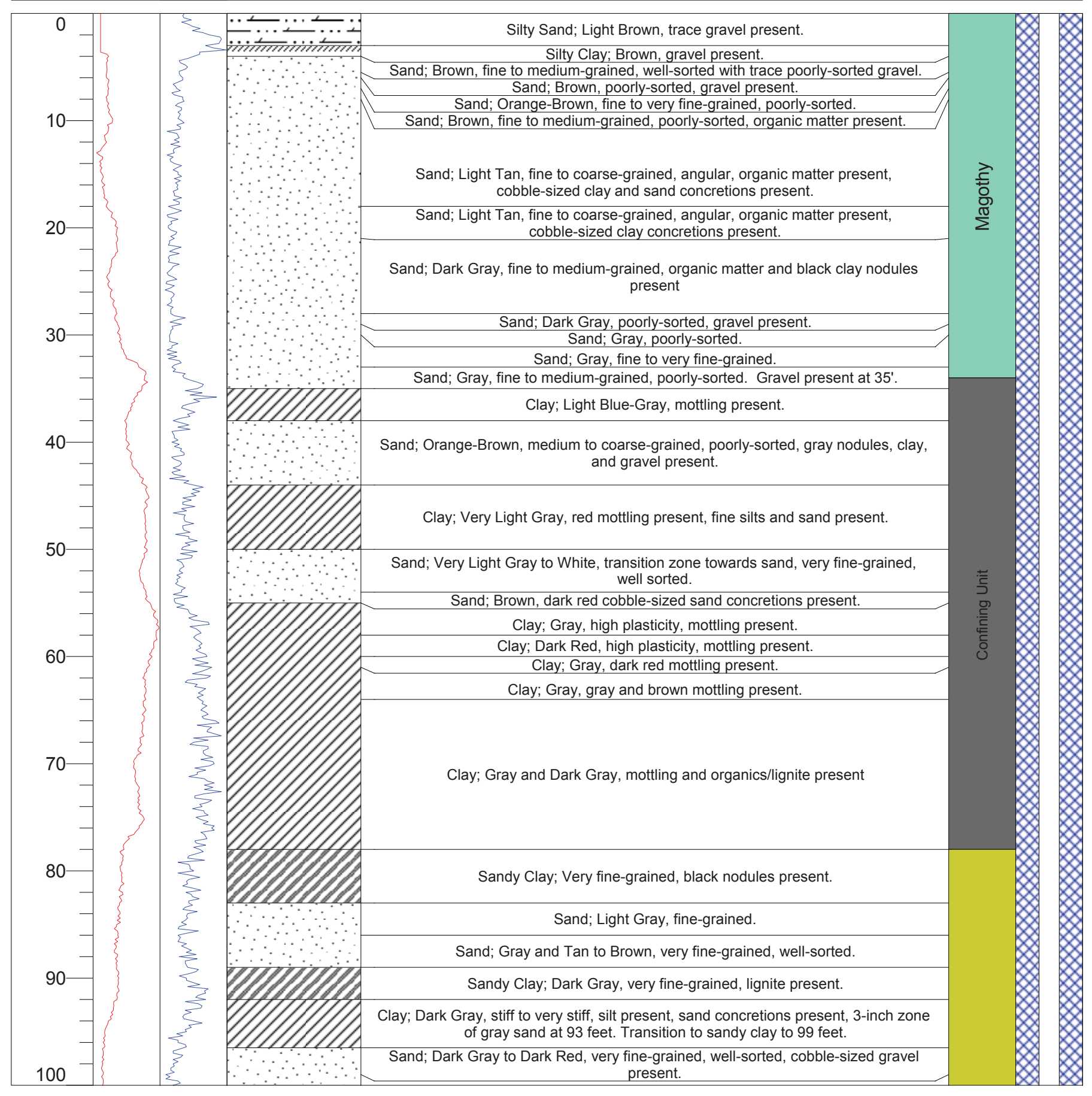

U.S. Department of the Interior U.S. Geological Survey
Well Construction

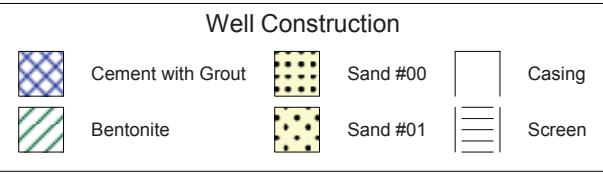

Matawan Confining Unit Confining Unit 


\begin{tabular}{|c|c|c|c|}
\hline $\begin{array}{l}\text { Station ID: } 392603075585603 \\
\text { Date Began: } 3 / 27 / 2010 \\
\text { Date Completed: } 3 / 27 / 2010 \\
\text { Logged By: A. Massey }\end{array}$ & $\begin{array}{l}\text { Boring Depth (Feet): } 198 \\
\text { Well Depth (Feet): } 198 \\
\text { Screen Size (Inches): } 0.02 \\
\text { Drilling Method: Sonic } \\
\text { Driller: Boart Longyear }\end{array}$ & $\begin{array}{l}\text { Latitude } \\
\text { (NAD 83): } 39^{\circ} 26^{\prime} 03.5^{\prime \prime} \mathrm{N} \\
\text { Longitude } \\
\text { (NAD 83): } 75^{\circ} 58^{\prime} 56.4^{\prime \prime W} \\
\text { Land Surface Elevation } 21.10 \\
\text { (NAVD 88): }\end{array}$ & $\begin{array}{c}\text { CE Dd 147 } \\
\text { Pearce Creek } \\
\text { Dredge Material Containment Area } \\
\text { Cecil County, Maryland }\end{array}$ \\
\hline 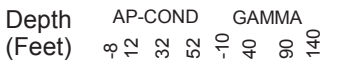 & $\begin{array}{l}\text { Lithologic } \\
\quad \text { Log }\end{array}$ & Lithologic Description & Aquifer \\
\hline
\end{tabular}

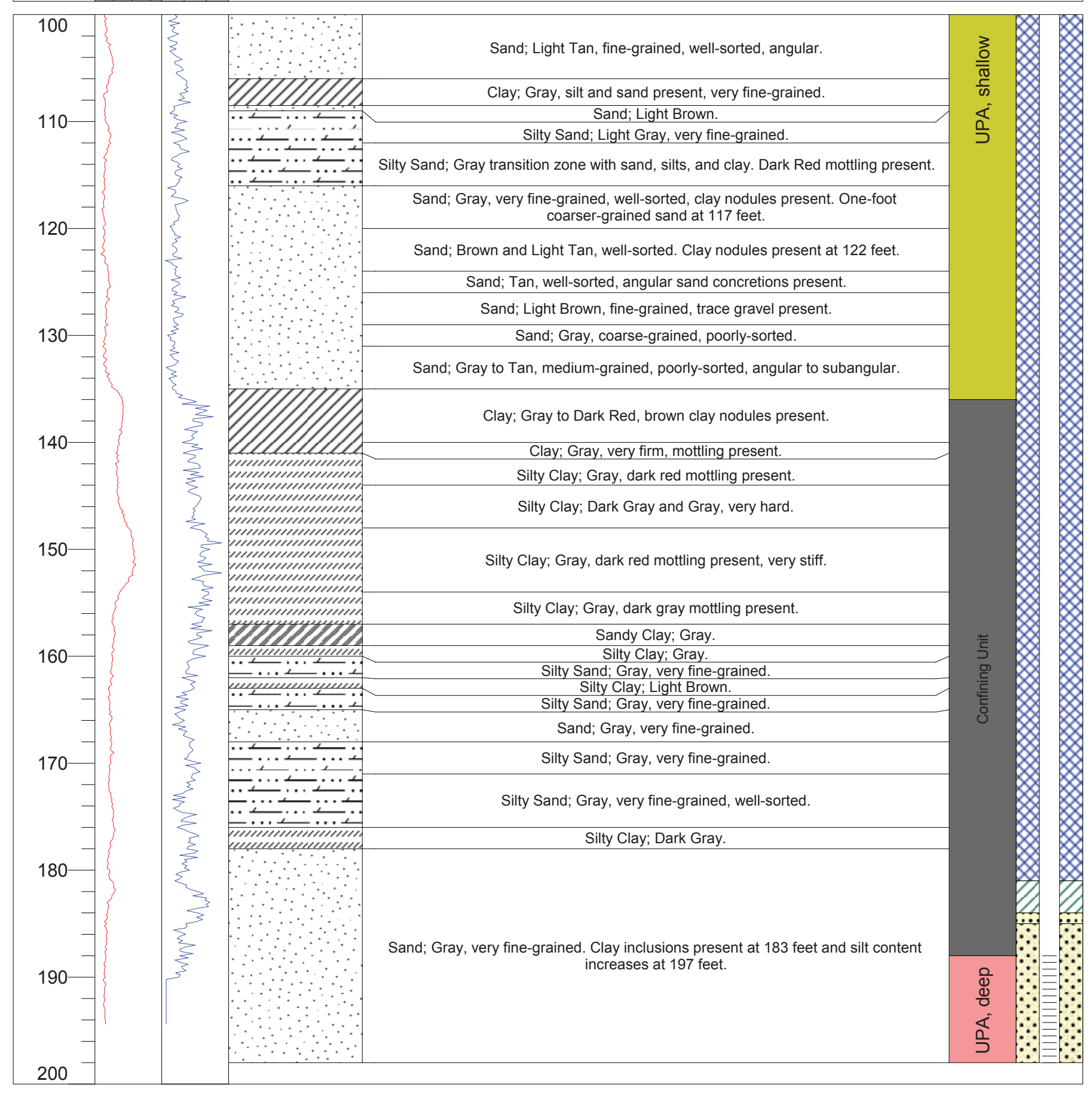

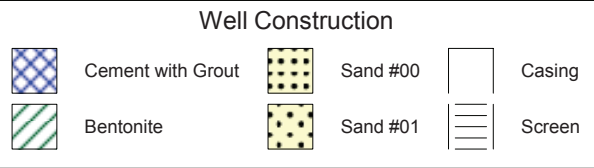

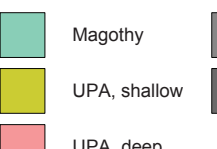
Matawan Confining Unit Confining Unit UPA, deep 


\begin{tabular}{|c|c|c|c|}
\hline $\begin{array}{l}\text { Station ID: } 392520075590401 \\
\text { Date Began: } 3 / 31 / 2010 \\
\text { Date Completed: } 3 / 31 / 2010 \\
\text { Logged By: J. Sorenson }\end{array}$ & $\begin{array}{l}\text { Boring Depth (Feet): } 48 \\
\text { Well Depth (Feet): } 40 \\
\text { Screen Size (Inches): } 0.02 \\
\text { Drilling Method: Sonic } \\
\text { Driller: Boart Longyear }\end{array}$ & $\begin{array}{l}\text { Latitude } \\
\text { (NAD 83): } 39^{\circ} 25^{\prime} 20.3^{\prime \prime} \mathrm{N} \\
\text { Longitude } 75^{\circ} 59^{\prime} 04.3^{\prime \prime} \mathrm{W} \\
\text { (NAD 83): } \\
\text { Land Surface Elevation } 37.06 \\
\text { (NAVD 88): }\end{array}$ & $\begin{array}{c}\text { CE Dd } 148 \\
\text { Pearce Creek } \\
\text { Dredge Material Containment Area } \\
\text { Cecil County, Maryland }\end{array}$ \\
\hline $\begin{array}{lc}\text { Depth } & \text { Lithologic } \\
\text { (Feet) } & \text { Log }\end{array}$ & & Lithologic Description & Aquifer \\
\hline
\end{tabular}

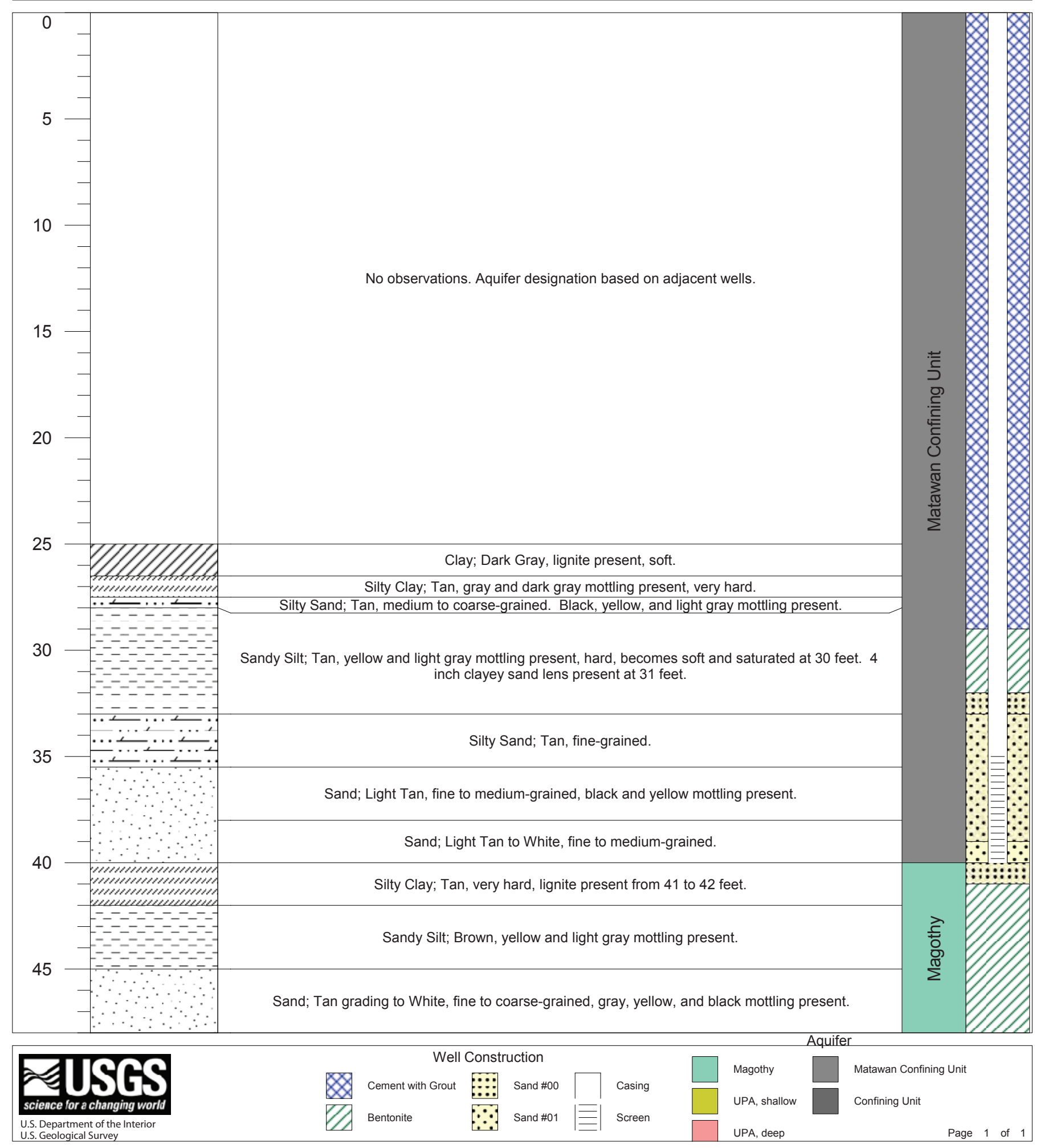




\begin{tabular}{|c|c|c|c|}
\hline $\begin{array}{l}\text { Station ID: } 392520075590402 \\
\text { Date Began: } 3 / 29 / 2010 \\
\text { Date Completed: } 3 / 30 / 2010 \\
\text { Logged By: J. Sorenson }\end{array}$ & $\begin{array}{l}\text { Boring Depth (Feet): } 118 \\
\text { Well Depth (Feet): } 118 \\
\text { Screen Size (Inches): } 0.02 \\
\text { Drilling Method: Sonic } \\
\text { Driller: Boart Longyear }\end{array}$ & $\begin{array}{l}\text { Latitude } \\
\text { (NAD 83): } 39^{\circ} 25^{\prime} 20.3^{\prime \prime} \mathrm{N} \\
\text { Longitude } 75^{\circ} 59^{\prime} 04.4 " \mathrm{~W} \\
\text { (NAD 83): } \\
\text { Land Surface Elevation } 36.98 \\
\text { (NAVD 88): }\end{array}$ & $\begin{array}{c}\text { CE Dd 149 } \\
\text { Pearce Creek } \\
\text { Dredge Material Containment Area } \\
\text { Cecil County, Maryland }\end{array}$ \\
\hline 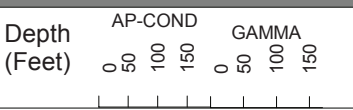 & $\begin{array}{l}\text { Lithologic } \\
\text { Log }\end{array}$ & Lithologic Description & Aquifer \\
\hline
\end{tabular}

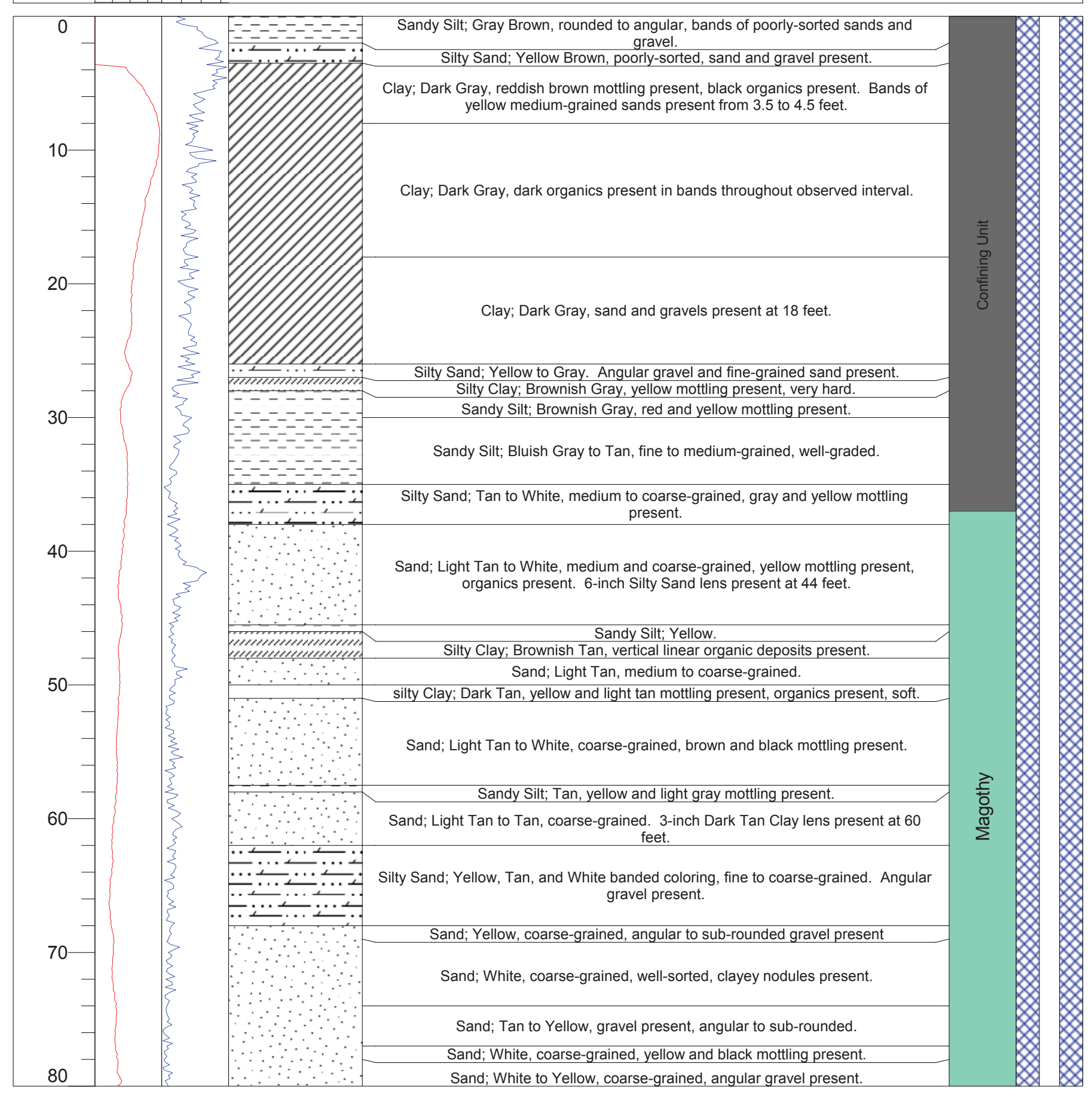

U.S. Department of the Interior U.S. Geological Survey
Well Construction

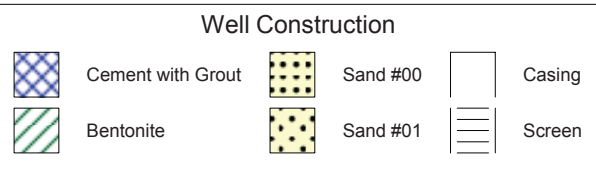

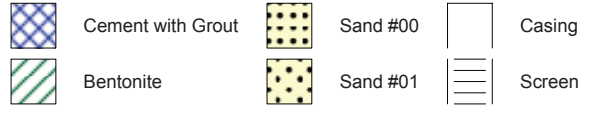

Matawan Confining Unit Confining Unit

\begin{tabular}{|c|c|}
\hline Magothy & Matawan Confining Unit \\
\hline UPA, shallow & Confining Unit \\
\hline UPA, deep & Page 1 of 2 \\
\hline
\end{tabular}




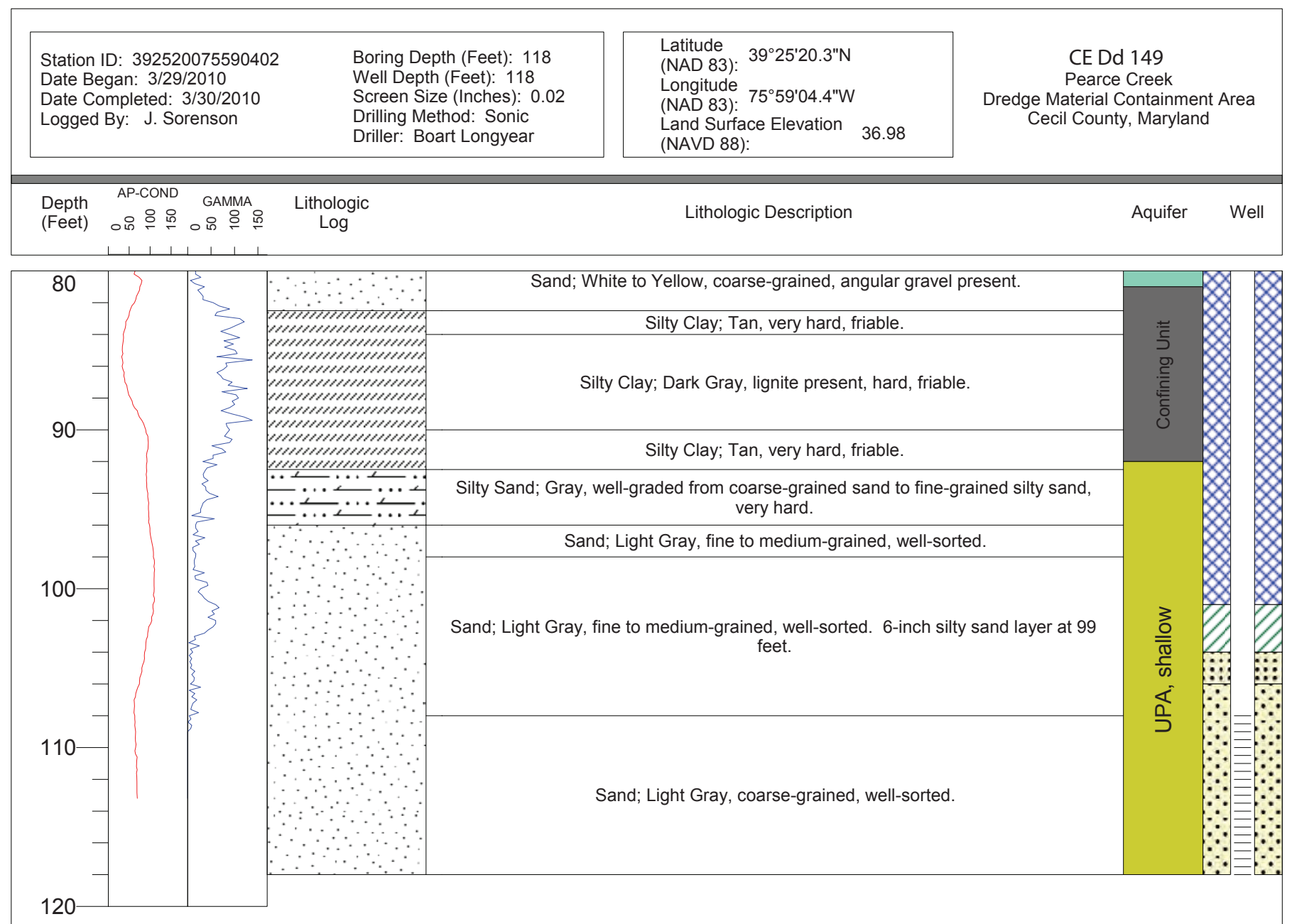

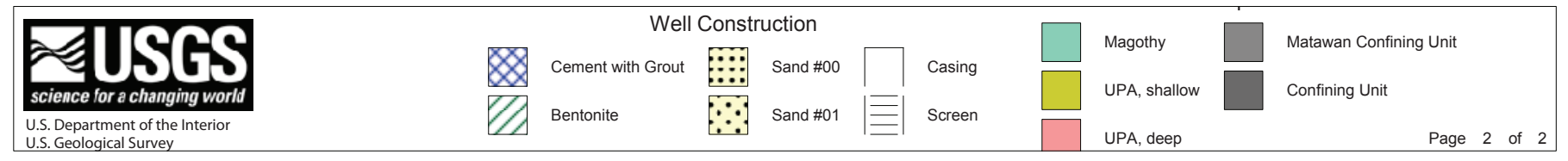




\begin{tabular}{|c|c|c|c|}
\hline $\begin{array}{l}\text { Station ID: } 392546075581902 \\
\text { Date Began: } 3 / 25 / 2010 \\
\text { Date Completed: } 3 / 27 / 2010 \\
\text { Logged By: J. Sorenson }\end{array}$ & $\begin{array}{l}\text { Boring Depth (Feet): } 248 \\
\text { Well Depth (Feet): } 145 \\
\text { Screen Size (Inches): } 0.015 \\
\text { Drilling Method: Sonic } \\
\text { Driller: Boart Longyear }\end{array}$ & $\begin{array}{l}\text { Latitude } \\
\text { (NAD 83): } 39^{\circ} 25^{\prime} 46.6^{\prime \prime} \mathrm{N} \\
\text { Longitude } 75^{\circ} 58^{\prime} 18.7^{\prime \prime} \mathrm{W} \\
\text { (NAD 83): } \\
\text { Land Surface Elevation } 16.45 \\
\text { (NAVD 88): }\end{array}$ & $\begin{array}{c}\text { CE Dd 150 } \\
\text { Pearce Creek } \\
\text { Dredge Material Containment Area } \\
\text { Cecil County, Maryland }\end{array}$ \\
\hline 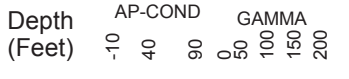 & $\begin{array}{l}\text { Lithologic } \\
\quad \text { Log }\end{array}$ & Lithologic Description & Aquifer \\
\hline
\end{tabular}

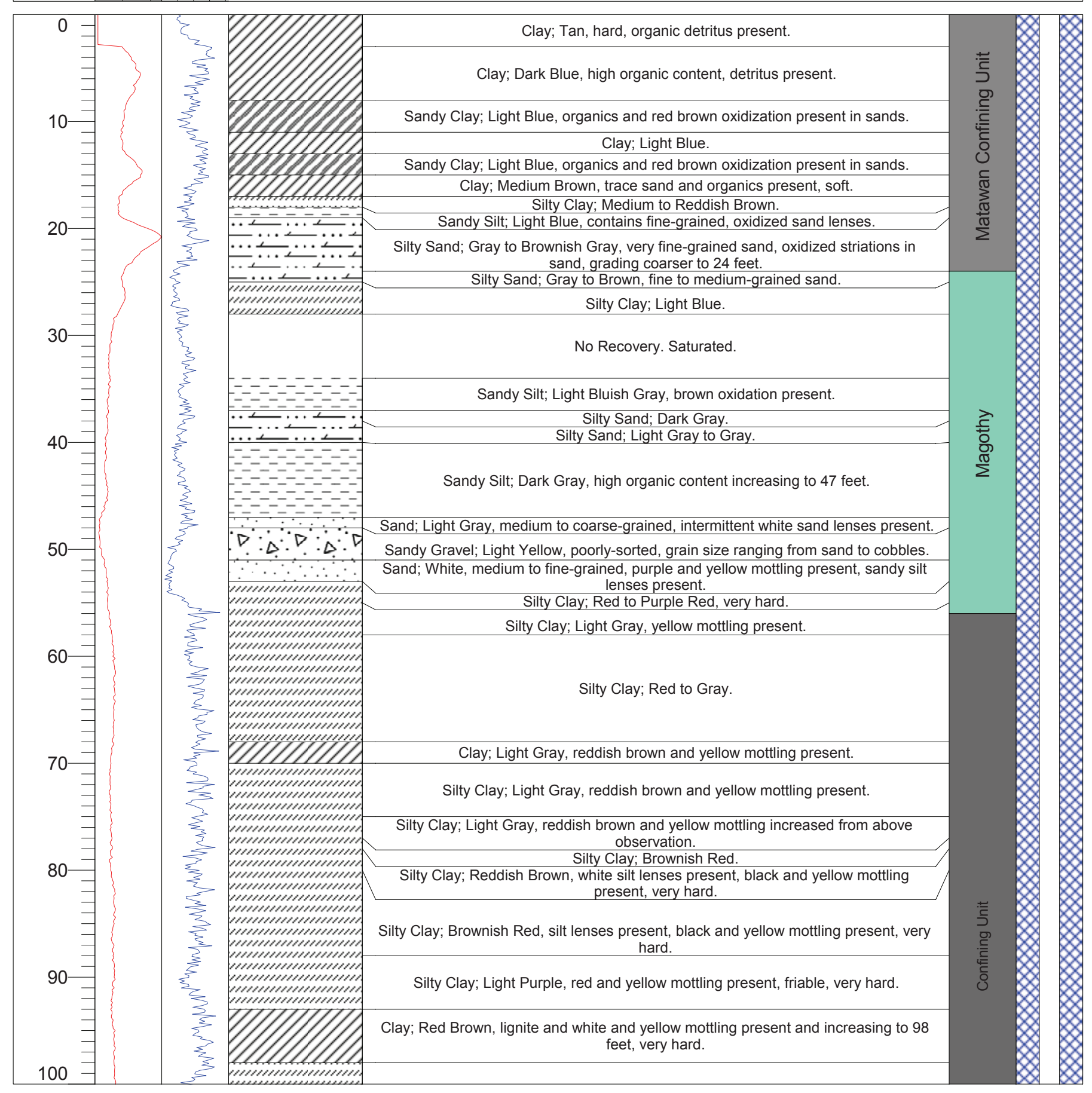

Well Construction
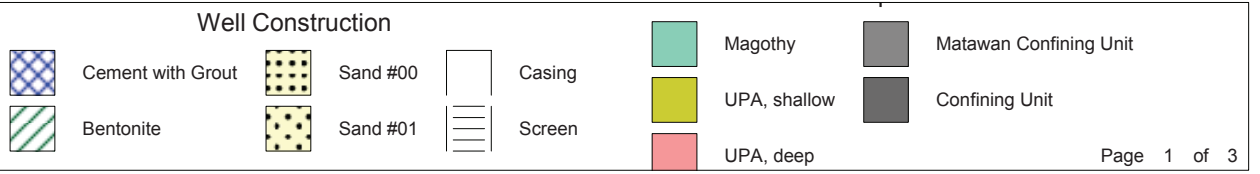


\begin{tabular}{|c|c|c|c|}
\hline $\begin{array}{l}\text { Station ID: } 392546075581902 \\
\text { Date Began: } 3 / 25 / 2010 \\
\text { Date Completed: } 3 / 27 / 2010 \\
\text { Logged By: J. Sorenson }\end{array}$ & $\begin{array}{l}\text { Boring Depth (Feet): } 248 \\
\text { Well Depth (Feet): } 145 \\
\text { Screen Size (Inches): } 0.015 \\
\text { Drilling Method: Sonic } \\
\text { Driller: Boart Longyear }\end{array}$ & $\begin{array}{l}\text { Latitude } \\
\text { (NAD 83): } 39^{\circ} 25^{\prime} 46.6 " \mathrm{~N} \\
\text { Longitude } 75^{\circ} 58^{\prime} 18.7 " \mathrm{~W} \\
\text { (NAD 83): } \\
\text { Land Surface Elevation } 16.45 \\
\text { (NAVD 88): }\end{array}$ & $\begin{array}{c}\text { CE Dd 150 } \\
\text { Pearce Creek } \\
\text { Dredge Material Containment Area } \\
\text { Cecil County, Maryland }\end{array}$ \\
\hline 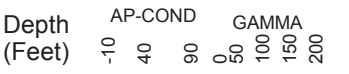 & $\begin{array}{l}\text { Lithologic } \\
\quad \text { Log }\end{array}$ & Lithologic Description & Aquifer \\
\hline
\end{tabular}

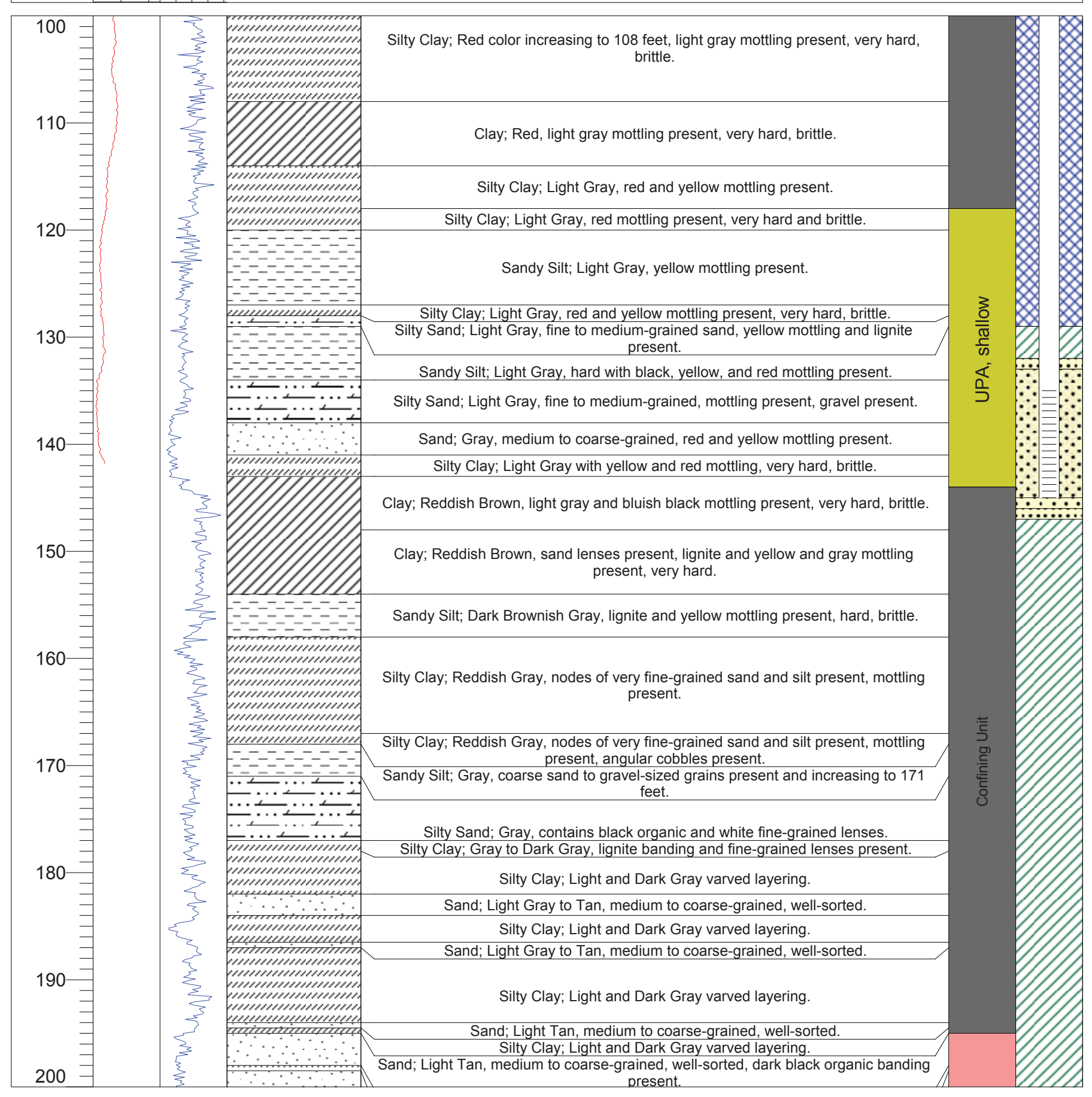
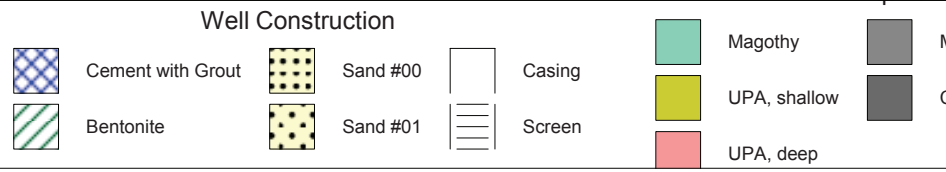

Matawan Confining Unit Confining Unit

UPA, deep 


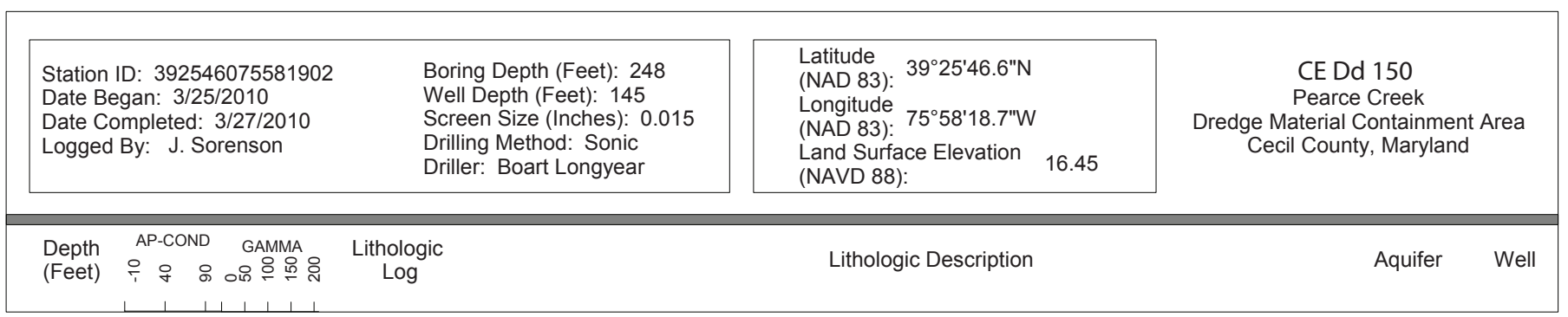

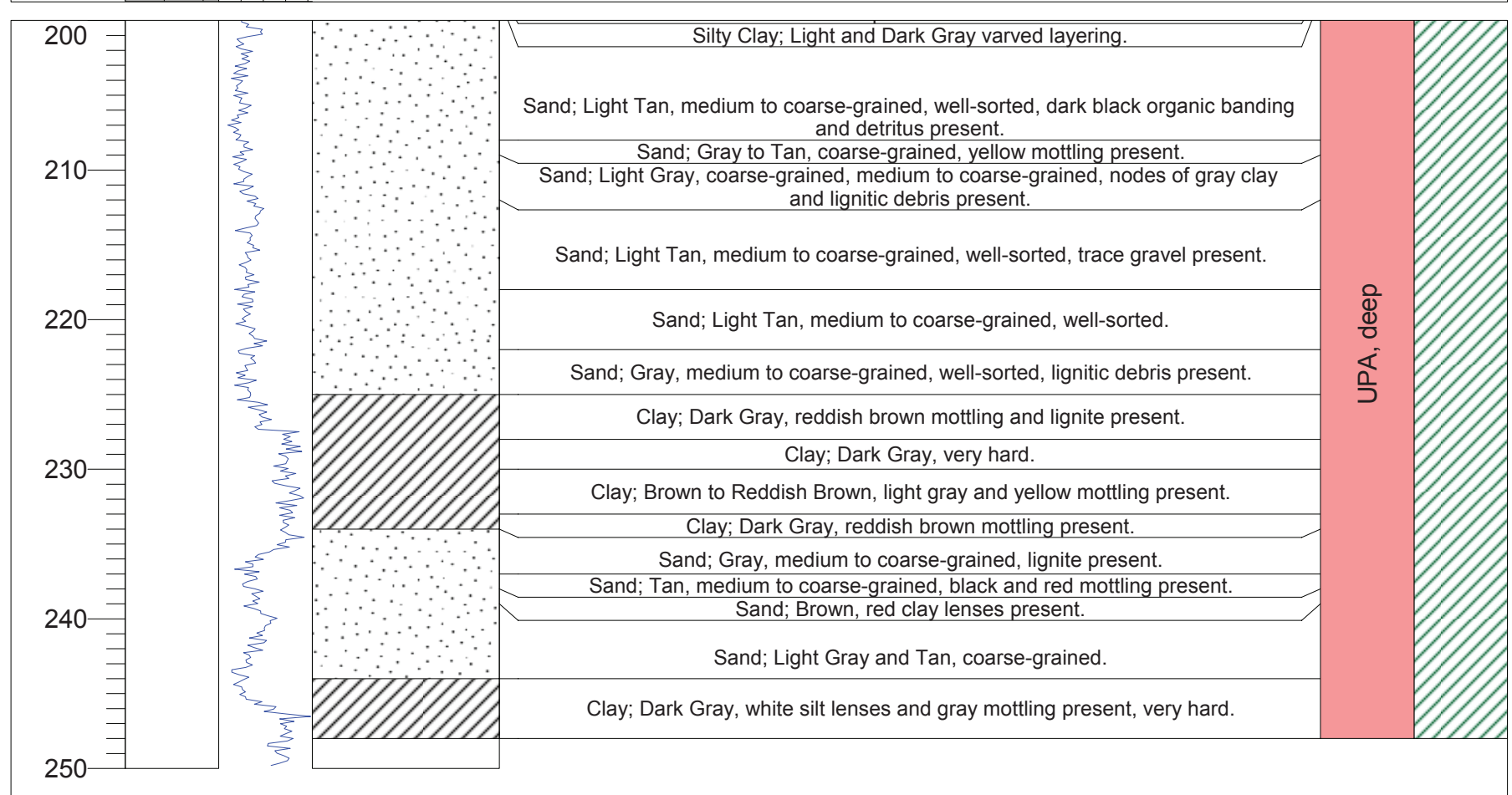

Q




\begin{tabular}{|c|c|c|c|}
\hline $\begin{array}{l}\text { Station ID: } 392537075593001 \\
\text { Date Began: } 3 / 30 / 2010 \\
\text { Date Completed: 4/1/2010 } \\
\text { Logged By: A. Massey }\end{array}$ & $\begin{array}{l}\text { Boring Depth (Feet): } 40 \\
\text { Well Depth (Feet): } 40 \\
\text { Screen Size (Inches): } 0.02 \\
\text { Drilling Method: Sonic } \\
\text { Driller: Boart Longyear }\end{array}$ & $\begin{array}{l}\text { Latitude } 39^{\circ} 25^{\prime} 36.8^{\prime \prime} \mathrm{N} \\
\text { (NAD 83): } \\
\text { Longitude } 75^{\circ} 59^{\prime} 29.9^{\prime \prime} \mathrm{W} \\
\text { (NAD 83): } \\
\text { Land Surface Elevation } 21.83 \\
\text { (NAVD 88): }\end{array}$ & $\begin{array}{c}\text { CE Dd 151 } \\
\text { Pearce Creek } \\
\text { Dredge Material Containment Area } \\
\text { Cecil County, Maryland }\end{array}$ \\
\hline $\begin{array}{lc}\text { Depth } & \text { Lithologic } \\
\text { (Feet) } & \text { Log }\end{array}$ & & Lithologic Description & Aquifer \\
\hline
\end{tabular}

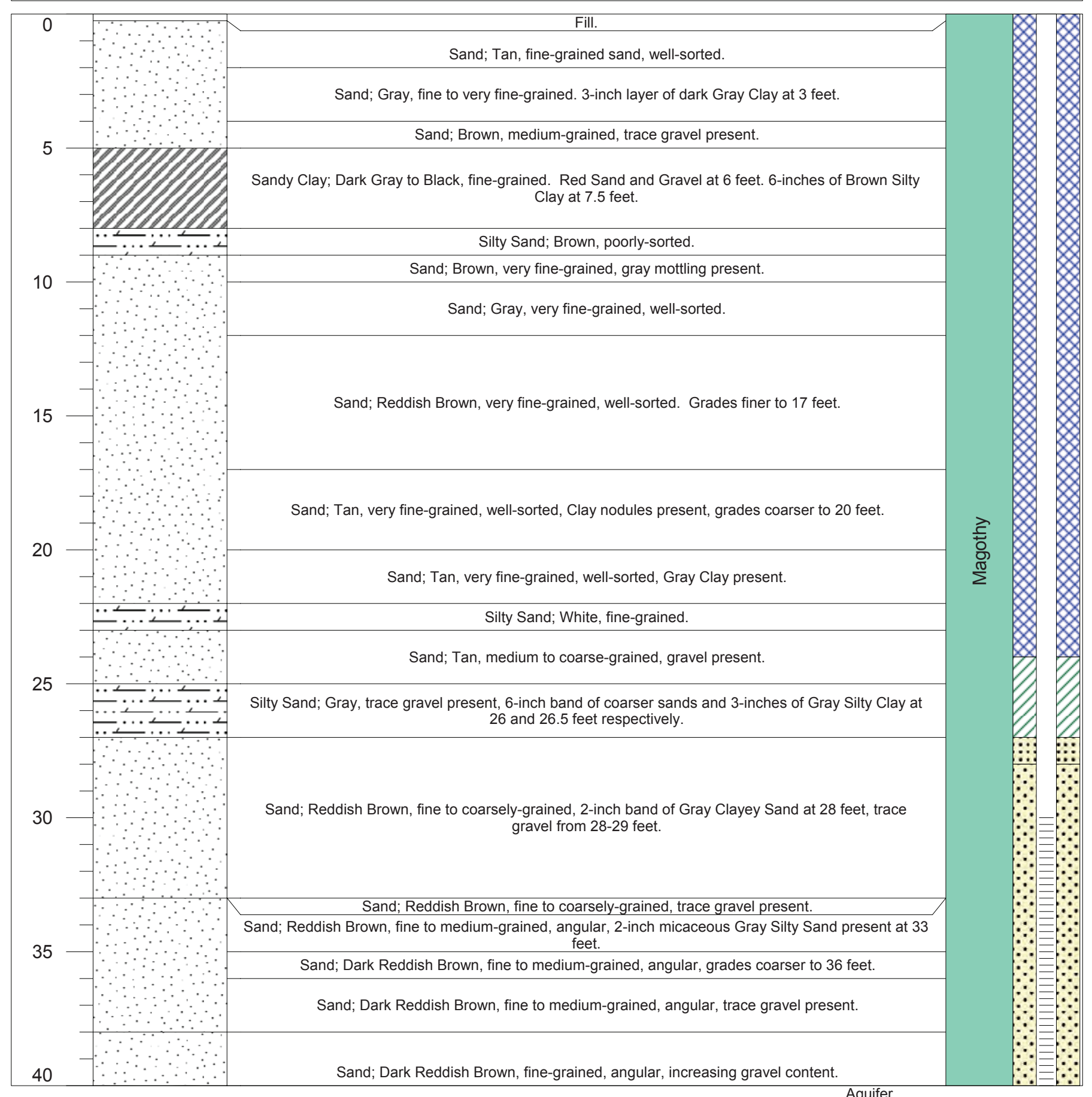

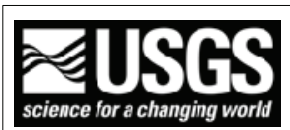

U.S. Department of the Interior U.S. Geological Survey

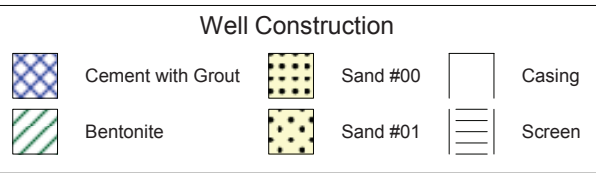

$\square$ Magothy
$\square$ UPA, shallow
$\square$ UPA, deep
Aquifer

Matawan Confining Unit Confining Unit

UPA, deep 


\begin{tabular}{|c|c|c|c|}
\hline $\begin{array}{l}\text { Station ID: } 392537075593002 \\
\text { Date Began: 3/30/2010 } \\
\text { Date Completed: } 3 / 31 / 2010 \\
\text { Logged By: A. Massey }\end{array}$ & $\begin{array}{l}\text { Boring Depth (Feet): } 217 \\
\text { Well Depth (Feet): } 177 \\
\text { Screen Size (Inches): } 0.02 \\
\text { Drilling Method: Sonic } \\
\text { Driller: Boart Longyear }\end{array}$ & $\begin{array}{l}\text { Latitude } \\
\text { (NAD 83): } 39^{\circ} 25^{\prime} 36.8^{\prime \prime} \mathrm{N} \\
\text { Longitude } 75^{\circ} 59^{\prime} 29.9^{\prime \prime} \mathrm{W} \\
\text { (NAD 83): } \\
\text { Land Surface Elevation } 21.99 \\
\text { (NAVD 88): }\end{array}$ & $\begin{array}{c}\text { CE Dd 152 } \\
\text { Pearce Creek } \\
\text { Dredge Material Containment Area } \\
\text { Cecil County, Maryland }\end{array}$ \\
\hline 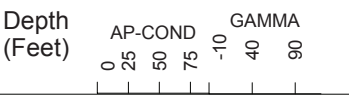 & $\begin{array}{l}\text { Lithologic } \\
\quad \text { Log }\end{array}$ & Lithologic Description & Aquifer \\
\hline
\end{tabular}

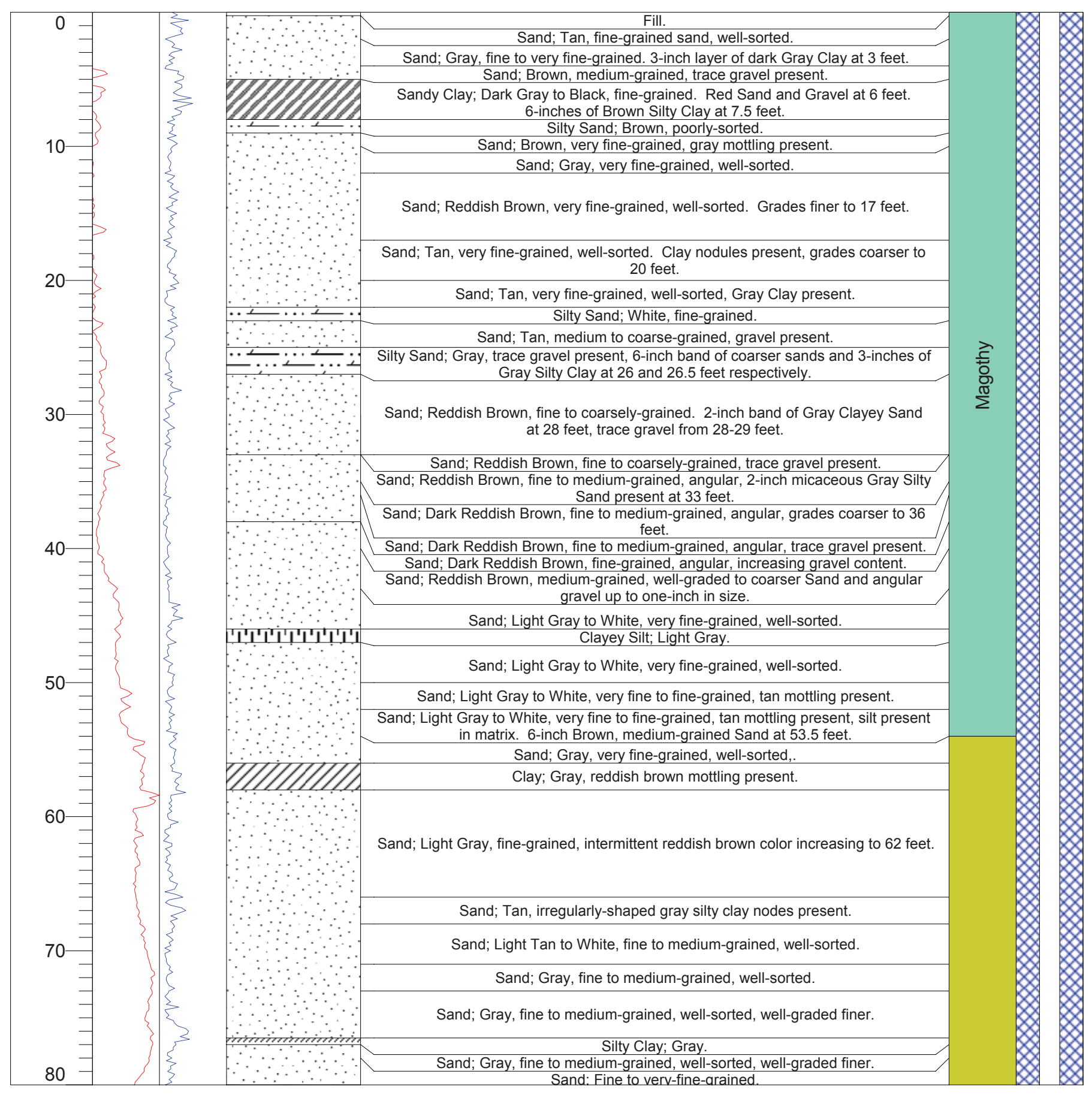

\section{Well Construction}

U.S. Department of the Interio U.S. Geological Survey
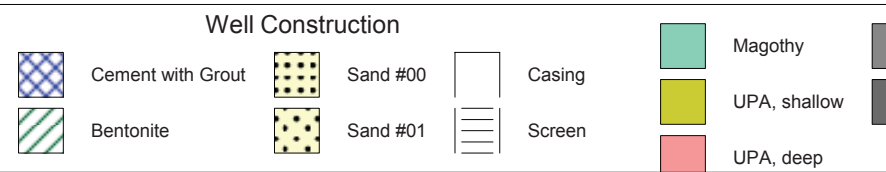

Matawan Confining Unit Confining Unit UPA, deep 


\begin{tabular}{|c|c|c|c|}
\hline 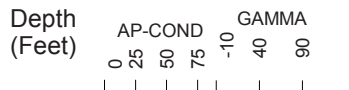 & $\begin{array}{c}\text { Lithologic } \\
\text { Log }\end{array}$ & Lithologic Description & Aquifer \\
\hline
\end{tabular}

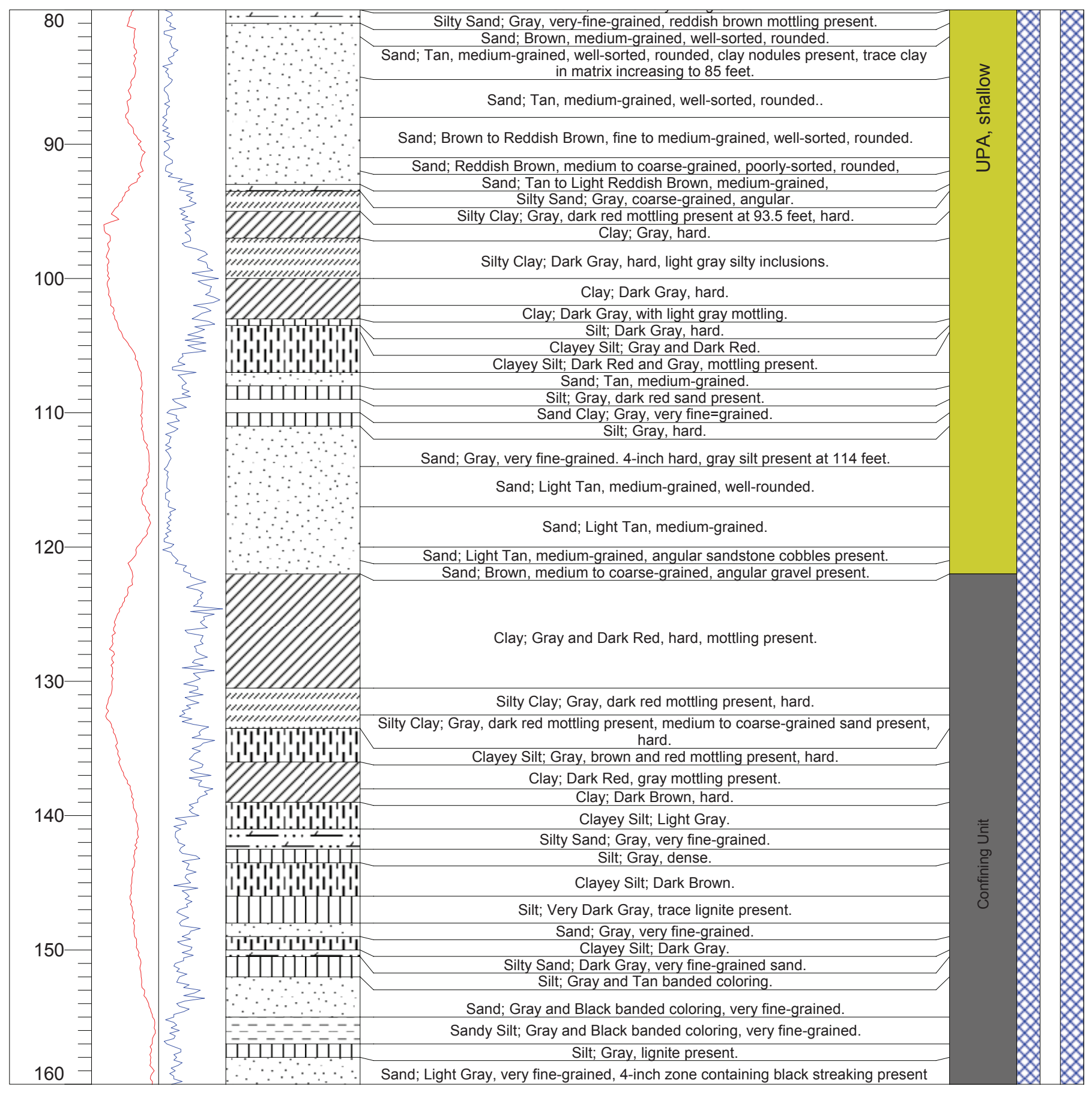

Department of the Interio U.S. Geological Survey
Well Construction

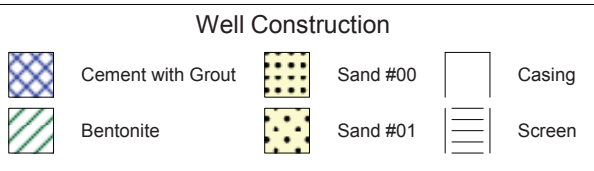

Matawan Confining Unit Confining Unit

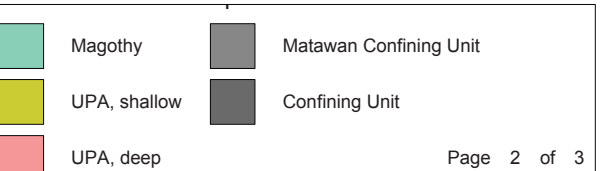




\begin{tabular}{|c|c|c|c|}
\hline $\begin{array}{l}\text { Station ID: } 392537075593002 \\
\text { Date Began: } 3 / 30 / 2010 \\
\text { Date Completed: } 3 / 31 / 2010 \\
\text { Logged By: A. Massey }\end{array}$ & $\begin{array}{l}\text { Boring Depth (Feet): } 217 \\
\text { Well Depth (Feet): } 177 \\
\text { Screen Size (Inches): } 0.02 \\
\text { Drilling Method: Sonic } \\
\text { Driller: Boart Longyear }\end{array}$ & $\begin{array}{l}\text { Latitude } \\
\text { (NAD 83): } 39^{\circ} 25^{\prime} 36.8^{\prime \prime} \mathrm{N} \\
\text { Longitude } \\
\text { (NAD 83): } 75^{\circ} 59^{\prime} 29.9^{\prime \prime W} \\
\text { Land Surface Elevation } 21.99 \\
\text { (NAVD 88): }\end{array}$ & $\begin{array}{c}\text { CE Dd } 152 \\
\text { Pearce Creek } \\
\text { Dredge Material Containment Area } \\
\text { Cecil County, Maryland }\end{array}$ \\
\hline $\begin{array}{l}\text { Depth AP-COND GAMMA } \\
\text { (Feet) } \\
\text { (t) }\end{array}$ & $\begin{array}{l}\text { Lithologic } \\
\text { Log }\end{array}$ & Lithologic Description & Aquifer \\
\hline
\end{tabular}

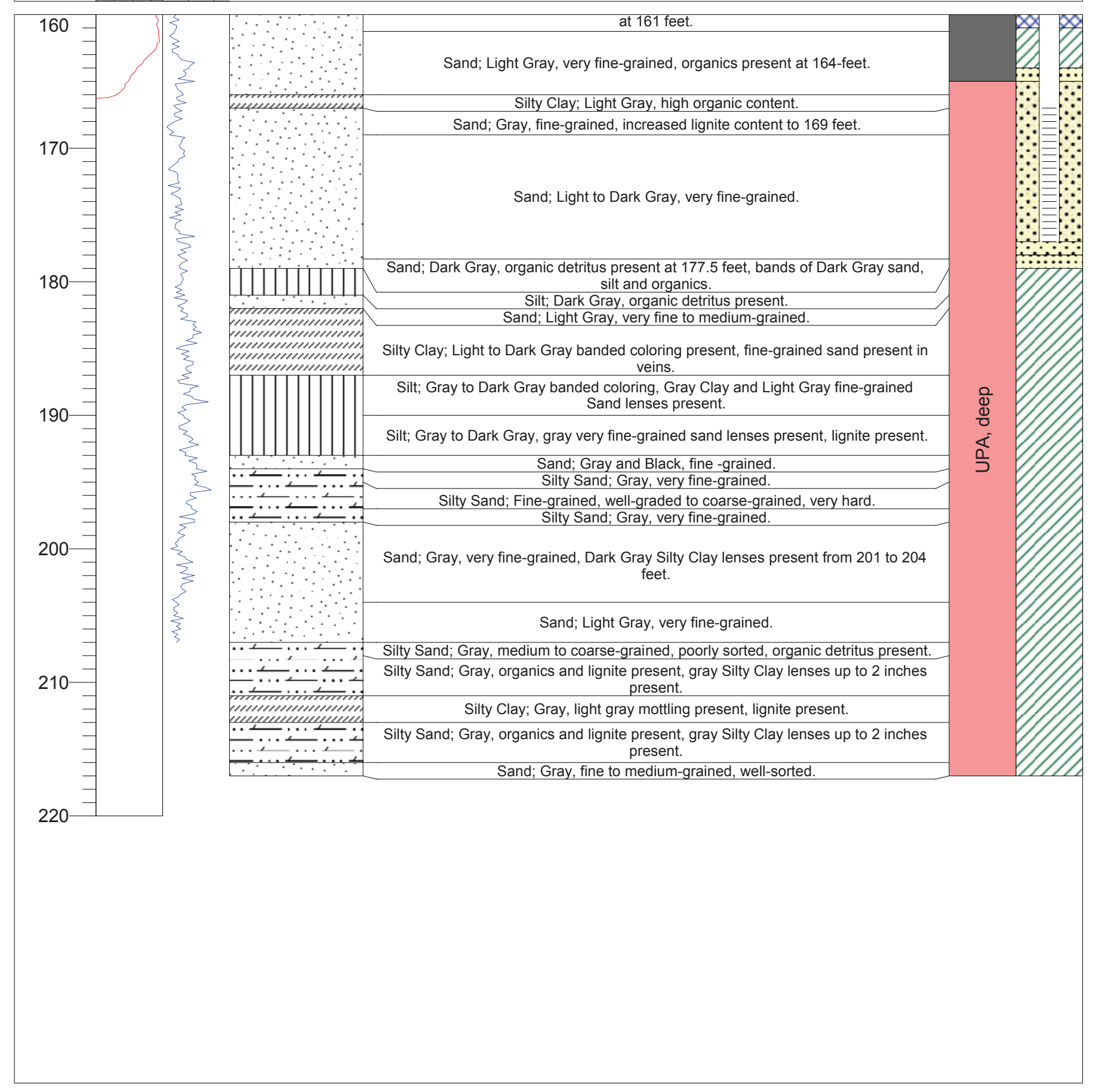

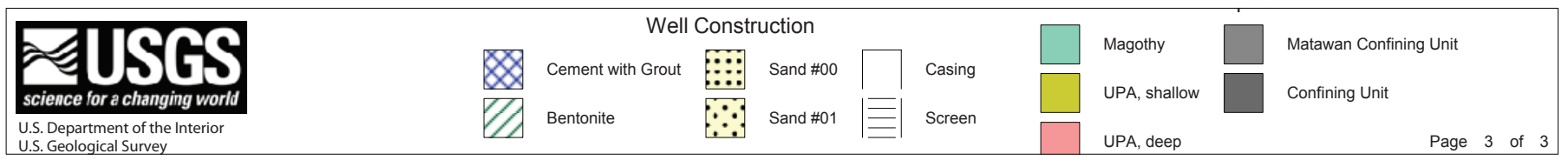




\begin{tabular}{|c|c|c|c|}
\hline $\begin{array}{l}\text { Station ID: } 392521075583301 \\
\text { Date Began: } 4 / 13 / 2010 \\
\text { Date Completed: } 4 / 14 / 2010 \\
\text { Logged By: C. Dieter }\end{array}$ & $\begin{array}{l}\text { Boring Depth (Feet): } 88 \\
\text { Well Depth (Feet): } 88 \\
\text { Screen Size (Inches): } 0.015 \\
\text { Drilling Method: Sonic } \\
\text { Driller: Boart Longyear }\end{array}$ & $\begin{array}{l}\text { Latitude } \\
\text { (NAD 83): } 39^{\circ} 25^{\prime} 20.7 " \mathrm{~N} \\
\text { Longitude } 75^{\circ} 58^{\prime} 33.2^{\prime \prime} \mathrm{W} \\
\text { (NAD 83): } \\
\text { Land Surface Elevation } 48.34 \\
\text { (NAVD 88): }\end{array}$ & $\begin{array}{c}\text { CE Dd } 153 \\
\text { Pearce Creek } \\
\text { Dredge Material Containment Area } \\
\text { Cecil County, Maryland }\end{array}$ \\
\hline $\begin{array}{lc}\text { Depth } & \text { Lithologic } \\
\text { (Feet) } & \text { Log }\end{array}$ & & Lithologic Description & Aquifer \\
\hline
\end{tabular}

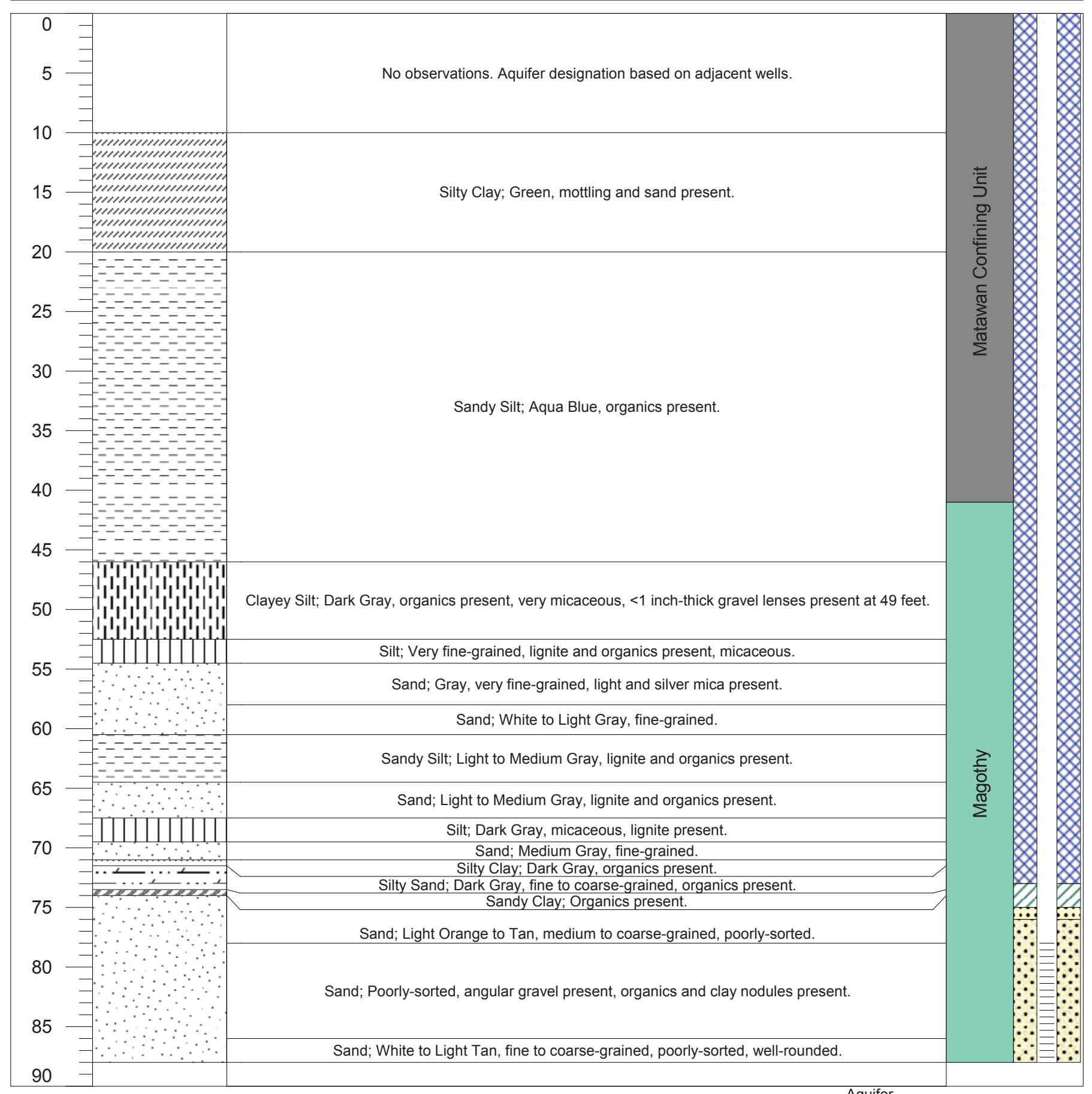

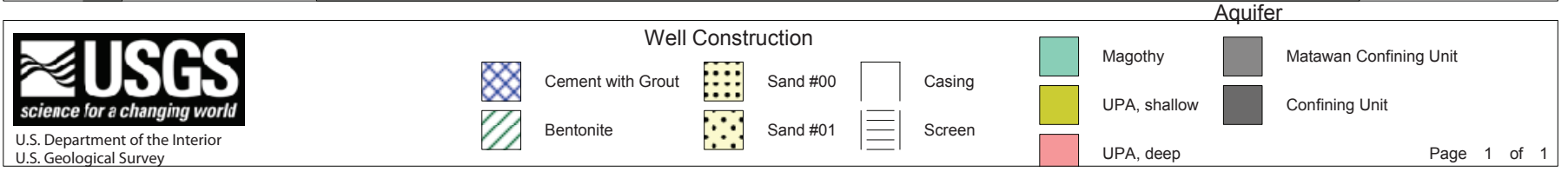




\begin{tabular}{|c|c|c|c|}
\hline $\begin{array}{l}\text { Station ID: } 392521075583302 \\
\text { Date Began: } 4 / 11 / 2010 \\
\text { Date Completed: } 4 / 12 / 2010 \\
\text { Logged By: A. Massey }\end{array}$ & $\begin{array}{l}\text { Boring Depth (Feet): } 167 \\
\text { Well Depth (Feet): } 162 \\
\text { Screen Size (Inches): } 0.015 \\
\text { Drilling Method: Sonic } \\
\text { Driller: Boart Longyear }\end{array}$ & $\begin{array}{l}\text { Latitude } 39^{\circ} 25^{\prime} 20.7 " \mathrm{~N} \\
\text { (NAD 83): } \\
\text { Longitude } 75^{\circ} 58^{\prime} 33.2^{\prime \prime} \mathrm{W} \\
\text { (NAD 83): } \\
\text { Land Surface Elevation } 47.61 \\
\text { (NAVD 88): }\end{array}$ & $\begin{array}{c}\text { CE Dd 154 } \\
\text { Pearce Creek } \\
\text { Dredge Material Containment Area } \\
\text { Cecil County, Maryland }\end{array}$ \\
\hline $\begin{array}{lc}\text { Depth } & \text { Lithologic } \\
\text { (Feet) } & \text { Log }\end{array}$ & & Lithologic Description & Aquifer \\
\hline
\end{tabular}

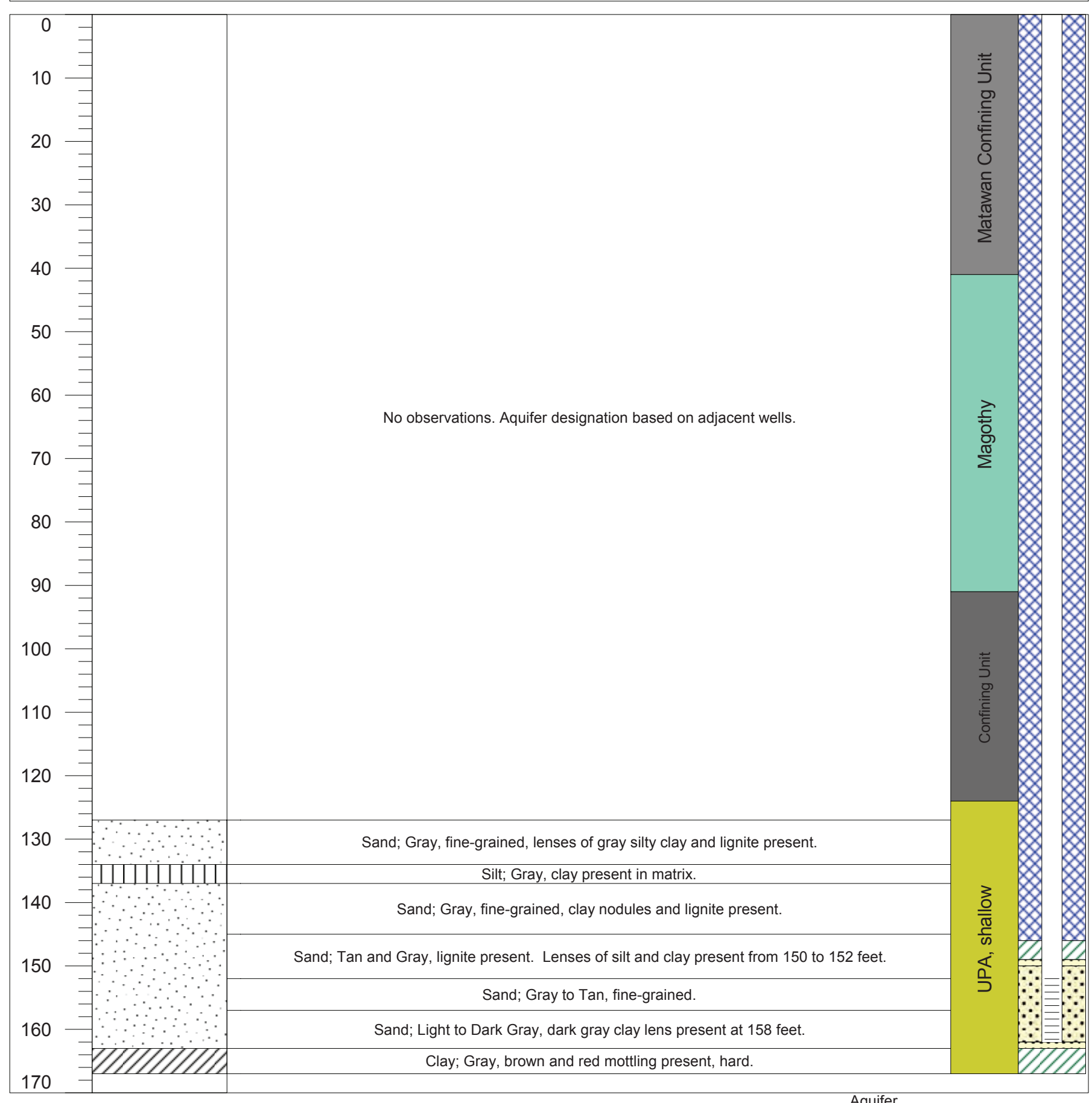

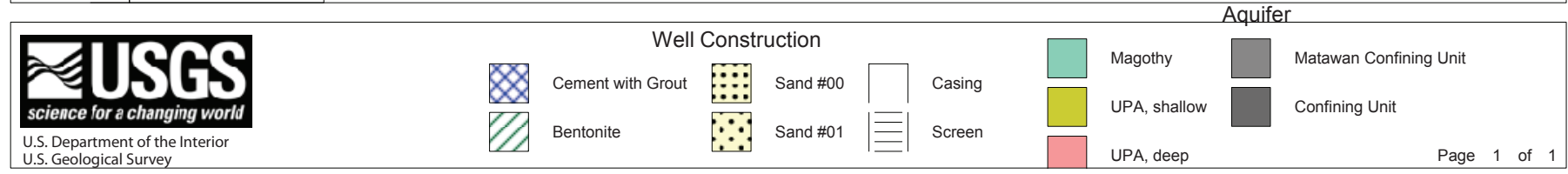




\begin{tabular}{|c|c|c|c|}
\hline $\begin{array}{l}\text { Station ID: } 392521075583303 \\
\text { Date Began: 4/8/2010 } \\
\text { Date Completed: 4/10/2010 } \\
\text { Logged By: J. Sorenson }\end{array}$ & $\begin{array}{l}\text { Boring Depth (Feet): } 287 \\
\text { Well Depth (Feet): } 223 \\
\text { Screen Size (Inches): } 0.02 \\
\text { Drilling Method: Sonic } \\
\text { Driller: Boart Longyear }\end{array}$ & $\begin{array}{l}\text { Latitude } \\
\text { (NAD 83): } 39^{\circ} 25^{\prime} 20.7 " \mathrm{~N} \\
\text { Longitude } \\
\text { (NAD 83): } 75^{\circ} 58^{\prime} 33.2^{\prime \prime} \mathrm{W} \\
\text { Land Surface Elevation } 46.99 \\
\text { (NAVD 88): }\end{array}$ & $\begin{array}{c}\text { CE Dd } 155 \\
\text { Pearce Creek } \\
\text { Dredge Material Containment Area } \\
\text { Cecil County, Maryland }\end{array}$ \\
\hline $\begin{array}{lll}\text { Depth } & \text { AP-COND } & \text { GAMMA } \\
\text { (Feet) } & \stackrel{7}{\infty} \infty & \infty\end{array}$ & $\begin{array}{l}\text { Lithologic } \\
\quad \text { Log }\end{array}$ & Lithologic Description & Aquifer \\
\hline
\end{tabular}

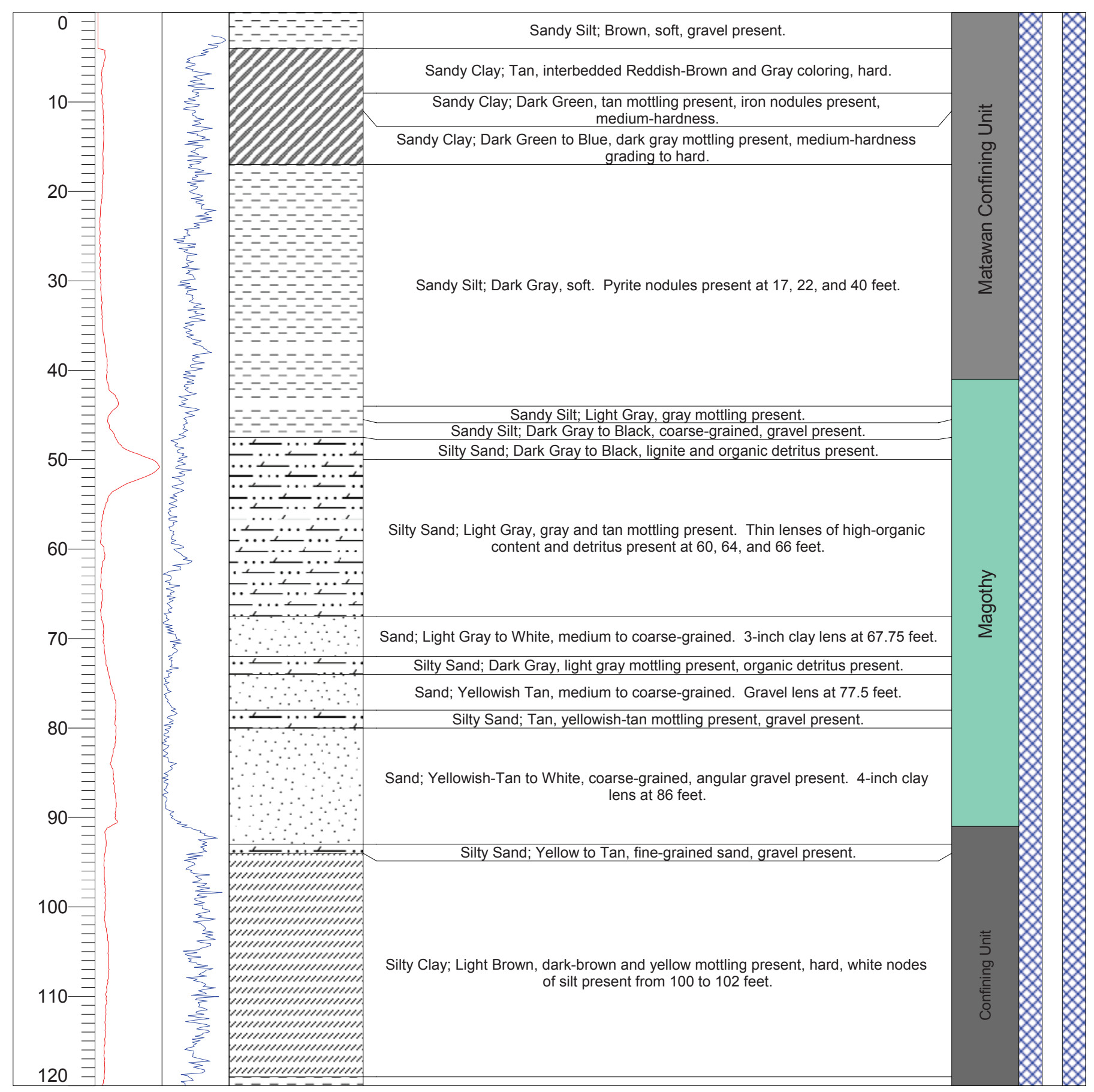

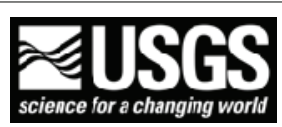

U.S. Department of the Interio U.S. Geological Survey
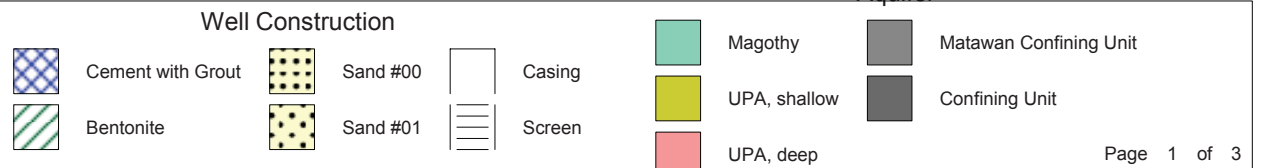


\begin{tabular}{|c|c|c|c|}
\hline $\begin{array}{l}\text { Station ID: } 392521075583303 \\
\text { Date Began: 4/8/2010 } \\
\text { Date Completed: 4/10/2010 } \\
\text { Logged By: J. Sorenson }\end{array}$ & $\begin{array}{l}\text { Boring Depth (Feet): } 287 \\
\text { Well Depth (Feet): } 223 \\
\text { Screen Size (Inches): } 0.02 \\
\text { Drilling Method: Sonic } \\
\text { Driller: Boart Longyear }\end{array}$ & $\begin{array}{l}\text { Latitude } \\
\text { (NAD 83): } 39^{\circ} 25^{\prime} 20.7^{\prime \prime} \mathrm{N} \\
\text { Longitude } 75^{\circ} 58^{\prime} 33.2^{\prime \prime} \mathrm{W} \\
\text { (NAD 83): } \\
\text { Land Surface Elevation } 46.99 \\
\text { (NAVD 88): }\end{array}$ & $\begin{array}{c}\text { CE Dd 155 } \\
\text { Pearce Creek } \\
\text { Dredge Material Containment Area } \\
\text { Cecil County, Maryland }\end{array}$ \\
\hline 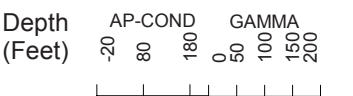 & $\begin{array}{l}\text { Lithologic } \\
\quad \text { Log }\end{array}$ & Lithologic Description & Aquifer \\
\hline
\end{tabular}

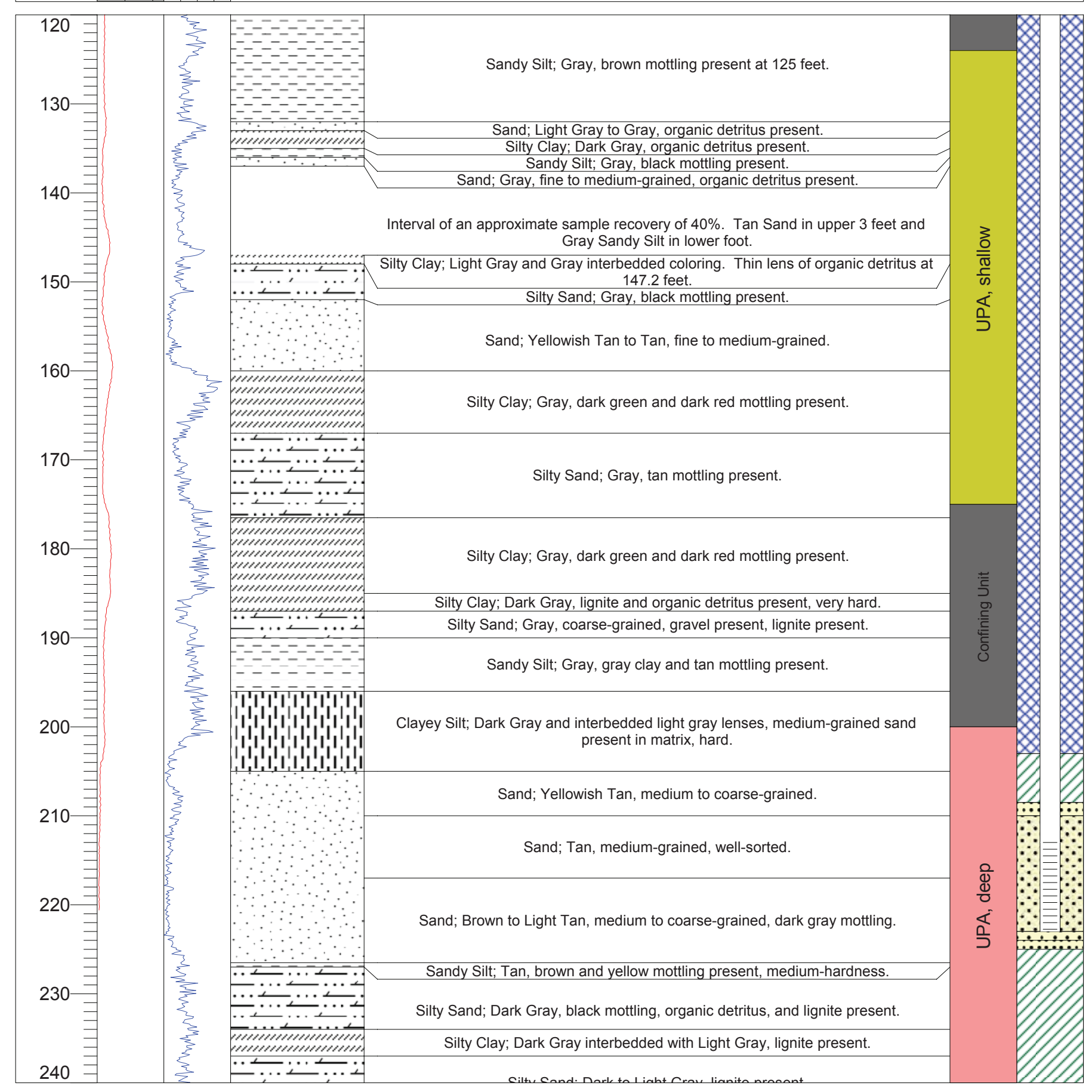

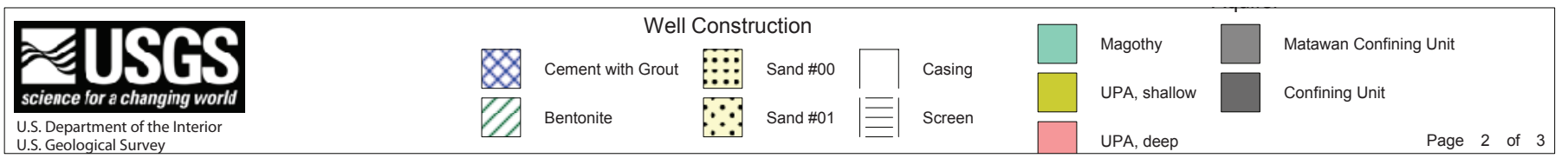




\begin{tabular}{|c|c|c|c|}
\hline $\begin{array}{l}\text { Station ID: } 392521075583303 \\
\text { Date Began: } 4 / 8 / 2010 \\
\text { Date Completed: } 4 / 10 / 2010 \\
\text { Logged By: J. Sorenson }\end{array}$ & $\begin{array}{l}\text { Boring Depth (Feet): } 287 \\
\text { Well Depth (Feet): } 223 \\
\text { Screen Size (Inches): } 0.02 \\
\text { Drilling Method: Sonic } \\
\text { Driller: Boart Longyear }\end{array}$ & $\begin{array}{l}\text { Latitude } \\
\text { (NAD 83): } 39^{\circ} 25^{\prime} 20.7 " \mathrm{~N} \\
\text { Longitude } 75^{\circ} 58^{\prime} 33.2^{\prime \prime} \mathrm{W} \\
\text { (NAD 83): } \\
\text { Land Surface Elevation } 46.99 \\
\text { (NAVD 88): }\end{array}$ & $\begin{array}{c}\text { CE Dd } 155 \\
\text { Pearce Creek } \\
\text { Dredge Material Containment Area } \\
\text { Cecil County, Maryland }\end{array}$ \\
\hline 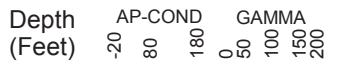 & $\begin{array}{l}\text { Lithologic } \\
\quad \text { Log }\end{array}$ & Lithologic Description & Aquifer \\
\hline
\end{tabular}

\begin{tabular}{|c|c|c|c|}
\hline 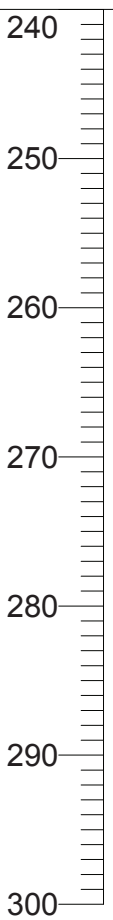 & 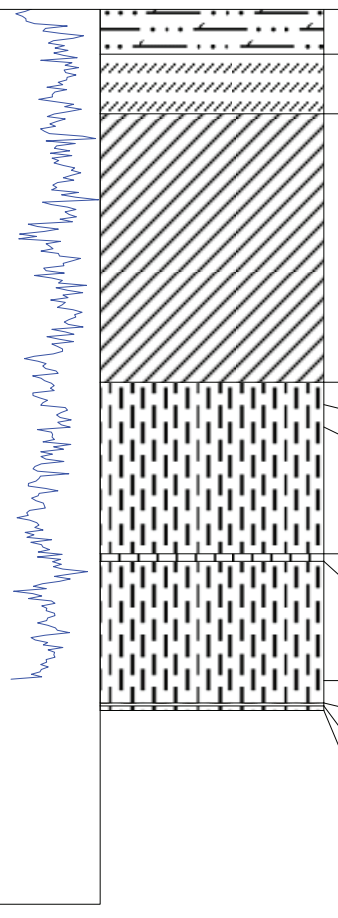 & $\begin{array}{l}\text { Clayey Silt; Light Gray, green and red mottling present. } \\
\text { Clayey Silt; Olive Green, light gray and red mottling, very hard. } \\
\text { Clayey Silt; Light Gray, mottling present, friable. } \\
\text { Silt; Gray, hard, silt concretions and sand present, saturated. } \\
\text { Clayey Silt; Reddish Brown, gray mottling, hard. } \\
\text { Clayey Silt; Dark Gray, light gray and black mottling, very hard. } \\
\text { Sandy Silt; Light Gray. } \\
\text { Clayey Silt; Dark Gray, light gray and black mottling, very hard. }\end{array}$ & VIIJ \\
\hline
\end{tabular}

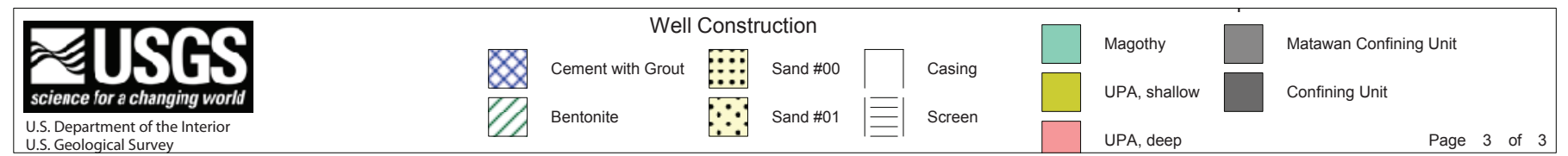




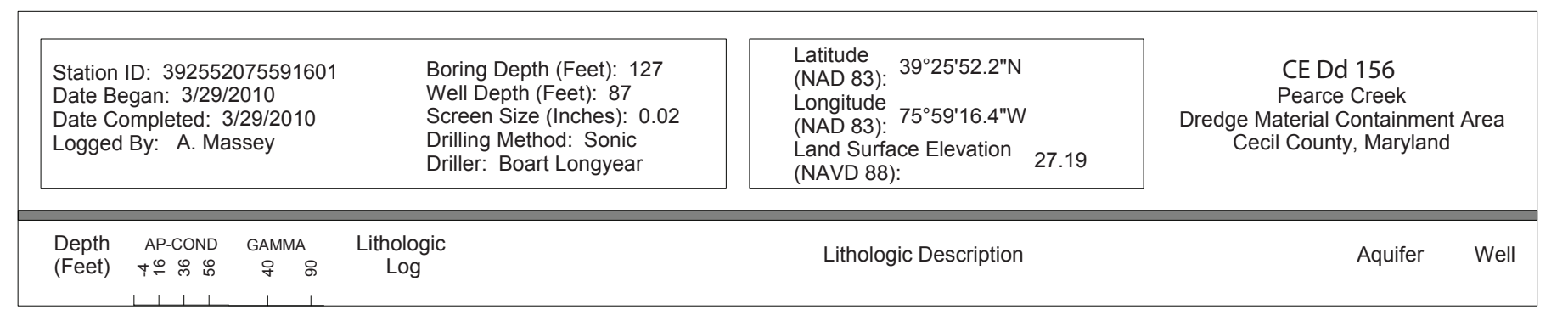

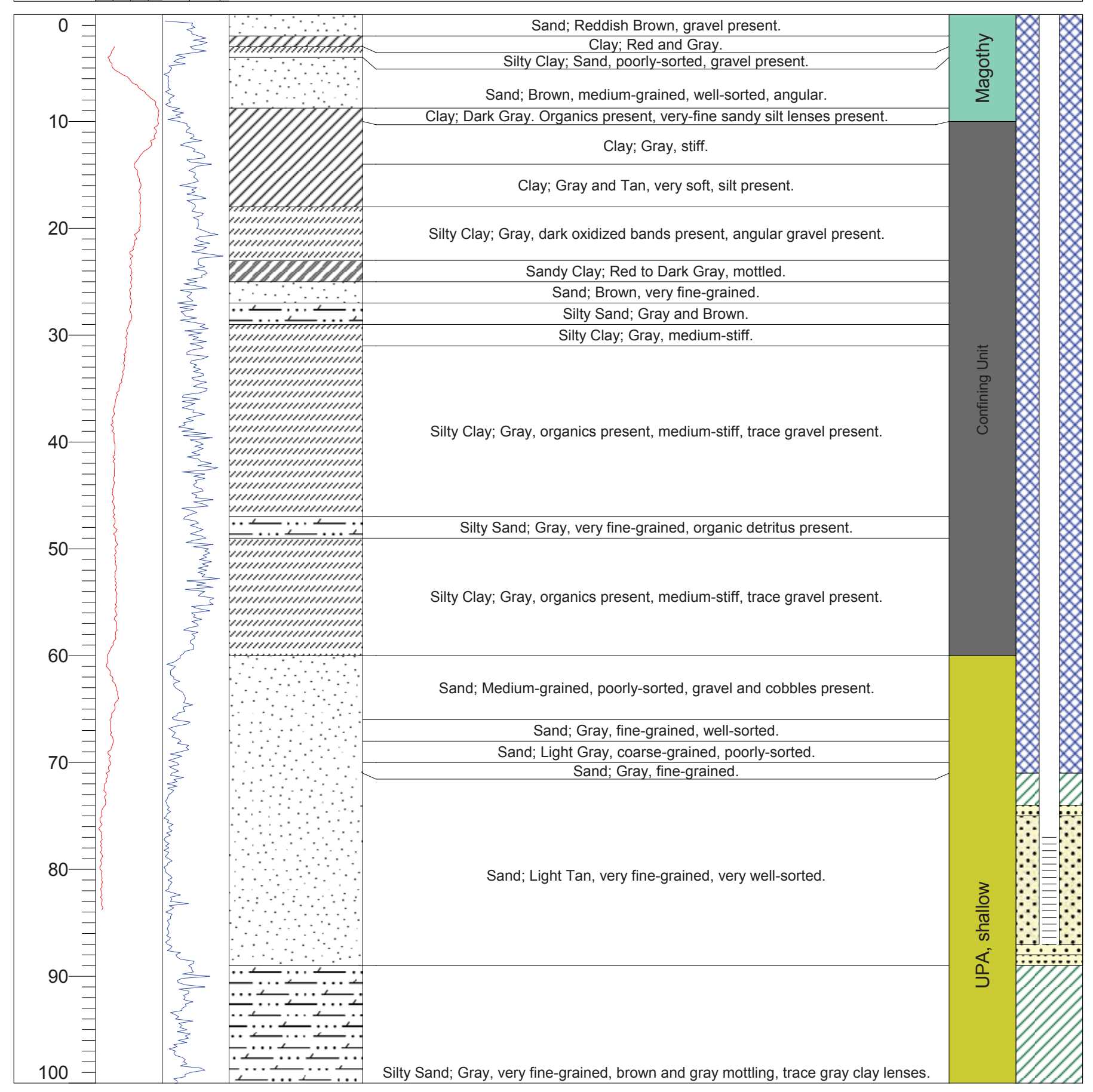




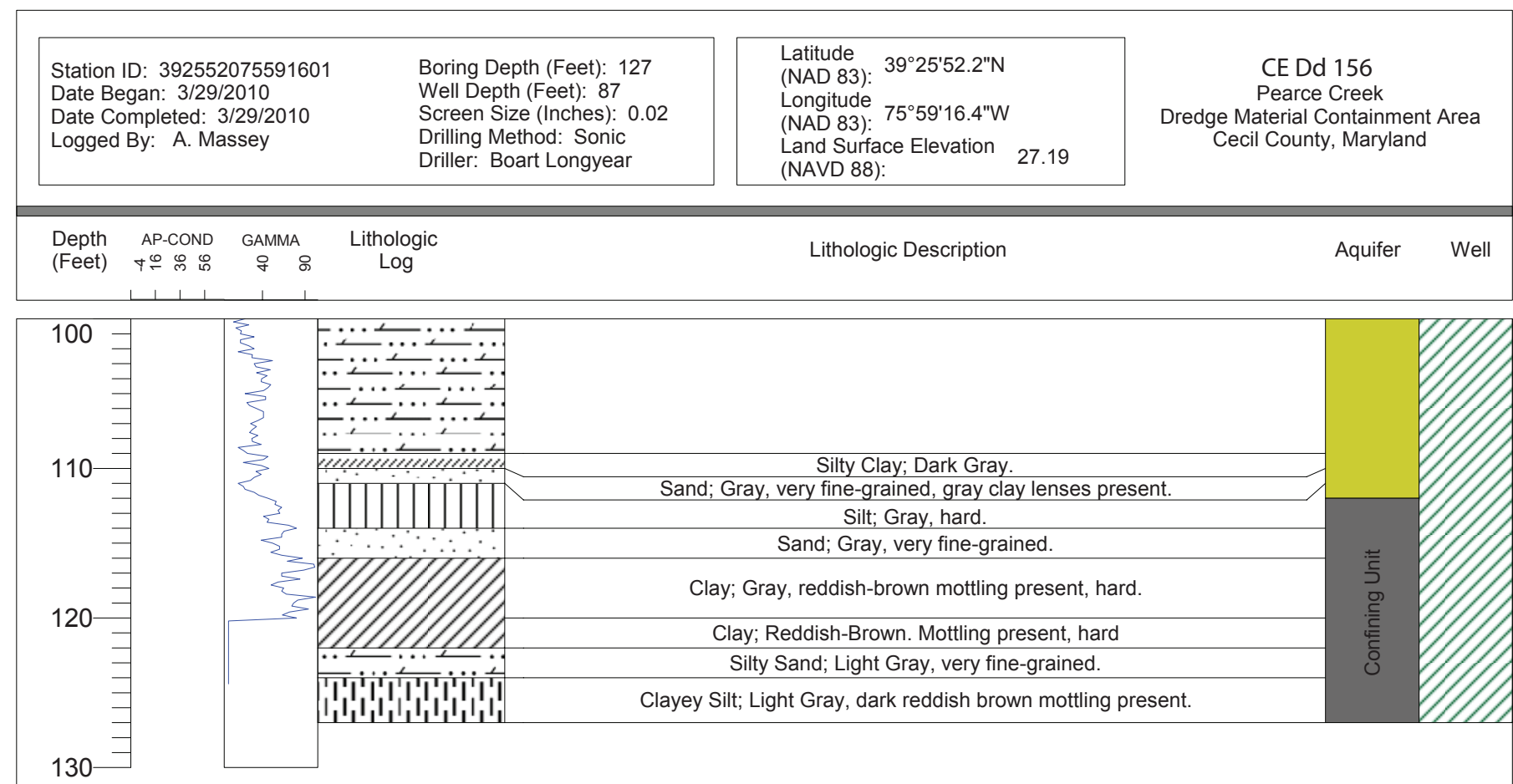

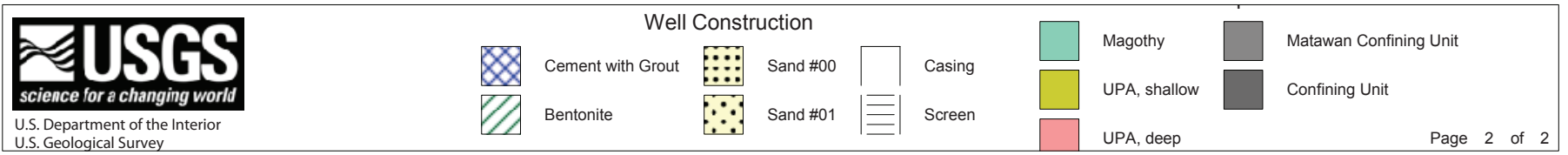




\begin{tabular}{|c|c|c|c|}
\hline $\begin{array}{l}\text { Station ID: } 392537075590101 \\
\text { Date Began: 4/7/2010 } \\
\text { Date Completed: 4/7/2010 } \\
\text { Logged By: J. Sorenson }\end{array}$ & $\begin{array}{l}\text { Boring Depth (Feet): } 58 \\
\text { Well Depth (Feet): } 56 \\
\text { Screen Size (Inches): } 0.02 \\
\text { Drilling Method: Sonic } \\
\text { Driller: Boart Longyear }\end{array}$ & $\begin{array}{l}\text { Latitude } \\
\text { (NAD 83): } 39^{\circ} 25^{\prime} 36.8^{\prime \prime} \mathrm{N} \\
\text { Longitude } 75^{\circ} 59^{\prime} 00.9^{\prime \prime} \mathrm{W} \\
\text { (NAD 83): } \\
\text { Land Surface Elevation } 38.22 \\
\text { (NAVD 88): }\end{array}$ & $\begin{array}{c}\text { CE Dd 157 } \\
\text { Pearce Creek } \\
\text { Dredge Material Containment Area } \\
\text { Cecil County, Maryland }\end{array}$ \\
\hline $\begin{array}{lc}\text { Depth } & \text { Lithologic } \\
\text { (Feet) } & \text { Log }\end{array}$ & & Lithologic Description & Aquifer \\
\hline
\end{tabular}

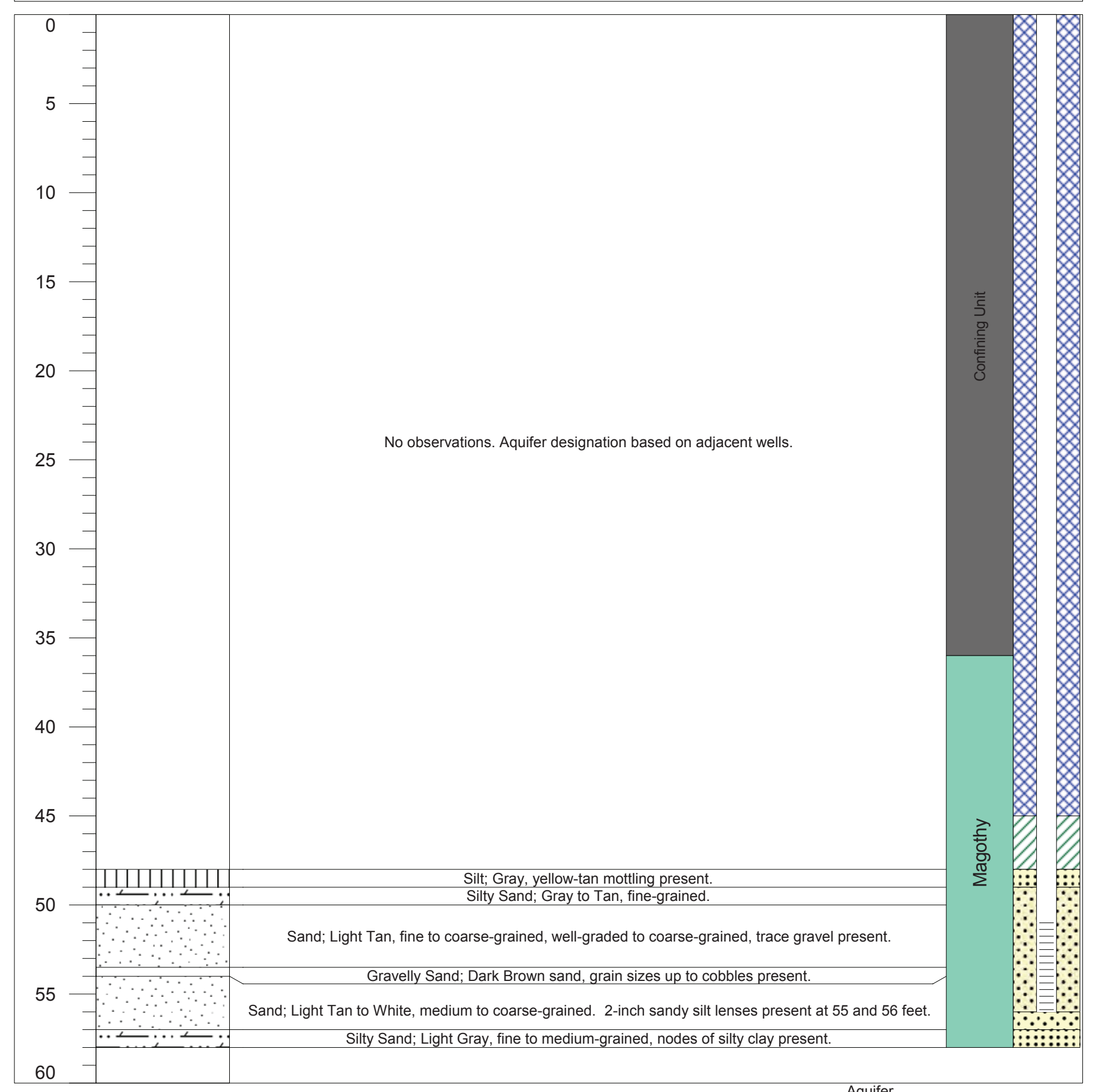

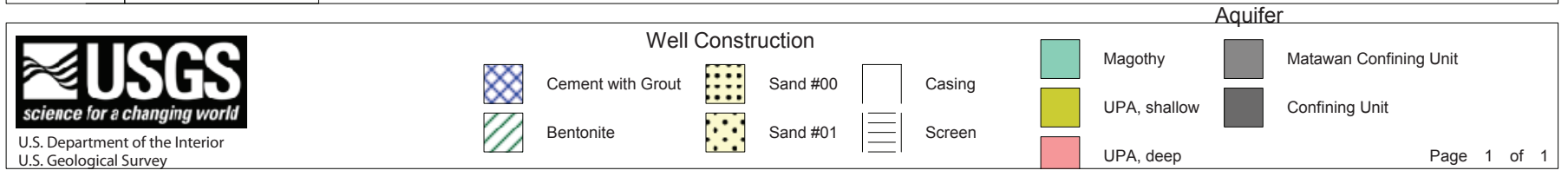




\begin{tabular}{|c|c|c|c|}
\hline $\begin{array}{l}\text { Station ID: } 392537075590102 \\
\text { Date Began: 4/6/2010 } \\
\text { Date Completed: 4/7/2010 } \\
\text { Logged By: A. Massey }\end{array}$ & $\begin{array}{l}\text { Boring Depth (Feet): } 148 \\
\text { Well Depth (Feet): } 112 \\
\text { Screen Size (Inches): } 0.02 \\
\text { Drilling Method: Sonic } \\
\text { Driller: Boart Longyear }\end{array}$ & $\begin{array}{l}\text { Latitude } 39^{\circ} 25^{\prime} 36.8^{\prime \prime} \mathrm{N} \\
\text { (NAD 83): } \\
\text { Longitude } 75^{\circ} 59^{\prime} 00.9^{\prime \prime W} \\
\text { (NAD 83): } \\
\text { Land Surface Elevation } 38.36 \\
\text { (NAVD 88): }\end{array}$ & $\begin{array}{c}\text { CE Dd } 158 \\
\text { Pearce Creek } \\
\text { Dredge Material Containment Area } \\
\text { Cecil County, Maryland }\end{array}$ \\
\hline 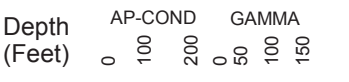 & $\begin{array}{l}\text { Lithologic } \\
\text { Log }\end{array}$ & Lithologic Description & Aquifer \\
\hline
\end{tabular}

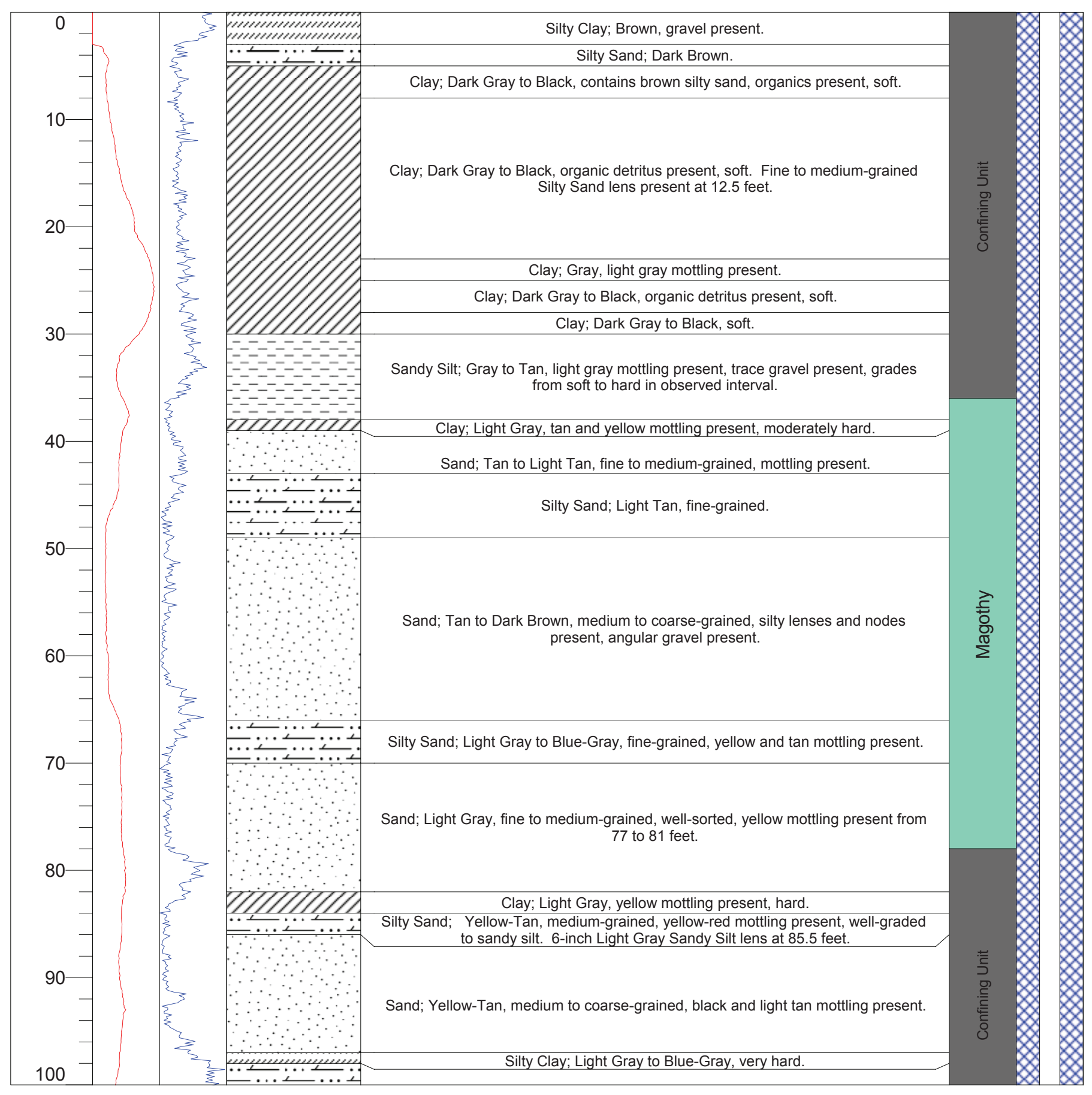

Well Construction

U.S. Department of the Interio U.S. Geological Survey

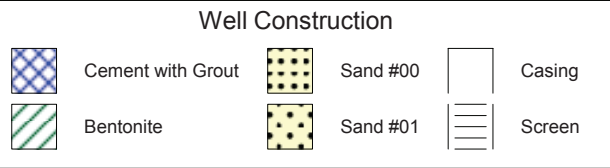

\begin{tabular}{|c|c|}
\hline Magothy & Matawan Confining Unit \\
\hline UPA, shallow & Confining Unit \\
\hline UPA, deep & Page 1 of 2 \\
\hline
\end{tabular}




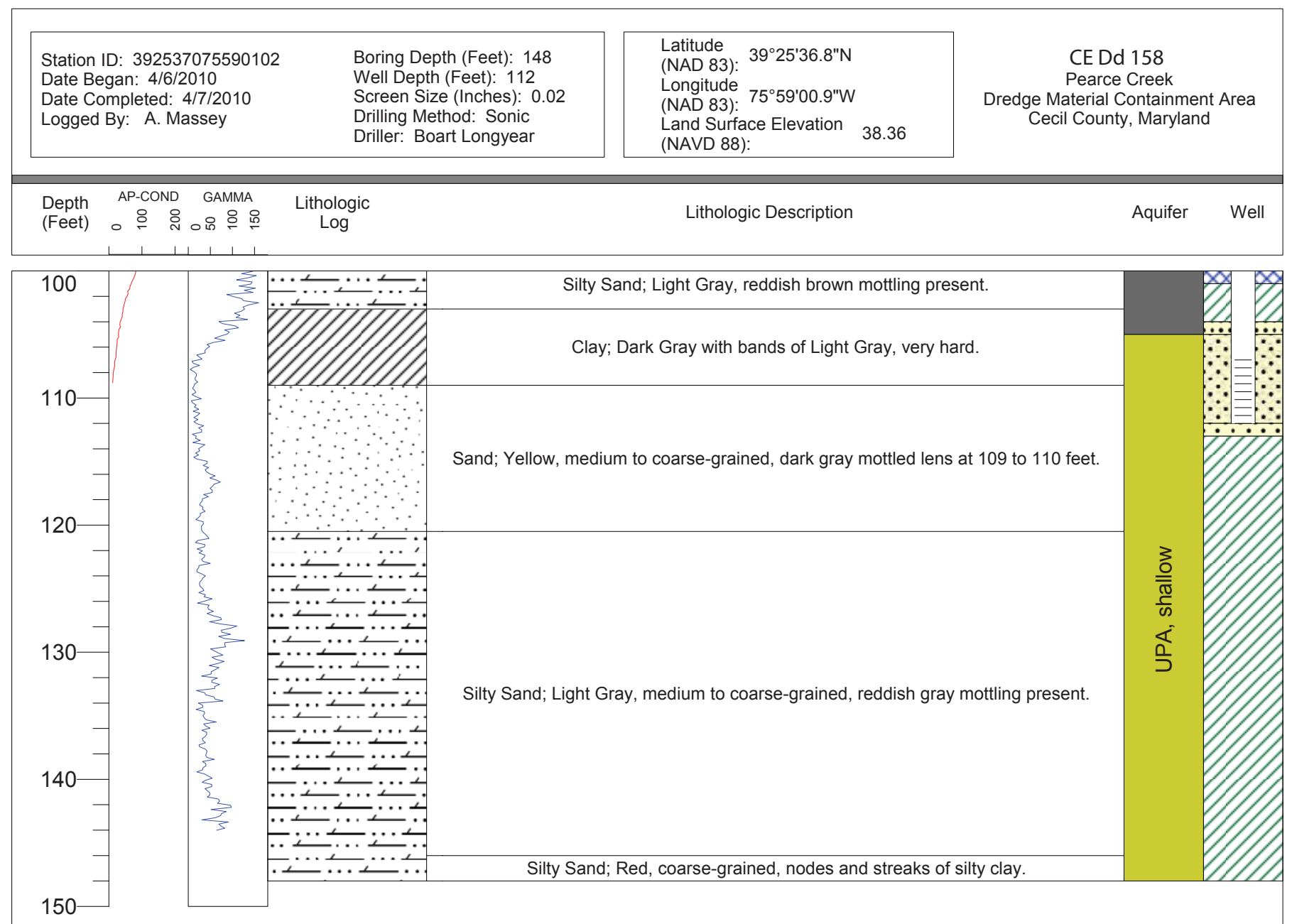

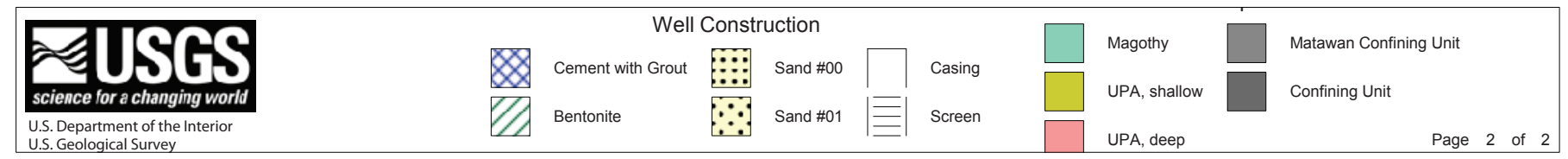




\begin{tabular}{|c|c|c|c|}
\hline $\begin{array}{l}\text { Station ID: } 392545075594601 \\
\text { Date Began: 4/6/2010 } \\
\text { Date Completed: 4/6/2010 } \\
\text { Logged By: M. Leipert (USACE) }\end{array}$ & $\begin{array}{l}\text { Boring Depth (Feet): } 121 \\
\text { Well Depth (Feet): } 35 \\
\text { Screen Size (Inches): } 0.02 \\
\text { Drilling Method: Sonic } \\
\text { Driller: Boart Longyear }\end{array}$ & $\begin{array}{l}\text { Latitude } \\
\text { (NAD 83): } 39^{\circ} 25^{\prime} 44.7^{\prime \prime} \mathrm{N} \\
\text { Longitude } 75^{\circ} 59^{\prime} 46.0^{\prime \prime W} \\
\text { (NAD 83): } \\
\text { Land Surface Elevation } 28.20 \\
\text { (NAVD 88): }\end{array}$ & $\begin{array}{c}\text { CE Dd } 159 \\
\text { Pearce Creek } \\
\text { Dredge Material Containment Area } \\
\text { Cecil County, Maryland }\end{array}$ \\
\hline $\begin{array}{lc}\text { Depth } & \text { GAMMA } \\
\text { (Feet) } & \circ \circ \stackrel{\circ}{\circ} \stackrel{\circ}{\circ}\end{array}$ & & Lithologic Description & Aquifer \\
\hline
\end{tabular}

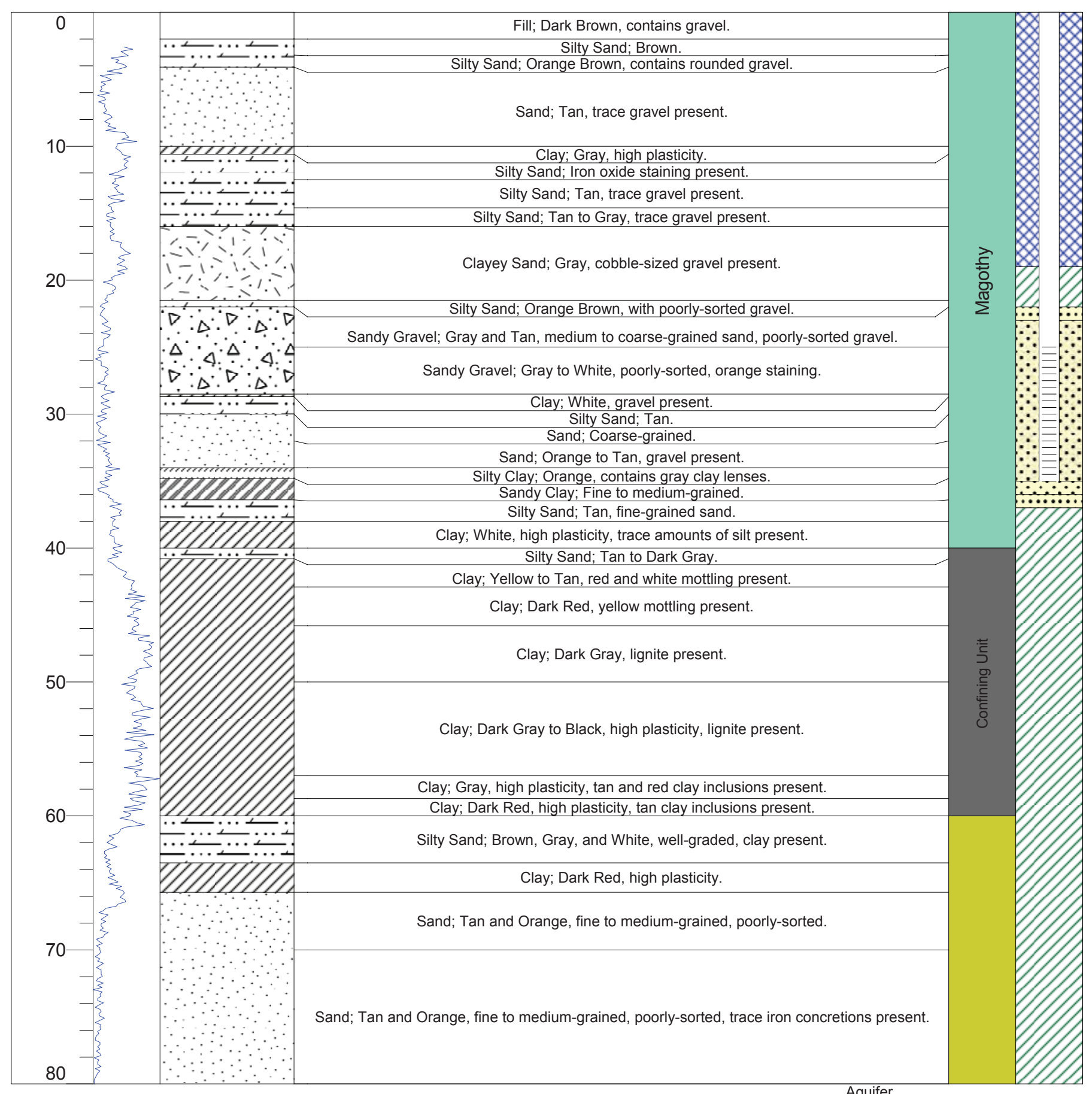

\begin{tabular}{|c|c|c|c|c|c|c|c|}
\hline \multirow{2}{*}{ science for a changing world } & \multirow{2}{*}{\multicolumn{5}{|c|}{ Well Construction }} & \multicolumn{2}{|c|}{ Aquifer } \\
\hline & & & & & & & \\
\hline
\end{tabular}




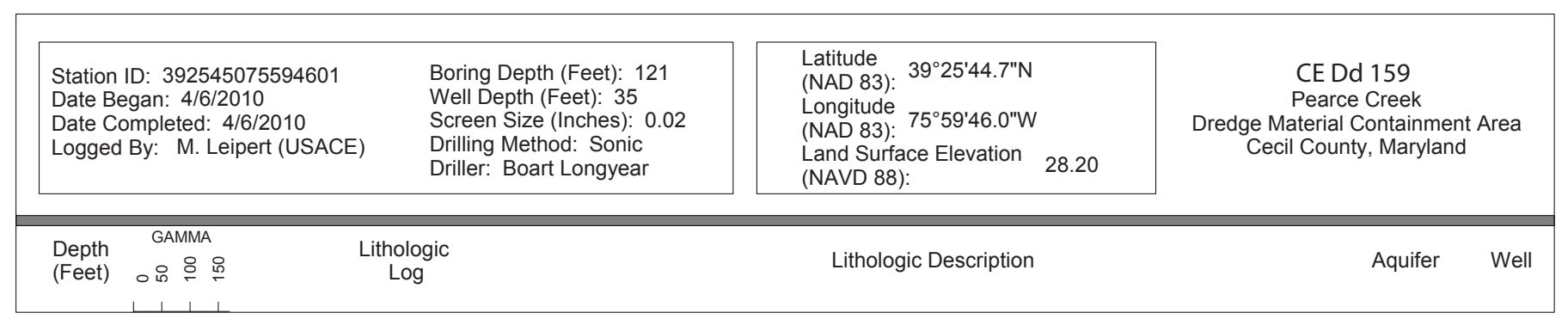

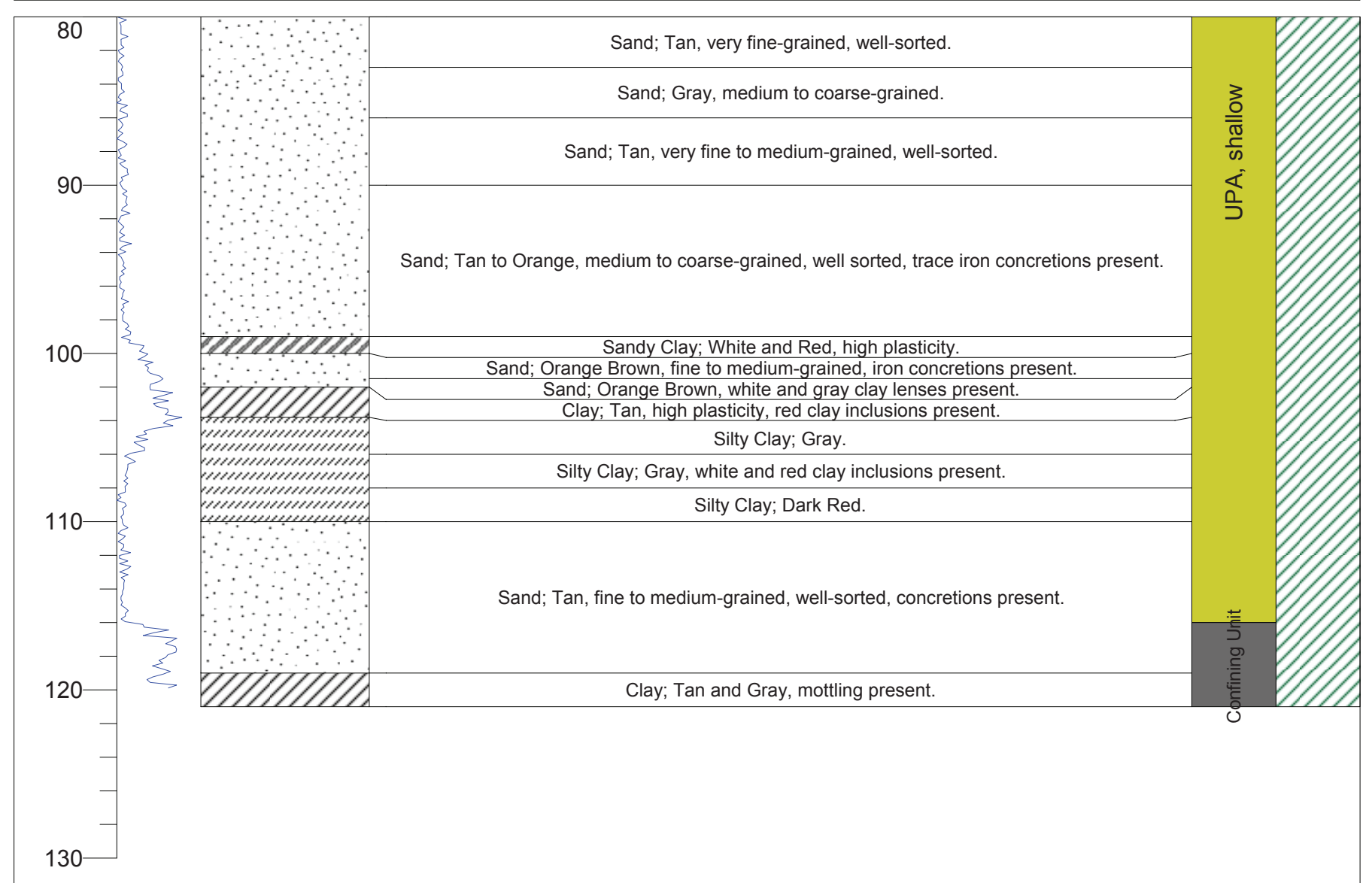

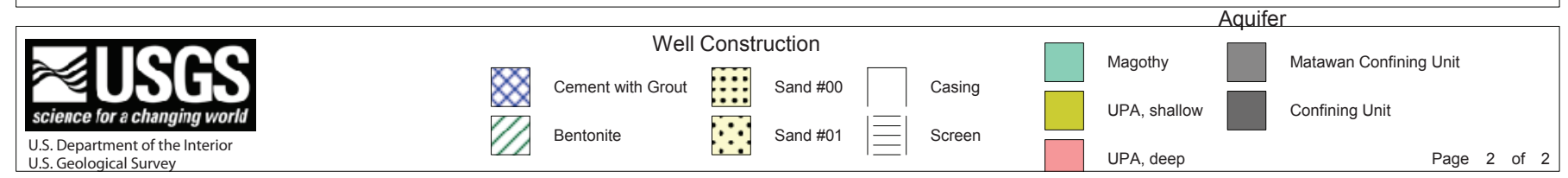




\begin{tabular}{|c|c|c|c|}
\hline $\begin{array}{l}\text { Station ID: } 392545075594602 \\
\text { Date Began: 4/9/2010 } \\
\text { Date Completed: 4/9/2010 } \\
\text { Logged By: J. Sorenson }\end{array}$ & $\begin{array}{l}\text { Boring Depth (Feet): } 120 \\
\text { Well Depth (Feet): } 116 \\
\text { Screen Size (Inches): } 0.02 \\
\text { Drilling Method: Sonic } \\
\text { Driller: Boart Longyear }\end{array}$ & $\begin{array}{l}\text { Latitude } 39^{\circ} 25^{\prime} 44.7^{\prime \prime} \mathrm{N} \\
\text { (NAD 83): } \\
\text { Longitude } 75^{\circ} 59^{\prime} 46.0^{\prime \prime} \mathrm{W} \\
\text { (NAD 83): } \\
\text { Land Surface Elevation } 27.64 \\
\text { (NAVD 88): }\end{array}$ & $\begin{array}{c}\text { CE Dd } 160 \\
\text { Pearce Creek } \\
\text { Dredge Material Containment Area } \\
\text { Cecil County, Maryland }\end{array}$ \\
\hline 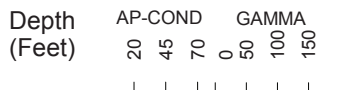 & $\begin{array}{l}\text { Lithologic } \\
\text { Log }\end{array}$ & Lithologic Description & Aquifer \\
\hline
\end{tabular}

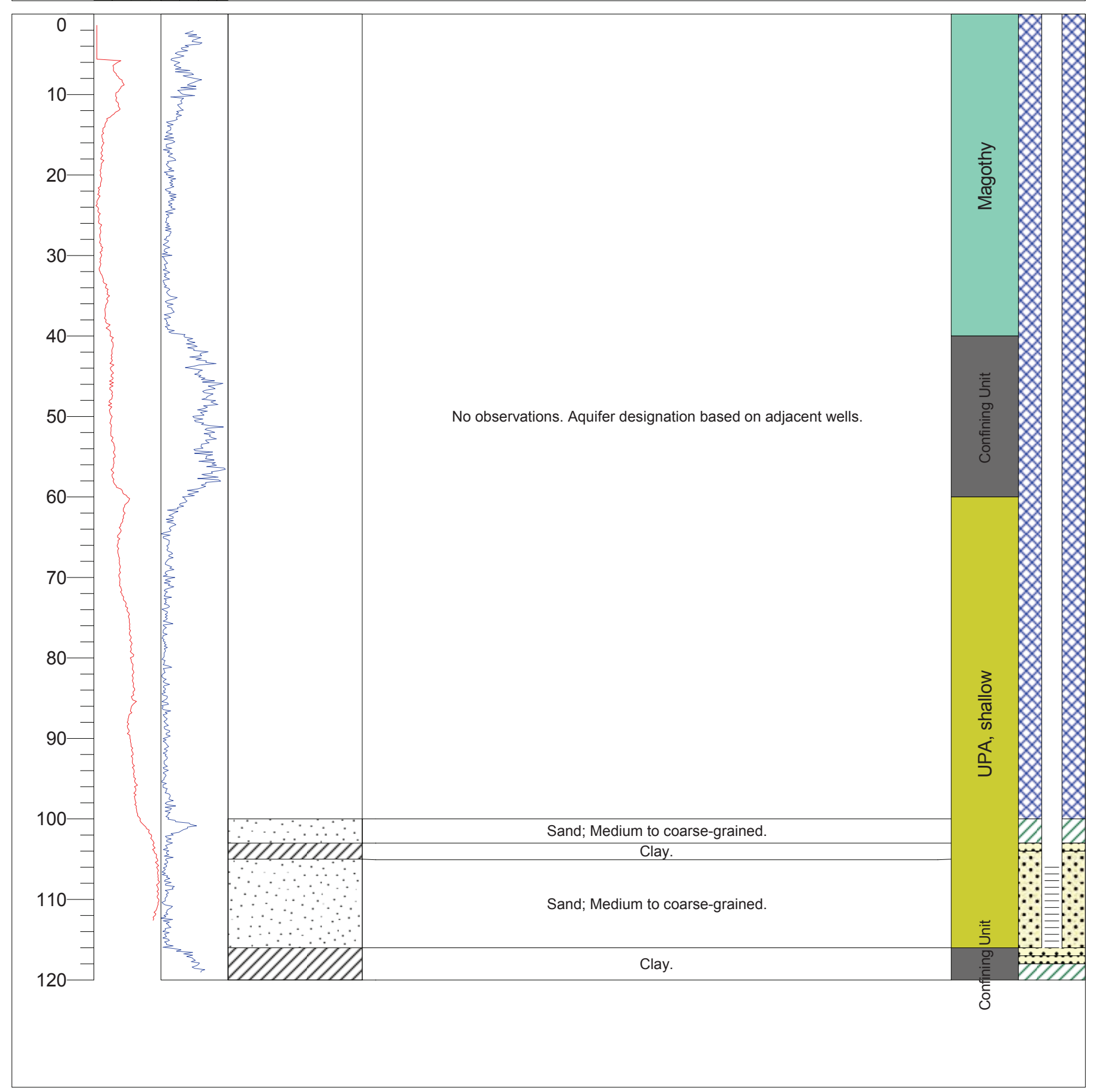

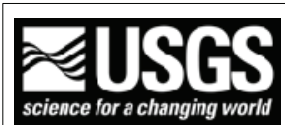

US. Department of the Interior

U.S. Geological Survey

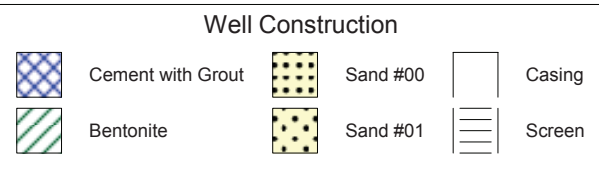

Well Construction

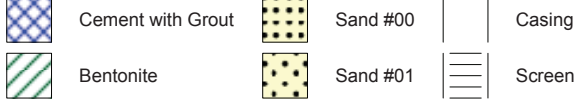

$\square$ Magothy
$\square$ UPA, shallow
UPA, deep

Matawan Confining Unit

Confining Unit

UPA, deep 


\begin{tabular}{|c|c|c|c|}
\hline $\begin{array}{l}\text { Station ID: } 392530075582001 \\
\text { Date Began: } 11 / 30 / 2010 \\
\text { Date Completed: } 12 / 3 / 2010 \\
\text { Logged By: C. Dieter }\end{array}$ & $\begin{array}{l}\text { Boring Depth (Feet): } 197 \\
\text { Well Depth (Feet): } 150 \\
\text { Screen Size (Inches): } 0.015 \\
\text { Drilling Method: Sonic } \\
\text { Driller: Boart Longyear }\end{array}$ & $\begin{array}{l}\text { Latitude } \\
\text { (NAD 83): } 39^{\circ} 25^{\prime} 30.3^{\prime \prime} \mathrm{N} \\
\text { Longitude } \\
\text { (NAD 83): } 75^{\circ} 58^{\prime} 20.5^{\prime \prime W} \\
\text { Land Surface Elevation } 21.49 \\
\text { (NAVD 88): }\end{array}$ & $\begin{array}{c}\text { CE Dd } 191 \\
\text { Pearce Creek } \\
\text { Dredge Material Containment Area } \\
\text { Cecil County, Maryland }\end{array}$ \\
\hline 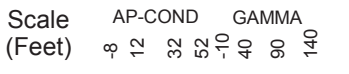 & $\begin{array}{l}\text { Lithologic } \\
\quad \text { Log }\end{array}$ & Lithologic Description & Aquifer \\
\hline
\end{tabular}

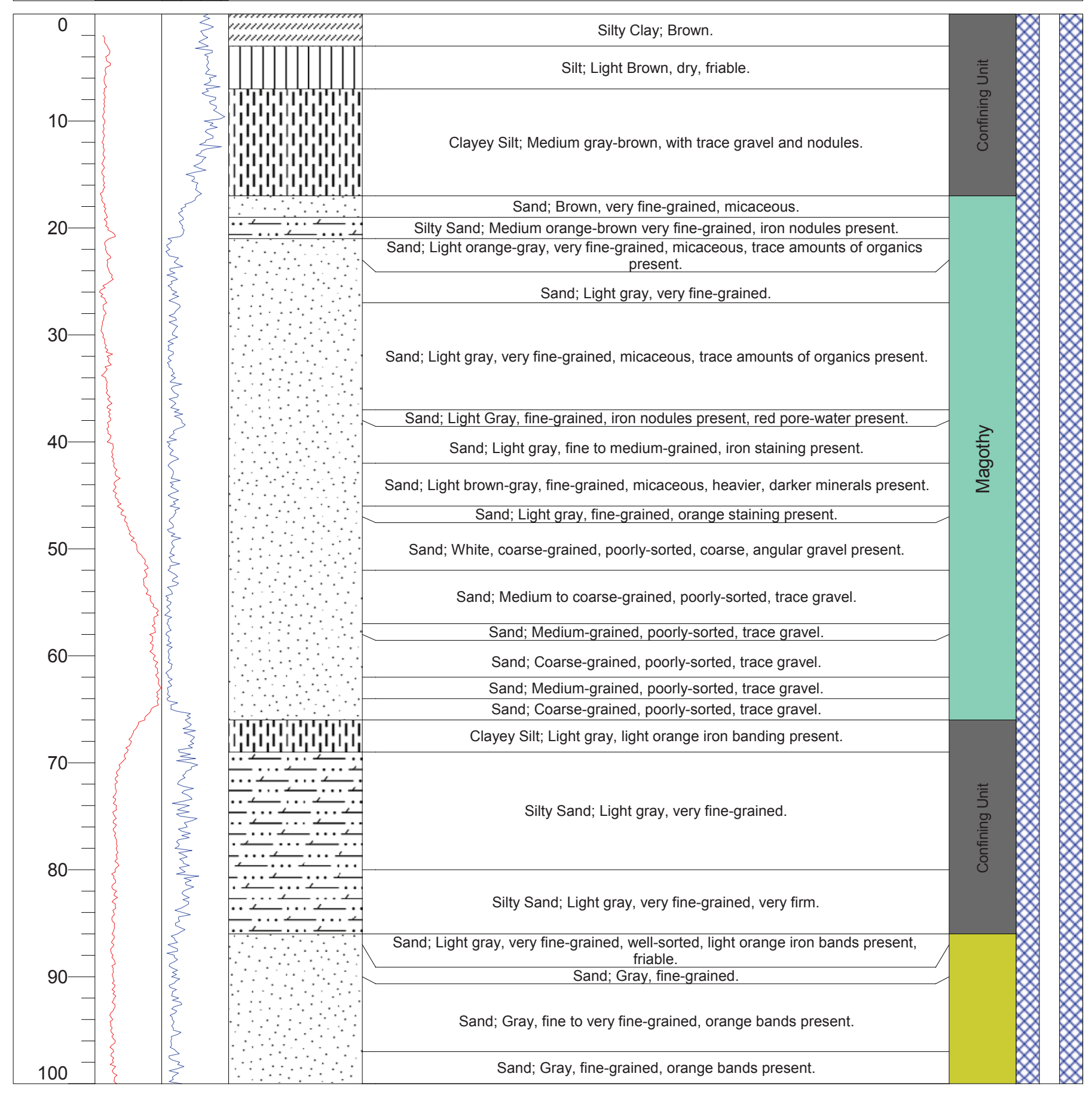

Well Construction

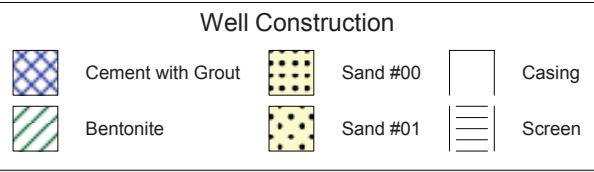

\begin{tabular}{l}
$\square$ Magothy \\
UPA, shallow \\
\hline UPA, deep
\end{tabular}

Matawan Confining Unit Confining Unit 


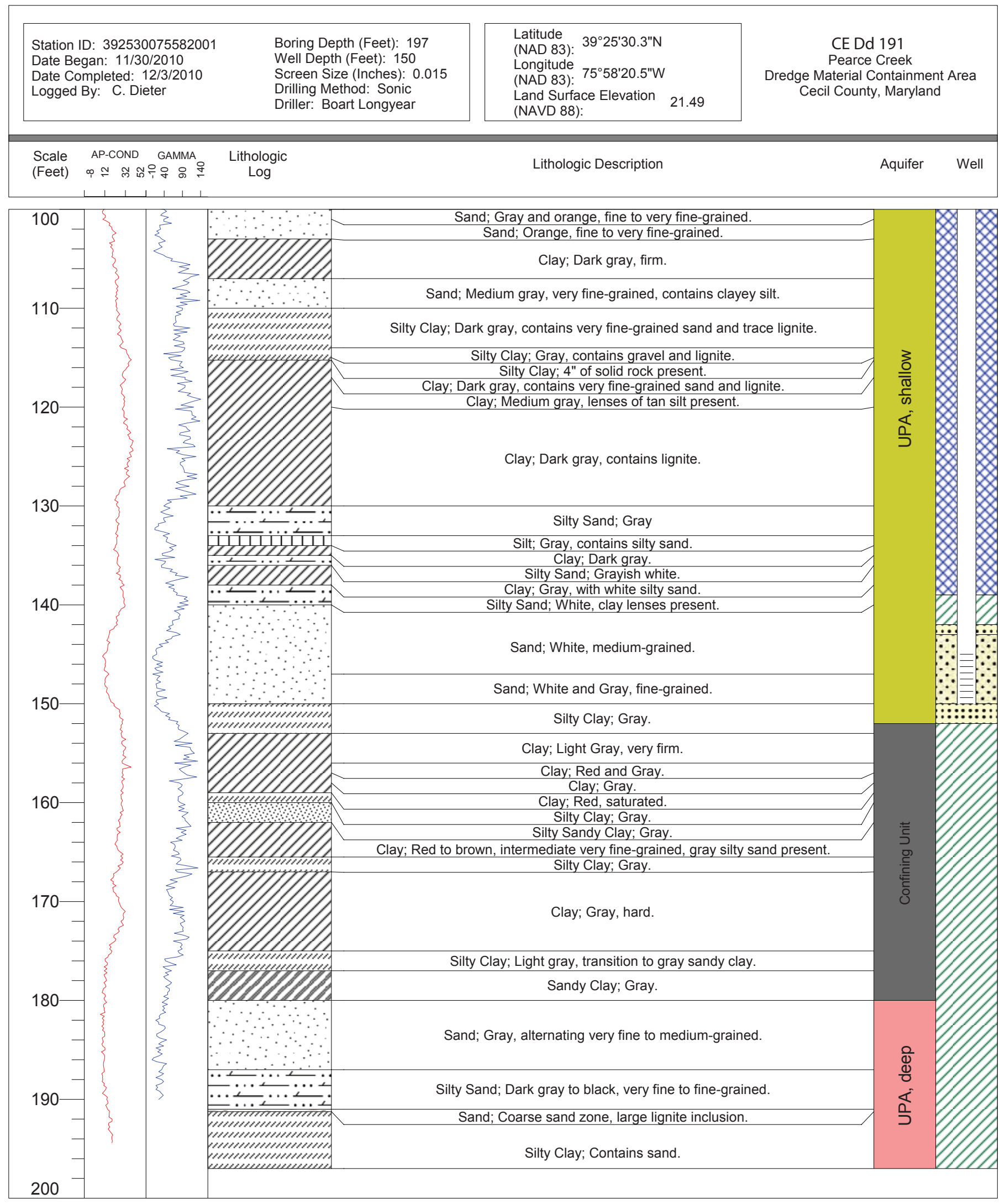

\begin{tabular}{|c|c|c|c|c|c|c|c|}
\hline & \multicolumn{5}{|c|}{ Well Construction } & \multirow{2}{*}{ Magothy } & \multirow{2}{*}{ Matawan Confining Unit } \\
\hline & $x$ & Cement with Grout & 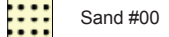 & & Casing & & \\
\hline S Denartment f the & 87 & Bentonite & $\because \because$ Sand $\# 01$ & $\equiv$ & Screen & & \\
\hline $\begin{array}{l}\text { U.S. Department of the } \\
\text { U.S. Geological Survey }\end{array}$ & & & & & & UPA, deep & Page 2 of 2 \\
\hline
\end{tabular}




\begin{tabular}{|c|c|c|c|}
\hline $\begin{array}{l}\text { Station ID: } 392530075582002 \\
\text { Date Began: } 12 / 4 / 2010 \\
\text { Date Completed: 12/4/2010 } \\
\text { Logged By: P. Lapa-Lilly }\end{array}$ & $\begin{array}{l}\text { Boring Depth (Feet): } 67 \\
\text { Well Depth (Feet): } 67 \\
\text { Screen Size (Inches): } 0.015 \\
\text { Drilling Method: Sonic } \\
\text { Driller: Boart Longyear }\end{array}$ & $\begin{array}{l}\text { Latitude } \\
\text { (NAD 83): } 39^{\circ} 25^{\prime} 30.3^{\prime \prime} \mathrm{N} \\
\text { Longitude } 75^{\circ} 58^{\prime} 20.5^{\prime \prime} \mathrm{W} \\
\text { (NAD 83): } \\
\text { Land Surface Elevation } 21.60 \\
\text { (NAVD 88): }\end{array}$ & $\begin{array}{c}\text { CE Dd } 192 \\
\text { Pearce Creek } \\
\text { Dredge Material Containment Area } \\
\text { Cecil County, Maryland }\end{array}$ \\
\hline $\begin{array}{lc}\text { Depth } & \text { Lithologic } \\
\text { (Feet) } & \text { Log }\end{array}$ & & Lithologic Description & Aquifer \\
\hline
\end{tabular}

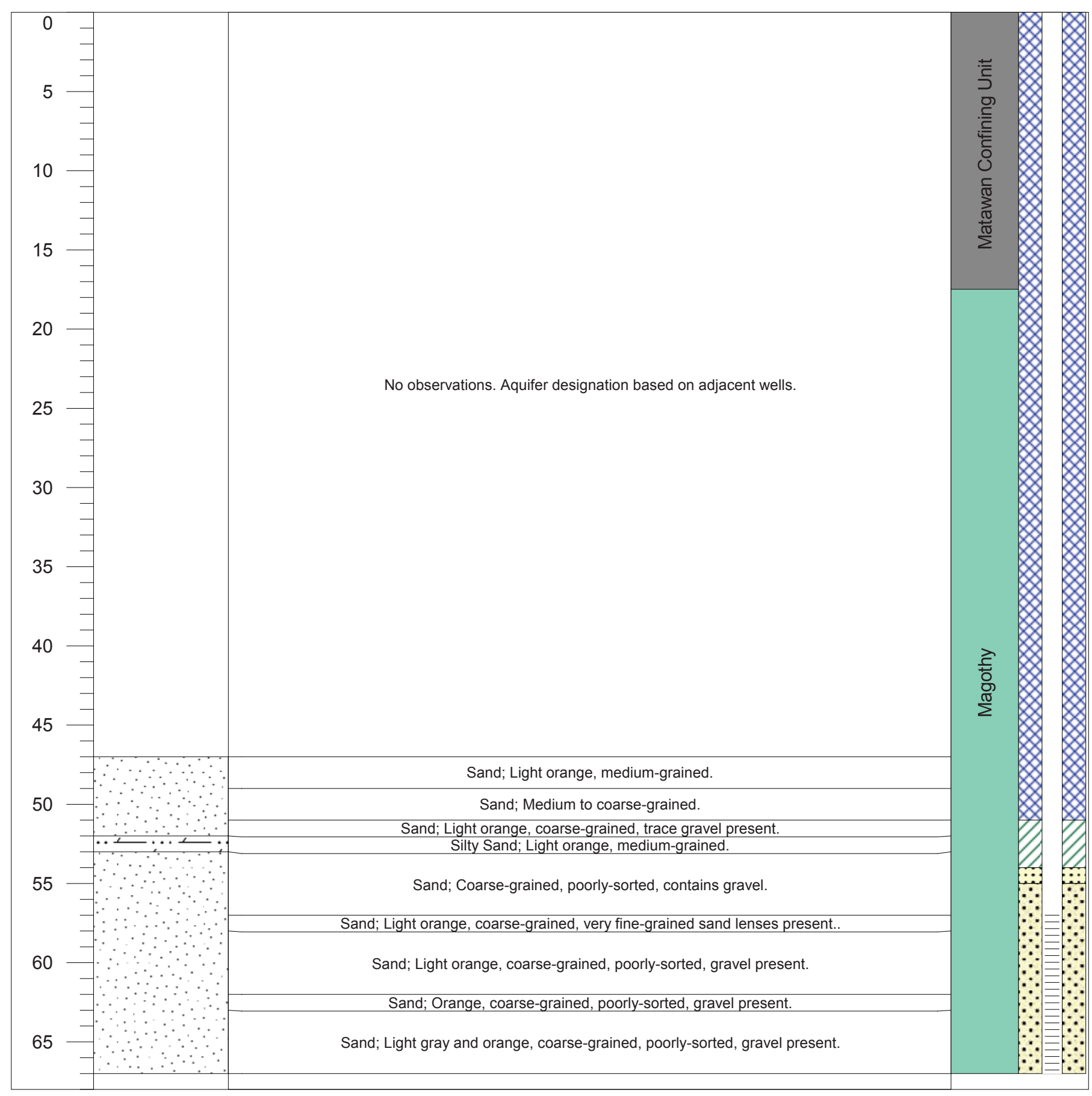

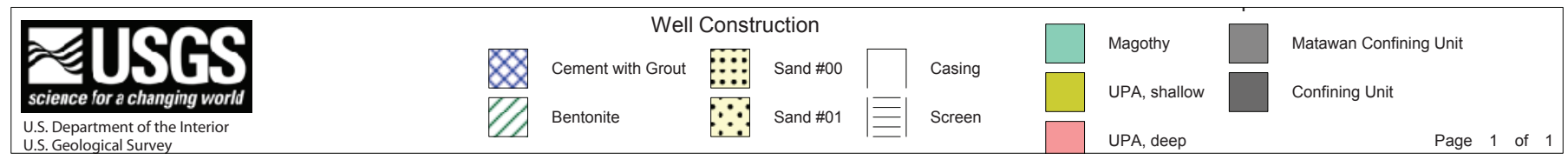




\begin{tabular}{|c|c|c|c|}
\hline $\begin{array}{l}\text { Station ID: } 392525075581401 \\
\text { Date Began: } 12 / 6 / 2010 \\
\text { Date Completed: } 12 / 7 / 2010 \\
\text { Logged By: C. Dieter }\end{array}$ & $\begin{array}{l}\text { Boring Depth (Feet): } 197 \\
\text { Well Depth (Feet): } 88 \\
\text { Screen Size (Inches): } 0.015 \\
\text { Drilling Method: Sonic } \\
\text { Driller: Boart Longyear }\end{array}$ & $\begin{array}{l}\text { Latitude } \\
\text { (NAD 83): } 39^{\circ} 25^{\prime} 24.6 " \mathrm{~N} \\
\text { Longitude } \\
\text { (NAD 83): } 75^{\circ} 58^{\prime} 14.5^{\prime \prime} \mathrm{W} \\
\text { Land Surface Elevation } 43.28 \\
\text { (NAVD 88): }\end{array}$ & $\begin{array}{c}\text { CE Dd } 193 \\
\text { Pearce Creek } \\
\text { Dredge Material Containment Area } \\
\text { Cecil County, Maryland }\end{array}$ \\
\hline 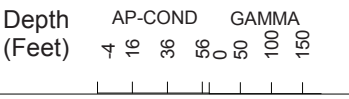 & $\begin{array}{l}\text { Lithologic } \\
\text { Log }\end{array}$ & Lithologic Description & Aquifer \\
\hline
\end{tabular}

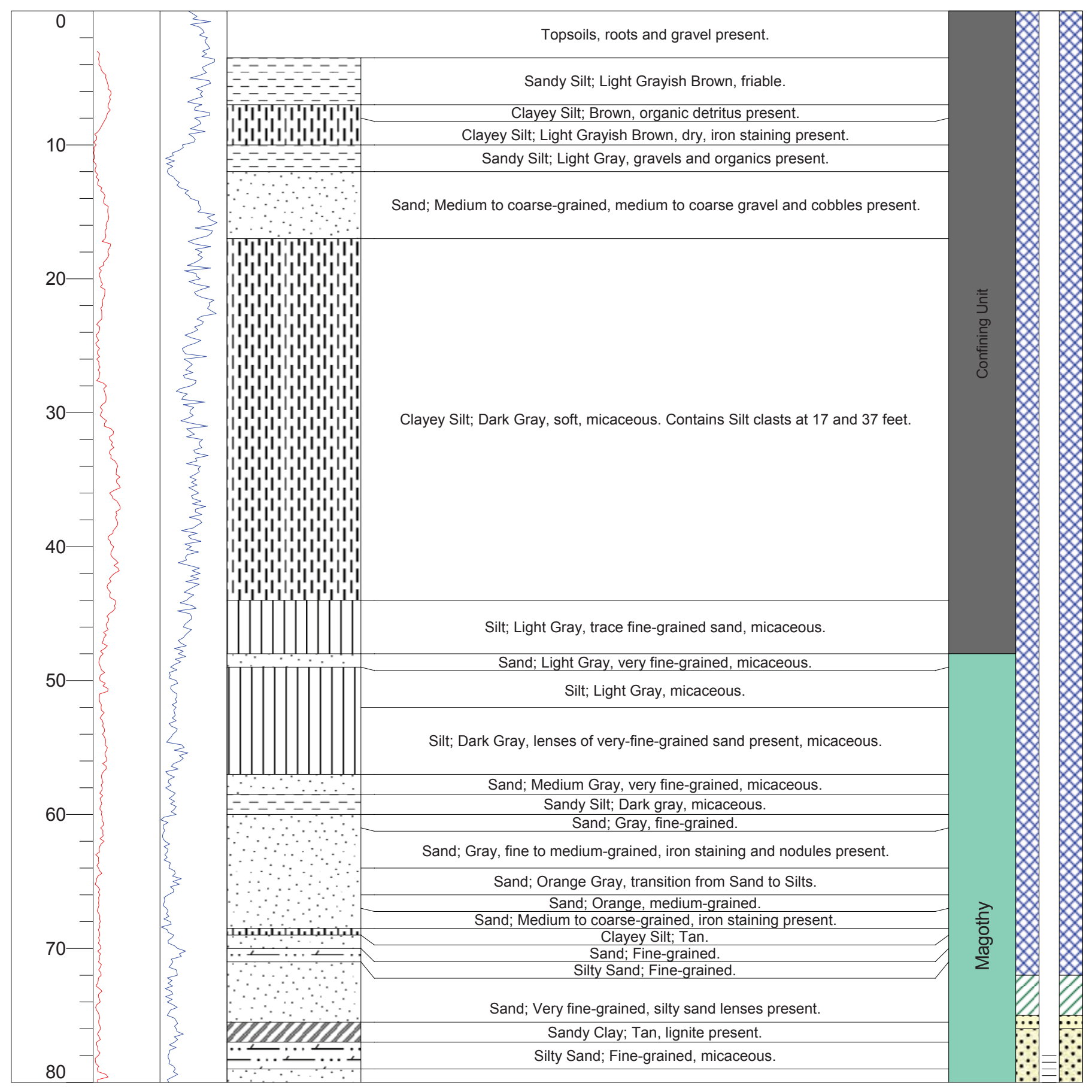

Well Construction

U.S. Department of the Interior U.S. Geological Survey

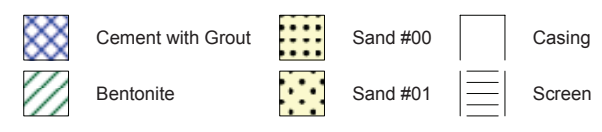

Matawan Confining Unit

Confining Unit
UPA, deep 


\begin{tabular}{|c|c|c|c|}
\hline $\begin{array}{l}\text { Station ID: } 392525075581401 \\
\text { Date Began: } 12 / 6 / 2010 \\
\text { Date Completed: } 12 / 7 / 2010 \\
\text { Logged By: C. Dieter }\end{array}$ & $\begin{array}{l}\text { Boring Depth (Feet): } 197 \\
\text { Well Depth (Feet): } 88 \\
\text { Screen Size (Inches): } 0.015 \\
\text { Drilling Method: Sonic } \\
\text { Driller: Boart Longyear }\end{array}$ & $\begin{array}{l}\text { Latitude } \\
\text { (NAD 83): } 39^{\circ} 25^{\prime} 24.6 " \mathrm{~N} \\
\text { Longitude } 75^{\circ} 58^{\prime} 14.5^{\prime \prime} \mathrm{W} \\
\text { (NAD 83): } \\
\text { Land Surface Elevation } 43.28 \\
\text { (NAVD 88): }\end{array}$ & $\begin{array}{c}\text { CE Dd 193 } \\
\text { Pearce Creek } \\
\text { Dredge Material Containment Area } \\
\text { Cecil County, Maryland }\end{array}$ \\
\hline 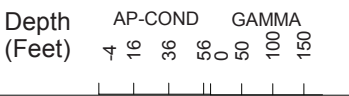 & $\begin{array}{l}\text { Lithologic } \\
\quad \text { Log }\end{array}$ & Lithologic Description & Aquifer \\
\hline
\end{tabular}

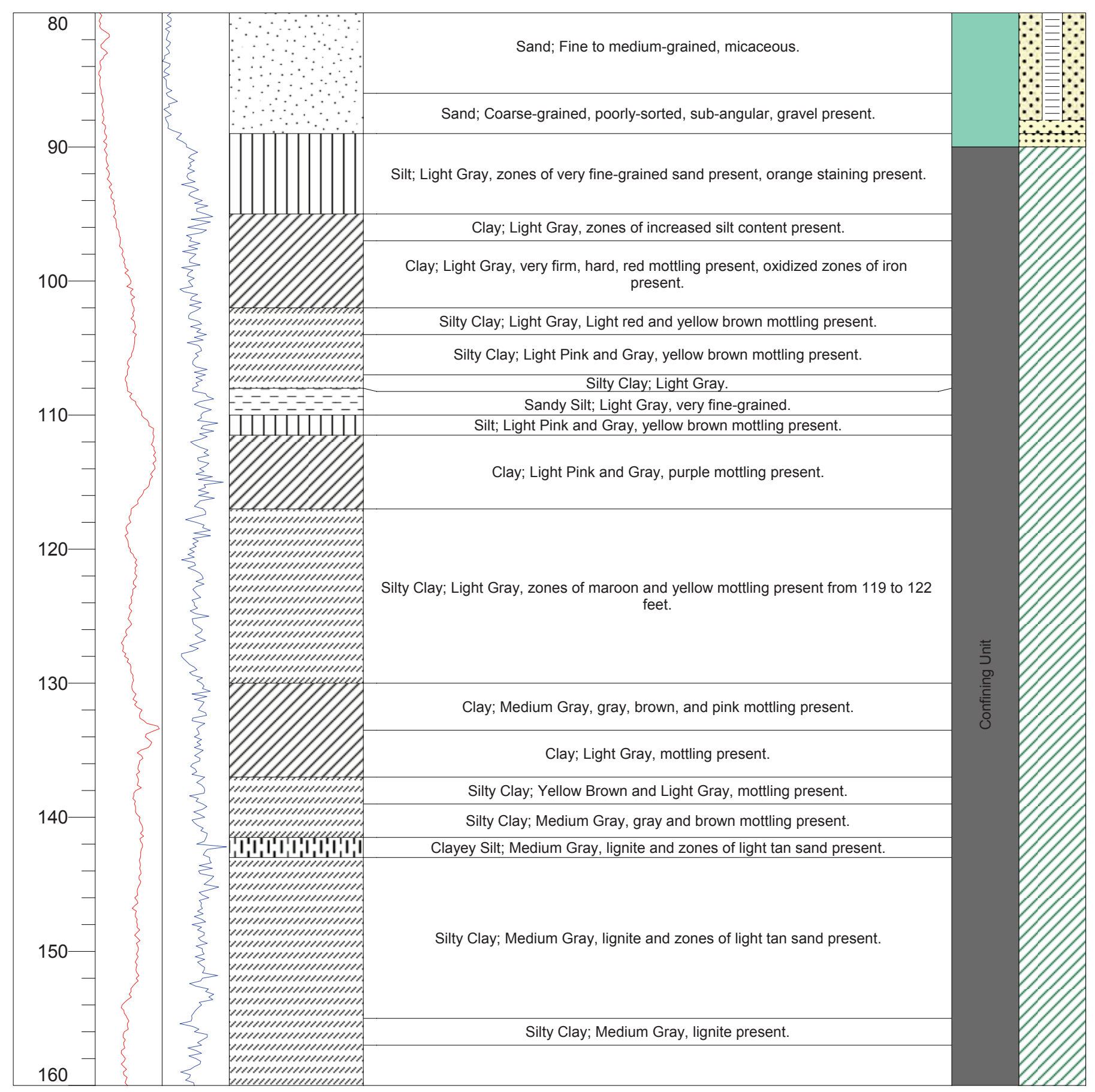

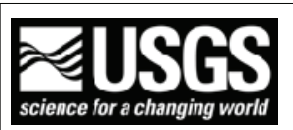

U.S. Department of the Interior U.S. Geological Survey

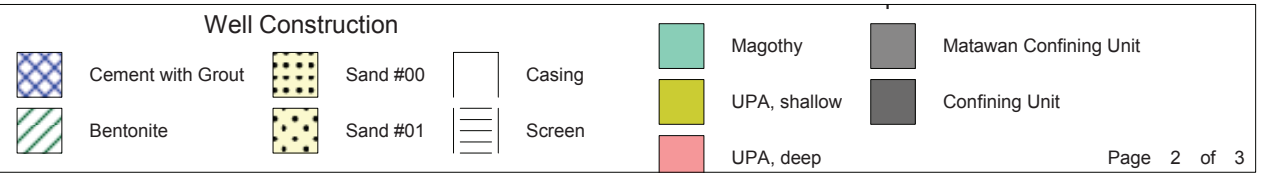




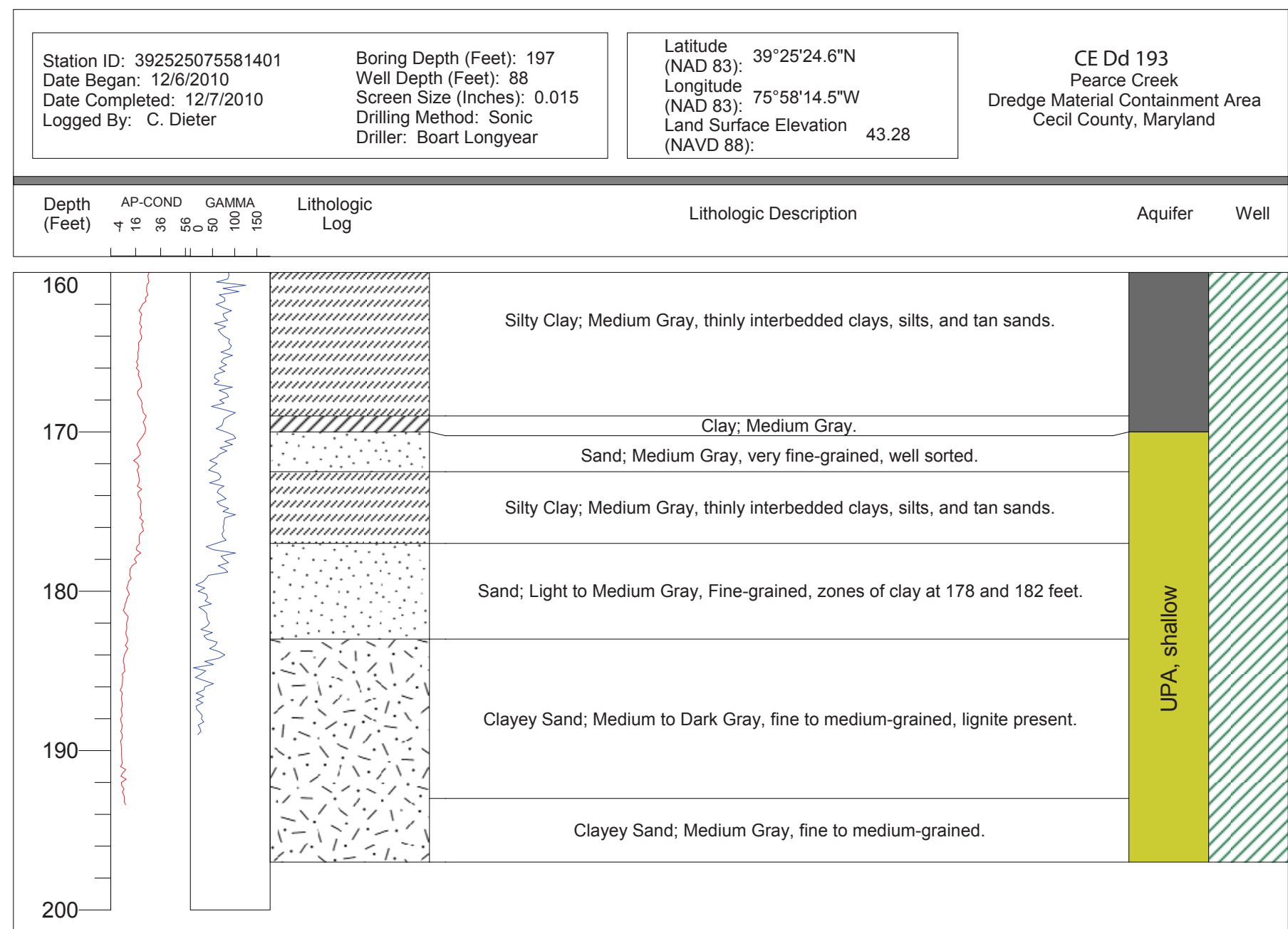

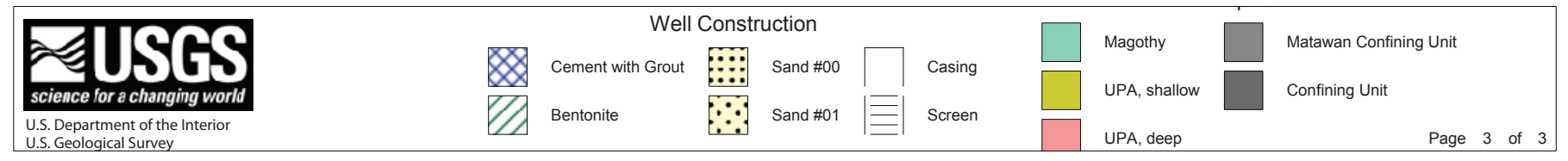




\section{Prepared by West Trenton and Rolla Publishing Service Centers}

For additional information, contact:

Director, MD-DE-DC Water Science Center

U.S. Geological Survey

5522 Research Park Drive

Baltimore, MD 21228

or visit our Web site at:

http://md.water.usgs.gov 



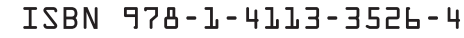

